\title{
Copyright law and the access to education and knowledge in the digital age
}

Citation for published version (APA):

Usadel, P. M. (2016). Copyright law and the access to education and knowledge in the digital age: matching limitations and exceptions in Portugal, Brazil and Mozambique. [Doctoral Thesis, Maastricht University]. Maastricht University. https://doi.org/10.26481/dis.20161220pu

Document status and date:

Published: 01/01/2016

DOI:

10.26481/dis.20161220pu

Document Version:

Publisher's PDF, also known as Version of record

\section{Please check the document version of this publication:}

- A submitted manuscript is the version of the article upon submission and before peer-review. There can be important differences between the submitted version and the official published version of record.

People interested in the research are advised to contact the author for the final version of the publication, or visit the DOI to the publisher's website.

- The final author version and the galley proof are versions of the publication after peer review.

- The final published version features the final layout of the paper including the volume, issue and page numbers.

Link to publication

\footnotetext{
General rights rights.

- You may freely distribute the URL identifying the publication in the public portal. please follow below link for the End User Agreement:

www.umlib.nl/taverne-license

Take down policy

If you believe that this document breaches copyright please contact us at:

repository@maastrichtuniversity.nl

providing details and we will investigate your claim.
}

Copyright and moral rights for the publications made accessible in the public portal are retained by the authors and/or other copyright owners and it is a condition of accessing publications that users recognise and abide by the legal requirements associated with these

- Users may download and print one copy of any publication from the public portal for the purpose of private study or research.

- You may not further distribute the material or use it for any profit-making activity or commercial gain

If the publication is distributed under the terms of Article $25 \mathrm{fa}$ of the Dutch Copyright Act, indicated by the "Taverne" license above, 


\section{Copyright Law and the Access to Education and Knowledge in the Digital Age}

Matching Limitations and Exceptions in Portugal, Brazil and Mozambique

\section{DISSERTATION}

to obtain the degree of Doctor at Maastricht University,

on the authority of the Rector Magnificus, Prof. dr. Rianne M. Letschert in accordance with the decision of the Board of Deans, to be defended in public, on Tuesday, 20 December 2016, at 9.45 hours

by

Philipp Maximilian Usadel 


\section{Supervisors:}

Prof. dr. A.W.J. Kamperman Sanders

Prof. dr. H.E.G.S. Schneider

\section{Assessment Committee:}

Prof. dr. B.E.F.M. de Witte (chairman)

Prof. dr. T.h.C.J.A. van Engelen

Dr. C. Heath, European Patent Office Munich, Germany

Dr. A.B. Quintela Ribeiro Neves Ramalho

Prof. dr. C.A. Souza, Rio de Janeiro State University, Brazil 


\section{Acknowledgments}

The present dissertation is the outcome of about five years of research as an external Ph.D. student at Maastricht University, starting in 2011. I am very thankful to everybody who has supported me and my work during that time. Especially, I want to thank my supervisor Prof. Hildegard Schneider for accepting the project and helping me to carve out the topic. Also I want to thank my supervisor Prof. Anselm Kamperman Sanders for giving me constructive feedback and motivational criticism everytime we met. Both to Prof. Schneider and Prof. Kamperman Sanders I am thankful for the kind and productive relationship and for sharing with me the warm and promotive atmosphere at Maastricht University. In addition, I would like to thank the members of the assessment committee Prof. Bruno de Witte, Prof. Dick van Engelen, Dr. Ana Ramalho, Dr. Christopher Heath and Prof. Carlos Affonso Souza for reading the manuscript and giving their conducive comments. In particular, I am very grateful to my dear wife without whose constant, knowing and patient support I would not have been able to accomplish the project. Finally, I want to thank my parents for their assurance and encouragement. 


\section{Table of Contents}

Acknowledgments ........................................................................................ I

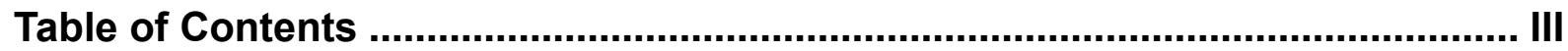

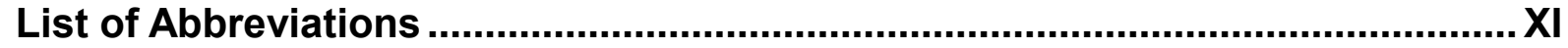

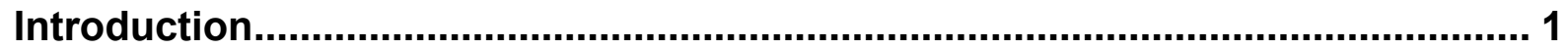

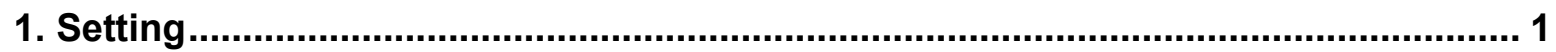

2. Problem Definition, Objective of the Study and Research Question ........................ 8

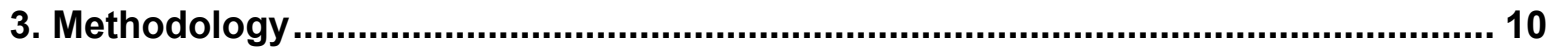

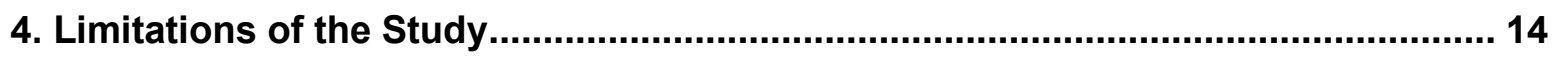

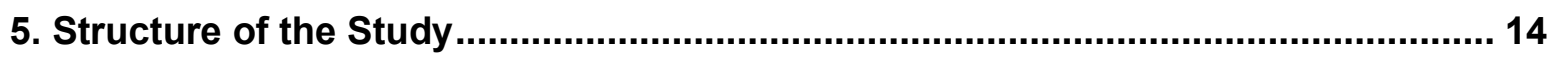

CHAPTER 1: Background and Context of the Study ..................................... 17

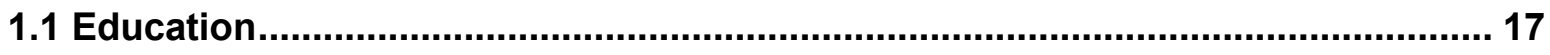

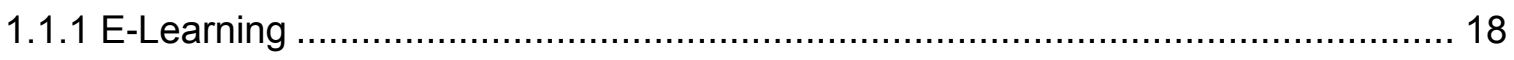

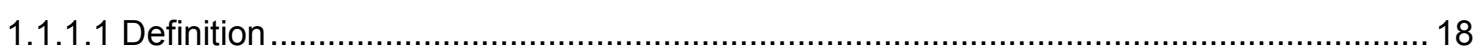

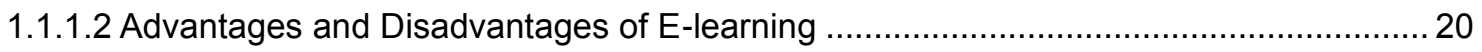

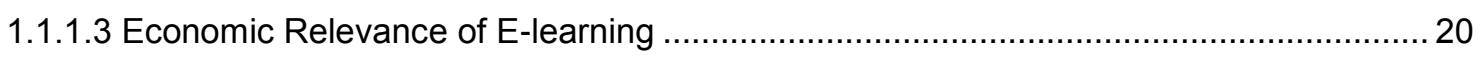

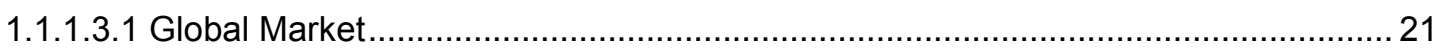

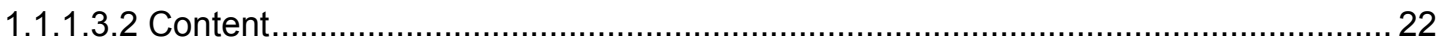

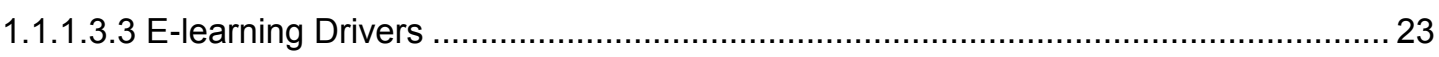

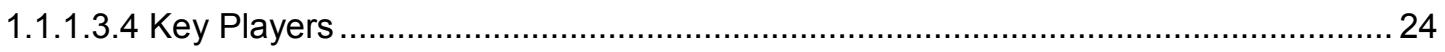

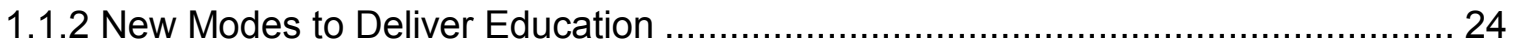

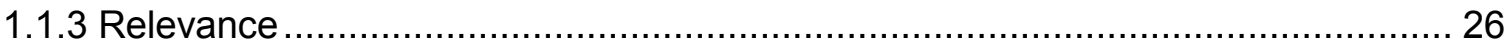

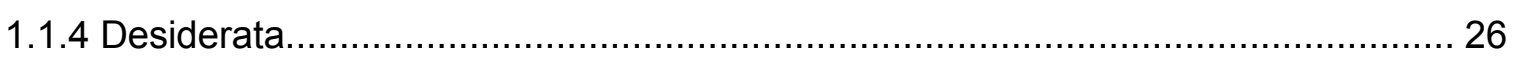

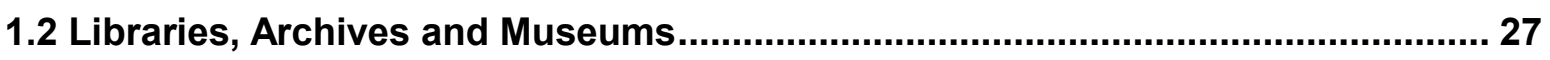

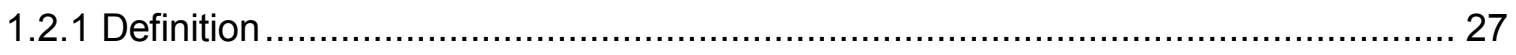

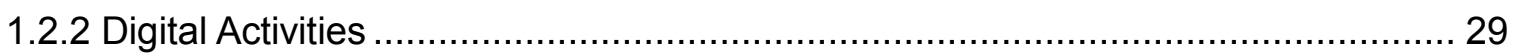

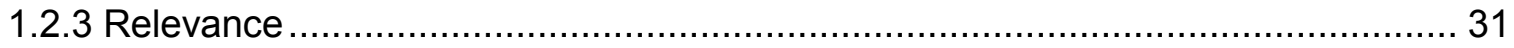

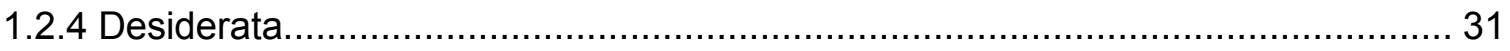

1.3 Copyright Law and the Access to Education and Knowledge .............................. 33

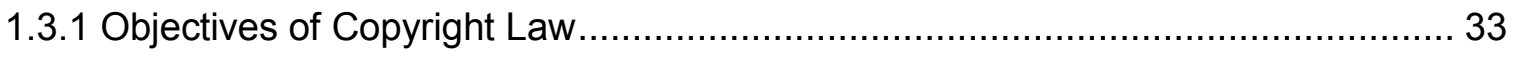

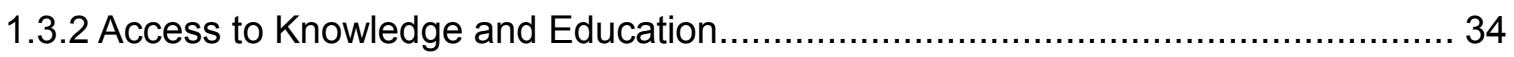

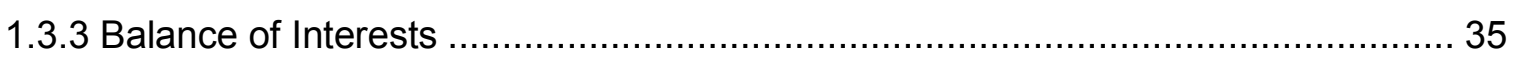

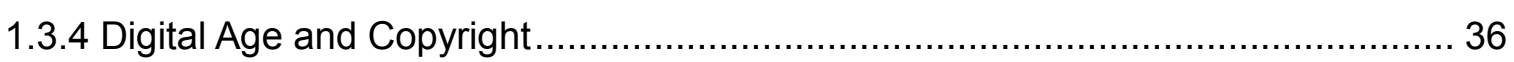

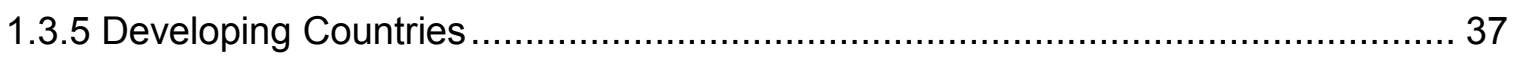

1.3.6 Limitations and Exceptions and Access to Education and Knowledge ................... 38

1.3.7 Limitations and Exceptions and International Copyright Policy ............................ 38 
CHAPTER 2: Significance of Limitations and Exceptions ................................ 43

2.1 Origins and Rationales of Copyright Protection ................................................ 43

2.1.1 Historical Development of Copyright Law ...................................................... 43

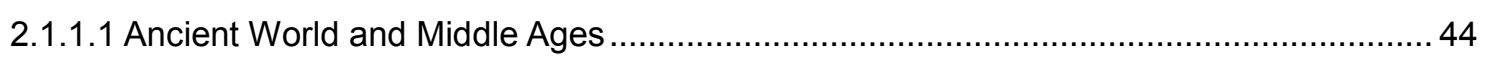

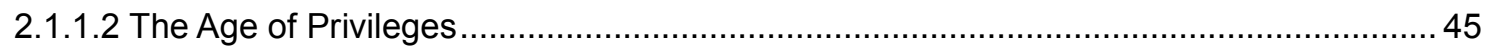

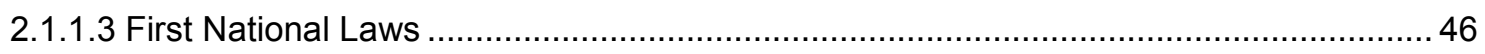

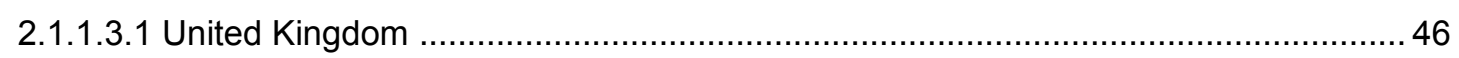

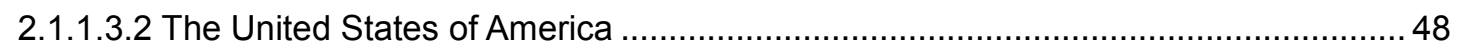

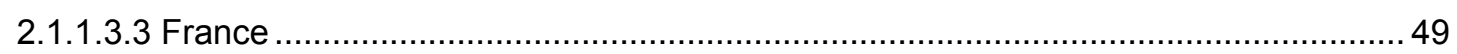

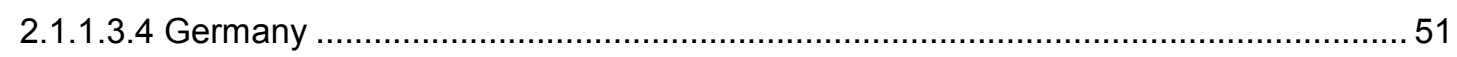

2.1.2 Copyright and Droit d`Auteur: Philosophical Foundations................................ 52

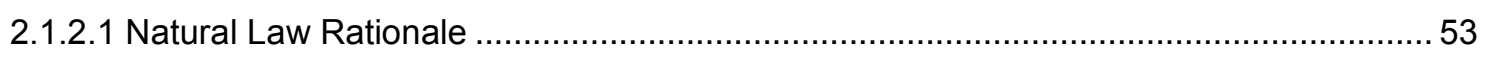

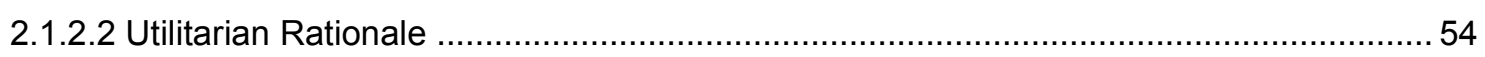

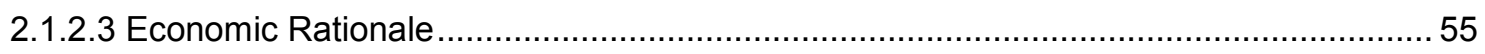

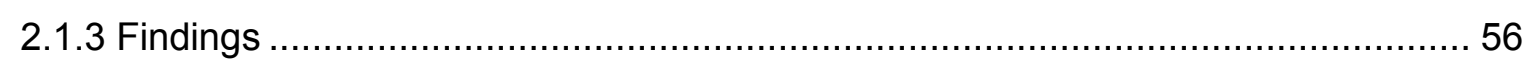

2.2 Limitations and Exceptions within the Copyright System ................................... 57

2.2.1 Legal Nature of Limitations and Exceptions.................................................. 57

2.2.2 Systematic Approaches to Limitations and Exceptions ..................................... 61

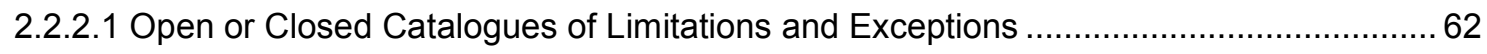

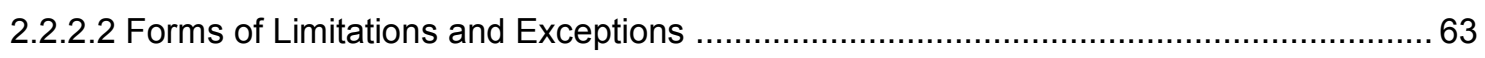

2.2.2.2.1 Limitations and Exceptions on Subject-Matter (Exemptions) ...............................63

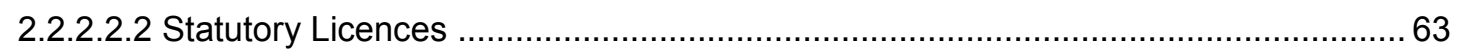

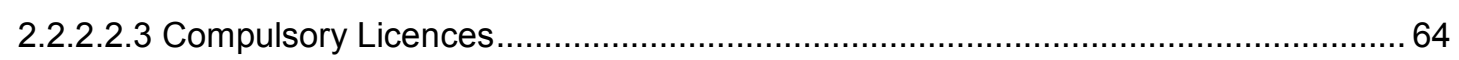

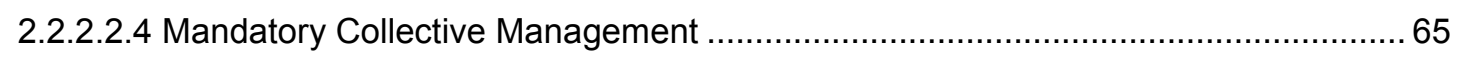

2.2.3 Justifications for Limitations and Exceptions on Authors` Exclusive Rights........... 65

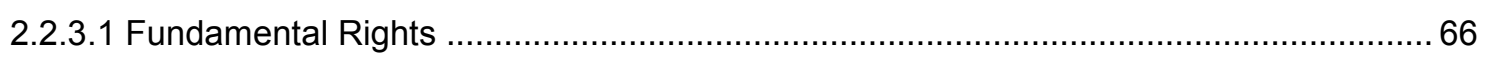

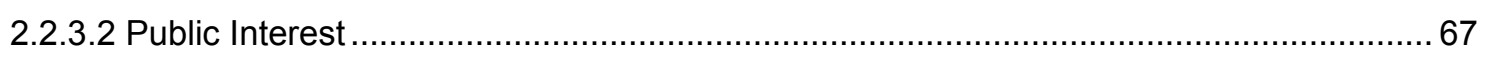

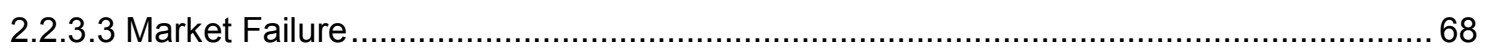

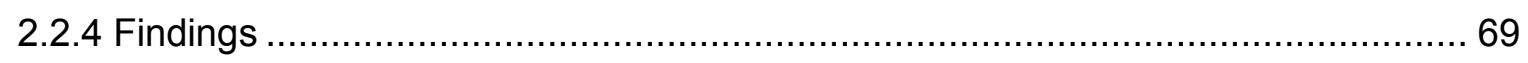

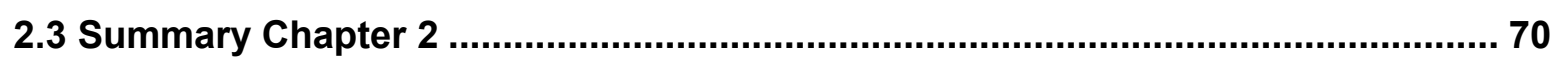

CHAPTER 3: International and European Legal Framework of Limitations and

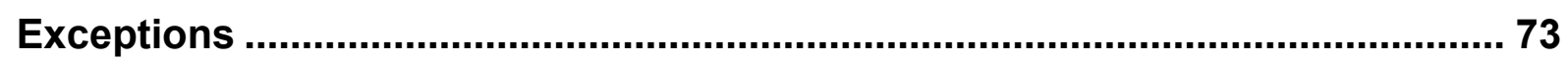

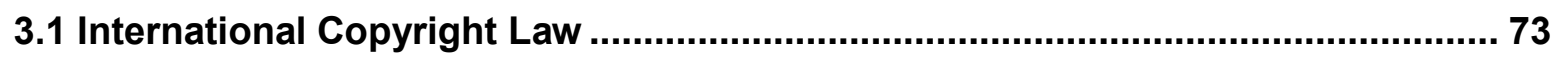

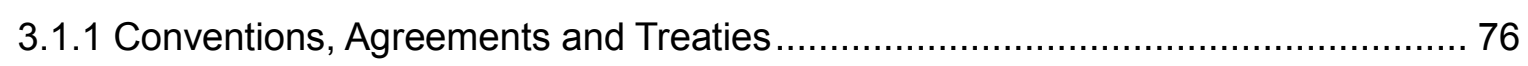

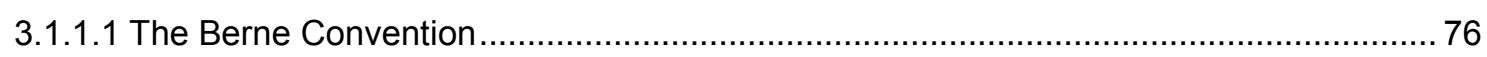

3.1.1.1.1 General Remarks and Elements of Protection ................................................ 77

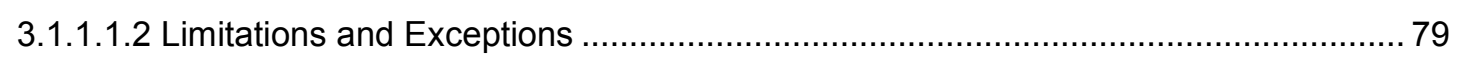

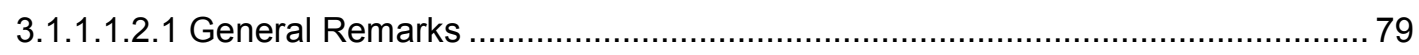


3.1.1.1.2.2 Limitations and Exceptions for Educational Purposes ................................ 80

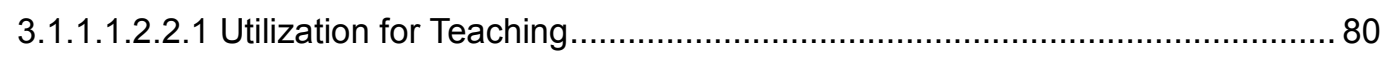

3.1.1.1.2.2.2 Quotations for Educational Purposes ............................................ 83

3.1.1.1.2.3 Limitations and Exceptions for Libraries and Archives................................ 84

3.1.1.1.2.4 The "Minor Reservations" Doctrine .................................................. 85

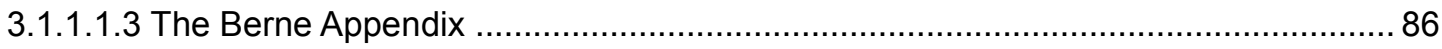

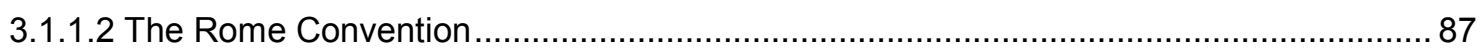

3.1.1.2.1 Scope of Application and Principles ........................................................ 88

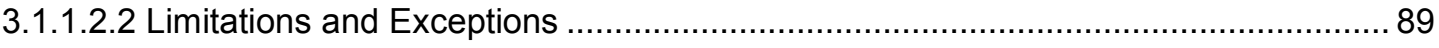

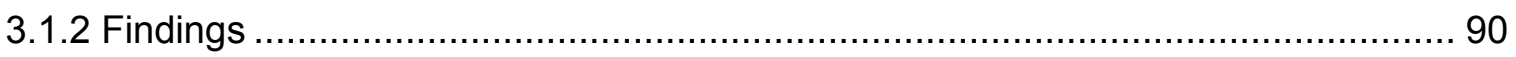

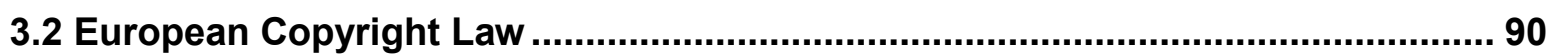

3.2.1 The Information Society Directive 2001/29/EC ................................................ 92

3.2.1.1 Limitations to the Reproduction Right in Favour of Libraries and Educational

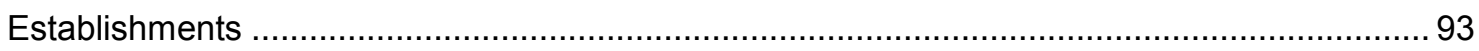

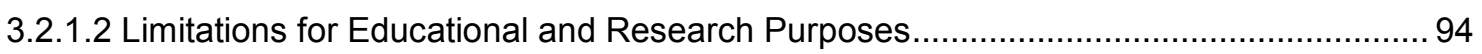

3.2.1.3 Limitations for Libraries and Educational Establishments for Communication and Making

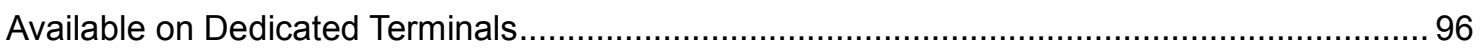

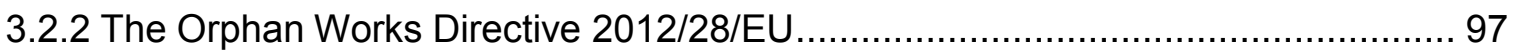

3.2.2.1 Limitation on the Right of Reproduction and the Right of Making Available to the Public

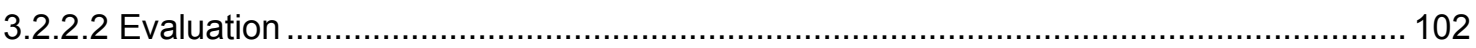

3.2.3 European Court of Justice Jurisdiction concerning Limitations and Exceptions .. 103

3.2.4 EU Copyright Reform Plans .............................................................. 105

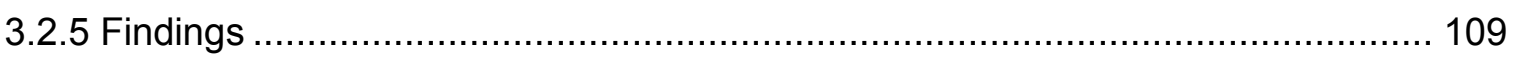

3.3 The Human Rights Perspective on Limitations and Exceptions.........................110

3.3.1 The Human Right to Education ................................................................. 111

3.3.2 The Human Right to take part in Culture Life and the Right of Authors to the Protection of their Moral and Material Interests ...................................................... 115

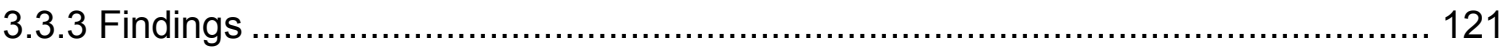

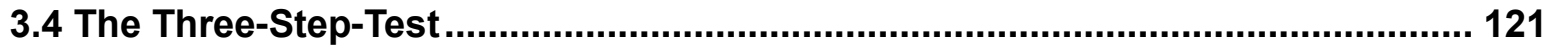

3.4.1 The Provisions Containing the Three-Step-Test ....................................... 121

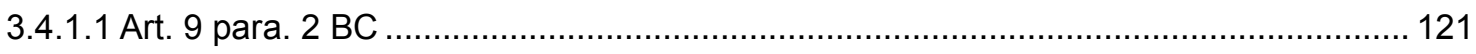

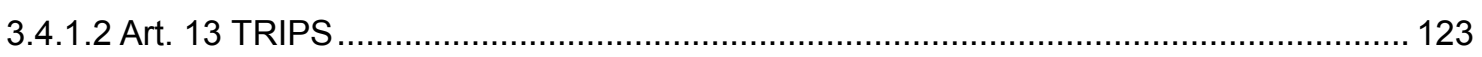

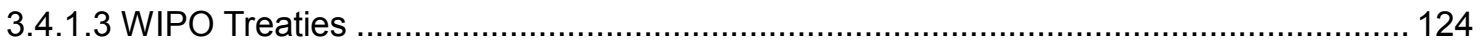

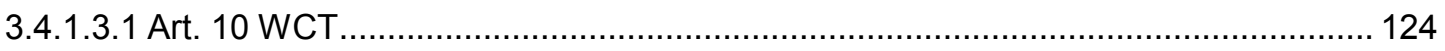

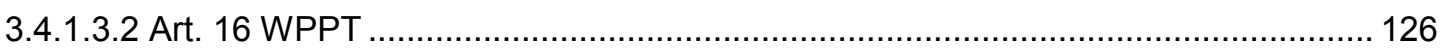

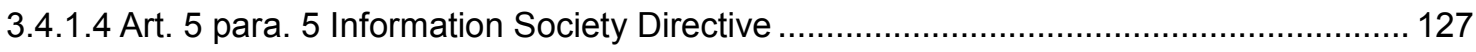

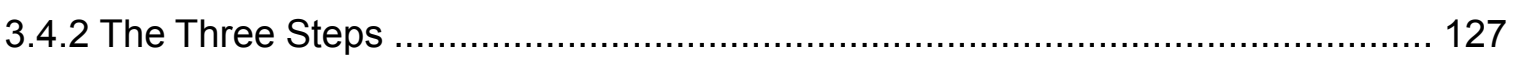

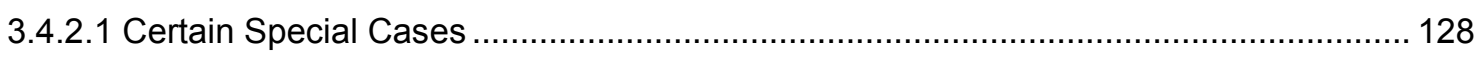

3.4.2.2 No Conflict with the Normal Exploitation of the Work .................................... 128 
3.4.2.3 No Unreasonable Prejudice to the Author's or Right Holders Legitimate Interests ..... 129

3.4.3 Alternative Approaches to the Three-Step-Test........................................... 130

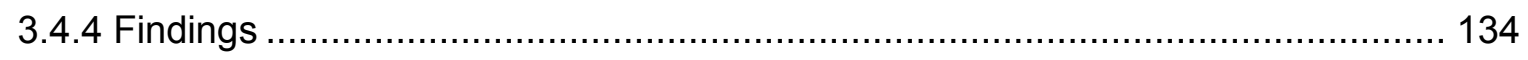

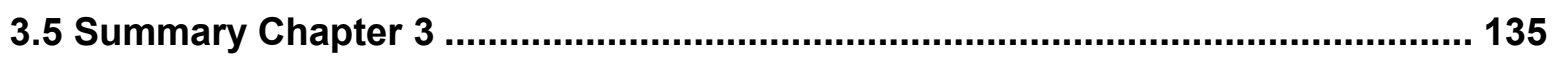

CHAPTER 4: Limitations and Exceptions for Education and Libraries in National Copyright Laws................................................................................ 137

Setting the Scene ................................................................................................. 137

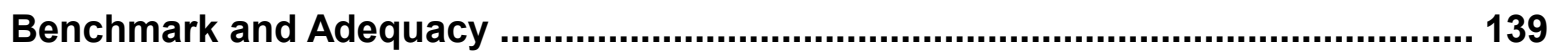

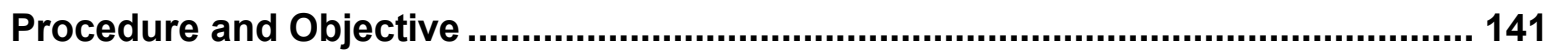

PART 1: Limitations and Exceptions for Educational Purposes and Libraries, Archives and similar Institutions in the United States of America, the United

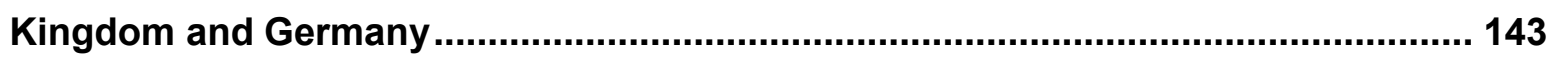

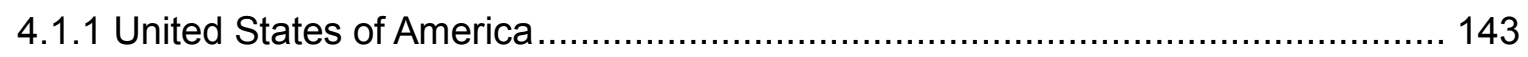

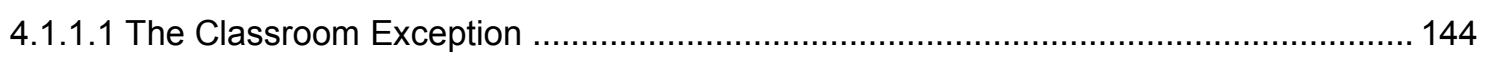

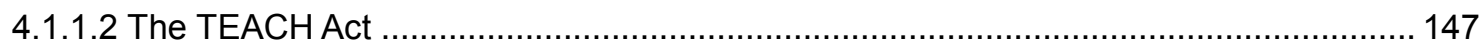

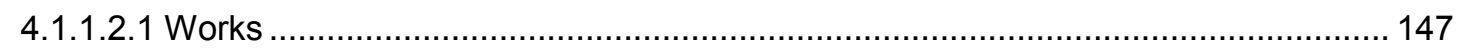

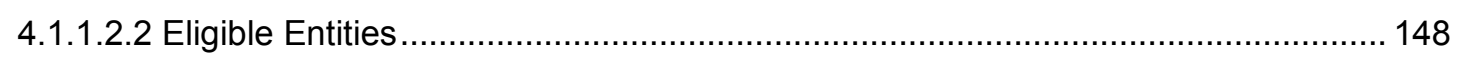

4.1.1.2.3 Mediated Instructional Activities .................................................................. 149

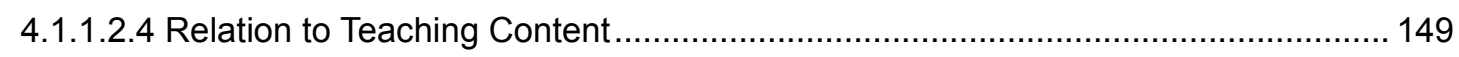

4.1.1.2.5 Limitation to Certain Recipients ................................................................. 150

4.1.1.2.6 Copyright Policy and Digital Rights Management............................................ 150

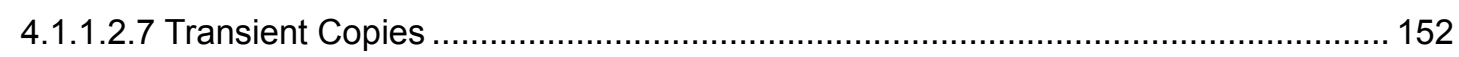

4.1.1.2.8 Copies and Ephemeral Recordings ………............................................... 152

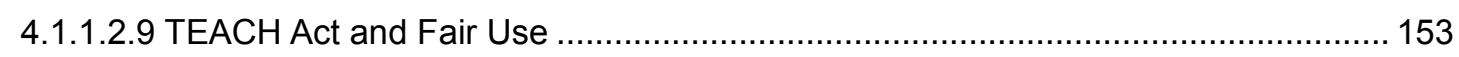

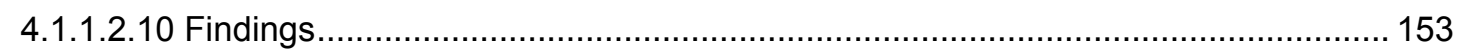

4.1.1.3 Limitations and Exceptions for Libraries and Archives ........................................... 154

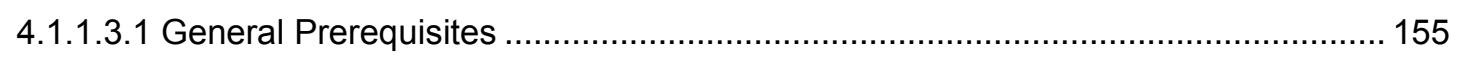

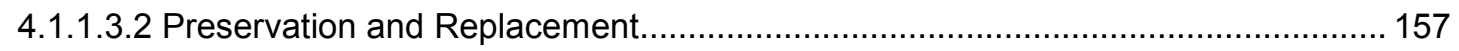

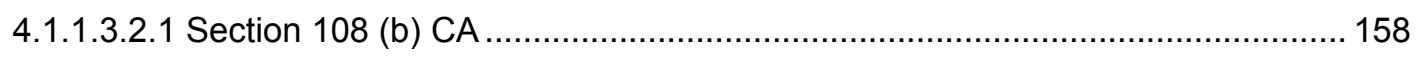

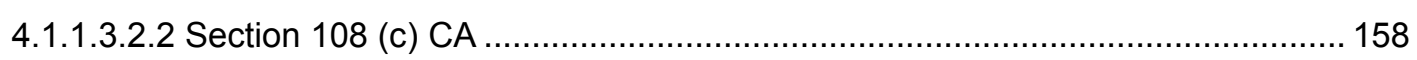

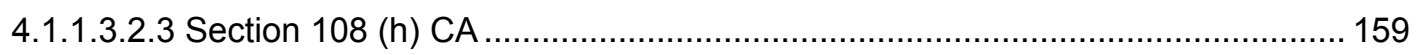

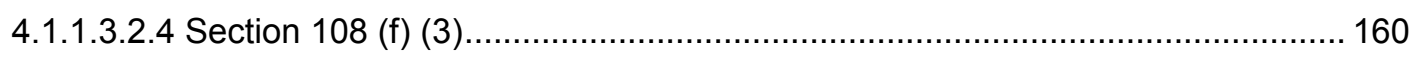

4.1.1.3.3 Copies for Private Study and Research, Interlibrary Loan ................................. 160

4.1.1.3.4 Liability for Unsupervised Reproducing Equipment, Fair Use ............................ 162

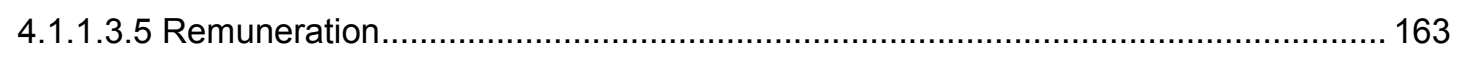

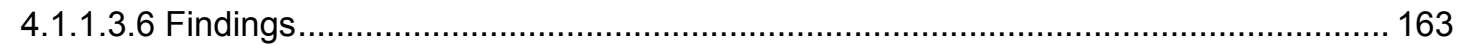

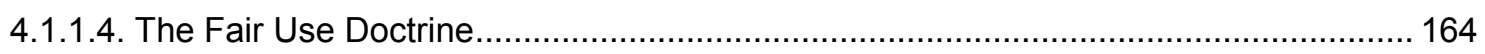

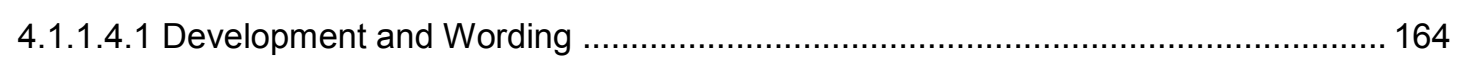

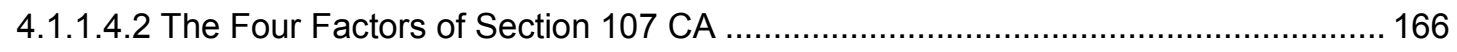

4.1.1.4.2.1 First Factor: The Purpose and the Nature of the Use .................................. 166 
4.1.1.4.2.2 Second Factor: The Nature of the Copyrighted Work ..................................... 166

4.1.1.4.2.3 Third Factor: The Amount and the Substantiality of the Portion Used ............. 167

4.1.1.4.2.4 Fourth Factor: The Effect on the Plaintiff's Potential Market ......................... 167

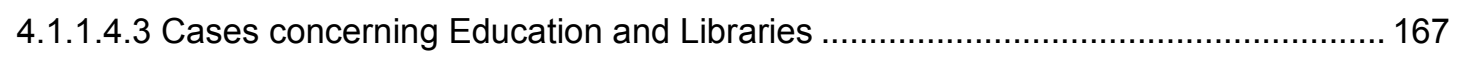

4.1.1.4.3.1 Williams \& Wilkins Co. v. United States .................................................... 168

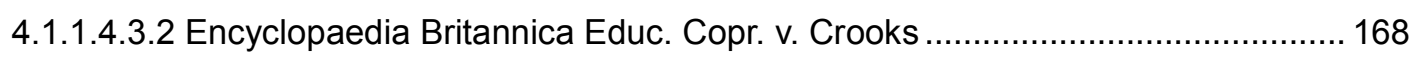

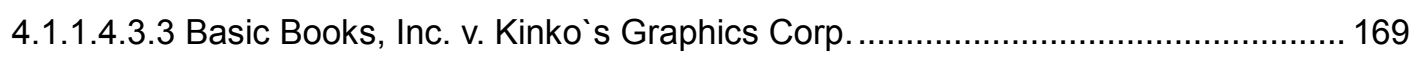

4.1.1.4.3.4 American Geophysical Union v. Texaco Inc. ............................................. 169

4.1.1.4.3.5 Princeton University Press v. Michigan Document Services............................ 169

4.1.1.4.3.6 Cambridge University Press, et al, v Becker, et al ........................................ 170

4.1.1.4.3.7 Authors Guild, Inc. v. Hathi Trust ............................................................... 171

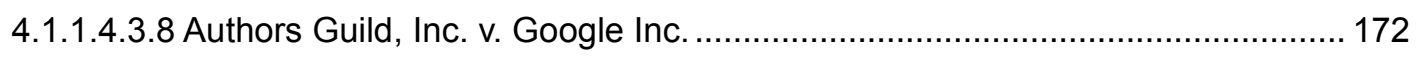

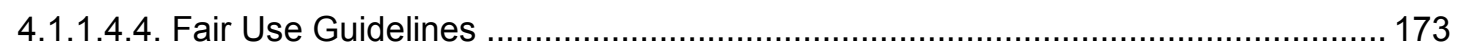

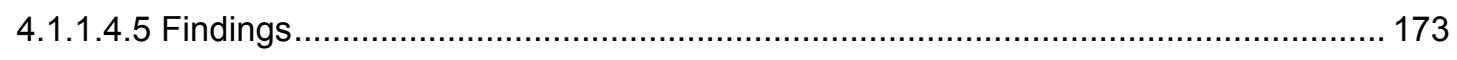

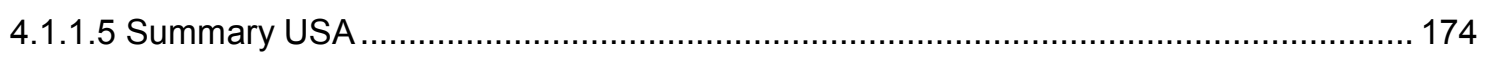

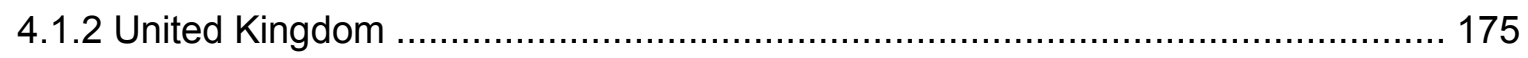

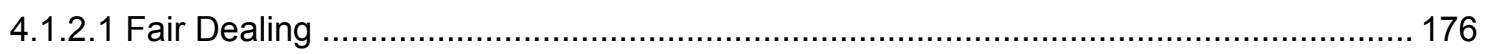

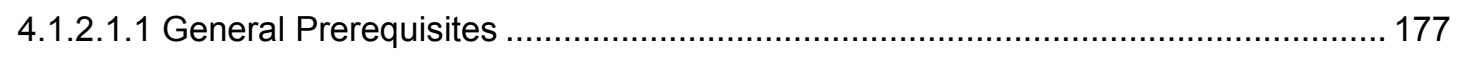

4.1.2.1.2 Fair Dealing for Research and Private Study ................................................. 178

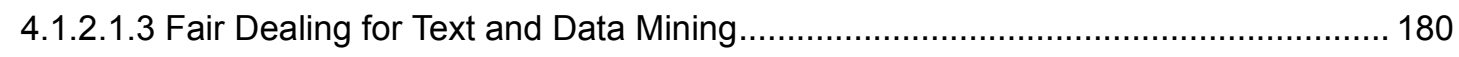

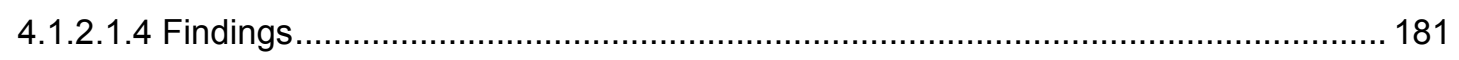

4.1.2.2 Limitations and Exceptions for Education ........................................................ 181

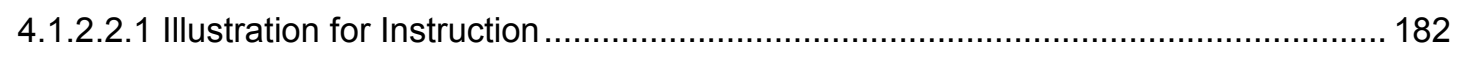

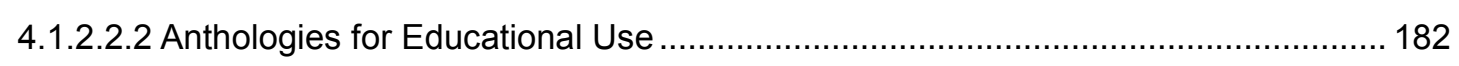

4.1.2.2.3 Performing, Playing or Showing Work in Course of Activities of Educational

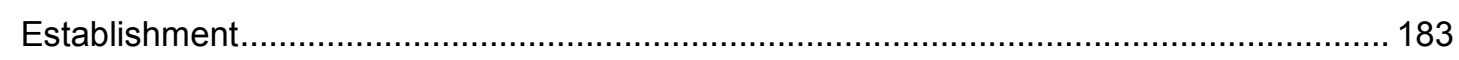

4.1.2.2.4 Recording by Educational Establishments of Broadcasts ................................... 184

4.1.2.2.5 Copying and Use of Extracts of Works by Educational Establishments................ 185

4.1.2.2.6 Lending of Copies by Educational Establishments ............................................ 186

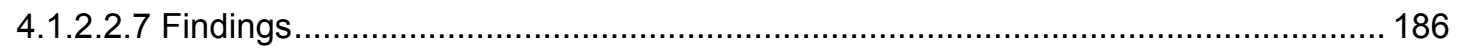

4.1.2.3 Limitations and Exceptions for libraries and archives ............................................ 187

4.1.2.3.1 Lending of Copies by Libraries and Archives.................................................. 187

4.1.2.3.2 Libraries and Educational Establishments etc.: Making Works Available through

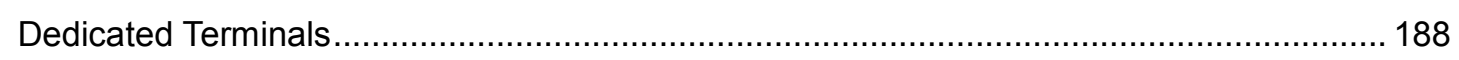

4.1.2.3.3 Copying by Librarians: Supply of Single Copies to Other Libraries ....................... 189

4.1.2.3.4 Copying by Libraries etc.: Replacement Copies of Works.................................... 189

4.1.2.3.5 Copying by Librarians: Single Copies of Published Works................................... 190

4.1.2.3.6 Copying by Librarians or Archivists: Single Copies of Unpublished Works ............ 191

4.1.2.3.7 Copy Required to be made as Condition of Export ........................................... 192

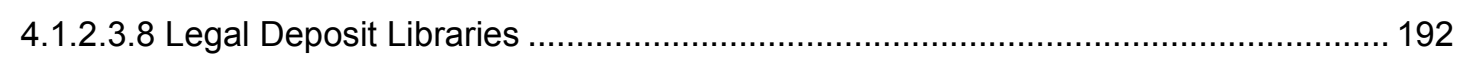

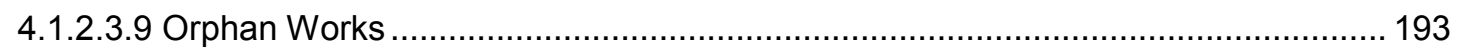




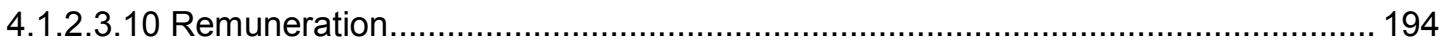

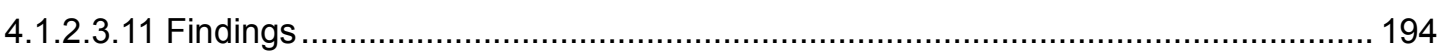

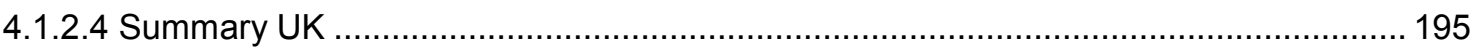

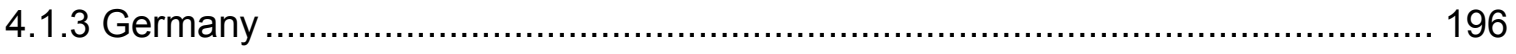

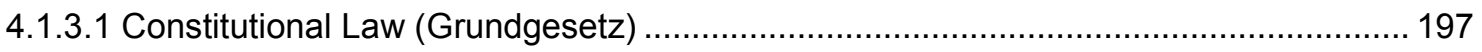

4.1.3.2 Limitations and Exceptions for Education and Libraries, Museums and Archives ....... 199

4.1.3.2.1 Making Available in Public for Instruction and Research .................................... 199

4.1.3.2.2 Display on Dedicated Terminals in Public Libraries, Museums and Archives........ 203

4.1.3.2.3 Anthologies for the Use in Churches, Schools or for Instruction .......................... 206

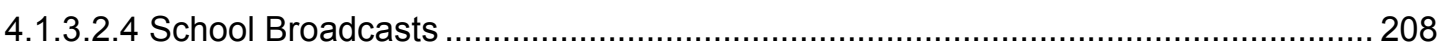

4.1.3.2.5 Reproduction for Private and Other Personal Use ............................................. 209

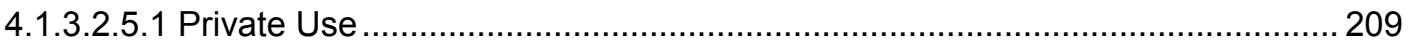

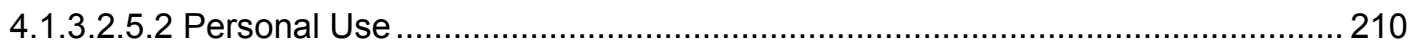

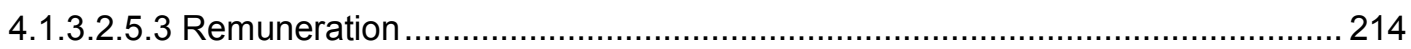

4.1.3.2.6 Distribution of Copies on Request ................................................................. 216

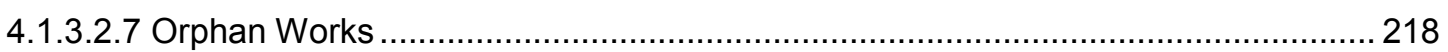

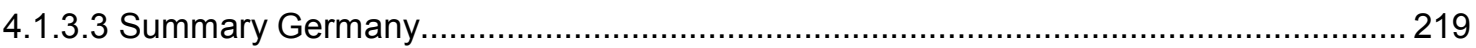

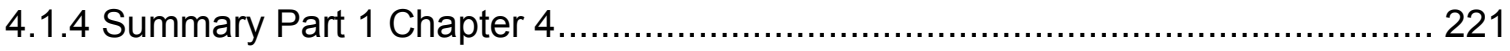

PART 2: Limitations and Exceptions for Educational Purposes and Libraries, Archives and Similar Institutions in Portugal, Brazil and Mozambique .................... 225

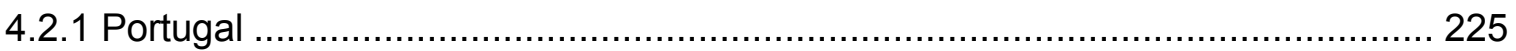

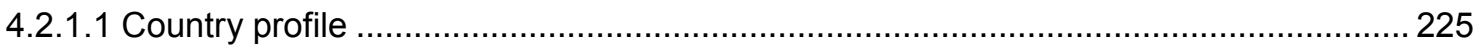

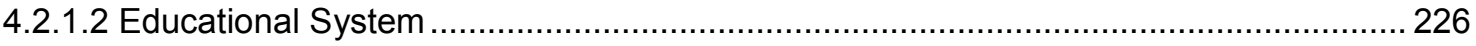

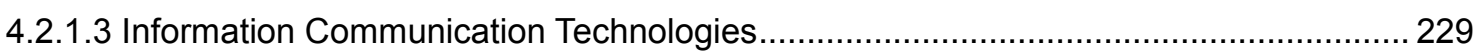

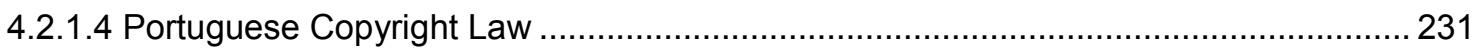

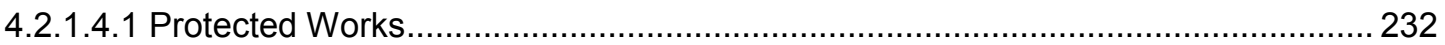

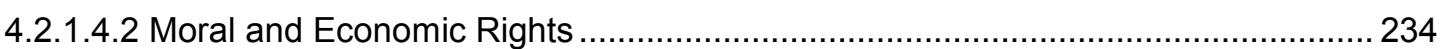

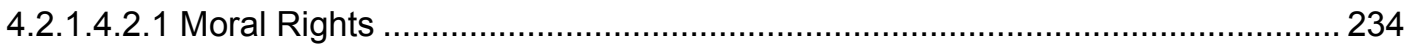

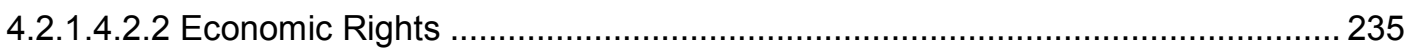

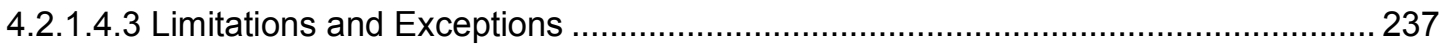

4.2.1.4.3.1 Reproduction and Making Available for the Purpose of Information ............... 238

4.2.1.4.3.2 Reproductions by Libraries and Educational Institutions ............................... 238

4.2.1.4.3.3 Reproduction, Distribution and Making Available of Parts of a Work .............. 239

4.2.1.4.3.4 Inclusion of Short Pieces of a Work for Education ........................................ 240

4.2.1.4.3.5 Making Available of Works on Dedicated Terminals .................................... 240

4.2.1.4.3.6 Reproduction and Making Available of Orphan Works.................................. 241

4.2.1.4.3.7 Three-Step-Test and Contract Clauses ........................................................ 242

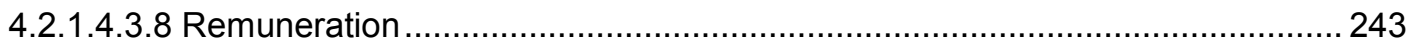

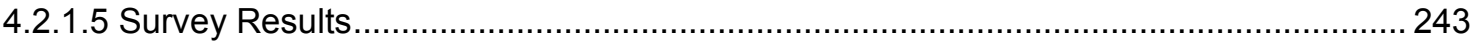

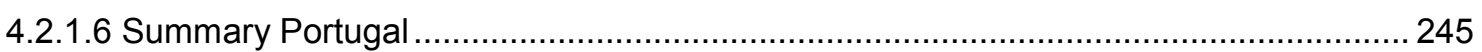

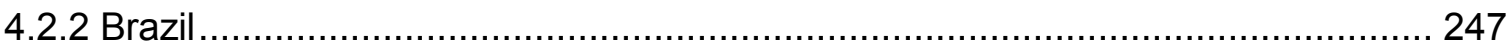




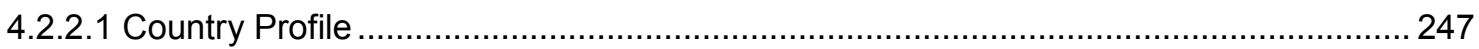

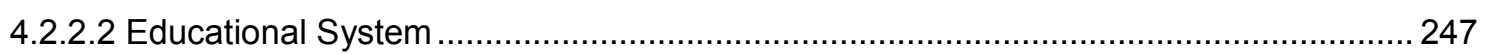

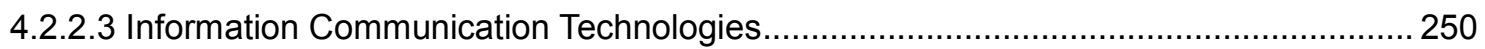

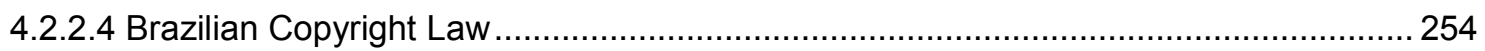

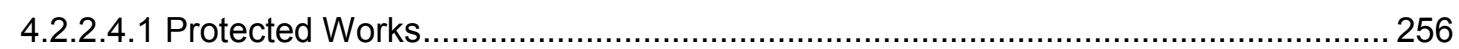

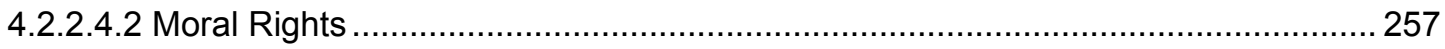

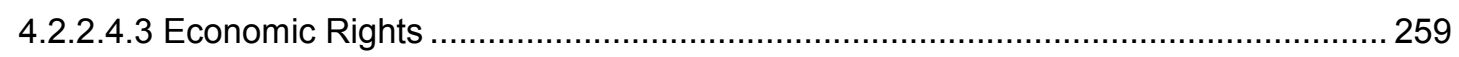

4.2.2.4.3.1 Right of Reproduction and Right of Communication to the Public .................. 260

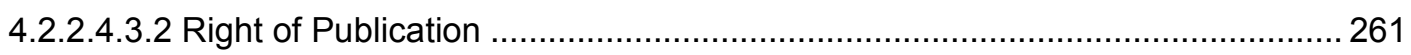

4.2.2.4.3.3 Right of Translation, Adaptation and other Alterations .................................. 261

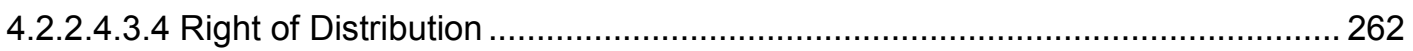

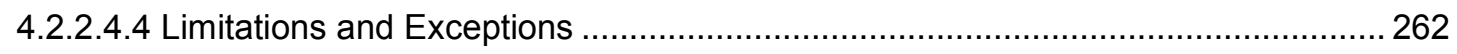

4.2.2.4.4.1 Justification, Objectives and Interpretation of Limitations ............................. 262

4.2.2.4.4.2 Limitations and Exceptions for Educational Purposes and Libraries .............. 264

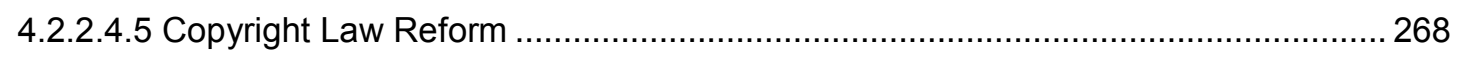

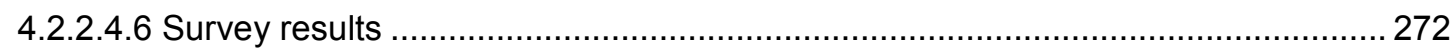

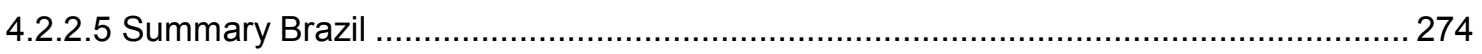

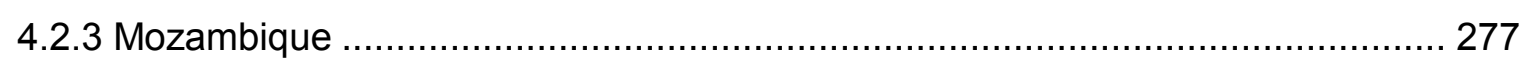

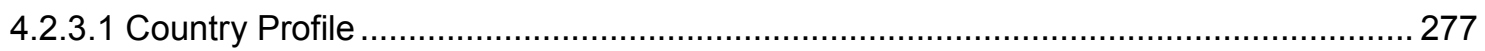

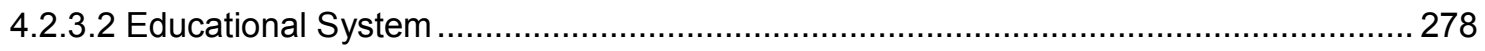

4.2.3.3 Access to Education and Information Communication Technologies ........................... 279

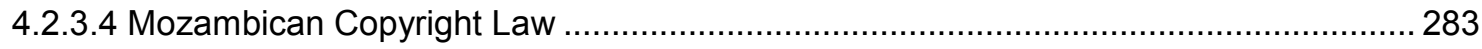

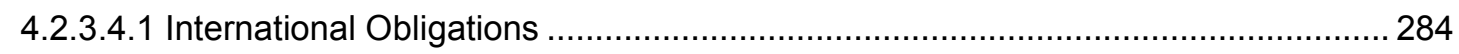

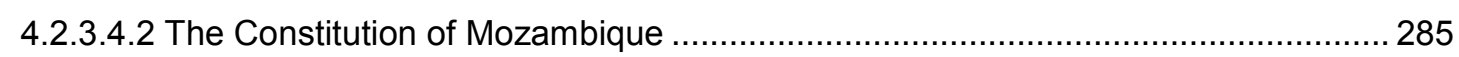

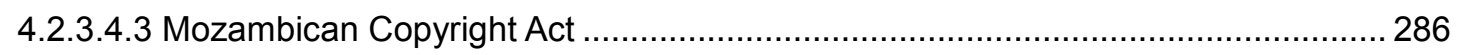

4.2.3.4.3.1 Preamble and Objective .................................................................... 286

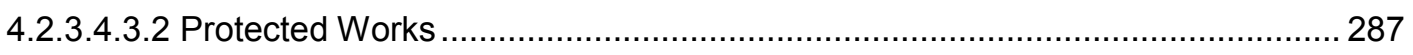

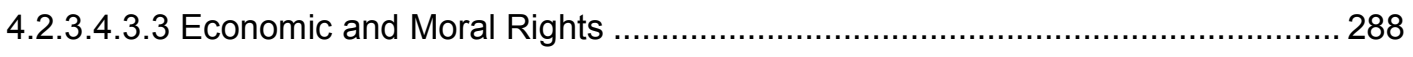

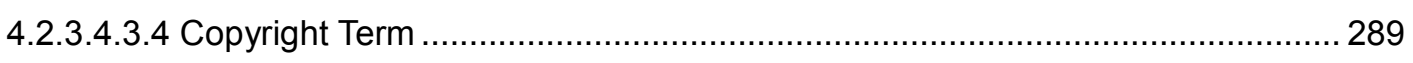

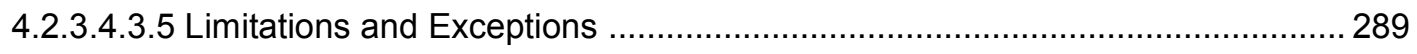

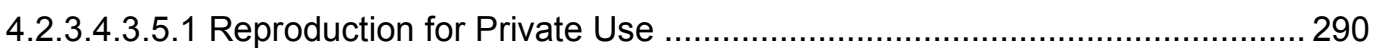

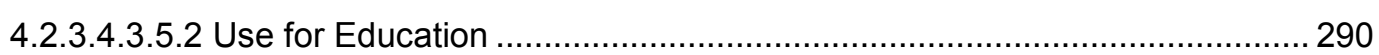

4.2.3.4.3.5.3 Reprographic Reproduction by Libraries and Archives ......................... 291

4.2.3.4.3.5.4 Resale and Public Lending ................................................................ 293

4.2.3.4.3.5.5 Import for Personal Purposes ........................................................... 294

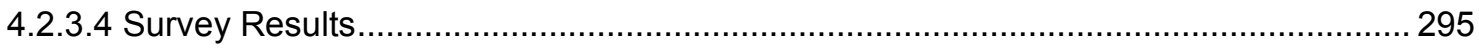

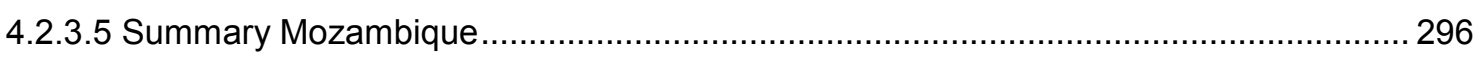

4.2.4 The Community of Portuguese Speaking Countries ..................................... 298

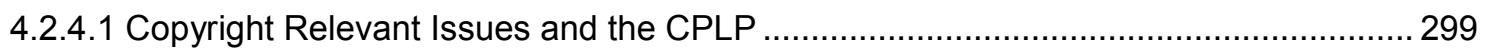

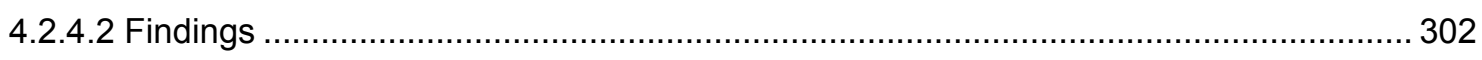

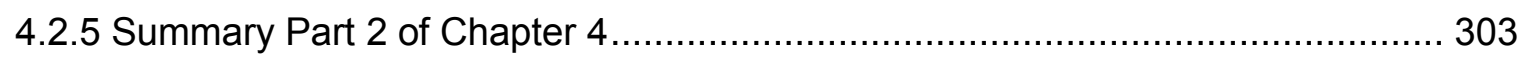




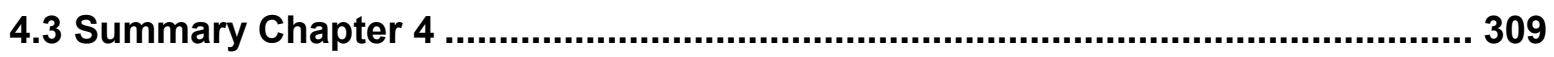

Conclusion .................................................................................................. 313

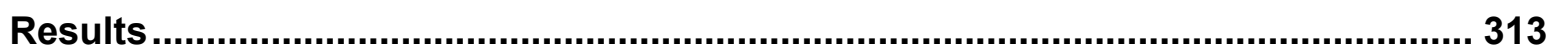

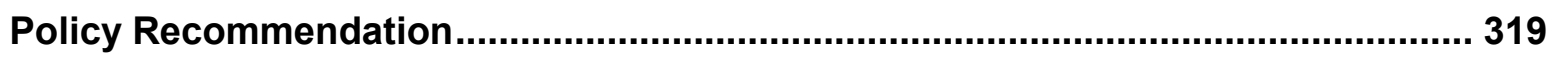

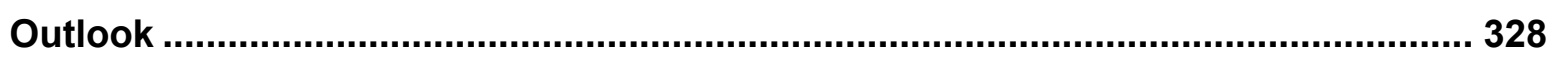

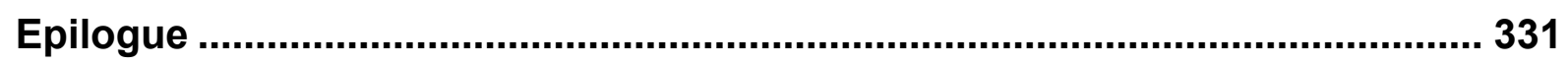

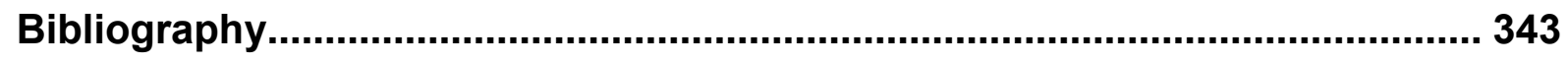

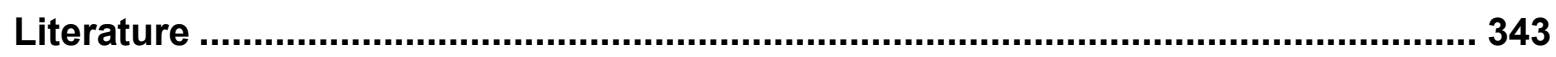

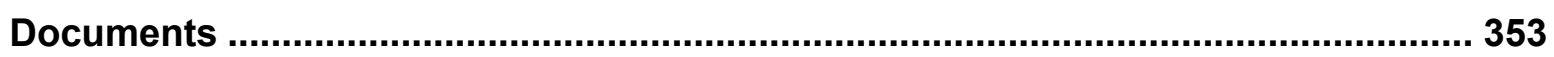

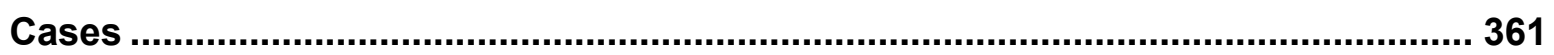

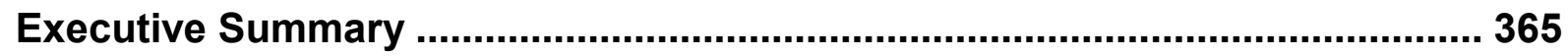

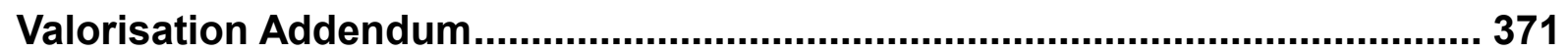

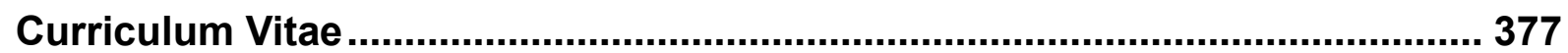




\section{List of Abbreviations}

\begin{tabular}{|c|c|}
\hline ABED & Associação Brasileira de Educação à Distância \\
\hline ALAl & Association littéraire et artistique internationale \\
\hline $\mathrm{BC}$ & Berne Convention \\
\hline BCA & Brazilian Copyright Act \\
\hline BOCES & Board of Educational Services \\
\hline $\mathrm{CA}$ & Copyright Act \\
\hline CAPES & Coordenação de Aperfeiçoamento de Pessoal de Nível Supersior \\
\hline CDA & Código do Direito de Autor e dos Direitos Conexos \\
\hline CDPA & Copyright Designs and Patents Act \\
\hline CIUEM & Centro de Informática da Universidade Eduardo Mondlane \\
\hline CONAES & Comissão Nacional de Avaliação da Educação Superior \\
\hline CONTU & National commission on New Technological Uses of Copyrighted Works \\
\hline CPLP & Comunidade dos Países de Língua Portuguesa \\
\hline DMCA & Digital Millenium Copyright Act \\
\hline DRM & Digital Rights Management \\
\hline ECJ & European Court of Justice \\
\hline EIFL & Electronic Information for Libraries \\
\hline ENEM & Exame Nacional do Ensino Médio \\
\hline EU & European Union \\
\hline GATT & General Agreement on Tariffs and Trade \\
\hline GEPAC & Gabinete de Estratégia, Planeamento e Avaliação Culturais \\
\hline GG & Grundgesetz \\
\hline ICA & International Council on Archives \\
\hline ICESCR & International Covenant on Economic, Social and Cultural Rights \\
\hline ICT & Information Communication Technology \\
\hline IFLA & International Federation of Library Associations and Institutions \\
\hline INED & Instituto Nacional de Educação à Distância \\
\hline \multirow[t]{2}{*}{ INPI Brazil } & Instituto Nacional da Propriedade Industrial, Ministério do \\
\hline & Desenvolvimento, Indústria e Comércio Exterior \\
\hline INPI Portugal & Instituto Nacional da Propriedade Industrial, Ministério da Justiça \\
\hline INTIC & Instituto Nacional das Tecnologias de Informação e Comunicação \\
\hline IPO & Intellectual Property Office United Kingdom \\
\hline ISCETEM & Instituto Superior de Ciencias e Tecnologia de Moçambique \\
\hline LDC & Least Developed Country \\
\hline
\end{tabular}




\begin{tabular}{|c|c|}
\hline MCA & Mozambican Copyright Act \\
\hline MCC & Multimedia Communication Centres \\
\hline MICTI & Mozambique Information and Communication Technology Institute \\
\hline MOOC & Massive Open Online Course \\
\hline MoReNeT & Mozambique Research and Education Network \\
\hline NABP & National Association of Book Publishers \\
\hline NATO & North Atlantic Treaty Organisation \\
\hline NEPAD & New Partnership for Africa's Development \\
\hline NIC & Newly Industrialised Country \\
\hline OCW & Open Course Ware \\
\hline OECD & Organisation for Economic Co-operation and Development \\
\hline OER & Open Educational Resources \\
\hline PALOP & Países Africanos da Língua Oficial Portuguesa \\
\hline $\mathrm{RC}$ & Rome Convention \\
\hline SCCR & Standing Committee on Copyright and Related Rights \\
\hline SINAES & Sistema Nacional de Avaliação da Educação Superior \\
\hline TEACH Act & Technology, Education and Copyright Harmonization Act \\
\hline TRIPS & Agreement Trade Related Aspects of Intellectual Property Rights \\
\hline UDHR & Universal Declaration of Human Rights \\
\hline UK & United Kingdom \\
\hline UN & United Nations \\
\hline UNESCO & United Nations Educational, Scientific and Cultural Organization \\
\hline UrhG & Urheberrechtsgesetz \\
\hline UrhWG & Urheberrechtswahrnehmungsgesetz \\
\hline USA & United States of America \\
\hline VGG & Verwertungsgesellschaftengesetz \\
\hline WCT & World Copyright Treaty \\
\hline WIPO & World Intellectual Property Organisation \\
\hline WPPT & WIPO Performances and Phonograms Treaty \\
\hline WTO & World Trade Organisation \\
\hline
\end{tabular}




\section{Introduction}

\section{Setting}

Knowledge is power. This famous aphorism attributed to the British philosopher Francis Bacon describes short and sweet the significance of knowledge. ${ }^{1}$ Anticipating an enlightened concept of man it defines knowledge as the basis for empowerment and emancipation of the human being. Through knowledge man will learn to control the forces of nature and in this way shapes his own destiny and foster the progress of society.

However, knowledge must be acquired. According to Francis Bacon the acquisition of knowledge takes place through the empirical analysis and observation of nature itself. ${ }^{2}$ This is of course still true. Yet, today the acquisition of knowledge happens primarily through education in schools, colleges and universities as well as through the study of other information sources such as books, newspapers, journals etc. for instance in libraries and above all through the Internet and digital mass media.

Today, the Internet provides for an unlimited source of information and has turned into probably the most important means for the acquisition of knowledge. The possibilities of the Internet to acquire knowledge are used on all levels of society. Individuals use the Internet for information and private study, educational institutions include information from the Internet in classroom activities or deliver their services over the Internet, institutions like libraries, archives and even museums offer their collections in digital format or make them available online, often for free and accessible from everywhere in the world. Thus, it appears, that the possibilities to access information and to acquire knowledge have never been greater in the history of mankind.

Unfortunately, this is only half the story. In 1970 American sociologists came up with the hypothesis of the so called "knowledge gap". ${ }^{3}$ They suggested that individuals belonging to a part of the population with higher socioeconomic status acquire information provided by mass media faster than individuals belonging to a part of the population with lower

\footnotetext{
${ }^{1}$ Vickers, Francis Bacon and the Progress of Knowledge, 1992, p. 512, fn. 47, who points out that the exact expression "knowledge is power" ("scientia potestas est") is not contained in the works of Bacon. In Bacon's Meditationes Sacrae, 1597, there is indeed the phrase "(nam et ipsa scientia potestas est)", which is translated as "for knowledge itself is a power (...)". However it is taken out of context, because Bacon refers to the knowledge of God, not of men. Nevertheless, the expression has become idomatic for what man can achieve through knowledge and/or education.

${ }^{2}$ Bacon, Novum Organum, 1620, Book I, Aphorism I: "Man, being the servant and interpreter of Nature, can do and understand so much and so much only as he has observed in fact or in thought of the course of nature: beyond this he neither knows anything nor can do anything."

${ }^{3}$ Tichenor/Donohue/Olien, Mass Media Flow and Differential Growth in Knowledge, 1970, p. 159-170.
} 
socioeconomic status. ${ }^{4}$ The socioeconomic status of an individual depends fundamentally from the level of education. ${ }^{5}$ The higher the level of education the higher the socioeconomic status. As a consequence, so the hypothesis, the gap in knowledge between these parts of the population increases. ${ }^{6}$

One must not share these assumptions. However, bearing in mind that knowledge is power, the knowledge gap hypothesis suggests that an increasing part of the population remains powerless, since its level of education is low. It is obvious that it has negative effects for the progress of society as a whole, if large parts of the population remain powerless, not to speak of the negative effects for the respective individual. Yet, the knowledge gap hypothesis implicates that improving the level of education will help to reduce the gap. In order to improve the level of education the access to education and knowledge must be promoted.

These reflections on the knowledge gap can be transferred to the Internet and digital media. We live in the so-called knowledge society. The Internet and digital media have largely replaced traditional mass media. Today, the Internet has become the main source of information. It is therefore vital to have access to the Internet and to be able to make use of the information it offers. Access to the Internet and the use of digital technologies however are not available for everybody. In industrialised countries, the possibilities are better among people with a higher level of education, whereas among people with a lower level of education possibilities are worse. People with a higher level of education normally also have the financial resources to afford the technology, which is necessary to access the Internet and make use of digital media. People with a lower level of education with less money may have difficulties to afford the necessary technology. As a consequence, a growing number of less educated people remains excluded from the benefits of the knowledge society. Therefore, one can speak of a digital divide in industrialised countries. To put it short "the educated information rich become richer and the less educated information poor become poorer. $^{7}$

Yet, the digital divide is particularly deep between developed or industrialised countries and developing or least developed countries. In developed countries, the information and communication infrastructure, which is necessary to make use of the Internet and digital technologies, is very elaborate and rather easily available, whereas in developing or least developed countries information and communication infrastructure is much less elaborate or does not even exist. Thus global inequality and access to information and communication

\footnotetext{
${ }^{4}$ Idem, p. $159 / 160$.

5 Ibid.

${ }^{6}$ Ibid.

${ }^{7}$ McNair, The Emerging Policy Agenda, 2000, p. 10.
} 
infrastructure are connected. ${ }^{8}$ According to the World Bank only $15 \%$ of the world's population can afford access to broadband Internet and $60 \%$ of the world's population have no access to the Internet at all. ${ }^{9}$ For 2015 the International Telecommunication Union (ITU) estimated a number of 3.2 billion Internet users worldwide. ${ }^{10}$ Two billion Internet users are from developing countries. ${ }^{11}$ Yet, four billion people in developing countries have no access to the Internet, which represents $2 / 3$ of the population of developing countries. ${ }^{12}$ With regard to least developed countries only 89 million people have access to the Internet compared to 940 million people living in least developed countries. ${ }^{13}$ As the ITU pointed out, by the end of 2015 only $34 \%$ of households in developing countries will have access to the Internet. ${ }^{14}$ In developed countries more than $80 \%$ of the households have Internet access. ${ }^{15}$ In least developed countries only $7 \%$ of households have access to the Internet. ${ }^{16}$ The worldwide average of Internet access in households is $46 \% .{ }^{17}$ Also the numbers regarding the percentage of individuals using the Internet via fixed or a mobile broadband access sustain the assumption of a digital divide between developed and developing respectively least developed countries. ${ }^{18}$

There is no doubt that the Internet and digital technologies have very positive effects on people's lives and have the potential to improve the access to information, knowledge and education, promote creativity and productivity and as a consequence foster social and economic development in general. ${ }^{19}$ However, those who do not have access to the Internet and information and communication technologies and/or do not possess the necessary skills and knowledge to use these technologies are excluded from the benefits of the knowledge society. Following the assumption of the knowledge gap hypothesis the number of people who is excluded from the benefits of the knowledge society is increasing the longer they do not have the possibility of participating in the opportunities offered by the Internet and information and communication technologies. As was shown above large parts of the world's population do not have access to the Internet and information and communication technologies. Therefore, people in developing and least developed countries are more and more excluded from social and economic developments. ${ }^{20}$ Without actions to confront this

\footnotetext{
${ }^{8}$ Cf. Fuchs/Horak, Africa and the digital divide, 2008, p. 100.

${ }^{9}$ World Bank, Digital Dividens, 2016, p. 6.

${ }^{10}$ ITU Facts \& Figures 2015.

${ }^{11} \mathrm{lbid}$.

12 Ibid.

${ }^{13} \mathrm{lbid}$.

${ }^{14}$ Ibid.

15 lbid.

${ }^{16}$ lbid.

17 Ibid.

${ }^{18}$ lbid.

${ }^{19}$ Cf. World Bank Group, Education Strategy 2020, p. 11; World Bank, Digital Dividens, 2016, p.8f.

${ }^{20}$ Fuchs/Horak, Africa and the digital divide, 2008, p. 102.
} 
trend social inequalities will aggravate and the digital divide will further deepen. ${ }^{21}$ Excluding large parts of the world's society from social and economic opportunities and benefits brought about by the knowledge society will eventually lead to social instability and political conflicts. In order to face the problem of digital exclusion it is not enough to create the necessary infrastructure for information and communication technologies. It is equally or even more important to enable people to acquire the knowledge, which is necessary to realise the potentials of the Internet and digital technologies. Thus, people need access to education.

Education and knowledge have outstanding significance for social and human development. In order to promote the access to education and knowledge in the 21 st-century, the potentials of the Internet and information and communication technologies must be made use of. This is true both for educational institutions like schools, colleges and universities as providers of education and libraries, archives, museums and similar institutions, which enable access to education and knowledge and preserve cultural and scientific heritage. Apart from the problem of creating the necessary infrastructure to make use of the Internet and digital technologies extensively in developing and least developed countries, the access to education and knowledge depends on the availability of the respective content, for instance learning materials. At this point copyright comes into play. Learning materials as well as the content collected and preserved by libraries, archives, museums and other similar institutions regularly is protected by copyright, which means that it is not available for free or at least not without the authorisation of the owner of copyright. The access to education and knowledge therefore can be restricted by copyright. However, since access to education and knowledge is of fundamental importance for the development of any society, the question arises if and to what extent copyright may encroach on the possibilities of access to education and knowledge.

Copyright protects intellectual creations, embodied in works such as books, musical notes, paintings, photographs etc. Copyright protects the creators of such works and/or the owner of rights in these works. ${ }^{22}$ The purpose of copyright law is to safeguard that authors and right holders benefit from the use of their works. The use of copyright protected works takes place for instance through reproduction, distribution, performing, translation, broadcasting and so forth. ${ }^{23}$ Now, copyright protects authors and right holders from unauthorised uses of their works in order to secure their financial income ("remuneration“). ${ }^{24}$ Provided that creators and right holders would not be protected by copyright, they would gain no financial income,

\footnotetext{
${ }^{21}$ Idem, p. 110/11.

${ }^{22}$ WIPO, Intellectual Property Handbook, no. 2.174 - 2.176.

${ }^{23}$ Idem, no. 2.178 - 2.199.

${ }^{24}$ Idem, no. 2.169.
} 
because everybody could freely make use of their works without having to pay for it. As a result there would be no more incentive to create works of intellect. This would most probably lead to a decrease of intellectual production with negative effects for the entire society for it must be stated that the production of intellectual works is essential for social and cultural development. ${ }^{25}$ In this regard the protection of copyright does not only have the purpose of securing the financial income of creators and right holders but also, and perhaps even more important, to promote the development of society in general.

Thus, copyright not only protects the interests of the individual creator and right holder but takes into account as well the interests of the general public to have access to as many works as possible. It is obvious, that, generally speaking, creators and right holders are interested in strong copyright protection in order to control the use of their works and to profit as far as possible from the uses made of them. It is also not surprising that individual users of copyright protected works and the general public are interested in far-reaching possibilities to freely make use of copyright protected works for purposes such as information and education. This said in advance it becomes clear that the position of creators and right holders on the one hand and the position of individual users and the general public on the other hand contradict each other. At the same time both sides depend on each other. Without an audience or a consumer the creator and/or right holder will not profit from his creation. Without a creator and/or right holder (who invests in the production of creative works) there is no intellectual output from which individuals and the society in general could profit. The goal of any copyright law system therefore must be to strike a fair and reasonable balance between the interests involved.

Since copyright is governed by the principle of territoriality there are different ways to achieve this balance of interests depending on the respective national copyright law system. Yet, they all have in common to give preference to one side under certain circumstances. ${ }^{26}$ For instance almost any copyright system traditionally includes privileges for educational institutions and/or public libraries and archives, because such institutions generally are considered to be particularly important for the development of any society. These privileges often called limitations and/or exceptions because they limit the general rule of exclusive copyright protection, have been established by national legislators reflecting social, political, technical and economic conditions of a certain time. As time passes the underlying conditions change. It is then very much the question, if legal provisions, in this case limitations and exceptions to copyright law, which were intended to deal with very different situations, still provide adequate solutions under conditions, which have significantly changed

\footnotetext{
${ }^{25}$ Idem, no. 2.166

${ }^{26}$ Idem, no. 2.225.
} 
compared to the time these provisions were established.

The development of digital technologies and the worldwide spread of the Internet have had a dramatic effect on copyright law. The possibilities to reproduce, distribute and make available copyright protected works without loss of quality and at very low cost across national borders are omnipresent and open to almost everybody, at least in developed countries. Nevertheless, copyright law remains dominated by the principle of territoriality, meaning that copyright is a matter of national legislation, ${ }^{27}$ which leads to a variety of different national copyright laws. Yet today, copyright relevant acts do not stop at national borders. Rather, the uses of copyright protected works have cross-border nature. ${ }^{28}$ Therefore, the territoriality of copyright law is increasingly regarded as an obstacle to the creation of common markets for digital goods. ${ }^{29}$ Moreover it effectuates the legal fragmentation of copyright, because for each national territory different right holders may own copyright. ${ }^{30}$ In view of the global nature of the Internet the principle of territoriality in particular and copyright law in general are challengend internationally. ${ }^{31}$ If national copyright laws can provide adaquate solutions in this context is very much the question. This is true especially for the area of limitations and exceptions. Their scope of application also varies from country to country. This has the effect that certain uses of copyright protected works may be allowed in one state and prohibited in another, which does neither promote the acceptance of copyright law nor improve legal certainty. ${ }^{32}$

At this point it is important to make reference to the principle of exhaustion. With regard to the exclusive distribution right the principle of exhaustion stipulates that once the original or a copy of a copyright protected work is sold with authorisation of the author or right holder copyright is exhausted, meaning that the author or right holder cannot control any further sale of that particular original or copy of the work. Because of the territorial nature of copyright, it is the decision of the national legislator to implement the principle of exhaustion into national copyright law. ${ }^{33}$ As a result the exhaustion of copyright relates to the respective

\footnotetext{
${ }^{27}$ Article 5 Berne Convention for the Protection of Literary and Artistic Works, Paris Act, July 24, 1971 and with regard to the European Union see ECJ Judgement of July 14, 2005, Lagardère Active Broadcast, C-192/04, no. 46.

${ }^{28}$ Mezei, Digital First Sale Doctrine Ante Portas, JIPITEC Vol. 6 (1) 2015, Chapter 1.

${ }^{29}$ See with regard to Europe, Reinbothe, Neue Entwicklungen in der EU-Urheberrechtspolitik, ZGE/IPJ, Vol. 7 (2015), p. 151/152. With regard to cross-border dissemination of copyrighted content in the EU single market see Commission of the EU, (Internal) White Paper - A Copyright Policy for Creativity and Innovation in the European Union, Brussels, XXX, (2014) XXX draft, p. 5 -7.

${ }^{30}$ For Europe see European Parliamentary Research Service, EU Copyright Reform: Revisting the Principle of Territoriality, 2015, p. 3 and Hugenholtz, Copyright Territoriality in the European Union, 2010, p. 6.

${ }^{31}$ Cf. Mezei, Digital First Sale Doctrine Ante Portas, JIPITEC Vol. 6 (1) 2015, Chapter 1.

${ }^{32}$ Cf. for Europe see European Parliamentary Research Service, EU Copyright Reform: Revisting the Principle of Territoriality, 2015, p. 5, where it is pointed out that one way to cope with the obstancles posed by the principle of territoriality may be a further harmonisation of limitations and exceptions.

${ }^{33}$ Article 6 para. 2 WIPO Copyright Treaty (WCT) and article 8 para. 2 WIPO Performances and Phonograms Treaty (WPPT)
} 
territory. Only with regard to that particular territory copyright is exhausted, if the original or a copy of the work is sold by the author or with his consent. Thereby the doctrine of exhaustion safeguards that copyright law and intellectual property rights in general do not conflict with the free movement of goods on a common market. ${ }^{34}$ Besides this function the principal of exhaustion is intended to achieve a fair balance between the interests involved, namely the author's or right holder's interest in controlling the number of copies on the market and the interests of the purchaser who may want to sell the copy he owns. ${ }^{35}$ Exhaustion of copyright however only takes place under the condition that a tangible copy of the work has been sold on the market by the author or with his consent. ${ }^{36}$ It is obvious that with regard to crossborder transfers of copyright protected rights in digital format over the Internet questions arise, which are difficult to answer. ${ }^{37}$ The Internet has created a worldwide market for intangible goods. However, since the principle of exhaustion only applies to tangible goods, it does not apply to the digital market and intangible goods. ${ }^{38}$ As a consequence authors and right holders can control any resale of their work on the digital market. This appears not to be a balanced solution. Therefore it is argued that the principle of exhaustion must be applied to intangible goods and digital markets, too. ${ }^{39}$

In any case, the increase of possibilities to use copyright protected works for all kinds of purposes on the one hand corresponds to a loss of control over their works by creators and right holders on the other hand. ${ }^{40}$ As a consequence creators and right holders generally advocate an expansion of copyright protection whereas from the viewpoint of individual users and the general public broad limitations and exceptions taking into account new technological developments regarding use of and access to copyright protected works are

\footnotetext{
${ }^{34}$ Spedicato, Online Exhaustion and the Bounderies of Interpretation, 2015, p. 32, who refers to the European Union. Mezei, Digital First Sale Doctrine Ante Portas, JIPITEC Vol. 6 (1) 2015, Chapter 2.3 explains the US approach to the principle of exhaustion, which called the "the first sale doctrine".

${ }^{35}$ Spedicato, Online Exhaustion and the Bounderies of Interpretation, 2015, p. 32/33 describes the positive effect of exhaustion, which is it supports so called secondary markets for resell of copyright protected works. Becuase of lower prices access is facilitated.

${ }^{36}$ Idem, p. 33. The market Spedicato refers to is the common market of the EU; only in that territory copyright in a tangible copy of the work is exhausted.

${ }^{37}$ See idem, p. 34.

${ }^{38}$ This understanding is sustained if not by the wording of article 6 WCT than by the intention of the international legislator. Also the European legislator is rather clear in excluding the applicability of the principle of exhaustion from online distribution of digital copies, as for instance the Information Society Directive 2001/29/EC states in article 3 that the principle of exhaustion does not apply to any act of communication or making available to the public, i.e. digital uses of intangible digital goods over the internet. See idem, p. 37 - 40.

${ }^{39}$ See for instance Mezei, Digital First Sale Doctrine Ante Portas, JIPITEC Vol. 6 (1) 2015, Chapter 6; Spedicato, Online Exhaustion and the Bounderies of Interpretation, 2015, p. 59/69; Hilty, "Exhaustion" in the Digital Age, 2015 , p. 19/20, who proposes an "implied license" as a solution to the problem. Also courts have addressed the issue of digital exhaustion several times. In the UsedSoft $v$ Oracle decision the ECJ ruled that the principle of exhaustion applies the download of a computer program over the Internet. Still it is not clear if this applies to ebooks, digital music files or other goods and services provide over the Internet as well. In Capitol Records, LLC, $v$. ReDigi Inc., the District Court for the Southern District of New York had to decide a similar case and rueld that since no material copy is transferred through a download the first sale doctrine does not apply.

${ }^{40}$ Dreier in Dreier/Schulze, 2015, UrhG, Einleitung, no. 23.
} 
favourable. ${ }^{41}$ These contradicting positions must be balanced sensibly.

\section{Problem Definition, Objective of the Study and Research Question}

The assumption is that in the last years, due to heavy lobbying by creators and right holders, national legislators have rather focused on the expansion of copyright protection than on considering appropriately the position of individual users and the general public with regard to access to information and knowledge. It is understandable that creators and right holders demand for strong copyright protection in order to protect their rights and investments in view of the challenges brought about by digital reproduction technologies and the Internet. ${ }^{42}$ Yet, the unilateral focus on the position of creators and right holders in the last 15 to 20 years of copyright legislation has endangered the balance of interests, which is essential for the functioning and the acceptance of copyright law. ${ }^{43}$ By taking into account more appropriately the interests of individual users and the general public, particularly with regard to access to education and knowledge, the balance can be recalibrated. In copyright law limitations and exceptions to exclusive rights of authors and right holders are appropriate means to achieve and secure a fair balance interests.

The current copyright systems in many countries of the world do not or only to a very small extent reflect the possibilities of digital technologies and the Internet in the area of access to knowledge and education. Limitations and exceptions to copyright, which privilege educational activities and the work of libraries and archives, are mostly difficult to understand, very narrowly constructed and not open to adapt to new technological developments and conditions. Sometimes such provisions hardly exist. As a consequence, educational institutions and libraries and archives are left with considerable legal uncertainty or even have to provide their services without legal coverage. This situation is aggravated through complicated legislative adjustments and modifications aiming at the expansion of copyright protection as a reaction to the massive spread of digital technologies and the Internet. Due to extensive lobbying legislators tend to concentrate mainly on the protection of authors and right holders. The effects of this one-sided approach are reinforced by the principle of restrictive interpretation, which dominates the understanding of limitations and exceptions to copyright in many countries. Compared with this the position of institutions providing access to knowledge and education in public interest is not considered appropriately in the context of these developments. Besides licensing contracts provide no real alternative to limitations and exceptions, because authors and right holders may dictate

\footnotetext{
${ }^{41}$ Idem, Rn. 24/25.

${ }^{42}$ Cf. Mezei, Digital First Sale Doctrine Ante Portas, JIPITEC Vol. 6 (1) 2015, Chapter 1.

${ }^{43}$ Cf. Spedicato, Online Exhaustion and the Bounderies of Interpretation, 2015, p. 29.
} 
the contractual conditions, licenses may not be available for all kinds of copyright protected work and the financial equipment of educational institutions and libraries and archives (especially in developing countries) may not be sufficient. In case of limitations and exceptions promoting access to knowledge, education and information fundamental rights and freedoms of individual members of society and the general public are concerned. The exercise and enforcement of these rights should not be left entirely to the free market. As will be shown licensing contracts may undermine the privileges granted by limitations and exceptions.

Therefore, the realisation of fundamental rights like access to knowledge and education is impeded or even completely inhibited by the overprotection of copyright. ${ }^{44}$ It is thus fair to say that copyright law inhibits the access to knowledge and education. In view of the possibilities of promoting access to knowledge and education in the digital age, the current copyright regimes do no longer provide for adequate solutions with regard to social and cultural participation. Indeed, the one-sided focus on the protection of authors and right holders reinforces the above mentioned digital divide within industrialised countries. Yet, the overprotection of copyright is especially problematic in developing and least developed countries, where the demand for access to knowledge and education is particularly urgent for the purpose of promoting social and economic development. Besides, the unilateral protectionist approach to copyright consolidates monopolies and thus intensifies the digital divide between industrialised and developing and least developed countries. As a consequence, it is necessary to readjust the balance of interests in copyright law by taking into account appropriately public interest considerations in particular access to knowledge, education and information. In this way the objective of copyright law to promote the progress of society (rather than to exclusively protect certain interest groups) will become visible and the acceptance for copyright rules in general will grow. The readjustment of the balance of interests will have to take into account that the Internet is a worldwide network and a marketplace without national boundaries. Therefore questions of copyright law can hardly be answered only on national level. In spite of copyright's territorial nature these questions demand for international or multinational solutions.

This study analyses the issues described above with special attention to copyright legislation in Portugal, Brazil and Mozambique. These countries have in common not only colonial history but are also linked by the Portuguese language. All three countries belong to the Droit d'Auteur tradition of copyright, each on with its own specialities. Besides Portugal, Brazil and Mozambique find themselves in different stages of social and economic development.

\footnotetext{
44 Ibid.
} 
Portugal is an industrialised country and a member of the European Union. Brazil is a newly industrialising and developing country. Mozambique is a least developed country. It will be interesting to see if and how the stage of social and economic development corresponds to issues of copyright law. Moreover, the need for access to knowledge and education is of particular importance in developing and least developed countries like Brazil and Mozambique, where large parts of the population live in poverty. These findings will be compared with the situation in an industrialised nation like Portugal. Since this study concentrates on questions of copyright law and access to knowledge and education in the digital age, the respective national policies to implement information and communication technologies are of interest, too. In view of the Internet's global nature and the linkage of Portugal, Brazil and Mozambique by the Portuguese language, it will be analysed, if there is a common market for digital goods, especially for educational materials, between these countries. To what extent the principle of territoriality and exhaustion impact on the access to copyright protected works for educational purposes remains to be seen. The goal of this study is to highlight the role of copyright limitations and exceptions for the purpose of promoting access to knowledge and education in the digital age with special focus to developing and least developed countries in general and in the Portuguese speaking world in particular. As will be shown the current systems of limitations and exceptions in the countries analysed here are not suitable in light of the importance of access to knowledge and education in the digital age. Reforms of the respective provisions are necessary both on international and national level. This hypothesis is further underlined by the analysis the copyright provisions promoting access to knowledge and education in the United States of America, the United Kingdom and Germany. In addition, the historical and philosophical underpinnings of copyright and limitations and exceptions as well as the international and European legislative framework will be examined to sustain this assumption. The study advocates for a more public good orientated approach to copyright and ends with a policy recommendation to achieve that goal.

Altogether the issues of the present study can be broken down into the following research question:

\section{Do limitations and exceptions to copyright law adequately promote the access to education and knowledge in the digital age?}

\section{Methodology}

The principal methodological approach this study pursues is the comparison of laws. 
Thereby it follows the functional concept of comparative law. ${ }^{45}$ In order to promote better understanding of the systems of copyright limitations and exceptions of the countries analysed here, to carve out internationally reliable principles of copyright interpretation and to develop practical solutions for the problems of coypright law and access to knowledge and education addressed here, the respective legal sources will be examined. ${ }^{46}$ This encompasses the relevant copyright laws and other legislative provisions as well as case law and legal literature. ${ }^{47}$ The study however is not limited to the examination of legal sources, but includes the evaluation of historical, political and social sources and circumstances of the respective country. ${ }^{48}$ For instance the common colonial history of Portugal, Brazil and Mozambique plays a part here. As well, the current political, social and economic situation, including educational and IT-related policies, will be taken into account. In addition, empirical data regarding e-learning activities and copyright limitations and exceptions in Portugal, Brazil and Mozambique are provided and evaluated. To obtain data questionnaires were sent to stakeholders in Portugal, Brazil and Mozambique, namely to educational institutions, right holders of e-learning materials (i.e. publishers) and government departments. Each stakeholder group received one of the following, especially designed questionnaires in Portuguese: ${ }^{49}$

\section{Questionnaire educational institutions:}

1. Do you use digital content (e-learning) for education and if so how do you use it? Do you produce digital / e-learning content yourself or do you purchase it or both?

2. Are copyright issues an important issue for your institution? Do you have a copyright policy, especially one with regard to the use if digital content?

3. Do you rely on limitations and exceptions for educational purposes regarding the use of copyrighted (digital) content for e-learning?

4. Have there been claims and / or lawsuits of right holders against your institution because of copyright infringements by using their content for education and e-learning?

5. Are there any agreements with holders of copyright, namely publishers and other content providers, regarding the use of (digital) content for education and e-learning (licensing agreements)?

6. Would broader limitations and exceptions for educational purposes, especially for elearning, improve the access to education? How should such limitations and exceptions look like? Which uses should be privileged in order to improve the access to education? Or do you prefer to license the use of content?

\footnotetext{
${ }^{45}$ See Haase, Einführung in die Methodik der Rechtsvergleichung, 2005, p. 235.

${ }^{46}$ See idem, p. 234.

47 See ibid.

${ }^{48}$ See idem, p. 235.

${ }^{49}$ For convenience of the reader the questionnaires are translated into English.
} 
7. Are you as a stakeholder engaged in copyright law making? How could copyright law improve the access to education in the digital age?

8. Do you produce and sell (digital) learning content, especially for e-learning, to other educational institutions in foreign countries of the Portuguese speaking world? Are the cooperations with educational institutions in other countries of the Portuguese speaking world with regard to the transfer of learning materials and in particular e-learning content?

9. Do you offer e-learning programmes (e.g. distance learning)? What is the targeted audience? In case you do not offer such programmes, would you do that if you were safeguarded by limitations and exceptions to copyright favouring such activities?

10. What is to your opinion on the future of higher education and e-learning and how does copyright law affect it? How can Portuguese/Brazilian/Mozambican society profit from elearning? What are the obstacles with regard to copyright law?

\section{Questionnaire right holders:}

1. What kind of learning materials do you produce? What role do digital learning content and e-learning materials play for your business?

2. Who are your customers? Private for-profit corporations or public non-profit institutions or both?

3. Does copyright law affect your business? If so, how? Do you use (technical) measures to protect the copyright of your firm?

4. How do you sell your products? Do you use licensing contracts? If so how do licensing contracts for digital learning content and e-learning materials look like?

5. In your licensing policy do you take into account limitations and exceptions for educational purposes and e-learning?

6. Are there infringements of your copyrights by licensing partners, e.g. educational institutions? Do the infringers invoke copyright limitations and exceptions for educational purposes? Do you sue the infringers?

7. Where do you sell your products? What are your key markets? Do you supply the entire Portuguese speaking world?

8. Are you engaged in copyright law making? Are you a member of a stakeholder association?

9. From your point of view, what should be done to promote the access to education in the digital age? What role should copyright law play regarding the access to education?

10. What is in your opinion the future of higher education and how does copyright law affect it? 


\section{Questionnaire government departments:}

1. Which groups are considered the most important stakeholders in copyright law making in general and with special regard to limitations and exceptions for educational purposes?

2. What are the paramount objectives of copyright law making? Is improving access to education in the digital age one of them? If so, what are the means and ways to improve access to education in the digital age? Is e-learning an important issue for copyright legislation?

3. What is the role of the state/government/lawmaker with regard to access to education and copyright law, especially limitations and exceptions for educational purposes?

4. How does the legislator balance the interests of stakeholders with regard to licensing practices and copyright limitations and exception for educational purposes?

5. Are there plans to introduce (new) copyright limitations and exceptions for education and e-learning (in the digital age)?

Further details concerning the response rate and the answers given, will be provided together with the evaluation in the respective country chapter.

To put the findings concerning Portugal, Brazil and Mozambique into context the respective legal provisions of the United States of America, the United Kingdom and Germany are evaluated, too. Here as well the study follows the methodology of comparative law. The analysis however focuses more on in the examination of legal sources, i.e. copyright law provisions, case law and legal literature. The high level of copyright literature and scholarship in the United States of America, the United Kingdom and Germany in many aspects provides examples for best practices concerning limitations and exceptions to copyright.

The understanding and interpretation of today's copyright limitations and exceptions in general and regarding access to knowledge and education in particular furthermore require to consider both historical legislative developments and philosophical justifications. Therefore the study examines the main historical sources and explains the principal lines of argument for the justification of copyright, taking into account the distinct legal traditions of Droit d'Auteur and Copyright systems. In addition, following a systematical analysis different legislative approaches to limitations and exceptions within copyright systems and the rationales for the limitation of exclusive rights are explained. Eventually, the international and European legal framework connected to copyright limitations and exceptions is examined.

In light of the challenges brought about by the digital age the technological and economical setting and the significance of the Internet and digital technologies for access to knowledge 
and education is highlighted based on the analysis of economic data, new business models and technological developments.

A comprehensive study taking into consideration the situation in developed and developing countries, namely the USA, the UK, Germany, Portugal, Brazil and Mozambique, with regard to limitations and exceptions to copyright and access to knowledge and education in the digital age does not exist.

Main research was accomplished end of February 2016 at the Max-Planck-Institute for Competition and Innovation in Munich. Corrections and amendments were brought to completion on September 1, 2016. All websites and hyperlinks were checked on November 6, 2016. The manuscript was finalised on November 13, 2016. Up to that date current developments were included as far as possible.

\section{Limitations of the Study}

The study focuses on copyright limitations and exceptions promoting access to knowledge and education in the digital age in the above said scope. Thus, some topics related to the issues discussed here are not addressed (in depth). In particular, these are questions regarding international and national policies to promote access to analogue learning materials and to information and communication technologies as well as policies to fight illiteracy. Besides the study does not touch issues of licensing contracts, collective licensing and collecting societies. Aspects of the copyright and access to knowledge and education debate like open access and creative commons licensing are touched only superficially. The same is true for access to education and knowledge and the principles of territoriality and exhaustion. Not discussed at all are questions regarding access and digital rights management.

\section{Structure of the Study}

The study comprises four chapters. Chapter 1 provides information on the background and the context of the study. Terminology is clarified and the position of the relevant stakeholders, namely educational institutions and libraries, archives and museums, are described taking into account the changes brought about by digital technologies and the Internet as well as the effects of these developments on the work of the respective institutions. The desiderata of the addressees of limitations and exceptions are summarized. Above that the area of conflict between copyright law and access to education is outlined, including an overview of 
the situation of developing countries and the general significance of limitations and exceptions to copyright. Chapter 2 deals with the historical origins of copyright protection and explains the philosophical foundations of copyright law as well as with the role of limitations and exceptions within the copyright system, in order to apply these findings for the ensuing analysis. Chapter 3 examines the international and European legal framework of limitations and exceptions to copyright law. The focus is on the provisions of the Berne Convention and the European Information Society Directive 2001/29/EC. Also, the provisions of the Orphan Works Directive 2012/28/EU are discussed. The legal sources of the human right to education and the human right to culture in international law are examined in detail. Special attention is paid to the Three-Step-Test and to alternative approaches to the Test, namely human rights. These provisions affect national copyright laws and must therefore be considered by legislators in case of reforming national law. Chapter 4 contains the analysis of national laws. In a general introduction a benchmark of permissible digital uses based on the desiderata carved out in Chapter 1 is presented. Against this benchmark national limitations and exceptions are measured with special focus to the underlying fundamental rights. In Part 1 of Chapter 4 the limitations and exceptions for educational purposes and libraries, archives, museums and similar institutions in the USA, the United Kingdom and Germany are examined. These countries have elaborate copyright systems and a high level of copyright enforcement. Due to this fact and their economic situation the USA, the UK and Germany are examples for other countries in the field of legislation in general and in particular in the field of copyright law. At the same time these countries have different copyright traditions and provide different legal solutions to the challenges of the digital age. The respective provisions are examined in detail, taking into account international and European obligations, constitutional underpinnings and relevant court decisions. Part 2 of chapter 4 subsequently examines limitations and exceptions for educational purposes and libraries, archives, museums and similar institutions in Portugal, Brazil and Mozambique. For background information the analysis of each country starts with a short profile, providing historical, geographical and statistical information. Afterwards the educational policies and the educational system as well as the integration of information communication technologies in education and in libraries, archives and similar institutions are explained. An overview of national copyright law is given before limitations and exceptions for educational purposes and libraries and archives are examined. Empirical data regarding e-learning activities of educational institutions as well as the respective policies and legislative initiatives is evaluated in order to put the law into practical context. Special attention is paid to the linkages between Portugal, Brazil and Mozambiquein terms of language, education and culture by examining the co-operations between the countries under the roof of the Community of Portuguese speaking Countries and the consequences for copyright law and 
limitations and exceptions.

Based on these findings the main problems in the area of copyright limitations and exceptions for educational purposes and libraries and archives are summoned. Under consideration of the differences and similarities of the countries under analysis, possible solutions for improving the access to knowledge and education through limitations and exceptions to copyright law are outlined focussing especially on fundamental and human rights aspects. The findings will suggest that both international and national copyright systems must be reformed. The study concludes with a proposal for an international treaty for limitations and exceptions in favour of educational establishments and libraries, archives and similar institutions. Further concrete legislative amendments of national copyright limitations and exceptions in favour of education and knowledge are proposed and measured against international and European law. At the end a short outlook for future developments is provided. 


\section{CHAPTER 1: Background and Context of the Study}

Copyright law and the access to education and knowledge is a complex and much debated issue. Here, contrary positions come into conflict. On the one hand there are authors of copyright protected works and right holders, who call for protection of their rights and investments. On the other hand there are users of copyright protected works and the general public, who demand free and open access to education and knowledge. These conflicting interests must be fairly balanced, which requires to take into account a variety of different factors. In the context of this study the tension-filled issue of copyright law and access to education and knowledge will be analysed with special regard to the changes for educational institutions as well as for libraries and similar institutions brought about by the development of digital technologies and the Internet. In addition attention will be paid to the question how developing countries deal with these issues.

In this chapter the relevant terms, factors and constellations as well as their understanding in the course of this study are explained and the background and context of the study are outlined. First, the term "education" is explained. After that the term "e-learning", which is under special consideration here, and its economic significance are examined in detail. Furthermore, new modes to deliver education are described. Subsequently, the terms "library", "archive" and "museum" are explained and the role of these institutions as intermediaries and preservers of knowledge and education in the digital age is looked at. The relevance of educational activities and of libraries and archives with regard to copyright law are underlined at the end of each section. Finally, the area of conflict between copyright law and access to education and knowledge considering the changes of the digital age and the special situation of developing and least developed countries is illustrated and the significance of limitations and exceptions to copyright law for access to education and knowledge is highlighted.

\subsection{Education}

Education is a human right. ${ }^{50}$ Education is a key element to social and human development. ${ }^{51}$ Education helps to eradicate poverty and hunger and through education people acquire skills, which enable them to improve their lives and participate in social, cultural and working life. ${ }^{52}$ The digital era has increased the significance of knowledge and innovation as drivers of the development, which means, that education is becoming even

\footnotetext{
${ }^{50}$ Article 26 of the 1948 Universal Declaration of Human Rights states that "everyone has the right to education".

${ }^{51}$ See United Nations, Education for All (EFA), available at

http://www.un.org/en/globalissues/briefingpapers/efa/index.shtml.

52 UNESCO, "Education Counts" (2011), available at

http://unesdoc.unesco.org/images/0019/001902/190214e.pdf.
} 
more important for social and human development. ${ }^{53}$ Moreover Information Communication Technologies (ICT) offer new possibilities of delivering education. ${ }^{54}$

This said in advance the understanding of the term "education" in the context of this study is wide and refers to education of all levels, encompassing school education as well as higher education in universities and other higher education institutions. The term "education" encompasses all kinds of educational activities, no matter if analogue or digital learning material is used and comprises education delivered in classroom als well as distance learning. The term "education" also encompasses (legal) expressions like "use for educational purposes" or "teaching". Some educational activities, for instance e-learning, mostly take place in higher education. In general, however, it is common that today additionally to analogue learning materials and media also digital learning material and infrastructure, which can be summoned under the term "e-learning" is used to deliver education at all levels. ${ }^{55}$ Thus, as long as not specifically indicated, the term "education" refers to all kinds of institutions and activities, under consideration of the respective legal prerequisites.

As already indicated above ICT play an increasingly important role in schools as they do generally in the knowledge society and are considered to have the capacity of preparing students for the challenges of the knowledge society, if properly integrated. ${ }^{56}$ Yet, in practice ICT are used less frequently than it would be possible in view of their availability in schools. ${ }^{57}$ In order to achieve greater integration of ICT in school education ICT capacities of teachers should be systematically trained. ${ }^{58}$ Of great importance is the use of digital media and learning materials in the context of e-learning.

\subsubsection{E-Learning}

\subsubsection{Definition}

There is no uniform understanding of the term e-learning. However, it is established that elearning describes the use of ICT to foster and promote individual learning at all levels. ${ }^{59}$ Nevertheless, e-learning today is mainly used in higher education, meaning colleges and

\footnotetext{
${ }^{53}$ UNESCO Education Strategy 2014 - 2021, p. 9, available at http://unesdoc.unesco.org/images/0023/002312/231288e.pdf.

54 lbid.

${ }^{55}$ Comission of the EU, Green Paper Copyright in the Knowledge Economy, Com (2008) 466/final, p. 16.

${ }^{56}$ See for Europe: Commission of the EU / European Schoolnet / University of Liège, Survey of Schools: ICT in Education, 2013, p. 13.

${ }^{57}$ Idem, p. 9.

${ }^{58}$ Idem, p. 14/15, which points out that the more students use ICT in class the more confident they become in their digital competence.

${ }^{59}$ OECD Policy Brief, 2005, p. 2.
} 
universities. ${ }^{60}$ It comprises different kinds of systems and methods, ranging from email communication and online access to course materials while following a presence course on campus to courses offered entirely online. E-learning takes into account the tendencies and developments towards a flexible, individual and independent educational system, using the advantages of Internet based digital technologies. Because of its variety of appearances elearning is generally divided into three basic types. Following Tony Bates` classification these are "technology-enhanced classroom teaching", "distance education" and "distributed learning". 61

"Technology-enhanced classroom teaching" embraces the integration of digital web and Internet technologies into the classroom itself where professor and students are present at the same time. This can be done by offering a course website, making course materials available online on the Internet or in closed intranets. Students can download materials or look at websites and sources linked by the professor. During lessons websites may be used for illustration and students may discuss lectures afterwards in forums and communities. Technology-enhanced classroom teaching probably still is the most used form of e-learning. ${ }^{62}$

Today "distance education", which has had quite a long tradition in Western Europe and the USA, profits from new possibilities offered by digital technology and the Internet. Depending on the educational institution distance education courses may be held in "dual-mode" or "single-mode". ${ }^{63}$ The term "dual-mode" describes that courses consist of presence based on campus elements as well as elements delivered using ICTs. "S4 "Single-mode" courses are characterised by using exclusively and massively ICTs. ${ }^{65}$ The institutions offering "singlemode" courses mostly have very large numbers of students, and try to reach students who otherwise could not access higher education. ${ }^{66}$

The most advanced and effective form of e-learning from a pedagogical point of view is "distributed learning". It consists of a mix of face-to-face teaching and online learning and therefore may fundamentally change how higher education institutes traditionally operate. ${ }^{67}$ So called "mixed mode" e-learning begins to replace classroom time by transposing it to the internet. "Mixed mode" or "blended learning" methods combine the benefits of presence on

\footnotetext{
60 Ibid.; Bates in UNESCO, p. 19.

${ }^{61}$ Bates UNESCO, 2001, p. 19 - 23; OECD Policy Brief, 2005, p. 2 only slightly differing "web-supplemented", "web-dependent" and mixed modes.

${ }^{62}$ Cf. Bates UNESCO, 2001, p. 19.

${ }^{63}$ Idem, p. 20.

64 lbid.

65 Idem, p. 21

${ }^{66}$ Ibid.

67 Ibid.

${ }^{68}$ Cf. OECD Policy Brief, 2005, p. 2.
} 
campus and online off campus learning. ${ }^{69}$

\subsubsection{Advantages and Disadvantages of E-learning}

The use of e-learning methods brings about numerous advantages for professors and students such as the instant and global access to educational resources from outside of the respective institution. ${ }^{70}$ Students and professors benefit from flexible and direct interaction through email communication and discussion forums. ${ }^{71}$ Course material is available for students at the time of their choice. The possibilities of combining different materials for instance texts, videos, music or graphics for educational purposes are manifold. ${ }^{72}$ E-learning methods moreover enable international and collaborative learning. ${ }^{73}$ Course material may be created at low cost for institutions and teachers as well. In addition e-learning methods help students to overcome great distances in order to participate in learning and to follow a more self-paced learning rhythm. These advantages have led to the rapid spread of e-learning methods over the last decade. At present the biggest advantage of e-learning is the individualisation of learning processes. ${ }^{74}$

Notwithstanding the great advantages of e-learning methods there are as well disadvantages. First, e-learning requires high investments for technology and staff because e-learning offers must be prepared and supervised with regard to content, design and softand hardware. ${ }^{75}$ Further, it is criticised that there is only little support of students and almost no interaction between students and professors, which may also lead to lack of motivation. ${ }^{76}$ Moreover, the quality and the choice of topics of e-learning products are doubted sometimes. ${ }^{77}$ Above that it is argued that e-learning is not the appropriate way of imparting any kind of subject matter for some studies demand a higher degree of social interaction and communication than others. In such cases, at least at the moment, e-learning products are not the right medium. ${ }^{78}$

\subsubsection{Economic Relevance of E-learning}

With the development of digital technologies and the worldwide spread of the Internet elearning as well as the strong demand of education in developed and even more in

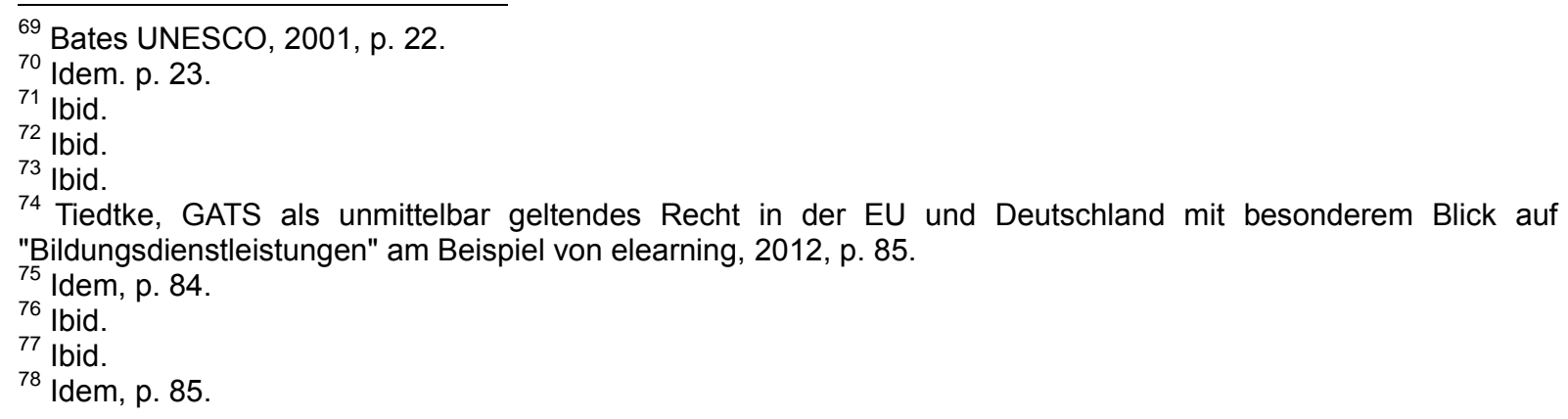


developing countries and least developed countries, e-learning has become the most rapidly growing sector of the educational market. Hereinafter I will therefore analyse the e-learning market in order to better understand the relevance of the related copyright issues.

It is important to keep in mind with regard to the e-learning market that there are two types of buyers of e-learning materials. On the one hand there are public, non-profit institutions of higher education, especially universities. On the other hand, there are private, for-profit corporations, which use e-learning methods for advanced training of the employees. Often the same publishing companies are providers for both public non-profit and private for-profit buyers. Concerning the topic of the present analysis the focus is on public non-profit institutions. Nevertheless I will also take a look at the e-learning market for private for-profit corporations when it makes sense.

\subsection{Global Market}

Regarding the global market for education in general there are several factors to be considered. There are 1.4 billion students out of a 7.1 billion world population. ${ }^{79}$ The global expenditure on education has been $\$ 4,450$ billion in $2012 .^{80}$ The expected compound annual growth rate of the global education market for 2012 to 2017 is around $7 \%$, which means that in 2017 the global education expenditure will in increase to $\$ 6,372$ billion. ${ }^{81}$ Of this total expenditure on education the lion's share is spent on so called K-12 education (formal education period up to 18 years of age) and summons up to $\$ 2,227$ billion for 2012 with a compound annual growth rate of only $6 \%$, so that in 2015 this amount will increase to \$ 2,625 billion and in 2017 to $\$ 2,930$ billion. ${ }^{82}$ Although this is the largest segment of the global educational market, it is not of primary interest here. More interesting is the segment of postsecondary or higher education. The worldwide expenditure on education in this segment in 2012 was $\$ 1,495$ billion. ${ }^{83}$ The compound annual growth rate is $8 \%$ so that in 2015 the estimated expenditure will be $\$ 1,883$ billion and in $2017 \$ 2,196$ billion. $^{84}$

The global expenditure on e-learning in general in 2012 only was \$ 90.9 billion, however the compound annual growth rate is $23 \%$, which means that by 2015 the global expenditure will have increased to $\$ 166.5$ billion and by 2017 even to $\$ 255.5$ billion. ${ }^{85}$ These figures encompass the expenditure for $\mathrm{K}-12$ e-learning as well as corporate e-learning and e-

\footnotetext{
${ }^{79}$ IBIS Capital, Global E-Learning Investment Review, 2013, p. 7.

${ }^{80}$ GSV Advisors, Education Sector Factbook, 2012, p. 1.

81 Ibid.; IBIS Capital, Global E-Learning Investment Review, 2013, p.7.

${ }^{82}$ GSV Advisors, Education Sector Factbook, 2012, p. 1.

$83 \mathrm{lbid}$.

84 lbid.

${ }^{85}$ Ibid.; IBIS Capital, Global E-Learning Investment Review, 2013, p. 7.
} 
learning in higher education. Yet, the strongest segment of the e-learning market is higher education. In 2012 the global expenditure for e-learning in higher education was \$ 48.8 billion. ${ }^{86}$ The estimated compound annual growth rate is $25 \%$ and the predicted expenditure in this segment in 2017 will be $\$ 149.0$ billion. $^{87}$

As one can see, the educational market is huge and especially for the e-learning segments high growth rates are predicted. With regard to e-learning higher education today is the strongest segment of the market. The economic relevance of e-learning in higher education becomes even more apparent if one takes into account that worldwide a number of 608.1 million students is currently engaged in higher education. ${ }^{88}$ Moreover the increasing penetration of the Internet and the accompanying growing number of Internet users especially favours the development of e-learning. ${ }^{89}$ This holds true on a regional as well as on a global level.

E-learning affects all levels of education. It provides new methods of creating, storing, distributing and producing learning content. As we have seen higher education is one of the two top fields of application for e-learning. The significance of e-learning to higher education is recognised by chief academic officers as $65.5 \%$ agree that e-learning is critical to the long-term strategy of their institution. ${ }^{90}$ Of those agreeing, $77 \%$ are from public, $69.1 \%$ from private, but non-profit and $54.2 \%$ from private for-profit institutions. ${ }^{91}$

\subsection{Content}

What is most important on the e-learning market is content. Of course, the technology used to distribute e-learning materials and the management of such distribution systems are very important, too. However, it is first of all content that is vital for e-learning, on a global as well as on a regional level. Thus content providers and content buyers, namely publishers and higher education institutions are key players on the e-learning market.

E-learning requires digital content. This includes the digitisation of already existing content as well as the production of new genuine digital content. Two recent developments on the global e-learning market with regard to content are the emergence of new local providers developing localised content and the emergence of providers that act trans-regional and

\footnotetext{
${ }^{86}$ GSV Advisors, Education Sector Factbook, 2012, p. 1.

${ }^{87}$ Ibid.

${ }^{88}$ GSV Advisors, Education Sector Factbook, 2012, p. 14.

89 Internet World Stats 2015.

90 IBIS Capital, Global E-Learning Investment Review, 2013, p. 17

91 Ibid.
} 
serve entire regions of the world. ${ }^{92}$ The lack of localised content in certain countries in the past hindered the spread of e-learning; the mere translation of content without regard for local conditions was rather unsuccessful and buyers refused such content. ${ }^{93}$ Yet this was an opportunity for local content providers to develop localised digital content on their own or as partners of international content providers. ${ }^{94}$ There is now a strong demand for such localised content. ${ }^{95}$ At the same time there is a trend towards trans-regional providers that addresses buyers in several countries of a world region, e.g. in Latin America where one of the major providers of e-learning content is based in Argentina and acts all over Spanish speaking South America. ${ }^{96}$ The same effect can be observed concerning content providers from Spain and Portugal, which are the major exporters of e-learning content to South America ${ }^{97}$ Providers in Portugal and Brazil as well export also to Portuguese speaking countries in Africa; lately providers in the African countries have even started to export content back to Portugal and Brazil. ${ }^{98}$

\subsection{E-learning Drivers}

Although there are significant differences and particularities of each national or regional elearning market, there are several factors, which can be observed in all countries of the world and which function as the main drivers of development of the global e-learning market.

First, governmental education policies promoting and funding the spread of information technology for learning purposes, e.g. the expansion of infrastructure, such as broadband Internet access or free computer hardware for pupils and students. ${ }^{99}$ Second, the advancing digitisation of educational content and the growing demand for genuine digital content, facilitate the use of e-learning methods and technology. ${ }^{100}$ Especially less developed and developing countries are pushing the digitisation of printed educational materials. ${ }^{101}$ Developed countries are demanding more and more genuine digital learning material, although the digitisation of all printed educational materials is not yet complete. ${ }^{102}$ Also, in all countries of the world, there are - third - large numbers of enrolments in online higher education. ${ }^{103}$ International as well as domestic providers of higher education e-learning are growing rapidly, for as of August 2012 there are more than 30 million higher education

\footnotetext{
${ }_{92}^{9}$ Ambient Insight, Worldwide Market for Self-paced elearning Products and Services, 2012, p. 13.

93 lbid.

94 Idem, p. 14.

95 lbid.

$96 \mathrm{lbid}$.

${ }^{97}$ Ibid.

98 Ibid.

99 Idem, p.16.

100 Idem, p. 17.

101 Ibid.

102 Idem, p. 18, with reference to projects creating digital content for adult education in Germany.

103 Ibid.
} 
students taking one or more of their classes online. ${ }^{104}$ In some countries e-learning is seen as the only way to cope with the enormous numbers of higher education students, because traditional campus facilities are not able manage the strong demand. ${ }^{105}$ Several countries lately have also founded national virtual universities funded by the government. ${ }^{106} \mathrm{~A}$ fourth factor for the recent development of the global e-learning market is the demand for learning technology and learning platforms, which goes hand in hand with the demand for e-learning digital content. ${ }^{107}$ Finally the fifth factor for the growth of the global e-learning market is the demand for customised content, which favours domestic and trans-regional providers. ${ }^{108}$

\subsection{Key Players}

As already indicated above the key players on the global e-learning market are publishers on the one hand and higher education institutions on the other hand. ${ }^{109}$ In countries where educational systems are centralised and run by government agencies or education ministries, higher education institutes are large buyers of e-learning materials. ${ }^{110}$ Also public libraries financed by the government buy such materials on a grand scale. ${ }^{111}$ Although the demand for certain e-learning materials differs from country to country, the strongest demand is for (packaged) content all over the world. ${ }^{112}$

On a global level there are some large corporations, which provide e-learning materials and content for higher education institutions. On of the biggest publishers of educational materials and e-learning content is Pearson PLC, seated in London. Also the US-based publisher McGraw-Hill is among the big e-learning content providers. Other providers of elearning materials and content are the developers Skillsoft, based in Ireland, Tata Interactive Systems, based in Mumbai, India and the French enterprise CrossKnowledge.

\subsubsection{New Modes to Deliver Education}

As costs of higher education increase and government budgets for education are cut, especially for the online market several cheaper alternatives of delivering higher education have developed. Regardless of the non-profit or for-profit nature of institutions offering such

\footnotetext{
104 Ibid.

${ }^{105}$ Idem, p. 17/18: e.g. in Nigeria, where government wants to double higher education enrolments within the next two years.

106 Idem, p. 19

107 Idem, p. 20: One has to distinguish commercial and public providers of such platforms, often on an open source basis. Latin-America has the second-highest demand for such platforms with a growth rate of $15.9 \%$.

108 Idem, p. 28

${ }^{109}$ Idem, p. 28, also corporations and PreK-12 institutions are among the top global buyers.

110 lbid.

111 lbid.

112 Idem, p. 29
} 
alternatives, there are various models currently used, such as for instance Open Course Ware (OCW) or more broadly speaking Open Educational Resources (OER) and Massive Online Open Courses (MOOCs).

OCW describes freely available learning material provided by universities or other higher education institutes under special licences (e.g. Creative Commons) and is slightly more specific then OER. ${ }^{113}$ OER means any educational resource that is openly available and can be used by educators and students without the obligation to pay licence fees. ${ }^{114}$ OER can be available in any medium, analogue or digital and is therefore not synonymous with elearning. ${ }^{115}$ The concept of OER is related to the concept open access, but the concept of open access is rather referring to research and scholarly publications as well as scientific journals published under an open license ${ }^{116}$ whereas OER refers to teaching and learning materials published under an open licence. ${ }^{117}$ Especially in higher education OER and open access overlap. ${ }^{118}$

MOOCs are courses delivered online to a theoretically unlimited number of participants. Key features are open access meaning that anyone can participate the online course for free and scalability, meaning that courses are designed to address an unlimited number of participants. ${ }^{119}$ MOOCs are a combination of traditional learning methods, such classic classroom setting on video, and modern forms of direct interaction between students and professors. ${ }^{120}$ Of course there are numerous other types of online courses. Some courses are accredited and subscription-based and students can earn a degree. Others are nonaccredited and completely free. And some offer "Do It Yourself Degrees", meaning that users are taking only tests and not classes.

Public and private non-profit institutions offer mainly OER and OCW. The platform edX is an example for a not for profit enterprise offering MOOCs. ${ }^{121}$ For-profit private institutions and corporations provide subscriptions-based courses. ${ }^{122}$

\footnotetext{
${ }^{113}$ Butcher, A basic Guide to Open Educational Resources (OER), 2015, p. 5.

114 Ibid.

115 Ibid.

116 UNESCO, Concepts of Openess and Open Access, 2015, p. 6.

117 lbid.

118 Ibid.

119 UNESCO Policy Brief, Introduction to MOOCs: Avalanche, Illusion or Augmentation?, 2013, p. 2.

${ }^{120}$ See ibidem for the different types of MOOCs, namely cMOOCs and XMOOCS, depending on the emphasis on pedagogy and organisation.

${ }_{121}$ edX (https://www.edx.org/) was created by MIT and Havard.

122 The biggest MOOCs platform is Coursera (https://www.coursera.org/), which is a for profit enterprise. Another big for profit player is Udacity (https://www.udacity.com/).
} 


\subsubsection{Relevance}

The actions relevant for copyright law occurring in the context of education are numerous. Any use of a copyright protected work includes at least its reproduction, which must be authorised by the author or right holder. Both the use analogue and digital learning materials concerns copyright. With regard to e-learning copyright protected works are made available to the public, communicated or distributed. Any of these uses require the prior authorisation of the author or right holder. An exception is OER, which allow the free use of protected works due to a respective licence issued by the author or right holder for educational purposes.

\subsubsection{Desiderata}

As was highlighted in the Introduction ${ }^{123}$ it appears that in view of the possibilities created by digital technologies and the Internet to use copyright protected works limitations and exceptions to copyright do not take into account the need for access to education and knowledge appropriately. This notion can be more or less generalised and thus holds true to a certain extent all over the world.

Considering what was explained before regarding the new possibilities of using copyright protected works for educational purposes the complaints and desires of both educational institutions and students may be condensed to the following ${ }^{124}$.

The restrictive interpretation of limitations for educational purposes results in legal uncertainty for educators and students. Copyright rules are considered to be very complicated, which impairs the use and development of new learning methods. Problems are encountered for instance with distance learning and cross-border uses of copyright protected works. The same is true for and virtual learning environments. Licensing solutions are very costly, negotiations with right holders are difficult and administration efforts extensive.

Thus, educational institutions and students alike favour broad and open, technologically neutral limitations, covering the use of all kinds of works, i.e. texts, films, multimedia as well

\footnotetext{
123 Introduction No. 2.

124 The opinions described hereinafter have been expressed by stakeholders during the public consultation on the review of the EU copyright rules, see European Commission, Report on the responses to the Public Consultation on the Review of EU Copyright Rules, July 2014, available at

http://ec.europa.eu/internal_market/consultations/2013/copyright-rules/docs/contributions/consultation-

report_en.pdf, in particular $\bar{p}$. 53/54. The opinions provided by stakeholders, namely end users and consumers as well as by institutional users, i.e. universities and individual teachers, have been summarised in order to explicitly name what is desirable with regard to limitations for educational purposes. Although the opinions expressed during the public consultation on the review of the EU copyright rules refer only to EU copyright law, they can be generalised and in principle be transferred to educational institutions outside the EU.
} 
as born digital content. Further, there should be no restrictions on the amount of the work that can be used. Limitations should cover the use of copyright protected works in the classroom as well as online education for non-commercial purposes. Moreover, there should be no restriction to certain types of institutions, but the applicability of the limitation should be determined by the purposes of teaching. Finally, it should be safeguarded that limitations for educational purposes cannot be overruled by licensing contracts.

In addition with regard to education and research stakeholders advocate for a limitation permitting text and data mining, ${ }^{125}$ which is considered a fundamental tool for education and research in the digital age. ${ }^{126}$

\subsection{Libraries, Archives and Museums}

\subsubsection{Definition}

The provision of access to knowledge, education and information as well as the preservation of cultural heritage is the task of libraries, archives and museums.

Libraries are gateways to knowledge. ${ }^{127}$ Libraries provide access to knowledge, culture, information and education for all. ${ }^{128}$ Access to knowledge, culture and information is a human right. ${ }^{129}$ Libraries support learning, literacy and education ${ }^{130}$ and are the primary providers of free access to information. ${ }^{131}$ The digital era has significantly changed and improved the way libraries work and provide their services. In particular questions arise with regard to digitisation and digital preservation of content, the use of orphan works in library collections, access to digital content and user-generated content. ${ }^{132}$ In general a library can be defined as the "collection or a group of collections of books and/or other print or a non-print materials

\footnotetext{
${ }^{125}$ According to a definition by the UK Intellectual Property Office (IPO) "Text and data mining is the use of automated analytical techniques to analyse text and data for patterns, trends and other useful information. Text and data mining usually requires copying of the work to be analysed.", IPO Intellectual Property - Guidance, Exceptions to Copyright, November 18, 2014, available at https://www.gov.uk/guidance/exceptions-to-copyright.

${ }^{126}$ See European Commission, Report on the responses to the Public Consultation on the Review of EU Copyright Rules, July 2014, available at http://ec.europa.eu/internal_market/consultations/2013/copyrightrules/docs/contributions/consultation-report_en.pdf, in particular p. 63/64. See The Hague Declaration on Knowledge Discovery in the Digital Age, available at http://thehaguedeclaration.com/the-hague-declaration-onknowledge-discovery-in-the-digital-age/, which names as one of the potential benefits of content mining the creation of tools for education and research (see also chapter 1.2.4).

${ }_{127}$ UNESCO, Public Library Manifesto; White, Guaranteeing Access to Knowledge: The Role of Libraries, 1994.

${ }^{128}$ Cf. UNESCO, Public Library Manifesto, 1994. This holds true for public libraries, but principally applies to school libraries and academic libraries as well. See also UNESCO, School Library Manifesto, 1999.

${ }^{129}$ Article 27 para. 1 of the 1948 Universal Declaration of Human Rights states that „Everyone has the right freely to participate in the cultural life of the community, to enjoy the arts and to share in scientific advancement and its benefits."

${ }^{130}$ White, Guaranteeing Access to Knowledge: The Role of Libraries, 2012.

131 Davies, Access v Contract: Competing Freedoms in the Context of Copyright Limitations and Exceptions for Libraries, 2013, p. 402.

${ }^{132}$ See Brindley, Phoenixes in the Internet Era - The changing role of Libraries, 2010, p. 176 - 186.
} 
organised and maintained for use (reading, consultation, study, research, etc.)." ${ }^{133}$ Libraries are usually funded by the public and can be divided into five categories, namely academic and research libraries, national libraries, public libraries, school libraries and special libraries. ${ }^{134}$ Each type of library provides a collection limited to the interests of the respective user group. ${ }^{135}$

The task of archives is more focused on the preservation of cultural heritage and knowledge to keep record of past and present documents and events. ${ }^{136}$ An archive is a facility to place in storage documents, "usually to preserve them as a historical, informational, legal, or evidential record, permanently or for a finite or indefinite period of time." ${ }^{137}$ The collections of an archive are available to the public, but not as openly as the collections of libraries. ${ }^{138}$

Museums provide access to knowledge through their collections and preserve them for future generations. ${ }^{139}$ Thereby they promote education, study and research. ${ }^{140}$ The possibilities to enable access to the collections of museums for the named porposes are enlarged through digital technologies and e-learning methods. ${ }^{141}$ Museums can be defined as "publicly or privately funded non-profit institutions, whose primary function is to preservation and display of collections of physical artefacts and specimens for the purpose of education, scholarship and enjoyment." ${ }^{142}$ Compared to libraries and archives museums focus on the display of their collections, for instance in form of exhibitions. Many museums also maintain special libraries with books and other reference materials regarding their collections and activities. ${ }^{143}$

Libraries, archives and museums have in common that they build and preserve their collections and provide access to them for the public. Because of the spread of the Internet and the rapid development of ICT, the way libraries, archives and museums work and provide their services, has changed significantly. ${ }^{144}$

In the course of this study the meaning of the terms "library", "archive" and "museum" is very

\footnotetext{
${ }^{133}$ Reitz, Online Dictionary for Library and Information Science (ODLIS), 2013, available at http://www.abcclio.com/ODLIS/odlis I.aspx.

${ }^{134}$ SCCR/23/3, "The case for a treaty on exceptions and limitations for libraries and archives: background paper by IFLA, ICA, EIFL and INNOVARTE", 2011, p. 2.

135 Ibid.

136 Ibid.

137 Reitz, Online Dictionary for Library and Information Science (ODLIS), 2013, available at http://www.abcclio.com/ODLIS/odlis_a.aspx.

${ }^{138}$ See Society of American Archivists, What Are Archives and How Do They Differ from Libraries?, 2012, available at http://archivists.org/usingarchives/whatarearchives.

${ }^{139}$ Canat, Guibault, Logeais, Study on Copyright Limitations and Exceptions for Museums, 2015, p. 9.

${ }^{140}$ Idem, p. 11.

141 Ibid.

142 Reitz, Online Dictionary for Library and Information Science (ODLIS), 2013, available at http://www.abcclio.com/ODLIS/odlis_m.aspx.

${ }^{143}$ Ibid.

${ }^{144}$ Comission of the EU, Green Paper Copyright in the Knowledge Economy, Com (2008) 466/final, p. 7.
} 
similar. Mostly, the term "library" will be used, because most copyright laws under consideration privilege specific uses of copyright protected works by libraries. Often, also "archives" are addressed. Rarely used is the term "museum". Since the rationale for the copyright law provisions privileging these institutions is the same - all serve the public interest by providing access to knowledge and education and preserving cultural heritage and the uses of protected works are comparable, the terms "library", "archive" and "museum" will be used interchangeably. As well sometimes reference will be made to "similar institutions", because besides libraries, archives and museums as well other institutions may use copyright protected works for the purpose of access to and the preservation of knowledge.

\subsubsection{Digital Activities}

Additionally to analogue media digital media and techniques have become increasingly important for libraries, archives and museums. The Institutions can build collections in digital form, digitising their analogue collections or using born digital content. ${ }^{145}$ Digitisation means "the process of converting data to digital format for processing by computer." ${ }^{146}$ Libraries, archives and museums and other institutions have begun to digitise their collections for the purpose of preservation and making available to the public. The term "mass digitisation" describes the large-scale conversion of text or images to digital format by using robotic equipment. ${ }^{147}$ But not only the collection of libraries are preserved in digital format. Libraries, archives and museums also collect (born) digital content from the Internet for the purpose of preservation, so called web-harvesting. ${ }^{148}$ Further, libraries and similar institutions offer text and data mining programms to their users. Text and data mining is defined as "the use of automated analytical techniques to analyse text and data for patterns, trends and other useful information. Text and data mining usually requires copying of the work to be analysed. ${ }^{\prime 149}$

A digital library is "a library, in which a significant proportion of the resources is available in

\footnotetext{
145 IFLA/UNESCO Manifesto for Digital Libraries, 2011, p.2; "Born Digital" means digital materials, which are not intended to have an analogue equivalent, either as the originating source or as a result of conversion to analogue form, see Digital Preservation Coalition, available at http://www.dpconline.org/advice/preservationhandbook/glossary\#B.

${ }^{146}$ Reitz, Online Dictionary for Library and Information Science (ODLIS), 2013, available at http://www.abcclio.com/ODLIS/odlis_d.aspx.

147 Ibid.

${ }^{148}$ According Recital 17 of the Commission Recomendation of October 27, 2011, on the digitisation and online accessibility of cultural material and digital preservation (2011/711/EU), "Web-harvesting is a new technique for collecting material from the Internet for preservation purposes. It involves mandated institutions actively collecting material instead of waiting for it to be deposited, thus minimising the administrative burden on producers of digital material, and national legislation should therefore make provision for it." As will be shown later of the European countries analised here only the UK has introduced a copyright limitation permitting web-harvesting.

${ }_{149}$ Definition by UK IPO, Intellectual Property - Guidance, Exceptions to Copyright, November 18, 2014, available at https://www.gov.uk/guidance/exceptions-to-copyright.
} 
machine-readable format, accessible by means of computers." ${ }^{150}$ The digital content may be locally held or accessed remotely via computer networks in full or in part. ${ }^{151}$ Digital libraries are normally searchable and search engines may located the exact position of word or phrase searched for. ${ }^{152}$ Through digital technologies research is facilitated. Physically digital collections occupy much less space. Moreover, digital collections can be made available to their users at times and places of their choice. However, to build and maintain digital collections and libraries is technically complex and costly. The same is true for digital archives, which use digital technologies for locating, storing and providing access to digital materials over a long term. ${ }^{153}$ Generally, with regard to preservation institutions must safeguard that materials remain readable in spite of technological changes.

A prominent example of a publicly funded digital library is the so-called "Europeana", which makes the scientific and cultural heritage of Europe available to the public displaying digitised items such as paintings, photos, texts, videos and phonograms. ${ }^{154}$ The Unesco World Digital Library is as well publicly funded. ${ }^{155}$ Another very well-known private project to create a digital library is the Google Books Library Project. ${ }^{156}$ The goal of the project is to digitise as many books as possible (using "mass digitisation techniques") and make them available to the public. The project started in 2005 and is carried out in corporation with several public and private libraries throughout the world. ${ }^{157}$ However, it includes the scanning of millions of books without the authorisation of the author or right holder, which has led to ongoing lawsuits between Google and representatives of the authors and right holders. ${ }^{158}$

But not only for the purposes of building digital collections and preservation of analogue and digital media ICT are indispensable for libraries, archives and museums. ICT open new possibilities to provide access to the collections of libraries, archives and museums to end users. Additionally to their traditional services such as reading rooms and/or exhibitions, institutions make their collections available in digital form on-site through dedicated terminals or similar and offsite via closed networks and over the Internet.

\footnotetext{
${ }^{150}$ Reitz, Online Dictionary for Library and Information Science (ODLIS), 2013, available at http://www.abcclio.com/ODLIS/odlis_d.aspx; cf. Akester, A Practical Guide to Digital Copyright Law, EIPR, 2008, no. 5-01.

${ }^{151}$ Besek, The Development of Digital Libraries in the United States, 2010, p. 188; Akester, A Practical Guide to Digital Copyright Law, EIPR, 2008, no. 5-01.

${ }_{152}$ Akester, A Practical Guide to Digital Copyright Law, EIPR, 2008, no. 5-03.

${ }_{153}$ Besek, The Development of Digital Libraries in the United States, 2010, p. 188.

154 www.europeana.eu.

$155 \mathrm{https}: / /$ www.wdl.org/en/.

156 https://books.google.com/.

157 See for instance Bayrische Staatsbibliothek München, available at https://www.bsb-muenchen.de/ueberuns/kooperationen/google/.

${ }^{158}$ Regarding the recent developments Xalabarder, Google Books and Fair Use: A Tale of two Copyrights?, 2014, para. 1f.; only on October 16, 2015, the US Court of Appeal for the Second Circuit decided after 10 years of litigation that Google Books is covered by fair use, see Chapter 4.1.1.4.3.7 and 4.1.1.4.3.8.
} 


\subsubsection{Relevance}

The activities of libraries, archives, museums and similar institutions described before regularly include the use of copyright protected works, which means that in principle the authorisation of the author or right holder is necessary, if the respective work is not in the public domain. Difficult copyright questions arise in connection with orphan works, which are works protected by copyright in the collections of libraries, archives and museums whose author or right holder is unknown and therefore cannot be asked to authorise certain uses of his work, especially making available to the public. ${ }^{159}$ Another problem arises from licensing contracts, which are concluded between libraries and publishers. These licensing contracts undermine the legal privileges of libraries, archives and museums. ${ }^{160}$ This study, however, focuses on the respective provisions of copyright law favouring libraries, archives, museums and similar institutions.

\subsubsection{Desiderata}

As was pointed out in the Introduction ${ }^{161}$ it appears that in view of the possibilities created by digital technologies and the Internet to use copyright protected works limitations and exceptions to copyright do not take into account appropriately the need for access to education and knowledge. This notion can be more or less generalised and thus holds true to a certain extent all over the world.

Considering what was explained before regarding today's possibilities to use copyright protected works by libraries, archives, museums and similar institutions the complaints and desires of these stakeholders may be summarised as follows ${ }^{162}$ :

With regard to preservation and archiving stakeholders complain that they are often only allowed to make a limited number of copies of works they wish to preserve. Further, so-

\footnotetext{
${ }^{159}$ Afori, The Battle over Public E-Libraries - taking stock and moving ahaed, 2013, p. 397/398. See Chapter 3.2.2. for the analysis of the EU Orphan Works Directive 2012/28/EU.

160 Davies, Access v Contract: Competing Freedoms in the Context of Copyright Limitations and Exceptions for Libraries, 2013, p. 402; Afori, The Battle over Public E-Libraries - taking stock and moving ahaed, 2013, p. 401.

161 Introduction No. 2.

162 The opinions described hereinafter have been expressed by stakeholders during the public consultation on the review of the EU copyright rules, see European Commission, Report on the responses to the Public Consultation on the Review of EU Copyright Rules, July 2014, available at http://ec.europa.eu/internal_market/consultations/2013/copyright-rules/docs/contributions/consultationreport_en.pdf, in particular p. 39 - 52. The opinions provided by stakeholders, namely end users and consumers as well as by institutional users, i.e. public libraries, archives, museums, film heritage institutions and research centers, have been summarised in order to explicitly name what is desirable for these institutions with regard to limitations to copyright. Although the opinions expressed during the public consultation on the review of the EU copyright rules refer only to EU copyright law, they can be generalised and in principle be transferred to libraries, archives, museums and similar institutions outside the EU. In addition the interests of libraries and archives are represented by IFLA (International Federation of Library Associations and Institutions) on an international level. IFLA is engaged in policy making especially in the field of copyright limitations and exceptions, see http://www.ifla.org/copyright-tlib.
} 
called format shifting is not allowed. ${ }^{163}$ Moreover, the establishment of cross-border digitisation projects is difficult, because of diverging limitations and exceptions. ${ }^{164}$ Therefore, libraries, archives, museums and similar institutions are in favour of limitations permitting format shifting and the cross-border uses of works. In addition mass digitisation of all kinds of works in the collections of libraries, archives and similar institutions should be allowed including so-called born-digital content. ${ }^{165}$ Furthermore limitations should not be overruled by contracts. ${ }^{166}$ In general, broad and open limitations for libraries and other cultural heritage institutions are favoured.

With regard to online access to library collections stakeholders wish that copyright limitations should cover on-site consultation as well as remote access to library collections for noncommercial uses, including the digitisation of protected works for this particular purpose. The same demand is made with regard to the use of copyright protected works for research purposes. Also, there should be no restrictions by the law or by licensing contracts concerning the amount of users that can access the respective works at the same time. As well in principle limitations privileging online access to library collections should not be overruled by licensing contracts.

Further, libraries, archives and similar institutions favour limitations for lending e-books (socalled e-lending). Institutions complain that only a small number of all published books are available for e-lending and that license agreements often conflict with granting access via elending. Limitations in this field should safeguard in particular that simultaneous loans of the same copy to more than one person are allowed and that cross-border e-lending is facilitated. ${ }^{167}$ In this regard it is argued that the principle of exhaustion should be extended to

\footnotetext{
163 The term "format shifting" describes the conversion of the copy of a protected work into a new format, which is especially important in case the format itself or the devices to read it become obsolete or unavailable, see EU copyright rules, see European Commission, Report on the responses to the Public Consultation on the Review of EU Copyright Rules, July 2014, p. 40. IFLA proposes a limitation regarding preservation and archiving (article 9) in its "treaty proposal on limitations and exceptions for libraries and archives", version 4.4, December 6, 2013, which was presented to the Standing Committee on Copyright and Related Rights at the WIPO, available at http://www.ifla.org/files/assets/hq/topics/exceptions-limitations/tlib_v4_4.pdf. According to the Explanatory Note to article 9 of the Treaty Proposal the provision aims at providing "flexibility to copy, format-shift and migrate copyright works and materials to different platforms and to use these copies in place of the original, so that the original itself is not damaged and is preserved for posterity".

${ }_{164}$ IFLA's Treaty Proposal demands in article 13 four a right to cross-border uses. According to the explanatory note article 13 is intended to safeguards "copies of works made under an exception in this Treaty may be sent and received across borders" by libraries and archives.

${ }^{165}$ Cf. IFLA, Treaty Proposal, article 9, Explanatory Note, saying that article 9 "permits libraries and archives to reproduce for preservation purposes as many copies of works or materials in as many formats as are technically needed in accordance with the standards of best professional preservation practice." In addition IFLA, Treaty Proposal, article 12 is intended to allow (mass) digitisation of orphan works, see Explanatory Note Article 12.

${ }^{166}$ IFLA, Treaty Proposal, article 15, which states that "contractual provisions that prohibit or restrict the exercise or enjoyment of the limitations and exceptions in copyright (...) shall be null and void."

${ }^{167}$ Cf. IFLA, Treaty Proposal, article 7, which deals with lending of tangible media and temporary access to copyrighted works in digital or other intangible media (i.e. elending). According to article 7, Explanatory Note, this provision is intended to enable "digital lending" as temporary access, as, an umbrella concept that accommodates an exception to the distribution right, or communication to the public right, or any such right
} 
the distribution and lending digital content. ${ }^{168}$

Concerning mass digitisation of copyright protected materials institutions demand for limitations that allow the cross-border use of digitised works. Moreover, limitations for mass digitisation should cover all kinds of out-of-commerce works and online access to digitised collections of cultural heritage institutions should not be limited to certain types of works. Were there are provisions concerning the (mass) digitisation of orphan works stakeholders complain about the requirement of diligent searches for right holders, which significantly complicates the process. ${ }^{169}$

Finally, stakeholders advocate for limitations for text and data mining both for commercial and non-commercial scientific research. ${ }^{170}$ Text and data mining is considered to be a fundamental tool for research and education in digital age.${ }^{171}$ However, there is considerable legal uncertainty whether text and data mining constitutes copyright infringement is or not. ${ }^{172}$

\subsection{Copyright Law and the Access to Education and Knowledge}

\subsubsection{Objectives of Copyright Law}

The main objectives of copyright law are the protection of authors rights and the promotion of innovation and development. ${ }^{173}$ The protection of authors includes the protection of right holders, such as publishers, film producers etc. Effective protection is vital for any copyright

pertaining to digital transmission, that might be adopted in national legislation and that would affect the ability of libraries to provide, upon request, for a limited time, a copy of a work in a digital or intangible format." See also IFLA, Key Initiative 2.2, Advocating for an equitable copyright framework, Activity 2.2.3 Work to improve the elending framework, available at http://www.ifla.org/node/10086.

${ }_{168}$ Cf. ibid, see also Introduction, 1. Setting.

${ }^{169}$ Also the IFLA, Treaty Proposal contains the condition of diligent search. Article 12 speaks of a "reasonable inquiry" for the author or right holder.

${ }^{170}$ See also IFLA, Key Initiative 2.2, Advocating for an equitable copyright framework, Activity 2.2.2 Promote the Hague Declaration on Text and Data Mining, available at http://www.ifla.org/node/10086. The Hague Declaration on Knowledge Discovery in the Digital Age is available at http://thehaguedeclaration.com/the-hague-declarationon-knowledge-discovery-in-the-digital-age/. The Hague Declaration on Knowledge Discovery in the Digital Age promotes the opinion that new digital technologies, like text, data and content mining, are "a key to knowledge discovery in the digital age". However, it is argued that current legal frameworks in many countries do not adequately promote the use of such technologies, in particular outdated intellectual property laws. According to the Hague Declaration this creates "inequalities in access to knowledge discovery in the digital age."' As a result, the Hague Declaration has developed a set of principles stating among others that intellectual property was not designed to regulate the free flow of facts, data and ideas but has as a key objective to promotion of research activity (principle 1), that licenses and contract terms should not restrict individuals from using facts, data and ideas (principle 3) and that innovation and commercial research based on the use of facts, data and ideas should not be restricted by intellectual property law (principle 5). Based on these principles the Hague Declaration explicitly demands that current copyright laws should be reformed in order to enable content mining and if limitations or exceptions are introduced into copyright law permitting content mining, such provisions should be mandatory and not be overridden by contracts.

${ }^{171}$ Cf. IFLA Statement on Text and Data Mining (2013), available at http://www.ifla.org/files/assets/clm/statements/iflastatement_on_text_and_data_mining.pdf. 172 Ibid.

${ }^{173}$ Depending on the legal tradition, Droit d Auteur or Copyright, see Chapter 2.1.2. 
system. At the same time it is vital that copyright systems take into account the interests of society and the general public as well as of the individual user. Innovation and development are promoted through the dissemination of knowledge and the access to education, including cultural participation. An efficient and balanced copyright system must consider equally and adequately both effective protection of copyright and dissemination of knowledge and access to education.

Generally it can be observed that more protection of copyright is associated with greater incentives to create innovations and thereby promote development. ${ }^{174}$ Yet, too much protection can also hinder innovation and development. ${ }^{175}$ If copyright law in the first place protects individual rights and economic interests of few authors and/or right holders, it must be doubted that society as a whole benefits from such copyright system. ${ }^{176}$ In view of the changes brought about by digital technologies and the Internet authors and right holders reacted with the expansion of copyright protection, which is somewhat understandable given the countless new possibilities to commit copyright infringements. However, the expansion of copyright protection did not go along with a greater consideration of the interests of the individual user and the general public, especially with regard to the dissemination of knowledge and the access to education. It must be stated that copyright law lately has given one-sided preference to the protection of protection authors and right holders, largely neglecting individual and public interests. Thus, copyright has lost sight of its objectives.

\subsubsection{Access to Knowledge and Education}

As was explained before one main objective of copyright law is the promotion of innovation and development. This includes the promotion of access to knowledge and education for the benefit of society as a whole. Thus, public interest in the promotion of access to knowledge and education is great. In view of the one-sided preference of protection of copyright it is argued that public interest should play a larger role in copyright law and prevail over private interests in certain situations. ${ }^{177}$ Excessive copyright protection may prejudice the possibilities to access knowledge and education, for instance through far reaching restrictions regarding the use of copyright protected works for educational activities or in libraries and archives.

In general, the concept of access to knowledge is very broad and includes the idea of access

\footnotetext{
${ }^{174}$ Shaver, Intellectual Property, Innovation and Development: The Access to Knowledge Approach, p. 2; see also Dreier, Limitations: The Centrepiece of Copyright in Distress - An Introduction, 2008, para. 2.

${ }_{175}$ Cf. Dreier, Limitations: The Centrepiece of Copyright in Distress - An Introduction, 2010, para. 11.

176 Idem, para. 3/4

177 Hugenholtz \& Okediji, Conceiving an International Instrument on Limitations and Exceptions to Copyright, 2008 , p. 30.
} 
to education and learning opportunities, but extends to information in general, literature, art, inventions, data as well as any kind of expressions of the human mind. ${ }^{178}$ Also the term "access" must be understood in a broad sense encompassing any kind of use of the respective work, product or object. ${ }^{179}$ In the context of this study the terms "access to education" and "access to knowledge" will be used almost synonymously, since both relate to the same objective, which is to facilitate and improve access to education and knowledge for overall social benefit.

\subsubsection{Balance of Interests}

A central issue of this study is how strong and effective copyright protection on the one hand and public interest in access to education and knowledge on the other hand, can be balanced sensibly and in a way that is profitable for the entire society.

As was said above both the protection of the rights of authors and right holders and the promotion of public interest in access to knowledge and education have underpinnings in human rights law. According to Art. 27 para. 2 of the 1948 Universal Declaration of Human Rights (UDHR) „Everyone has the right to the protection of the moral and material interests resulting from any scientific, literary or artistic production of which he is the author." The protection of intellectual property and copyright consequently is regarded as a basic human right, which underlines the significance of this position. Following article 27 para. 1 UDHR „Everyone has the right freely to participate in the cultural life of the community, to enjoy the arts and to share in scientific advancement and its benefits." This position is specified and strengthened by article 26 para. $1 \mathrm{~s}$. 1 UDHR, which states that „Everyone has the right to education." Both last statements of UDHR highlight the significance of social participation and access to knowledge and education.

The challenge for legislators is to balance the interests of all stakeholders, taking into consideration adequately the significance of each position. ${ }^{180}$ To achieve a fair balance is difficult. Moreover, the balance has to be adjusted constantely, because the underlying conditions and value decisions change in the course of time. This means that what is considered a fair balance of interest today must not necessarily be a fair balance tomorrow. As a consequence legislators have always to take into account social and technological developments in order to find adequate and up-to-date solutions in the balancing process. ${ }^{181}$

\footnotetext{
178 See "Access to Knowledge Treaty", 2005, available at http://www.cptech.org/a2k/a2k_treaty_may9.pdf. ${ }^{179}$ Cf. ibid.

180 Okediji, The International Copyright System: Limitations, Exceptions and Public Interest Considerations for Developing Countries, 2006, p. 7.

${ }^{181}$ Dreier, Limitations: The Centrepiece of Copyright in Distress - An Introduction, 2010, para. 10.
} 
This study focuses on the public interest in access to education and knowledge. Thus, the stakeholders, whose positions are examined with priority and in detail here, are educational institutions, comprising all kinds of institutions, such as primary and secondary schools, colleges, universities, adult education institutions etc., as providers of access to education, as well as libraries, archives, museums and similar institutions as providers of access to knowledge and education and preservers of cultural heritage. Furthermore, to a certain extend the position of the individual, who seeks access to education and knowledge, is taken into consideration, too. The interests of authors and right holders as counterweights in the balancing process are illustrated as far as necessary and appropriate.

\subsubsection{Digital Age and Copyright}

The worldwide spread of the Internet and the rapid development of digital technologies have dramatically changed the world in the past two decades. These changes embrace all areas of economic, social and private life, including the way education is delivered and access to knowledge is provided today. The possibilities of using digital technologies in education and in libraries are manifold and over the Internet information is available for everybody for free and at anytime. As well education and library services are provided online. In the course of this study the terms "digital age" or "digital era" refer to the developments described before.

Regularly, most of these activities of educational institutions and libraries, archives and similar institutions involve the use copyright protected works. Yet, the changes brought about by the Internet and digital technologies not or only to a very small extent reflected by copyright law, which has the effect that from a factual point of view access to and use of materials is very easy, but from a legal point of view copyright may be infringed. As was said above the reaction is the expansion of copyright protection (often caused by massive lobbying from the copyright industry ${ }^{182}$ ). In view of the opportunities of digital technologies and the Internet for access to knowledge and education, it appears that legislators have unduly taken into account the position of authors and right holders and not sufficiently considered the position of the users of copyright protected materials and the objectives they pursue. ${ }^{183}$ Regarding access to knowledge and education the Internet and digital technologies have the potential to improve conditions of access on a grand scale. It is therefore in the public interest to reduce the obstacles created by excessive copyright protection and to create the legal conditions to realise the potential for education and knowledge in the digital age.

\footnotetext{
${ }_{182}^{182}$ Dreier, Limitations: The Centrepiece of Copyright in Distress - An Introduction, 2010, para. 2.

183 Idem, para. 3.
} 


\subsubsection{Developing Countries}

Access to knowledge and education is crucial to social and human development in any society. ${ }^{184}$ In developing and least developed countries, however, this is even more important, because knowledge and education are key factors in the fight against poverty. ${ }^{185}$ The Internet and digital technologies have the potential to provide access to knowledge and education to large parts of the population at no or very low cost, provided that a minimum of technical infrastructure exists (which often is a problem). Via distance education for example students from poor rural areas may participate university lectures without having to undertake long and costly travels. In developing and least developed countries, where large parts of the population live in poverty and cannot afford to buy learning materials, libraries often are the only possibility of gaining access to the necessary information. Through libraries learning materials are available for everybody. Moreover, libraries regularly provide access to digital collections and the Internet through specific access points and terminals.

In this study the situation of Brazil and Mozambique with regard to copyright law and access to education and knowledge is examined. As will be shown later both countries do not classify as developed countries in view of their economic situation. Yet, there are different methods to determine the category a country fits in, depending on the respective organisation, i.e. United Nations, International Monetary Fund, or World Bank. ${ }^{186}$ A consistent terminology does not exist. ${ }^{187}$ Nevertheless, the classification into developed and developing countries is widespread and sensible. ${ }^{188}$ From developing countries are to be distinguished so-called Least Developed Countries (LDC), who are particularly poor. A list of 48 LDC is issued by the United Nations. ${ }^{189}$ Furthermore there are so called Newly Industrialised Countries (NIC). These are developing countries, which have achieved a certain level of social, political and economic development. ${ }^{190}$ With regard to Brazil and Mozambique in the course of this study the terms "developing country" and "least developed country" are used. From a copyright point of view these terms can be used interchangeably.

\footnotetext{
${ }^{184}$ See United Nations Education for All (EFA), available at

http://www.un.org/en/globalissues/briefingpapers/efa/index.shtml.

${ }^{185}$ UNESCO, "Education Counts", 2011, available at

http://unesdoc.unesco.org/images/0019/001902/190214e.pdf.

${ }^{186}$ Nielsen, Classifications of Countries Based on Their Level of Development: How it is Done and How it Could be Done, 2001, p. 3.

187 Ibid.

188 Idem, p.4.

189 United Nations, List of LDCs 2014, available at

http://www.un.org/en/development/desa/policy/cdp/ldc/ldc_list.pdf.

${ }_{190}$ Encyclopaedia Britannica, available at http://www.britannica.com/topic/newly-industrialized-country.
Enclist.ped.
} 


\subsubsection{Limitations and Exceptions and Access to Education and Knowledge}

Limitations and exceptions to copyright law permit specific uses of copyright protected works without the prior authorisation or consent of the author or right holder. They are the decisive means to realise the balance between the interests of authors and right holders regarding exclusive control over their works and the interests of individuals and/or the public regarding certain uses of protected works in the context of social and cultural participation ${ }^{191}$, although limitations and exceptions are not considered as rights of the person or institutions relying on them. ${ }^{192}$ In particular limitations and exceptions are based on different rationales, e.g. freedom of expression and information or the promotion of social, cultural or political objectives. ${ }^{193}$ Most prominent among these objectives are limitations and exceptions privileging education, research and the access to knowledge. Through limitations and exceptions legislators may promote specific goals such as wide and uncomplicated access to education and knowledge. ${ }^{194}$ In light of the developments of the digital age it must however be doubted, if the interests of authors and right holders regarding the protection of copyright and the interests of the general public regarding limitations and exceptions promoting the access to education and knowledge are still fairly balanced.

In the context of this study the legal meaning and understanding as well as the different forms of "limitations and exceptions" are explained. ${ }^{195}$ The terms "limitations", "exceptions" and "limitations and exceptions" will be used synonymously.

\subsubsection{Limitations and Exceptions and International Copyright Policy}

From the viewpoint of international law it must be noted that the protection of the rights of authors and right holders is compulsory, whereas limitations and exceptions are mostly optional. ${ }^{196}$ It is therefore argued that a minimum of compulsory limitations and exceptions should be introduced into international law. ${ }^{197}$ There are considerable efforts by stakeholders, such as library associations and other interest groups advocating access to education and knowledge, to incorporate into international law compulsory limitations and

\footnotetext{
${ }^{191}$ UNHCR, Farida Shaheed "copyright policy and the right to science and culture", 2014, para 61.

192 Dreier, Limitations: The Centrepiece of Copyright in Distress - An Introduction, 2010, para. 3; Eleni-Synodinou, The Lawful User and a Balancing of Interests in European Copyright Law, 2010, p. 819.

${ }^{193}$ Dreier, Limitations: The Centrepiece of Copyright in Distress - An Introduction, 2010, para. 4; in detail see Chapter 2.2.3.

194 UNHCR, Farida Shaheed "copyright policy and the right to science and culture",2014, p. 64.

${ }^{195}$ See Chapter 2.2.

196 Idem, p. 15; Dreier, Limitations: The Centrepiece of Copyright in Distress - An Introduction, 2010, para. 3; Cf. Guibault, Why Cherry-Picking never leads to harmonisation: The Case of the Limitations on Copyright under Directive 2001/29/EC, 2010, para. 13; Hugenholtz \& Okediji, Conceiving an International Instrument on Limitations and Exceptions to Copyright, 2008, p. 36.

${ }^{197}$ Cf. Okediji, The International Copyright System: Limitations, Exceptions and Public Interest Considerations for Developing Countries, 2006, p. 22/23; Gwen Hinze, Making Kowledge Accessible across Borders: the Case for Mandantory Minimum International Copyright Exceptions and Limitations for Education, Capacity Building and Development, 2008, p. 5.
} 
exceptions privileging specific uses, especially for educational purposes and in libraries and archives. In particular developing countries favour broad compulsory limitations and exceptions to Copyright privileging libraries and archives and educational purposes. Together with the other interest groups they advocate for respective treaties with the World Intellectual Property Organisation (WIPO). ${ }^{198}$ Since 2008 the Standing Committee on Copyright and Related Rights (SCCR) has discussed continuously the changes brought about by the Internet and the development of digital technologies and the impact on the work of providers of education and libraries, archives and other institution preserving cultural heritage, such as museums. In March 2008 at the 16th session Brazil, Chile, Nicaragua and Uruguay proposed that the SCCR should work on limitations and exceptions, especially in for educational purposes, libraries and archives as well as for visually impaired people. ${ }^{199}$ At the 17th session of SCCR in November 2008 a study by Prof. Kenneth Crews regarding limitations and exceptions for libraries and archives was presented. ${ }^{200}$ At the 19 th session in December 2009 five studies dealt with limitations and exceptions for educational purposes in all regions of the world. ${ }^{201}$ In June 2010 at the 20th session the African group presented a "Draft WIPO Treaty on exceptions and limitations for the disabled, educational and research institutions, libraries and archives Centres“. ${ }^{202}$ In June 2011 the African group presented another draft treaty. ${ }^{203}$ At the 23rd session in November and December 2011 limitations and exceptions for libraries and archives were discussed and the USA ${ }^{204}$ as well as Brazil, Ecuador and Uruguay $^{205}$ presented proposals for compulsory limitations and exceptions. Further proposals for limitations and exceptions for educational purposes and libraries and archives were presented at the 24th session in July 2012. ${ }^{206}$ At the 26th session in December 2013 limitations and exceptions for libraries and archives and educational purposes were discussed again. ${ }^{207}$ Although not in the field of education and libraries, but with strong social and humanitarian background, on June 27, 2013, the "Marrakesh Treaty to Facilitate Access to Published Works for Persons Who Are Blind, Visually Impaired, or Otherwise Print Disabled“ was adopted. ${ }^{208}$ It requires contracting parties to introduce a standard set of limitations and exceptions to copyright rules in order to permit reproduction, distribution and making available of published works in formats designed to be accessible to Visually

\footnotetext{
${ }^{198}$ See Civil Society statement on exceptions and limitations for education, WIPO 24th SCCR, Geneva, 16-24, July 2012, available at https://www.eff.org/de/document/civil-society-statement-exceptions-and-limitationseducation-wipo-24th-sccr-geneva-16-24.

${ }^{199}$ WIPO SCCR/16/2.

200 WIPO SCCR/17/2.

201 WIPO SCCR/19/4-8.

202 WIPO SCCR/20/11.

${ }^{203}$ WIPO SCCR/22/12.

${ }^{204}$ WIPO SCCR/23/4.

${ }^{205}$ WIPO SCCR/23/5.

${ }^{206}$ WIPO SCCR/24/6-8.

${ }^{207}$ WIPO SCCR/26/3, 4 and 8

${ }^{208}$ Marrakesh Treaty to Facilitate Access to Published Works for Persons Who Are Blind, Visually Impaired, or Otherwise Print Disabled, available at http://www.wipo.int/wipolex/en/treaties/text.jsp?file_id=301016.
} 
Impaired Persons, and to permit exchange of these works across borders by organizations that serve those beneficiaries. At the 27th session in April/May 2014 the USA submitted a paper presenting objectives and principles for exceptions and limitations for educational, teaching and research institutions. ${ }^{209}$ At the 28th session in July 2014 proposals for appropriate international instruments regarding limitations and exceptions for libraries and archives as well as educational teaching and research institutions were discussed. At the 30th session in July 2015 a new study regarding limitations and exceptions for museums was presented. ${ }^{210}$ As well at the 31 st session from December 7 to December 11, 2015, in Geneva, limitations and exceptions in favour of educational and research institutions and for libraries and archives were on the draft agenda again ${ }^{211}$, but more than a proposal to analyse copyright law with regard to the digital environment by the Group of Latin American and Caribbean Countries was not achieved. ${ }^{212}$ Nevertheless a binding declaration or even a treaty incorporating such compulsory limitations and exceptions for educational purposes and libraries, archives and museums could not yet be concluded. The 32nd session from May 9 to May 13, 2016 focused again on this issue ${ }^{213}$ and a draft of a study on limitations and exceptions for educational activities was presented. ${ }^{214}$ For the next session from November 14 to 18, 2016, limitations and exceptions for both educational purposes and libraries and archives are on the agenda. ${ }^{215}$ In view of technological developments and Internet a proposal presented by the Republic of Argentina advocates for harmonising limitations and exceptions with regard to digital cross-border uses of protected works in the field of access to education and knowledge. ${ }^{216}$

The UN special rapporteur in the field of cultural rights Farida Shaheed emphasised the urgent need for a readjustment of the balance of interests in copyright law and called for a list of minimum limitations and exceptions privileging libraries and education in international copyright law. ${ }^{217}$ Stakeholders heavily supported the statement of the UN special rapporteur ${ }^{218}$ and also among scholars it is consensus that binding limitations and exceptions, which cannot be overridden by contract, must be introduced into international copyright law. ${ }^{219}$

\footnotetext{
${ }^{209}$ WIPO SCCR/27/8.

${ }^{210}$ WIPO SCCR/30/2

${ }^{211}$ WIPO SCCR/31/1 Prov.

212 WIPO SCCR/31/4.

${ }^{213}$ WIPO SCCR/32/1 Prov.

${ }^{214}$ WIPO SCCR/32/4.

${ }^{215}$ WIPO SCCR/33/1 Prov.

${ }^{216}$ WIPO SCCR/33/4.

217 UNHCR, Farida Shaheed "copyright policy and the right to science and culture", 2014, para. 109.

${ }^{218}$ IFLA, Global library and archives community welcomes new report from United Nations special rapporteur on copyright policy and the right to science and culture, 2015, available at

http://www.ifla.org/files/assets/clm/statements/global-library-and-archives-community-welcomes-new-report-from-

${ }_{219}^{\text {un }}$ Hugenholtz \& Okediji, Conceiving an International Instrument on Limitations and Exceptions to Copyright,
} 


\subsection{Summary Chapter 1}

The aim of Chapter 1 was to illustrate the background and context for the study of limitations and exceptions to copyright law for educational purposes and libraries and archives and to create an awareness for the issues under consideration. Therefore, the terms "education" and "e-learning" were clarified. The prominent role of e-learning was highlighted. New modes to deliver education, such as OER and MOOCs were described. The understanding of the terms "libraries", "archives" and "museums" and the activities of these institutions with regard to copyright law where explained. The general significance of copyright law and its objectives as well as the significance of access to knowledge and education were highlighted. The challenges to create a fair balance of interests in light of changes of the digital age and the needs of developing and least developed countries were pointed out. Finally, the significance of limitations and exceptions to copyright law in the area of access to education and knowledge and developments of international copyright policy were demonstrated. Against this backdrop the reader shall be able to put the following detailed analysis of copyright law and limitations and exceptions for educational purposes and libraries and archives into context.

2008, p. 38; Okediji, The International Copyright System: Limitations, Exceptions and Public Interest Considerations for Developing Countries, 2006, p. 22/23; Davies, Access v Contract: Competing Freedoms in the Context of Copyright Limitations and Exceptions for Libraries, 2013, p. 413/414; Afori, The Battle over Public ELibraries - taking stock and moving ahaed, 2013, p. 409. 


\section{CHAPTER 2: Significance of Limitations and Exceptions}

The creation of works of intellect takes place in a social context. The creator needs his audience and vice versa. The creator demands protection for his work, the audience (or the simple consumer) demands access to the work. Considering this interplay, copyright law tries to establish a just balance of the interests involved. In favour of the creator it provides exclusive protection rights to safeguard the personal connections to and the financial exploitation of the work. Those exclusive rights, however, are not unrestricted. In order to enable the public and private consumption of the works protected, copyright systems mostly provide for carefully balanced legal constructions of so called limitations or exceptions to the creators 'exclusive rights, that exempt certain actions from the control of the creators or set limits to their sphere of influence.

The systematic realization of the interplay between exclusive rights and limitations, however, differs from country to country. For the purpose of understanding the solutions offered by copyright law, one must start with analysing the various historical developments as well as the different philosophical and systematic approaches that underlie the respective conception of copyright and its limitations.

In the paragraphs hereafter, the historical development of copyright law from the first conceptions in the ancient world over the system of privileges to the first national laws will be described and explained. Subsequently, the philosophical foundations of copyright law will be outlined and put in context with today`s copyright laws.

\subsection{Origins and Rationales of Copyright Protection}

Considering the great variety of today's national copyright laws and the systematical separation of copyright law into two legal traditions, on the one hand the common law copyright tradition and on the other hand the civil law authors' right tradition, it is surprising that at the beginning of what we now conceive as copyright law one will come across the same historical roots and developments as starting points of current copyright systems. This holds true too for the philosophical attempts to justify copyright protection and the limitations of exclusive rights.

\subsubsection{Historical Development of Copyright Law}

Taking a look back into the history of copyright law, one soon will notice that the various constructions established to protect the creations of the human mind depend to a great 
extend on the social, political and technical evolutions within a certain time. Thus, none of the theoretical approaches pursued in the course of history can claim to be the only possible solution. On the contrary, each of them reflects the particular conditions of society at a specific point of time and therefore is not absolute in its principles and stipulations.

This holds true as well today for the two main traditions of copyright law which have evolved in the eighteenth century. The distinction between "Copyright" and "Authors' Right" approach is not logically consistent, but a result of historical, legal and philosophical development.

\subsubsection{Ancient World and Middle Ages}

The complaint about plagiarism has always been made by authors of literary, musical and artistic works and is as old as the first traces of copyright itself. ${ }^{220}$ In the ancient GrecoRoman world authors did not in the first place strive after remuneration for their works, because they often received a honorarium from a rich patron (or Maecenas) to promote their creative work. ${ }^{221}$ Above all authors were seeking personal fame and recognition of their authorship. Consequently, the complaints did not primarily concern the unauthorized copy and dissemination of a work for commercial purposes, but rather the assumption of authorship. ${ }^{222}$ The roman poet Martial described this practice of unauthorised copying in his famous epigram, in which he compared one of his poems that had been passed off by another writer as his own, to a child who had fallen into the hands of an abductor, Latin "plagiarius". ${ }^{223}$ Hence the term "plagiarism".

In the middle ages, there is less evidence for complaints about plagiarism. During this period creative work was carried out mostly by craftsmen or monks and performed for the honour of God, not for the author's individual vanity. ${ }^{224}$ Often, authors from that period of time are not known by their name. As members of guilds or monasteries the "artists" were socially secured and received remuneration for their works. ${ }^{225}$ Moreover, the reproduction of manuscripts was a very laborious and time-consuming work, mainly done by monks for religious purposes. ${ }^{226}$ And beyond that the majority of the population was illiterate and therefore not interested in books. Thus, the massive copying of books and other creative works during the Middle Ages was neither technically possible nor socially demanded. Nevertheless, there are reports on complaints about plagiarism, for example by Albertus

\footnotetext{
${ }^{220}$ Boytha, Whose right is copyright?,1983, p. 379.

221 Schack 2015, no. 103.

222 Ibid.; Copinger and Skone James 2011, no. 2-08.

223 Schack 2015, no. 103; György Boytha, Whose right is copyright?, 1983, p. 379; Eggert, Der Rechtsschutz der Urheber in der römischen Antike, 1999, p. 188.

224 Stig Strömholm, Copyright - National and international development, 2007, p. 3 - 4.

225 Schack 2015, no. 104.

${ }^{226}$ Copinger and Skone James 2011, no. 2-08.
} 
Magnus or Eike von Repgow. The latter was especially afraid of a mischievous distortion of his work that could be published in his name and therefore put a spell on his books cursing everybody who would infringe his rights. ${ }^{227}$

\subsubsection{The Age of Privileges}

The fifteenth century brought a major technical change in Europe, the invention of the letterpress with movable types by Johannes Gutenberg around $1440 .{ }^{228}$ This invention for the first time in history made the mass production of literature and any other printable work possible. However, not the author of a book was normally protected by the precursors of copyright. It was the printer or publisher who was granted an exclusive printing or publishing right by the respective authority, a so called privilege. ${ }^{229}$ The reasons for granting such privileges were very similar all over Europe at that time. First of all, the authorities used privileges as a means of censorship in order to control the information disseminated by printed material, secondly privileges were supposed to promote a new and promising industry to further develop and finally, printers and publishers were seeking protection for their investments against unfettered competition by creating monopolies. ${ }^{230}$

The first privilege in history was granted to Johannes of Speyer in 1469 by the city of Venice and held that he was exclusively allowed to print in Venetian territory and its dominions for a period of five years. ${ }^{231}$ This privilege consequently established a monopoly for a limited period of time in a limited territory safeguarding the commercial interests of his owner. As one can observe here clearly, the protection of the printer of a work was intended, not the protection of the author. Thus, privileges of this kind are called "printing privileges". Only in the sixteenth century one will find so called "author privileges" granted to an author in order to protect his work against illegal reproduction. ${ }^{232}$ The first of this kind of privileges was granted to the historian Marco Antonio Sabellico by the city of Venice in 1486 to authorize the publication of his work on Venetian history. ${ }^{233}$ Nevertheless, the predominant motive of such "author privileges" was the protection of commercial exploitation of a work in favour of the author, not the recognition of a "copyright law of property" in a modern sense. A third way of protecting printers, publishers and authors of the commercial disadvantages caused by unauthorized reprints was the installation of so called "reprint prohibitions" or print monopolies which, different than the individual privileges, established general interdictions to

\footnotetext{
227 Schack 2015, no. 104.

228 Schack 2015, no. 105.

${ }^{229}$ Ricketson/Ginsburg, 2006, no. 1.01.

230 Ibid.; Boytha, Whose right is copyright, 1983, p. 379.

${ }^{231}$ Kostylo, Johannes of Speyer's Printing Monopoly (1469), 2008.

232 Schack 2015, no. 107.

${ }^{233}$ Marco Antonio Sabellico's Printing Privilege (1486).
} 
reprint or generally granted a printing monopoly. ${ }^{234}$ For the latter kind of protection, the Royal Charter of the Company of the Stationers' is the first example. In 1557, it legally established the company and conferred on her the exclusive control over printing in England. ${ }^{235}$ In the company's register all rights had to be entered which concerned material that could be reproduced by print. On that basis members of the company were conceded the "right to copy" for their lifetime, which after the death of the beneficiary fell back to the company and was conferred on another member. ${ }^{236}$

As one can observe, the privileges in general had the character of measures of protection against unfair competition, securing the investments made by printers and publishers. The authors, however, mostly did not have the financial power to publish their works on their own. Moreover the opinion still was dominant that an artist in his work was expressing some divine gift and therefore no remuneration had to be paid for the intellectual work itself. At most, the artist received a compensation for the raw material from which he had created his work. Finally, this was also due to the fact that the self-conception of authors at that time was more of craftsmen than of artists. With the oncoming ideas of the Renaissance this attitude was changing gradually into a more conscious belief in the value of one's works as an artist. Consequently, the personality of the author, his interests, needs and rights are much more reflected in the respective legal provisions in the period following the age of privileges.

\subsubsection{First National Laws}

The systematic change from individual privileges to general acts of law regulating the issues connected with printing and publishing did not come all of a sudden but happened gradually. Thus, the first acts of national legislation often only mirror the preceding achievements. Certainly, step by step new ideas of justifying the protection granted for intellectual works strengthening the position of the author towards the printer and publisher find entrance into the oncoming legislation.

\subsection{United Kingdom}

As one of the first acts of copyright legislation the United Kingdom enacted in 1710 the "Statute of Anne", upholding the legislative tradition of the afore mentioned "Company of the Stationers". ${ }^{237}$ The act did not establish a totally new and different system of regulation but it concentrated the various means of regulation used before in one legislative act passed by

\footnotetext{
234 Schack 2015, no. 107.

235 Stationers' Charter (1557).

${ }^{236}$ Boytha, Whose right is copyright? 1983, p. 379.

${ }^{237}$ Ricketson/Ginsburg, 2006, no. 1.02.
} 
the Crown in Parliament. ${ }^{238}$ Although the "Statute of Anne" was mainly a summary of the previous legislation, it introduced two major extensions. One was the acknowledgement of the author's role as a main figure next to the printer and publisher, the other was the principle of a limited term protection for published works. ${ }^{239}$ These innovations are already expressed in the preamble of the Act: "An act for the encouragement of learning, by the vesting of copies of printed books in the authors or purchasers of such copies, during the time therein mentioned. 240 The Act granted the authors of works already published the exclusive right of printing them for a term of 21 years from the date of the entry in power of the Act. ${ }^{241}$ For unpublished books the Act provided for the protection of exclusive printing rights during a term of 14 years from the day of the first publication to the author or his cessionary under the condition that the work concerned had previously been entered in the register of the company of the Stationers. ${ }^{242}$ After this 14 years period the exclusive printing right fell back to the author, if he was still alive, and was granted for another term of 14 years. ${ }^{243}$ Although the provisions of the "Statute of Anne" in the first place still protected the interest of the printers and publishers organized in the company of the Stationers, the status of the authors was changing slowly but significantly. ${ }^{244}$

Another important period in the development of copyright in the United Kingdom from a printing monopoly under public law to an assignable property of the author under civil law started in 1731. After 21 years the above mentioned monopoly of the company of the Stationers to print books already published by the time the "Statute of Anne" had come into force expired. Scottish printers and publishers took advantage of the expiry and put new editions of old books formerly protected by the monopoly on the market. ${ }^{245}$ This evoked the opposition of booksellers and publishers from London who had been the beneficiaries of the monopoly. In various cases before the English and Scottish courts the booksellers argued that by common law authors had perpetual rights to authorize printing independent from the grants of the "Statute of Anne". These rights had been assigned to them, the booksellers, and could therefore be bequeathed to their heirs. ${ }^{246}$ The fundamental question was whether an author had by nature arising from the act of creation the exclusive and inalienable right of property of his work (including the right to copy) or if the copyright was only granted by

\footnotetext{
${ }^{238}$ Bently, Global Copyright, 2010, p. 8.

239 Copinger and Skone James 2011, no. 2-16.

${ }^{240}$ Statute of Anne, 1710, 8 Anne, c. 19.

${ }^{241}$ Copinger and Skone James 2011, no. 2-16.

242 Strömholm, Copyright - National and international development, 2007, p. 6.

${ }^{243}$ Strömholm, Copyright - National and international development, 2007, p. 6; Copinger and Skone James 2011, no. 2-16.

244 Ricketson/Ginsburg, 2006, no. 1.02.

${ }^{245}$ Copinger and Skone James 2011, no. 2-17.

${ }^{246}$ Ibid.
} 
statute and thus was thereby limited. ${ }^{247}$ In 1769, the Court of King's Bench in the case of Millar v. Taylor held that regardless of the provisions of the "Statute of Anne" an author enjoyed the exclusive and perpetual right of publishing his work. ${ }^{248}$ In the case of Donaldson v. Beckett in 1774 the House of Lords however came to the paradox conclusion that common law copyright very well existed but nevertheless was overruled by the provisions of the "Statute of Anne". ${ }^{249}$ This decision thus abolished the common law copyright in all published literary works and set an end to the literary property debate.

What can be observed very clearly regarding the history of copyright in the United Kingdom is the commercial origin of the right. Less important than in the continental civil law tradition are moral rights of the author, based in natural law thinking. Copyright is regarded rather as a commercial asset than an institute reflecting the author's personality.

\subsection{The United States of America}

The history of copyright in the United Kingdom is the prehistory of copyright in the USA. ${ }^{250}$ The first federal law of copyright, the Federal Copyright Act of 1790 is largely modelled after the "Statute of Anne". ${ }^{251}$ But already before the first federal US copyright act the influence of British law was strong on the regulation of printing and publishing in the then colony. Local directives similar to the privileges known in Europe existed with the paramount aim to facilitate censorship and to protect commercial interests of printers or publishers. ${ }^{252}$ The first of such "colonial privileges" was granted in the year 1673 in the state of Massachusetts in order to protect a certain publisher from competition. ${ }^{253}$ It had a duration of seven years and did not refer to authorship or common law copyright at all. ${ }^{254}$ Local privileges of this kind, however, remained the only copyright legislation in the colony until in 1783 the first general copyright act came into force in the state of Connecticut and was passed in twelve of the then thirteen states of the Union until $1786 .{ }^{255}$ The influence of British law is conspicuous as already the title "An Act for the Encouragement of Literature and Genius 1783" reveals which was inspired by the preamble of the "Statute of Anne" ${ }^{256}$ Although the statute was referring vigouresly to natural rights, common law copyright and the protection of authors reflecting the

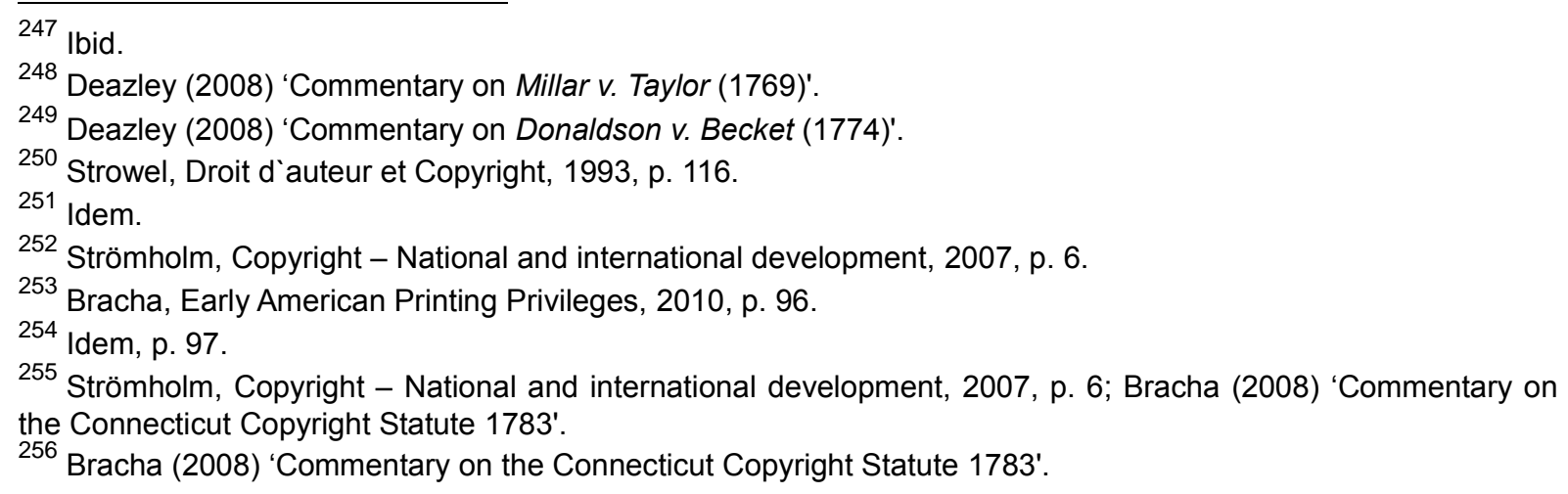


ideological discussions caused by the claim of literary property in England (s. above p. 6/7), it provided for plenty of rules and formalities restricting protection, e.g. protection limited to residents of the respective state or a state that had issued copyright laws. ${ }^{257}$ Nevertheless, these copyright acts are the first laws in US history representing a new author-based copyright ideology justified by natural law and public interest, which prepared the ground for the developments still lying ahead. ${ }^{258}$

The ideas expressed in the Connecticut Act 1783 and the following state acts finally found entrance into the initially mentioned Federal Copyright Act in 1790. The US constitution, which had come into force in 1789 had established Congress and conferred upon it the power "to promote the progress of science and useful arts, by securing for limited times to authors and inventors the exclusive right to their respective writings and discoveries". 259

The Federal Copyright Act itself was entitled "an act for the encouragement of learning, by securing the copies of maps, charts, and books, to the authors and proprietors of such copies, during the times therein mentioned". It was obviously inspired by the "Statute of Anne", which has almost the same title. ${ }^{260}$ But the similarities continue throughout the entire act. It was necessary for example to register a work in order to obtain protection and the duration of copyright was limited to 14 years with the possibility of renewal for another 14 years if the author was still alive by the end of the first term. ${ }^{261}$ As a heritage of the privileges one must consider the restriction that the persons entitled to protection had to be citizens of the United States. This led especially in the nineteenth century to unbridled piracy of English books. ${ }^{262}$ Nonetheless the Federal Copyright Act of 1790 clearly placed the author of a work at the centre of copyright and stated that all other entitlements were derivative of those of authors. ${ }^{263}$

\subsection{France}

In France the first legislation on copyright, which abolished the regime of the privileges, was passed in 1790 shortly after the Revolution in 1789. Before the Revolution as well all over Europe as in France a system of privileges was in power protecting in the first place the commercial interests of printers and publishers and facilitating censorship by the authorities.

260 The "Statute of Anne" is entitled "An Act for the Encouragement of Learning, by Vesting the Copies of Printed Books in the Authors or Purchasers of such Copies, during the Times therein mentioned".

261 Bracha (2008) 'Commentary on the U.S. Copyright Act 1790'.

262 Schack 2015, no. 115; Strömholm, Copyright - National and international development, 2007, p. 7.

263 Bracha (2008) 'Commentary on the U.S. Copyright Act 1790'.
} 
The privileges were granted by the King to certain printers and publishers securing their monopoly in editing books already belonging to public domain. ${ }^{264} \mathrm{New}$ books had to be submitted to a University board for approbation. In fact, the King was using this procedure to effectively exercise censorship because the final permission to print depended on his consent. ${ }^{265}$ The author however normally did not benefit from the protection by a privilege even if in some cases he obtained an individual privilege. However, the only possibility for an author to profit from that individual privilege often was to assign it to a printer or bookseller. ${ }^{266}$ Privileges usually had a short duration period of three to ten years in order to enable the printer or publisher to regain his investments but not more. ${ }^{267}$ After this period the works fell into public domain. It was only in 1566 when the ordinance of Moulins stipulated that printers and publishers had to indicate their name and the privilege which entitle them to print a certain work. ${ }^{268}$ From 1610 they had to enrol these information in a register in which all privileges were entered. ${ }^{269}$ But very rarely the names of the authors were mentioned in these contexts. Throughout the entire Ancien Régime the system of privileges remained valid and was only overcome by the Revolution and its aftermaths.

Two revolutionary decrees consequently are considered milestones in the history of copyright, at least in continental civil law tradition because they clearly describe for the first time the idea of copyright or droit d'auteur as a right of property. ${ }^{270}$ The first decree, passed in two sessions on thirteenth and nineteenth of January 1791 established the "right of public performance". An author thus could henceforth decide if his work was to be performed in public. During the proceedings the delegate Isaac René Guy Le Chapelier made his famous statement underlining the absolute character of this new kind of property. ${ }^{271}$ The second decree dates from the year 1793 and was again passed in two sessions, on the nineteenth and twenty-fourth of July. This law provided for the author's "right of reproduction", compromising the exclusive right to sell, let others sell, and distribute their works on the territory of the republic, and to transfer that property in full or in part. The new right was given to authors of all kind, writers, composers, painters as well as drawers engraving paintings. ${ }^{272}$

\footnotetext{
${ }^{264}$ Strowel, Droit d`auteur et Copyright, 1993, p. 83.

265 Ibid.

266 Ibid.

267 Strömholm, Copyright - National and international development, 2007, p. 5.

${ }^{268}$ Latournerie, Petite histoire des batailles du droit d'auteur, 2001/2, p. 37.

269 lbid.

270 Schmidt-Szaleski, Die theoretischen Grundlagen des französischen Urheberrechts im 19. und 20. Jahrhundert, 1993 , p. 187.

${ }^{271}$ Strowel, Droit d`auteur et Copyright, 1993, p. 90: "La plus sacrée, la plus légitime, la plus inattaquable et, si je puis parler ainsi, la plus personnelle de toutes les propriétés, est l'ouvrage, fruit de la pensée d'un écrivain..."

${ }^{272}$ Art. 1 Décret de la Convention National du 19 Juillet 1793: „Les auteurs d'écrits en tout genre, les compositeurs de musique, les peintres et dessinateurs qui feront graver des tableaux et dessins, jouiront, durant leur vie entière du droit exclusif de vendre, faire vendre, distribuer leurs ouvrages dans le territoire de la République, et d'en céder la propriété en tout ou en partie."
} 
Following Art. 2 of the decree this right remained with the heirs of the author or with the person it had been transferred to for ten years after the author's death (post mortem auctoris) before it became public domain (domaine public). ${ }^{273}$ The possibility for the author of transfering his property "in full" to someone else however involved the danger that after having transferred the full property the acquirer, most often a publisher, of course could do whatever he wanted to do with it, even modify it. ${ }^{274}$ This legislation remained effective until March 11, 1957. It was superseded by a new law, which should have adapted the old provisions to modern times. ${ }^{275}$

\subsection{Germany}

The situation in Germany was again different. A uniform development concerning copyright legislation was almost impossible until the foundation of the Reich in 1871 because of the fragmentation of the country into lots of independent and autonomous territories. Therefore the system of privileges prevailed in some territories for a much longer period than in others. ${ }^{276}$ Electoral Saxony for example was one of the most progressive states and issued already in 1773 a statute summarising the traditional privileges into one reliable decree prohibiting unauthorised reprints. ${ }^{277}$ This legislative activity was due to the fact that the city of Leipzig had developed into a major centre of book-trade and the printing and publishing industry hosting the famous book fair twice a year. ${ }^{278}$ Of course, the Saxon statute only provided for the protection of commercial interests of book-traders, printers and publishers, the authors however were not mentioned at all. The impetus to the new legislation thus was the political and commercial aim to strengthen the position of Leipzig as the centre of book production in the Holy Roman Empire. ${ }^{279}$

In 1794 Prussia issued its famous Prussian Statute Book. ${ }^{280}$ It contained some very general provisions referring to publishing rights and reprints though nothing was said about the character of copyright and the way the author's interests should be safeguarded in relation to printers and publishers. ${ }^{281}$

\footnotetext{
${ }^{273}$ French Literary and Artistic Property Act (1793).

${ }^{274}$ Strömholm, Copyright - National and international development, 2007, p. 8

275 Schmidt-Szaleski, Die theoretischen Grundlagen des französischen Urheberrechts im 19. und 20. Jahrhundert, 1993, p. 188.

${ }^{276}$ Especially in Southern Germany privileges remained constitutive of copyright protection, cf. Schack 2015, no. 116.

${ }^{277}$ Loewenheim/Vogel in Loewenheim, 2010, § 2 no. 5.

278 Ibid.

${ }^{279}$ Vogel, From privilege to modern copyright law, 2010, p. 116.

${ }^{280}$ Preußisches Allgemeines Landrecht (1794)

${ }^{281}$ Loewenheim 2003, § 2 Rn. 11, p. 10; Schack 2015, no. 116, p. 59, Vogel, From privilege to modern copyright law, 2010, p. 119.
} 
In 1815 the Congress of Vienna passed the obligation for the German Confederation to prohibit the continuing unauthorised reprinting of books, which only in 1835 led to the prohibition of reprinting throughout the territory of the German Confederation. ${ }^{282}$ Eventually in 1837 the Prussian "Law for the Protection of Property in Works of Scholarship and the Arts against Reprinting and Reproduction" came into force and took the role of the pioneer within the German Confederation. It focused on the author and provided him with far-reaching rights at that time such as the right of reproduction, the right of distribution, performing rights and the right to publish his work. ${ }^{283}$ All these rights were granted thirty years post mortem auctoris. ${ }^{284}$ The act influenced various laws of other German territories, e.g. Saxony in 1844 and Bavaria in 1865, and inspired significantly the Copyright Act of the North German Confederation in 1870, which was adopted by the German Empire in 1871.

\subsubsection{Copyright and Droit d’Auteur: Philosophical Foundations}

In the course of history numerous philosophical concepts have been pursued in order to justify the respective copyright system. It would however go beyond the scope of this analysis to describe all opinions held, which is why only the two main lines of argument shall be presented in the following. These are the individual natural law rationale and the utilitarian rationale. Additionally, a short presentation of the so called economic rationale of copyright law shall conclude this paragraph.

The study of the philosophical foundations of copyright systems is not a merely theoretical or academic question. ${ }^{285}$ In fact it is essential for the profound understanding of practical applications and functions of the copyright system. The rationales behind the rights conferred and the limitations provided is based on specific philosophical reflections, which have developed over centuries and still hold true today. When it comes to interpret the law in case of uncertainties one will turn towards the rationales behind a provision for the purpose of finding the balance between the various interests involved.

The above mentioned two main lines of argument have to be divided in the individualistic natural law based ideas generally associated with the continental civil law droit d'auteur systems on the one hand and on the other hand the utilitarian concepts normally associated with the Anglo-American common law copyright systems. Although it is assumed that these

\footnotetext{
282 Loewenheim 2003, § 2 Rn. 11, p. 10; Vogel, From privilege to modern copyright law, 2010, p. 120.

${ }^{283}$ Vogel, From privilege to modern copyright law, 2010, p. 120.

284 Schack 2015, no. 117.

285 Guibault, Copyright Limitations and Contracts, 2002, p. 7.
} 
two rationales are completely contrasting, this is true only in part. Of course considering the basic ideas (on the one hand personality rights of the author, on the other hand public interest in education and culture) the contrast is fundamental, but there are several overlaps, which proof that a sharp division into two entirely separate systems is not possible. Nevertheless, the following overview will be divided into a natural law and a utilitarian part. Finally, the economic rationale as a younger and entirely different approach to copyright justification will complete the presentation.

\subsubsection{Natural Law Rationale}

The natural law theory finds the paramount objective of copyright in the protection of the author's property in his creation. Through the act of creation he by nature acquires "intellectual property" which provides him with moral as well as economic rights regarding his work. Both the moral and the economic aspect of the property right emanate from the "personal creation" which describes the special relationship between the author and his work. ${ }^{286}$ Centred on the person of the author the natural law rationale for copyright protection is a primarily individualistic one. It has its origins in the new conception of man that emerged throughout the periods of Enlightenment and Renaissance. By emphasising individuality the person of the author begins to occupy centre stage. According to natural law philosophy, the author's rights are not granted by law but exist by nature and accrue to the author through the act of creation. ${ }^{287}$ In the above mentioned French revolutionary laws of 1791 and 1793 the natural law ideas find their first legal expression, the philosophical concept lying underneath however had already been devised by John Locke in his famous Second Treatise of Civil Government of $1690 .^{288}$

Therein Locke describes a world of abundance where the supply of resources never runs dry and everybody is free to pick up the fruits of the earth. ${ }^{289}$ The earth's fruits belong however in a state of nature to the commons by the will of God. Only the effort ("labour") one invests to pick up the fruits or create something from the raw material provided by nature justifies the acquisition of private property. Locke assumes that a man`s labour amends something to the pure thing in his state of nature, increases his value so to speak: "That labour put a distinction between them and common: that added something to them more than nature, the common mother of all, had done; and so they became his private right." ${ }^{290}$ Yet the Lockean labour theory refers to the acquisition of private property in tangible goods but nothing is said

\footnotetext{
${ }^{286}$ Guibault, Copyright Limitations and Contracts, 2002, p. 8.

287 Grosheide, Auteursrecht op Maat, 1986, p. 128.

288 Locke's Second Treatise on Government (1690).

289 Strowel, Droit d’auteur et Copyright, 1993, p. 184

290 Locke's Second Treatise on Government (1690), Chapter V, Section 28.
} 
about property in intangible goods i.e. works of intellect. The real world generally is not characterised by the abundance of things, nonetheless regarding intangible goods a world of abundance is conceivable more easily. ${ }^{291}$ One must only imagine for example the pool of ideas and creations that exist in form of cultural heritage, which for countless generations of authors has been a rich source of inspiration without diminishing the actual amount of ideas and creations itself. ${ }^{292}$ Finally also the individualistic side to the natural law approach finds expression in Locke's treatise for he focuses on the individual labourer the moment acquiring property instead of turning to the effects of the acquisition of property for the entire society. ${ }^{293}$

The natural law rationale is generally associated with the droit dauteur systems of continental Europe. Traditionally moral rights evolving from the personality of the author play a more important role than in the Anglo-American copyright systems but of course economic interests of the author are protected, too.

\subsubsection{Utilitarian Rationale}

According to the utilitarian rationale the main objective of copyright is to foster social benefit by encouraging the creation and the dissemination of new works to the public. ${ }^{294}$ Utilitarian philosophy analyses legal norms and provisions following their utility for society. ${ }^{295}$ The central aim is to achieve "the greatest good for the greatest number". Based on the ideas of the English philosopher Jeremy Bentham and later on John Stuart Mill Utilitarianism follows the assumption that human behaviour is aligned only by the pursuit for the avoidance of "pain" and the achievement of "pleasure" by way of action. ${ }^{296}$ Under the "principle of utility" an action is therefore deemed utile when it augments "pleasure", no matter if it is the "pleasure" of the community or the "pleasure" of the individual. ${ }^{297}$ After Bentham also a "measure of government" is an action and consequently has to be evaluated by applying the "principle of utility". ${ }^{298}$ Legislation as a "measure of government" thus is to be considered utile when the sum of individual interests i.e. social welfare of the community is augmented. ${ }^{299}$ In order to achieve this goal the legislator usually grants special rights to individuals and prohibits certain undesired individual behaviours.

\footnotetext{
291 Senftleben, Copyright, Limitations and the Three-Step-Test, 2004, p. 11.

292 Ibid.

293 lbid.

294 Guibault, Copyright Limitations and Contracts, 2002, p. 8.

295 Leistner/Hansen, Die Begründung des Urheberrechts im digitalen Zeitalter, 2008, p. 481.

296 Bentham, An Introduction into the Principles of Morals and Legislation (1789), Chapter 1, Section I.

297 Ibid.

298 Idem, Chapter 1, Section VII.

299 Idem, Chapter 1, Section IV.
} 
Mainly the Anglo-American copyright tradition grounds on the utilitarian understanding and interpretation of legal norms. According to the US Constitution, for instance, the purpose of copyright legislation is "to promote the progress of science and the useful arts". ${ }^{300}$ Consequently from a utilitarian point of view copyright law is assessed by its value ("utility") for society. The role of the author is less important. He does not necessarily play the lead. However, it is accepted that an author will not create anything new unless he will receive protection for the result of the labour invested. The protection is guaranteed through the grant of exclusive rights, which enable the author to control the use of his work by third parties and as a consequence allow him to draw economic profits from certain uses of a work. These profits thus are the "incentive" for the author to create new works. ${ }^{301}$ It is between these two poles, the social welfare by dissemination of intellectual works to the public on the one hand, the control of dissemination of intellectual works through exclusive protection rights granted to the authors on the other, where the balance is to be achieved.

\subsubsection{Economic Rationale}

Built upon the utilitarian rationale of copyright law there is a third way of justifying copyright protection, the so called economic rationale. As a branch of the economic analysis of law the economic analysis of copyright law seeks to interpret legal norms less from the natural law based moral rights point of view but much more regarding the economic effect obtained by the respective copyright provisions on fostering innovations and social welfare. ${ }^{302}$ This neoclassical approach takes into account the growing economic importance of copyright. ${ }^{303}$

Following the economic rationale all intangible goods have the character of public goods. ${ }^{304}$ Public goods can be identified by non-excludability and non-rivalry. ${ }^{305}$ Non-excludability means that if a good, here a creative work, once is provided to the market people cannot be stopped from consuming it, even if they do not pay for the consumption. For example national defence or street lighting provided by the state are non-excludable because even if one person does not pay his part it will nevertheless be provided for. The economic effect is that there is no incentive to pay for a good that will be available anyway. However, if too many people refuse to pay, the good will not be produced.

\footnotetext{
${ }^{300}$ Article I, Section 8, Clause 8 Constitution of the United States of America.

${ }^{301}$ Senftleben, Copyright, Limitations and the Three-Step-Test, 2004, p. 13.

${ }^{302}$ Metzger, Urheberrechtsschranken in der Wissensgesellschaft: "Fair Use" oder enge Einzeltatbestände?, 2010 , p. 4.

${ }^{303}$ Senftleben, Copyright, Limitations and the Three-Step-Test, 2004, p. 14; Strowel, Droit dauteur et Copyright, 1993, p. 194.

${ }^{304}$ Landes/Posner, An Economic Analysis of Copyright Law, 1989, p. 326; Guibault 2002, Copyright Limitations and Contracts, p. 13; Benkler, Intellectual Property and the Organization of Information Production, 1999, p. 2.

305 Strowel, Droit d`auteur et Copyright, 1993, p. 204.
} 
A good is deemed to be non-rival if its consumption does not prevent the consumption of the same good by another person. ${ }^{306}$ For instance downloading a song from the Internet will not impede another person downloading the same song from the same source. Since the price of a non-rival good cannot be higher than the cost of consumption, which is (almost) zero it is very likely that the production of this good will decrease. Again there is no incentive to create new works because no economic revenue can be expected.

In order to avoid the underproduction of intellectual works the copyright system provides for exclusive protection rights (property rights) safeguarding the interests of authors and right holders. At the same time the general public and consumers are interested in far reaching free access to protected works hence every consumer is a potential author himself. By granting copyrights and other intellectual property rights to authors they can profit from their work and have the incentive to create new works which in turn is the benefit desired by society. ${ }^{307}$ Through copyright protection intellectual works become exclusive and rival goods on a free market where without the artificial allocation of protection they would lead to market failure because of actual non-excludability (i.e. free-riding). ${ }^{308}$ Following the economic analysis the copyright system is justified hence it provides the incentive for authors to create new works while enabling public access to these works. Whether the "incentive" approach to copyright pursued by the economic analysis has any effect on the creation of new works though has never been proven empirically. ${ }^{309}$

\subsubsection{Findings}

It is established in copyright literature and science that the rationales for granting exclusive (protection) rights to authors and right holders derive from legal developments in history and in philosophy. Therefore, as already stated initially it is necessary to bear in mind the historical roots and philosophical reflections underlying copyright law in order to understand and properly interpret today`s legal provisions. As will become clearer later on in this study knowing the history and the rationale of the respective national laws is essential regarding the efforts of international and European copyright harmonisation. Especially in the field of limitations and exceptions to copyright the different historical and philosophical origins are decisive factors on the way to a fair balance of interests.

\footnotetext{
${ }^{306}$ Strowel, Droit d’auteur et Copyright, 1993, p. 203.

307 Landes/Posner, An Economic Analysis of Copyright Law, 1989, p. 326.

308 Strowel, Droit d`auteur et Copyright, 1993, p. 204.

${ }^{309}$ Leistner/Hansen, Die Begründung des Urheberrechts im digitalen Zeitalter, 2008, p. 484.
} 


\subsection{Limitations and Exceptions within the Copyright System}

After having explained the different origins and rationales of copyright law in general one must now focus on the various legal embodiments of limitations and exceptions to copyright law in particular. Initially, the legal nature of copyright limitations will be analysed. Following this the most commonly used legal constructions establishing limitations and exceptions will be described and afterwards the justifications invoked for the existence of the respective provisions stipulating limitations and exceptions shall be discussed. Beforehand, however, I will try to standardise the terminology in regard to copyright limitations. There are several terms used in literature to describe the derogations from copyright, such as exceptions, exemptions, restrictions or limitations. Of course, it depends on the legal tradition which terms are used and what are the special implications indicating something about the notions lying underneath. Moreover, a common terminology does not exist. Nevertheless, there are implications of terms like "exceptions" or "exemptions" for instance which suggest the assumption that there is a general rule of copyright which can be broken only in very narrow special cases, where as the terms "restrictions" or "limitations" have a broader and more open meaning. ${ }^{310}$ Less common is the term "restriction", so that as a generic term "limitations" appears appropriate and will be used in the following.

\subsubsection{Legal Nature of Limitations and Exceptions}

The legal nature of copyright limitations is an issue of great importance to the perception of the copyright system as a whole. There are of course different notions about the legal nature of copyright limitations and its implications for the entire copyright system. Depending on what role one assigns to the limitations, there are significant consequences for interpreting the range of author's rights. Seeking to establish a just balance between the public interests incorporated in several limitations on the one hand and the interests of authors and right holders on the other it is obvious that copyright limitations are the counterpart to the author's rights and function as "tools par excellence for "fine-tuning" the rights protected under copyright". ${ }^{311}$ But not only the interplay between rights and limitations must be considered defining the legal nature of copyright limitations. The definition moreover strongly depends on the question which social and economic goals and effects we strive to achieve through copyright systems in general. Is it preferable to protect above all the interests of authors and right holders, namely (intellectual) property and personality rights or should we put public and private user interests, namely freedom of speech, freedom of information and the right to privacy first, for the cost of authors and right holders? None of these two extremes is

\footnotetext{
${ }^{310}$ Guibault. Copyright Limitations and Contracts, 2002, p. 16.

${ }^{311}$ Hugenholtz, „Fierce creatures, copyright exemptions: towards extinction?“, 1997, no. 2, p. 4.
} 
desirable. What counts is striking a just and proper balance. Finding that balance eventually depends on how the legal nature of copyright limitations is defined.

There are two aspects that have to be considered in search of copyright limitations' legal nature. First, do users of copyrighted works have a right to the privileged use by a certain limitation or do limitations only respect fundamental right and public and private interest in a certain privileged use? Of course, having a right to use a protected work in a certain way gives the user a much stronger position in face of the author or right holder who may want to prohibit this particular use. A mere interest, even a legitimate one, however, leaves the user to the author's randomness without any means to enforce his position. ${ }^{312}$ In legal literature these questions are subject to highly controversial discussions. The predominant opinion is that only the author is entitled by a right. In contrast, the limitations merely reflect the interests of the general public. ${ }^{313}$ This viewpoint is not surprising because especially in countries with droit d auteur legal tradition the central and strong position of the author as the key figure within the copyright system provides the source for all other considerations regarding user rights or interests. ${ }^{314}$ In fact, the wording of the preamble of WIPO treaty 1996 says "Recognizing the need to maintain a balance between the rights of authors and the larger public interest...". Following this, one has to distinguish between "rights of the authors" and "public interests". This distinction suggests a gap or hierarchy between the position of the author and the user to the cost of the latter. Consequently, the user's position weighs less and therefore will be considered less important than the position of the author within the balancing process. Yet, it must be doubted that fair results can be achieved by balancing positions of different weight because the balance most likely will strike to the side that weighs more, which is the side of the authors and right holders. Nevertheless it is legitimate and reasonable to highlight the author's position within the copyright system for it is him whose creativity shall be fostered for the benefit of society. Not as clear as the wording of the 1996 WIPO treaty's preamble is the wording of recital 31 of the European Information Society Directive 2001/29/EC that says " $A$ fair balance of rights and interests between the different categories of right holders, as well as between the different categories of right holders and users of protected subject-matter must be safeguarded". The above mentioned gap between rights and interests is less obvious here or even does not exist anymore. Still it is stated that "a fair balance" between the positions involved must be achieved. According to this the users position is not automatically the weaker one within the balancing process. All the more, because they are the addressees of participation rights laid down in many national constitutions and international conventions, such as for instance the United Nations

\footnotetext{
312 Geiger, Der urheberrechtliche Interessenausgleich in der Informationsgesellschaft, 2004, p. 817.

${ }^{313}$ Hilty, Urheberrecht in der Wissengesellschaft: "Wer will was von wem woraus?, 2003, p. 983.

${ }^{314}$ Geiger, Der urheberrechtliche Interessenausgleich in der Informationsgesellschaft, 2004, p. 817.
} 
Universal Declaration of Human Rights. Art. 26 para. 1 Universal Declaration of Human Rights stipulates that "everyone has the right to education." and art. 27 para. 1 Universal Declaration of Human Rights establishes that "Everyone has the right freely to participate in the cultural life of the community, to enjoy the arts and to share in scientific advancement and its benefits". As a counterpart article 27 para. 2 of the Universal Declaration of Human Rights though clarifies that "Everyone has the right to the protection of the moral and material interests resulting from any scientific, literary or artistic production of which he is the author".

If one puts these statements in context the only conclusion can be that not only authors do have rights, but also users. A gap or hierarchy between the weight of the different positions therefore does not exist. This assumption moreover is supported by the fact that fundamental rights provide for justifications of copyright law and its limitations. ${ }^{315}$ Hence everyone can rely on fundamental rights, a distinction between the positions of users and authors does not seem consistent. Besides, the content of authors rights is defined to a large extent by its limitations for they set limits to the reach of authors' rights and thereby clarify what they are and what they are not. ${ }^{316}$ Thus, the non-discrimination of both sides must be the logic consequence so that in regard to copyright limitations we should speak of users rights, which are equivalent to authors` rights.

The second important aspect relating to copyright limitations' legal nature is a terminological, yet as well a theoretical one. As already mentioned above the terminology regarding copyright limitations is not uniform. ${ }^{317}$ The use of different terms however implies a different understanding of the actual meaning. The term "exception" or "exemption" suggests that the respective use privileged is a mere exception to the general rule that exclusive authors' rights prevail over user interests. ${ }^{318}$ This observation leads to the assumption of a hierarchy between the positions involved. ${ }^{319}$ The term "limitation" though has another implication. Bearing in mind that the content of exclusive authors ' rights is defined by its limitations, the conclusion can only be that there is no general rule saying authors' rights regularly prevail over user interests but limitations and authors' rights face each other on the same level, thus are to be considered equivalent. ${ }^{320}$ Therefore, copyright limitations are not exceptions to

\footnotetext{
${ }^{315}$ Idem, p. 818; Hugenholtz: „Adapting copyright to the information super highway“ in The Future of Copyright in a Digital environment, 1996, p. 94.

${ }^{316}$ Geiger, Der urheberrechtliche Interessenausgleich in der Informationsgesellschaft, 2004, p. 818.

317 See Chapter 2.2.

318 Hugenholtz, „Fierce creatures, copyright exemptions: towards extinction?“, 1997, no. 2, p. 4.

${ }^{319}$ Geiger, Die Schranken des Urheberrechts im Lichte der Grundrechte - Zur Rechtsnatur der Beschränkungen des Urheberrechts, 2004, p. 150.

${ }^{320}$ Geiger, Die Schranken des Urheberrechts als Instrumente der Innovationsförderung, p. 461; Geiger, Der urheberrechtliche Interessenausgleich in der Informationsgesellschaft, 2004, p. 819.
} 
authors` exclusive rights but instruments to define the content and limits of those rights. ${ }^{321}$

Now, the question is what consequences are to be drawn from copyright limitations' legal nature for their interpretation and application. Considering the legal conception of copyright in countries of the droit d'auteur tradition the general rule is established that the author is placed at the centre of copyright law and exclusive rights safeguard his personal and financial interests. Thus, limitations setting limits to those exclusive rights are the exception to the rule and therefore have to be interpreted strictly and narrowly. ${ }^{322}$ The analogue application of copyright limitations to uses originally not privileged by them is principally prohibited for the purpose of safeguarding the financial interest of the author or right holder. ${ }^{323}$ This conception of course impedes the adaption of the law to new technological developments because the principle lying underneath states that the criteria for its interpretation are the actual circumstances the legislators had to deal with when he issued the respective norm. ${ }^{324}$ To put it straight, this inflexible and rigid interpretation and application of copyright exceptions "is ill-conceived" 325 and not appropriate to the digital environment of today. ${ }^{326}$ However, the dogma of strict interpretation of copyright limitations is gradually abandoned in order to take into account more appropriately the interest privileged by the respective limitation. ${ }^{327}$

The conception of copyright limitations providing for user rights leads to another conclusion. Considering this there is no reason for principally deciding in favour of the author. By contrast especially the countries of droit d'auteur tradition face great difficulties in adapting their copyrights laws to social and technical changes because of narrow and strict norm providing limitations. ${ }^{328}$ Though the need to adapt the law to new circumstances is essential in order to maintain a just balance of the positions involved. Moreover, considering the technological changes brought by the digital environment a strong expansion of the protection of authors rights can be observed without reassessing the new demands of the users coming along with technological change. If one seriously regards copyright limitations as norms providing for users ' rights it is necessary to interpret these norms with respect to the underlying

\footnotetext{
${ }^{321}$ Hugenholtz 1997, „Fierce creatures, copyright exemptions: towards extinction?“, no. 2, p. 4.

322 Geiger, Der urheberrechtliche Interessenausgleich in der Informationsgesellschaft, 2004, p. 819; for Germany see Götting in Loewenheim, 2010, § 30 no. 11.

${ }^{323}$ Geiger, Der urheberrechtliche Interessenausgleich in der Informationsgesellschaft, 2004, p. 819; for Germany see Götting in Loewenheim, 2010, § 30 no. 11; see also BGHZ 17, 266 - Grundig-Reporter.

324 BGHZ 17, 266 - Grundig-Reporter.

${ }^{325}$ Hugenholtz, „Fierce creatures, copyright exemptions: towards extinction?“, 1997, no. 2, p. 4.

${ }^{326}$ There are tendencies to overcome this principle, see for instance Metzger, Urheberrechtsschranken in der Wissensgesellschaft, 2010, and Hugenholtz/Senftleben, Fair use in Europe. In Search of Flexibilities, 2011.

327 Götting in Loewenheim, 2010, § 30 no. 12.

${ }^{328}$ Geiger, Der urheberrechtliche Interessenausgleich in der Informationsgesellschaft, 2004, p. 819;
} 
fundamental rights and therefore as equivalent to authors' rights. ${ }^{329}$ This approach can be justified in particular with regard the human right to education and the human right to take part in cultural, which both underpin limitations and exceptions promoting access to education and knowlegde. The realisation of both rights is the precondition for social and economic progress, since they safeguard individual formation and cultural participation through access to education and knowledge to the greater public good. Their significance for the development of open and inclusive societies is universally acknowledged and undisputed. Above that as regards international human rights law, the human right to education and the human right to take part in cultural life have the same level in terms of hierarchy as the right of authors to the protection of their moral and material interest, ${ }^{330}$ which also is based on the fundamental right to property. ${ }^{331}$ Thus it is clear that fundamental rights underlying both copyright protection and limitations and exceptions to copyright are equally important. In that case it is inconsistent to treat these positions differently on the level of copyright law and value authors principally more than users. As a result when it comes to balancing the positions at stake the underlying fundamental rights must be considered alike, which has not been the case lately. In order to readjust the balance in copyright law authors and user must meet on the same level. Therefore limitations and exceptions should be understood as user rights. In view of the digital environment, the increase of possibilities to access information from everywhere through the Internet and the author-oriented copyright policies in the last two decades, this is all the more necessary.

\subsubsection{Systematic Approaches to Limitations and Exceptions}

It is generally recognized in all national copyright systems, even in those which provide for strongest protection of authors 'exclusive rights, that in particular cases there is the need to limit these exclusive rights. This is because in certain special cases the rights and interests protected by copyright limitations outweigh authors' exclusive rights. The justifications invoked for granting such limitations can be reduced to three major categories: fundamental rights, public interest and market failure. ${ }^{332}$ Depending on the justification and the effects of the limitation itself on authors 'rights one will come across similar forms of implementing limitations into practice throughout all national copyright systems. Moreover copyright limitations limit author's economic rights. Moral rights protecting the personal and ideational interests of the authors are not abridged by certain limitations privileging special uses of a work. ${ }^{333}$ And last but not least there are strong systematic differences regarding limitations

\footnotetext{
329 Ibid.

${ }^{330}$ See in detail Chapter 3.3.

${ }^{331}$ Article 17 Universal Declaration of Human Rights.

332 Hugenholtz, "Fierce creatures, copyright exemptions: towards extinction?", 1997, no. 7, p. 11/12.

333 Ulmer 1980, p. 292.
} 
depending on the particular copyright system, notably common or civil law tradition.

\subsubsection{Open or Closed Catalogues of Limitations and Exceptions}

The necessary limitations of authors' exclusive rights and their implementation into practice differ significantly according to the copyright system`s legal tradition.

Usually in copyright systems of the civil law droit d'auteur tradition one encounters enumerative lists of certain specific uses of copyright protected works that are exempted from the author's protection rights. ${ }^{334}$ The closed character of this approach to copyright limitations constrains however to a narrow interpretation of the provisions granting limitations and principally forbids in such cases the analogue application of the law. ${ }^{335}$ The reason for this narrow interpretation is the perception that limitations are only exceptions to the general rule that authors' rights take precedence over users' rights and relates to the natural law rationale of droit dauteur legal tradition which places the author and the protection of his rights at the centre of copyright. ${ }^{336}$ Thus, authors' economic rights are interpreted in a broad and open way for the purpose of securing their financial interests as far as possible. ${ }^{337}$ As a consequence limitations are strictly defined and narrowly interpreted. ${ }^{338}$ However, there are growing tendencies to gradually move away from the narrow interpretation of limitations among scholars since considering that the technological changes happing with great pace lawmakers more and more are unable to anticipate and picture all developments lying ahead. ${ }^{339}$ Consequently, this has the very negative effect that the law is often not up to the mark and the courts interpreting it are in great difficulties to provide for the necessary flexible solutions in order to maintain a just balance of interests. Yet, the enumerative lists of limitations have the advantage of legal certainty on their side and in theory enable stakeholders to better assess their own legal position.

Taking, however, a look at the copyright systems of countries of the common law tradition, notably the United States of America, the alleged advantage of legal certainty is abolished in favour of open and vague "fair use" provisions such as sec. 107 U.S. Copyright Act in order to facilitate flexible and just decisions by the courts from case to case. ${ }^{340}$ Considering the utilitarian rationale underlying common law copyright systems the main goal of U.S. copyright

\footnotetext{
${ }^{334}$ Hugenholtz/Senftleben, Fair use in Europe, 2011, p. 6.

335 Melchiar in Schricker/Loewenheim, 2010, Vor § 44a ff. No. 18; Götting in Loewenheim, 2010, § 30 No. 11.

${ }^{336}$ See Chapter 2.1.2.1 and 2.2.1.

337 Metzger, Urheberrechtsschranken in der Wissensgesellschaft: "Fair Use" oder enge Einzeltatbestände?, 2010, p. 14; Schricker in Schricker/Loewenheim, 2010, § 11, No. 3.

${ }^{338}$ Strowel, Copyright et Droit d’auteur, 1993, p. 144; RGZ 130, p. 196, 206 - Codex aureus ("exceptiones sunt strictissimae interpretationis").

${ }^{339}$ Hugenholtz/Senftleben, Fair use in Europe, 2011, p. 7, 8; Loewenheim 2010, § 30 no. 12/13.

340 Idem, p. 8.
} 
law is to "promote the progress of science and useful arts". ${ }^{341}$ The exemption of certain "fair" uses of copyright protected works by the courts in concrete cases thus is essential for achieving the goal of producing and disseminating creative works for the benefit of society. ${ }^{342}$ It is evident that courts must have a wide range interpreting "fair use" provisions in order to find adequate solutions for all possible circumstances. Enumerative and closed lists of limitations obviously do not serve this purpose. Compared with this the "relative legal uncertainty" is acceptable in view of the flexibility. ${ }^{343}$ The open and rather vague wording of "fair use" provisions finally does not necessarily lead courts to always decide in favour of the user of a protected work. By contrast, common law courts can be much stricter in defining what is to be considered "fair use" in a particular case than their civil law counterparts bound by the anticipated legislative decisions.

\subsubsection{Forms of Limitations and Exceptions}

Independently from arranging copyright limitations in openly formulated "fair use" norms or providing enumerative lists of the privileged actions there are four main types of limitations to be found in almost all national laws. Again, terminology regarding the different forms of limitations is not consistent. Here in the following I will use the terms subject-matter limitations (or full exemptions), statutory licences, compulsory licenses and mandatory collective management.

\subsubsection{Limitations and Exceptions on Subject-Matter (Exemptions)}

The most severe encroachment of author's rights is the full exemption. ${ }^{344}$ In these cases a copyrighted work can be used freely without permission of the author and without paying any remuneration. For example quotations or ephemeral copies of a work or the use in school broadcasting are fully exempted from the author`s exclusive protection rights. ${ }^{345}$

\subsection{Statutory Licences}

Statutory licences provide for limitations of economic rights to the effect that the use of a work is permitted without the author's authorisation but bound to appropriate

\footnotetext{
${ }^{341}$ Article I section 8 Constitution of the United States of America.

342 Hugenholtz/Senftleben, Fair use in Europe, 2011, p. 7; Guibault, Copyright Limitations and Contracts, 2002, p. 20.

${ }^{343}$ Metzger, Urheberrechtsschranken in der Wissensgesellschaft: "Fair Use" oder enge Einzeltatbestände?, 2010, p. 24.

344 Melchiar in Loewenheim/Schricker, 2010, Vor §§ 44a ff. UrhG, no. 6, p. 937.

345 Götting in Loewenheim, 2010, § 30 no. 16.
} 
remuneration. ${ }^{346}$ The permission to use a copyrighted work in a certain way therefore is given by the law and the economic rights are alleviated to mere remuneration rights. ${ }^{347}$ Generally two reasons are invoked for implementing statutory licences. The first is that such licences provide for a compromise between authors and users because the use permitted by the law does not unduly harm authors interests and is bound to appropriate remuneration by the users. ${ }^{348}$ The second reason relates to market failure considerations. In order to cope with the difficulties emerging from the advancement of technology in the field of reproduction of copyrighted works and the effect on authors' financial interests legislators create norms generally exempting certain uses that cannot or only with great difficulties be inhibited by authors. ${ }^{349}$ Since authors cannot control anymore a particular exempted use of their works they at least have to receive the payment of proper remuneration for the purpose of safeguarding their legitimate financial interests. ${ }^{350}$ In almost all national laws examples for statutory licences exist for private copying or the usage of works for educational purposes and in libraries. ${ }^{351}$

\subsubsection{Compulsory Licences}

In contrast to statutory licences compulsory licences do not permit a certain use of a work without prior authorisation of the author. ${ }^{352}$ The author is much more obliged to contract with the user that asks for permission of usage under the terms provided by the law and of course against the payment of appropriate remuneration. ${ }^{353}$ Thus the compulsory licence strictly speaking is not an exception to the rule of exclusive authors 'right but only a limitation on the author's freedom of contract. There are some examples of compulsory licences in national copyright laws. ${ }^{354}$ The best-known and internationally applicable compulsory licences however can be found in art. 11 bis (2) and art. 13 of the Berne Convention concerning the broadcasting of literary and artistic works as well as the recording of musical works.

\footnotetext{
346 Ibid.; Melchiar in Loewenheim/Schricker, Vor §§ 44a ff. UrhG, no. 6, p. 937; Guibault, Copyright Limitations and Contracts, 2002, p. 22, Sterling, 2008, no. 10.20, p. 536.

347 Ulmer 1980, p. 292.

348 Ricketson/Ginsburg, 2006, no. 13.01.

${ }^{349}$ BGHZ 17, 266 - Grundig-Reporter; Guibault, Copyright limitations and contracts, 2002, p. 23.

350 One must bear in mind that market failure considerations for copyright limitations strongly depend on technological developments with the effect that as technology advances the reason for introducing certain statutory licences disappears (cf. Hugenholtz, "Fierce creatures, copyright exemptions: towards extinction?", 1997, no. 7, p. 13).

${ }^{351}$ Guibault, Copyright limitations and contracts, 2002, p. 24; Melchiar in Loewenheim/Schricker, 2010, Vor $\S \S$ 44a ff. UrhG, no. 6, p. 937.

352 Ulmer 1980, p. 292.

353 Götting in Loewenheim, 2010, § 30 no. 18; Melchiar in Loewenheim/Schricker, 2010, Vor §§ 44a ff. UrhG, no. 6, p. 937; Sterling, 2008, no. 10.20, p. 536; Ulmer, 1980, p. 292.

${ }^{354}$ Cf. $\S 42$ a UrhG and $\S 115$ U.S.C.A. both relate to the compulsory licence for making (and distributing) phonorecords.
} 


\subsubsection{Mandatory Collective Management}

The least severe encroachment of authors' economic rights is mandatory collective management, which in theory does not provide for limitations on authors` rights but forces authors and right holders to exercise economic rights in a certain predetermined way. ${ }^{355}$ The necessity to manage authors 'rights collectively is either a factual one, which means that for authors it is impossible to effectively administer the exploitation of the works due to their massive use. This is for instance the case for the public performance of musical works (or on the radio) where the number of uses is practically countless. Yet, collective management of authors` rights can be mandatory by law. In Europe mandatory collective management was introduced by the Satellite Broadcasting and Cable Retransmission Directive. ${ }^{356}$ The Directive stipulates in its Art. 8 the cable retransmission right as an exclusive author's right that must however according to Art. 9 para. 1 be exercised through a collecting society. ${ }^{357}$ This has to be safeguarded by the national legislator. ${ }^{358}$

Formally speaking, mandatory collective management does not deprive authors of their exclusive protection rights. Nevertheless in practice the author is not free to decide in favour of managing his rights on an individual basis. He is forced to contract with a collecting society and assign to it the right to exercise his economic rights. The collective society itself is then forced to authorise the use a work as long as appropriate remuneration is paid by the user. What is appropriate remuneration in these circumstances is fixed in so called bulk-licence agreements that are negotiated among collecting societies and user organisations. ${ }^{359}$ For authors this practice actually has almost the same effect as a compulsory licence. ${ }^{360}$ It shall be mentioned finally that the mandatory collective management of exclusive rights is very seldom. Very common however is the practice that the right of appropriate remuneration can only be exercised by a collecting society. ${ }^{361}$

\subsubsection{Justifications for Limitations and Exceptions on Authors` Exclusive Rights}

There are different rationales that are invoked in order to justify the existence of copyright limitations. Generally they can be divided into three main categories. Each category aims at protecting or safeguarding different interests that in the situations circumscribed by the

\footnotetext{
355 Götting in Loewenheim, 2010, § 30 no. 19, p. 414; Guibault, Copyright limitations and contracts, 2002, p. 26; Melchiar in Loewenheim/Schricker, 2010, Vor §§ 44a ff. UrhG, no. 38, p. 950.

${ }^{356}$ Directive 93/83/EEC of September 27, 1993.

357 Sterling, 2008, no. 26C.12(b), p. 1019.

358 Sterling, 2008, no. 10.21 , p. 536.

${ }^{359}$ Guibault, The Nature and Scope of Limitations and Exceptions to Copyright and Neighbouring Rights with Regard to General Interest Missions for the Transmission of Knowledge, 2003, p. 26.

360 Melchiar in Loewenheim/Schricker, 2010, Vor §§ 44a ff. UrhG, no. 38, p. 950.

${ }^{361}$ In Germany examples are § 52a para. 4 and $\S 52 b$ UrhG.
} 
respective limitation shall prevail above authors' interests. The first and probably most important category compromises limitations protecting fundamental rights such as freedom of expression and information or the right to privacy. The second category consists of limitations serving public interest. Limitations for educational purposes and libraries and archives can be located here. The third category of limitations wants to smoothen the effects of what is called market failure.

\subsubsection{Fundamental Rights}

Although many constitutions do not expressively mention copyright as a subject of protection it is nonetheless embraced by the right of physical property and thus enjoys constitutional protection. ${ }^{362}$ But as well on an international and European level copyright is anchored in several treaties, conventions and charters. ${ }^{363}$ It is regarded as a fundamental (property) right and protected as such. ${ }^{364}$ Copyright aims at securing the economic interests of the author by granting economic rights. The personality of the author expressed in his work is safeguarded by moral rights. Copyright's character as a fundamental right thus entails the legislators to provide for adequate protection in order to secure authors' rights. But the same holds true for the constitutionally rooted fundamental rights of the individual user of a copyright protected work. These fundamental rights are above all the freedom of expression and its particular characteristics, such as the freedom of information, ${ }^{365}$ the freedom of science and the freedom of the arts. Also, the right to privacy and the right of informational self-determination, which are facets of the personality right, have to be mentioned here. In the context of this study however most important to mention are human right to education and the human right to take part in cultural life. ${ }^{366}$

It is the task of legislators and courts to establish a just balance between the mitigating positions. On the one hand, authors' fundamental rights are protected by exclusive moral and economic rights in order to safeguard authors legitimate interests. The fundamental freedoms of users forming the general public on the other hand are reflected in the limitations on authors 'rights and serve as justifications for restricting authors' exclusive rights. ${ }^{367}$ Traditionally, limitations whose rationale traces back to fundamental rights are limitations for the purpose of criticism, news reporting, parody or scientific research. ${ }^{368}$

\footnotetext{
${ }^{362}$ E.g. article 14 GG (Germany); very explicitly article I section 8 clause 8 Constitution of the USA.

${ }^{363}$ Berne Convention, TRIPS, WIPO Copyright treaties, European Copyright Directives (esp. InfoSoc 2001/29/EC).

${ }^{364}$ See article 17 para. 2 Charter of Fundamental Rights of the European Union.

${ }^{365}$ See article 10 European Convention of the Protection of Human Rights and Fundamental Freedoms.

${ }^{366}$ See in detail Chapter 3.3.

367 Senftleben, Copyright, Limitations and the Three-Step-Test, 2004, p. 24; Geiger, Der urheberrechtliche Interessenausgleich in der Informationsgesellschaft, 2004, p. 817.

${ }^{368}$ Hugenholtz 1997, "Fierce creatures, copyright exemptions: towards extinction?", no. 7, p. 11.
} 


\subsubsection{Public Interest}

Some, if not the majority of limitations on copyright derive their justification from the rather abstract notion of "public interest". In this category can be located limitations for libraries and archives, educational purposes or cultural institutions such as museums as well as limitations in favour of blind and handicapped persons. All of these provisions have in common that they serve the overall objective of disseminating information and knowledge embodied in copyrighted works among members of society. ${ }^{369}$ Thereby governments pursue their goal to enhance democracy within society and foster information and education among its members. ${ }^{370}$ The existence of limitations serving public interest also expresses the conviction of lawmakers that within the process of balancing the different positions involved the benefit for society is greater when certain uses of copyright protected material are excluded from authors' protection rights. The prevalence of public interest considerations over authors' exclusive rights however does not necessarily mean that the authors have to tolerate the privileged use of their work without receiving appropriate remuneration. The legislators for instance can provide for statutory licences in order to safeguard authors' financial interests. $^{371}$

In this context it is important to clarify that limitations to copyright justified by "public interest" do not intend to facilitate the individual remuneration-free use of copyright protected works in general. By contrast, the author has only to accept certain determined uses of his work serving specific public interests. ${ }^{372}$ Limitations for educational purposes for example are justified only because society has a considerable interest in acquainting the young generation with works of intellect. ${ }^{373}$

Consequently, copyright law serves authors to protect their moral and financial independence on the one hand and the public on the other by enabling the free flow and the dissemination of information and knowledge as well as democracy enhancing free intellectual dispute. ${ }^{374}$ The utilitarian based copyright approach, which places the idea of copyright law serving public interest at the centre of reasoning finds its clear expression in art. I sec. 8 clause 8 of the US Constitution which states that "Congress shall have the power to promote

\footnotetext{
${ }^{369}$ Guibault, The Nature an Scope of Limitations an Exceptions to Copyright and Neighbouring Rights with regard to general Interests for the Transmission of Knowledge, 2003, p. 10; Senftleben 2004, p. 30.

${ }_{370}$ Guibault, The Nature an Scope of Limitations an Exceptions to Copyright and Neighbouring Rights with regard to general Interests for the Transmission of Knowledge, 2003, p. 30; Guibault, Copyright Limitations and Contracts, 2002, p. 69.

${ }^{371}$ Cf. in Germany $\S \S 52$ a, 52b UrhG, which provide for a statutory licence and mandatory collective management.

${ }_{372}$ Schricker, Urheberrecht zwischen Industrie- und Kulturpolitik, p. 245/246.

373 Ibid.

${ }^{374}$ Geiger, Der urheberrechtliche Interessenausgleich in der Informationsgesellschaft, 2004, p. 816.
} 
the progress of science and the useful arts, by securing for limited times to authors and inventors the exclusive right to their respective writings and discoveries." Thus if public interest justifies the existence of copyright itself, copyright law must serve public interest as well. In order to achieve this aim there are limitations on copyright. Hence public interest justifies copyright protection and copyright limitations. ${ }^{375}$

\subsubsection{Market Failure}

The third category of justifications for copyright limitations is the market failure argument. It is generally associated with the utilitarian rooted common law copyright system of the USA and a result of the economic analysis of copyright law. ${ }^{376}$ Therefore it is less utilized in European legal theory and practice for the purpose of justifying copyright limitations although for instance the rationale for private copy exceptions in Europe is often in addition to fundamental rights found in market failure considerations. ${ }^{377}$

Market failure takes place when certain goods that are demanded for are not produced and thus the existing demand cannot be satisfied. ${ }^{378}$ Generally, market failure always occurs when there are only public goods on the market and therefore the goods must be considered non-excludable and non-rival. ${ }^{379}$ Copyrighted works, i.e. intellectual goods are characterised by these features. They are non-excludable because their consumption cannot be easily limited to a group of persons or a single person and they are non-rival because once produced their consumption for a large or even unlimited number of persons is possible at little or no cost without loss of quality. ${ }^{380}$ Thus, works of intellect must be considered public goods. As a consequence intellectual goods will not be produced for these features hinder to trade them in an economically sensible way. Copyright law therefore pursues the goal of correcting this effect of market failure in order to foster the production of intellectual goods.

Market failure is also said to occur when high transaction costs impede the normal economic trade of goods. Concerning intellectual goods this is the case when authors are practically unable to control the uses of their works and claim adequate remuneration for it because the cost for doing so would be to high. ${ }^{381}$ In order to counteract these effects in continental

\footnotetext{
${ }^{375}$ Schricker, Urheberrecht zwischen Industrie- und Kulturpolitik, p. 245/246.

${ }^{376}$ Guibault, Copyright Limitations and Contracts, 2002, p. 78; see above 2.1.2.3.

377 Senftleben, Copyright, Limitations and the Three-Step-Test, 2004, p. 31; Hilty, Vergütungssystem und Schrankenregelungen Neue Herausforderungen an den Gesetzgeber, 2005, p. 822; Helberger/Hugenholtz, No Place like Home for making a Copy, 2007, p. 1071.

${ }_{378}$ Goldhammer, Wissenschaftsgesellschaft und Informationsgüter aus ökonomischer Sicht, 2006, p. 82.

${ }^{379}$ Idem, p. 84; see above 2.1.2.3.

380 Goldhammer, Wissenschaftsgesellschaft und Informationsgüter aus ökonomischer Sicht, 2006, p. 85; Guibault, Copyright Limitations and Contracts, 2002, p. 83/84.

${ }_{381}$ Guibault, Copyright Limitations and Contracts, 2002, p. 81; Senftleben, Copyright, Limitations and the ThreeStep-Test, 2004, p. 31.
} 
European copyright law there are limitations mostly in from of statutory licences, which allow for instance private copying against remuneration. ${ }^{382}$ The author or right holder has to tolerate the limitation of his exclusive economic right but at least the problem of rights enforcement is alleviated by subjecting the right of proper remuneration to mandatory collective management. ${ }^{383}$

Justifying copyright limitations with market failure considerations however has no moral or ethnical substance, for as soon as there is a means to cope with the effects of market failure the concept loses its right to exist. ${ }^{384}$ In the digital networked environment one possible solution to overcome market failure, is provided by technological protection measures and digital rights management (DRM) for thereby transaction costs could be significantly reduced and the excludable character of intellectual goods could be strengthened. ${ }^{385}$

As a result limitations on copyright that are justified only by market failure considerations have, other than limitations reflecting fundamental rights or public interest, no more reason to exist than market failure itself.

\subsubsection{Findings}

Copyright's paramount aim is to establish a just balance of the various interest involved when works of intellect are used. Depending on the different legal traditions the shape of this balance of interest varies widely form country to country. The utilitarian rooted US and UK system generally is less focused on the individual interest of authors for copyright is supposed to serve the wealth and development of the entire society. Where as in the natural law tradition of continental Europe the protection of authors' personal and financial interests is normally weighed higher than the social benefits derived from the use of a work of intellect.

Limitations on authors' exclusive copyrights are an integral part of copyright systems independently of the respective legal tradition. This is because they enable users to legitimately make use of copyright protected works in order to realise the fundamental freedoms and public interest objectives that serve as justifications for limitations on copyright. As was pointed out previously limitations reflecting fundamental rights and freedoms as well as public policy objectives have to be considered on the same level as the copyrights

\footnotetext{
${ }^{382}$ Helberger/Hugenholtz, No Place like Home for making a Copy, 2007, p. 1071.

${ }^{383}$ Guibault, Copyright Limitations and Contracts, 2002, p. 82; Hilty, ergütungssystem und Schrankenregelungen Neue Herausforderungen an den Gesetzgeber, 2005, p. 820/821; Helberger/Hugenholtz, No Place like Home for making a Copy, 2007, 1071.

${ }^{384}$ Senftleben, Copyright, Limitations and the Three-Step-Test, 2004, p. 31.

385 Goldhammer, Wissenschaftsgesellschaft und Informationsgüter aus ökonomischer Sicht, 2006, p. 90; Helberger/Hugenholtz, No Place like Home for making a Copy, 2007, p. 1071.; Guibault, Copyright Limitations and Contracts, 2002, p. 85/86.
} 
granted to authors for the protection of their moral and economic interests. Thus, the interests of the public and the users must be treated equally as the interests of authors and right holders in the balancing process for only by doing so a just balance of interests can be achieved.

Consequently, legislators are called to create the preconditions of establishing a just balance of the interests involved in copyright law. This task is clearly expressed in two norms of international and European law. The 1996 WIPO Copyright Treaty recognises in its preamble "...the need to maintain a balance between the rights of authors and the larger public interest, particularly education, research and access to information...". In this sense also the European Information Society Directive 2001/29/EC states in recital 31 that "A fair balance of rights and interests between the different categories of rightholders, as well as between the different categories of rightholders and users of protected subject-matter must be safeguarded". Article 27 of the Universal Declaration of Human Rights gets to the heart of the matter by stating in para. 1 and 2: "(1) Everyone has the right freely to participate in the cultural life of the community, to enjoy the arts and to share in scientific advancement and its benefits. (2) Everyone has the right to the protection of the moral and material interests resulting from any scientific, literary or artistic production of which he is the author."

Of course, these statements say nothing on what in concreto has to be considered a just and fair balance, but the concept of balancing interests is a shifting one. It has to be adapted to the always changing economic and technical circumstances in order to adequately depict the changes within society coming along. In achieving the goal of a just and fair balance of interests copyright limitations play a decisive role because they safeguard that there is a counterweight against authors exclusive rights. This is particularly important with regard to limitations and exceptions for educational purposes and libraries and archives under consideration here. The significance of access to education and knowledge for human and social development cannot be overestimated. In view of the changes brought about by the Internet and ICT regarding the possibilities to use copyright protected works, which authors and right holders encounter with the expansion of copyright protection and which is not reflected appropriately concerning limitations and exceptions, the fundamental principles and rationales of copyright law all the more have to be taken into account in order to create a just and fair balance of interests.

\subsection{Summary Chapter 2}

Chapter 2 examined the historical development of copyright law, its legal traditions and the 
different rationales. The legal nature of copyright limitations and exceptions and the different ways to incorporate limitations and exceptions into copyright systems were analysed. Above that, the various justifications for limitations and exceptions were explained and the significance of a fair balance of interests was highlighted. In the course of the following chapters these findings will be necessary to interpret the respective provisions of copyright law and to understand the patterns of argument behind. 


\section{CHAPTER 3: International and European Legal Framework of Limitations and Exceptions}

In the previous Chapter 2 the origins, the philosophical underpinnings and justifications as well as the functions and systematics of limitations and exceptions and their significance have been explained. Now it is time to focus on the respective provisions regarding limitations and exceptions in international and European law. Therefore in the following, the origin and the scope of the most important international treaties namely the Berne Convention, the Rome Conventions, the TRIPS agreement and the WIPO copyright treaties shall be outlined and interpreted. As well the relevant provisions of European law, namely the Information Society Directive 2001/29/EC and the Orphan Works Directive 2012/28/EU, will be analysed. Subsequently, the role of the Three-Step-Test in the context of limitations and exceptions will be examined.

\subsection{International Copyright Law}

Taking a look at the international dimension of copyright law one has to bear in mind the particularities of works of intellect. Books, compositions and artistic creations in general are independent of national boundaries. That means that their consumption and enjoyment is possible by the people in one country as well as by those in another, even if for instance a book needs to be translated in order to be understood entirely. ${ }^{386}$ This is not only true today were the dissemination of works of intellect appears to be a simple thing, but was a reality in the past as well. The unauthorized reproduction and use of (domestic) and foreign works have therefore always been a characteristic of cultural and social life. ${ }^{387}$ By establishing national copyright codes these problems could be diminished. Today, however, due to the possibilities offered by computer technology and the internet regarding the reproduction of works of intellect, the massive unauthorized reproduction and use of works today have reached unforeseen dimensions. Yet, in the $19^{\text {th }}$ century "piracy" and "counterfeiting" especially of foreign works developed into a major problem that was difficult to address for most national states had a rather bigot attitude towards that issue. On the one hand they were eager to protect the works of their national authors, on the other hand they did not fight against unauthorized reproduction of foreign works nor was this practice considered unfair or immoral. ${ }^{388}$ In some countries it was even regarded as an important contribution to the development of society and the divulgation of knowledge and education among its members that was achieved at very low cost by simply copying the original works without the authors

\footnotetext{
${ }_{386}^{386}$ Ricketson/Ginsburg, 2006, no. 1.20.

${ }_{387}^{387}$ Ibid.

388 Ibid.
} 
consent and the payment of royalties. ${ }^{389}$ The cheaply produced illegal copies of a work often did not only furnish the foreign market but found their way back into the country of origin of the original work where they competed at lower price with the original. ${ }^{390}$ In European history one can find numerous examples of copying foreign works throughout all ages, but it would break the mould of this chapter go into details here. Nevertheless, it is worth mentioning that until today countries with a high level of artistic and cultural production suffer more intensely from piracy than such countries that have a comparably low output of artistic and cultural works. ${ }^{391}$

Historically, it was the realisation that international piracy had to be prevented which gradually led to the development of international copyright relations during the $19^{\text {th }}$ century. ${ }^{392}$ Of course, the positive effects of cheap pirate copies were apparent and did not differ significantly from the arguments invoked to justify the unauthorized copying of works today. Unauthorized copies were cheaper and therefore their availability was greater which fostered the dissemination of the copied work not only abroad but also in the country of origin. ${ }^{393}$ The counter position mainly grounded on two arguments: the moral argument that it was unfair to deprive the author of the fruits of his labour and on the economic / pragmatic argument that the protection of a work of intellect in order to safeguard the benefit of the author provided for an incentive to create new works. ${ }^{394}$ Following this, the production of new works would diminish because of piracy and all countries would therefore be poorer. ${ }^{395}$

The growing awareness of the problems caused by the copying of foreign works, however brought about a development towards the gradual elimination of international piracy at least in Europe. The reasons for this can be found in the spread of the French droit dauteur doctrine (author's rights approach). ${ }^{396}$ Based on natural law philosophy the author of a work of intellect occupied centre stage according to the author's rights approach. Through the act of creation personal inalienable and economic rights accrue to the author by nature, independently of his nationality or the country where the work has been created. Thus, these rights cannot be restricted by such artificial creation as national boundaries and territorial

\footnotetext{
389 Ibid

390 lbid.

${ }^{391}$ Idem, no. 1.21; today the situation of developing countries must be observed in this context.

392 Ibid.

393 Idem, no. 1.22 .

394 See Chapter 2 for natural law rationale (2.1.2.1) and economic rationale (2.1.2.3).

${ }^{395}$ If that is in fact true remains a highly controversial issue until today and is highlighted in the context of music downloads via filesharing platforms, see Michael: The Impact of Digital Filesharing on the Music Industry: An Empirical Analysis (2006); Liebowitz: Filesharing - Creative Destruction or Just Plain Destruction? (2005); Liebowitz \& Watt: How to Best Ensure Remuneration for Creators in the Market for Music? Copyright and its Alternatives (2006) and Oberholzer / Strumpf: The Effect of Filesharing on Record Sales - an Empirical Analysis

$(2004)$.
396 See above 2.1.2.
} 
rights. ${ }^{397}$ This perception of the author's position found entrance into the French copyright decree from $1852^{398}$ and granted protection by French copyright law to all authors, no matter what provenience and regardless of the protection granted for French works by the country of origin of the author. ${ }^{399}$ The universal character of copyright expressed in the French doctrine and copyright decree served as an example for many European states with the effect that the protection of foreign works was gradually achieved.

The first step into the direction of protecting foreign works was pursued through national laws as France did in the afore-mentioned decree of 1852. The protection promised by the French decree yet did not guarantee the complete assimilation of foreign authors for they were only protected under French law as far as they were in their country of origin. ${ }^{400}$ In order to receive the same level of protection as French authors there had to be some kind of bilateral treaty between France and the country of origin of the foreign author that guaranteed national treatment. ${ }^{401}$ The laws of most countries however were much stricter, limiting the protection of foreign authors and their works to special criteria, for instance Germany that provided protection depending on the nationality (of the author) meaning that only German authors received protection. ${ }^{402}$ Foreign authors for instance were only protected in Germany if their works were published by a German publisher. ${ }^{403}$ In some more progressive countries it was only decisive where a work was published. This so called principle of territoriality consequently applied to all works published within the respective territory regardless of the nationality of the authors. ${ }^{404}$

The legal situation of authors abroad nonetheless was rather insecure because the question remained whether the rights of the author concerned could eventually be enforced in court. Anyway this was a costly and time consuming procedure and therefore did not meet with practical necessities of international copyright protection. A better and more reliable way of safeguarding copyrights at an international level was to make agreements between different states in which the precise conditions of reciprocal protection could be determined. ${ }^{405}$ Such agreements were concluded mostly on a bilateral level and laid the ground for the next step in the development of international copyright law, the conclusion of multilateral agreements of which the Berne Convention is the most prominent example. During the $19^{\text {th }}$ century the

\footnotetext{
${ }^{397}$ Ricketson/Ginsburg, 2006, no. 1.24 .

398 Decree-law of March 28, 1852.

399 Ricketson/Ginsburg, 2006, no. 1.24.

400 Idem, no. 1.25.

401 Idem, no. 1.25: only the later Belgium copyright law provided for complete equal treatment of national and foreign authors, except for the duration of protection.

402 Idem, no. 1.26, e.g. Nationality in the German Law of June 11, 1870, art. 61.

403 Ibid.

${ }^{404}$ E.g. UK, Austria, Italy or the Netherlands.

${ }^{405}$ Ricketson/Ginsburg, 2006, no. 1.28.
} 
conclusion of bilateral agreements led to a complex network of conventions whose content varied significantly. Nevertheless some main provisions were established as standard contents of bilateral agreements, e.g. the principle of national treatment, restrictions on reproduction rights ${ }^{406}$, the duration of protection and provisions concerning censorship by national authorities. ${ }^{407}$ Although there was some kind of reliability for authors who were seeking protection for their works abroad, the legal and actual situation was complicated and demanded further developments towards common international standards of copyright protection.

\subsubsection{Conventions, Agreements and Treaties}

As a sensible means to achieve the goal of common protection standards in international copyright law multilateral agreements appeared to be convenient and began to emerge gradually. The Berne Convention for the Protection of Literary and Artistic Works (hereinafter $\mathrm{BC}$ ) dating from the year 1886 is the first and most important of these agreements. But there are other important agreements such as the International Convention for the Protection of Performers, Producers of Phonograms and Broadcasting Organizations from 1961 (so called Rome Convention), the Agreement on Trade-Related Aspects of Intellectual Property Rights (so called TRIPS Agreement), the WIPO Copyright Treaty dating from 1996 (hereinafter WCT) and the WIPO Performances and Phonograms Treaty from 1996 (hereinafter WPPT). All these agreements have the purpose of establishing protection regimes for intellectual works by setting guidelines for national legislators. In part they compromise provisions regarding the protection of not only copyrights but related rights as well, which is the case for the Rome Convention, the TRIPS Agreement and the WPPT. In the following I will take a closer look at the contents of these multilateral agreements with special attention to the provisions concerning limitations for educational purposes.

\subsubsection{The Berne Convention}

The negative effects of the deficient protection of authors 'rights at an international level were one of the reasons that led to the formation of the Association Litteraire et Artistique Internationale ( $A L A l)$ in 1878 , the oldest professional association of copyright. ${ }^{408}$ In order to produce solutions to the problems of international copyright protection ALAI initiated four congresses in years 1882 until 1886. The first congress was held in Rome, the three others in Berne, where finally on September 9, 1886 a convention was adopted with the title Convention concernant la création d'une Union Internatinale pour la protection des oeuvres

\footnotetext{
${ }^{406}$ Among these were limitations for teaching and educational purposes (Ricketson/Ginsburg, 2006, no. 1.37).

${ }^{407}$ A detailed explanation of bilateral agreements gives Ricketson/Ginsburg, 2006, no. 1.29-1.42.

${ }^{408}$ Sterling, 2008, no. 18.01; Ulmer, 1980, § 14, p. 85.
} 
littéraires et artistiques. ${ }^{409}$ This convention was signed by Belgium, France, Germany, Haiti, Italy, Liberia, Spain, Switzerland and Tunisia, forming the first member countries of the Berne Union. ${ }^{410}$ It bears the name Berne Convention and since its first revision in 1908 in Berlin it has been also called the Revised Berne Convention. ${ }^{411}$ Until today there have been several revision conferences that improved the scope of protection step by step. These are:

- $\quad$ Additional Act of Paris, May 4, 1896

- Revised Berne Convention of Berlin, November 13, 1908

- Berne Additional Protocol, March 20, 1914

- $\quad$ Rome Act, June 2, 1928

- Brussels Act, June 26, 1948

- Stockholm Act, July 14, 1967

- Paris Act, July 24, 1971

It has however to be remarked that the basic principles which were established at the very beginning of the Berne Convention have remained almost the same in spite of all revisions. The present analysis in the following will refer to the provisions of the Paris Act $1971 .{ }^{412}$

\subsection{General Remarks and Elements of Protection}

The most important principle of the Berne Convention is "national treatment", which states that the works of authors whose country adheres to the union must be protected by national laws of another country adhering to the union in the same way that works of national authors. ${ }^{413}$ As we have seen before the principle of national treatment was not invented by the Berne Convention, but rather evolved in the course of the $19^{\text {th }}$ century and was incorporated in bilateral agreements. It was however fixed for the first time in the Berne Convention, expressing the claim for universal copyright protection. The principle of national treatment is enshrined in art. $3 \mathrm{BC}$.

The second principle governing the Berne Convention is the so called "minimum rights" standard. This means that all member countries of the union must provide for a minimum level of protection, which is defined by the Convention. ${ }^{414}$ These minimum standards of protection are the following:

\footnotetext{
${ }^{409}$ Ulmer, 1980, § 14, p. 85.

${ }^{410}$ Sterling, 2008, no. 18.01 .

${ }^{411}$ Nordemann/Vinck/Hertin/Meyer, 1990, Introduction No. 2.

412 This version of Berne Convention will be abbreviated as BC hereinafter.

${ }^{413}$ Nordemann/Vinck/Hertin/Meyer, 1990, Introduction No. 22.

414 Idem, Introduction No. 23.
} 
- Art. 5 para. $2 \mathrm{BC}$ states that "the enjoyment and the exercise of these rights shall not be subject to any formalities". Consequently, in all countries of the union copyright protection must be granted without the condition of prior registration or deposition of copies of the respective work. ${ }^{415}$

- Art. 2 BC sets out which kind of works shall be subject to protection. The wording of art. 2 para. $1 \mathrm{BC}$ repeats the expression "literary and artistic works" given by Art. 1 $\mathrm{BC}$ and adds a non-exhaustive, illustrative list of works protected. ${ }^{416}$ Art. 2 para. 1 defines the principle categories of works, the other paragraphs of art. 2 (except for art. 2 para. $6 \mathrm{BC}$ ) specify these categories and partly enlarge them. ${ }^{417}$

- Art. 2 para. $6 \mathrm{BC}$ provides that the protection granted by the Convention for the works thereby comprised "... shall operate for the benefit of the author and his successors in title.". 418

- In several provisions the BC contains the rights that must be protected by the Convention. The economic rights comprise the right of translation (art. $8 \mathrm{BC}$ ), the right of reproduction (art. $9 \mathrm{BC}$ ), the right of public performance (art. $11 \mathrm{BC}$ ), the right of communication to the public by transmission (art. 11bis $B C$ ), the right of public recitation (art. 11ter $\mathrm{BC}$ ), the right of adaptation (art. $12 \mathrm{BC}$ ) and the right of making cinematographic adaptation and reproduction of works as well as the right to distribute such works (art. $14 \mathrm{BC}) .{ }^{419}$ National laws thus must comply with these minimum standards.

- Art. 6bis BC states that authors must be granted inalienable "moral" rights, independently of economic rights. Inalienable because this rule shall apply even after the transfer of economic rights. Moral rights encompass the author's right to claim authorship, to object distortion, mutilation or other modification of his work as well as any derogatory action in relation to his work which would prejudice his honour or reputation.

- Art. $7 \mathrm{BC}$ establishes as a minimum duration of protection the life of the author and fifty years after his death. ${ }^{420}$ There are, however some deviant rules for certain categories of works, such as cinematographic works (cf. art. 7 para. 2 BC). In this case the term of protection is not linked to the author's death, but to the moment when the work in question was made available to the public with the consent of the

\footnotetext{
${ }^{415}$ Ricketson/Ginsburg, 2006, no. 6.102.

${ }^{416}$ Ricketson/Ginsburg, 2006, no. 8.09.

${ }_{417}^{41}$ Ricketson/Ginsburg, 2006, no. 8.74.

${ }^{418}$ In case of cinematographic works (art. 14bis BC) the question of ownership is left to national legislation. In Germany $\S 89$ UrhG provides for instance that in case of doubt economic rights are conceded to the producer of a cinematographic work.

${ }_{419}$ Art. 14ter BC contains the „droit de suite“ which is however subject to reprocity (cf. Art. 14ter para. 2 BC).

${ }^{420}$ Some countries go beyond the fifty years limit, e.g. Germany where $\S 64$ UrhG states that copyright ceases to exist seventy years after the death oft he authors.
} 
author, or, alternatively, to the making of the work itself. Thus, protection expires fifty years after the said points in time. Art. 7 para. 4 BC includes special rules for photographic works or works of applied arts which shall be protected at least for a term of twenty-five years after their making.

\subsection{Limitations and Exceptions}

A very important and fiercely disputed aspect of the "minimum rights" standard set by the BC is the question of limitations and exceptions to authors rights. This topic is at the centre of the present study and therefore shall be discussed afterwards more thoroughly with special attention to the limitations and exceptions for educational purposes and libraries and archives.

\subsection{General Remarks}

In order to maintain a just balance between the interest of the authors and/or right holders of protected works and the users of such works the Berne Convention provides for certain limitations on exclusive rights. These limitations can be divided into three groups. ${ }^{421}$ First, there are limitations that stipulate the complete exclusion of certain kinds of works from protection, for instance art. 2 para. 4 BC (official texts of legislative, administrative or legal nature), art. 2 para. $8 \mathrm{BC}$ (news of the day) and art. 2bis para. $1 \mathrm{BC}$ (speeches delivered in the course of legal proceedings). Second, there are limitations which allow that protected works maybe used without the author's or right holder's consent and without payment of remuneration. These limitations describe what can be called "permitted uses". ${ }^{422}$ Among these provisions are art. 2bis para. $2 \mathrm{BC}$ (reproduction and communication to the public of public addresses, lectures etc. by the press), art. 9 para. $2 \mathrm{BC}$ (certain exceptions to the reproduction right), art. $10 \mathrm{BC}$ (quotation and use for teaching purposes) and art. 10bis $\mathrm{BC}$ (certain uses for reporting of news). Third, there so called compulsory licences that allow certain uses of a work but subject them to the payment of remuneration. In the Berne Convention such provisions are incorporated in art. 11bis para. 2 BC (compulsory licences concerning the broadcasting of works) ${ }^{423}$, art. $13 \mathrm{BC}$ (compulsory licences concerning the recording of musical works) and in the Appendix to the Paris Act of Berne with respect to developing countries. ${ }^{424}$

\footnotetext{
${ }^{421}$ See Above 2.2.2.2.

${ }^{422}$ Ricketson/Ginsburg, 2006, No. 13.01.

${ }^{423}$ Art. 11 bis para. 3 BC provides that members of the Union are free to make exceptions for ephemeral or transitory recordings are made in order to exercise the rights mentioned in art. 11 bis para. $1 \mathrm{BC}$.

${ }^{424}$ Following the Appendix developing countries are free to provide for compulsory licences regarding translation and reproduction of works, e.g. for educational purposes.
} 
In the context of the present analysis, further attention will be dedicated later on in this Chapter to art. 9 para. 2 BC and the so called Three-Step-Test therein contained. Right now I will concentrate on the limitations serving educational purposes under the Berne Convention.

\subsection{Limitations and Exceptions for Educational Purposes}

\subsection{1 Utilization for Teaching}

The use of copyright protected works for the purpose of teaching has been subject to the $\mathrm{BC}$ from its very beginning. Art. 8 of the first version of the $B C$ of the year 1886 provided that

"the liberty of extracting portions from literary or artistic works for use in publications destined for educational or scientific purposes, or for chrestomathies, the effect of the legislation of the countries of the Union, and of special arrangements existing or to be concluded between them is not effected by the present Convention." ${ }^{425}$

As a result of the 1928 Berlin Conference art. 8 was renumbered as art. 10 but remained unchanged in its wording. ${ }^{426}$ By the Brussels Act of 1948 art. 10 para. 2 then was modified and now reads:

"The right to include excerpts from literary or artistic works in educational or scientific publications, or in chrestomathies, in so far as this inclusion is justified by the purpose, shall be a matter for legislation in the countries of the Union, and for special Arrangements existing or to be concluded between them."

This new wording brought no substantial changes for art. 10 para. 2 apart from the qualification that the regulation of the use of the mentioned excerpts was only subject to national legislation "in so far as this inclusion is justified by the purpose". ${ }^{427}$

Further, as a result of the 1967 Stockholm Conference art. 10 para. 2 received its current shape, which reads as follows:

"It shall be a matter for legislation in the countries of the Union, and for special agreements existing or to be concluded between them, to permit the utilization, to the

\footnotetext{
${ }^{425}$ Nordemann/Vinck/Hertin/Meyer, 1990, Original Version Berne Convention 1887.

${ }^{426}$ Nordemann/Vinck/Hertin/Meyer, 1990, Berlin Version Berne Convention 1908.

${ }^{427}$ Ricketson/Ginsburg, 2006, no. 13.44.
} 
extent justified by the purpose, of literary or artistic works by way of illustration in publications, broadcasts or sound or visual recordings for teaching, provided such utilization is compatible with fair practice."

Before the specific wording of the provision will be interpreted it must be noted that limitations for educational purposes under art. 10 para. $2 \mathrm{BC}$ are not mandatory but members of the Union are free to enact national rules in this area or to do so by concluding bilateral agreements. $^{428}$

Art. 10 para. $2 \mathrm{BC}$ applies to literary or artistic works. This term refers to art. 2 para. $1 \mathrm{BC}$ and is to be understood as stipulated there ${ }^{429}$ Hence, the catalogue of works listed by art. 2 para. $1 \mathrm{BC}$ is not exhaustive, it comprises every production in the literary, scientific and artistic domain. ${ }^{430}$

Replacing the word excerpts as it was used in the Brussels Version of 1948 by the word utilization opened the possibility of not only using parts of copyrighted works but entire works as long as the other requirements of art. 10 para. $2 \mathrm{BC}$ are met. Especially, the utilization must be justified by the purpose and compatible with fair practice.

Furthermore, the utilization must be made by way of illustration and for teaching in order to be covered by the limitation. These requirements led to the fiercely disputed issue at the Stockholm Conference to what kind of educational institutions art. 10 para. 2 BC should apply. The reports of the Conference clarify that "the word "teaching" was to include teaching at all levels - in educational institutions and universities, municipal and State schools, and private schools." 431 As a consequence, the limitation applies to "both elementary and university teaching, in both private and public institutions, as well as distance teaching." ${ }^{432}$ This strict interpretation thus excludes the use of copyrighted works in courses of adult education or of commercial nature, such as driving schools, or courses organised by trade unions and companies for their members and employees. ${ }^{433}$ Yet, if the institutions privileged by the limitation themselves offer e.g. adult education courses, this activity would be covered by the provision. In developing countries adult literacy campaigns would not be covered by

\footnotetext{
${ }^{428}$ Ricketson/Ginsburg, 2006, No. 13.45; Dreier in Dreier/Hugenholtz, Concise Copyright, Berne Convention, art. 10 note 3 .

${ }^{429}$ Ricketson/Ginsburg Vol. 1 No. 13.45.

430 Dreier in Dreier/Hugenholtz, Concise Copyright, Berne Convention, art. 10 note 3.

431 Report of the Main Committee I, Records 1967, 1148; cf. Ricketson/Ginsburg, 2006, no. 13.45; Nordemann/Vinck/Hertin/Meyer, 1990, Art. 10 (2) BC, No. 2; Dreier in Dreier/Hugenholtz, Concise Copyright, Berne Convention, art. 10 note 3 .

${ }_{432}$ Xalabarder, WIPO Study 2009 , p. 14.

${ }^{433}$ Nordemann/Vinck/Hertin/Meyer, 1990, Art. 10 BC No. 2; Dreier in Dreier/Hugenholtz, Concise Copyright, Berne Convention, art. 10 note 3 .
} 
art. 10 para. $2 \mathrm{BC}$, but may be allowed under the Appendix to the Paris Act. ${ }^{434}$

An aspect of great importance in the digital age is the question whether the term teaching refers only to instruction activities in classroom where teachers and pupils communicate face-to-face or whether new forms of online teaching or internet-based courses should be excluded. The word teaching itself indicates no such exclusion. Above that, in 1967 when the current version of art. 10 para. $2 \mathrm{BC}$ was elaborated, the intention of the Berne Convention was to enable educators to make use of new technologies in order to foster the goal of disseminating knowledge. ${ }^{435}$ This intention has therefore to be considered interpreting art. 10 para. $2 \mathrm{BC}$ in the light of today's technical possibilities and leads to the conclusion that the above mentioned online and internet-based instruction methods must fall in the scope of art. 10 para. 2 BC. ${ }^{436}$

The use of protected material for teaching is moreover only permitted to the extent justified by the purpose. This means that the use of a work must be necessary for the purpose of illustrating the subject taught. Consequently, it is only allowed to make use of the parts of a work actually needed in order to achieve the respective goal pursued by teaching. Albeit, the use of an entire work is covered by the limitation if it is necessary for the teaching purpose. ${ }^{437}$

Art. 10 para. 2 BC covers uses made by way of illustration in publications, broadcasts or sound or visual recordings. This prerequisite widened the scope of the provision compared to its predecessors for it allowed educators to take advantage of technologies that were new in 1967 when the provisions was passed. ${ }^{438}$ As pointed out above this ratio must be considered still today interpreting art. 10 para. 2 BC. Besides, art. 10 para. 2 BC does not impose any restrictions concerning the number of copies made in case of publications and sound or visual recordings made for teaching purposes. ${ }^{439}$ Hence there is no restriction in regard of the public reached by a broadcast for teaching purposes as a result there can be no restriction on the number of copies of publications and sound or visual recordings made for teaching purposes. ${ }^{440}$ In view of new possibilities for teaching offered by digital technologies, the question arises whether, for example, on-demand digital transmissions are allowed under art. 10 para. $2 \mathrm{BC}^{441}$ According to art. 11 bis para. $1 \mathrm{BC}$ broadcasting means "wireless

\footnotetext{
${ }^{434}$ Ricketson/Ginsburg, 2006, No. 13.45.

435 Ibid.; Xalabarder, WIPO Study 2009, p.14

${ }^{436}$ As Ricketson/Ginsburg point out, it is in this context not very consistent to hold up the distinction between educational institutions and adult education courses, cf. Ricketson/Ginsburg, 2006, No. 13.45.

${ }^{437}$ Dreier in Dreier/Hugenholtz, Concise Copyright, Berne Convention, art. 10 note 3; Nordemann notes that this prerequesite is the application of fair parctice, Nordemann/Vinck/Hertin/Meyer, 1990, Art. 10 BC No. 1 c).

${ }^{438}$ Ricketson/Ginsburg, 2006, No. 13.45.

${ }^{439}$ Ricketson, WIPO Study 2003, p. 15.

440 lbid.

${ }^{441}$ Ricketson/Ginsburg, 2006, No. 13.45.
} 
diffusion" and therefore includes satellite and terrestrial broadcasting as well as radio and television. ${ }^{442}$ Following this, on-demand transmissions are not covered by art. 10 para. 2 $\mathrm{BC}{ }^{443}$ Aside from that, the provision does not impose any further restriction on the kind of copy made for teaching purposes. For instance, there is no distinction between digital or analogue data carriers.

Finally, the use of a work for teaching purposes must be compatible with fair practice. This prerequisite functions as a flexible limitation to the range of application of art. 10 para. $2 \mathrm{BC}$ for it provides that a proper balance between the interests involved, namely the teaching purposes on the one hand and the author's right to control the uses made of his work in order to safeguard just remuneration on the other, must be maintained. Considering this, it would be incompatible with fair practice, for example, if the number of copies made for teaching purposes was so high that the normal exploitation of a work by the author would be prejudiced. ${ }^{444}$

Art. 10 para. $3 \mathrm{BC}$ eventually provides that

"Where use is made of works in accordance with the preceding paragraphs of this Article, mention shall be made of the source, and of the name of the author if it appears thereon."

The paternity right ${ }^{445}$ of the author is hereunder protected, yet limited to cases in which the name or the pseudonym of the author appears on the respective work and does not exist in cases where the works has been published anonymously. ${ }^{446}$ Moreover the name of the author and the source of the work used must be indicated for the person consuming a work for teaching purposes shall be enabled to clearly identify the work concerned. ${ }^{447}$

\subsection{Quotations for Educational Purposes}

Alongside the explicit limitations granted under art. 10 para. $2 \mathrm{BC}$ for educational purposes also art. 10 para. $1 \mathrm{BC}$ may function as a limitation for quotations made for educational purposes. Art. 10 para. $1 \mathrm{BC}$ reads as follows:

\footnotetext{
${ }^{442}$ Dreier in Dreier/Hugenholtz, Concise Copyright, Berne Convention, art. 11 bis, note 2 (b).

${ }^{443}$ The characteristic feature of on-demand transmissions is that they can be consumed at moments and places chosen by the recipients. This is the case for most internet-based applications. Broadcasting however does not leave this choice to recipients.

${ }^{444}$ If remuneration for the author can be secured by providing compulsory licences such uses may be more compatible with fair practice (cf. Ricketson, WIPO Study 2003, p. 15).

${ }^{445} \mathrm{Cf}$. article 6 bis BC.

${ }^{446}$ Dreier in Dreier/Hugenholtz, Concise Copyright, Berne Convention, art. 10 note 4.

447 Ibid., e.g. the work's title, the year of publication, volume etc.
} 
"It shall be permissible to make quotations from a work which has already been lawfully made available to the public, provided that their making is compatible with fair practice, and their extent does not exceed that justified by the purpose, including quotations from newspaper articles and periodicals in form of press summaries."

The provision was first incorporated into the Berne Convention at the 1928 Rome Conference but received its actual wording only at the Stockholm Conference in 1967.448

Furthermore art. 10 para $1 \mathrm{BC}$ does not contain any restrictions in regard to the kind of a work, the only prerequisite is that the quoted work must have been lawfully made available to the public. Besides the quotation must be compatible with fair practice which would be the case if it does not prejudice the normal exploitation of the quoted work and does not harm the legitimate interests of the author. ${ }^{449}$ Moreover the quotation is permitted if it does not exceed the extent justified by the purpose meaning that "no more may be quoted than is necessary in order to support or illustrate the ideas expressed by the person making the quotation for (...) educational or even artistic purposes." ${ }^{450}$ The last two prerequisites of art. 10 para. $1 \mathrm{BC}$ also determine the length of the quotation and enable a flexible application of the norm for in particular cases even the quotation of an entire work can be permissible (e.g. paintings, photographs). Hence there is no restriction regarding the addressees of the provision or the technology used for quoting, quotations may be made e.g. in digital format or on paper by teachers and students likewise as long as their extent is justified by the purpose and they are compatible with fair practice. ${ }^{451}$ As it is the case for art. 10 para. $2 \mathrm{BC}$, on quotations under art. 10 para. $1 \mathrm{BC}$ the name of the author and the source of the quoted work must be indicated in order to comply with art. 10 para. 3 BC. Finally, it has to be noted that art. 10 para. $1 \mathrm{BC}$ is of mandatory character, i.e. member states are obliged to include a quotation exception in their national laws. It is the only mandatory limitation within the Berne Convention`s system of limitations and exceptions.

\subsection{Limitations and Exceptions for Libraries and Archives}

The Berne Convention contains no provision addressing limitations and exceptions for the benefit of libraries and archives. Thus, the authority to an act limitations and exceptions for libraries and archives in accordance with the Berne Convention derives from article 9 para. 2

\footnotetext{
${ }^{448}$ Xalabarder, WIPO Study 2009, p.18.

${ }^{449}$ Nordemann/Vinck/Hertin/Meyer, 1990, Art. 10 BC No. 1 b).

${ }^{450}$ Dreier in Dreier/Hugenholtz, Concise Copyright, Berne Convention, art. 10 note 2 (a); cf. Ricketson, WIPO Study 2003, p. 13.

${ }^{451}$ Xalabarder, WIPO Study 2009, p. 19.
} 
BC. ${ }^{452}$ This provision stipulates that "it shall be a matter for legislation countries of the union to permit the reproduction of such works in certain special cases, provided that such reproduction does not conflict with the normal expectation of the work and is not unreasonably prejudice the legitimate interests of the author." The so-called Three-StepTest, which will be discussed later in this chapter in more detail, explicitly allows countries adhering to the Berne Convention to enact limitations and exceptions to the reproduction right, provided that the further prerequisites of article 9 para. $2 \mathrm{BC}$ are fulfilled. ${ }^{453}$ The ThreeStep-Test shall safeguard, that limitations and exceptions in national law are in conformity with the Berne Convention. ${ }^{454}$

\subsection{The "Minor Reservations" Doctrine}

In the context of limitations and exceptions it is necessary to mention another source of restrictions on authors 'rights. That is the so called "minor reservations" doctrine. The "minor reservations" doctrine roots in the protocols of the Brussels and the Stockholm Conferences. ${ }^{455}$ At the Brussels Conference the newly introduced art. 11 para. 1 gave rise to the question whether prior limitations in national laws of the member states on the right of public performance now embodied in art. 11 para. 1 were still permitted or required a explicit authorisation by the Berne Convention. It was concluded that such general provision, which would allow member states to uphold the respective limitations in their national laws should not be introduced for neither could the list of exempted uses be exhaustive nor should the member states that had not yet incorporated such limitations be motivated to include them now. Consequently, no provision regarding the right of public performance was proposed. ${ }^{456}$ However, the rapporteur general of the Conference, Marcel Plaisant, made the following statement:

"Your rapporteur général has been entrusted with making an express mention of the possibility available to national legislation to make what are commonly called minor reservations. The Delegates of Norway, Sweden, Denmark and Finland, the Delegate of Switzerland and the Delegate of Hungary, have all mentioned these limited exemptions allowed for religious ceremonies, military bands and the needs of child and adult education. These exceptional measures apply to Articles 11bis, 11bis, 13 and 14. You will understand that these references are just lightly pencilled in here, in

\footnotetext{
${ }_{452}^{452}$ Kenneth Crews, WIPO Study 2008, p. 19.

453 lbid.

454 Ibid.

${ }^{455}$ Cf. Ricketson, WIPO Study 2003, p. 34 -36; Ricketson/Ginsburg, 2006, No. $13.79-13.81$.

${ }^{456}$ Ricketson, WIPO Study 2003, p. 34; Ricketson/Ginsburg, 2006, No. 13.79, both with further references.
} 
order to avoid damaging the principle of the right. ${ }^{, 457}$

Thereby the idea to allow certain "minor reservations" existing in national laws on the right of public performance was extended to art. $11 \mathrm{bis}, 11 \mathrm{ter}, 13$ and 14. As a result, member states were free to provide for exceptions to these rights in their national laws under the condition that the uses exempted could be regarded as de minimis, meaning that the use is at least of little or no economic relevance. ${ }^{458}$ This understanding of the statement of the rapporteur general was confirmed by the delegates of the Stockholm Conference in $1967 .{ }^{459}$

Although the "minor reservations" doctrine is not part of the actual text of the Convention it can nonetheless be regarded as part of the "context" of the Berne Convention ${ }^{460}$ and therefore provides for some "legitimate supplementary aid to the interpretation of (...) all other limitations and exceptions expressly or impliedly permitted under the Berne Convention". ${ }^{461}$

In the present context the "minor reservations" doctrine is of special relevance for two reasons. Frist, the incorporation of limitations for educational purposes is expressly mentioned in the statement of Marcel Plaisant ("The Delegates (...) have all mentioned these limited exemptions allowed for (...) the needs of child and adult education."). ${ }^{462}$ Second, because thereby the assumption is endorsed that the use of copyright protected material for educational purposes under art. 10 para. $2 \mathrm{BC}$ is not limited to the uses therein mentioned, namely "publications, broadcast or sound or visual recordings" but is also permitted in case of the rights enshrined in art. 11bis, 11 ter, 13 and $14 \mathrm{BC}$.

It is clear however that the use of a copyrighted work for educational purposes under the "minor reservations" doctrine is only allowed under national law as long as the reservation is of "restricted character" (de minimis non curat lex) ${ }^{463}$ and complies with the Three-Step-Test enshrined in art. 9 para. 2 BC. ${ }^{464}$

\subsubsection{The Berne Appendix}

The Berne Convention includes since the Paris Act of 1971 a special set of rules taking into

\footnotetext{
${ }_{457}$ Ricketson, WIPO Study 2003, p. 34 with reference to Brussels Documents 1948, p. 100 in footnote 86.

458 Ricketson, WIPO Study 2003, p. 35.

${ }^{459}$ The „minor reservations" doctrine was even further extended to the right of translation (art. 8), cf. Ricketson, WIPO Study 2003, p. 35.

${ }^{460}$ Ricketson, WIPO Study 2003, p. 36

${ }^{461}$ Dreier in Dreier/Hugenholtz, Concise Copyright, Berne Convention, art. 9 note 4.

${ }^{462}$ Xalabarder, WIPO Study 2009, p. 21

463 Ibid; cf. Ricketson, WIPO Study 2003, p. 35; Brussels Documents 1948, p. 100.

${ }^{464}$ See below, 3.4 .
} 
account the needs of developing countries. The so-called Berne Appendix contains provisions, which allow developing countries under certain conditions to adopt compulsory translation and reproduction licenses. ${ }^{465}$ Developing and least developed countries regularly are concerned to promote literacy and development through access to education and knowledge. To achieve this goal it is required to access educational and informational materials. ${ }^{466}$ The authors and right holders of such works are protected by copyright and will authorise specific uses of their works, such as reproductions, translations or other only against payment, which is regularly difficult for developing and least developed countries because of lacking financial resources. ${ }^{467}$ However, most developing and least developed countries have the necessary copying technologies to reproduce copyright protected works and supply their markets with cheap copies. ${ }^{468}$ These copies of course must be available in the respective language, which causes another problem, because the exclusive translation right is granted to the authors and right holders. ${ }^{469}$ In order to solve this problem the Berne Appendix was established. The circulation and availability of copyright protected works in developing and least developed countries should be facilitated. ${ }^{470}$ Yet, the Berne Appendix provides for an extremely complicated licensing system regarding the reproduction right and the translation right. ${ }^{471}$ It must be doubted that the Berne Appendix has improved the situation of developing and least developed countries. Only a very small number of countries has made the declarations necessary for the application of the Berne Appendix. ${ }^{472}$ Even less of these countries have finally made use of the licensing system of the Berne Appendix. ${ }^{473}$ It appears, that the Berne Appendix has been a failure. ${ }^{474}$ Nevertheless, the Berne Appendix was included in the TRIPS Agreement ${ }^{475}$ and the WCT. ${ }^{476}$ Despite its deficiencies the Berne Appendix is the only provision in international copyright law taking explicitly into account the necessities of developing and least developed countries. ${ }^{477}$ Thus, a reform of the Berne Appendix with special regard to digital issues is demanded. ${ }^{478}$

\subsubsection{The Rome Convention ${ }^{479}$}

The Rome Convention dating from October 26, 1961, is the first and most important

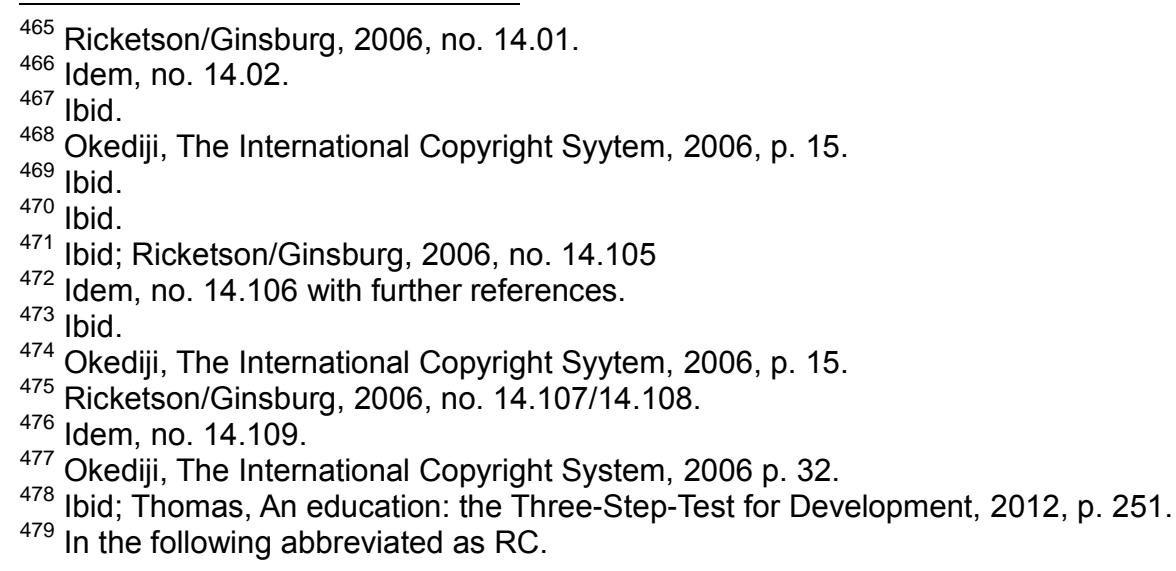


convention in the field of so-called neighbouring or related rights. Those are the rights of performers, producers of phonograms and broadcasting organisations. In this analysis they have been addressed as right holders.

In the early $20^{\text {th }}$ century it was realized that copyright and neighbouring rights differ considerably from each other regarding their nature. ${ }^{480}$ Moreover, the producers of sound recordings found themselves without international protection against piracy whereas the producers of cinematographic works received some protection under the Berne Convention. ${ }^{481}$ This was the case as well for performers involved in the production of sound recordings and films whose works neither were protected internationally. ${ }^{482}$ And it was in that age around 1920 when public broadcasting was introduced and soon developed to be the third party striving for international protection for its creative and organisational investments. ${ }^{483}$ From the 1930 s on there were several drafts for international conventions resulting finally in the passing of the International Convention for the protection of performers, producers of phonograms and broadcasting organisations in Rome (so-called Rome Convention). ${ }^{484}$

\subsection{Scope of Application and Principles}

Art. $1 \mathrm{RC}$ clarifies that the protection of performers, producers of phonograms and broadcasting organisations shall not prejudice the protection of copyright. Thereby the prevalence of the Berne Convention is safeguarded. Following art. 24 para. 2 RC member of the Convention can only become who is a member of the Berne Convention or the Universal Copyright Convention. The Rome Convention applies to the persons listed above which are defined more precisely in art. 3 RC. Art. 4, 5 and 6 RC describe to what achievements these provisions are attached in order to prompt the RC's protection regime.

Like the Berne Convention the Rome Convention follows the principles of national treatment (art. 2 RC) and minimum rights (art. 7, 10 and $13 \mathrm{RC}$ ). According to art. $7 \mathrm{RC}$ performers are granted the possibility of preventing certain acts without their consent. This however contains no obligation for the member states of the RC to grant performers an exclusive protection right. ${ }^{485}$ By contrast, according to art. $10 \mathrm{RC}$ and art. $13 \mathrm{RC}$ producers of phonograms ${ }^{486}$ and

\footnotetext{
480 Schack 2015, no. 972.

${ }^{481}$ Sterling 2008, no. 20.01, who explains the reasons for the different protection regimes.

482 lbid.

483 Ibid.

${ }^{484}$ Cf. Schack 2015, no. 972; Sterling 2008, no. 20.01.

485 Brison in Dreier/Hugenholtz, Concise Copyright, Rome Convention, art. 7 note 2.

${ }^{486}$ Producers of phonograms receive protection moreover under the Convention for the Protection of Producers of Phonograms Against Unauthorised Duplication of their Phonograms (Geneva Convention) of 1971.
} 
broadcasting organisations both enjoy exclusive rights emerging directly from the Rome Convention. ${ }^{487}$

\subsection{Limitations and Exceptions}

Under art. $15 \mathrm{RC}$ member states are free to allow certain limitations on the rights granted by the Rome Convention. Art. 15 para. 2 RC contains a general limitation stating that national lawmakers may permit the same limitations provided for copyright holders as well for performers, producers of phonograms and broadcasting organisations. ${ }^{488}$ The reason for this limitation can be found in the attempt to avoid inconsistencies with copyright regulation (cf. art. $1 \mathrm{RC}){ }^{489}$

Following art. 15 para. $1 \mathrm{RC}$ special limitations on the rights granted under the Rome Convention may be stipulated regarding (a) private use, (b) use of short excerpts in connection with the reporting of current events, (c) ephemeral fixation by a broadcasting organisation by means of its own facilities and for its own broadcasts and (d) use solely for the purpose of teaching or scientific research.

In the context of the present analysis letter (d) is of particular interest for it provides for a limitation on related rights for the purpose of teaching. The wording is wider than the one of the comparable provision of art. 10 para. 2 BC which speaks only of "illustration for teaching" 490 and refers to "publications, broadcasts or sound or visual recordings for teaching". There is however no reason why the words "publications, broadcasts and recordings" used by art. 15 para. 1 (d) RC should be understood differently. Furthermore, as explained above, "illustration for teaching" in art. 10 para. 2 BC must be understood not as a restriction of the scope of application, but as "teaching" as such. Finally, it has to be presumed that the legislator of the RC wanted the same uses to be exempted under the RC as under the Berne Convention, which sustains the assumption that these two provisions, although of different wording, must be understood and interpreted in the same way. ${ }^{491}$ Eventually, limitations to copyright and neighbouring rights are the same in most national laws, which is why it is justified to apply the same interpretation to the provisions here in question. ${ }^{492}$

\footnotetext{
${ }^{487}$ Brison in Dreier/Hugenholtz, Concise Copyright, Rome Convention, art. 10 note $1 / 2$ and art. 13 note 2.

${ }^{488}$ Art. 15 para. 2 says: "Irrespective of paragraph 1 of this Article, any Contracting State may, in its domestic laws and regulations, provide for the same kinds of limitations with regard to the protection of performers, producers of phonograms and broadcasting organisations, as it provides for, in its domestic laws and regulations, in connection with the protection of copyright in literary and artistic works. However, compulsory licences may be provided for only to the extent to which they are compatible with this Convention."

${ }^{489}$ Brison in Dreier/Hugenholtz, Concise Copyright, Rome Convention, art. 15 note 6.

${ }^{490}$ Xalabarder, WIPO Study 2009, p. 30.

491 Xalabarder, WIPO Study 2009, p. 30

492 Ibid.
} 


\subsubsection{Findings}

The Berne Convention is the basis for safeguarding common protection standards for authors 'rights. It provides for minimum standards of protection and mainly focuses on the position of the author. However, the Berne Convention contains several provisions dealing with limitations and exceptions. Among the objectives of these provisions are "teaching" and "educational purposes". Not explicitly addressed are limitations and exceptions in favour of libraries and archives. Yet the open, flexible and neutral wording of the Berne Conventions enables national legislators to adapt national provisions adequately in order to create norms that help to find a proper balance between the interests of authors and the public interest. Further, the so-called "minor reservations" doctrine and of course the Three-Step-Test, which will be discussed later in this chapter, may provide authority for limitations and exceptions.

The Berne Appendix moreover is the source of a special regime of licensing for developing and least developed countries, which have to be taken into account in view of the countries under consideration in this study. As was explained before the significance of the Berne Appendix in practice, however, is rather limited.

According to the Rome Convention, finally, national legislators may enact the same limitations and exceptions for performers, producers of phonograms and broadcasting organisations as for authors and holders of copyright. Above that the Rome Convention explicitly allows limitations and exceptions for the purpose of teaching or scientific research. Copyright law and neighbouring rights are treated the same in most national laws. For the sake of completeness the provisions of the Rome Convention are mentioned here.

Especially the provisions of the Berne Convention, which provide the fundament for copyright protection on an international level, must be kept in mind hearing after.

\subsection{European Copyright Law}

There is no uniform comprehensive Copyright Law in Europe. ${ }^{493} \mathrm{EU}$ member states rather have their own national Copyright laws, based on the principle of territoriality. However European directives directly govern national Copyright laws by forcing member states to implement the directives' provisions for the purpose of harmonising the law Europe wide. Yet, it is not required that the implementation of the directives into national law is done

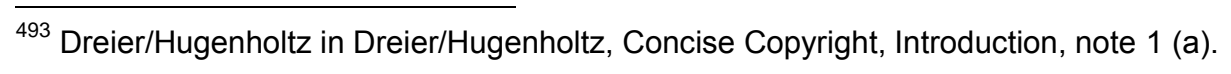


literally. ${ }^{494}$

The EU derives the competency for legislation in the field of Copyright from article 114 Treaty on the Functioning of the European Union (TFEU). ${ }^{495}$ This provision authorises the EU to enact legislation for the purpose of creating the internal market. ${ }^{496}$ According to article 26 para. 2 TFEU the internal market is "an area area without internal frontiers in which the free movement of goods, persons, services and capital (...)". The EU copyright directives thus are means to overcome the obstacles arising by diverging national copyright laws to the internal market and cross-border trade. ${ }^{497}$ Therefore, as long as there is a cross-border relevance article 114 TFEU provides for a solid foundation for EU copyright legislation. ${ }^{498}$ This is the case both for the Information Society Directive and the Orphan Works Directive. ${ }^{499}$

In 2010 article 118 TFEU was introduced, which explicitly states that the European Parliament and the Council "shall establish measures for the creation of European intellectual property rights to provide uniform protection of intellectual property rights throughout the Union". This provision may be the basis for uniform EU copyright legislation and the creation of one single EU copyright title valid in all member states. ${ }^{500}$ However, in the field of copyright law article 118 TFEU has not yet been made use of. ${ }^{501}$

Furthermore intellectual property is protected by article 17 para. 2 Charter of Fundamental Rights of the European Union. Yet, this protection is not without limit. According to article 52 para. 1 Charter of Fundamental Rights of the European Union all rights and freedoms granted by the Charter have to be balanced against one another. In case of intellectual property conflicting rights may be especially the Freedom of the arts and sciences, protected by article 13 Charter of Fundamental Rights of the European Union, the Right to Education, protected by article 14 Charter of Fundamental Rights of the European Union, and the Freedom of Expression and Information, protected by Charter of Fundamental Rights of the European Union.

\footnotetext{
494 Idem, Introduction, note 1 (b).

495 Ibid; Ramalho, Conceptualising the European Union`s Competence in Copyright - What Can the EU Do?, IIC (2014) 45, p. 179.

${ }^{496}$ Before article 114 TFEU was enacted the competency for legislation in the field of Copyright law was derived from article $95 \mathrm{EC}$-Treaty, which dealt with the creation of the internal market.

${ }^{497}$ Ramalho, Conceptualising the European Union`s Competence in Copyright - What Can the EU Do?, IIC (2014) 45, p. 181.

498 Ibid.

499 The recitals of the Information Society Directive and of the Orphan Works Directive repeatedly refer to the concept of the internal market.

${ }^{500}$ Ramalho, Conceptualising the European Union`s Competence in Copyright - What Can the EU Do?, IIC (2014) 45, p. 184; Dreier/Hugenholtz in Dreier/Hugenholtz, Concise Copyright, Introduction, note 1 (a).

501 The pros and cons of article 118 TFEU as a source of competence for future EU wide copyright legislation are discussed by Ramalho, Conceptualising the European Union`s Competence in Copyright - What Can the EU Do?, IIC (2014) 45, p. 184/185.
} 
The European Union has so far enacted nine directives concerning Copyright law, the socalled aquis communautaire of copyright. ${ }^{502}$ Regarding limitations and exceptions for educational purposes and for libraries and archives the most important directive is the Information Society Directive 2001/29/EC. ${ }^{503}$ In addition the Orphan Works Directive 2012/28/EU ${ }^{504}$, which introduced for the first time since the Information Society Directive the obligation for member states to provide for a limitation or exception regarding the use of socalled orphan works ${ }^{505}$, is of particular interest in the context of access to knowledge and education. Therefore, the relevant provisions of these two directives shall be examined in the following. Afterwards the jurisdiction of the European Court of Justice relevant with regard to limitations and exceptions as well as the EU copyright reforms plans will be examined.

\subsubsection{The Information Society Directive 2001/29/EC}

The Information Society Directive incorporates the WIPO Treaties, the WCT and WPPT, into European law. The directive however goes beyond the obligations of the WIPO Treaties in several regards. ${ }^{506}$ The directive was adopted on 22 May 2001. The main goal of the directive is to harmonize certain basic economic rights and the respective limitations as well as the protection of technological measures and digital rights management (cf. article 6 Information Society Directive) in the EU member states. ${ }^{507}$ Especially article 5 Information Society Directive was debated very controversially. This provision contains limitations to the reproduction right (art. 2 Information Society Directive) and the right of communication to the public (art. 3 Information Society Directive).

According to recital 32 it provides for a conclusive list of limitations. However, following article 5 para. 1 Information Society Directive only the implementation of limitations for transient and incidental reproductions is mandatory for member states. ${ }^{508}$ The provision clarifies that reproduction of copyright protected works, "which are transient or incidental [and] an integral

\footnotetext{
502 Satelite and Cable Directive (93/83/EEC), Database Directive (96/9/EC), Information Society Directive (2001/29/EC), Resale Right Directive (2001/84/EC), Rental and Lending Right Directive (2006/115/EC), Copryright Term Directive (2006/116/EC), Computer Programs Directive (2009/24/EC), Orphan Works Directive (2012/28/EU) and Collective Rights Management Directive (2014/26/EU). The Enforcement Directive (2004/48/EC) concerns the enforcement of intellectual property rights, including but not only copyright.

503 In the following "Information Society Directive".

504 In the following "Orphan Works Directive".

${ }^{505}$ Guibault in Dreier/Hugenholtz, Concise Copyright, Orphan Works Directive, Article 6, note 1.

${ }^{506}$ Bechtold in Dreier/Hugenholtz, Concise Copyright, InfoSocDir., Introductory Remarks, note 2.

507 Bechtold in Dreier/Hugenholtz, Concise Copyright, InfoSocDir., Introductory Remarks, note 1.

508 The EU member states, whose national copyright laws are examined here, namely the United Kingdom, Germany and Portugal, have all implemented article 5 para. 1 Information Society Directive. In the UK the respective provision was introduced by "The Copyright and Related Rights Regulations 2003 (S.I. 2003/2498)" and is enshrined in article 28A Copyright, Designs and Patents Act. In Germany the coresponding provision is $\S$ 44a Urheberrechtsgesetz, which as introduced by the "Gesetz zur Regelung des Urheberrechts in der Informationsgesellschaft vom 10.09.2003 (BGBI. I S. 1774). In Portugal article 75 para. 1 Código do Direito de Autor e dos Direitos Conexos, which was introduced by Law No. 50/2004, of August 24, 2004, transposes the provision into national law.
} 
and essential part of a technological process and whose sole purpose is to enable: (a) a transmission in a network between third parties by an intermediary, or (b) a lawful use of a work or other subject-matter to be made, and which have no independent economic significance, shall be exempted from the reproduction right (...)" ${ }^{509}$ This limitation for socalled transient copies of course is no specific limitation for educational purposes, but it makes digital uses of copyrighted materials, i.e. browsing on the Internet, possible with out infringing copyrights, which is an indispensable prerequisite for any online activity. ${ }^{510}$

Regarding the limitations provided for by article 5 para. 2 and 3 Information Society Directive implementation is optional for member states. This includes limitations for educational purposes and libraries and archives.

Concerning limitations for educational purposes and libraries and archives art. 5 para. 2 (c) and para. 3 (a) and (n) Information Society Directive are of interest.

\subsubsection{Limitations to the Reproduction Right in Favour of Libraries and Educational Establishments}

Some acts of teaching maybe exempted under the limitations to the reproduction right granted by art. 5 para. 2 (c) Information Society Directive. According to this provision member states may provide for exceptions and limitations to the reproduction right:

"in respect of specific acts of reproduction made by publicly accessible libraries, educational establishments or museums, or by archives, which are not for direct or indirect economic or commercial advantage"

Following to art. 5 para. 2 (c) Information Society Directive "specific acts of reproduction" of any kind of work are allowed.

Since there is no restriction to analogue reproductions, this leads to the conclusion that digital reproductions of a work are covered, too. ${ }^{511}$ As Recital 40 declares "the exception or limitation should not cover uses made in the context of on-line delivery of protected works (...)". This means that communicating a work to the public is not covered by art. 5 para. 2 (c) Information Society Directive. As a consequence, digital or virtual libraries are not allowed to transmit or present copies of a work to their users online, although digital copies nonetheless

\footnotetext{
${ }^{509}$ Article 5 para. 1 Information Society Directive.

${ }^{510}$ Cf. Bechtold in Dreier/Higenholtz, Concise Copyright, InfoSocDir, art. 5 note 2 (a).

${ }^{511}$ Xalabarder, "Copyright Exceptions for teaching purposes in Europe" (2004), no. 2c); Xalabarder, WIPO Study 2009, p. 117.
} 
maybe made in conformity with art. 5 para. 2 (c) Information Society Directive. ${ }^{512}$ The provision addresses libraries, educational establishments, museums and archives, but there is no further definition of these institutions. What they all have in common is a non-profit purpose and the pursuit of educational or scientific goals. ${ }^{513}$ The term "educational establishments" comprises at least schools, universities and institutions for adult education. ${ }^{514}$ Moreover it is difficult to define what is meant by "publicly accessible" because except for archives institutions have to be "publicly accessible" in order to benefit form the limitation. ${ }^{515}$ Yet, this does not mean that no fee can be charged for the access to and the use of these institutions. The access to the respective institutions must be open for a general public on a non-discriminatory basis. ${ }^{516}$ As well private schools or museums may benefit from the limitation. Finally, art. 5 para. 2 (c) Information Society Directive does not extend to libraries and educational establishments which strive for direct or indirect economic or commercial advantage. As a consequence, a library or an educational establishment that uses the access fees to generate additional profits cannot appeal to art. 5 para. 2 (c) Information Society Directive. ${ }^{517}$ The implementation of fair compensation with regard to art. 5 para. 2 (c) Information Society Directive for the exempted uses is not required, but may be demanded by the member states as is strengthened by recital $36 .{ }^{518}$

\subsubsection{Limitations for Educational and Research Purposes}

According to art. 5 para. 3 (a) Information Society Directive member states may provide for limitations or exceptions to the right of reproduction and the right of communication to the public in the following cases:

"Use for the sole purpose of illustration for teaching or scientific research, as long as the source, including the author's name, is indicated, unless this turns out to be impossible and to the extent justified by the non-commercial purpose to be achieved".

Art. 5 para. 3 (a) Information Society Directive is modelled after art. 10 para. 2 BC..$^{519}$ It is a technologically neutral provision and comprises face-to-face as well as distance education. The use of digital means is covered, too. Recital 42 speaks of "distance learning" and Recital 44 as well as the Explanatory Memorandum accompanying the initial proposal for the

\footnotetext{
$\overline{512}$ Xalabarder, WIPO Study 2009, p. 117.

${ }_{514}$ Bechtold in Dreier/Hugenholtz, Concise Copyright, InfoSocDir., art. 5 note 3 (f).

${ }^{514}$ Ibid.

515 Cf. Recital 40: "(...) certain non-profit making establishments, such as publicly accessible libraries and equivalent institutions, as well as archives."

${ }^{516}$ Bechtold in Dreier/Hugenholtz, Concise Copyright, InfoSocDir., art. 5 note 3 (f).

517 Ibid.; see also Xalabander, WIPO Study 2009, p. 117.

${ }^{518}$ Eventually, the Three-Step-Test (s. below 3.4.) may require fair compensation.

${ }^{519}$ Proposal for a European Parliament and Council Directive, Com (97) 628 final - 97/0359 (COD), p. 32.
} 
Information Society Directive refer to the "new electronic environment". 520

As already said above the scope of art. 5 para. 3 (a) Information Society Directive relates to the right of reproduction and the right of communication to the public. The latter includes the right of making works available online, too. ${ }^{521}$ According to art. 5 para. 4 Information Society Directive member states may extend similar limitations to the distribution right regulated in art. 4 Information Society Directive.

Art. 5 para. 3 (a) Information Society Directive does not apply to certain kinds of educational institutions but takes into focus the "non-commercial purpose" of the use of a work for education and research. The reason for this approach is that the European legislator wanted to privilege all institutions providing education and research, independently of their public or private, commercial or non-commercial nature. In this context Recital 42 of the Information Society Directive may provide some help to understand what is meant by "non-commercial purpose" for it reads:

"When applying the exception or limitation for non-commercial educational and scientific research purposes, including distance learning, the non-commercial nature of the activity in question should be determined by that activity as such. The organisational structure and the means of funding of the establishment concerned are not the decisive factors in this respect."

According to this, the educational activity itself shall be the crucial factor to determine whether the use of a work must be considered commercial or not. In theory, public and private institutions will profit from the limitation of art. 5 para. 3 (a) Information Society Directive. In practice, it will be difficult to define, which activities are of commercial or noncommercial nature. ${ }^{522}$ Moreover, art. 5 para. 3 (a) Information Society Directive does not indicate the persons, which shall benefit from the limitation, for instance only teachers or teachers and students. ${ }^{523}$ The exact determination is left to the member states.

Art. 5 para. 3 (a) Information Society Directive only allows uses for the "sole purpose of illustration for teaching or scientific research". Consequently, the use of a work that pursues another purpose than the illustration for teaching or scientific research is not covered by the limitation. Finally, the source of the work must be indicated according to art. 5 para. 3 (a)

\footnotetext{
${ }^{520}$ Xalabarder, WIPO Study 2009, p. 62/63; Recitals 21 and 29 of the Proposal for a European Parliament and Council Directive, Com (97) 628 final ofDecember 10, 1997.

${ }_{521}$ Bechtold in Dreier/Hugenholtz, Concise Copyright, InfoSocDir., art. 3 note 2 (b).

${ }_{522}$ Cf. Xalabarder, WIPO Study 2009, p. 64.

${ }^{523} \mathrm{lbid}$.
} 
Information Society Directive. This special emphasis on the indication of the author's respectively the right holders name is peculiar for it regulates the right of attribution, belonging to the category of moral rights, and those have not yet been subject to harmonisation effort of the EU. ${ }^{524}$

Fair compensation for the uses exempted by art. 5 para. 3 (a) Information Society Directive is not required, but according to Recital 36 it is left to the discretion of the member states to provide for fair compensation rules regarding any limitation or exception. ${ }^{525}$

\subsubsection{Limitations for Libraries and Educational Establishments for Communication and Making Available on Dedicated Terminals}

According to art. 5 para. $3(n)$ Information Society Directive member states may provide for limitations and exceptions to rights protected under the art. 2 and 3 Information Society Directive for:

"use by communication or making available, for the purpose of research or private study, to individual members of the public by dedicated terminals on the premises of establishments referred to in paragraph 2(c) of works and other subjectmatter not subject to purchase or licensing terms which are contained in their collections."

The provision applies to institutions and establishments such as libraries, educational establishments, museums and archives, which all share the feature of non-profit purpose. ${ }^{526}$ These institutions and establishments may be allowed to communicate or make available works or other subject matter, i.e. European neighbouring rights ${ }^{527}$, available to individual members of the public. By implication this means any communication to the general public is not allowed by the limitation. ${ }^{528}$ The provision addresses individual users of the respective institution, who must access the work for research or private study. Furthermore the works communicated or made available through "dedicated terminals", i.e. computers or other electronic devices for digital access, must be located on the "premises" of the respective institution. This excludes any online access to works made available by other institutions. ${ }^{529}$ Further, the privileged use is only feasible in case no license for the respective use, i.e. communicating or making available in digital form, exists on the market. After all, art. 5 para.

\footnotetext{
${ }^{524}$ Bechtold in Dreier/Hugenholtz, Concise Copyright, InfoSocDir., art. 5 note 4 (b).

${ }^{525}$ Xalabarder, WIPO Study 2009, p. 65.

${ }^{526}$ Cf. art. 5 para. 2 (c) Information Society Directive.

${ }_{528}^{527}$ Bechthold in Dreier/Hugenholtz, Concise Copyright, art. 5 InfoSocDir, art. 5 note 4 (o).

${ }_{529}^{528}$ Ibid.

529 Ibid.
} 
3 (n) Information Society Directive has only a limited field of application. Especially that the online access to collections of other libraries is not covered and the application of the provision depends on the availability of licences for digitisation considerably reduces its utility.

\subsubsection{The Orphan Works Directive 2012/28/EU}

The main goal of the Orphan Works Directive is to enable mass digitisation and making available of copyright protected works and phonograms contained in the collections of cultural heritage institutions. ${ }^{530}$ In particular the directive deals with orphan works, which are works or phonograms whose author or right holder cannot be identified or located. In order to digitise or make such works or phonograms available to the public, the authorisation of the author or right holder is necessary. Without the authorisation the digitisation and making available of orphan works would be copyright infringements. To prevent this and to promote cross-border digitisation and dissemination of works in the single market the Orphan Works Directive is intended to provide a common European legal framework. ${ }^{531}$ In that sense recital 3 of the Directive declares:

"Creating a legal framework to facilitate the digitisation and dissemination of works and other subject-matter which are protected by copyright or related rights and for which no rightholder is identified or for which the rightholder, even if identified, is not located - so-called orphan works - is a key action of the Digital Agenda for Europe, as set out in the Communication from the Commission entitled · A Digital Agenda for Europe ·."

Therefore the orphan works directive aims at the EU-wide harmonisation of certain permitted uses of orphan works. The directive was adopted on October 25, 2012. Member states had time to implement the directive into national law until October 29, 2014. ${ }^{532}$ Meanwhile, all member states have transposed the directive into national law. ${ }^{533}$ Until the adoption of the directive in most member states there were no rules regarding how cultural heritage institutions had to deal with orphan works. ${ }^{534}$ Only Denmark, Finland, Hungary, Sweden, France and the UK had addressed the orphan works issue in national legislation at all. ${ }^{535}$ According to recital 8 the European legislator found that different national approaches to the recognition of a work as an orphan could have negative effects on the internal market and on

\footnotetext{
${ }^{530}$ Guibault in Dreier/Hugenholtz, Concise Copyright, Orphan Works Directive, Introductory Remarks, note 1.

${ }^{531}$ Idem.

${ }^{532}$ Article 9 para. 2 Orphan Works Directive.

533 See for national implementation measures

http://eur-lex.europa.eu/search.html?or0=DN\%3D72012L0028*,DN-old\%3D72012L0028*\&qid=1470076117318\& DTS_DOM=NATIONAL_LAW\&type=advanced\&lang=de\&SUBDOM_INIT=MNE\&DTS_SUBDOM=MNE\&page=1. ${ }_{534}$ Guibault in Dreier/Hugenholtz, Concise Copyright, Orphan Works Directive, Introductory Remarks, note 3 (a). 535 Idem.
} 
the use of and the cross-border access to works. Moreover restrictions on the free movement of goods and services were feared. Thus, in order to provide legal certainty a solution on the level of the European Union was deemed appropriate. ${ }^{536}$

With regard to access to knowledge the orphan works issue is particularly important because orphan works in the collections of libraries, archives, museums and other cultural heritage institutions are a major impediment to the creation of digital libraries. ${ }^{537}$ One of the most controversial projects to create a digital library is the Google books library. ${ }^{538}$ The project was initiated by Google in 2004 and pursues the objective of creating a comprehensive digital library. ${ }^{539}$ In view of the Google books library, the ensuing lawsuits ${ }^{540}$ and the Google Books Settlement the European legislator realised that if there was no legislative action to address the problem of orphan works Google would create facts also in Europe and European initiatives to establish digital libraries, such as the Europeana ${ }^{541}$, would be left standing. ${ }^{542}$ The European legislator even feared the development of an international knowledge gap in case the Google library was the only library with online access to orphan works in Europe and therefore endorsed the issuance of a directive creating a statutory exception allowing the use of orphan works under certain conditions. ${ }^{543}$ Consequently, the Orphan Works Directive must be seen as a reaction to Google and the Google Books Settlement. ${ }^{544}$

Against that backdrop recital 1 of the Orphan Works Directive states:

"Publicly accessible libraries, educational establishments and museums, as well as archives, film or audio heritage institutions and public-service broadcasting organisations, established in the Member States, are engaged in large-scale digitisation of their collections or archives in order to create European Digital Libraries. They contribute to the preservation and dissemination of European cultural heritage, which is also important for the creation of

\footnotetext{
${ }^{536}$ See recital 25 Orphan Works Directive.

${ }^{537}$ Afori, The Battle over Public E-Libraries - taking stock and moving ahaed, 2013, p. 397; de la Durantaye, Orphan Works: A comparative and international perspective, in International Intellectual Property: A Handbook of Contemporary Research (2015), p. 191.

${ }^{538}$ Cf. Rosati, The Orphan Works Directive, or throwing a stone and hiding the hand, JIPLP, 2013, Vol. 8, No. 4, p. 303.

${ }^{539}$ de la Durantaye, Orphan Works: A comparative and international perspective, in International Intellectual Property: A Handbook of Contemporary Research (2015), p. 191.

${ }^{540}$ See 4.1.1.4.3.8.

541 See 1.2.2.

542 Commission staff working paper Impact assessment on the cross-border online access to orphan works accompanying the document "proposal for a directive of the European Parliament and of the Council on certain permitted uses of orphan works", 24 May 2011, SEC (2011) 615 final, p. 6/7; de la Durantaye, Orphan Works: A comparative and international perspective, in International Intellectual Property: A Handbook of Contemporary Research (2015), p. 193.

${ }^{543}$ Commission staff working paper Impact assessment on the cross-border online access to orphan works accompanying the document "proposal for a directive of the European Parliament and of the Council on certain permitted uses of orphan works", 24 May 2011, SEC (2011) 615 final, p. 8 and 24.

544 de la Durantaye, Orphan Works: A comparative and international perspective, in International Intellectual Property: A Handbook of Contemporary Research (2015), p. 203.
} 
European Digital Libraries, such as Europeana. Technologies for mass digitisation of print materials and for search and indexing enhance the research value of the libraries' collections. Creating large online libraries facilitates electronic search and discovery tools which open up new sources of discovery for researchers and academics who would otherwise have to content themselves with more traditional and analogue search methods."

\subsubsection{Limitation on the Right of Reproduction and the Right of Making Available to the Public}

In order to achieve these goals and to promote learning and the dissemination of culture ${ }^{545}$ the Orphan Works Directive contains the obligation for EU member states to provide for a limitation or exception to the right of reproduction and the right of making available to the public. The limitation of article 6 Orphan Works Directive is mandatory for member states. ${ }^{546}$ According to recital 20 this limitation complements the limitations and exceptions provided for in article 5 of the Information Society Directive. In addition to the institutions privileged by article 5 para. 2 (c) of the Information Society Directive also non-profit film or audio heritage institutions and public service broadcasting organisations shall be allowed to reproduce and make available orphan works to the public "provided that such use fulfils their public interest missions, in particular the preservation of, the restoration of, and the provision of cultural and educational access to, their collections, including their digital collections". ${ }^{547}$ Recital 20 Orphan Works Directive further clarifies that the new limitation to use orphan works is without prejudice to the limitations and exceptions provided for by the Information Society Directive and like those subjected the Three-Step-Test.

The obligation for member states to provide such limitation or exception derives from article 6 of the orphan works directive, which bears the title "permitted uses of orphan works". The beneficiaries of the provision are the organisations referred to in article 1 para. 1 of the Directive, namely "publicly accessible libraries, educational establishments and museums as well as archives, film or audio heritage institutions and public-service broadcasting organisations, established in the member states (...)", pursuing their public-interest missions. The list of organisations is longer than in article 5 para. 2 (c) of the Information Society Directive, because otherwise the Orphan Works Directive could not achieve its goal stated by recital 5 , which is the promotion of mass-digitisation of Europe's cultural heritage ${ }^{548}$ Article 1 para. 2 Orphan Works Directive defines the categories of copyright protected works the directive applies to. The enumeration is exhaustive and encompasses four types of orphan

\footnotetext{
${ }_{545}$ Cf. recital 20 Orphan Works Directive.

${ }^{546}$ Guibault in Dreier/Hugenholtz, Concise Copyright, Orphan Works Directive, Article 6, note 1.

${ }^{547}$ Recital 20 Orphan Works Directive.

${ }^{548}$ Guibault in Dreier/Hugenholtz, Concise Copyright, Orphan Works Directive, Article 1, note 1 (a).
} 
works, namely writings, cinematographic or audiovisual works, phonograms and embedded copyright protected works. ${ }^{549}$ Provided that the work in question is an orphan work and is contained in their collections the organisations referred to in article 1 para. 1 Orphan Works Directive shall be allowed to make available orphan works to the public (article 6 para. 1 (a)) and reproduce them for the purposes of indexing, cataloguing, preservation or restoration (article 6 para. 1 (b)). Under which circumstances a work can be considered an orphan work is defined by article 2 of the directive. This is the case for works or phonograms "if none of the rightholders in that work or phonogram is identified or, even if one or more of them is identified, non is located despite a diligent search for the rightholders having been carried out and recorded in accordance with Article 3. ${ }^{1550}$ The condition for granting the orphan works status thus is a diligent search for the right holder. The rules for a diligent search contains article 3 Orphan Works Directive. A diligent search by one of the privileged institutions has to comply with the following requirements: (a) before a work or phonogram is used a diligent search must be carried out in "good faith" for "each work"; (b) "appropriate sources for the category of works" must be consulted; (c) member states shall determine "the sources that are appropriate for each category of works",;51 (d) privileged institutions are obliged to keep records of their diligent searches and the results of these searches, and provide this information to the relevant national authorities. ${ }^{552}$

Once the status of the orphan work has been ascertained by the respective institution, article 6 Orphan Works Directive permits the reproduction and making available to the public. ${ }^{553}$ Due to the reference of article 6 para. 1 (a) Orphan Works Directive to article 3 Information Society Directive, which contains the general right of communication to the public, it is not entirely clear, whether the legislator wanted to permit only online activities or also other forms of communicating the work to the public. ${ }^{554}$ There is every indication that only online activities should be addressed by article 6 para. 1 (a) Orphan Works Directive since the objective of the directive is the creation of European digital libraries. ${ }^{555}$ Thus, it appears that the European legislator wanted to enable cultural heritage institutions to make orphan works available online in a way that their users as members of the public may access orphan works

\footnotetext{
${ }^{549}$ Suthersanen/Frabboni, The Orphan Works Directive, in EU Copyright Law (2014), no. 13.10.

${ }_{550}^{5}$ Article 2 para. 1 Orphan Works Directive.

${ }^{551}$ Article 3 para. 2 Orphan Works Directive, which also refers to the Annex of the directive containing a list of relevant sources that have at least to be included by the member states.

${ }_{552}$ Cf. Suthersanen/Frabboni, The Orphan Works Directive, in EU Copyright Law (2014), no. 13.31.

${ }^{553}$ Another effect of a work being considered an orphan work is that such work shall be considered an orphan work in all member states of the EU according to article 4 Orphan Works Directive. Thus, article 4 also stipulates that such work "may be used and accessed in accordance with the orphan works directive in all member states".

${ }^{554}$ Guibault in Dreier/Hugenholtz, Concise Copyright, Orphan Works Directive, Article 6, note 1 (a), who argues that "making available" according to article 6 para. 1 (a) is meant to cover only online activities as forms of dissemination of digitised works by making reference to recital 19 of the Public Sector Information Directive 2013/37/EU and the Council conclusions of 10 May 2012 on the digitisation and online accessibility of cultural material and digital preservation (OJ C 169, 15.6.2012, p. 5) cited therein.

555 See recital 1 Orphan Works Directive.
} 
from a place and at a time individually chosen by them. Consequently, it would have been more precise to refer to article 3 para. 2 Information Society Directive instead of generally referring to article 3 Information Society Directive. ${ }^{556}$ The reference made by article 6 para. 1 (b) Orphan Works Directive to the right of reproduction is more precise than the reference made by article 5 para. 2 (c) Information Society Directive, which applies only to "specific acts of reproduction made by publicly accessible libraries, educational establishments or museums, or by archives, which are not for direct or indirect economic commercial advantage." 557 By contrast the limitation of the Orphan Works Directive refers to reproductions "for the purposes of digitisation, making available, indexing, cataloguing, preservation or restoration."

According to article 6 para. 2 sentence 1 Orphan Works Directive the privileged institutions are only allowed to use an orphan work in the ways described before "in order to achieve aims related to their public-interest missions, in particular the preservation of, the restoration of, and the provision of cultural and educational access to, works and phonograms contained in their collection." However, it is allowed that the institutions generate revenues using orphan works, as long as the only purpose of these revenues is to cover the costs of digitisation and making available of orphan works to the public. ${ }^{558}$ As stated by recital 21 the generation of revenues is understood as an incentive for the digitisation as part of the publicinterest mission of the privileged institutions. To achieve the goal of digitising orphan works and making them available to the public also public-private partnerships are considered appropriate solutions. ${ }^{559}$ This approach is underlined by recital 22 , which acknowledges the role of contracts between cultural heritage institutions and commercial partners with regard to the digitisation of Europe's cultural heritage. ${ }^{560}$

Eventually article 6 para. 5 Orphan Works Directive establishes the obligation for member states to safeguard that fair compensation is paid to right holders for the uses that have been made of their works by the privileged institutions in case they put an end to the orphan work status of their works. ${ }^{561}$ This provision raised concerns of cultural heritage institutions to be exposed to sudden claims of right holders for compensation for uses made of their works in

\footnotetext{
${ }_{556}^{5}$ Guibault in Dreier/Hugenholtz, Concise Copyright, Orphan Works Directive, Article 6, note 1 (a).

${ }_{557}$ Guibault in Dreier/Hugenholtz, Concise Copyright, Orphan Works Directive, Article 6, note 1 (b).

${ }^{558}$ Article 6 para. 2 sentence 2 Orphan Works Directive.

${ }_{559}$ Recital 21 Orphan Works Directive.

560 Suthersanen/Frabboni, The Orphan Works Directive, in EU Copyright Law (2014), no. 13.53, who point out that it may be difficult to separate whether orphan works are used in the context of public interest missions or for the generation of revenues. Yet, recital 22 sentence 3 Orphan Works Directive clarifies that commercial partners are not granted any rights to use or control the use of orphan works.

${ }^{561}$ Article 5 Orphan Works Directive establishes that right holders of works considered orphan works must have the right to end the orphan works status in so far as his rights are concerned. The provision appears to be very clear. However, it does not explain how a right holder has to prove that he is the owner of copyright and in which jurisdiction a right holder may claim his rights, see Suthersanen/Frabboni, The Orphan Works Directive, in EU Copyright Law (2014), no. 13.48.
} 
the past. ${ }^{562}$ According to article 6 para. 5 Orphan Works Directive it is left to the member states to determine the circumstances under which payment of fair compensation is organised. In this context recital 18 gives indications for the parameters that should be taken into account when determining the level of fair compensation. Among others these are "Member States' cultural promotion objectives, of the non-commercial nature of the use made by the organisations in question in order to achieve aims related to their public-interest missions, such as promoting learning and disseminating culture, and of the possible harm to rightholders." 563 In view of these restrictions excessive claims by rightsholders for compensation after the end of the orphan works status appear rather unlikely. ${ }^{564}$

\subsubsection{Evaluation}

As described above article 6 para. 1 orphan works directive explicitly permits the making available of orphan works to the public as well as the reproduction of such works. This means that a great number of copyright protected works of all kinds will be digitised and made available by cultural heritage institutions, including libraries, educational establishments, museums and archives and be accessible to individual users online. Thus, it must be stated that the limitation provided for by the Orphan Works Directive potentially promotes the access to knowledge and education in the digital age.

Nevertheless, one may criticise that the directive only allows for the use of orphan works by public non-profit cultural heritage institutions. ${ }^{565}$ Digitisation and making available of orphan works to the public by private individuals and companies is not privileged by the limitation, even if they do not pursue commercial interests. ${ }^{566}$ Furthermore, in practice privileged institutions still have to carry out complicated and expensive searches for right holders, especially in case there are several right holders in a work. ${ }^{567}$ Besides, the limitation of the Orphan Works Directive only refers to the right of reproduction and the right of making available to the public. As a consequence, cultural heritage institutions may not distribute,

\footnotetext{
562 Guibault in Dreier/Hugenholtz, Concise Copyright, Orphan Works Directive, Article 6, note 5; Suthersanen/Frabboni, The Orphan Works Directive, in EU Copyright Law (2014), no. 13.55.

${ }_{563}$ Recital 18 Orphan Works Directive.

${ }^{564}$ However, since member states may chose diverse approaches to the organisation of fair compansation, this may on the other hand have the result that some member states become more attractive than others for cultural heritage institutions to set up digitisation projects, which would be contrary to the objective of the Orphan Works Directive to prevent fragmentation of the rules on the use of orphan works through national legislation, see Rosati, The Orphan Works Directive, or throwing a stone and hiding the hand, JIPLP, 2013, Vol. 8, No. 4, p. 309.

${ }^{565}$ de la Durantaye, Orphan Works: A comparative and international perspective, in International Intellectual Property: A Handbook of Contemporary Research (2015), p. 204.

${ }^{566}$ Ibid. In that sense, Rosati, The Orphan Works Directive, or throwing a stone and hiding the hand, JIPLP, 2013, Vol. 8, No. 4, p. 309, points out that one objective of the directive was to make the EU attractive for digitisation projects like Google Books. This objective obviously cannot be achieve by privileging public non-profit institutions only. Commercial digitsation projects thus still depend on the grant of permissions.

567 Idem, p. 205.
} 
perform, or publicly display orphan works. ${ }^{568}$ With regard to access to knowledge it would have been more favourable to privilege such uses as well. ${ }^{569}$ Finally, it can be criticised that the directive only provides for a rather vague set of provisions, which alone is not sufficient to promote the use of orphan works adequately with regard to facilitating copyright clearance and cross-border licensing. ${ }^{570}$

\subsubsection{European Court of Justice Jurisdiction concerning Limitations and Exceptions}

The interpretation the European Directives is strongly influenced by the jurisdiction of the European Court of Justice. This holds true for copyright law as well. The interpretation and understanding of national copyright laws of the European member states therefore has to take into account the ECJ's jurisdiction. The most important decisions of the ECJ regarding limitations and exceptions to copyright law are of interest in the context of this study.

Regarding the interpretation of limitations for temporary reproductions as addressed by article 5 para. 1 Information Society Directive the ECJ stated in the Infopaq decision that this provision must be interpreted strictly. ${ }^{571}$ According to the court's opinion such strict interpretation was necessary, because the provision is an exception to the general principle, that the author or right holder has the exclusive right to permit any reproduction of his work. ${ }^{572}$ Moreover the Three-Step-Test enshrined in article 5 para. 5 Information Society Directive would demand a strict interpretation. ${ }^{573}$ Considering the need of legal certainty for authors and right holders postulated by recitals 4, 6 and 21 Information Society Directive, article 5 para. 5 Information Society Directive was to be interpreted strictly. ${ }^{574}$ The principle of strict interpretation was however softened by the ECJ in the Murphy decision with regard to article 5 para. 1 Information Society Directive. ${ }^{575}$ The court clarified, that article 5 para. 1 Informationa Society Directive "must allow and ensure the development and operation of new technologies and safeguard a fair balance between the rights and interests of right holders, on the one hand, and of users of protected works who wish to avail themselves of those new technologies, on the other. ${ }^{\text {‘576 }}$ In the Painer decision the court applied these principles to the limitation for quotations enshrined in article 5 para. 3 d) Information Society Directive. ${ }^{577}$ Also

\footnotetext{
568 Ibid.

569 The explanation is probably the focus of the EU on public non-profit digital libraries, see de la Durantaye, Orphan Works: A comparative and international perspective, in International Intellectual Property: A Handbook of Contemporary Research (2015), p. 205.

${ }^{570}$ Rosati, The Orphan Works Directive, or throwing a stone and hiding the hand, JIPLP, 2013, Vol. 8, No. 4, p. 310.

${ }^{571}$ ECJ, Judgement of the Court of July 16, 2009, Case C-5/08, no. 56.

${ }^{572}$ ECJ, Judgement of the Court of July 16, 2009, Case C-5/08, no. 57.

${ }^{573}$ ECJ, Judgement of the Court of July 16, 2009, Case C-5/08, no. 58.

${ }^{574}$ ECJ, Judgement of the Court of July 16, 2009, Case C-5/08, no. 59.

575 ECJ, Judgement of the Court of October 21, 2011, Cases C-403/08 and C-429/08, no. 163.

${ }^{576}$ ECJ, Judgement of the Court of October 21, 2011, Cases C-403/08 and C-429/08, no. 164.

577 ECJ, Judgement of the Court of December 1, 2011, Case C-145/10, no. 132.
} 
in the TU Darmstadt vs. Eugen Ulmer decision, in which the court had to decide on the interpretation of article 5 para. $3 \mathrm{n}$ ) Information Society Directive, it was outlined, that the interpretation of the provision had to "maintain a fair balance between the rights and interests of rightholders, on the one hand, and, on the other hand, users of protected works who wish to communicate them to the public for the purpose of research or private study undertaken by individual members of the public. “578 The TU Darmstadt vs. Eugen UImer decision was the first decision of the ECJ in the area of copyright limitations for education and libraries. ${ }^{579}$ Generally, the ECJ clings to the principle of strict interpretation of limitations and exceptions, but the court is obviously willing to take into account technological developments of the digital era.

In the context of this study another very recent decision of the ECJ is of interest. In the case of Vereniging Openbare Bibliotheken vs. Stichting Leenrecht, C-174/15, the court ruled that under specific conditions the lending of electronic books (e-books) can be equated with the lending of traditional books. ${ }^{580}$ The court had to decide whether the socalled "One-copy-oneuser" model, which allows a library user to make one download of a digital copy of a book from the server of a public library on his personal computer and use that copy for a certain lending period ${ }^{581}$, is covered by the Rental and Lending Right Directive 2006/115/EC. ${ }^{582}$ This directive establishes that the author of a book has the exclusive right to permit or prohibit the renting or lending of his work. ${ }^{583}$ Member states may, however, establish exceptions to this rule in favour of public lending provided that the author receives fair remuneration. ${ }^{584}$ The court found no reason to generally exclude digital copies and intangible objects from the scope of Directive 2006/115/EC. ${ }^{585}$ Such understanding would contradict the objective of the directive 2006/115/EC, especially as pronounced by recital 4, which states that copyright must adapt to new economic developments and new forms of exploitation. ${ }^{586}$ Digital lending is a new form of exploiting copyright. ${ }^{587}$ Furthermore, the complete exclusion of digital lending from the scope of directive 2006/115/EC would infringe the principle of a high level of protection for authors. ${ }^{588}$ Starting from there, the court answered the questions presented by the Rechtbank Den Haag, the district court of the Hague, Netherlands, and stated firstly that the "One-copy-one-user" model is covered by the Directive 2006/115/EC since the meaning

\footnotetext{
${ }^{578}$ ECJ, Judgement of the Court of September 11, 2014, Case C-117/13, no. 31.

${ }^{579}$ See in more detail below 4.1.3.2.2.

${ }^{580}$ Court of Justice of the European Union, press release no. 123/16, November 10, 2016.

581 lbid.

582 Directive 2006/115/EC of the European Parliament and of the Council of 12 December 2006 on rental right and lending right and on certain rights related to copyright in the field of intellectual property.

${ }_{583}$ Court of Justice of the European Union, press release no. 123/16, November 10, 2016.

584 lbid.

${ }^{585}$ ECJ, Judgement of the Court of November 10, 2016, Case C-174/15, no. 44.

${ }^{586}$ ECJ, Judgement of the Court of November 10, 2016, Case C-174/15, no. 45.

${ }^{587}$ ECJ, Judgement of the Court of November 10, 2016, Case C-174/15, no. 45.

${ }^{588}$ ECJ, Judgement of the Court of November 10, 2016, Case C-174/15, no. 46.
} 
of "lending" as used by article 1(1), article 2(1)(b) and article 6(1) of the directive 2006/115/EC encompasses digital copies of a book under the specific conditions on the case in question. ${ }^{589}$ Secondly, the court found that with regard to the principle of exhaustion laid down in article 4(2) Information Society Directive 2001/29/EC member states may make the application of article $6(1)$ of the directive $2006 / 115 / E C$, i.e. exceptions to the exclusive right of the author to permit or prohibit renting or lending of his work, "subject to the condition that the digital copy of a book made available by the public library must have been put into circulation by a first sale or other transfer of ownership of that copy in the European Union by the holder of the right of distribution to the public or with his consent. ${ }^{\prime 590}$ Thirdly, the court stated that article $6(1)$ of directive $2006 / 115$ is not applicable if a public library makes available the digital copy of a book from an illegal source..$^{591}$

\subsubsection{EU Copyright Reform Plans}

Since its entry into force the Information Society Directive has been criticised. ${ }^{592}$ It was argued that its provisions would not take into account appropriately the technological developments and the possibilities of digital technology and the Internet. ${ }^{593}$ Also it was criticised that the Information Society Directive was inflexible and could not sufficiently adapt to future developments with the consequence that its provisions were outdated by the time they were enacted. Moreover it was felt that interests of the general public were not taken into account adequately and interest of right holders and authors were given precedence too often. Instead of helping to create a single European market, copyright got stock in national fragmentation. This feeling of imbalance grew over the past years, especially because the provisions of the Information Society Directive could not keep up with new possibilities to use protected works due to the development of digital technologies.

The European Commission acknowledged the need for reform and for further harmonisation and decided to promote a copyright law reform in order to establish a legal framework, which would meet the requirements of the digital era appropriately. On account of the European Commission a public consultation was initiated, starting on December 5, 2013, and lasting until March 3, 2014. ${ }^{594}$ All citizens and organisations were invited to participate the consultation in order to gather information from all stakeholders concerning a review of the EU copyright rules. Strong emphasis was laid on the perception of stakeholders regarding

\footnotetext{
${ }^{589}$ ECJ, Judgement of the Court of November 10 of 2016, Case C-174/15, no. 54.

${ }^{590}$ ECJ, Judgement of the Court of November 10 of 2016, Case C-174/15, no. 65.

${ }^{591}$ ECJ, Judgement of the Court of November 10 of 2016, Case C-174/15, no. 72.

${ }^{592}$ See for instance Mazziotti, Copyright in the EU Digital Single Market, 2013.

${ }^{593}$ Kuhlen, Die Allgemeine Bildungs- und Wissenschaftsschranke im Urheberrecht, Information. Wissenschaft \& Praxis 2016; 67 (1), p. 53/54.

${ }^{594}$ Commission of the EU, Public Consultation on the review of the EU copyright rules, available at http://ec.europa.eu/internal_market/consultations/2013/copyright-rules/index_en.htm.
} 
limitations and exceptions to copyright law. Most of the respective issues of the consultation paper dealt with limitation and exceptions for educational purposes and in libraries as well as research. Questions were asked regarding preservation, archiving, off-premises access to library collections, E-lending and mass digitisation. Moreover the consultation paper addressed issues like teaching, research, disabilities, text and data mining as well as user generated content. The results of the consultation were published by the European Commission. ${ }^{595}$ Namely on that basis the new European Commission of Jean-Claude Juncker will prepare a proposal for new European copyright legislation as a part of the Strategy of the European Digital Single Market. ${ }^{596}$ A first proposal was announced for the end of $2015 .{ }^{597}$ On July 9, 2015, the European Parliament accepted a report by the delegate Julia $\mathrm{Reda}^{598}$, which demands for an adequate balance between the interests of authors and users of copyright protected works. ${ }^{599}$ This especially includes improved access to knowledge and education. The version adopted by the EU-Parliament varies slightly compared to the initial report by Julia Reda. In same aspects a more reluctant language was preferred.

The Resolution adopted by the European Parliament emphasises that a "revision of Directive 2001/29/EC is central to the promotion of creativity and innovation, cultural diversity, economic growth, competitiveness, the Digital Single Market and to access to knowledge and information (...) ${ }^{4600}$. The changes brought about by the Internet and digital technologies and the significance of fundamental freedoms including the right to education make a reform of European copyright rules particularly urgent. ${ }^{601}$ One possible solution could be a single European Copyright Title. ${ }^{602}$ Therefore the EU-Parliament demands that the Commission analyses if such European Copyright Title would have positive effects on the jobs and innovation and the interest of all copyright stakeholders. ${ }^{603}$ The second part of the Resolution

\footnotetext{
595 Commission of the EU, Public Consultation on the review of the EU copyright rules, available at http://ec.europa.eu/internal_market/consultations/2013/copyright-rules/docs/contributions/consultationreport_en.pdf.

${ }^{596}$ Commission of the EU, A Digital Single Market for Europe: Commission sets out 16 initiatives to make it happen, Press Release, May 6, 2015, available at http://europa.eu/rapid/press-release_IP-15-4919_de.htm. 597 lbid.

${ }^{598}$ Reda, Draft Report on the implementation of Directive 2001/29/EC of the European Parliament and of the Council of 22 May 2001 on the harmonisation of certain aspects of copyright and related rights in the information soc iety, 2014/2256(INI), January 15, 2015, available at http://www.europarl.europa.eu/sides/getDoc.do?pubRef=//EP//NONSGML+COMPARL+PE-546.580+02+DOC+PDF+V0//EN\&language=EN.

${ }^{599}$ European Parliament, "Copyright reform: promote cultural diversity and ensure access to it, say MEPs", Press Release of July 9, 2015, available at http://www.europarl.europa.eu/news/en/newsroom/content/20150703IPR73903/html/Copyright-reform-promote-cultural-diversity-and-ensure-access-to-it-sayMEPs.

${ }^{600}$ European Parliament resolution of 9 July 2015 on the implementation of Directive 2001/29/EC, para. A.

${ }^{601}$ European Parliament resolution of 9 July 2015 on the implementation of Directive 2001/29/EC, para. C, H and K.

${ }^{602}$ Preparatory work for a single European Copyright Title has been done by the so called Wittem Project, a group of copyright scholars, who developed a European Copyright Code. The Code is intended to contribute further harmonisation of copyright law in Europe. The Code was published in 2010 and is available at http://copyrightcode.eu/index.php?websiteid=3.

${ }^{603}$ European Parliament resolution of 9 July 2015 on the implementation of Directive 2001/29/EC, no. 28.
} 
deals with „Exceptions and Limitations“ in view of the challenges of the digital age ${ }^{604}$ To start with the EU-Parliament reminds the EU legislator of the importance of „safeguarding a fair balance between the different categories of rightholders and users of protected subjectmatter, as well as between the different categories of rightholders". ${ }^{605}$ Further, the significance of copyright for cultural production and educational and research activities is highlighted. ${ }^{606}$ The Resolution demands that the EU-Commission examines the existing limitations and exceptions in order to better adapt them to the digital environment, while maintaining the balance of interests. ${ }^{607}$ The EU-Parliament explicitly addresses the need to "strengthen exceptions for institutions of public interest, such as libraries, museums and archives, in order to promote wide-ranging access to cultural heritage, including through online platforms". ${ }^{608}$ The development of digital networks facilitating access to knowledge and cultural heritage is welcomed, but it is stressed that efficient protection as well as the right to remuneration and fair compensation have to be balanced with public interest. ${ }^{609}$ The EU-Parliament underlines the significance of access to educational materials and cultural goods for the development of the knowledge society and therefore demands for "an exception for research and education purposes, which should cover not only educational establishments but also accredited educational or research activities, including online and cross-border activities, linked to an educational establishment or institution recognised by the competent authorities, or legislation, or within the purview of an educational programme“ ${ }^{610}$ In addition the EU-Parliament highlights the role of libraries with regard to access to knowledge and demands for a limitation permitting public and research libraries to "legally lend works to the public in digital formats for personal use, for a limited duration, through the internet or the libraries' networks, so that their public interest duty of disseminating knowledge can be fulfilled effectively and in an up-to-date manner; recommends that authors should be fairly compensated for e-lending to the same extent as for the lending of physical books according to national territorial restrictions. " 611 Moreover, the EU-Parliament calls for a limitation in favour of libraries to digitise content for the purposes of consultation, cataloguing and archiving. ${ }^{612}$ The Resolution contains further statements and demands concerning the reform of the European copyright framework. A comprehensive reform proposal as announced by the Commission for the end of 2015 has not yet been presented. However, on December 9, 2015, the Commission presented a proposal for a regulation to the cross-

\footnotetext{
${ }^{604}$ European Parliament resolution of 9 July 2015 on the implementation of Directive 2001/29/EC, no. 33f.

605 European Parliament resolution of 9 July 2015 on the implementation of Directive 2001/29/EC, no. 33.

${ }^{606}$ European Parliament resolution of 9 July 2015 on the implementation of Directive 2001/29/EC, no. 34.

607 European Parliament resolution of 9 July 2015 on the implementation of Directive 2001/29/EC, no. 35.

${ }^{608}$ European Parliament resolution of 9 July 2015 on the implementation of Directive 2001/29/EC, no. 39

${ }^{609}$ European Parliament resolution of 9 July 2015 on the implementation of Directive 2001/29/EC, no. 42.

${ }^{610}$ European Parliament resolution of 9 July 2015 on the implementation of Directive 2001/29/EC, no. 50/51.

${ }^{611}$ European Parliament resolution of 9 July 2015 on the implementation of Directive 2001/29/EC, no. 53.

${ }^{612}$ European Parliament resolution of 9 July 2015 on the implementation of Directive 2001/29/EC, no. 54.
} 
border portability of online content services in the internal market. ${ }^{613}$ Thereby the Commission met the demands of the EU-Parliament at least partly. ${ }^{614}$ Also on December 9, 2015, the Commission presented a paper outlining the shape of possible copyright reforms. ${ }^{615}$ Shortly before, on November 24, 2015, the Vice-President of the Commission in charge of the Digital Single Market Andrus Ansip made clear that the Commission is determined to reform European copyright law in order to further adapt it to the digital age. ${ }^{616}$ Especially the importance of digital technologies for access to knowledge, education and research was emphasised by the Commissioner. ${ }^{617}$

Only on September 14, 2016 the Commission of the EU presented a new proposal for a directive on copyright in the digital single market. ${ }^{618}$ In this proposal the Commission specifically addresses crucial issues with regard to access to education and knowledge in the digital age. The proposal contains among others provisions concerning digital and crossborder uses in the field of education, text and data mining in the field of scientific research and the preservation of cultural heritage.$^{619}$ Obviously, the Commission is eager to address the concerns of the stakeholders expressed during copyright consultations and therefore announces to introduce mandatory limitations and exceptions for research, education and preservation of cultural heritage ${ }^{620}$ as well as for text and data mining. ${ }^{621}$ In order to promote digital distance education across borders on all levels mandatory limitations and exceptions for non-commercial educational activities shall be introduced. ${ }^{622}$ Regarding preservation activities of cultural heritage institutions the Commission also favours mandatory limitations and exceptions. ${ }^{623}$ Finally, the Commission addresses digitisation and dissemination of out of commerce works by cultural heritage institutions. ${ }^{624}$ Yet, this sounds convincing only in the first place. If one looks at the actual provisions proposed by the Commission, one will find that the scope of the provisions is narrow and not particulary forward-looking. As regards the exception for text and data mining, it is the only one which cannot be overridden by licensing contracts. ${ }^{625}$ Besides, right holders may apply security measures regarding the works used

\footnotetext{
${ }^{613}$ Commission of the EU, Proposal for a Regulation of the European Parliament and of the Council on ensuring the cross-border portability of online content services in the internal market, $\operatorname{COM}(2015) 627$ final, available at http://ec.europa.eu/newsroom/dae/document.cfm?action=display\&doc_id=12524.

${ }^{614}$ See European Parliament resolution of 9 July 2015 on the implementation of Directive 2001/29/EC, no. 9.

${ }^{615}$ Commission of the EU, Towards a modern, more European copyright framework, COM(2015) 626 final, available at http://ec.europa.eu/newsroom/dae/document.cfm?action=display\&doc_id=12526.

${ }^{616}$ Ansip, The Future of Copyright Reform in the EU, November 24, 2015.

617 Ibid.

${ }^{618}$ Commission of the EU, Proposal for a Directive of the European Parliament and of the Council on Copyright in the Digital Single Market, COM (2016) 593 final.

${ }^{619}$ Idem, p. 2.

620 Idem, p. 13 (recital 5).

621 Idem, p. 14 (recital 10).

622 Idem, p. 15 (recital 14 and 15).

${ }^{623}$ Idem, p. 16 (recital 18).

624 Idem, p. 17 (recital 22).

${ }^{625}$ Idem, p. 24 (article 3 para. 2).
} 
for text and data mining, which may encroach on the use actually permitted. ${ }^{626}$ In particular, the proposed provision for the use of works in digital and cross-border teaching activities is disappointing. The digital use of works or other subject matter is only allowed for the purpose of illustration for teaching, provided that they use takes place on the premises of an educational establishment or through a secure electronic network, which is only accessible by pupils, students and teaching stuff of the respective educational establishment. ${ }^{627} \mathrm{~A}$ clearer statement in favour of remote access would have been desirable. Moreover, the limitation may be overruled by licensing contracts as long as they are easily available in the market. ${ }^{628}$ Thus, the central demand to exclude limitations in the field of access to education from being overruled by licensing contracts is neglected.

In the end, until now there has not been much progress regarding the European Copyright reform. Anyway the need to reform particularly in the field of limitations and exception cannot be doubted. Yet opinions differ, how to achieve the goal of making copyright law fit for the challenges of the digital age while harmonising the European digital single market. Some consider the existing European copyright to be sufficient. ${ }^{629}$ Others advocate political and legislative action. ${ }^{630}$

\subsubsection{Findings ${ }^{631}$}

The sections of article 5 para. 2 and 3 Information Society Directive explained before are intended to establish a framework within which member states can provide adequate limitations for the use of copyrighted works in the Information Society. In this regard elearning activities and digital uses of protected works by libraries and archives have been addressed, too. However, the requirements of the directive are narrow and do not leave much discretion for member states, because the European legislator feared to unjustly prejudice authors and right holders by giving vast room for limitations. As the decisions of the ECJ show there are many questions arising in connection with the provisions of the Information Society Directive and their transposition into member states' national laws. Also the unquestionable need for a EU copyright reform, which in many regards refers to

\footnotetext{
${ }^{626}$ Idem, p. 24 (article 3 para. 3).

627 Idem, p. 24 (article 4 para. 1(a)).

628 Idem, p. 24 (article 4 para. 2).

${ }^{629}$ See for instance Reinbothe, Neue Entwicklungen in der EU-Urheberrechtspolitik, ZGE/IPJ, Vol. 7 (2015), p. 156f. and p. 159/160, who argues that the existing copyright aquis communautaire, in particular the Directive 2001/29/EC generally provides for apropriate solutions and rather opposes a hasty copyright reform.

630 See Kuhlen, Die Allgemeine Bildungs- und Wissenschaftsschranke im Urheberrecht, Information. Wissenschaft \& Praxis 2016; 67 (1), p. 55/56, who is of the opinion that the time is ripe for a general clause favouring education and research in German and European copyright law.

${ }^{631}$ The mere reproduction of a work on paper or other analogue medium is treated by art. 5 para. 2 (a). It is normally combined with levies raised on the machines carrying out the reproduction (e.g. Xerox). A special purpose for the copies made is not mandatory.
} 
limitations and exceptions promoting access to education and knowledge, proves the insufficiency of the current EU copyright system. This estimate is not changed by the fact that the European legislator has introduced the Orphan Works Directive, which has led to the implementation of a limitation for the use of orphan works by cultural heritage institutions in the member states. Surely, the Orphan Works Directive has the potential to promote the access to knowledge and education by permitting the digitisation and making available of orphan works to the public through cultural heritage institutions, including among others educational establishments, libraries, archives and museums. Thereby the Orphan Works Directive explicitly permits digital uses of orphan works. However, the scope of the limitation provided for by the Orphan Works Directive quite restricted, because it privileges only public non-profit institutions and refers only to the right of reproduction and the right of making available to the public. Moreover, it is criticised that the provisions of the Orphan Works Directive are rather vague. Thus, it must be concluded that the Orphan Works Directive addresses the orphan works issue, which is of high relevance in the context of access to knowledge and education in the digital age, but only provides for a very specific, not to say narrow solution.

\subsection{The Human Rights Perspective on Limitations and Exceptions}

With regard to human rights and intellectual property rights there have been two main approaches to the topic, one, which points out the negative effects of intellectual property on fundamental rights such as freedom of expression or the right to health, and one, which highlights that both human and intellectual property rights equally pursue the goal of achieving a balance. ${ }^{632}$ It appears that the second approach is the one to follow, because only by creating a fair balance of the interests involved, the intended social benefit for all stakeholders will be achieved. ${ }^{633}$

In the context of this study the area of conflict lies between the right of authors of copyrighted works to protect their exclusive rights on the one hand and the right to education and culture of users of copyrighted works on the other. Especially with regard to the design of limitations and exceptions promoting access to education and knowledge contradicting interests of authors and users of protected works become apparent.

As was already implied before and will be elaborated in more detail hereinafter, both copyright law and the right to education and culture are considered fundamental human

\footnotetext{
${ }^{632}$ Gervais, How Intellectual Property and Human Rights: Can Live Together: An Updated Perspective, in Intellectual Property Law and Human Rights (2015), p. 3.

${ }^{633}$ In that sense Sganga, Right to culture and copyright: participation and access, in Research Handbook on Human Rights and Intellectual Property (2015), p. 563.
} 
rights and thus carry a lot of weight into the balancing process. Further, the significance of a human rights approach in the discussion about limitations and exceptions to copyright is even more important in view of the tendencies to approach copyright law from a mainly economic point of view leading to an overprotection of the rights of authors and right holders.

\subsubsection{The Human Right to Education}

The human right to education is enshrined in article 26 of the Universal Declaration of Human Rights (UDHR). ${ }^{634}$ Article 26 UDHR stipulates that

(1) Everyone has the right to education. Education shall be free, at least in the elementary and fundamental stages. Elementary education shall be compulsory. Technical and professional education shall be made generally available and higher education shall be equally accessible to all on the basis of merit.

(2) Education shall be directed to the full development of the human personality and to the strengthening of respect for human rights and fundamental freedoms. It shall promote understanding, tolerance and friendship among all nations, racial or religious groups, and shall further the activities of the United Nations for the maintenance of peace.

(3) Parents have a prior right to choose the kind of education that shall be given to their children.

Article 26 para. 1 UDHR contains the right to free, fundamental education in a broad sense. ${ }^{635}$ The term "free" probably refers to education itself, which has to be free of charge, but this does not mean that students have to bear certain costs. ${ }^{636}$ The provision does not make a distinction between elementary and fundamental education, but it is clear that elementary education has to be compulsory. ${ }^{637}$ It can be assumed that elementary education embraces learning to read, to write, to do the maths and other basic social abilities. ${ }^{638}$ Article 26 para. 2 UDHR further highlights the importance of education for the development of the human personality and the strengthening of respect for human rights. This is in line with the preamble of the UDHR, which refers to the "inherent dignity" of all human beings as the source of human rights in general. ${ }^{639}$

\footnotetext{
${ }_{634}$ The UDHR was adopted by the United Nations General Assembly resolution 217 (III) A of December 10, 1948.

${ }^{635}$ Foster, The Conflict between the Human Right to Education and Copyright, in Intellectual Property Law and Human Rights (2015), p.341.

${ }^{636}$ Ibid.

637 Ibid.

638 Ibid.

639 Helfer, The Right to Education and Copyright in Learning Materials, in Human Rights and Intellectual Property (2011), p. 328.
} 
However, the UDHR cannot be considered as legally binding according to international law, because neither it has the status of a treaty or convention, nor the right to education has reached the level of customary international law. ${ }^{640}$ This is why a binding treaty was concluded, which explicitly addresses the objectives of the UDHR. ${ }^{641}$ This treaty is the International Covenant on Economic, Social and Cultural Rights (ICESCR). ${ }^{642}$

The right to education is enshrined in articles 13 and 14 ICESCR, which provide the following:

\section{Article 13}

1. The States Parties to the present Covenant recognize the right of everyone to education. They agree that education shall be directed to the full development of the human personality and the sense of its dignity, and shall strengthen the respect for human rights and fundamental freedoms. They further agree that education shall enable all persons to participate effectively in a free society, promote understanding, tolerance and friendship among all nations and all racial, ethnic or religious groups, and further the activities of the United Nations for the maintenance of peace.

2. The States Parties to the present Covenant recognize that, with a view to achieving the full realization of this right:

(a) Primary education shall be compulsory and available free to all;

(b) Secondary education in its different forms, including technical and vocational secondary education, shall be made generally available and accessible to all by every appropriate means, and in particular by the progressive introduction of free education;

(c) Higher education shall be made equally accessible to all, on the basis of capacity, by every appropriate means, and in particular by the progressive introduction of free education;

(d) Fundamental education shall be encouraged or intensified as far as possible for those persons who have not received or completed the whole period of their primary education;

(e) The development of a system of schools at all levels shall be actively pursued, an adequate fellowship system shall be established, and the material conditions of teaching staff shall be continuously improved.

3. The States Parties to the present Covenant undertake to have respect for the liberty of parents and, when applicable, legal guardians to choose for their children

\footnotetext{
${ }^{640}$ Foster, The Conflict between the Human Right to Education and Copyright, in Intellectual Property Law and Human Rights (2015), p.341/342.

641 Idem, p. 342.

${ }^{642}$ The ICESCR was adopted by the United Nations General Assembly resolution 2200A (XXI) of December 16, 1966 and came into force on January 3, 1976.
} 
schools, other than those established by the public authorities, which conform to such minimum educational standards as may be laid down or approved by the State and to ensure the religious and moral education of their children in conformity with their own convictions.

4. No part of this article shall be construed so as to interfere with the liberty of individuals and bodies to establish and direct educational institutions, subject always to the observance of the principles set forth in paragraph I of this article and to the requirement that the education given in such institutions shall conform to such minimum standards as may be laid down by the State.

\section{Article 14}

Each State Party to the present Covenant which, at the time of becoming a Party, has not been able to secure in its metropolitan territory or other territories under its jurisdiction compulsory primary education, free of charge, undertakes, within two years, to work out and adopt a detailed plan of action for the progressive implementation, within a reasonable number of years, to be fixed in the plan, of the principle of compulsory education free of charge for all.

As one can see these provisions are much more specific than article 26 UDHR. According to article 13 para. 1 ICESCR education is explicitly connected not only to "the full development of the human personality", as is pointed out by article 26 para. 2 UDHR, but also to "the sense of its dignity". Further, it is explicitly emphasised that education has the objective of enabling "all persons to participate effectively in a free society". In that sense General Comment No. 13 of the Committee on Economic, Social and Cultural Rights ${ }^{643}$ states that "Education is both a human right in itself and an indispensable means of realizing other human rights. As an empowerment right, education is the primary vehicle by which economically and socially marginalized adults and children can lift themselves out of poverty and obtain the means to participate fully in their communities." highlights the fundamental significance of the right to education and of education as such for human and social development.

In the context of this study of particular importance are the principles established by article 13 para. 2 ICESCR, because the provision deals with the right to receive an education. Following article 13 para. 2 ICESCR education on all levels and in all forms must have the

\footnotetext{
${ }^{643}$ The Committee on Economic, Social and Cultural Rights is a sub-committee of the United Nations Economic and Social Council, which was established by the UN Charter of October 24, 1945.

${ }_{644}$ Committee on Economic, Social and Cultural Rights, Implementation of the International Covenant on Economic, Social and Cultural Rights, General Comment No. 13, the right to education (article 13 of the Covenant), E/C.12/1999/19, December 8, 1999, para. 1.
} 
features of availability, accessibility, acceptability and adaptability. ${ }^{645}$ The principle of availability refers to the functioning of educational institutions and programs, which have to be available in sufficient quantity within a certain jurisdiction. ${ }^{646}$ What is exactly required for the functioning of educational institutions depends among others on the state of development of a country. ${ }^{647}$ Most educational institutions and programs will among others require buildings, sanitation facilities, trained teachers and teaching materials; in other cases this criterion may relate to libraries, computers and information technology. ${ }^{648}$ The principle of accessibility means that educational institutions and programs must be accessible to everyone without discrimination. ${ }^{649}$ Non-discrimination means that education must be accessible to all, prohibiting in particular the discrimination of children, women and indigenous people as well as racial discrimination. ${ }^{650}$ Moreover, accessibility means that education has to be physically accessible in the sense that "education has to be within safe physical reach, either by attendance at some reasonably convenient geographic location (e.g. a neighbourhood school) or via modern technology (e.g. access to a "distance learning" programme); “651 Finally, accessibility also means economic accessibility, i.e. education has to be affordable to all. ${ }^{652}$ With regard to the economic aspect of accessibility it has to be noted that according to article 13 para. 2 ICESCR only primary education has to be available "free to all" whereas free secondary and higher education shall be progressively introduced. ${ }^{653}$ The principle of acceptability relates to the form and content of education, e.g. teaching methods, relevance and quality. ${ }^{654}$ The principle of adaptability means that education has to be flexible in order to adapt to social changes and different cultural environments. ${ }^{655}$

With regard to access to knowledge and education especially the principles of availability and accessibility as well as the principle of adaptability are of interest, since especially in developing countries learning materials and facilities often are not or not sufficiently available. Schools, universities, libraries and other institutions are not accessible in a physical sense, e.g. because of long distances or insufficient ICT infrastructure. In addition, education may not be accessible because of economic obstacles, i.e. the costs of learning materials. Even though stated differently by Article 13 para. 2 (a) ICESCR the problem of economic inaccessibility also affects primary education, at least in developing countries, not

\footnotetext{
${ }^{645}$ Committee on Economic, Social and Cultural Rights, Implementation of the International Covenant on Economic, Social and Cultural Rights, General Comment No. 13, the right to education (article 13 of the Covenant), E/C.12/1999/19, December 8, 1999, para. 6.

646 Idem, para. 6 (a).

647 Ibid.

648 lbid.

649 Idem, para. 6 (b).

650 Idem, para. 6 (b)(i) and para. 31 - 37.

${ }^{651}$ Idem, para. 6 (b)(ii).

652 Idem, para. 6 (b)(iii).

653 lbid.

654 Idem, para. 6 (c).

655 Ibid
} 
to speak of secondary and higher education, especially where the use of ICT is necessary. ${ }^{656}$

Article 14 ICESCR emphasises the practical side of the right to education by establishing the obligation for states party to the ICESCR to adopt detailed plans for the implementation compulsory primary education free for all.

All together, the right to education, as stipulated by article 13 and 14 ICESCR, is of vital importance. ${ }^{657}$ The right to education is considered an economic, social and cultural right. ${ }^{658}$ To say it with the exact words of the Committee on Economic, Social and Cultural Rights: "It is also, in many ways, a civil right and a political right, since it is central to the full and effective realization of those rights as well. In this respect, the right to education epitomizes the indivisibility and interdependence of all human rights. "659 The significance of the right to education is thus important that not even parents, guardians or the state are allowed to decide whether a child should have access to primary education or not. ${ }^{660}$

\subsubsection{The Human Right to take part in Culture Life and the Right of Authors to the Protection of their Moral and Material Interests}

In the context of access to knowledge and education not only the human right to education but also the right to take part in cultural life is of great significance. The human right to take part in cultural life is enshrined in article 27 UDHR, which reads as follows:

(1) Everyone has the right freely to participate in the cultural life of the community, to enjoy the arts and to share in scientific advancement and its benefits.

(2) Everyone has the right to the protection of the moral and material interests resulting from any scientific, literary or artistic production of which he is the author.

As one can see this provision also enshrines the right of authors to the protection of their moral and material interests. Consequently, both the right to take part in cultural life and the right of authors to the protection of moral and material interests have the status of a human right. ${ }^{661}$ It is not surprising that the inclusion of these contradicting rights into one article

\footnotetext{
${ }^{656}$ Cf. Helfer, The Right to Education and Copyright in Learning Materials, in Human Rights and Intellectual Property (2011), p. 332 - 334, who especially refers to the availability respectively the unavailability of textbooks and learning materials.

${ }^{657}$ Committee on Economic, Social and Cultural Rights, Substantive Issues arising in the Implementation of the International Covenant on Economic, Social and Cultural Rights, General Comment No. 11, plans of action for primary education, (article 14 of the Covenant), E/C.12/1999/4, May 10, 1999, para. 2.

658 lbid.

659 lbid.

660 Idem, para. 6.

${ }^{661}$ Foster, The Conflict between the Human Right to Education and Copyright, in Intellectual Property Law and Human Rights (2015), p. 344.
} 
created the potential for conflicts. ${ }^{662}$

As was explained above with regard to the human right to education of article 26 UDHR only the provisions of the ICESCR are considered to be legally binding, not the UDHR itself. Article 15 ICESCR further elaborates in para. 1 (a) and (b) the right to take part in cultural life, whereas article 15 para. 1 (c) is the counterpart to article 27 para. 2 UDHR, containing the right of authors to protection of moral and material interests in their creations. Article 15 ICESCR states:

\section{Article 15}

1. The States Parties to the present Covenant recognize the right of everyone:

(a) To take part in cultural life;

(b) To enjoy the benefits of scientific progress and its applications;

(c) To benefit from the protection of the moral and material interests resulting from any scientific, literary or artistic production of which he is the author.

2. The steps to be taken by the States Parties to the present Covenant to achieve the full realization of this right shall include those necessary for the conservation, the development and the diffusion of science and culture.

3. The States Parties to the present Covenant undertake to respect the freedom indispensable for scientific research and creative activity.

4. The States Parties to the present Covenant recognize the benefits to be derived from the encouragement and development of international contacts and co-operation in the scientific and cultural fields.

The potential field for conflict between the right to participate cultural life and enjoy the benefits of scientific progress and the right of authors to the protection of their moral and material interests carries forward here. In view of the unclear wording of the provision and the neglect of possible conflicts between author's rights and human rights, especially the right to education, it appears that at the time article 15 ICESCR was drafted it was not anticipated that intellectual property would become as important for trade, development or education as it is today. ${ }^{663}$

The area of conflict and the tensions between intellectual property rights and human rights were only addressed by the UN Sub-Commission on Human Rights, which emphasised the significance of human rights especially in view of the protection of author's rights by the

\footnotetext{
662 Ibid.

${ }^{663}$ Foster, The Conflict between the Human Right to Education and Copyright, in Intellectual Property Law and Human Rights (2015), p. 349.
} 
TRIPS agreement. ${ }^{664}$ The UN Sub-Commission on Human Rights among others pointed out that author's rights as guaranteed in article 27 para. 2 UDHR and article 15 para. 1 (c) ICESCR are subject to limitations in the public interest ${ }^{665}$ and that because human rights, in particular the right to participate in cultural life and enjoy the benefits of scientific progress and its applications, have not been adequately taken into consideration in the TRIPS Agreement, there are apparent conflicts between intellectual property rights and human rights. ${ }^{666}$ Furthermore, governments and intergovernmental organisations are requested to integrate into their legislation and policies provisions to protect a social function of intellectual property as an outcome of human rights. ${ }^{667}$ Also, it is requested that the WTO takes "fully into account the existing State obligations under international human rights instruments. "668 Finally, the Committee on Economic, Social and Cultural Rights is encouraged to clarify the relationship between intellectual property rights and human rights by drafting a general comment on this topic. ${ }^{669}$

Starting from there, the Committee on Economic, Social and Cultural Rights issued two General Comments regarding article 15 ICESCR, namely General Comment No. 17 on the right of authors to the protection of their moral and material interests ${ }^{670}$ and General Comment No. 21 on the right of everyone to take part in cultural life. ${ }^{671}$

General Comment No. 17 indicates what the Committee on Economic, Social and Cultural Rights defines as the scope of application of article 15 para. 1 (c) ICESCR and the connection between human rights and intellectual property rights. To begin with, it is stated that the rights protected by article 15 para. 1 (c) ICESCR are human rights, which derive from "the inherent dignity and worth of all persons." human rights enshrined in the ICESCR, including the right of everyone to benefit from the protection of the moral and material interests resulting from any scientific, literary or artistic production of which he or she is the author, and the rights protected by intellectual property

\footnotetext{
${ }^{664}$ Office of the High Commissioner for Human Rights, Sub-Commission on Human Rights, Intellectual Property Rights and Human Rights, resolution 2000/7, UN Doc. E/CN/Sub.2/RES/2000/7, August 17, 2000.

665 Idem, para. 1.

666 Idem, para. 2.

${ }^{667}$ Idem, para. 5 and 6.

668 Idem, para. 8

669 Idem, para. 11.

${ }^{670}$ Committee on Economic, Social and Cultural Rights, The Right of Everyone to benefit from the Protection of the Moral and Material Interests resulting from any Scientific, Literary or Artistic Production of which he or she is the Author (article 15, paragraph 1 (c), of the Covenant), General Comment No. 17, E/C.12/GC/17, January 12, 2006.

${ }^{671}$ Committee on Economic, Social and Cultural Rights, The Right of Everyone to take part in Cultural Life (art. 15, para. 1 (a), of the International Covenant on Econimic, Social and Cultural Rights), General Comment No. 21, E/C.12/GC/21, December 21, 2009.

${ }^{672}$ Committee on Economic, Social and Cultural Rights, The Right of Everyone to benefit from the Protection of the Moral and Material Interests resulting from any Scientific, Literary or Artistic Production of which he or she is the Author (article 15, paragraph 1 (c), of the Covenant), General Comment No. 17, E/C.12/GC/17, January 12, 2006, para. 1.
} 
systems. ${ }^{673}$ Further, it is pointed out that human rights are fundamental, inalienable and universal rights, which belong to individuals. ${ }^{674}$ Compared with this intellectual property rights, with the exception of moral rights, are limited in time and scope and can be traded, amended or even for forfeited. ${ }^{675}$ The human right of article 15 para. 1 (c) ICESCR is intended to protect the personal connection of the author to his work and his basic interests in exploiting his work to achieve an adequate standard of living, whereas intellectual property rights normally protect commercial interests and investments. ${ }^{676}$ Because of these differences the human rights protected by article 15 para. 1 (c) ICESCR cannot be equated to intellectual property rights. ${ }^{677}$ Thus, when it comes to balancing intellectual property rights with human rights, it should be taken into account that they do not have the same level of significance ${ }^{678}$ Further, it is clarified that the protection of article 15 para. 1 (c) ICESCR only accrues to natural persons, not to corporations, whose interests however maybe protected by intellectual property regimes. ${ }^{679}$ The protection of moral rights is justified with the close personal link between the author and his creation. ${ }^{680}$ The protection of material interests roots in the connection of intellectual and physical property, the latter being recognised by article $17 \mathrm{UDHR}^{681}$ It is also established that the right to the protection of the moral and material interests resulting from one's scientific, literary and artistic creations can be limited and has to me balanced with other rights protected by the ICESCR. ${ }^{682}$ Limitations must be proportionate and take into account the personal connection between the author and his work and his interests in achieving an adequate standard of living. ${ }^{683}$ Under certain conditions the introduction of limitations may require a payment of fair compensation. ${ }^{684}$ Finally, is stipulated that states party to the ICESCR have the obligation to strike an adequate balance between the protection of the rights granted by article 15 para. 1 (c) ICESCR and the other rights protected by the ICESCR. ${ }^{685}$ Thereby the private interests of authors shall not be favoured inadequately and the public interest in broad access to works protected by intellectual property should be adequately considered. ${ }^{686}$ National intellectual property regimes should not hinder states to fulfil their obligation with regard to the rights to food,

\footnotetext{
673 Ibid.

674 Ibid.

675 Idem, para. 2.

676 Ibid.

677 Idem, para. 3

${ }^{678}$ Sganga, Right to culture and copyright: participation and access, in Research Handbook on Human Rights and Intellectual Property (2015), p. 569.

${ }^{679}$ Committee on Economic, Social and Cultural Rights, The Right of Everyone to benefit from the Protection of the Moral and Material Interests resulting from any Scientific, Literary or Artistic Production of which he or she is the Author (article 15, paragraph 1 (c), of the Covenant), General Comment No. 17, E/C.12/GC/17, January 12, 2006 , para. 7.

680 Idem, para. 12.

${ }^{681}$ Idem, para. 15

682 Idem, para 22.

683 Idem, para. 23.

${ }^{684}$ Idem, para. 24.

685 Idem, 35.

686 Ibid.
} 
health and education as well as the right to take part in cultural life ${ }^{687}$ Because of the social function of intellectual property states also have the obligation to avoid unreasonably high costs for the access to essential medicines, plant seeds or other means of food production, or for school books and learning materials, by which the rights of large parts of the population with regard to health, food and education could be undermined. ${ }^{688}$ As a result, intellectual property and in particular copyright legislation both on international and national level must be measured against these human rights obligations.

General Comment No. 21 explains the interpretation of article 15 para. 1 (a) ICESCR by the Committee on Economic, Social and Cultural Rights. First, it is clarified that the right of everyone to take part in cultural life is closely connected with the other rights granted by the ICESCR and especially with the rights enshrined in article 15 ICESCR, in particular the right to enjoy the benefits of scientific progress and its applications (article 15 para. 1 (b) ICESCR) and the right of everyone to benefit from the protection of moral and material interest resulting from any scientific, literary or artistic production which he or she is the author (article 15 para. 1 (c) ICESCR). ${ }^{689}$ It is also pointed out that the right of everyone to take part in cultural life is "intrinsically linked to the right to education" contained in article 13 and 14 ICESCR. ${ }^{690}$ The right to take part in cultural life is defined as a freedom, meaning that states have to safeguard that the decision to exercise or not to exercise the right is recognised, respected and protected. ${ }^{691}$ Further, it is established that the right to take part in cultural life is characterised by three main features linked to each other, i.e. participation, access and contribution. ${ }^{692}$ Participation relates to everyone's freedom to act freely, to make his own choices, to engage in political or social life, to express oneself in whatever form. ${ }^{693}$ Compared with this, contribution means that everyone has the right to be involved in cultural processes related to the community to which a person belongs. ${ }^{694}$ Finally, the term access is defined as the right of everyone "to know and understand his or her own culture and that of others through education and information, and to receive quality education and training with due regard for cultural identity. "695 Moreover, it is clarified that everyone has the right to "learn about forms of expression and dissemination through any technical medium of information communication (...) And to benefit from the cultural heritage and the creation of other

\footnotetext{
687 Ibid.

688 Ibid.

${ }^{689}$ Committee on Economic, Social and Cultural Rights, The Right of Everyone to take part in Cultural Life (art. 15, para. 1 (a), of the International Covenant on Econimic, Social and Cultural Rights), General Comment No. 21, E/C.12/GC/21, December 21, 2009, para. 2.

690 lbid.

${ }^{691}$ Idem, para. 6 and 7.

692 Idem, para. 15.

693 Idem, para. 15 (a)

694 Idem, para. 15 (c)

${ }^{695}$ Idem, para. 15 (b)
} 
individuals and communities. ${ }^{696}$ Although here possible conflicts between the right to take part in cultural life and the right of authors appear, the issue is not further treated there. Yet, it is acknowledged that due to the connection between the right to take part in cultural life and other human rights, states have the obligation to ensure that the implementation of article 15 para. 1 (a) ICESCR does not negatively affect the exercise the human rights. ${ }^{697}$ Therefore, under certain conditions it may be necessary to proportionately limit the right of everyone to take part in cultural life. ${ }^{698}$ Here as well the interplay between the right of everyone to take part in cultural life and other human rights shines up. Furthermore, states are obliged to safeguard that the right of everyone to take part in cultural life is respected, protected and fulfilled. ${ }^{699}$ Thus it must be ensured that everyone can make a free choice, enjoys the freedom of opinion, expression and creation, has access to his or her own cultural and linguistic heritage and may participate freely in decision-making processes (obligation to respect). ${ }^{700}$ In addition, it must be safeguarded that no one is prevented from exercising the rights listed before because of the interference of third parties (obligation to protect). ${ }^{701}$ Finally, states have the obligation to fulfil, meaning that they have to facilitate, promote and provide access, participation and contribution to cultural life. ${ }^{702}$ This obligation includes a variety of measures, such as financial aids for the creation of public institutions and infrastructure as well as the enactment of supportive legislation, ${ }^{703}$ for instance programmes for preserving and restoring cultural heritage ${ }^{704}$ the inclusion of cultural education at every level in school, ${ }^{705}$ and the guarantee of access for all to museums, libraries, cinemas and theatres and cultural activities, services and events. ${ }^{706}$ With regard to the implementation of national legislation it is clarified that the right to take part in cultural life should not only relate to "material aspects of culture (such as museums, libraries, theatres, cinemas, monuments and heritage sites)" but should also include "effective access by all to intangible cultural goods (such as language, knowledge and traditions). ${ }^{707}$

Both General Comment No. 17 and General Comment No. 21 imply that the right of authors to the protection of their moral and material interests, the right to take part in cultural life as well as the right to education are interchangeably connected to each other. It is also implied that none these rights are without limitations. General Comment No. 17 clarifies that the right

\footnotetext{
696 Ibid.

697 Idem, para. 17.

698 Idem, para. 19

699 Idem, para. 48.

700 Idem, para. 49.

${ }^{701}$ Idem, para. 50.

702 Idem, para. 51.

703 Idem, para. 52.

704 Idem, para. 54 (b)

705 Idem, para. 54 (c).

${ }^{706}$ Idem, para. 54 (d)

707 Idem, para. 70.
} 
of authors to the protection of their moral and material interests is "intrinsically linked" to the other rights enshrined in article 15 ICESCR and thus their relationship is "at the same time mutually reinforcing and reciprocally limitative." ${ }^{708}$ General Comment No. 17 also explicitly highlights the linkage between access to education and knowledge and intellectual property and reminds that a fair balance between the interests of authors and the public must be achieved. ${ }^{709}$

\subsubsection{Findings}

Although not being very explicit or even silent with regard to the connection of human rights and intellectual property, one can deduce from the analysis of the provisions of the UDHR, the ICESCR and the General Comments that states should not implement legislation, which impairs or inhibits the exercise of the human rights to education and to take part in the cultural life. The overprotection of authors' rights in view of the challenges of the digital age has had exactly this effect. Thus, legislation in this field and in particular in the context of access to education and knowledge and copyright law should focus on the achievement of a fair balance. An appropriate means to achieve this goal are limitations and exceptions to exclusive rights based on the entrenchment of the human right to education and culture in international in international law.

\subsection{The Three-Step-Test}

The limitations to exclusive rights set by national legislators must not only be applicable in accordance with the express requirements explained afore but also comply with the criteria of the so-called Three-Step-Test. The Three-Step-Test thus functions as a limit to all kinds of (national) limitations and at the same time provides for a general rule authorising national legislators to enact new limitations. ${ }^{710}$ The Three-Step-Test is found in several norms of international law and European law, which shall be briefly examined hereinafter.

\subsubsection{The Provisions Containing the Three-Step-Test}

\subsubsection{Art. 9 para. $2 \mathrm{BC}$}

The idea of the Three-Step-Test was presented at the Stockholm Revision Conference in

\footnotetext{
${ }^{708}$ Committee on Economic, Social and Cultural Rights, The Right of Everyone to benefit from the Protection of the Moral and Material Interests resulting from any Scientific, Literary or Artistic Production of which he or she is the Author (article 15, paragraph 1 (c), of the Covenant, General Comment No. 17, E/C.12/GC/17, January 12, 2006, para. 4 .

${ }^{709}$ Idem, para. 35.

710 This balanced understanding is endorsed by Dreier, Limitations: The Centrepiece of Copyright in Distress - An Introduction, 2010, para. 9.
} 
1967 regarding the right of reproduction, which was for the first time to be recognised by the Conference as part of the minimum rights standard of the Berne Convention. ${ }^{711}$ The member states had indeed incorporated in their national laws the right of reproduction as the economic right par excellence serving to exploit copyrighted works. However, on the level of international copyright law the Berne Convention did not contain such right until the Stockholm Conference. ${ }^{712}$ Together with the discussions concerning the scope of the reproduction right the question arose whether the Berne Convention should provide for a special rule allowing member states to maintain their already existing national limitations or to impose limitations on the reproduction right under national laws. ${ }^{713}$ As in the case of the above explained "minor reservations" doctrine the idea of a provision containing an exhaustive list of the permitted limitations on the reproduction right was dropped for it was realised that such list could never encompass all exceptions in national laws and would as well have the effect that member states were encouraged to introduce all limitations allowed which would as a result undermine authors 'exclusive reproductions rights and the right to equitable remuneration. ${ }^{714}$ Therefore, it was concluded that a general provision would serve best the goal of safeguarding the reproduction right against the negative effects of wide ranging national limitations on the one hand and sustaining the freedom of decision of the member states to implement national limitations which appear them to be adequate to fulfil the respective cultural and social needs on the other hand. ${ }^{715}$ After long discussions and several amendments art. 9 para. 2 BC was accepted. ${ }^{716}$ At the Paris Revision Conference in 1971 this version of the test was confirmed without any changes. ${ }^{717}$ Art. 9 para. 2 BC reads as follows:

"It shall be a matter for legislation in the countries of the Union to permit the reproduction of such works in certain special cases, provided that such reproduction does not conflict with a normal exploitation of the work and does not unreasonably prejudice the legitimate interests of the author."

Under the conditions set up by the Three-Step-Test member states are free to enact limitations on the reproduction right granted by art. 9 para. $1 \mathrm{BC}$.

\footnotetext{
${ }_{711}^{71}$ Senftleben, Copyright, Limitations and the Three-Step-Test, 2004, p. 47; Ricketson/Ginsburg, 2006, No. 13.04.

712 Senftleben, Copyright, Limitations and the Three-Step-Test, 2004, p. 47; Ricketson/Ginsburg, 2006, no. 13.03/13.04.

${ }^{713}$ Senftleben, Copyright, Limitations and the Three-Step-Test, 2004, p. 47/48; Dreier in Dreier/Hugenholtz, Concise Copyright, Berne Convention, art. 9 note 4 (b).

${ }^{714}$ Ricketson/Ginsburg, 2006, No. 13.07

715 Senftleben, Copyright, Limitations and the Three-Step-Test, 2004, p. 48; Ricketson/Ginsburg, 2006, no. 13.03 -13.09 .

${ }_{716}^{716}$ Ricketson/Ginsburg, 2006, no. 13.09.

717 Senftleben, Copyright, Limitations and the Three-Step-Test, 2004, p. 52.
} 


\subsubsection{Art. 13 TRIPS}

As an outcome of the negotiations of the Uruguay Round of $\mathrm{GATT}^{718}$ the TRIPS Agreement (Agreement on Trade Related Aspects of Intellectual Property Rights) was adopted on April 15, 1994 as an annex to the new WTO Agreement. TRIPS binds all WTO members, including the European Union and its member states. ${ }^{719}$

The Three-Step-Test is enshrined in art. 13 TRIPS which reads as follows:

"Members shall confine limitations or exceptions to exclusive rights to certain special cases which do not conflict with the normal exploitation of the work and do not unreasonably prejudice the legitimate interests of the right holder."

According to this wording art. 13 TRIPS opens a broader scope of application for the ThreeStep-Test than art. 9 para. $2 \mathrm{BC}$ for it is not limited to the reproduction right only but refers to "exclusive rights" in general. Above that art. 13 TRIPS concerns the "legitimate interests of the right holder" whereas art. 9 para. 2 BC does only speak of the "author". The Three-StepTest of art. 13 TRIPS is applicable not only to all rights granted by TRIPS but as well to minimum rights and exceptions of the Berne Convention and also comprises the rights conferred under the "minor reservations" doctrine. ${ }^{720}$ This extension of applicability of TRIPS and the Three-Step-Test is made by reference to art. 9 para. 1 sen. 1 TRIPS which states that "Members shall comply with Articles 1 through 21 of the Berne Convention (1971) and the Appendix thereto." However, according to art. 9 para. 1 sen. 2 TRIPS the reference does not include the moral rights granted by art. 6 bis $\mathrm{BC}$. The omission of protecting moral rights thus is not subject to WTO Dispute Settlement although this is a relevant factor in international trade. $^{721}$

Because of this reference made by art. 9 para. 1 sen. 1 TRIPS to the Berne Convention the question arises whether the provisions of TRIPS and of the BC in general and art. 13 TRIPS and art. 9 para. $2 \mathrm{BC}$ in particular come into conflict with each other. It is yet established that the provisions of TRIPS shall support those of the $B C{ }^{722}$ This holds true as well for the Three-Step-Test under TRIPS, which was created to extend the scope of application of the rules concerning already existing copyright limitations and thus is intended to function as an

\footnotetext{
${ }_{718}^{718}$ General Agreement on Tariffs and Trade.

${ }^{719}$ Dreier/Hugenholtz in Dreier/Hugenholtz, Concise Copyright, TRIPS, Introductors Remarks, note 1.

720 Dreier in Dreier/Hugenholtz, Concise Copyright, TRIPS, art. 13 note 1.

721 Dreier in Dreier/Hugenholtz, Concise Copyright, TRIPS, art. 9 note 2 (b); Schack 2015, no. 998.

722 Gervais, TRIPS, 2012, no. 1.17; Schack 2015, no. 998; this can be deduced from art. 20 BC (more extensive rights granted by bilateral agreements) and art. 2 para. 2 TRIPS (no derogation of Berne or Rome provisons by TRIPS).
} 
additional safeguard to the Three-Step-Test originally embodied in art. 9 para. 2 BC. ${ }^{723}$ Art. 13 TRIPS therefore can be qualified as a "Berne-Plus" provision. ${ }^{724}$

\subsubsection{WIPO Treaties}

In the course of the 1990s due to the growing importance of digital technologies and the changes brought about by the Internet the effects on copyright protection became visible and called for new international instruments to cope with these challenges. ${ }^{725} \mathrm{~A}$ revision of the Berne Convention in order to adapt it to the digital age seemed infeasible. ${ }^{726}$ Therefor WIPO decided to fill the gap by adopting on December $20^{\text {th }}, 1996$ the WIPO Copyright Treaty (WCT) and the WIPO Performances and Phonograms Treaty (WPPT), addressing for the first time the copyright issues raised by new digital technologies and the worldwide spread of the Internet. The WCT provides for rules concerning copyright, the WPPT deals with neighbouring rights. In both treaties the Three-Step-Test is enshrined, namely in art. 10 WCT and art. 16 WPPT which will afterwards be analysed shortly.

\subsection{Art. 10 WCT}

As art. 13 TRIPS as well art. 10 WCT refers to the original version of the Three-Step-Test embodied in art. 9 para. $2 \mathrm{BC}$. It extends, however, the scope of the test to the new rights granted under WCT, which are the distribution right (art. 6 WCT), the rental right (art. 7 WCT), the right of communication to the public and the right of making available (art. 8 WCT). ${ }^{727}$ Art. 10 WCT reads as follows:

(1) Contracting Parties may, in their national legislation, provide for limitations of or exceptions to the rights granted to authors of literary and artistic works under this Treaty in certain special cases that do not conflict with a normal exploitation of the work and do not unreasonably prejudice the legitimate interests of the author.

(2) Contracting Parties shall, when applying the Berne Convention, confine any limitations of or exceptions to rights provided for therein to certain special cases that do not conflict with a normal exploitation of the work and do not unreasonably prejudice the legitimate interests of the author.

In order to fully understand the scope of art. 10 WCT the Agreed Statement hereto must be

\footnotetext{
${ }_{723}^{723}$ Senftleben, Copyright, Limitations and the Three-Step-Test, 2004, p. 90.

724 Ibid.; Schack 2015, no. 998.

725 Senftleben, Copyright, Limitations and the Three-Step-Test, 2004, p. 91; Senftleben in Dreier/Hugenholtz, Concise Copyright, WCT, Introductory Remarks, note 2.

${ }^{726}$ Schack 2015, no. 1005.

727 Xalabarder, WIPO Study 2009, p. 23.
} 
considered as well. It has the following wording:

"It is understood that the provisions of Article 10 permit Contracting Parties to carry forward and appropriately extend into the digital environment limitations and exceptions in their national laws which have been considered acceptable under the Berne Convention. Similarly, these provisions should be understood to permit Contracting Parties to devise new exceptions and limitations that are appropriate in the digital network environment."

According to art. 10 para. 1 WCT national legislators must comply with the prerequisites of the Three-Step-Test when setting limits to the rights granted by art. 6, 7 and 8 WCT. ${ }^{728}$ Art. 10 para. 1 WCT is directly applicable to national limitations. ${ }^{729}$ Hence art. 10 para. 2 WCT deviates slightly in its wording from the Berne version of the Three-Step-Test and the Agreed Statement must be considered additionally regarding the interpretation of art. 10 para. 2 WCT, complex questions arise how the provisions of the two set of rules interoperate. An exhaustive analysis of these issues would go beyond the scope of the present study. ${ }^{730}$ Nonetheless, the problem shall be addressed here in short.

The question is whether art. 10 para. 2 WCT applies to all rights granted by the Berne Convention and thus provides for an additional requirement the members of the WCT must fulfil when introducing limitations under the Berne Convention into national law. ${ }^{731}$ It is yet established that art. 10 para. $2 \mathrm{BC}$ functions as a supplementary provision which ascertains the limitations granted under the Berne Convention by forcing members of the WCT to not only comply with the Three-Step-Test under Berne but as well under WCT. ${ }^{732}$ The Agreed Statement though relativises the effect of art. 10 para. 2 WCT. In sentence 1 it is clarified that members of the WCT are not hindered by the art. 10 WCT to create national limitations for the digital environment as long as these limitations are in accordance with the Three-StepTest of the Berne Convention. Sentence 2 was added for it should be made clear that art. 10 para. 2 WCT in its function as an additional safeguard to Berne limitations should not narrow at the same time the scope of application of limitations permitted under the Berne Convention. ${ }^{733}$ Thus art. 10 para. 2 WCT neither reduces nor extends the scope of limitations granted under the Berne Convention. ${ }^{734}$

\footnotetext{
${ }^{728}$ Senftleben in Dreier/Hugenholtz, Concise Copyright, WCT, art. 10 note 2 (a). ${ }^{729}$ Ibid.

${ }^{730}$ A detailed analysis of the issues concerned gives Ricketson, WIPO Study 2003, p. 56 - 63.

${ }^{731}$ Cf. Ricketson, WIPO Study 2003, p. 61.

${ }_{732}$ Senftleben in Dreier/Hugenholtz, Concise Copyright, WCT, art. 10 note 2 (b).

${ }^{733}$ Idem, art. 10 note 6 (b)

734 Ibid.; Xalabarder WIPO Study 2009, p. 24.
} 


\subsection{Art. 16 WPPT}

Art. 16 WPPT refers to neighbouring rights and finds its older relative for the analogue world in art. 15 Rome Convention. Art. 16 WPPT provides for possible limitations on the protection of performers and producers of phonograms in paragraph 1 and at the same time sets the limits for such limitations by incorporating the Three-Step-Test in paragraph 2. Interpreting art. 16 WPPT one has to consider the two agreed statements enacted together with the norm. The whole set of rules reads as follows:

"(1) Contracting Parties may, in their national legislation, provide for the same kinds of limitations or exceptions with regard to the protection of performers and producers of phonograms as they provide for, in their national legislation, in connection with the protection of copyright in literary and artistic works.

(2) Contracting Parties shall confine any limitations of or exceptions to rights provided for in this Treaty to certain special cases which do not conflict with a normal exploitation of the performance or phonogram and do not unreasonably prejudice the legitimate interests of the performer or of the producer of the phonogram."

Agreed statement concerning Articles 7, 11 and 16:

"The reproduction right, as set out in Articles 7 and 11, and the exceptions permitted thereunder through Article 16, fully apply in the digital environment, in particular to the use of performances and phonograms in digital form. It is understood that the storage of a protected performance or phonogram in digital form in an electronic medium constitutes a reproduction within the meaning of these Articles."

Agreed statement concerning Article 16:

"The agreed statement concerning Article 10 (on Limitations and Exceptions) of the WIPO Copyright Treaty is applicable mutatis mutandis also to Article 16 (on Limitations and Exceptions) of the WIPO Performances and Phonograms Treaty."

Art. 16 para. 1 WPPT equates the rights of performers and producers of phonograms to those of authors of literary and artistic works under national law. ${ }^{735}$ Art. 16 para. 2 WPPT contains the Three-Step-Test and uses almost the same words as art. 10 para. 1 WCT. ${ }^{736}$ The function of the First Agreed Statement in this context is to clarify that limitations on the reproduction right based on art. 16 WPPT do cover digital reproductions, too. ${ }^{737}$ The same clarification is provided by the Second Agreed Statement stating that member states are allowed to extend already existing limitations under national laws into or craft new limitations

\footnotetext{
${ }_{735}$ Cf. article 15 para. 2 Rome Convention.

${ }^{736}$ See above 3.4.1.3.1.

${ }^{737}$ The digital storage shall be comprised by this wording as well, cf. Brison in Dreier/Hugenholtz, Concise Copyright, WPPT, art. 16 note 4 (a); Ricketson, WIPO Study 2003, p. 65.
} 
for the digital environment as long as such limitations are in accordance with the Berne Convention. ${ }^{738}$

\subsubsection{Art. 5 para. 5 Information Society Directive}

Article 5 para. 5 Information Society Directive stipulates that "the exceptions and limitations provided for in paragraphs 1, 2, 3 and 4 shall only be applied in certain special cases which do not conflict with a normal exploitation of the work or other subject-matter and do not unreasonably prejudice the legitimate interests of the rightholder." Thus the Three-Step-Test is part of the Information Society Directive. Consequently, limitations and exceptions must comply with the requirements of the test. This requirement is strengthened by recital 44 of the Information Society Directive, which states that the application of limitations and exceptions should only take place "in accordance with international obligations." Further recital 44 clarifies that "exceptions and limitations may not be applied in a way which prejudices the legitimate interests of the rightholder or which conflicts with the normal exploitation of his work or other subject-matter." Recital 44 also points out that member states should take into account especially the economic impact of limitations and exceptions in the digital environment, which may have the consequence that "the scope of certain exceptions or limitations may have to be even more limited when it comes to certain new uses of copyright works and other subject-matter."

\subsubsection{The Three Steps}

It was already pointed out that the Three-Step-Test serves as a general limit to national limitations. By implementing national provisions setting limits on authors' exclusive rights, legislators thus have to comply with the prerequisites therein set forth. At the same time the Three-Step-Test should be understood as a general rule authorising national legislators to enact new limitations.

It has to be noticed that until now there is no official interpretation of the original Berne Version of Three-Step-Test, for there has been no dispute among member states of the Berne Union on treaty interpretation. ${ }^{739}$ According to art. $33 \mathrm{BC}$ any such dispute would finally be brought before the International Court of Justice. Yet, this has never happened. However, the Three-Step-Test enshrined in art. 13 TRIPS has been subject to extensive interpretation by a WTO dispute settlement panel ${ }^{740}$ and as well some national courts have at

\footnotetext{
${ }_{738}^{738}$ Brison in Dreier/Hugenholtz, Concise Copyright, WPPT, art. 16 note 4 (b); Ricketson, WIPO Study 2003, p. 65.

739 Dreier in Dreier/Hugenholtz, Concise Copyright, Berne Convention, art. 9 note 4 (b).

740 The panel had to interpret the Three-Step-Test with regard to Section 110 (5) US Copyright Act (cf. WTO Document DS160, United States - Section 110 (5) of US Copyright Act).
} 
least taken into account the Three-Step-Test. ${ }^{741}$ Furthermore, it has to be noticed here again that the Berne Version of the Three-Step-Test refers only to the reproduction right. This limited scope of application has been overcome by the later versions of the Test as incorporated in the TRIPS agreement, the WIPO treaties and the Information Society Directive.

Therefore, in the following the several steps of the Three-Step-Test, which must be complied with cumulatively ${ }^{742}$, shall be described shortly and in general terms including all versions of the Test.

\subsubsection{Certain Special Cases}

The first step of the Three-Step-Test has the widest application for the national limitation or exception being tested must only be restricted to "certain special cases". This means the provisions has to be "sufficiently precise" and "limited in scope with regard to the exclusive right". ${ }^{74}$ It is unclear though how exactly the limited scope shall be determined, whether economically or in abstract terms, and whether the limitations granted shall be examined individually or generally. ${ }^{744}$ As the above mentioned WTO panel report stated, "certain special cases" can be assumed if national limitations are "clearly defined", "narrow in quantitative as well as qualitative sense" and "described in terms of beneficiaries of the exceptions, equipment used, types of works or by other factors". ${ }^{745}$

\subsubsection{No Conflict with the Normal Exploitation of the Work}

The second step of the Three-Step-Test requires that the respective national limitation does not cause "conflict with the normal exploitation of the work". It is established that "normal exploitation" comprises all kinds of ordinary exploitation of a work as well as possible future ways of exploitation. ${ }^{746}$ However, not any future exploitation of a work must be included for if done so no limitation would ever pass the Test. ${ }^{747}$ Moreover "normal exploitation" cannot mean that the full use of the exclusive right is permitted because otherwise limitations again

\footnotetext{
${ }^{741}$ Cf. Germany, BGH, I ZR 118/96 - Kopienversanddienst; BGH, I ZR 255/00 - elektronischer Pressespiegel; Dreier in Dreier/Hugenholtz, Concise Copyright, Berne Convention, art. 9 note 4 (b), with further references.

${ }^{442}$ This already follows from the enumerative wording of the test, cf. Dreier in Dreier/Hugenholtz, Concise Copyright, Berne Convention, art. 9 note 4 (b). This understanding is however much criticised, because it leads to a very narrow interpretation of the test and leaves only little room for limitations and exceptions, cf. Hugenholtz \& Okediji, Conceiving an International Instrument on Limitations and Exceptions to Copyright, 2008, p. 21.

${ }^{743}$ This already follows from the enumerative wording of the Test, cf. Dreier in Dreier/Hugenholtz, Concise Copyright, Berne Convention, art. 9 note 4 (b).

${ }_{744}^{74}$ Dreier in Dreier/Hugenholtz, Concise Copyright, Berne Convention, art. 9 note 4 (b).

745 WTO Document DS160, United States - Section 110 (5) of US Copyright Act, p. 33 para. 6.108 - 6.110.

${ }^{746}$ Cf. Ricketson/Ginsburg, 2006, No. 13.17.

${ }^{747}$ Dreier in Dreier/Hugenholtz, Concise Copyright, Berne Convention, art. 9 note 4 (b).
} 
would never pass the Test. ${ }^{748}$ The definition of "normal exploitation" is especially difficult considering the new digital forms of exploitation. A strong indicator for what can be deemed a "normal exploitation" is whether the author or the holder of an exclusive right is able to generate economic profit from the particular exploitation. In that context according to the WTO panel report "normal exploitation" can be defined as "a dynamic element capable of taking into account technological and market developments". ${ }^{749}$ It is albeit not sufficient to compensate the uses allowed under a limitation by simply granting authors and right holders a claim for just remuneration under national laws. ${ }^{750}$ This alone does not make a limitation compatible with the Test's second step. Thus it remains a question to be answered anew in each individual case.

As a result "conflict with the normal exploitation" occurs only "if uses, that in principle are covered by that right but exempted under the exception or limitation, enter into economic competition with the ways that right holders normally extract economic value from that right to the work (i.e., the copyright) and thereby deprive them of significant or tangible commercial gains." ${ }^{751}$ After all, a resilient definition of this prerequisite of the Three-Step-Test does not yet exist.

\subsubsection{No Unreasonable Prejudice to the Author's or Right Holders Legitimate Interests}

Finally, according to the third step of the Test a limitation must "not unreasonably prejudice the author's or right holder's legitimate interests". Here, the various public and private interests involved have to be balanced against each other. This step leaves great flexibility in order to find a just solution for each individual case.

The economic exploitation of a work by the author and the payment of remuneration fees for the use of it may be considered "legitimate interests" in this context. ${ }^{752}$ However, in order to find out whether the prejudice done to these interests is reasonable and thus has to be tolerated by the author or is unreasonable and therefore not compatible with the Three-StepTest, one has to take into account public and private interests such as the access to information or the maintaining of fair competition. ${ }^{753}$ Generally speaking, the reasons for introducing a limitation have to be weighed against the author's economic or moral interests. The prejudice done to the author may eventually be prevented or at least minimized by

\footnotetext{
${ }_{748}^{748}$ Dreier in Dreier/Hugenholtz, Concise Copyright, TRIPS, art. 13 note 2 (b).

${ }^{749}$ WTO Document DS160, United States - Section 110 (5) of US Copyright Act, p. 47 para. 6.178.

750 Dreier in Dreier/Hugenholtz, Concise Copyright, Berne Convention, art. 9 note 4 (b).

${ }^{751}$ WTO Document DS160, United States - Section 110 (5) of US Copyright Act, p. 48 para. 6.183.

${ }^{752}$ Moral rights may be taken into account here as well, cf. Ricketson/Ginsburg, 2006, No. 13.24

753 Dreier in Dreier/Hugenholtz, Concise Copyright, Berne Convention, art. 9 note 4 (b).
} 
providing for just remuneration or fair compensation for the uses made under a limitation. ${ }^{754}$

\subsubsection{Alternative Approaches to the Three-Step-Test}

Three-Step-Test, especially in its TRIPS version has become the bottleneck for most limitations and exceptions to intellectual property rights on an international level, including of course copyright law. ${ }^{755}$ As was shown above the interpretation of the Three-Step-Test by the WTO panel focuses mainly on economic aspects, which is not surprising since intellectual property has become more and more aligned with international trade law. ${ }^{756}$ This connection has increased the potential for conflicts between human rights and intellectual property rights, namely the right to education and culture and the right of authors to the protection of their interests. ${ }^{757}$

However, there are several alternative approaches to the interpretation of the Three-StepTest, which intend to confront the dominance of the economic approach with more valuebased considerations.

For instance, it is argued that the preamble and article 7 and 8 of the TRIPS Agreement open a way to the normative interpretation of the Three-Step-Test, especially of the second step. ${ }^{758}$ Both article 7 and 8 TRIPS protect rights to access, which are necessary in the context of education. ${ }^{759}$ According article 7 TRIPS intellectual property protection has to contribute to the "promotion of technological innovation and the transfer and dissemination of technology, to the mutual advantage of producers and users of technological knowledge and in a manner conducive to social and economic welfare, and to a balance of rights and obligations." 760 Obviously, not only the interests of right holders but also of users of protected content are addressed. A balance between these interests is explicitly deemed necessary. Thus, next to economic positions as well other interests maybe included in the interpretation. ${ }^{761}$ Further, article 8 TRIPS stipulates that members to the agreement may "promote the public interest in sectors of vital importance to their socioeconomic and technological development (...)". ${ }^{762}$

\footnotetext{
${ }^{754}$ Given that the use permitted does not already "conflict with the normal exploitation of the work", see ibid.

755 Gervais, How Intellectual Property and Human Rights: Can Live Together: An Updated Perspective, in Intellectual Property Law and Human Rights (2015), p. 8.

${ }^{756}$ Idem, p. 7.

${ }^{757}$ Foster, The Conflict between the Human Right to Education and Copyright, in Intellectual Property Law and Human Rights (2015), p.351.

${ }_{758}$ Geiger, Gervais, Senftleben, The Three-Step Test Revisited: How to use the Test's Flexibilities in National Copyright Law, American University International Law Review, Volume 29, Issue 3, p. 597.

${ }^{759}$ Foster, The Conflict between the Human Right to Education and Copyright, in Intellectual Property Law and Human Rights (2015), p.354.

${ }^{760}$ Article 7 TRIPS Agreement.

${ }^{761}$ Geiger, Gervais, Senftleben, The Three-Step Test Revisited: How to use the Test's Flexibilities in National Copyright Law, American University International Law Review, Volume 29, Issue 3, p. 598.

${ }^{762}$ Article 8 para. 1 TRIPS Agreement.
} 
This provision at least contains the reference to the public interest, which may be used as a starting point for introducing other than purely economic arguments. Assuming that it is argued that the provisions of article 13 TRIPS should be interpreted generously "to allow the broadest possible exceptions to promote access to educational materials for purposes of

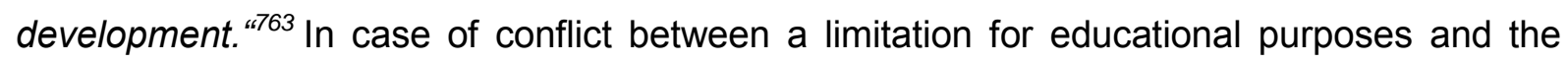
Three-Step-Test the public policy objectives of the respective limitation, such as development, should be considered first of all. ${ }^{764}$ Moreover, the preamble of the TRIPS Agreement emphasises to take into account "underlying public policy objectives of national systems for the protection of intellectual property, including developmental and technological objectives“. ${ }^{765}$ These national intellectual property and copyright policies may provide for more value-oriented arguments. Finally, the preamble of the TRIPS Agreement takes into consideration the "special needs of the least-developed country Members in respect of maximum flexibility in the domestic implementation of laws and regulations". ${ }^{766}$ These references imply the existence of the principle of proportionality in international trade law, which may open a way to provide solutions when values come into conflict. ${ }^{767}$

Another approach to add value-based arguments to the economic interpretation of TRIPS comes from patent law. ${ }^{768}$ The WTO panel ${ }^{769}$, which had to deal with the protection of a pharmaceutical product in Canada, followed a normative interpretation of article 30 TRIPS. ${ }^{770}$ This Provision contains a version of the Three-Step-Test, which applies to limitations to patents. ${ }^{771}$ It is argued that this version of the Three-Step-Test, which in its second step stipulates that "exceptions must not unreasonably conflict with a normal exploitation of the patent", is more open to the introduction of interests other than those of the right holder. ${ }^{772}$ By contrast the version of the Three-Step-Test enshrined in article 13 TRIPS only refers to "conflict with a normal exploitation of the work" and therefore contains no such starting point. Yet, it is suggested that there is no reason for treating copyright holders and patent owners

\footnotetext{
${ }^{763}$ Chon, Intellectual Property "from Below": Copyright and Capability for Education, 40 U.C. Davis Law Review (2007), p. 843.

764 Idem, p. 844.

${ }^{765}$ Preambel TRIPS Agreement.

766 lbid.

767 Geiger, Gervais, Senftleben, The Three-Step Test Revisited: How to use the Test's Flexibilities in National Copyright Law, American University International Law Review, Volume 29, Issue 3, p. 599.

${ }^{768}$ See with regard to the right to health, Wager, Watal, Human rights and international intellectual property law, in Research Handbook on Human Rights and Intellectual Property (2015), p. $161 \mathrm{ff}$.

769 WTO Panel Report, Canada - Patent Protection of Pharmaceutical Products, April 7, 2000, WtO Doc. WT/DS114/R.

${ }_{770}$ Geiger, Gervais, Senftleben, The Three-Step Test Revisited: How to use the Test`s Flexibilities in National Copyright Law, American University International Law Review, Volume 29, Issue 3, p. 599.

${ }^{771}$ Article 30 TRIPS: "Members may provide limited exceptions to the exclusive rights conferred by a patent, provided that such exceptions do not unreasonably conflict with a normal exploitation of the patent and do not unreasonably prejudice the legitimate interests of the patent owner, taking account of the legitimate interests of third parties."

772 Geiger, Gervais, Senftleben, The Three-Step Test Revisited: How to use the Test's Flexibilities in National Copyright Law, American University International Law Review, Volume 29, Issue 3, p. 600.
} 
differently. ${ }^{773}$

Another, value-orientated approach to the Three-Step-Test is pursued with the introduction of human and fundamental rights, rooted in international law. ${ }^{774}$ In particular the UDHR and the ICESCR are the sources of human rights, such as the right to education and culture. These instruments provide for guidelines for the interpretation of the TRIPS Agreement and consequently also of the Three-Step-Test. ${ }^{775}$ Especially when it comes to human rights particularly relevant for the individual as well as for society as a whole, the significance of UDHR and the ICESCR cannot be completely ignored. ${ }^{776}$ It is even argued that International human rights instruments are higher ranking than trade laws, which is why trade laws must be interpreted in the light of human rights. ${ }^{777}$ In that sense human rights would have a kind of Drittwirkung in the area of intellectual property and trade law. ${ }^{778}$ The significance of human rights with regard to TRIPS Agreement and therefore to the Three-Step-Test has been pointed out by the Sub-Commission on Human Rights. ${ }^{779}$ It recommended that international organisations, including the UN Conference on Trade and Development, "continue and deepen their analysis of the impacts of the TRIPS Agreement, including consideration of its human rights implications. "780

With regard to the third step of the Three-Step-Test there is more room for flexibilities. According to the text of article 13 TRIPS limitations and exceptions shall not "unreasonably prejudice the legitimate interests of the right holder." The wording of the provision implies that the right holder may has to tolerate a certain level of prejudice. This may be the case when the prejudice is justified by values deemed superior to the right holders interests. ${ }^{781}$ Which interests have to be given precedence is the outcome of the balancing process. This said in advance the third step opens the way to a kind of proportionality test, which is regularly used to solve conflicts between fundamental rights. ${ }^{782}$

In view of the dominant economic approach to the interpretation of Three-Step-Test in particular and of intellectual property and copyright law in general leading to a one-sided

\footnotetext{
773 Ibid.

774 Idem, p. 601/602.

775 Idem, p. 602.

776 Ibid.

777 Ibid; see also Sganga, Right to culture and copyright: participation and access, in Research Handbook on Human Rights and Intellectual Property (2015), p. 573, with regard to the right to take part in cultural life of article 15 para. 1 (a) ICESCR.

778 Cf. Sganga, Right to culture and copyright: participation and access, in Research Handbook on Human Rights and Intellectual Property (2015), p. 573.

${ }_{779}$ Office of the High Commissioner for Human Rights, Sub-Commission on Human Rights, Intellectual Property Rights and Human Rights, resolution 2000/7, UN Doc. E/CN/Sub.2/RES/2000/7, August 17, 2000, para. 2. ${ }^{780}$ Idem, para. 12.

${ }^{781}$ Geiger, Gervais, Senftleben, The Three-Step Test Revisited: How to use the Test's Flexibilities in National Copyright Law, American University International Law Review, Volume 29, Issue 3, p. 604.

782 Idem, para. 604/605.
} 
focus on the interest of authors and right holders, it is necessary to turn more towards the main objectives of intellectual property and copyright law of promoting public interest in human and social development. The human rights based approach to the Three-Step-Test supports this recollection. Human rights approaches bring back values to the system. ${ }^{783}$ In contrast to the differences of national legal systems human rights are acknowledged almost all over the world and therefore could lay the ground for international harmonisation. ${ }^{784}$ It could thus makes sense to refer directly to the UDHR in the TRIPS Agreement in order to provide for guidelines for the interpretation of the agreement in the light of human rights. ${ }^{785}$ such measures could confront the tendencies to interpret the provisions of TRIPS systematically from an economic author-centred view towards a more value-oriented and ethical approach. ${ }^{786}$

However, it seems to go to far to generally consider human rights superior to intellectual property rights and copyright. Indeed, this would place public interest and human rights directly into the intellectual property and copyright system overruling any inferior position. ${ }^{787}$ Yet, this understanding would neglect that also human rights may be limited, especially by other rights, all the more by rights of the same rank, ${ }^{788}$ which is the case for intellectual property rights and copyright, because as was explained above both the right to education and culture and the right of authors to the protection of their moral and material interests are human rights.

Instead of overemphasising the human rights approach by imposing it to intellectual property and copyright regimes, it appears more sensible to open up existing instruments like the Three-Step-Test to a more balanced and human rights based interpretation, as promoted by the Declaration on the Balanced Interpretation of the Three-Step-Test in Copyright Law. ${ }^{789}$ This declaration, issued by the Max Planck Institute for Intellectual Property, Competition and Tax Law, and Queen Mary, University of London, in 2010, notes in its preface that the ThreeStep-Test has on the one hand effectively prevented an excessive implementation and

\footnotetext{
${ }^{783}$ Gervais, How Intellectual Property and Human Rights: Can Live Together: An Updated Perspective, in Intellectual Property Law and Human Rights (2015), p. 17.

${ }^{784}$ Geiger, Reconceptualizing the Constitutional Dimension of Intellectual Property, in Intellectual Property Law and Human Rights (2015), p. 141.

${ }_{785} \mathrm{lbid}$, making reference to the resolution of Office of the High Commissioner for Human Rights, SubCommission on Human Rights, Intellectual Property Rights and Human Rights, resolution 2000/7, UN Doc. E/CN/Sub.2/RES/2000/7, August 17, 2000 and Pointing out that this resolution has no binding character.

${ }^{786}$ Geiger, Reconceptualizing the Constitutional Dimension of Intellectual Property, in Intellectual Property Law and Human Rights (2015), p. 142.

${ }^{787}$ See Hugenholtz \& Okediji, Conceiving an International Instrument on Limitations and Exceptions to Copyright, 2008 , p. 30

${ }^{788}$ Cf. idem , p. 31

${ }^{789}$ Geiger / Hilty / Griffiths / Suthersanen, Declaration - A Balanced Interpretation Of The "Three-Step Test" In Copyright Law. jipitec, Vol. 1, 2010, p. 119 - 121.
} 
application of limitations and exceptions at disadvantage of authors and right holders. ${ }^{790}$ It is further noted that on the other hand there is no mechanism that safeguards that limitations and exceptions are not excessively restricted at a disadvantage of its beneficiaries. ${ }^{791}$ In order to achieve a fair balance of interest signatories of the declaration take a stand for a balanced approach to the Three-Step-Test. ${ }^{792}$ While it is demanded that the test is subject to an overall assessment and not a step-by-step analysis, the declaration underscores in particular the significance of fundamental rights with regard to public interest considerations in the balancing process and states that there is room for a balance between economic and social interests. ${ }^{793}$ It is also established that limitations and exceptions must not be interpreted narrowly, but rather according to the objectives and purposes. ${ }^{794}$ This again opens the door for public interest and fundamental rights approaches. Finally, the declaration makes explicit reference to third-party interests, namely human rights and fundamental freedoms, as well as to public interests like scientific progress and cultural, social and economic development. ${ }^{795}$

Altogether, it appears that a value-oriented human rights based understanding in the context of an overall assessment of the Three-Step-Test could pave the way to a fair balance of interest in copyright law.

\subsubsection{Findings}

The Three-Step-Test has transformed from a provision of international copyright law to a provision of international trade law, which has led to a concentration on the interests of the right holder and not as intended by the original version of the Berne Convention the interests of the author. ${ }^{796}$ This transformation has led to the understanding of the Three-Step-Test as a means to set limits to limitations and exceptions. Yet it should be understood as a means to enable limitations and exceptions, too. ${ }^{797}$ This is all the more necessary in order to achieve a fair balance of interests taking into account especially the interests of the individual and collective general public. ${ }^{798}$ The importance of a fair balance of interests and the significance of education and access to knowledge is highlighted in the preamble of the WIPO Copyright Treaty where it says "Recognizing the need to maintain a balance between the rights of

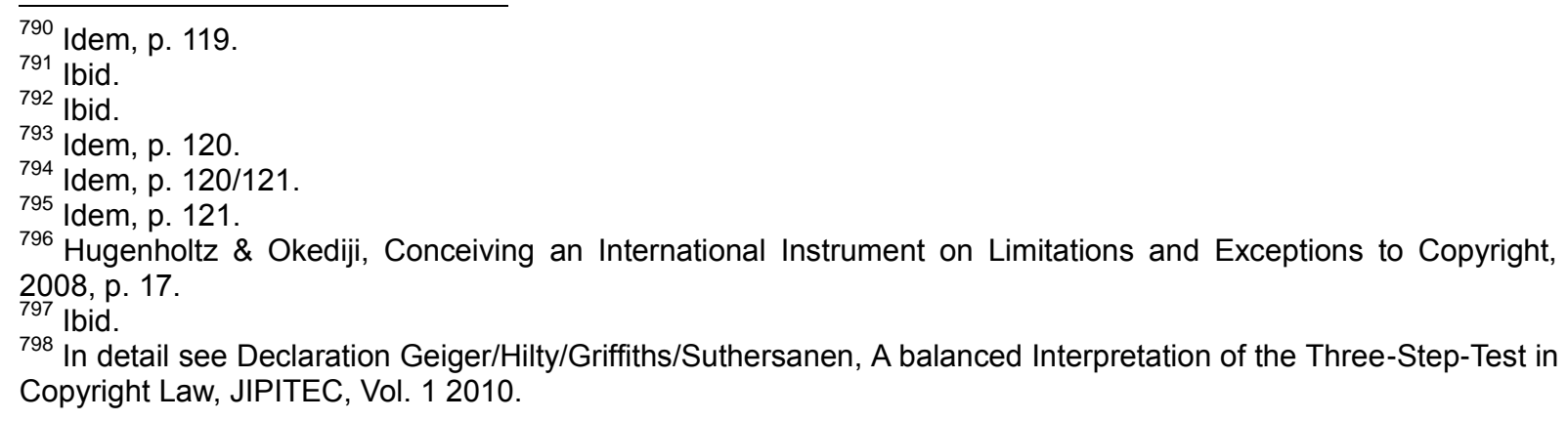


authors and the larger public interest, particularly education, research and access to information". Only through a "comprehensive overall assessment, rather than the step-bystep application that its usual" the three-step test can be applied sensibly, which includes that "no single step is to be prioritised". ${ }^{799}$ Especially when fundamental rights of third parties, meaning the larger general public, are concerned, the Three-Step-Test should pay special attention to these values. ${ }^{800}$ In view of the significance of education and the access to knowledge through libraries and archives this interpretation of the Three-Step-Test is inevitable.

\subsection{Summary Chapter 3}

As was demonstrated in this chapter there are several international treaties, agreements, conventions and directives that must be considered discussing limitations and exceptions on copyright and related rights in general and with special regard to educational purposes and libraries and archives. The one-sided author oriented approach to copyright limitations and exceptions starts on the international level, in particular with the restrictive interpretation of the Three-Step-Test. Public interest and human rights considerations have been rather neglected in the last years and led to an overprotection of authors and right holders to the detriment of individual users and the general public. Since national copyright law provisions have to comply with the prerequisites set forth in the norms examined before, the imbalance in copyright law carries forward to the national level. It was however demonstrated that there are possibilities for national legislators, jurisdictions and scholars within the international and European copyright law framework to take into account more appropriately public interest and fundamental and human rights when applying or creating new or applying existing limitations in order to achieve a balance of interests. The obligations and possibilities deriving from international and European copyright will be taken into consideration in the following analysis of national copyright laws and limitations and exceptions for educational purposes and libraries and archives. 


\section{CHAPTER 4: Limitations and Exceptions for Education and Libraries in National}

\section{Copyright Laws}

\section{Setting the Scene}

Access to education and knowledge is a key element for the successful development of societies. This is true for developed countries, but even more so for developing and least developed countries. Article 26 of the Universal Declaration of Human Rights stipulates that "everyone has the right to education". In order to deliver education and enable access to knowledge one must be allowed to use information. In that sense article 27 para. 1 of the Universal Declaration of Human Rights states that "Everyone has the right freely to participate in the cultural life of the community, to enjoy the arts and to share in scientific advancement and its benefits.", which includes the access to information. At the same time article 27 para. 2 of the Universal Declaration of Human Rights establishes that "Everyone has the right to the protection of the moral and material interests resulting from any scientific, literary or artistic production of which he is the author." Information is often embodied in copyright protected works. As a consequence this means that who controls the use of copyright protected works at the same time controls to a large extent the use of information. Who controls the use of information therefore controls the access to education and knowledge. This is why copyright systems all over the world not only grant exclusive rights to authors and right holders but also set limits to exclusive rights. For the purpose of maintaining a fair balance of the interests of authors and right holders to have control over their works and exploit them financially on the one side and the interests of the general public in human and social development through access to knowledge and education on the other side, copyright systems include certain value decisions determining under which circumstances which side has to be given the preference. The protection of authors 'rights as well as the access to education and knowledge both are of great interest for a society. This however does not necessarily mean that the value decisions taken by legislators always achieve a fair balance of interests. Moreover in times of the Internet and the rapid development of digital technologies legal provisions that some years ago appeared to be upto-date are already outdated and do not reflect the current necessities and realities.

Regarding the access to education and knowledge educational institutions and libraries are key figures. In order to enable access to education and knowledge both educational institutions and libraries as well as other institutions such as archives and museums depend on the use of copyright protected works. Thus almost any copyright system of the world provides for some limitations and exceptions privileging educational institutions and/or libraries. However, the methods of delivering education as well as the work carried out by 
libraries today have significantly changed because of digital technologies and the Internet. Today a growing part of education is delivered online or via digital networks using e-learning methods and technologies. Also libraries make use of digital technologies at a grand scale in order to provide access to their collections and preserve them. Many of the respective limitations and exceptions in national copyright laws were enacted at a time when the possibilities of digital technologies and the Internet as we know them today were not imaginable. And even where legislators tried to take into account future developments and possibilities very often the respective provisions soon proved to be not adequate to meet the new challenges. Precisely because access to education and knowledge is vital for the future of any society it is important that copyright law does not unduly prevent educational institutions and libraries from fulfilling their functions by making use of digital technologies and the Internet, which however must be feared in view of the expansion of copyright protection without sufficient consideration of limitations and exceptions.

With regard to developing and least developed countries the problem of insufficient limitations and exceptions and copyright law restricting access to education and knowledge is exacerbated, because in these countries the need for access to education and knowledge is particularly pressing. In addition, the majority of right holders is located in developed countries and the production of intellectual goods including learning materials in developing and least developed countries is comparatively low. Thus, also from the view point of intellectual property and copyright law developing and least developed countries depend from developed countries. Of course, authors and right holders have a vital interest in deriving profit from the exploitation of their works, which extends as well to the markets of developing and least developed countries. However, educational institutions and libraries, archives and similar institutions in developing and least developed countries often do not have the financial resources to purchase quality learning materials, not to speak of the students themselves. Limitations and exceptions to exclusive rights could help to solve this problem by allowing the use of copyright protected learning materials for the purpose of improving access to education and knowledge, either without payment of remuneration or at least at affordable prices. As was pointed out several times so far in the course of this study digital technologies and the Internet provide for an unlimited source of information of all kind, including copyright protected learning materials. In view of the needs of developing and least developed countries the possibilities of the digital age could promote social and human development, provided that these sources can successfully be rendered accessible. Again, limitations and exceptions promoting access to education and knowledge could contribute to achieve this goal, even if it has to be admitted that in developing and least developed countries not only copyright law but also other reasons such as insufficient ICT infrastructure 
are obstacles for access to education and knowledge in the digital age.

In this chapter limitations and exceptions for educational purposes and libraries, archives and similar institutions in several developed (USA, UK, Germany, Portugal) and developing and least developed (Brazil, Mozambique) countries will be examined, taking into special account the applicability of these provisions to digital uses of copyright protected works. In order to evaluate if the respective national system of limitations and exceptions provides for adequate solutions with regard to access to education and knowledge in the digital age, the findings of the analysis are measured against a benchmark of (digital) uses of copyrighted works, which from the viewpoint of relevant stakeholders, such educational establishments, libraries, archives and similar institutions should be permitted.

\section{Benchmark and Adequacy}

As laid out before ${ }^{801}$ there is a variety of uses of copyright protected works, which according to stakeholders should be not controlled by authors and copyright holders and thus be covered by limitations and exceptions, given the possibilities for the use of copyrighted works in the context of education and in libraries, archives and similar institutions provided by the Internet and digital technologies. These opinions serve as the basis for the following benchmark of permissible digital uses:

Limitations and exceptions for educational purposes should:

- be broad, open and technologically neutral in order to adapt to new developments.

- apply to all kinds of works including born digital content.

- apply to all kinds of uses, especially reproduction and making available to the public.

- not restrict the amount of the work that can be used.

- permit (digital) uses in classroom.

- permit online and distance education.

- allow text and data mining.

- not be overridden by contracts.

Limitations and exceptions for libraries, archives and similar cultural heritage institutions should:

- be broad, open and flexible in order to adapt to changing technological environments.

- apply to all kinds of works including born digital content.

- apply to all kinds of uses, especially reproduction and making available to the public.

\footnotetext{
${ }^{801}$ See Chapter 1.1.4 and 1.2.4.
} 
- not restrict the number of copies of works made for preservation purposes.

- allow format shifting.

- permit on-site access to collections libraries, archives and similar cultural heritage institutions.

- permit remote access to collections libraries, archives and similar cultural heritage institutions.

- permit libraries, archives and similar cultural heritage institutions to digitise analogue works in their for the purpose of making available to the public.

- not restrict the amount of users that can access a work at the same time, both on-site and remote.

- permit e-lending, including simultaneous loans of the same copy to more than one person.

- allow mass digitisation of all kinds of works in the collections of libraries, archives and similar institutions, including born digital content, out-of-commerce works and orphan works.

- allow access to all types of works.

- permit web-harvesting.

- permit text and data mining.

- not be overridden by contracts.

In general, limitations and exceptions should apply only to non-commercial purposes and use clear and uncomplicated wording in order that norm addressees, i.e. educational establishments and libraries, archives and similar institutions and their staff as well as individual users, for the sake of legal certainty can understand its scope and check whether the intended use is covered or not.

Since the benchmark includes demands for quite far-reaching limitations and exceptions, it can be assumed that these ideas are representative for stakeholders in all of the countries examined here. Nonetheless, the particularities and special conditions of each country will be taken into account.

Whether national limitations and exceptions can be considered adequate in the context of this study results from the comparison of the respective provisions currently in force and the benchmark skechted above. In principle a provision is deemed adequate, if the objective of improving access to education and knowledge is promoted. It is assumed here that the importance of this objective is undisputed and generally acknowledged. The justifications for limitations and exceptions in favour of education and knowledge ground in fundamental and human rights as well as in related public interest considerations such as the promotion of human and social development, which are universally recognised and inherent to copyright 
law itself.

Apart from that, it is self-evident that limitations and exceptions should not excessively encroach on the rights of authors and copyright owners. Thus, limitations and exceptions could also be considered inadequat, if they unduly harm the interests of authors and right holders. Thus, very generally speaking, limitations are adequate, if a fair balance of conflicting interests is achieved. However, in view of the already existing author-centered unilateral legislation in the field of copyright law this study lays the focus on the access related interests of general public and individual users. Therefore, a provision is deemed to be adequate, if access to education and knowledge is improved.

Finally, the stage of development of a country must be taken into consideration when assessing, whether limitations and exceptions provide for adequate solutions or not. In view of the widespread use of digital technologies in developed countries, limitations and exceptions in favor of education and knowledge will only be deemed adequate, if they meet all or at least most of the requirements set out be the benchmark. By contrast, in developing and least developed countries limitations and exceptions may already be considered adequate, if they enable the use of digital technologies for education and in libraries at all. In this regard there may be also differences between metropolitan and rural areas.

\section{Procedure and Objective}

Part 1 of the chapter examines limitations and exceptions to copyright law for educational purposes and libraries, archives and similar institutions in the United States of America, the United Kingdom and Germany. These countries are developed countries. To some extent they are very well comparable because of the high level of copyright protection. As well the level of copyright scholarship is high. The USA, the UK and Germany have a long tradtion of copyright law. Their influence on the development of copyright law has been great. Although sharing common western values and history, they follow different legal traditions, namely the Common Law tradition of the USA and the UK and the Droit d'Auteur tradition of Germany, which may lead to different solutions for the issues of limitations and exceptions discussed here. This is why the USA, the UK and Germany often serve as examples for other countries in the field of copyright legislation.

Part 2 of this chapter examines limitations and exceptions to copyright law for educational purposes and libraries, archives and similar institutions in Portugal, Brazil and Mozambique. These countries are linked by Portuguese language. They share a common colonial history, 
at least partly. Portugal is a member of the EU and a developed country, Brazil, the biggest country in South America, is an emerging nation, yet at the same time a developing country, and Mozambique is among the poorest countries of the world and is a least developed country. Especially in Brazil and Mozambique the need for access to education and knowledge is evident, because large parts of the population live in poverty.

The analysis of national limitations and exceptions is conducted according to the following procedure:

Initially, the relevant provisions are analysed successively as they appear in the respective national codifications on the basis of legislative materials, reports, case law (if available), literature and according to general principles of legal interpretation, i.e. text, history, systematics and objectives. Depending on the respective construction of the law the analysis is divided into sub-chapters. Results of the analysis are presented at the end of each sub chapter and/or in a summary for the respective country and measured against the benchmark sketched above. The results of Part 1 and Part 2 of the chapter are summarised at the end of each part. The Chapter concludes with an overall summary.

The objective of this chapter is to show that the current copyright legislation in the field of copyright limitations in the countries under observation here is mostly insufficient and unbalanced and therefore hinders the access to education and knowledge. It will also be shown that copyright law is an impediment to the advantageous application of digital technologies and the Internet for the promotion of access to education and knowledge especially in developing and least developed countries like Brazil and Mozambique. 
PART 1: Limitations and Exceptions for Educational Purposes and Libraries, Archives and similar Institutions in the United States of America, the United Kingdom and Germany

In the following Part 1 of Chapter 4 limitations and exceptions for educational purposes and libraries, archives and similar institutions in the USA, the UK and Germany with special attention to the use of digital technologies are examined. After a short overview over the international obligations and the (constitutional) underpinnings of copyright law of each country, the respective limitations are examined according to the procedure explained above.

\subsubsection{United States of America}

The USA adhere to the Berne Convention ${ }^{802}$ and to the WIPO Copyright Treaty ${ }^{803}$ as well as to the WIPO Performances and Phonograms Treaty ${ }^{804}$. As a WTO member the USA are also party to the TRIPS Agreement.

US copyright law is governed by the US Copyright Act of October 19, 1976 ${ }^{805}$, which since then has been amended several times. The objective of protection of US Copyright Law is determined by article 1 section 8 US Constitution, which proclaims that "Congress shall have power (...) to promote the Progress of Science and useful Arts, by securing for limited Tımes to Authors and Inventors the exclusive Right to their respective Writings and Discoveries". With this proviso copyright protection in the USA serves public interest ${ }^{806}$, which finds expression particularly in the context of limitations to copyright. ${ }^{807}$

US Copyright law provides for several limitations to exclusive rights, which are intended to allow and facilitate the use of copyrighted materials for educational purposes and in libraries and archives. There is the classroom use exception incorporated in section 110 (1) CA, there are the provisions of the "Technology, Education and Copyright Harmonization Act", so called TEACH Act, in section 110 (2) CA and there is as a broad and general exception, the fair use doctrine, codified in section $107 \mathrm{CA}$. Limitations in favour of libraries and archives are enshrined in section $108 \mathrm{CA}$.

The question is if and how these limitations can fulfil their purpose of facilitating and allowing the use of copyright protected material in a digital environment. Some limitations were made

\footnotetext{
${ }^{802}$ Accession on November 16, 1988, in Force since March 1, 1889.

${ }^{803}$ Signature on April 12, 1997, ratification on September 14, 1999, in force since March 6, 2002.

804 Signature on April 12, 1997, ratification on September 14, 1999, in force since March 6, 2002.

80517 United States Code (in the following CA).

${ }^{806}$ See above 2.2.3.2.

${ }^{807}$ See Ng, Copyright Law and the Progress of Science and the Useful Arts, 2011, p. 38, who underlines the importance of copyright for cultural and social development.
} 
especially for the digital age, but are outdated due to rapid technological development. Others stem from the analogue world and do not even have the intention to exempt certain digital uses, which are common today in education and in libraries and archives. And further, the question remains if the open and flexible fair use doctrine is able to provide adequate answers to these questions.

\subsubsection{The Classroom Exception}

Section 110 (1) CA, which was introduced in 1976, contains statutory limitations for certain uses of protected works made for educational purposes. It states that the following acts are not infringements of copyright:

"Performance or display of a work by instructors or pupils in the course of face-to-face teaching, activities of a nonprofit educational institution, in a classroom or similar place devoted to instruction, unless, in the case of a motion picture or other audiovisual work, the performance, or the display of individual images, is given by means of a copy that was not lawfully made under this title, and that the person responsible for the performance knew or had reason to believe was not lawfully made."

The relatively clear wording of this provision has been explained by a Report of the House of Representatives. ${ }^{808}$ According to this report section 110 (1) CA wants to clarify the conditions under which performances and displays of protected works in face-to-face teaching activities must not be considered copyright infringements. Educational broadcasting however is not covered by the limitation. ${ }^{809}$ This implies the understanding of performances and displays for "face-to-face" teaching activities. Meant are performances and displays, which are not transmitted. ${ }^{810}$ By using the words "in course of face-to-face teaching activities" any broadcastings or transmissions of protected works from outside the location where the instruction takes place and instructors and pupils are together shall not be covered by the limitation. As the report points out instructors and pupils must not necessarily be in the same classroom so that performances and displays under section 110 (1) CA may extend to an entire building or a bigger area. ${ }^{811}$ However, the performances and displays must serve instructional purposes in order to fall within the scope of the limitation. Consequently, performances and displays of protected works for entertainment or recreation are excluded. $^{812}$

\footnotetext{
$\overline{{ }^{808} \text { Copyright Law Revision } 17 \text { USC }} \S 110$ (1976) by the House of Representatives, House Report No. 94 - 1476 (in the following cited as "House Report 1976").

809 House Report 1976, p. 81.

810 lbid.

811 Ibid.

812 Ibid.
} 
Section 110 (1) CA does not constrain the limitation to certain kinds of works but rather encompasses all kinds of works as long as the other prerequisites of the provision are met. ${ }^{813}$ The performance or display of any kind of work must be made by "instructors or pupils". This means that performances and displays by people from outside the school such as professional actors, singers or musicians are not covered by the limitation. As the House Report points out the term "instructors" is wide enough to comprise also guest lectures, provided that their activities are restricted to classroom situations. ${ }^{814}$ "Pupils" are all enrolled members of a class. ${ }^{815}$ Section 110 (1) CA further only applies to "non-profit educational institutions", which means that all profitmaking institutions, e.g. private language schools, cannot benefit from the limitation. Eventually, the performance or display must take place "in a classroom or similar place, devoted to instruction". This means that performances and displays in locations where the audience is not limited to the members of a certain class, such as school plays or sport events, fall out of the scope of the provision. ${ }^{816}$ The criterion "similar place, devoted to instruction" widens the scope of the provision and encompasses places, which are commonly and systematically used for instruction, such as studios, gymnasiums, libraries or training fields. ${ }^{817}$

The last part of section 110 (1) CA contains rules for the special case of unlawfully made copies of motion pictures or other audio-visual works. If the person responsible for the performance or display knows or has reason to believe that the copy was not lawfully made, the limitation is not applicable. It is however applicable in cases concerning the performance or display of lawfully made copies, which were stolen or converted. ${ }^{818}$

What is finally important to mention is that section 110 (1) CA is not restricted to particular projection devices but permits the use of any sort of device or process as long as there is no transmission beyond the place where the copy is located. ${ }^{819}$

After having explained the prerequisites of section 110 (1) CA in detail it must be doubted that this limitation provides adequate and sensible solutions of educational uses of copyright protected works in the digital age. Although it was intended to "cover all of the various methods which performances and displays in the course of systematic instruction take

\footnotetext{
${ }^{813}$ House Report 1976, p. 81/82.

814 House Report 1976, p. 82.

815 lbid.

816 Ibid.

817 Ibid.

818 Ibid.

819 Ibid.
} 
place, ${ }^{, 820}$ and was carved as a broad and technology neutral limitation, the provision does not meet with the demands of new instruction methods based on digital technology. It was designed to cover traditional instruction settings, taking place in a classroom. Of course, these situations exist still today, e.g. when a teacher shows power point slides containing third-party content in class; the same holds true for students. In such cases the classroom use exception applies.

The problem is that many new teaching methods and e-learning activities go beyond the traditional classroom situation, for instance a webpage, which can be accessed by instructors and pupils. Moreover, pupils fall out of the scope of protection of the limitation in case they use copyright protected material not as part of face-to-face teaching, e.g. for homework or any other web-based educational project that extends beyond the classroom. A further problem is that section 110 (1) CA exempts only the "performance and display" but not the reproduction of a work, although incidental reproductions are intrinsic to digital technology. ${ }^{821}$ However, such reproductions are probably covered by fair use. ${ }^{822}$ Nevertheless, the classroom use exception could be more effective if other rights would be covered, too. ${ }^{823}$

With regard to the benchmark for permissible digital uses it must be stated that indeed the provision, which applies only to non-commercial educational institutions, is not restricted to certain types of works or analogue media. Further, there is no restriction to the amount of the works and the devices that can be used. Also, the wording of the provision is rather clear. However, the provision only provides for a limitation for performances and displays in face-toface teaching, whereas reproduction and making available of protected works are not covered, although these uses are fundamental for e-learning activities and new forms of delivering education in class. Text and data mining for educational purposes is not addressed. Moreover, the provision can be overruled by licensing contracts, since there is no contrary statement that this would be prohibited.

Based on this, the provision cannot be considered an adequate limitation for education. In view of the potentials of digital technologies for the delivery of education also in face-to-face teaching, section 110 (1) CA does not adequately promote access to education and knowledge.

After all, section 110 (1) CA is a rather narrow limitation, which aims at a traditional instruction setting and thus cannot cope with the needs and problems of e-learning and the

\footnotetext{
${ }^{820}$ House Report 1976, p. 81.

${ }^{821}$ Berkmann Center, The Digital Learning Challenge, Part II, 3.1.1.

822 Ibid.

${ }^{823}$ Ibid.
} 
use of digital technology for educational purposes.

\subsubsection{The TEACH Act}

The "Technology, Education and Copyright Harmonization Act", the so called TEACH Act came into force in 2002 after the United States Congress had passed it in 2001. According to the Senate Report 107-31 of June 5, 2001 the purpose of the TEACH Act was and still is to update "the distance education provisions of the Copyright Act for the $21^{\text {st }}$ Century". ${ }^{224}$ At the end of the 1990s it became clear that the provisions of section 110 (2) CA regarding distance education, which had been enacted in 1976 were not up to date any longer for they had been made for distance education using television and radio. ${ }^{825}$ Therefore a study was ordered by US-Congress, carried out by the United States Copyright Office making recommendations for changes of the law. ${ }^{826}$ The challenge was to "promote distance education through digital technologies (...), while maintaining an appropriate balance between the rights of copyright owners and the needs of users of copyrighted works". ${ }^{827}$ If this goal has been achieved, especially if the provisions of the TEACH Act still foster e-learning activities shall be examined in the following.

The centrepiece of the TEACH Act is section 110 (2) CA. It states that the uses of copyright protected works are not considered copyright infringements as long as they meet the requirements of the provision.

\subsection{Works}

The TEACH Act has extended section 110 (2) CA and it now encompasses performances and displays of all categories of copyrighted works ${ }^{828}$ with the exception of works, which are

"produced or marketed primarily for performance or display as part of mediated instructional activities transmitted via digital networks, or a performance or display that is given by means of a copy or phonorecord that is not lawfully made and acquired under this title, and the transmitting government body or accredited nonprofit educational institution knew or had reason to believe was not lawfully made and acquired".

\footnotetext{
824 U.S. Senat Report 107-31, 2001, Technology, Education and Copyright Harmonization Act of 2001 (in the following cited as "Senate Report 2001"), p. 3.

${ }^{825}$ Berkmann Center, The Digital Learning Challenge, Part II, 3.1.2.

${ }^{826}$ See Report of the Register of Copyrights on Copyright and Digital Distance Education, U.S. Copyright Office, 1999 (in the following "Copyright Register Report 1999").

827 Senate Report 2001, p. 5.

${ }^{828}$ Senate Report 2001, p. 7.
} 
But the TEACH Act limits the performance of works, which are not performances of nondramatic literary or musical works, to "reasonable and limited portions". This means it is only allowed to use less than the entire work. According to the Senate Report one should take a look at the nature of the market for that particular work and at the pedagogical purpose of the performance in order to find out what is a reasonable and limited portion of a work. ${ }^{829}$

Further section 110 (2) CA distinguishes performances and displays. Displays of works are allowed as long as they are limited to "an amount comparable to that which is typically displayed in the course of a live classroom session". This restriction wants to prevent that the display of a work entirely substitutes for the purchase of the work, as it would be e.g. the case with e-books. ${ }^{830}$ However, in some cases it is still feasible to display an entire work as long as this would also occur in a traditional classroom setting. ${ }^{831}$

Moreover, one must observe the two types of works contained in section 110 (2) CA. First, it is not allowed to use works that are "produced or marketed primarily for performance or display as part of mediated instructional activities transmitted via digital networks". This part aims at the protection of the primary market for materials especially produced for e-learning and distance education activities. ${ }^{832}$ Second, performances and displays of a work "that is given by means of a copy or phonorecord that is not lawfully made and acquired under this title, and the transmitting government body or accredited nonprofit educational institution knew or had reason to believe was not lawfully made and acquired" do not benefit from the provision. Here we can refer to what was already said above with regard to the classroom exception of Section 110 (1) CA.

\subsection{Eligible Entities}

The institutions that may invoke section 110 (2) CA are government bodies or accredited non-profit educational institutions. The Senate Report strengthens that non-profit educational institutions must be accredited in order to safeguard that the institution is trustworthy. ${ }^{833}$ This is necessary, according to the Senate Report, to hinder not trustworthy non-profit educational institutions from making unjustified use of the limitation, which would be very easy given the possibilities of the Internet. What is meant by "accredited" clarifies section 1(b)(2) of the TEACH Act. In any case the accreditation shall be made by the state.

\footnotetext{
${ }^{829}$ Senate Report 2001, p. 7/8.

${ }^{830}$ Senate Report 2001, p. 8.

831 lbid.

832 Ibid.

${ }^{833}$ Senate Report 2001, p. 9.
} 


\subsection{Mediated Instructional Activities}

In order to benefit from the limitation of section 110 (2) (A) CA the performance or display of the work must be "made by, at the direction of, or under the actual supervision of an instructor as an integral part of a class session offered as a regular part of the systematic mediated instructional activities".

According to the Senate Report, the first feature "made by, at the direction of, or under the actual supervision of an instructor" means that the performance or display may be initiated by an instructor, but may also be made by students enrolled in class. ${ }^{834}$ In this case however the instructor must direct the performance or display or it must be made by the students under the supervision of the instructor. Moreover, the supervision must be actual, i.e. there must be some supervision of class activities by the instructor. ${ }^{835}$ Yet, the prerequisite of "actual supervision" is not intended to hinder asynchronous learning at the pace of the students. ${ }^{836}$ Further, the performance or display must be made as an "integral part of a class session". This means it must not only be used as additional teaching material but must be part of the class itself. ${ }^{837}$ The performance or display must then be part of "mediated instructional activities". According to section 1(b)(2) of the TEACH Act this means that the performance or display of the work must be "analogous to the type of performance or display that would take place in a live classroom setting". For instance it is not allowed under section 110 (2) (A) CA to display an entire textbook in the form of an e-book as only supplementary reading material because such use could not be considered analogous to displays that would take place in a live classroom setting. ${ }^{838}$ Section 1(b)(2) of the TEACH Act further clarifies that no activities shall be covered by the limitation that use works "which are typically purchased or acquired by the students in higher education for their independent use or retention (...)". Consequently the term "mediated instructional activities" must be understood in connection with the term "work produced or marketed primarily for performance or display as part of mediated instructional activities transmitted via digital networks" of the initial clause of section 110 (2) $\mathrm{CA}$. Both intend to adequately limit the scope of the provision by referring to the nature of the activity as well as to the nature of the material used. ${ }^{839}$

\subsection{Relation to Teaching Content}

Section 110 (2) (B) CA requires that the performance or display is "directly related and of

\footnotetext{
834 Ibid.

835 lbid.

836 Ibid.

837 Ibid.

838 Senate Report 2001, p. 10.

${ }^{839}$ Ibid.
} 
material assistance to the teaching content of the transmission".

This clause was already incorporated in the old section 110 (2) CA and has been adopted into the new law. It demands some connection of the material used to the curriculum and shall safeguard that it is not just performed or displayed for mere entertainment of the students. $^{840}$

\subsection{Limitation to Certain Recipients}

The predecessor of Section 110 (2) (C) CA required that the transmissions of copyrighted works had to be received in classrooms or similar places devoted to instruction. ${ }^{841}$ Only in special cases, e.g. the recipient was inhibited from attending a classroom because of disabilities, there was an exception from this prerequisite. However, it was acknowledged that the great advantage of digital distance education and e-learning lies in the possibility to reach students beyond the classroom. ${ }^{842}$ Therefore the criterion of reception in classrooms or similar places was dropped. Instead, section 110 (2) (C) CA demands that "the transmission is made solely for, and, to the extent technologically feasible, the reception of such transmission is limited to-(i) students officially enrolled in the course for which the transmission is made; or (ii) officers or employees of governmental bodies as a part of their official duties or employment". The provision requires that only authorised and identified recipients shall have access to the transmitted performance or display of a work, which could be safeguarded for instance by installing password systems or other safety measures. ${ }^{843}$

\subsection{Copyright Policy and Digital Rights Management}

In order to cope with the difficulties digital technology poses to authors and right holders regarding the transmission, copying and dissemination of their works section 110 (2) (D) CA provides for additional safeguards.

To comply with these provisions the transmitting body or institution must establish "policies regarding copyright, provide(s) informational materials to faculty, students, and relevant staff members that accurately describe, and promote compliance with, the laws of the United States relating to copyright, and provides notice to students that materials used in connection with the course may be subject to copyright protection".

\footnotetext{
${ }_{840}$ Senate Report 2001, p. 11, which makes reference to Copyright Register Report 1999, p. 80.

841 Senate Report 2001, p. 11.

842 Ibid.

843 Ibid.
} 
Thereby especially the recipients of the transmitted work shall be informed of duties and responsibilities under US copyright law and future infringements shall be inhibited. ${ }^{844}$

In case of digital transmissions according to section 110 (2) (D) (ii) (I) CA the transmitting body or institution must safeguard two different things. It must apply "technological measures that reasonably prevent - (aa) retention of the work in accessible form by recipients of the transmission from the transmitting body or institution for longer than the class session" and (bb) unauthorized further dissemination of the work in accessible form by such recipients to others".

The retention of the work shall be limited to the duration of "class session". This term makes reference to the prerequisite that the performance must be made as an "integral part of a class session" and thus must be understood as a normal face-to-face class session. ${ }^{845}$ Consequently, under this provision students generally are allowed to access the work in digital form on the server of the institution for such period. ${ }^{846}$ However the exact duration of the period cannot be determined for this would counteract the characteristics and advantages of asynchronous distance education and e-learning. ${ }^{847}$ Despite the flexibilities needed it must be secured that the digital copy of the work performed or displayed under these circumstances does not "remain in the possession of the recipient in a way that could substitute for acquisition or for uses other than use in the particular class session" ${ }^{848}$ The retention of the work mentioned in section 110 (2) (D) (ii) (I) (aa) CA addresses only the retention made by the recipient of the transmission. ${ }^{849}$ Under the new section 112 (f) $\mathrm{CA}$ the transmitting institution is allowed to retain copies of the transmitted works on its servers for longer periods, e.g. an entire course or more, and make them accessible to recipients for the above mentioned period. ${ }^{850}$ In order to fully comply with Section 110 (2) (D) (ii) (I) (aa) CA technological measures must prevent the retention of the work in "accessible form". This means that either no permanent copy can be made on the recipient's computer or at least that the copy cannot be accessed because it is encrypted and only accessible with a password during the time of a class session. ${ }^{851}$ By complying with the above described prerequisites the "unauthorised further dissemination of the work in accessible form" should also be prevented.

\footnotetext{
844 Ibid.

${ }^{845}$ Senate Report 2001, p. 12.

846 lbid.

847 lbid.

848 Ibid.

849 lbid.

850 Ibid.

851 Ibid.
} 
Moreover, according to section 110 (2) (D) (ii) (II) CA the transmitting body or institution "does not engage in conduct that could reasonably be expected to interfere with technological measures used by copyright owners to prevent such retention or unauthorized further dissemination".

\subsection{Transient Copies}

Regarding the uses of protected works privileged by section 110 (2) CA the law declares in section $110 \mathrm{CA}$ that there shall be no liability for the transmitting institution for infringements of copyright caused by "the transient or temporary storage of material carried out through the automatic technical process of a digital transmission of the performance or display of materials".

This clarification takes into account the necessities of digital transmission technologies, which use "caches" or random access memories (RAM) in order to properly store material on computers and make it accessible to the user. The so occurring reproductions principally are infringements of copyright. For the purpose of facilitating digital distance education, elearning such copyright relevant reproduction due to automatic technical processes are exempted from copyright protection.

\subsection{Copies and Ephemeral Recordings}

In order to make use of the advantages of digital distance education and e-learning the providing institutions must be able to store digital copies of the learning materials on their servers and networks. Under section 112 (f) CA this is now possible without infringing copyright law. Section 112 (f) CA allows as many copies as are necessary to carry out digital transmissions. Yet, the prerequisites of the provision must be met. This is the case if " $(A)$ such copies or phonorecords are retained and used solely by the body or institution that made them, and no further copies or phonorecords are reproduced from them, except as authorized under section 110(2); and (B) such copies or phonorecords are used solely for transmissions authorized under section 110(2)".

Regarding the digitisation of analogue works section 112 (f) (2) CA contains special provisions, which principally prohibited the digitisation of analogue works into digital form "except that such conversion is permitted hereunder, only with respect to the amount of such works authorized to be performed or displayed under section 110(2), if - (A) no digital version of the work is available to the institution; or $(B)$ the digital version of the work that is 
available to the institution is subject to technological protection measures that prevent its use for section 110(2)".

\subsection{TEACH Act and Fair Use}

Both the Senate Report ${ }^{852}$ and the Copyright Register's Report ${ }^{853}$ finally give a clear statement concerning the relationship of the so called fair use doctrine ${ }^{854}$ and the TEACH Act. The TEACH is not in any way intended to limit or modify the scope of the fair use doctrine with regard to distance education and e-learning. As the Copyright Register's Report notes "not only instructional performances and displays, but also other educational uses of works, such as the provision of supplementary materials or student downloading of course materials, will continue to be subject to the fair use doctrine. Fair use could apply as well to instructional transmissions not covered by the changes to section 110 (2) recommended above. ${ }^{\text {,855 }}$

Moreover the Copyright Register's Report points out that "the fair use doctrine is technologically neutral and applies to activities in the digital environment and the lack of established guidelines for any particular type of use does not mean that fair use is inapplicable.

\subsection{Findings}

As could be shown the TEACH Act covers only a very limited area of educational uses of copyrighted works. The provisions of Section 110 (2) CA are quite complicated and make it very hard for educational institutions and educators to comply with the prerequisites. Admittedly, in case all requirements are met liability for copyright infringements is excluded. However, because of the narrow construction of the provision this will only happen in very few cases. So despite the undeniable progress made by the TEACH Act regarding digital distance education and e-learning its scope is rather limited. Above that the inclusion of technological measures to protect digital education materials poses financial and legal obstacles to many educational institutions. In the end it must be stated the potential benefits of the TEACH Act are consumed by its deficiencies.

With regard to the benchmark for permissible uses it must be stated that section 110 (2) CA

\footnotetext{
${ }^{852}$ Senate Report 2001, p. 15.

${ }^{853}$ Copyright Register Report 1999, p. 161/162.

${ }^{854}$ See below 4.1.1.4.

855 Ibid.

${ }^{856}$ Ibid.
} 
only partly meets with the requirements. Indeed, the provision applies only to noncommerical educational institutions and covers all types of protected works, but there are restrictions to the amount of a work that can be used, i.e. the use of entire works is prohibited. As well it is not allowed to use works that were especially produced for digital and online education. Furthermore, the provision only refers to performance and display of protected works, not to reproduction and making available to the public, which are essential for any digital uses and in particular for e-learning and digital distance education. Online delivery of education is possible under section 110 (2) CA, however only within narrow limits, because the performace or display must be integral part of a class session. This restriction significantly reduces the scope of the provision, since the real advantages of digital distance education and e-learning thereby are excluded, especially self-paced learning by students at times and places of their choice. Digital reproductions of the works are permitted only under the conditions that they are necessary for digital transmissions allowed by section 110 (2) CA. Also, the digitisation of analogue materials may be exceptionally permitted, but only in case no digital version is available or the digital version available cannot be used due to technological protection measures. As one can see the use of protected works is feasible only in very narrow bounds. Text and data mining for educational purposes is not addressed. Moreover, the provision can be overruled by licensing contracts. In addition the wording is very complicated and difficult to understand. Legal certainty thus is not achieved. With regard to the demand of the benchmark that limitations and exceptions should be broad, open and technologically neutral, it has to be noted that the fair use doctrine applies without restrictions alongside with section 110 (2) CA and may cover any use of protected works in connection with e-learning and digital distance education.

Nevertheless, in view of the significance of the right to education section 110 (2) CA does not provide for adequate solutions to promote and access to education and knowledge in the digital age.

\subsubsection{Limitations and Exceptions for Libraries and Archives}

Libraries and archives are of great importance in an open and democratic society to enable and safeguard the access of the public to intellectual, cultural and scientific resources. Therefore, libraries and archives, at least if they are open to the public, serve the public interest of education and information. Any member of society has the opportunity for education and learning, no matter if she or he can afford to pay for the information she or he wants to access. Also libraries and archives collect and preserve copyright protected works as part of the intellectual, cultural and scientific heritage for future generations and make it available to anyone. As well thereby they serve public interest. Nevertheless, one must not 
forget the legitimate interest of authors and right holders, who depend on the sale of their works. Their interests may be unduly harmed by granting libraries and archives far reaching privileges to use copyright protected works. Consequently limitations and exceptions for libraries and archives must maintain a just balance of the interests involved.

Until the introduction of section 108 CA in 1976 the balance of interest should have been safeguarded by an agreement, concluded in 1935 between the National Association of Book Publishers (NABP) and the Joint Committee on Materials for Research of the American Council of Learned Societies, which was called the "Gentlemen`s Agreement". ${ }^{857}$ The agreement established certain rules concerning the reproduction of copyright protected works by libraries, archives and museums and referred strongly on fair use principles. ${ }^{858}$ When in 1976 the Copyright Act came into force section 108 CA was subject to intense debates, especially copying for users of libraries and archives as well as interlibrary loan. ${ }^{859}$ As a consequence the National commission on New Technological Uses of Copyrighted Works (CONTU) set out guidelines for these uses. ${ }^{860}$ Generally, section108 CA privileges preservation, private studies and interlibrary loan. It was enacted to improve legal certainty for libraries and archives. At the same time it should balance the exclusive rights of authors and right holders to achieve just remuneration for the investments made with the interests of libraries and archives to provide access to information. ${ }^{861}$ Over the years several amendments of section $108 \mathrm{CA}$ have been made. Yet the provision has never been adapted to the new practices and realities of libraries and archives and their users in the digital age. In the following it is examined if section $108 \mathrm{CA}$ is nevertheless capable of dealing with the challenges posed by digital technologies and the Internet.

\subsection{General Prerequisites}

Section 108 CA applies only to libraries and archives. Other institutions, which serve public interest are not privileged, especially not museums. This is surprising because in the above mentioned "Gentlemen`s Agreement" of 1935 museums where included. ${ }^{862}$ However there is no real explanation why museums were not included, it is likely that they were left out because at the time the provisions of Copyright Act were discussed and finally passed in 1976 museums did not play an important role as providers of information protected by copyright and copyright issues were not of great importance to them. ${ }^{863}$ This is different today

\footnotetext{
${ }_{857}$ Copyright Register Report 1983, p. 14/15.

858 Ibid.

${ }^{859}$ Study Group Section 108 CA, p. 16.

860 lbid.

861 lbid.

862 Study Group Section 108 CA, p. 31.

${ }^{863}$ Study Group Section 108 CA, p. 31/32.
} 
because reproduction technologies have changed and museums are able to make reproductions of works they could not reproduce in 1976. Museums like libraries and archives serve the public interest by providing access to cultural, intellectual and scientific materials. Therefore it is proposed to include museums in section $108 \mathrm{CA}^{864}$

Further it has to be noted that by the time section $108 \mathrm{CA}$ was enacted the notion of libraries and archives was one of physical, not virtual institutions. Mainly or exclusively virtual libraries and archives are quite common today. Even when the Digital Millennium Copyright Act (DCMA) was passed and made amendments to section 108 CA in 1998, Congress was not willing to make any modification in that direction although the new reality was acknowledged. ${ }^{865}$ It rather confirmed that "premises of the library or the archive" is meant only in a physical sense. ${ }^{866}$ Moreover it is not clear which institutions qualify as libraries and archives for a definition is not given.

As a general rule section 108 a) CA only establishes that libraries and archives are allowed to make one copy of a copyright protected work or to distribute such copy if the reproduction or distribution is made without direct or indirect commercial purpose, the library or archive making or distributing the copy is open to the public or available not only for the researches affiliated with the library or archive and the reproduction or distribution of the work includes a notice of copyright that appears on the copy or at least a notice that the work copied may be protected by copyright. ${ }^{867}$ These criteria are very broad. Also private for-profit institutions may invoke section 108 a) CA in their favour, although the provision was designed to privilege libraries and archives, which serve the public interest. ${ }^{868}$ Consequently the Section 108 Study Group recommended several alterations of section 108 a) CA. Among others it was proposed to explicitly include the non-profit public service mission of libraries and archives as a requirement for the application of section 108 a) CA. ${ }^{869}$

Another proposal to adapt section $108 \mathrm{CA}$ to the digital age is to extend the provision to works, which are not in the collections of the respective institution and allow libraries and archives to reproduce and store works available on the Internet. ${ }^{870}$ After a reasonable period of time the users of the library or archives shall have access to such copies, which must be marked as an archived copy. ${ }^{871}$

\footnotetext{
864 Ibid.

865 Senate Report 1998, p. 62.

${ }^{866}$ Ibid.

${ }^{867}$ Cf. section 108 (a) CA.

${ }^{868}$ Cf. Study Group Section 108 CA, p. 35/36.

869 Study Group Section 108 CA, p. 36/37.

${ }^{870}$ Study Group Section 108 CA, p. 80 ff.; so called Web Harvesting.

${ }^{871}$ Section 108 Study Group, p. 84.
} 


\subsection{Preservation and Replacement}

Under certain conditions section $108 \mathrm{CA}$ allows libraries and archives to make copies of copyright protected works for preservation and replacement. The relevant subsections are section 108 (b) CA, section 108 (c) CA, section 108 (h) CA and section 108 (f) (3).

Section 108 (b) CA allows the making of up to three copies of an unpublished work solely for the purpose of preservation or for deposit for research use in another library or archives. Section 108 (c) permits up to three copies of a published work for the purpose of replacement in case of damage, deterioration, loss or theft of a copy or in case the format in which the work is available is outdated. Section 108 (h) CA allows reproduction, distribution, display or performance of copies of published works during their last 20 years of term of copyright. Section 108 (f) (3) CA indirectly allows libraries and archives to make a limited number of reproductions of audiovisual news programs and to distribute such copies.

Generally, section 108 CA regarding preservation and replacement activities of libraries and archives distinguishes between published works (section 108 (b) CA) and unpublished works (section 108 (c) CA), whereby the right to make copies of unpublished works is slightly broader. The rationale for the distinction between published and unpublished works is unclear and even the legislative history does not provide an explanation. ${ }^{872}$ It may be that of unpublished works often no or only very few copies exist. This means that such unique unpublished works can be destroyed or lost and no copy is left, which is why libraries and archives shall be allowed to make copies of such works for preservation before they are irretrievably destroyed or lost. ${ }^{873}$ This is different with published works where in case of destruction or loss a replacement copy can be purchased and if that is not possible at a fair price it is permitted to make a copy. ${ }^{874}$ It can be doubted if considering the making available of works via the Internet and by other electronic means the distinction between published and unpublished works provides a sensible starting point for encompassing all kind of works or if the distinction would not be better made between publicly disseminated and not publicly disseminated works. ${ }^{875}$ It is moreover argued that libraries and archives should be allowed to make more than just three copies of a work, because the use of digital technologies requires multiple copying. ${ }^{876}$ Thus a limited number of copies "as reasonably necessary" shall be permitted. $^{877}$

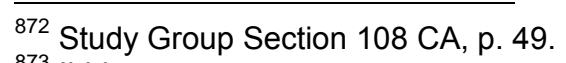

${ }^{873}$ Ibid.

874 lbid.

${ }^{875}$ Study Group Section 108 CA, p.47-50, where it is proposed to have "publicly disseminated works" as a third category of works next to "published" and "unpublished" works.

${ }^{876}$ Study Group Section 108 CA, p. 53 and 64.

877 Ibid.
} 


\subsection{Section 108 (b) CA}

Section 108 (b) CA applies only to unpublished works. In addition to the above mentioned prerequisites section 108 (b) CA requires that "(1) the copy reproduced is currently in the collections of the library and archives; and (2) any such copy that is reproduced in digital format is not otherwise distributed in that format and is not made available to the public in that format outside the premises of the library or archives."

Only if these criteria are met it is feasible to make up to three copies of an unpublished work solely for purposes of preservation and security or for deposit for research in another library or archives. It is not a problem to deal with the criteria that the copy must be currently in the collections of the respective institution and it is further clear that the distribution of the copies is not allowed. It is however more difficult to deal with copies made available to the public outside the premises of the respective institution. ${ }^{878}$ Because the Digital Millennium Copyright Act (DMCA) in 1998 allowed the making of up to three digital copies for preservation ${ }^{879}$, this concession was limited to the premises ${ }^{880}$ of the library or archives in order to protect the interests of authors and copyright holders from (financial) damages through mass reproduction of their works. ${ }^{881}$ It is argued that it should at least be allowed to make available digital replacement copies fixed on physical data carriers such as DVDs outside the premises of the institution, if this was permitted already for the original work. ${ }^{882}$ Permitting libraries and archives to make copies of unpublished works available on the Internet is debated controversially. ${ }^{883}$

\subsection{Section 108 (c) CA}

Section 108 (c) CA applies to published works. In addition to the above mentioned prerequisites section 108 (c) CA requires that "(1) the library or archives has, after a reasonable effort, determined that an unused replacement cannot be obtained at a fair price; and (2) any such copy that is reproduced in digital format is not made available to the public in that format outside the premises of the library or archives in lawful possession of such copy."

If these requirements are met it is allowed to make up to three copies of a work for the

\footnotetext{
878 Study Group Section 108 CA, p. 65 - 68.

${ }^{879}$ This was not allowed until the DMCA amendment. Copying was limited to a single copy "in facsimile form", cf. Senate Report 1998, p. 61.

${ }^{880}$ According to Senate Report 1998, p. 62, "premises" means only the physical grounds of the library or archives and does not extend to websites or similar virtual areas.

${ }^{881}$ Cf. Senate Report 1998, p. 61.

${ }^{882}$ Section 108 Study Group, p. 66.

${ }^{883}$ Section 108 Study Group, p. 66 - 68.
} 
purpose of replacement of a copy that is damaged, deteriorating, lost, or stolen, or if the existing format in which the work is stored has become obsolete. ${ }^{884}$

There have been some proposals for reform of this provision. It was proposed to add the criterion "fragile" to section 108 (c) CA as a reason to allow a library or archives to make replacement copies. ${ }^{885}$ It was further proposed to replace "unused" in section 108 (c) (1) CA by "usable" in order to facilitate the inquiries the institution has to undertake before being allowed to make a copy. ${ }^{886}$ Another issue in the context of section 108 (c) CA is when a copy "can be obtained at a fair price". ${ }^{887}$ As with section 108 (b) CA also section 108 (c) CA does not allow the institution to make available to the public digital copies outside of its premises. As for section 108 (b) CA the rationale for this restriction amended by the DMCA is the protection of the interests of authors and right holders from (financial) damages through "unlimited access to digital copies from any location". ${ }^{888}$ It is argued that it should at least be allowed to make available digital replacement copies fixed on physical data carriers such as DVDs outside the premises ${ }^{889}$ of the institution, if this was permitted already for the original work. ${ }^{890}$ With regard to making copyright protected works publicly available via electronic means, especially on the Internet, there are good arguments for both sides. ${ }^{891}$

\subsection{Section $108(h) C A$}

In the course of the DMCA in 1998 section 108 (h) CA was introduced because the copyright term was generally extended from 50 years after the death of the author to 70 years after the death of the author. ${ }^{892}$ The provision applies to all kinds of works. ${ }^{893}$ Section 108 (h) permits libraries or archives to reproduce, distribute, display and perform in facsimile or digital form a copy of a published work during the last 20 years of its term of copyright protection for purposes of preservation, scholarship, or research. Libraries and archives are however only allowed to make such copies in accordance with section 108 (h) (2) CA if they beforehand have ensured by a reasonable investigation that " $(A)$ the work is not subject to normal commercial exploitation, $(B)$ a copy of the work cannot be obtained at a reasonable price and

\footnotetext{
${ }^{884}$ Section 108 (c) CA defines that "a format shall be considered obsolete if the machine or device necessary to render perceptible a work stored in that format is no longer manufactured or is no longer reasonably available in the commercial market place."

${ }^{885}$ Section 108 Study Group, p. 54.

886 Idem, p. 55.

${ }^{887}$ Idem, p. 56: The Study Group proposes to answer this question in each individual case by taking into account the nature of the license obtainable and the cost of that license, because only thereby the actual situation of the respective institution is judged fairly.

${ }^{888}$ Senate Report 1998, p. 61/62.

889 Idem, p. 62.

890 Section 108 Study Group, p. 57.

891 Section 108 Study Group, p. 57 - 60.

892 Idem, p. 20.

893 Ibid.
} 
(C) the author or copyright holder has not notified the register of copyrights that at least one of the criteria established by $(A)$ and $(B)$ applies."

\subsection{Section 108 (f) (3)}

According to section 108 (f) (3) CA libraries and archives are allowed to make a limited number of reproductions of an audiovisual news program and distribute such copies by lending. The provision was introduced in 1976 in order to put several television news archives on legal basis, recognising the transient nature of such programs and their importance for scholarship and research. ${ }^{894}$ Section 108 (f) (3) speaks of distribution by lending of copies, which implicates that the copy lent must be returned to the library or archives $^{895}$ and further implicates that only physical copies, for instance videotapes, are encompassed. Although this section does not explicitly mention preservation as a purpose, nonetheless it applies to preservation activities of libraries and archives. ${ }^{896}$ It is argued that section 108 (f) (3) CA should be modified in order to cover so-called view-only transmission of audiovisual news programs, especially streaming, for the purpose of private study, scholarship, or research. ${ }^{897}$ However this should only be allowed after a reasonable period of time has passed since the original transmission. ${ }^{898}$ In any case libraries and archives should not be allowed under section 108 (f) (3) CA to transmit downloadable copies. ${ }^{899}$

\subsection{Copies for Private Study and Research, Interlibrary Loan}

In order to promote private study and research sections 108 (d) and (e) CA permit libraries and archives to make one single copy of a copyright protected work from their collections upon the request of a user. The provisions apply to requests of the user of the library or archives making the copy and to requests of another library or archives for one of their users within the context of an interlibrary loan.

Section 108 (d) CA allows one single copy "of no more than one article or other contribution to a copyrighted collection or periodical issue, or to a copy or phonorecord of a small part of any other copyrighted work." Section 108 (e) CA allows libraries or archives to make one single copy of "the entire work, or (to) a substantial part of it (...) if the library or archives has first determined, on the basis of a reasonable investigation, that a copy or phonorecord of the

\footnotetext{
${ }_{894}$ Section 108 Study Group, p. 88/89.

${ }^{895}$ House Report 1976, p. 77.

${ }^{896}$ Section 108 Study Group, p. 20.

897 Section 108 Study Group, p. 89.

${ }^{898}$ Ibid.

899 Ibid.
} 
copyrighted work cannot be obtained at a fair price."

According to sections 108 (d)(1) and (2) CA and 108 (e)(1) and (2) CA both provisions only apply if "(1) the copy or phonorecord becomes the property of the user, and the library or archives has no notice that the copy or phonorecord would be used for any purpose other than private study, scholarship, or research; and (2) the library or archives displays prominently, at the place where orders are accepted, and includes on its order form, a warning of copyright in accordance with requirements that the register of copyrights shall prescribe by regulation."

The applicability of sections 108 (d) and (e) CA however depends on several conditions established by sections 108 (g) and (i) CA. Section 108 (i) CA contains restrictions concerning the reproduction and distributing of certain types of works, such as graphic works, illustrations, diagrams or the like. Further restrictions are made by section 108 (g) CA, which generally extends the rights granted by section $108 \mathrm{CA}$ "to the isolated and unrelated reproduction or distribution of a single copy (...) Of the same material on separate occasions", but then limits these rights on conditions set forth in sections 108 (g) (1) and (2) CA. Following subsection $108(\mathrm{~g})(1)$ CA libraries and archives cannot rely on the limitations of sections 108 (d) and (e) CA if they or one of their employees knows or has grounded reason to believe that the copy provided by the library or archives is used for further multiple copies. ${ }^{900}$ Section 108 (g)(2) CA solely applies to section 108 (d) CA and stipulates that this limitation is not applicable "where the library or archives, or its employee engages in the systematic reproduction or distribution of single or multiple copies or phonorecords of material described in subsection (d): provided, that nothing in this clause prevents a library or archive from participating in interlibrary agreements that do not have, as their purpose or effect, that the library or archive is receiving such copies or phonorecords for distribution does so in such aggregate quantities as to substitute for a subscription to or purchase of such work."

This provision wants to inhibit libraries and archives from avoiding the costs of periodicals or the like by participating in interlibrary loan agreements, because such behaviour would unduly harm the legitimate interests of authors and right holders of the respective works. ${ }^{901}$ Regarding section 108 (g)(2) CA the guidelines issued by the National Commission on New Technology Uses of Copyrighted Works (CONTU), which shall be consulted for

\footnotetext{
${ }^{900}$ Section $108(\mathrm{~g})(1)$ CA: “... is aware or has substantial reason to believe that is engaging in the related or concerted reproduction or distribution of multiple copies of phonorecords of the same material, whether made on one occasion or over a period of time, and whether intended for aggregate use by one or more individuals or four separate use by the individual members of the group."

901 House Report 1976, p. 75.
} 
interpretation ${ }^{902}$, recommend that the distribution of copies of an article or articles published in any periodical is feasible, if the requesting entity does not request more then five copies of such article from the last five years before the request within one single calendar year. ${ }^{903}$ These guidelines further recommend that it is only feasible to make five copies per year of other works. ${ }^{904}$

Concerning section 108 (d) CA it is argued that it should be allowed for libraries and archives to provide a single digital copy of protected works to their users upon request also by electronic means. ${ }^{905}$ For this purpose libraries and archives should be allowed to make a limited number of copies that are reasonably necessary and only if such digital copies are protected adequately. ${ }^{906}$ The restriction to one single copy practically excludes digital transmissions, because multiple copies are unavoidable. ${ }^{907}$ Nevertheless, digital transmissions probably covered by fair use are common in library practice. ${ }^{908}$ Further it is demanded that electronic interlibrary loan should be possible, however under the condition that users should be obliged to address their request to their own library and not directly to the library providing the copy. ${ }^{909}$ As well copies distributed by electronic interlibrary loan should be protected by technical protection measures in order to prevent that users further reproduce or distribute such copies. ${ }^{910}$

\subsection{Liability for Unsupervised Reproducing Equipment, Fair Use}

Sections 108 (f) (1) CA establishes that libraries or archives are not liable for copyright infringements committed through the unsupervised use of reproducing equipment, which is located on its premises, given that the equipment displace a notice that the making of a copy may be subject to copyright law.

Section 108 (f) (2) CA provides that no one who uses such reproducing equipment or who requests a copy from a library or archives is excused from liability, if such use or of any later use of the copying exceeds fair use.

Section 108 (f) (4) CA clarifies that section 108 CA does not overrule any contractual obligations of a library or archives. It further clarifies that section 108 CA does not affect "in

\footnotetext{
902 Idem, p. 72 - 74.

${ }^{903}$ CONTU, Final Report, p. 55/56.

904 lbid.

905 Section 108 Study Group, p. 98.

906 lbid.

${ }^{907}$ Besek, The Development of Digital Libraries in the United States, 2010, p. 197.

908 lbid.

${ }^{909}$ Section 108 Study Group, p. 98.

910 Ibid.
} 
any way (...) the right of fair use as provided by section $107 C A$ ". Hence fair use under section 107 CA especially privileges activities such as teaching, scholarship and research, an activity that exceeds the scope of section 108 CA may be covered by fair use. This possibility was intended already in 1976 when section 108 CA was introduced. ${ }^{911}$ At the same time some activities may be privileged by section $108 \mathrm{CA}$, which cannot be considered fair use. ${ }^{912}$

\subsection{Remuneration}

According to section $108 \mathrm{CA}$ there is no remuneration to be paid to authors and right holders for a use privileged by this provision. This is by the way also true for uses privileged by fair use doctrine. Thus, the use either is permitted without remuneration or it is not allowed at all. ${ }^{913}$

\subsection{Findings}

After all section 108 CA cannot be considered up to date. The provision is not able to cope with the challenges of the digital age. Many uses of copyright protected works in libraries and archives as well as user practices are not reflected by the provision at all. Due to the very narrow construction and complicated language libraries and archives as well as their users in many cases are left in legal uncertainty. In order to avoid problems libraries and archives back away from certain (digital) uses. Relying on fair use in these cases nevertheless carries the risk of legal dispute.

With regard to the benchmark of permissible uses it has to be stated that the limitations and exceptions for libraries and archives currently in force in the USA do not meet the requirements. First, the provisions apply only to libraries and archives. Other cultural heritage institutions are not addressed. Further, they are very complicated and detailed and digital issues are hardly taken into account. Thus, section 108 CA contains no broad, open and technologically neutral limitations and exceptions, but libraries and archives may at least be covered by fair use. There are also several restrictions on the number of copies. Libraries and archives are allowed to make only one copy, and distribute such copy, provided that there is no commercial purpose, and at most three copies of works in their collections under very narrow conditions for preservation and replacement. According to the benchmark there

\footnotetext{
911 House Report 1976, p. 73.

912 House Report 1976, p. 74.

${ }^{913}$ There is however a discussion among US copyright law scholars and jurisdiction whether in some cases more adequate results could be achieved by introducing something like a right to be remunerated for authors and right holders instead of just leaving them with the right to either permit or interdict they use, see Okediji/Reichmann, When Copyright Law and Science Collide, 2012, p.1434 f.
} 
should be no restrictions on the number of copies, at least if they are made within the scope of the non-commercial public interest missions of libraries and archives. A restriction to the number of copies is not in line with the use of digital technologies, which demands multiple copying. The provisions only refer to reproduction and distribution. Making available of digital works is restricted to the premises of the institutions. Thus, remote access is inhibited. In view of the limited number of copies libraries and archives are allowed to have available simultaneous digital access for users is restricted to these copies. Further, libraries and archives are not permitted to make reproductions of works available on the Internet, i.e. webharvesting. The provisions generally do not relate to all kinds of works. E-lending, format shifting and text and data mining are not addressed. This is true as well for mass digitisation of orphan and out-of-commerce works. Above that limitations and exceptions may be overruled by licensing contracts. As was said above limitations and exceptions for libraries and archives use a complicated wording and it is difficult for addressees to understand and comply with the prerequisites.

Against the background of the right to education and the right of everyone to take part in cultural life, section 108 CA does not take into account sufficiently the importance of libraries, archives and similar institutions as providers of access to knowledge and education in the digital age. Thus, the provisions of section $108 \mathrm{CA}$ cannot be considered adequate to promote achieving these objectives.

\subsubsection{The Fair Use Doctrine}

Educators, educational institutions and libraries and archives may also invoke the so called Fair Use Doctrine in order to defend educational uses of copyrighted works against infringement claims of authors and right holders. Broadly speaking fair use is a very general limitation to copyrights. In the following I will explain in short the development and the wording of the Fair Use Doctrine. Then I will take a look at some interesting cases regarding educational fair use. I will discuss finally the advantages and disadvantages of the Fair Use Doctrine in general and concerning educational and library uses in particular.

\subsubsection{Development and Wording}

The idea of fair use, which actually originates from English Common law ${ }^{914}$ was first pronounced in the United States by Justice Joseph Story in the 1841 case of Folsom $v$. Marsh. ${ }^{915}$ In that particular case the court found that an author could use significant parts of

\footnotetext{
${ }^{914}$ Silberberg, Preserving Educational Fair Use, 2001, p. 619

${ }^{915}$ Folsom 9 F. Cas. 342 (D. Mass 1841).
} 
the work of another author as long as the use was "fair and reasonable". ${ }^{916}$ In order to find out what was "fair and reasonable" the court "look(ed) to the nature and objects of the selections made, the quantity and value of the materials used, and the degree in which the use may prejudice the same, or diminish the profits, or supersede the objects, of the original work. ${ }^{\prime \prime 17}$ and weighed these factors against each other. The quoted part of the decision already contains the factors, which in 1976 became Section 107 CA codifying fair use. Section 107 CA reads as follows:

Notwithstanding the provisions of sections 106 and 106A, the fair use of a copyrighted work, including such use by reproduction in copies or phonorecords or by any other means specified by that section, for purposes such as criticism, comment, news reporting, teaching (including multiple copies for classroom use), scholarship, or research, is not an infringement of copyright. In determining whether the use made of a work in any particular case is a fair use the factors to be considered shall include-

(1) the purpose and character of the use, including whether such use is of a commercial nature or is for non profit educational purposes;

(2) the nature of the copyrighted work;

(3) the amount and substantiality of the portion used in relation to the copyrighted work as a whole; and

(4) the effect of the use upon the potential market for or value of the copyrighted work.

The fact that a work is unpublished shall not itself bar a finding of fair use if such finding is made upon consideration of all the above factors.

Section 107 CA however leaves the power of common law untouched. ${ }^{918}$ Fair use under section $107 \mathrm{CA}$ therefore is not intended as a strict rule but rather provides general guidelines how to decide from case to case. ${ }^{919}$

With regard to educational uses of copyrighted works Section 107 CA seems to offer some guidance for it explicitly mentions "teaching" as an example of fair use. Further following the text of Section $107 \mathrm{CA}$ it shall be considered whether the use is made for "non-profit educational purposes" in order to find out whether the use is fair or not. Although it appears that educational uses of copyrighted works are more likely to profit from the fair use defence, this is not confirmed in practice. ${ }^{920}$ However, educational institutions must rely on fair use in

\footnotetext{
916 Idem at 344 .

917 Idem at 348

918 Silberberg, Preserving Educational Fair Use, 2001, p. 627.

919 Ibid.

920 See Jaszi, Fair Use and Education, 2013, p. 3, who declares that there is "little if any evidence that education actually enjoys (...) a preferential position in the array of positive human activities that, from time to time, may lay claim to special treatment under copyright law." This is according to Jaszi also the case with fair use.
} 
order to delivery their services. ${ }^{921}$ Because of the case-by-case application fair use does not provide reliable legal certainty for educators, educational institutions and libraries and archives. ${ }^{922}$ Moreover, there are few court decisions concerning fair use for educational purposes and library uses, which could provide guidance.

\subsection{The Four Factors of Section 107 CA}

When applying the Fair Use Doctrine courts follow the enumeration prescribed in Section 107 CA. They must determine the concrete meaning of each of the four factors in each individual case anew and decide how much weight shall be given to each factor within the balancing process.

\subsection{First Factor: The Purpose and the Nature of the Use}

With regard to this factor courts must find out the nature of the use of a copyrighted work, especially whether it was a commercial or non-profit educational use. Thereto courts concentrate on the actual use of the work itself and not on the institution using it. ${ }^{923}$ If a commercial use is found, this however does not automatically exclude the application of fair use. ${ }^{924}$ Particularly in case of so called transformative uses the commercial use may be outweighed to some extent. ${ }^{925} \mathrm{~A}$ transformative use can be found for instance when a new work of own intellectual or creative value is created by using another work. ${ }^{926}$ In order to further privilege educational uses it is argued that educational institutions should always argue that the use of copyrighted works in education is transformative. ${ }^{927}$

\subsection{Second Factor: The Nature of the Copyrighted Work}

The second factor focuses on the nature of the work used, whether it is fictional or factual and whether it was already published or not. Courts grant protection rather for fictional than

\footnotetext{
${ }_{921}$ Jaszi, Fair Use and Education, 2013, p. 9, See also Keller/Vats, Centering Education in the Next Great Copyright Act, 2015, p. $1 \mathrm{f}$.

${ }_{922}$ Berkmann Center, Digital Learning Challenge, 3.2.1.

${ }_{923}$ Silberberg: Preserving Educational Fair Use, 2001, p. 627/628.

924 Ibid.

925 American Geophysical Union v. Texaco Inc., 60 F. 3d 913, 920 (2d Cir. 1994).

${ }^{926}$ Cf. Kenneth Crews: What is Fair Use?, available at http://copyright.columbia.edu/copyright/fair-use/what-isfair-use/.

${ }_{927}$ Jaszi, Fair Use in Education, 2013, p. 3, who underlines the special significance of education, which is why it should receive special attention in the context of copyright policy and fair use ("educational exceptionalism"). Jaszi suggests that educational institutions should always rely on fair use and try to convince courts of "educational exceptionalism", see idem, p. 6. According to Jaszi this is the only change they have hence legislative improvements like broader statutory limitations or revised Fair Use Guidelines (see 4.1.1.4.4.) are not in sight, idem, p. 3. Jaszi`s opinion is countered by Keller/Vats, Centering Education in the Next Great Copyright Act, 2015, p. 20f., who advocate for a new copyright act, which should point out education as a central pupose of copyright and take into account appropriatly the needs of eductional institutions in the digital era.
} 
for factual works, due to the rationale of copyright as a protection of creative works. ${ }^{928}$ Thus the use of a factual work is more likely to be fair. If the work used has not been published, this normally argues against fair use. ${ }^{929}$

\subsection{Third Factor: The Amount and the Substantiality of the Portion Used}

Although there is no general quantity that indicates if the amount copied cannot be considered fair anymore, usually the more of a work is copied the heavier this weighs against fair use. ${ }^{930}$ What is more important is to look at the context in and purpose for which the copied portion is used and to judge whether the amount copied still fits in that context and serves that purpose. ${ }^{931}$ Further even the use of a very small portion may be considered unfair if the portion used contains the essential parts of the original work and therefore benefits from its unique economic value. ${ }^{932}$

\subsection{Fourth Factor: The Effect on the Plaintiff's Potential Market}

Regarding the fourth factor it must be shown by the author or right holder that copyright infringement directly causes potential harm to his market. ${ }^{933}$ It is sufficient that some meaningful likelihood of harm exists. ${ }^{934}$ Courts have to analyse whether the use would negatively effect the market for the author's or right holder's work, provided that the use becomes widespread. ${ }^{935}$ Within the analysis of the market and the potential harm it may become relevant to what extent the use is transformative according to the first factor for a high degree of transformation will probably not be considered a substitute of the original. ${ }^{936}$

As Carol Silberberg points out "the extent and weight of the potential for market harm must be carefully considered, or else the fourth factor will always favour the copyright holder.937

\subsection{Cases concerning Education and Libraries}

As explained before the interpretation of the four factors of the fair use doctrine is the task of

\footnotetext{
${ }_{928}$ Silberberg, Preserving Educational Fair Use, 2001, p. 628.

${ }^{929}$ Kenneth Crews: What is Fair Use?, available at: http://copyright.columbia.edu/copyright/fair-use/what-is-fairuse/.

${ }_{930}$ American Geophysical Union v. Texaco Inc., 60 F. 3d 913, 920 (2d Cir. 1994).

931 Silberberg, Preserving Educational Fair Use, 2001, p. 629; Campbell v. Acuff-Rose Music, Inc. 510 U.S. 569 at 586 (1994).

932 Harper \& Row Publishers, Inc. V. Nation Enterprises, 471 U.S. 539 (1984), at 565.

933 Cf. Sony Corp. of America v. Universal City Studios, Inc. 464 U.S. 417 (1984).

${ }^{934}$ See idem at 451; Silberberg, Preserving Educational Fair Use, 2001, p. 629.

${ }^{935}$ Silberberg, Preserving Educational Fair Use, 2001, p. 629.

${ }^{936}$ Campbell v. Acuff-Rose Music, Inc. 510 U.S. 569 at 591 (1994).

937 Silberberg, Preserving Educational Fair Use, 2001, p. 617.
} 
the courts. However, there are few cases explicitly dealing with fair use and education and even fewer cases dealing with digital uses of works for educational purposes. In the following four cases shall be presented in order to illustrate how courts apply fair use in the area of education.

\subsection{Williams \& Wilkins Co. v. United States ${ }^{938}$}

In this case, which was decided under the 1909 Copyright Act, the National Institute of Health and the National Library of Medicine were sued for infringing copyrights by making copies of medical journals for members of their staff. The court stated that generally photocopying by libraries was covered by fair use. Despite the fact that entire articles were copied it further stated that due to the non-profit nature of medical research any potential damage to the right holder was outweighed. There was no general rule that an entire work should be excluded from fair use, said the court. ${ }^{939}$ The non-profit nature of the library and the fact that the copying had not been made with any commercial intent were also strong arguments in favour of fair use..$^{940}$

\subsection{Encyclopaedia Britannica Educ. Copr. v. Crooks ${ }^{941}$}

In this case the Board of Educational Services (BOCES) in Erie County, New York, had established a library for videotapes including a film print library and programs to make duplications. The content provided by BOCES consisted among others of recorded educational broadcasts, which had been freely available over public radio waves. BOCES distributed these recordings to educational institutions on videotape or via television transmissions. The producers of the recorded educational broadcasts sued BOCES for copyright infringement by unauthorised reproduction, distribution and performance. The defense was fair use.

However, the US District Court for the Southern District of New York found that the activities of BOCES were not covered by fair use. The court acknowledged that the purpose of the use was non-commercial and educational. Nevertheless, the copying done by BOCES was so extensively that it outweighed the purpose. ${ }^{942}$ Moreover, the activities of BOCES had negative effects on the market for the works of the suing producers, because BOCES had

\footnotetext{
${ }^{938}$ Williams \& Wilkins Co. v. United States 487 F.2d 1345 (1973).

${ }^{939}$ Williams \& Wilkins Co. v. United States 487 F.2d 1345, 1353 (1973).

${ }^{940}$ Williams \& Wilkins Co. v. United States 487 F.2d 1345, 1354 (1973).

${ }^{941}$ Encyclopaedia Britannica Educ. Copr. v. Crooks, 542 F. Supp. 1156 (S.D.N.Y. 1982).

942 Encyclopaedia Britannica Educ. Copr. v. Crooks, 542 F. Supp. 1156, 1175 (S.D.N.Y. 1982).
} 
made identical copies of the broadcasts. ${ }^{943}$

\subsection{Basic Books, Inc. v. Kinko`s Graphics Corp. ${ }^{944}$}

The Kinko copying service used course reading list from college professors for creating coursepacks, which were sold to students for profit. Kinko had no permission by the professors to use the materials. Therefore Kinko was sued by the publishers who owned some of the publications used in the coursepacks. Kinko invoked fair use.

The US District Court for the Southern District of New York decided that Kinko could not rely on fair use because Kinko had used the materials without permission for commercial purposes. ${ }^{945}$ Besides it constituted no educational purpose pursued by Kinko that students, who bought the coursepacks, used them for educational purposes. ${ }^{946}$ The court also found that the activities of Kinko infringed the Agreement on Guidelines for Classroom Copying in Not-For-Profit Educational Institutions (Classroom Guidelines 1976). ${ }^{947}$

\subsection{American Geophysical Union v. Texaco Inc. ${ }^{948}$}

In this decision the court again had to decide on photocopying journal articles for research purposes by Texaco. It stated that photocopying was not covered by fair use because of the commercial nature of the use and because licensing was available for Texaco. Commercial use was assumed because Texaco's research aimed at the development of new profitable products. $^{949}$

\subsection{Princeton University Press v. Michigan Document Services ${ }^{950}$}

This case dealt with the photocopying by a copy shop called Michigan Document Services. The copy shop made photocopies of course materials (so called "course packs") for professors copying entire articles without modification and sold these course packs to students without holding the necessary copyright permissions. ${ }^{951}$ The court found that the photocopying was not fair use since the nature and the purpose of the use had to be

\footnotetext{
943 Encyclopaedia Britannica Educ. Copr. v. Crooks, 542 F. Supp. 1156, 1179 (S.D.N.Y. 1982).

944 Basic Books, Inc. v. Kinko`s Graphics Corp., 758 F. Supp. 1522 (S.D.N.Y. 1991).

945 Basic Books, Inc. v. Kinko`s Graphics Corp., 758 F. Supp. 1522, 1531/1532 (S.D.N.Y. 1991).

946 Basic Books, Inc. v. Kinko`s Graphics Corp., 758 F. Supp. 1522, 1531 (S.D.N.Y. 1991).

${ }^{947}$ Basic Books, Inc. v. Kinko`s Graphics Corp., 758 F. Supp. 1522, 1534f. (S.D.N.Y. 1991); See also Chapter 4.1.1.4.4.

${ }_{948}$ American Geophysical Union v. Texaco Inc. 60 F. 3d 913 (2d Cir. 1994).

${ }^{949}$ American Geophysical Union v. Texaco Inc. 60 F. 3d 913, 921/922 (2d Cir. 1994).

${ }^{950}$ Princeton University Press v. Michigan Document Services 99 F.3d 1381 (6th Cir. 1996).

951 Silberberg, Preserving Educational Fair Use, 2001, p. 632.
} 
considered commercial and non-transformative. ${ }^{952}$ Moreover the court affirmed the third and the fourth factor because of the amount copied and the harm done by to the plaintiff's market for the defendants copying had widespread effect. ${ }^{953}$

\subsection{Cambridge University Press, et al, v Becker, et al ${ }^{954}$}

This very recent case is especially interesting because it deals with the application of fair use to digital uses for educational purposes. Background of the case is that Georgia State University (GSU) was sued by three publishing companies because of alleged copyright infringements making, without the consent of the publishers, portions of their copyrighted works available on its website as electronic course reserves (e-reserves) and allowing students to download and print copies for free. ${ }^{955}$

The deciding judge Evans applied the four factors of the fair use doctrine and found in the end that GSU`s uses in most cases had to be considered fair. ${ }^{956}$ Before starting the analysis of the four factors the judge pointed out that all factors had to be viewed and weighed together ${ }^{957}$ and clarified that in the present case one had to deal with "unpaid copying of excerpts of copyrighted material by a non-profit college or university for non-profit educational use in a graduate or upper level college courses." ${ }^{958}$ The first factor was then in favour of GSU for it is a non-profit educational institution and the portions were used for educational purposes. According to the judge the second factor, the nature of the copyrighted work, also was in favour of GSU because the materials used were non-fictional and thus more likely to be fair use. ${ }^{959}$ Regarding the third factor the judge developed some kind of general rule before unknown to the fair use doctrine by stating that unpaid copying up to 10 $\%$ of a book not divided into chapters or with less than 10 chapters should be covered by fair use. In case the copied book has 10 chapters or more, the copying of up to one chapter should be deemed fair use. Always provided that access to these excerpts is only granted to students enrolled in the course and only for the term of the course ${ }^{960}$ Factor four was interpreted as well in favour of GSU because no reasonably priced licences were available for the portions used. ${ }^{961}$ Moreover, the court could not find that students would not have bought the books the excerpts were taken from and thus the excerpts could not be

\footnotetext{
952 Princeton University Press v. Michigan Document Services 99 F.3d 1381, 1389/1390 (6th Cir. 1996).

953 Princeton University Press v. Michigan Document Services 99 F.3d 1381, 1389 (6th Cir. 1996).

954 Cambridge University Press v. Becker, 863 F. Supp. 2d 1190 (N.D. Georgia 2012).

955 Plovnick/Nguyen: All's fair in university copying case, Intellectual Property Magazin Nov. 2012, p. 66.

${ }_{956}$ Cambridge University Press v. Becker, 863 F. Supp. 2d 1190 (N.D. Georgia 2012).

${ }^{957}$ Campbell v. Acuff-Rose Music, Inc. 510 U.S. 569 at 578 (1994).

958 lbid.

959 lbid.; see above 4.1.1.4.2.2.

960 See Plovnick/Nguyen: All's fair in university copying case, Intellectual Property Magazin Nov. 2012, p. 66

961 Idem, p. 67.
} 
considered substitutes for the original works. ${ }^{962}$

The case went on appeal to the US Circuit Court of Appeals for the Eleventh Circuit in September 2012. Among others the plaintiffs claimed that the decision violated the principles established in Princeton University Press v. Michigan Document Services ${ }^{963}$ and that judges Evans' interpretation of the third and fourth factor constituted a misapplication of fair use principles. ${ }^{964}$ On October $17^{\text {th }}, 2014$, the Court of Appeals for the Eleventh Circuit reversed the lower court's decision and remanded for reconsideration, because it had found that the second and the third factor had not been properly considered by the lower court. ${ }^{965}$

\subsection{Authors Guild, Inc. v. Hathi Trust ${ }^{966}$}

In this case several universities participated in the Google Books Project, which digitises library collections. In 2008, a group of these universities founded the Hathi Trust, which should administer the Hathi Trust Digital Library. The Hathi Trust Digital Library is a digital repository containing more than 10 million digital copies of copyrighted works. These copies were used to first created a database for full-text search for the public, second allow library user with print disabilities to access entire works and third permit libraries to replace their original items in case they are lost, destroyed or stolen and no other replacement was available at a fair price. Authors and authors' associations filed an appeal against the district court's decision, which had ruled that the activities of the Hathi Trust Digital Library were covered by fair use. ${ }^{967}$

The US States Court of Appeals for the Second Circuit found that these activities at least partly had to be considered fair use. The court decided that the creation of a database for full-text search was fair use. ${ }^{968}$ The use was considered transformative because, "the use the result of a word search is different in purpose, character, expression, meaning, and message from the page (and the book) from which it is drawn." 969 Besides the court found no excessive copying because it was necessary to digitise the entire book in order to enable fulltext search. ${ }^{970}$ Also the full-text search was no harm to existing or potential markets for the

\footnotetext{
962 Idem.

963 Princeton University Press v. Michigan Document Services 99 F.3d 1381 (6th Cir. 1996).

964 See Plovnick/Nguyen: All's fair in university copying case, Intellectual Property Magazin Nov. 2012, p. 67

965 US Circuit of Appeals for the $11^{\text {th }}$ Circuit, Cambridge University Press, et al v Becker, et al, Civil Action No. 1:08-cv-1425-ODE, October 17, 2014.

${ }_{966}$ Authors Guild, Inc. v. Hathi Trust, 755 F. 3d 87 (2d Cir. 2014).

${ }^{967}$ Authors Guild, Inc. v. Hathi Trust, 902 F. Supp. $2 d 445$ (S.D.N.Y. 2012).

${ }_{968}$ Authors Guild, Inc. v. Hathi Trust, 755 F. 3d 87, 97 (2d Cir. 2014).

969 lbid.

${ }^{970}$ Authors Guild, Inc. v. Hathi Trust, 755 F. 3d 87, 98 (2d Cir. 2014).
} 
respective works. ${ }^{971}$ The court further decided that providing access to print-disabled was covered by fair use, because enabling access for blind or print-disable to copyrighted works is a typical example of fair use even if the use itself is not transformative. ${ }^{972}$ However, the court vacated the decision of the district court, because it did not "believe plaintiffs have standing to bring this claim, and this concern does not present a live controversy for adjudication. ${ }^{4973}$ The case was insofar remanded to the district court to determine if there is a live controversy for adjudication, which it had simply assumed. ${ }^{974}$

\subsection{Authors Guild, Inc. v. Google Inc. ${ }^{975}$}

This very recent case is similar to Authors Guild, Inc. v. Hathi Trust. In this case Google had a collaboration with several research libraries in connection with the Google Books Project in order to digitise their collections. Google was sued for copyright infringement by the Authors Guild, Inc.. It was complained that Google had scanned more than twenty million books and made available digital copies to its library partners. Moreover, Google had made available snippets of the scanned text to the public through search engines. The Authors Guild, Inc. claimed that Google had done this using books protected by copyright without authorisation. The US District Court for the Southern District of New York ruled that Google was covered by fair use. Against this decision the Authors Guild, Inc. went on appeal.

However, the US Court of Appeals for the Second Circuit court also found that Google could rely on fair use. Both the digitisation and the subsequent uses were covered by fair use. The Court decided that the use made by Google was transformative, "which augments public knowledge by making available information about Plaintiffs' books without providing the public with a substantial substitute for matter protected by the Plaintiffs' copyright interests in the original works or derivatives of them. ${ }^{* 976}$ Besides the Court ruled that it was no copyright infringement that Google had left copies of the scanned books to its partner libraries. ${ }^{977}$ Google had advised its partners to make only non-infringing uses and thus could not be held liable for infringements allowed by its partner despite Google`s advice. Finally, also the provision of snippets by Google constituted fair use, according to the court, because Google limited the amount of the work displayed to the public and the unauthorised use by Google did not harm the licensing markets of members of the Authors Guild, Inc. substantially. ${ }^{978}$ The

\footnotetext{
${ }_{971}^{97}$ Authors Guild, Inc. v. Hathi Trust, 755 F. 3d 87, 99 (2d Cir. 2014).

${ }_{972}$ Authors Guild, Inc. v. Hathi Trust, 755 F. 3d 87, 102f. (2d Cir. 2014).

${ }_{973}^{9}$ Authors Guild, Inc. v. Hathi Trust, 755 F. 3d 87, 104. (2d Cir. 2014).

974 lbid.

${ }_{975}$ Authors Guild, Inc. v. Google Inc., No. 13-4829-cv (2d Cir. Oct. 16, 2015).

${ }_{976}$ Authors Guild, Inc. v. Google Inc., No. 13-4829-cv (2d Cir. Oct. 16, 2015), p. 4.

${ }^{977}$ Authors Guild, Inc. v. Google Inc., No. 13-4829-cv (2d Cir. Oct. 16, 2015), p. 4.

${ }^{978}$ Authors Guild, Inc. v. Google Inc., No. 13-4829-cv (2d Cir. Oct. 16, 2015), p. 4 and 46.
} 
functions offered by Google varied significantly from those provided by the members of the Authors Guild, Inc. ${ }^{979}$ Not even the for-profit motivation of Google excluded fair use. ${ }^{980}$

\subsection{Fair Use Guidelines}

In order to provide greater certainty for educators regarding the use of copyrighted material for educational purposes together with the codification of the fair use doctrine in 1976 so called "Educational Guidelines" were introduced. ${ }^{981}$ These guidelines should provide what is often called a "safe harbour" for educational uses. ${ }^{982}$ By establishing concrete rules for the educational use of copyright protected materials for instance setting numerical limits on the amount copied from a work the guidelines however diminish the scope of fair use and take much of its flexibility. ${ }^{983}$ Furthermore, the guidelines have been criticised for creating even more confusion on the application of fair use because although they shall only provide the minimum of uses it allowed many educational institutions to have adopted the guidelines as more or less strict rules in order to definitively avoid legal controversy. ${ }^{984}$ This approach further narrows the scope of fair use. ${ }^{985}$ Additionally some courts have found the guidelines persuasive in their decisions although they are not part of the law and therefore not binding. ${ }^{986}$

In order to come to an agreement on more appropriate guidelines especially taking into account digital developments, in 1994 the Conference on Fair Use (CONFU) was established. Yet, because of the very diverse interests of educators and publishers no consensus could be reached. ${ }^{986 a}$

\subsection{Findings}

As could be shown it is difficult to apply the open and broad language of the Fair Use Doctrine to cases concerning educational uses of copyrighted works. Results are hard to predict, also because there is relatively little case law regarding fair use, education and libraries and archives. This unpredictability creates uncertainty for educators, educational

\footnotetext{
${ }^{979}$ Authors Guild, Inc. v. Google Inc., No. 13-4829-cv (2d Cir. Oct. 16, 2015), p. 4.

${ }_{980}^{9}$ Authors Guild, Inc. v. Google Inc., No. 13-4829-cv (2d Cir. Oct. 16, 2015), p. 4.

981 House Report 1976, p. 68.

982 Silberberg, Preserving Educational Fair Use, 2001, p. 636.

${ }_{983}$ See Berkmann Center, The Digital Learning Challenge, Part II, 3.2.3.

984 Silberberg, Preserving Educational Fair Use, 2001, p. 637.

985 Cf. Aufderheide/Jaszi, Reclaiming Fair Use, 2011, p. 110/111, who point out that althought these guidelines were negotiated by educators and publishers together they mainly represent the interests of publishers. According to Aufderheide /Jaszi the Guidelines have been unbalanced and very restrictive from the start. Meanwhile they are outdated. See also Jaszi, Fair Use and Education, 2013, p. 3.

986 Silberberg, Preserving Educational Fair Use, 2001, p. 637.

986a Idem, p. 639/640.
} 
institutions as well as for libraries and archives and may have the effect that they back away from certain uses fearing to be sued for copyright infringement. On the other hand the openness and flexibility of the Fair Use Doctrine brings about the advantage to adopt the law to new circumstances and new technologies, which is very problematic in the case of statutory limitations.

With regard to the benchmark of permissible uses the fair use doctrine provides of course for a broad, open and technologically neutral limitation, which in principle my cover all kinds of uses of protected works both for educational establishments and for libraries, archives and similar institutions. Apart from the problem of unpredictability and legal uncertainty, which is to a certain extent unavoidable, the fair use doctrine can be considered an adequate means to promote access to education and knowledge in the digital age. However, in view of the human rights dimension of limitations and exceptions in favour of access to education and knowledge, these fundamental values should be considered to a much larger extend in the context of fair use decisions.

\subsubsection{Summary USA}

US copyright law contains several limitations and exceptions favouring education, explicitly distance and e-learning, as well as libraries and archives. However, none of these limitations provides adequate solutions for those institutions, which would like to realise the full potential of digital technologies and the Internet.

The classroom exception of section 110 (1) CA does hardly cover e-learning activities because it is very narrow and was conceived for traditional classroom settings. The TEACH Act of section 110 (2) CA was a step into the right direction but its provisions are very complicated and hard to comply with. The benefits of the TEACH Act for educational institutions thus are quite limited. Regarding libraries and archives section $108 \mathrm{CA}$ provides for very complicated rules, which do not take into account the possibilities of digital technologies and thus do not provide adequate solutions for the respective institutions. Finally, the Fair Use Doctrine can be invoked as a defence against the allegation of copyright infringement by educational institutions and libraries and archives. It is important to mention that the fair use defence is never excluded by invoking a statutory limitation. Yet, because the application of the Fair Use Doctrine is left to the courts on a case-by-case basis and there are relatively few recent precedents concerning fair use, education and libraries, it appears quite risky for educational institutions and libraries and archives to rely on fair use. Nevertheless, the Fair Use Doctrine is capable to provide flexible and up-to-date solutions for educational institutions and libraries and archives in the digital age. 
Concerning the benchmark for permissible uses it was found that the statutory limitations for educational puproses and libraries and archives mostly do not meet the requirements. However, the Fair Use Doctrine provides for an open, broad and technologically neutral limitation. However, in the context of adequacy and in view of the human rights dimension of limitations and exceptions in favour of access to education and knowledge, it these fundamental values should be taken into consideration to a larger extend when applying fair use.

\subsubsection{United Kingdom}

In the United Kingdom copyright law is governed by the Copyright, Designs and Patents Act 1988. ${ }^{987}$ The CDPA has been altered several times since it has come into force. Nevertheless especially the limitations and exceptions to copyright have not been subject to many alterations deriving from international obligations such as the Berne Convention, the Rome Convention, the TRIPS agreement and the WIPO treaties. ${ }^{988}$ The influences of European law are more visible in UK copyright law. ${ }^{989}$ The Software Directive, the Databases Directive and the Information Society Directive have all at least in part been implemented into UK Copyright Law ${ }^{990}$ and require the legislator to provide certain limitations to exclusive rights. ${ }^{991}$ Above that, the limitations and exceptions to exclusive rights provided by UK Copyright Law are influenced in their interpretation by the European Convention on Human Rights ${ }^{992}$ and the jurisdiction of the European Court of Justice in Strasbourg. ${ }^{993}$ Most important is article 10 of the European Convention on Human Rights, which guarantees freedom of expression. ${ }^{994}$

Especially important regarding the field of education and research as well as for libraries and archives was the alteration implementing parts of the European Information Society Directive 2001/29/EC in 2003 by the Copyright and Related Rights Regulation. ${ }^{995}$ The next step to implement the Information Society Directive only followed in 2014. The Copyright and Rights in Performances (Research, Education, Libraries and Archives) Regulations 2014 implements articles 5(2)(c) and 5(3)(a) Information Society Directive. It came into force on

\footnotetext{
${ }^{987}$ In the following abbreviated as "CDPA".

988 Bently/Sherman, Intellectual Property Law (2014), p. 40 - 44.

989 Idem, p. 46 - 55.

990 Copyright (Computer Programs) Regulations 1992 no. 3233; The Copyright and Rights in Databases Regulation 1997 no. 3032; The Copyright and Related Rights Regulations 2003 no. 2498

991 Software Directive Art. 5 and 6; Database Directive Art. 6; Information Society Directive Art. 5

992 Since 1998 in the UK the Human Rights Act is in force, which binds courts to take into direct consideration the fundamental rights of the European Convention on Human Rights, courts have to interpret national laws in accordance with the convention as far as possible, see article 3 Human Rights Act.

${ }_{993}$ Laddie, Prescott and Vitoria, The Modern Law of Copyright, 2011, no. 21.16.

994 lbid.

${ }^{995}$ Copyright and Related Rights Regulations 2003 no. 2498.
} 
June 1, 2014. ${ }^{996}$ These alterations brought about the relevant provisions for education and research as well as for libraries and archives in the UK. The alterations intended to make the CDPA fit for the challenges of the digital age. The Copyright and Rights in Performances (Certain Permitted Uses of Orphan Works) Regulations 2014 introduced the Orphan Works Directive into national copyright law. It came into force October 29, 2014. ${ }^{997}$

Original works, created by a qualified national that have been fixed or recorded in some form, are protected under the CDPA. ${ }^{998}$ The CDPA permits various uses of copyright protected works under the given prerequisites. These permissions therefore limit the exclusive rights of authors and right holders. Regarding the use of copyrighted works for educational purposes, e-learning and research as well as in libraries and archives there are some provisions of the CDPA that have to be looked at. Therefore I will analyse in the following the provisions containing the fair dealing exception and the specific limitations for education and libraries, archives and museums. Most of these provisions have been changed by the latest copyright reform in 2014.

\subsubsection{Fair Dealing}

The fair dealing exception has partly been changed by the 2014 copyright reform. Yet, the concept of fair dealing remained untouched. Like the fair use doctrine in US Copyright Law the CDPA includes the concept of fair dealing under which certain uses of copyrighted materials may be allowed or to put it otherwise, which can be used as a defence against alleged copyright infringement. The concept of fair dealing was developed in the $18^{\text {th }}$ and $19^{\text {th }}$ century by the jurisdiction. Courts provided flexible criteria for balancing the rights of authors, right holders, users and the general public. Using the fair dealing consent courts could in each individual case decide according to their overall impression what was to be considered fair. In the course of time however, the scope of fair use was narrowed, also because of the influence of international copyright law such as the Berne Convention of 1886. This development was continued by the Copyright Act of 1911, which only should have codified the existing case law, and the Copyright Act of 1956, which introduced "permitted" and "nonpermitted" purposes for fair dealing. This classification of course led to a growing inflexibility

\footnotetext{
${ }^{996}$ Copyright and Rights in Performances (Research, Education, Libraries and Archives) Regulations 2014 no. 1372.

997 The Copyright and Rights in Performances (Certain Permitted Uses of Orphan Works) Regulations 2014 , no. 2861.

${ }^{998}$ The CDPA establishes that creation enjoy copyright protection if the fall in one of the eight categories of "works" named by article 1 para. 1 CDPA. These categories are: "(a) original literary, dramatic, musical or artistic works, (b) sound recordings, films or broadcasts, and (c) the typographical arrangement of published editions." Traditionally this list of categories was considered to be exhaustive, meaning that creations belonging to other categories were not protected. In course of the intergration of EU directives and the efforts to achieve EU-wide harmonisation of Copyright the ECJ has begun to gradually abandon the viewpoint of an exhaustive list. See in detail Bently/Sherman, Intellectual Property (2014), p. 59 - 63.
} 
of the fair dealing concept. The Copyright Act of 1988 further limited the scope of fair dealing because of specific provisions for uses of copyright protected works such as education and libraries and archives. ${ }^{998 a}$

The concept of fair dealing today is enshrined in section 29,30, 30A and 32 CDPA and states that the use of protected works for the purpose of private study or research, criticism or review or news reporting, caricature, parody and pastiche as well as illustration for instruction constitutes no copyright infringement as long as this use can be considered fair dealing. However, any use for another than one of these named purposes no matter how fair it may be, can never be fair dealing. ${ }^{999}$ Compared to the US fair use doctrine the UK approach is rather narrow and strict because fair dealing only applies to specific purposes of use and to specific types of works. ${ }^{1000}$ Yet the results produced by fair dealing are more predictable hence the interpretation of what should be considered fair dealing is not entirely left to courts. $^{1001}$

\subsection{General Prerequisites}

Fair dealing has some general prerequisites, which can be reduced to "dealing", "purpose", "fairness" and "sufficient acknowledgement". The first of these prerequisites "dealing" only means that it must be made used of a copyright protected work. ${ }^{1002}$ As said before fair dealing is only permitted for the purposes named by the respective provision. The scope of application of the fair dealing concept is thus quite limited. In contrast US copyright law provides a general limitation independently of any purpose by the fair use doctrine. ${ }^{1003}$ In order to determine whether a use falls within a privileged purpose courts have to take an objective viewpoint; that means that the subjective view of the person using a copyright protected work is not decisive for the purpose. ${ }^{1004}$

Moreover, the dealing must be fair. As it is known from the US fair use doctrine also the concept of fair dealing does not follow precise criteria, but there are several factors, which apply from case to case and depending on the purpose of the use. ${ }^{1005}$ Factors relevant for determining whether the dealing is fair are if the work in question has not yet been published

\footnotetext{
998a With regard to the historical development of fair dealing in the UK see in detail de la Durantaye, "Allgemeine Bildungs- und Wissenschaftsschranke" (2014), p. 117/118.

${ }_{999}$ Copinger Skone James 2011, no. 9-23; Bently/Sherman, Intellectual Property (2014), p. 224.

1000 Ballard, Fair use and fair dealing, 2006, p. 240; cf. Bently/Sherman, Intellectual Property (2014), p. 224;

1001 Ballard, Fair use and fair dealing, 2006, p. 240.

1002 Bently/Sherman, Intellectual Property (2014), p. 224.

1003 Ibid.; Copinger Skone James 2011, no. 9-23.

1004 Bently/Sherman, Intellectual Property (2014), p. 224.

1005 Here the above mentioned Human Rights Act 1998 and the freedom of expression are factors, which must be considered too, cf. Copinger Skone James 2011, no. 9-25.
} 
or made available to the public, how the work was obtained, if it was for instance stolen or legally acquired, the amount taken, meaning the quantity and quality of the work used or of parts of the work (substantiality), the use made of the work, for instance if a commercial profit has been achieved by the use of the work, the motives for the dealing, are they honourable or dishonourable, the consequences of the dealing, meaning that the use of the work may have had a harmful or harmless impact on authors and right holders. ${ }^{1006}$ And finally, it can be asked whether the purpose could have been achieved by different means, especially by a more sparing use. ${ }^{1007}$ Above that, the dealing must be accompanied by "sufficient acknowledgement" in order to be fair. ${ }^{1008}$ This means that the author and the work must be identifiable, unless this is "impossible for reasons of practicality or otherwise". ${ }^{1009}$

\subsection{Fair Dealing for Research and Private Study}

With regard to access to knowledge and education it is important to take a look at section 29 CDPA because this provision allows certain uses for the purpose of research for a noncommercial purpose and for the purpose of private study. The justification for this defence against copyright infringement is the assumption that research and private study are necessary for the production of new works. ${ }^{1010}$ The old section 29 CDPA was criticised a lot for being too narrow and limited in scope. ${ }^{1011}$ It applied only to literary, dramatic, musical and artistic works as well as to the typographical formats of published works. Moreover, fair dealing under the old section 29 CDPA only covered single copies made by professors for their own research or by students made for private study. ${ }^{1012}$ The application to computer programs was also very limited. ${ }^{1013}$

The new section 29 CDPA now refers only to "works" meaning all kinds of copyright protected works and therefore provides a more open approach. ${ }^{1014}$ Above that section 29 CDPA has not been subject to many changes. As before it is not considered fair dealing if a person other than the researcher or the student himself makes copies of a protected work and in case of a librarian or a person acting on behalf of the librarian, that person does anything, which is not permitted under the new section 42 A CDPA or in any other case, the

\footnotetext{
1006 Bently/Sherman, Intellectual Property (2014), p. 224 - 226.

1007 Idem, p. 226

1008 Idem, p. 228.

1009 Depending on the respective fair dealing provision suffiencient acknowledgement is required for only for some works (section 29 (1B) CDPA or all works (section 30 (1) and (2) CDPA). According to section 30 (3) CDPA no acknowledgement is required in connection with reporting of current events by means of a sound recording, film or broadcast where this would be impossible for reasons of practicality or otherwise.

1010 Bently/Sherman, Intellectual Property (2014), p. 235/236.

1011 Bently/Sherman, Intellectual Property (2009), p. 207.

1012 Secker, Copyright for e-learning (2010), p. 9.

1013 Cf. Section 29 (4) and (4A) CDPA (2003).

1014 IPO, Modernising Copyright, p. 32.
} 
person making the copies knows or has reason to believe that it will result in copies of this substantially the same material being provided to more than one person at substantially the same time and for substantially the same purpose. ${ }^{1015}$ Yet, section 29 has been extended and now states that any contractual term, which prevents or restricts fair dealing activities in accordance with section 29 CDPA is not enforceable. ${ }^{1016}$ In order to invoke the fair dealing defence the use of a protected work must be made for a privileged purpose, namely noncommercial research and private study.

Regarding non-commercial research the legislator has implemented article 5 para. 3 lit. a) Information Society Directive. ${ }^{1016 a}$ It is however difficult to determine if research is done for commercial or for non-commercial purposes. ${ }^{1017}$ In the case of HM Stationery Office v Green Amps Ltd. the High Court decided that research, which is directed to financial gain and therefore has financial value, also pursues a commercial purpose ${ }^{1018} \mathrm{~A}$ company had used copyright protected maps in order to develop a geographical information system, which should be used for wind turbines. The company argued that the use of the copyright protected material was non-commercial research purposes because the information system the company was developing was not yet on the market. The court found that the use of the copyright protected material was commercial because it was used within a commercial enterprise and thus the research done for the development system was for commercial purposes. ${ }^{1019}$ According to the Information Society Directive it however does not matter whether research is done for a commercial enterprise as long as the research itself is for non-commercial purpose. ${ }^{1020}$ What is decisive is whether the activity as such is commercial, which it was in that case. Although this decision brought some clearance, there are of course several other questions, which remain unanswered, ${ }^{1020 a}$ especially in the case of libraries. ${ }^{1020 \mathrm{~b}}$

Regarding private study fair dealing of a work does not infringe copyright according to section 29 (1C) CDPA. Fair dealing for private study is however not permitted if is directly or indirectly for a commercial purpose. ${ }^{1021}$ Private study covers all uses, which are private, for

\footnotetext{
1015 Cf. section 29 (3) CDPA.

${ }^{1016}$ Cf. section 29 (4B) CDPA; IPO, Modernising Copyright, p. 19.

1016a Bently/Sherman, Intellectual Property (2014), p. 236, fn. 136.

1017 Cornish, Llewelyn \& Aplin, Intellectual Property (2013), p. 12-39, who give some examples where the distiction between commercial and non-commercial research is difficult.

1018 HM Stationery Office v Green Amps (2007) EWHC 2755 (Ch).

1019 HM Stationery Office v Green Amps (2007) EWHC 2755 (Ch), para. 21.

${ }^{1020}$ Recital 42 Information Society Directive.

1020a Cf. Bently/Sherman, Intellectual Property (2014), p. 227.

$1020 \mathrm{~b}$ See with further reference de la Durantaye, "Allgemeine Bildungs- und Wissenschaftsschranke" (2014), p. 126.

${ }^{1021}$ See section 178 CDPA.
} 
instance photocopying from a book as preparation for class. ${ }^{1022}$ The provision has to be interpreted in accordance with article 5 para 2 lit. b) Information Society Directive ${ }^{1022 a}$ and consequently only applies to natural persons and moreover does not cover the publicly making available of a work. The person relying on the fair dealing defence for private study herself must pursue non-commercial purposes. ${ }^{1023}$ Although recital 35 of the Information Society Directive and article 5 para. 2 (b) Information Society Directive stipulate differently, no remuneration is to be paid for uses of a copyright protected work permitted by the fair dealing exception. ${ }^{1023 a}$

Apart from being used for private study or non-commercial research the dealing with the work must be fair, too. In order to find that out courts apply the above-mentioned factors objectively. ${ }^{1023 b}$ Especially important in the context of fair dealing for private study and research is the amount to which the work is used respectively copied (substantiality). ${ }^{1024}$ Further it is important, whether a "fair-minded and honest person" would have used the work for the same purpose in the same way as the defendant infringer. ${ }^{1025}$

The new section 29 CDPA is a general defence for uses of a copyright protected work that are fair and done for non-commercial research or private study. All kinds of uses are covered except for publicly making available of the work. The provision has been opened only in so far as it now applies to all kinds of works and clarifies that contract terms preventing from the use of a copyright protected work under the fair dealing exception of section 29 CDPA is unenforceable.

\subsection{Fair Dealing for Text and Data Mining}

In connection with the fair dealing exception of section 29 CDPA the 2014 reform implemented section 29A CDPA, which allows text and data mining for non-commercial research. ${ }^{1026}$ Section 29A CDPA is not a typical fair dealing provision but is located among the general limitations and exceptions of Chapter III of the CDPA and contains elements of fair dealing. As recommended ${ }^{1027}$ section 29A CDPA was introduced in order to enable the use of new technologies for research purposes, which otherwise would have been inhibited

\footnotetext{
1022 Cf. Bently/Sherman, Intellectual Property (2014) p. 236.

${ }^{1022 a}$ Bently/Sherman, Intellectual Property (2014), p. 236, fn. 137.

1023 Bently/Sherman, Intellectual Property (2014), p. 236/237.

${ }_{1023 a}$ In that sense cf. Bently/Sherman (2014), p. 235, however in the context of section 28B CDPA "Personal Copies for Private Use".

$1023 \mathrm{~b}$ Cf. Holyoak \& Torremans. Intellectual Property Law (2013), p. 301.

1024 Universities U.K. v. Copyright Licensing Agency Ltd. (2002) RPC 693, 702, para. 34.

${ }^{1025}$ HM Stationery Office v Green Amps (2007) EWHC 2755 (Ch), para. 24.

1026 See Bently/Sherman, Intellectual Property (2014), p. 237, who argues that the restriction to non-commercial research considerably reduces the scope of the provision.

${ }^{1027}$ Hargreaves Report, para. 5.26.
} 
by copyright. ${ }^{1028}$ The introduction of a limitation for text and data mining was much debated among stakeholders, namely researchers and publishers, arguing on the one side that it would improve research and on the other side that licensing solutions with regard to access to protected works were preferable. ${ }^{1029}$ The legislator finally decided in favour of the provision. ${ }^{1030}$ The provision is applicable in case a person has lawful access to the work. It permits the copying of the work in order to analyse its content by a technical process. According to section 29A (5) CDPA no contract term may prevent the making of a copy under this exception.

\subsection{Findings}

The fair dealing provisions of the CDPA safeguard the flexibility of the system of limitations and exceptions. The fact that the legitimate purposes of fair dealing are explicitly mentioned in the law increases legal certainty. Digital issues have been taken into account by opening fair dealing to all kinds of works and including a limitation for text and data mining. Very important to mention is that fair dealing and the text and data mining limitation cannot be overruled by contracts. Thus the 2014 reform of the provisions discussed before promotes the access to knowledge and education.

With regard to the benchmark of permissible uses the fair dealing provisions of the CDPA examined above meet the requirements. Both limitations are broad, open and flexible and apply only, if non-commercial purposes are pursued. Neither of the provisions may be overruled by licensing contracts. Section 29A CDPA contains an explicit limitation for text and data mining. The wording is rather clear, but due to the fair dealing nature, uncertainties remain.

Apart from these uncertainties it must be stated that both provisions adequately promote the access to knowledge and education, especially by enabling the use of new digital technologies for non-commercial research.

\subsubsection{Limitations and Exceptions for Education}

The 2014 copyright reform has also brought amendments for limitations regarding uses of copyright protected works for educational purposes. As before these limitations can be found in section 32 CDPA to section 36A CDPA, although elderly section 32, section 35 and section 36 CDPA have been altered. Section 33, section 34 and section 36A CDPA have been left

\footnotetext{
1028 IPO, Modernising Copyright, p. 36/37.

1029 IPO, Modernising Copyright, p. 36, see also Bently/Sherman, Intellectual Property (2014), p. 237/238.

1030 IPO, Modernising Copyright, p. 37.
} 
unaltered. The goal of the legislator was to adapt these provisions to the digital age and the realities of education and teaching in the 21 st century as well as to provide more flexibility for educational uses and enhance new forms of education such as e-learning and distance learning. ${ }^{1031}$

\subsection{Illustration for Instruction}

In order to achieve this goal the legislator has introduced the new section 32 CDPA, which is now constructed as a fair dealing exception. According to the new section 32 CDPA the use of a copyright protected work "for the sole purpose of illustration for instruction does not infringe copyright in the work provided that the dealing is (a) for a non-commercial purpose, (b) by a person giving or receiving instruction (or preparing for giving or receiving instruction), and (c) accompanied by a sufficient acknowledgement (unless this would be impossible for reasons of practicality or otherwise)." The new wording of the provision shall allow what has been allowed under the old section 32 CDPA $^{1032}$ and moreover permits the use of copyright protected works for educational purposes as long as these uses can be considered so minor that they do not conflict with the normal exploitation of the work. ${ }^{1033}$ The provision covers actions by the instructor such as the preparation of a class as well as the act of instruction itself. ${ }^{1034}$ It also covers actions of the person receiving the instruction, for instance note taking in class. ${ }^{1035}$ As section 32 (3) CDPA declares the use of works under the educational fair dealing exception cannot be leveraged by any licensing contract provided that the prerequisites of section 32 (1) CDPA are complied with. The new wording of section 32 (1) CDPA also suggests that the provision applies to all kinds of institutions, organisations and individuals, not only to those defined as "educational establishments" in the CDPA. ${ }^{1036}$

\subsection{Anthologies for Educational Use}

Section 33 CDPA has been left unaltered by the Copyright and Related Rights Regulation of 2003. As well the Copyright and Rights in Performances (Research, Education, Libraries and Archives) Regulations 2014 have not touched this provision. Section 33 CDPA establishes that it is no infringement of copyright, if a short passage from a published literary or dramatic work is included into a collection provided that the collection "(a) is intended for use in educational establishments and is so described in its title, and in any advertisements issued

\footnotetext{
1031 IPO, Modernising Copyright, p. 39.

1032 Section 32 CDPA 2003 permitted non-reprographic copying for the purpose of instruction and copying for the purpose of examination.

${ }^{1033}$ IPO, Modernising Copyright, p. 40.

1034 Bently/Sherman, Intellectual Property (2014), p. 254.

1035 Ibid.

1036 IPO, Modernising Copyright, p. 40; see section 174 CDPA
} 
by or on behalf of the publisher, and (b) consists mainly of material in which the copyright subsists. ${ }^{1037 " ~ A d d i t i o n a l l y ~ a c c o r d i n g ~ t o ~ s e c t i o n ~} 33$ (1) CDPA the work from which the short passage is taken must itself not be intended for the use in educational establishments. However, the anthology must be clearly intended for educational use. ${ }^{1038}$ Above that sufficient acknowledgement is required. Furthermore, section 33 (1) CDPA does not apply if the same publisher over a period of five years includes in collections more than two short passages from copyright protected works by the same author. ${ }^{1039}$ Because of the very narrow scope of application, the provision hardly reflects the necessities of educational establishments and has almost no practical significance. ${ }^{1040}$

\subsection{Performing, Playing or Showing Work in Course of Activities of Educational}

\section{Establishment}

As well section 34 CDPA was not changed by the reforms of 2003 and 2014. Section 34 (1) CDPA determines that "the performance of a literary, dramatic or musical work before an audience consisting teachers and pupils at an educational establishment and other persons directly connected with the activities of the establishment (a) by a teacher or pupil in the course of the activities of the establishment, or (b) at the establishment by any person for the purposes of instruction, is not a public performance for the purposes of infringement of copyright." Exactly speaking the provision is no defence against the accusation of copyright infringement. It rather exempts the described activities from the control of the author or right holder by declaring that the right of public performance is not affected at all. ${ }^{1041}$ Section 34 (3) CDPA does not apply to performances before parents or other persons, which are only indirectly related to the activities of the educational establishment. Consequently, the performance of a work before the parents of the pupils requires the permission of the right holder. ${ }^{1042}$

Further following section 34 (2) CDPA it is not considered a performance of a copyright protected work in public, if a sound recording, film or broadcast is played before an audience as described in section 34 (1) CDPA for the purposes of instruction.

\footnotetext{
1037 See Section 33 (1) CDPA.

1038 Holyoak \& Torremans, Intellectual Property Law (2013), p. 311.

1039 See Section 33 (2) CDPA.

1040 Bently/Sherman, Intellectual Property (2014), p. 255.

1041 Cf. section 19 CDPA, which defines copyright infringement by performance, showing or playing of a work in public.

${ }_{1042}$ Holyoak \& Torremans. Intellectual Property Law (2013), p. 311; Bently/Sherman, Intellectual Property Law (2014), p. 255.
} 


\subsection{Recording by Educational Establishments of Broadcasts}

Section 35 CDPA concerns the recording of broadcast by educational establishments. This provision has been changed slightly in the latest 2014 reform. The changes have been in the first place editorial and only in the second place regarding content, because the provision was considered to be fit to take into account adequately the interests of educational establishments as well as authors and right holders. ${ }^{1043}$ In order to be more easily applicable the requirement for licences to be certified by the Secretary of State, which the old provision prescribed, was removed. ${ }^{1044}$

The new section 35 (1) CDPA permits the recording of broadcasts ${ }^{1045}$ or any protected work included in it by educational establishments for educational purposes, if "(a) the educational purposes are non-commercial, and (b) the recording or copy is accompanied by a sufficient acknowledgement (unless this would be impossible for reasons of practicality or otherwise)." Furthermore, section 35 (2) CDPA declares that it is no copyright infringement if the recording of a broadcast or the copy of such a recording is communicated by or on behalf of the educational establishment to the pupils or the staff, provided that this communication takes place for non-commercial educational purposes. With regard to the educational practices and possibilities of digital technologies, section 35 (3) CDPA then establishes that the communication of the recording of a broadcast "outside the premises of the establishment" is now permitted provided that it "is made by means of secure electronic network accessible only by the establishment's pupils and staff". This was not allowed on that the old section 35 CDPA of 2003. ${ }^{1046}$ Although, in order to take into account properly the interests of authors and right holders, the limitations of section 35 CDPA only apply, if no "licences are available authorising the acts in question and the educational establishment responsible for those acts new or ought to have been aware of that fact. ${ }^{11047}$ The rationale behind this provision is that the legislator found that widening the limitations regarding the recording and communication of broadcasts by educational establishments would unduly harm the interests of right holders and diminish incentives for authors of works and thus would conflict with the Three-Step Test enshrined in the Berne Convention. ${ }^{1048}$ Therefore it was decided to retain the requirement of licences for educational establishments in that area. Section 35 (5) and (6) CDPA finally contain definitions concerning subsequent infringing copies.

\footnotetext{
$\overline{1043}$ IPO, Modernising Copyright, p. 41.

1044 Ibid.

${ }_{1045}$ According section 1(1)(b) CDPA broadcasts are protected by copyright as independent works.

1046 Section 35 (1A) CDPA 2003 said that "Copyright is not infringed where a recording of the broadcast (..) Is communicated to the public by a person is situated within the premises of an educational establishment provided that the communication cannot be received by any person situated outside the premises of that establishment."' 1047 Section 35 (4) CDPA.

1048 IPO, Modernising Copyright, p. 41.
} 


\subsection{Copying and Use of Extracts of Works by Educational Establishments}

Section 36 CDPA deals with copying of protected works and the use of extracts of such works by educational establishments. The old section 36 CDPA was considered to be too narrow for meeting the challenges of education in the digital age. ${ }^{1049}$ The old provision spoke of reprographic copying by educational establishments and only allowed the copying of no more than $1 \%$ of a protected work per quarter of a year. ${ }^{1050}$ Digital uses were not addressed at all.

The new section 36 (1) CDPA now applies to all kinds of copyright protected works. It covers the copying of extracts of any kind of copyright protected work by educational establishments "provided that (a) the copies made for the purposes of instruction for non-commercial purposes, and (b) the copy is accompanied by a sufficient acknowledgement (unless this would be impossible for reasons of practicality or otherwise)." In order to take into account properly in the necessities and realities of education in the digital age section 36 (2) and (3) CDPA permit the use of copyright protected works outside of the premises of an educational establishment, for instance for the purpose of distance education and e-learning. ${ }^{1051}$ It is therefore allowed for an educational establishment to communicate a copy of a work made under section 36 (1) CDPA to its pupils or staff for the non-commercial purposes of instruction. ${ }^{1052}$ According to section 36 (3) CDPA the communication, which can be received outside of the premises of the respective educational establishment, is however only allowed, if it is made "by means of a secure electronic network accessible only by the establishments pupils and staff." This extension of the scope of the provision appears to be a real step forward regarding the digital possibilities for education.

The uses permitted by section 36 (1), (2) and (3) CDPA however do not apply to broadcasts and artistic works as long as they are not incorporated into another work. ${ }^{1053}$ Section 36 (5) CDPA further restricts the copying of educational establishments under section 36 CDPA to not more then $5 \%$ of a work within a period of 12 months. As said above the old section 36 (2) CDPA only permitted the copying of not more than $1 \%$ of a work within the quarter of a year. The new provision thus allows to copy slightly more.

Section 36 (6) and (7) CDPA practically retain the old section 36 (3) and (4) CDPA

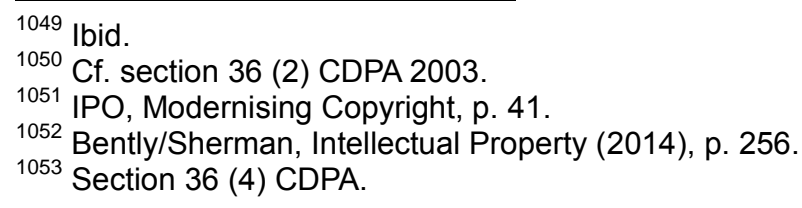


determining that the permissions of section 36 CDPA do not apply "if, or to the extent that, licenses are available authorising the act in question and the educational establishment responsible for dose acts knew or ought to have been aware of that fact." ${ }^{1054}$ According to section 36 (7) CDPA license terms aiming at the restriction of the amount of a work that may be copied to less than that which is allowed under section 36 CDPA are invalid. ${ }^{1055}$ By maintaining these corresponding provisions the legislator wants to safeguard that authors and right holders still benefit from licences for uses of their works. ${ }^{1056}$

Section 36 (8) and (9) CDPA finally contain definitions concerning subsequent infringing copies.

\subsection{Lending of Copies by Educational Establishments}

Section 36A CDPA has not been changed by the 2014 reform. It maintained its name and wording unaltered. This provision determines that the lending of copies of a copyright protected work by an educational establishment constitutes no copyright infringement. Section 36A CDPA was introduced in the course of the implementation of the Rental Right and Lending Right Directive 92/100/EEC of 19 November 1992. It refers to article 5 (3) of that directive, which states that "Member States may exempt certain categories of establishments from the payment of the remuneration (...). "Consequently section 36A CDPA does not require the payment of remuneration.

\subsection{Findings}

In the course of the 2014 reform the limitations and exceptions for education have partly been adapted to the realities of the digital era. The provisions for anthologies for educational use, for performances of protected works in educational establishments as well as the lending of copies by educational establishments have not been modified. Either practical relevance is limited or the provision also functions with regard to digital technologies and the Internet.

With regard to the benchmark of permissible uses of protected works for educational

\footnotetext{
1054 Section 36 (3) CDPA 2003 said that "copying is not authorised by this section if, or to the extent that, licenses are available authorising the copying in question and the person making the copies knew or ought we have been aware of that fact."

1055 Section 36 (7) CDPA 2003 said that "the terms of a licence granted to an UK some establishment authorising the reprographic copying for the purposes of instruction of passages from published works of no effect so far as they purport to restrict the proportion of work which may be copied (whether on payment or free of charge) to less than that which would be permitted under this section."

${ }^{1056}$ IPO, Modernising Copyright, p. 41.
} 
purposes it can be noted that the reformed CDPA in part meets the requirements. There is an open and technologically neutral limitation in the form of article 32 CDPA. This fair dealing provision now applies to all kinds of works and all kinds of institutions, organisations and individuals. The provision cannot be overruled by contract. Concerning digital technologies educational establishments may now record entire broadcasts and communicate these broadcasts even outside of the premises of the establishment under certain conditions. Moreover, educational establishments are allowed copy extracts of all kinds of copyright protected works and may even communicate these copies outside of their premises under certain conditions. The use of entire works however is not allowed, but distance learning and e-learning activities are partly covered. However, these limitations can be overruled by licensing contracts. Text and data mining is not addressed. The wording of the provisions is quite clear, at least concerning statutory limitations. With regard to fair dealing in spite of supposedly clear wording, uncertainties remain.

From the perspective of adequacy limitations and exceptions for educational purposes of the CDPA do not fully achieve the objective of promoting access to education and knowledge in the digital age.

\subsubsection{Limitations and Exceptions for libraries and archives}

Sections 40A CDPA to 44A CDPA contain new limitations and exceptions regarding the use of copyright protected works by libraries and archives, especially the purposes of preservation and archiving. The old provisions were enshrined in sections 37 CDPA to 44A CDPA. They were considered to be very narrow, complicated to apply and simply outdated in order to provide legal certainty for the addressed institutions in the digital age. ${ }^{1057}$ Therefore the legislator has now introduced new limitations and exceptions for libraries and archives, which are intended to take properly into account the necessities and possibilities of the work of libraries and archives as well as other institutions acting in public interests in the digital age. ${ }^{1058}$ The respective new provisions shall be analysed in the following.

\subsubsection{Lending of Copies by Libraries and Archives}

Section 40A CDPA still deals with the lending of copies by libraries or archives and is this by the latest reform very similar to its predecessor. Nevertheless, there are some changes, which reflect digital reality. According to section 40A CDPA it is no copyright infringement if a

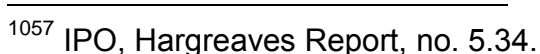

1058 IPO, Modernising Copyright, p. 44/45.
} 
public library regarding a book within the public lending right scheme ${ }^{1059}$ lends the book or regarding an audio-book or e-book makes copies or issues copies of that book if this happens incidentally to lending the book. The newly introduced section 40A (1A) CDPA defines the meaning of "book", "audio-book" and "e-book" as well as "the public lending right scheme" and "lending". Section 40A (2) CDPA further stipulates that the lending of copies of any protected work by a library or archive, which is not a public library, constitutes no copyright infringement as long as the library or archive is not conducted for profit.

\subsection{Libraries and Educational Establishments etc.: Making Works Available through Dedicated Terminals}

Section 40B CDPA provides a completely new regulation for the making available of copyright protected works on dedicated terminals, which the legislator had announced. ${ }^{1060}$ The provision stipulates that it is no infringement of copyright if a library, an archive, a museum or an educational establishment communicates a copyright protected work to the public or makes it available to the public by means of a dedicated terminal on its premises provided that the institution has lawfully acquired the work or a copy of the work and the communication or the making available is for the sole purpose of research or private study and takes place in accordance with the licensing terms to which the work is subject.

The intention of section $40 \mathrm{~B}$ CDPA is to facilitate private study and research regarding materials preserved by the respective institutions in digital format. ${ }^{1061}$ At the same time the costs of keeping physical copies of works available shall be reduced. ${ }^{1062}$ Section 43A (2)(a) CDPA defines what is meant by "library". Library in that context is either a library, which is publicly accessible or a library of an educational establishment. The definition of the term "educational establishment" is provided by section 174 CDPA. According to section 43A (3) CDPA a museum includes a gallery. There is however no definition of the term "archive".

Section 40B CDPA finally implements article 5 (3) (n) Information Society Directive. Its scope however remains narrow. ${ }^{1063}$ For instance, it is not clarified explicitly if the provision also covers the digitisation of works and/or the printing of the works made available. ${ }^{1064}$ The wording only refers to "making available". The introduction of this limitation is to be welcomed

\footnotetext{
${ }_{1059}^{105}$ Article 5 Rental Right and Lending Right Directive 92/100/EEC of November 19, 1992.

1060 IPO, Modernising Copyright, p. 35.

1061 Ibid.

1062 lbid.

1063 Bently/Sherman, Intellectual Property (2014), p. 258.

1064 Ibid. The ECJ Jugdement in Case C-117/13 Technische Universität Darmstadt $v$ Eugen Ulmer KG has answered these questions. The digitisation of works as well as the printing is encompassed by article 5 (3) (n) Information Society Directive. See also 4.1.3.2.2.
} 
but is also long overdue.

\subsection{Copying by Librarians: Supply of Single Copies to Other Libraries}

Section 41 CDPA deals with single copies of librarians ${ }^{1065}$ for other libraries. It is similar to the old a section 41 CDPA, which dealt with the same type of use. However, the old provision applied mainly to articles in periodicals and only under special conditions regarding the types of works. ${ }^{1066}$ According to the new provision a librarian is allowed to make "a single copy of the whole or part of a published work and supply it to another library, without infringing copyright in the work." ${ }^{1067}$ In order to invoke this limitation the librarian has to comply with the conditions set forth in section 41 (2) CDPA. These are that "(a) the copy is supplied in response to a request from a library which is not conducted for profit, and (b) at the time of making the copy the librarian does not know, or could not reasonably find out, the name and address of a person entitled to authorise the making of a copy of the work." In case an article in a periodical is requested by another library section 41 (3) CDPA establishes that the reasonable inquiry according to section 41 (2)(b) CDPA is not necessary.

The library making the copy can only claim the reimbursement of the costs that were produced making the copy. ${ }^{1068}$ Finally, section 41 (5) CDPA declares that contractual agreements restricting the making of copies permitted by section 41 CDPA have no effect.

Yet apart from the general extension to all kinds of copyright protected works the new section 41 CDPA is no real improvement.

\subsection{Copying by Libraries etc.: Replacement Copies of Works}

The new section 42 CDPA regulates the copying of libraries, archives or museums for the purpose of preservation and/or replacement. Section 42 CDPA now applies to any type of copyright protected work, which means that also films, broadcasts, sound recordings and artistic works, such as photographs and of course literary, dramatic and musical works may be copied under that limitation. ${ }^{1069}$ Also museums and galleries ${ }^{1070}$ can now invoke the

\footnotetext{
${ }^{1065}$ According to section 43A (5) CDPA "reference to a librarian, archivist or curator include a person acting on behalf of a librarian, archivist or curator."

${ }^{1066}$ According to section 41 (2) CDPA 2003 works other than articles in periodicals were only allowed to copy, if the librarian making the copy did not know or could not ascertain by a reasonable inquiry, the name and address of the person entitled to authorise the making of the copy.

1067 Section 41 (1) CDPA.

1068 Section 41 (4) CDPA.

1069 IPO, Modernising Copyright, p. 45

1070 See section 43A (3) CDPA.
} 
limitation. ${ }^{1071}$ The old provision only permitted the copying for preservation and replacement of literary, dramatic or musical works. ${ }^{1072}$

According to section 42 (1) CDPA a library, an archive or a museum may make a copy of an item ${ }^{1073}$ meaning a work, which is in its permanent collection "(a) in order to preserve or replace that item in that collection, or (b) where an item in the permanent collection of another library, archive or museum has been lost, destroyed or damaged, in order to replace the item in the collection of that other library, archive or museum." Such copying is however only permitted if following section 42 (2) CDPA the item is "(a) included in the part of the collection kept wholly or mainly for the purposes of reference on the institution's premises, (b) included in a part of the collection not accessible to the public, or (b) available on loan only to other libraries, archives or museums." The feasibility of such copies further requires "that it is not reasonably practicable to purchase a copy of the item to achieve either of the purposes mentioned in subsection (1)." ${ }^{1074}$ Above that, copies for replacement in other libraries, archives or museums, as determined by section 42 (1)(b) CDPA, are only permitted, if the institution requesting the copy is not conducted for profit. ${ }^{1075}$ In case of a copy made for another library, archive or museum according to section 42 (5) CDPA the institution making the copy can only claim reimbursement of the costs that were produced making the copy. Finally section 42 (7) CDPA safeguards that the acts permitted cannot be undermined by contractual agreements.

\subsection{Copying by Librarians: Single Copies of Published Works}

Section 42A CDPA now deals with single copies of published works made by libraries. Previously this was regulated by section 39 CDPA 2003. The new provision is much more detailed. But it can be doubted that this is an improvement, because it makes the handling also more complicated.

Following section 42A (1) and (2) CDPA it is not an infringement of copyright if a librarian of a library not conducted for profit makes and supplies a single copy of "(a) one article in any one issue of a periodical, or (b) a reasonable proportion of any other published work"1076 provided that "(a) the copy is supplied in response to a request from a person who has provided the librarian with a declaration in writing which includes the information set out in subsection (3),

\footnotetext{
1071 Ibid.

1072 Cf. section 42 (1) CDPA 2003.

1073 Cf. section 42 (6) CDPA: " (...) "“item" means a work or a copy of a work."

1074 Section 42 (3) CDPA.

1075 See section 42 (4) CDPA: "“'Conducted for profit", in relation to a library, archive or museum, means a body of that kind which is established or conducted for profit or which forms part of, or is administered by, a body established or conducted for profit."

${ }^{1076}$ Section 42A (1) CDPA.
} 
and (b) the librarian is not aware that the declaration is false in a material particular."1077 Section 42A (3) CDPA provides that such declaration must contain the name of the person requiring the copy and the material, which is required, ${ }^{1078}$ a statement that the person has not been previously supplied with that material by any other library, ${ }^{1079}$ a statement that the copy is required for the purposes of non-commercial research or private study and that the copy will not be given to any other person, ${ }^{1080}$ and finally "a statement that to the best of the person's knowledge, no other person with whom the person works or studies has made, or intends to make, at or about the same time as the person's request, a request for substantially the same material for substantially the same purpose." 1081 This last and very complicated prerequisite is due to the fact that the provision is dealing with copies of published works. Thus, there is a higher interest that such copies are exclusively used for purposes of research and private study, because otherwise copies made under this limitation could have negative market effects for right holders. If the declaration described before is false, the person requesting the copy is liable for infringing copyright as if that person had made the copy itself. ${ }^{1082}$ Moreover the copy that was supplied under false conditions has to be treated as an infringing copy. ${ }^{1083}$

In case there are costs charged by the library making the copy, reimbursement can only be claimed for the costs actually incurred by making the copy. ${ }^{1084}$ Eventually, section 42A (6) CDPA safeguards that the privileged acts cannot be undermined by contract.

\subsection{Copying by Librarians or Archivists: Single Copies of Unpublished Works}

Under very similar conditions section 43 CDPA permits libraries and archives to make single copies of unpublished works. ${ }^{1085}$ The person requesting the copy must also provide a declaration containing the same information as set forth in section 42A (3) CDPA except for the statement demanded by section 42A (3)(d) CDPA. ${ }^{1086}$ Yet, according to section 43 (3) CDPA it constitutes an infringement of copyright if "(a) the work had been published or communicated to the public before the date it was deposited in the library or archive, or (b) the copyright owner has prohibited the copying of the work, and at the time of making the copy of the librarian or archivist is, or ought to be, aware of that fact." This provision takes

\footnotetext{
1077 Section 42A (2) CDPA.

1078 Cf. section 42A (3)(a) CDPA.

1079 Cf. section 42A (3)(b) CDPA.

1080 Cf. section 42A (3)(c) CDPA.

1081 Cf. section 42A (3)(d) CDPA.

1082 Cf. section 42A (5)(a) CDPA.

1083 Cf. section 42A (5)(b) CDPA.

1084 Cf. section 42A (4) CDPA.

1085 Copying of unpublished literary, dramatic or musical works was regulated by section 43 CDPA 2003.

${ }^{1086}$ Cf. section 43 (2) CDPA.
} 
properly into account that section 43 CDPA deals with unpublished works. As section 42A (4) and (5) CDPA determine also section 43 (4) and (5) CDPA to establish that only the costs actually incurred by making the copy can be reimbursed and that a false declaration leads to the liability for copyright infringement of the person making such false declaration.

\subsection{Copy Required to be made as Condition of Export}

Section 44 CDPA has been left unchanged and allows to make copies of articles of cultural or historical importance if otherwise such articles could not be exported from the United Kingdom.

\subsection{Legal Deposit Libraries}

Section 44A CDPA was not modified by the last reform in 2014 . The provision permits the copying of works from the Internet meaning non-print works by a deposit library. The exact function of a deposit library is prescribed by the Legal Deposit Libraries Act 2003 and the Legal Deposit Libraries (Non-Print Works) Regulations 2013. Besides the publication copied from the Internet or the person publishing it they must be connected to the United Kingdom and the copying must be done in accordance with the prescribed conditions. ${ }^{1087}$ According to section 44A (2) CDPA in connection with section 7 of the Legal Deposit Libraries Act 2003 other uses of copyright protected works may be allowed by regulation.

The activities permitted for deposit libraries are contained in sections 19 to 31 Legal Deposit Libraries (Non-Print Works) Regulations 2013. They include among others the lending of the materials to other libraries, ${ }^{1088}$ review and maintenance, ${ }^{1089}$ own non-commercial research, ${ }^{1090}$ granting access to the materials to readers on a computer terminal provided that it is ensured that the material is not available on more than one terminal to save time. ${ }^{1091}$ Institutions are thus permitted to collect and store offline non-print works (e.g. works on CDROM) and online publications. ${ }^{1092}$ Also so called web-harvesting shall be facilitated. ${ }^{1093}$ Legal deposit libraries may also make copies of the material for their readers and supply them with such copies provided that the library ensures that uses the material only for non-commercial research, private study, criticism or review or reporting current events, parliamentary or

\footnotetext{
1087 Section 44A (1) CDPA.

1088 Section 19 Legal Deposit Libraries (non-print works) Regulations 2013.

1089 Section 20 (a) Legal Deposit Libraries (non-print works) Regulations 2013.

1090 Section 20 (b) this Legal Deposit Libraries (non-print works) Regulations 2013.

1091 Section 23 Legal Deposit Libraries (non-print works) Regulations 2013.

1092 Bently/Sherman, Intellectual Property (2014), p. 260.

1093 lbid.
} 
judicial proceedings or a Royal Commission or statutory inquiry. ${ }^{1094}$ Above that legal deposit libraries are allowed to make copies of the material for replacement and adapt the material for such replacements. ${ }^{1095}$

\subsection{Orphan Works}

The Copyright and Rights in Performances (Certain Permitted Uses of Orphan Works) Regulations 2014 implemented the Orphan Works Directive 2012/28/EU in the UK. It introduced article 44B CDPA and article 76A CDPA as well as schedule ZA1. These two provisions do not actually contain the rules on how to deal with orphan works. They rather make reference to schedule ZA1, which transposes the demands of the Orphan Works Directive almost literally and permits the use of orphan works under certain circumstances. According to Schedule ZA1 No. 1 and 2 publicly accessible libraries, educational establishments or museums, archives, film or audio heritage institutions, or public service broadcasting organisations ("relevant bodies") are allowed to make the orphan work available to the public or to reproduce the orphan work for the purposes of digitisation, making available, indexing, cataloguing, preservation or restoration. The rules for diligent searches for the right holder in order to determine whether a work can be considered orphan or not and the sources that have to be consulted are enshrined in Schedule ZA1 No. 5.

Together with the implementation of the Orphan Works Directive the UK legislator introduced a new licensing scheme for orphan works. ${ }^{1096}$ The United Kingdom was one of the few countries that had already dealt with orphan works before the EU started acting in that field by granting licences for the use of orphan works issued by a public body. ${ }^{1097}$ According to article 190 para. 1 CDPA the Copyright Tribunal may "give consent in a case where the identity or whereabouts of the person entitled to the reproduction right cannot be ascertained by reasonable inquiry", if someone applies for making a copy of a recording or performance. Further provisions regarding the procedure for licensing orphan works contain articles $116 \mathrm{~A}$, $116 \mathrm{C}$ and 116D CDPA.

The licensing scheme and the provisions introduced in order to implement the Orphan Works Directive are complementary but separate. ${ }^{1098}$ Whereas the provisions going back to the

\footnotetext{
1094 Section 27 (1) and (2)(a) Legal Deposit Libraries (non-print works) Regulations 2013.

1095 Section 29 and 30 Legal Deposit Libraries (non-print works) Regulations 2013.

1096 Press Release UKIPO, October 29, 2014: "UK Opens access to 91 million orphan works", available at https://www.gov.uk/government/news/uk-opens-access-to-91-million-orphan-works.

${ }^{1097}$ de la Durantaye, Orphan Works: A comparative and international perspective, in International Intellectual Property: A Handbook of Contemporary Research (2015), p. 195.

1098 Press Release UKIPO, October 29, 2014: "UK Opens access to 91 million orphan works", available at https://www.gov.uk/government/news/uk-opens-access-to-91-million-orphan-works.
} 
Orphan Works Directive provide for a statutory limitation allowing mass digitisation and making available of written, cinematic or audiovisual works and sound recordings by nonprofit cultural heritage organisations, the licensing scheme for orphan works applies all kinds of orphan works and enables commercial as well as non-commercial uses. ${ }^{1099}$

\subsection{Remuneration}

Copyright law in the United Kingdom does not know levies for copying devices or data carriers, as they are common for instance in Germany. Also there is no obligation to assign remuneration claims to collecting societies. Remuneration claims through collecting societies can only be based on license agreements. ${ }^{1099 a}$ Thus fair dealing for private study and research is remuneration free. ${ }^{1100}$ Indeed this contradicts article 5 para. 2 (b) Information Society Directive, which obliges member states to allow private copying only against just remuneration. Nevertheless, the British legislator has retained fair dealing for private study and research remuneration free. ${ }^{1101}$

License agreements therefore are very important for the use of copyright protected works for the purpose of education and research as well as for libraries and archives. There is however no legal framework for the negotiation of licenses. ${ }^{1102}$ There are provisions concerning license agreements in the educational sector. Section 137 CDPA to section 141 CDPA deal with licenses for reprographic copying by educational establishments. In case the Secretary of State intervenes under the circumstances of section 137 (2) CDPA in a license agreement, right holders may file a complaint against such intervention to the Copyright Tribunal. ${ }^{1103}$ Also users and institutions may appeal to the Copyright Tribunal in case they are unable to agree with a collecting society upon a license or in case they are not allowed to take part in a licensing scheme already existing. ${ }^{1104}$ The Copyright Tribunal examines whether licence fees are adequate. ${ }^{1104 a}$

\subsection{Findings}

The 2014 reform has hardly changed limitations and exceptions for libraries, archives and

\footnotetext{
1099 lbid.

1099a de la Durantaye, "Allgemeine Bildungs- und Wissenschaftsschranke" (2014), p. 154.

1100 Sections 93B, 182D, 191G CDPA establish the right to fair remuneration under special conditions, see de la Durantaye, "Allgemeine Bildungs- und Wissenschaftsschranke" (2014), p. 154, fn. 1200.

1101 Section 29 CDPA.

1102 See Picciotto, Copyright Licensing, p. $438 \mathrm{ff}$.

1103 Section 139 (1) CDPA.

1104 Section $117 \mathrm{ff}$. CDPA.

1104a Regarding the jurisdication of the Copyright Tribunal see Holyoak \& Torremans, Intellectual Property Law (2013), p. 335/336
} 
museums. Under certain conditions libraries and archives are now allowed to lend audiobooks and e-books. Also, libraries, archives, museums and educational establishments are allowed to make copyright protected works available on dedicated terminals. Several changes were made regarding the copying of protected works by libraries and librarians. Generally the scope of application was enlarged to any type of work, including digital works. The provision for replacement copies now also applies to museums and galleries. The limitations concerning the copying by libraries and librarians cannot be overruled by contract. Regarding orphan works there is now a statutory limitation in addition to a licensing scheme.

As regards the benchmark of permissible uses of copyrighted works by libraries, archives and other cultural heritage institutions it must be stated that not all requirements are met despite the latest copyright reform. There is no broad and open provision privileging libraries and similar institutions. Making available of protected works through dedicated terminals is now covered, but is limited to on-site consultation. In this regard it is not clarified whether digitisation of works by the respective institution for the purpose of making available is covered and whether users are allowed to print the consulted works completely or in part, but there is no restriction to the amount of the work that is made available. The provision can be overruled by licensing contracts. E-lending and the lending of audio-books is now allowed. Nothing is said of simultaneous loans of e-books. A copy for replacement and/or preservation of any type of work can be made by libraries, archives and museums. Following the wording of the provision only one copy is permitted, but the limitation cannot be overridden by licensing contracts. This is true as well for copies by librarians of published and unpublished works. Deposit libraries are allowed to make copies of non-print works from the Internet and online publications, including replacement copies and web-harvesting. Mass digitisation of orphan works in library collections is permitted as well making available of these works by libraries, archives and other cultural heritage institutions. Out-of-commerce works are not addressed. Format shifting is not explicitly addressed, but may be permitted for deposit libraries. And there is no provision on text and data mining. Concerning the wording of the provisions, they are rather difficult to understand and it must be doubted that addressees can easily comply with the prerequisites therein set forth.

In terms of adequacy the limitations and exceptions for libraries, archives and similar institutions of the CDPA only in part contain up-to-date provisions, which promote access to knowledge and education in the digital age sufficiently.

\subsubsection{Summary UK}

The new copyright law of the United Kingdom has adapted to realities in the digital age. The 
provisions regarding education and research as well as uses for libraries and archives today allow the use of all kinds of copyright protected works. It is now permitted to make available copyright protected works via networks and terminals to persons residing outside of the premises of a privileged institution. Also libraries and archives are allowed to use any kind of copyright protected work. More over the new exceptions apply as well to museums and galleries. Because of the implementation of the Orphan Works Directive cultural hertitage organisations, among them publicly accessible libraries, educational establishments, museums and archives, now may digitise orphan works contained in their collections and make them available to the public. With regard to access to knowledge and education in the digital age this appears to be a step forward. Nevertheless, most of the provisions are still quite narrow and have many prerequisites, which are difficult to comply with. In some areas the new law has made a step forward. In many areas risks remain that uses of copyright protected works are not covered. Whether the 2014 reform has significant positive effects with regard to access to education and knowledge in practice remains to be seen.

In view of the benchmark of permissible uses not all demands are met, but several important aspects are addressed. Especially, the combination of open fair dealing provisions and statutory limitations appears to be a suitable construction for copyright exceptions, providing both flexibility and legal certainty. Moreover, there are no restrictions to certain types of works and new forms of use like text and data mining are permitted. Above that contractual overrule is largely inhibited.

In view of the objectives pursued by limitations and exceptions for educational purposes and libraries, archives and similar institutions as well as their underpinnigs in public interest and human rights, it would be desirable to make reference to these objectives more explicitly when limitations and exceptions are interpreted and applied. This holds true in particular for fair dealing exceptions.

\subsubsection{Germany}

Germany adheres to the Berne Convention ${ }^{1105}$ and the Rome Convention. ${ }^{1106}$ As a WTO member Germany is also party to the TRIPS Agreement. Moreover Germany has signed the WIPO Copyright Treaty ${ }^{1107}$ and the WIPO Performances and Phonograms Treaty. ${ }^{1108}$

\footnotetext{
1105 Signature September 9, 1886; ratification September 5, 1887; in force since December 5, 1887.

1106 Signature October 26, 1961; ratification July 21, 1966; in force since October 21, 1966.

1107 Signature December 20, 1996; ratification: December 14, 2009, in force March 14, 2010.

1108 Signature December 20, 1996; ratification: December 14, 2009, in force March 14, 2010.
} 
German copyright law is governed by the Urheberrechtsgesetz ${ }^{1109}$, which came into force on September 9, 1965. It has been amended several times. Especially the implementation of the Information Society Directive made changes necessary, which are of interest in the context of this study. With the Law Regulating Copyright in the Information Society of September 10, $2003^{1110}$ the first step of implementation was taken. The law introduced among others the right of making available in public, which is now enshrined in § 19a UrhG. However, in order to adapt German Copyright Law to the reality of the information society further changes were necessary, which were enacted by the Second Law Regulating Copyright in the Information Society of October 26, $2007^{1111}$. Among others $\S 52 \mathrm{~b}$ UrhG was introduced, which allows the making available of protected works on dedicated terminals in libraries, archives and museums. As well, the other European directives related to copyright were transposed into German Law. Yet, these changes do not significantly concern the present topic.

Before I start with the analysis of the current provisions of the UrhG, I will give a brief overview of the constitutional entrenchment and the legal background of German Copyright law as well as the special interpretation of copyright limitations.

\subsubsection{Constitutional Law (Grundgesetz)}

Different from the Weimar Constitution, which declared in article 158 para. 1 that authors ${ }^{1112}$, inventors and artists enjoy the protection and welfare of the German Reich, or art. 27 para. 2 of the Universal Declaration of Human Rights which establishes that "everyone has the right to the protection of the moral and material interests resulting from any scientific, literary or artistic production of which he is the author", the German Grundgesetz ${ }^{1113}$ of 1949 contains no explicit and programmatic statement regarding the protection of the author or other right holders. Article 73 Nr. 9 GG mentions the Urheberrecht, however only for the purpose of assigning it to the exclusive legislation of the federal state. Nonetheless, there is no doubt about it that the Urheber and the right holder are protected by the Grundgesetz. ${ }^{1114}$

German Copyright Law follows the so called "Monistic Theory", which declares that both personal and financial interests are protected. ${ }^{1115}$ Personal interests fall in the scope of article 1 para. 1 , article 2 para. 1 GG, which refer to human dignity and freedom of

\footnotetext{
${ }_{1109}$ In the following abreviated as "UrhG".

${ }_{1110}$ Gesetz zur Regelung des Urheberrechts in der Informationsgesellschaft vom 10.09.2003, BGBI I S. 1774, Berichtigung BGBI 2004 I S. 312.

${ }_{1111}$ Zweites Gesetz zur Regelung des Urheberrechts in der Informationsgesellschaft vom 26.10.2007, BGBI. I, p. 2513.

1112 The German term for author is "Urheber".

1113 In the following Grundgesetz will be abbreviated by GG.

1114 Loewenheim/Vogel in Loewenheim, 2010, § 2 no. 26.

1115 Schricker/Loewenheim in Schricker/Loewenheim, 2010, Einleitung, No. 28 and 110.
} 
personality. ${ }^{116}$ This aspect of the Urheberrecht finds its expression in moral rights, especially the recognition of authorship and the right to prevent distortions of the work. ${ }^{1117}$ Although the personal side of the Urheberrecht must not be underestimated, it is the financial side, which is of even greater importance. The economic interests of the author emerging from the creation of his work are constitutionally protected in their existence (so called "Bestandsgarantie"), for they are considered as part of property, which is guaranteed by Art. 14 para. 1 GG. ${ }^{1118}$ In several decisions the Federal Constitutional Court (Bundesverfassungsgericht) has confirmed this opinion. ${ }^{1119}$ More difficult to determine is the actual content of the Urheberrecht (so called "Institutsgarantie"). According to the Federal Constitutional Court there is no absolute predefined notion of the Urheberrecht. ${ }^{1120}$ Following article 14 para. 1 s. 2 GG it is rather the task of the legislator to define the scope of the economic rights of the Urheber and its limitations. ${ }^{1121}$ However, the legislator is not free to act at random, but must safeguard the economic rights assigned to the author adequately and at the same time take the interests of the public into account. ${ }^{1122}$ Like physical property the Urheberrecht as part of intellectual property is according to article 14 para. 2 GG as well subject to a social obligation (so called "Sozialbindung"). According to this only limitations in favour of the public interest may justify limitations of the rights of the author. ${ }^{1123}$ When limiting the scope of the Urheberrecht the legislator has to respect the constitutional framework in particular the principle of proportionality (so called "Verhältnismäßigkeitsprinzip"), which prohibits to strain the author disproportionally. ${ }^{1124}$ Moreover, in every single case the interests involved must be weighed considering that the reasons for limiting the Urheberrecht have to be the more substantial the more the limitation encroaches on the constitutionally protected rights of the author. ${ }^{1125}$ Finally, the social obligation of article 14 para. 2 GG does not imply that the author must provide his achievements to the public without payment. ${ }^{1126}$ Yet, limitations and exceptions on the exclusive rights of the author are necessary for the purpose of fostering the public interest of social and cultural education and the dissemination of knowledge. On that account it must be accepted that the exclusive power of disposition of the author concerning the uses of his work is restricted. ${ }^{1127}$

\footnotetext{
${ }^{1116}$ Vogel in Loewenheim, 2010, § 2 no. 26; Schack 2015, no. 90.

1117 Cf. Schack 2015, no. 90, who explains the constitutional entrenchment of moral rights in Germany.

1118 Vogel ibid.; Schack 2015, no. 91; Melchiar in Schricker/Loewenheim, 2010, Vor §§ 44a ff. UrhG, no. 7.

1119 Cf. BVerfGE 31, 229, 239 - Kirchen- und Schulgebrauch; BVerfGE 49, 382, 392 - Kirchenmusik.

1120 BVerfGE 31, 229, 240 - Kirchen- und Schulgebrauch.

1121 BVerfG 31, 270, 272 - Schulfunksendungen.

1122 Melchiar in Schricker/Loewenheim, 2010, Vor §§ 44a ff. UrhG, no. 8; Ulmer 1980 § $11 \mathrm{I}$.

${ }^{1123}$ Schack 2015, no. 93.

1124 Melchiar in Schricker/Loewenheim, 2010, Vor §§ 44a ff. UrhG, no. 8.

1125 Idem, no. 9; BVerfGE 49, 382, 400 - Kirchenmusik.

1126 Ulmer 1980 § $11 \mathrm{I}$; Melchiar in Schricker/Loewenheim, 2010, Vor §§ 44a ff. UrhG, no, 11; BVerfGE 31, 229, 244 - Kirchen- und Schulgebrauch; BVerfGE 49, 382, 400 - Kirchenmusik.

${ }_{1127}$ As explained above the power of disposition of the author is regularly reduced to a right of equitable remuneration, see 2.2.2.2.
} 


\subsubsection{Limitations and Exceptions for Education and Libraries, Museums and}

\section{Archives}

The UrhG contains several limitations and exceptions privileging educational uses of copyright protected works as well as copyright relevant activities of libraries. Some of these provisions were introduced before the spread of the Internet and digital technologies. This is why it must be doubted, if they still provide adequate solutions today for the situations under consideration here. ${ }^{1128}$ As was said above some of these provisions were introduced in order to implement the Information Society Directive into German copyright law. The question is, whether these "new" provisions are able to provide adequate solutions to the new possibilities of delivering education and library services in the digital age.

In the following I will therefore analyse the limitations to copyright law in the UrhG for educational purposes and in favour of libraries and archives. In particular these privileged uses are the making available for instruction and research (§ 52a UrhG), the use of protected works in anthologies for churches, schools or for instruction (§ 46 UrhG), school broadcasts ( $₫ 47$ UrhG), reproductions for private or other personal use ( 53 UrhG), the distribution of copies on request ( $\S 53 a$ UrhG) and the display of protected works on dedicated terminals in public libraries, museums and archives ( $552 b$ UrhG). For the entire analysis it must be kept in mind that German copyright limitations and exceptions generally must be interpreted restrictively. ${ }^{1129}$ The general rule is the protection of the exclusive author's right and the right of equitable remuneration, the exception to this rule is the limitation, which therefore requires a restrictive understanding. ${ }^{1130}$ This is why there is no application of limitations and exceptions by analogy. ${ }^{1131}$ Open clauses like the fair use doctrine in the USA or fair dealing in the UK do not exist in German copyright law. ${ }^{1132}$

\subsection{Making Available in Public for Instruction and Research}

$\S 52 a$ UrhG was introduced in the German Urheberechtsgesetz in $2003 .{ }^{1133}$ The provision privileges the making available in public of copyright protected works of small quantity, small portions of protected works and contributions from newspapers or magazines for the purpose of illustration for instruction and research. On November 29, 2012, the application of the provision was once more limited until December 31, 2014. The German government had

\footnotetext{
1128 Dreier in Dreier/Schulze, 2015, UrhG, Vor § 44a no. 7.

${ }^{1129}$ Melchiar in Schricker/Loewenheim, 2010, Vor § 44a ff UrhG, no. 18ff; Dreier in Dreier/Schulze, 2015, UrhG, Vor § 44a no. 7.

1130 Melchiar in Schricker/Loewenheim, 2010, Vor § 44a ff UrhG, no. 18ff.

1131 Dreier in Dreier/Schulze, 2015, UrhG, Vor § 44a no. 7.

1132 lbid.

1133 Gesetz zur Regelung des Urheberrechts in der Informationsgesellschaft vom 10.09.2003, BGBI I S. 1774, Berichtigung BGBI 2004 I S. 312.
} 
announced to introduce a new limitation for teaching and research until then, which should provide a more balanced solution. ${ }^{134}$ This promise was not kept, but the temporary limitation of $\S 52$ a UrhG was finally abolished on December 5, 2014. ${ }^{1135}$

$\S 52 \mathrm{a}$ UrhG refers to different kinds of copyright protected works, namely small portions of a work (kleine Werkteile), works of small quantity (Werke geringen Umfangs) and single works from periodicals. The interpretation of these features still is widely unclear and has been subject to fierce disputes among scholars. ${ }^{1136}$ However the German Federal Court (BGH) ruled on the question of what can be considered a small portion of a work. ${ }^{1137}$ The court decided that in case $12 \%$ of a protected literary work and not more than 100 pages of such work are made available for the purpose of illustration for teaching in a higher education institution, this portion qualifies as a small portion under $\S 52 a$ UrhG. ${ }^{1138}$ Still unclear is what are works of small quantity. It is however established that in this case the entire work can be made available. ${ }^{1139}$ In order to determine what kind of work qualifies as a work of small quantity some scholars refer to the type of work and its creative content. ${ }^{1140}$ Others, which follow a more restrictive interpretation, want to level works of small quantity and small portions of a work. ${ }^{1141}$ Finally, $§ 52$ a UrhG permits to make single works from periodicals available in public. According to the wording of the provision it is allowed to use the entire work. The German term Beiträge means contributions and thus encompasses all kinds of works such as texts, poems, photos etc. ${ }^{1142}$ Nevertheless the contributions used must itself be considered small portions of the entire periodical. ${ }^{1143}$ This is necessarily vague but one can ask if the addressed user would be prevented from buying the periodical because of the contributions made available in public. In case yes the contribution made available does not qualify as a small portion of the periodical and thus is not covered by $\S 52 a$ UrhG.

Until the above cited decision of the $\mathrm{BGH}$ there was controversy regarding the feature illustration for teaching (Veranschaulichung im Unterricht). ${ }^{1144}$ Some scholars were of the opinion that the materials could be only made available for online use during a certain lesson ("im" Unterricht). ${ }^{1145}$ Others demanded a direct relation to the content of a certain lesson, i.e.

\footnotetext{
${ }^{1134}$ Koalitionsvertrag CDU, CSU und SPD 27.11.2013, p. 22/23

1135 10. UrhÄndG, BGBII S. 1974.

${ }^{1136}$ E.g. Hoeren, ZUM 2012, 636; Hoeren ZUM 2011, 369; Berger GRUR 2010, 1058; Lorenz ZRP $2008,261$.

1137 BGH Urteil v. 28.11.2013, Az. I ZR 76/12 - Meilensteine der Psychologie, headnote 1.

1138 lbid.

1139 Hoeren ZUM 2011, 369, 371.

1140 Ibid.

1141 Berger GRUR 2010, 1058, 1062.

1142 Hoeren ZUM 2011, 369, 371; Loewenheim in Schricker/Loewenheim, 2010, § 53 UrhG, no. 53.

1143 Hoeren ZUM 2011, 369, 371; Loewenheim in Schricker/Loewenheim, 2010, § 53 UrhG, no. 53.

1144 Cf. Hoeren, ZUM 2012, 636; Hoeren ZUM 2011, 369; Berger GRUR 2010, 1058; Loewenheim in Schricker/Loewenheim, 2010, § 52a UrhG, no. 9.

${ }_{1145}$ Loewenheim in Loewenheim, 2010, § 31 no. 44.
} 
preparation or revising at home. ${ }^{1146}$ The $\mathrm{BGH}$ now stated that the making available in public in accordance with $\S 52 a$ para. 1 no. 1 UrhG is for illustration for teaching if it promotes the understanding of the learning material. This is the case, said the court, when the lecture of texts made available is able to deepen or endorse the learning material taught. ${ }^{1147}$

Furthermore, $\S 52 a$ para. 1 no. 1 UrhG demands that the works concerned are only made available to a limited group of persons attending a lesson (bestimmt abgegrenzter Kreis von Unterrichtsteilnehmern). In this regard there is consensus that this feature is fulfilled when the work is made available in public to the students and teachers attending a certain lesson. ${ }^{1148}$ Above that the number of students attending a lesson does not matter as long as the works are only available to these persons. ${ }^{1149}$ In order to safeguard this the institution should provide access controls, e.g. passwords or other access authorisation. The limitation to a certain group of persons is moreover ensured through the enrolment.

Also the making available in public according to $\S 52$ a para. 1 no. 1 UrhG must be required by the purpose of illustration for teaching (zu dem jeweiligen Zweck geboten) and justified by the non-commercial purpose (zur Verfolgung nicht kommerzieller Zwecke gerechtfertigt). Normally it is not difficult to determine whether the use is for non-commercial purpose. Everything that goes beyond a mere expense allowance can be considered for commercial purpose. ${ }^{1150}$ It is more difficult to determine whether the use is required by the purpose (Gebotenheit). This question has been subject to debates among scholars and jurisdiction. Consensus was established that this feature demands a decision in each individual case. ${ }^{1151}$ To make copyrighted works available in public according to $\S 52$ a para. 1 no. 1 UrhG is therefore not required by the purpose if another possibility of communicating the work exists. ${ }^{1152}$ Yet this does not include the recourse to analogue copies of the work for this would undermine the intention of $\S 52$ a I no. 1 UrhG to facilitate digital uses. ${ }^{1153}$ However in case the work can be acquired in digital form from the author under appropriate conditions, which may also include payment, the making available in accordance with § 52a para. 1 no. 1 UrhG is not required be the purposes any longer. ${ }^{1154}$ In its above cited decision the BGH has confirmed this understanding and declared that the making available under $\S 52 a$ para. 1 no. 1 UrhG is not required by the purpose in case the right holder offers to license the work in

\footnotetext{
${ }^{1146}$ Berger GRUR 2010, 1058, 1063.

${ }_{1147}$ BGH Urteil v. 28.11.2013, Az. I ZR 76/12 - Meilensteine der Psychologie, headnote 2.

1148 Hoeren ZUM 2011, 373; Berger GRUR 2010, 1058, 1064.

1149 Hoeren ZUM 2011, 373.

1150 lbid.

1151 lbid.

1152 Loewenheim in Schricker/Loewenheim, 2010, § 52a UrhG, no. 14.

1153 lbid.; Hoeren ZUM 2011, 373.

1154 Ibid.; Berger GRUR 2010, 1058, 1064, who in this regard refers to the second step of the Three-Step-Test "no conflict with the normal exploitation of the work" (see Chapter 3.4.2.2).
} 
digital form under appropriate conditions, especially against payment of an adequate license fee. ${ }^{1155}$ Furthermore, the offer must be easy to find and the work must be available quickly and without complications. ${ }^{1156}$

Another question with regard to the making available under $\S 52 a$ UrhG was whether the provision also covers reproductions of the work made available by the user, e.g. printing on paper. The problem arouses because of $\S 52$ a para. 3 UrhG, which allows the necessary reproductions for making available in public. The intention of this provision is primarily to take into account the inevitable digital reproductions preceding any making available in public online, e.g. scanning, copying on a webserver etc. ${ }^{1157}$ The wording yet does not cover reproductions by the user of the work. Thus it was argued that if a work is made available not only for reading on a computer screen but also with the possibility for the user to make reproduction, the entire limitation should not be applicable. ${ }^{1158}$ The $\mathrm{BGH}$ now clarified that $\S$ 52a UrhG also covers the making available in public of works that can be reproduced by the user. ${ }^{1159}$

Above that $\S 52 a$ para. 2 UrhG contains special rules for the making available in public of works destined for educational uses in schools and for cinematic works. In both cases the feasibility of making available in public depends on the author's or right holders consent. Concerning cinematic works the consent is only necessary during a period of two years from the start of the regular exploitation of the work in German movie theatres. ${ }^{1160}$ The intention is to protect the market for schoolbooks a cinematic works, which could be prejudiced be works made available in public according to $\S 52 a$ UrhG. ${ }^{1161}$

Finally, according to $\S 52$ a para. 4 UrhG the making available in public following § 52a para. 1 UrhG is subject to payment of fair remuneration for the author or right holder. ${ }^{162}$ Thereby the encroachment of exclusive rights shall be at least partly absorbed. The right to fair remuneration can only be exercised through a collecting society. ${ }^{1163}$

\footnotetext{
$\overline{1155}$ BGH Urteil v. 28.11.2013, Az. I ZR 76/12 - Meilensteine der Psychologie, headnote 4.

1156 Ibid.

1157 Loewenheim in Schricker/Loewenheim, 2010, § 52a UrhG, no. 18.

1158 Ibid.; OLG Frankfurt, Urteil v. 24.11.2009, Az. 11 U 40/09.

1159 BGH Urteil v. 28.11.2013, Az. I ZR 76/12 - Meilensteine der Psychologie, headnote 3.

1160 Films for TV are covered, too. Omission of the legislator, see Loewenheim in Schricker/Loewenheim, 2010, § 52a UrhG, no. 17.

1161 Idem, no. $16,17$.

1162 Idem, no. 19.

1163 Idem, no. 20. Currently it is debated how the claim for fair remuneration established by $\S 52 a$ UrhG may be realised in practice. An agreement concluded between the VG Wort (collecting society) and the KMK (conference of German ministers of education) end of September 2016, so called "Rahmenvertrag zur Vergütung von Ansprüchen nach $\S 52 a$ UrhG" is fiercely rejected by universities and higher education institutions (see for instance Aktionsbündnis "Urheberrecht für Bildung und Wissenschaft", press release 2/16, October 11, 2016, available at http://www.urheberrechtsbuendnis.de/pressemitteilung0216.html.en), because it stipulates a very complicated accounting system. In order to collect remuneration for the amount of a work that can be used under
} 


\subsection{Display on Dedicated Terminals in Public Libraries, Museums and Archives}

$\S 52 \mathrm{~b} \mathrm{~s}$. 1 UrhG permits that publicly accessible libraries, museums or archives, which do not have a direct or indirect commercial purpose make published works from their own stock available on dedicated electronic terminals on the premises of the respective institution for the purpose of research and private study, as long as there are no contradicting contractual agreements. The provision implements article 5 para. $3(n)$ Information Society Directive. The legislator wanted to enable the use of digital media for the users of public libraries and noncommercial archives in the same way as analogue media could be used. ${ }^{1164}$

The provision privileges libraries, museums and archives, which must be publicly accessible. This wording makes clear that not only publicly funded libraries shall benefit from the limitation but all libraries, museums and archives accessible to the public. ${ }^{1165}$ Not so clear is whether the prerequisite of non-commercial purpose refers to all institutions named or only to archives. The genesis of the provision however suggests that this prerequisite refers only to archives. ${ }^{1166}$ The provision only allows the making available of published works, which belong to the stock of the respective institution. ${ }^{1167}$ This means that the works must be permanently available, but must not necessarily be property of the respective institution. ${ }^{1168}$ Furthermore according to $\S 52 \mathrm{~b} \mathrm{~s} .2$ UrhG it is not allowed to make available on dedicated electronic terminals at the same time more digital copies of a work than there are analogue copies of the work in the stocks of the institution. This provision aims at the protection of the publishing industry, whose interests could be harmed if libraries would be allowed to make any number of digital copies available although they have only purchased one analogue copy of the work. ${ }^{1169}$ Only in case of a load peak institutions shall be allowed to make at the same time more copies available than they have in their stocks. ${ }^{1170}$ The prerequisite of "dedicated electronic terminals" means that these terminals enable reading in digital form. ${ }^{171}$ Further the terminals must be especially dedicated for the making available of a work in electronic form and shall not be used for other purposes, for instance access to the Internet. ${ }^{1172}$ They must be located on the premises of the respective institution, which means that an online

\footnotetext{
$\S 52 a$ UrhG (12\% or up to max. 100 pages) the respective institutions shall gather each single page of a work and transmit the information to the VG Wort. The remuneration that has to be paid normally is so low that the effort that has to be undertaken to gather and transmit the information is completely out of proportion.

1164 Government Draft BT-Drucks. 16/1828, p. 26.

1165 Loewenheim in Schricker/Loewenheim, 2010, § 52b UrhG, no. 3.

1166 Government Draft BT-Drucks. 16/1828, p. 40.

1167 So called „Bestandakzessorietät“.

1168 Loewenheim in Schricker/Loewenheim, 2010, § 52b UrhG, no. 6.

1169 Government Draft BT-Drucks. 16/1828, p. 40.

1170 Loewenheim in Schricker/Loewenheim, 2010, § 52b UrhG, no. 7.

1171 Not only reading but also the use in form of an audiobook is covered, cf. Loewenheim in Schricker/Loewenheim, 2010, § 52b UrhG, no. 8.

1172 lbid.
} 
access via Internet from outside of the premises of the institution is prohibited. ${ }^{1173}$ The making available of works on dedicated electronic terminals finally is only permitted for research and private study. If $\S 52 b$ UrhG applies, depends from the purpose pursued by the user, not by the institution. ${ }^{1174}$

The provision is only applicable if no contractual agreements between the right holder, namely the publisher, and the respective institution contradict the making available of protected works on dedicated electronic terminals. In order to safeguard a fair balance of interests contractual agreements shall prevail over the limitation, because otherwise the interests of right holders would be prejudiced. ${ }^{1175}$ In any case this means that contractual agreements, which have been concluded between a publisher and the respective institution, exclude the application of the limitation. Since the wording of $\S 52 \mathrm{~b}$ s. 1 UrhG is not clear, disputes arose among scholars if already the mere offer to conclude a contractual agreement would be sufficient to prevent the application of the limitation. ${ }^{1176}$

Furthermore, it was unclear whether $\S 52 b$ UrhG allowed not only to read or otherwise enjoy a copyright protected work on a dedicated electronic terminal but permitted also further uses of the work such as printing or saving on a digital data carrier. It was argued that the restrictions of the provision, which serve to protect the interests of publishers (solely on the premises of the institution, not more digital copies than analogue copies in stocks), would make no sense, if users were allowed to print or to save works. ${ }^{1177}$ It was also distinguished between printing and saving the work on a digital data carrier and found that printing the work was feasible, but not saving it. ${ }^{1178}$

Finally it was unclear whether $\S 52 \mathrm{~b}$ UrhG permitted that the privileged institutions could digitise analogue copies of the work in order to make them available on dedicated electronic terminals in case a digital copy of the work was not at hand in the respective institution (so called "Annexvervielfältigungen"). Different from § 52a UrhG the wording of § 52b UrhG gives no clue. It was however argued that $\S 52 b$ UrhG would have no scope of application in case digitisations as described before would not be covered. ${ }^{1179}$

\footnotetext{
1173 Ibid.

1174 Idem, no. 9.

1175 Recital 45 Information Society Directive.

1176 See Loewenheim in Schricker/Loewenheim, 2010, § 52b UrhG, no. 10 with further refernces.

1177 OLG Frankfurt a.M. GRUR-RR 2010, 1, 3 - Elektronische Leseplätze; LG Frankfurt a.M. GRUR 2011, 616 Elektronische Leseplätze.

${ }_{1178}$ Printing should be feasible in oder to equate digital and analogue uses, cf. LG Frankfurt a.M. GRUR-RR 2009, 330, 331 - Elektronische Leseplätze; BGH GRUR 2013, 503 no. 24, 30 and 32.

1179 OLG Frankfurt a.M. GRUR-RR 2010, 1, 3 - Elektronische Leseplätze; LG Frankfurt a.M. GRUR 2011, 616 Elektronische Leseplätze.
} 
These disputes have occupied German courts ${ }^{1180}$ and finally led to a decision of the European Court of Justice. ${ }^{1181}$ The Bundesgerichtshof submitted the case to the ECJ and asked for a preliminary ruling. ${ }^{1182}$ The ECJ ruled that the mere offer by a publisher to conclude a contractual agreement with a privileged institution, e.g. a library, does not prevail over the limitation, but article 5 para. 3 (n) Information Society Directive rather requires that a contractual agreement must actually be concluded. ${ }^{1183}$ Otherwise publishers could easily prevent the privileged institutions from applying the limitation, which would contradict the rationale of article 5 para. $3(\mathrm{n})$ Information Society Directive to promote private study and research in public interest. ${ }^{1184}$ Further the ECJ declared that article 5 para. 3 (n) Information Society Directive covers the digitisation of analogue copies of works in the stocks of the respective institution in order to make those available on dedicated electronic terminals, because otherwise the provision would have no scope of application. ${ }^{1185}$ The institutions however are not allowed to digitise their entire collections. ${ }^{186}$ Regarding the printing and saving on digital data carriers of works made available on dedicated electronic terminals the ECJ found that article 5 para. 3 (n) Information Society Directive does not permit such uses. ${ }^{1187}$ The provision allows to communicate the work and not to copy it, which however must be seen in the printing and saving it. ${ }^{1188}$ Yet such uses may be permitted under national laws with regard to article 5 para. 2 (a) and (b) Information Society Directive as long as a fair balance of interests is maintained. ${ }^{1189}$

Taking into account the ECJ's decision the Bundesgerichtshof finally decided the case with judgement dated April 16, 2015. ${ }^{1190}$ The case was dismissed, because the court found that $\S$ 52b UrhG was applicable. The application of the provision was not excluded because the publisher had made an offer to the library to conclude a licence agreement, which was not concluded in the end. The application of $\S 52 \mathrm{~b}$ UrhG is only excluded, if a licence agreement between the publisher and the library exists. Furthermore, the Bundesgerichtshof decided that a library is permitted to digitise books from its collection and make them available on dedicated terminals, although § 52b UrhG does not explicitly allow the digitisation. However, if such digitisation was not allowed, the scope of application of the provision would be too narrow, the court found. Moreover it was considered feasible that library users have the

\footnotetext{
1180 LG Frankfurt a.M. GRUR-RR 2009, 330, 331 - Elektronische Leseplätze; OLG Frankfurt a.M. GRUR-RR 2010, 1, 3 - Elektronische Leseplätze.

1181 ECJ, Jugdement of the Court, September 11, 2014, C-117/13 - TU Darmstadt vs. Eugen Ulmer KG.

1182 BGH GRUR 2013, 503 - Elektronische Leseplätze.

1183 ECJ, Jugdement of the Court, September 11, 2014, C-117/13 - TU Darmstadt vs. Eugen UImer KG, no. 35.

${ }^{1184}$ Idem, no. 27.

1185 Idem, no. 43, 49

1186 Idem, no. 45.

1187 Idem, no. 50

1188 Idem, no. 52 .

1189 Idem, no. 55.

1190 BGH, Urteil v. 16.04.2015, Az.: I ZR 69/11 - Elektronische Leseplätze II.
} 
possibility of printing the work made available on a dedicated terminal or save it on a portable data carrier. This interpretation was justified with the Information Society Directive, which in this regard contains no restriction. Above that, the Bundesgerichtshof found that such printing and saving by library users in most cases would be covered by the private copy limitation of $\S 53$ UrhG. Regarding this last point, the ECJ had not made a decision, but clarified that it is in the discretion of the member states of the EU to enact appropriate rules.

Eventually $\S 52 \mathrm{~b} \mathrm{s.} 3$ UrhG requires that just remuneration is paid to authors and right holders. The claim for just remuneration can only be exercised by a collecting society.

\subsection{Anthologies for the Use in Churches, Schools or for Instruction}

$\S 46$ UrhG deals with the use of anthologies of copyright protected works in churches, schools or for non-commercial education. The provision was reformed in 2003 with regard to article 5 para. 3 (a) Information Society Directive, which allows exceptions from exclusive rights "for the sole purpose of illustration for teaching (...) to the extent justified by the noncommercial purpose to be achieved." This provision bases on article 10 para. 2 BC. ${ }^{1190 a}$ Furthermore, § 46 UrhG now only refers to published works. ${ }^{1191}$ It is now allowed to publicly make anthologies available privileged by $\S 46$ UrhG.

The provision permits the reproduction, distribution and the making parts of works available, namely literary works or musical works of small size, single works of art or photographs previously published as elements of an anthology, which encompasses the works of a larger number of authors and which is destined for instruction in schools, non-commercial institutions for further or vocational education or for the use in churches. ${ }^{1192}$ The provision protects anthologies. ${ }^{1193}$ Not only books can be anthologies but also other data carriers, especially digital or electronic media. ${ }^{1194} \S 46$ UrhG allows reproduction, distribution and publicly making anthologies available. This means that also digital online media is covered

\footnotetext{
${ }^{1190 a}$ Melchiar in Schricker/Loewenheim, 2010, § 46 UrhG, no. 5.

1191 Cf. $\S 6$ para. 1 UrhG: "Ein Werk ist veröffentlicht, wenn es mit Zustimmung des Berechtigten der Öffentlichkeit zugänglich gemacht worden ist."

${ }_{1192}$ Cf. § 46 para. 1 UrhG: "Nach der Veröffentlichung zulässig ist die Vervielfältigung, Verbreitung und öffentliche Zugänglichmachung von Teilen eines Werkes, von Sprachwerken oder von Werken der Musik von geringem Umfang, von einzelnen Werken der bildenden Künste oder einzelnen Lichtbildwerken als Element einer Sammlung, die Werke einer größeren Anzahl von Urhebern vereinigt und die nach ihrer Beschaffenheit nur für den Unterrichtsgebrauch in Schulen, in nichtgewerblichen Einrichtungen der Aus- und Weiterbildung oder in Einrichtungen der Berufsbildung oder für den Kirchengebrauch bestimmt ist.“

${ }^{1193}$ Cf. § 4 UrhG para. 1 UrhG: "Sammlungen von Werken, Daten oder anderen unabhängigen Elementen, die aufgrund der Auswahl oder Anordnung der Elemente eine persönliche geistige Schöpfung sind (Sammelwerke), werden, unbeschadet eines an den einzelnen Elementen gegebenenfalls bestehenden Urheberrechts oder verwandten Schutzrechts, wie selbständige Werke geschützt."

${ }_{1194}$ Melchiar in Schricker/Loewenheim, 2010, § 46 UrhG, no. 7.
} 
by the provision. ${ }^{1195}$ The publicly making available of an anthology is however only feasible within the limits of the provision, meaning that this only happens for the purpose of instruction, which must be safeguarded by the respective institution. ${ }^{1196}$ An anthology must be exclusively destined for instruction in schools, non-commercial institutions for further or vocational education. Schools or institutions for adult education are not addressed, which means that universities or other institutions of higher education cannot invoke the provision. ${ }^{1197}$ The anthology must be literally used in school, meaning that anthologies for the use at home are not covered. ${ }^{1198}$ This is also true for the use in churches. ${ }^{1199}$ According to $\S$ 46 para. 2 UrhG anthologies for instruction in music schools cannot rely on the limitation as long as it concerns musical works. Thereby it shall be prevented that the market for books made especially for musical instruction is prejudiced by the limitation. ${ }^{1200}$ Further it must be recognisable in form and content that the anthology is destined for the privileged purposes. ${ }^{1201}$ Additionally $\S 46$ para. 1 s. 3 UrhG determines that the non-commercial purpose for instruction must be made clear on the copies and in the course of the publicly making available. As was already said above § 46 UrhG now only covers published works. Works, which are destined for instructional use in schools, can only be made publicly available, if the author or right holder agrees. ${ }^{1202}$ This rule shall prevent that privileged uses covered by $\S 46$ UrhG prejudice the schoolbook market and harm the interests of authors and right holders. ${ }^{1203} \S 46$ UrhG permits to include "parts of a work" ${ }^{1204}$ which must be judged in relation to the entire work the parts are taken from. ${ }^{1205}$ The provision allows also to include musical works as long as they are of small size and works of art as well as photographs. It is however only allowed to include single works, meaning only a few. ${ }^{1206}$

$\S 46$ para. 3 UrhG contains further prerequisites regarding the reproduction and the publicly making available. According to this provision reproduction and publicly making available may only start after the author or right holder has been informed by registered mail and two weeks have passed since the mail was dispatched. In case the whereabouts of the right holder is unknown, the notification can also be made in the Federal Gazette. Moreover according to $\S$ 46 para. 5 UrhG the author may forbid the privileged use, if the work does not reflect his

\footnotetext{
1195 Melchiar in Schricker/Loewenheim § 46 no. 8

1196 ibid.

1197 Idem, no. 10.

1198 Idem, no. 11.

1199 lbid.

1200 Idem, no. 12.

1201 Idem. no. 13

1202 Cf. $\$ 46$ para. 1 s. 3 UrhG.

1203 Melchiar in Schricker/Loewenheim, 2010, § 46 UrhG, no. 17.

1204 „Teile eines Werkes“, s. § 46 para. 1 s. 1 UrhG.

1205 Melchiar in Schricker/Loewenheim 2010, § 46 UrhG, no. 18.

1206 Idem, no. 21.
} 
conviction any more. Finally the explicit indication of source is always required. ${ }^{1207}$

$\S 46$ para. 4 UrhG establishes that the author has the right to just remuneration for the uses privileged under $\S 46$ para. 1 and 2 UrhG. It is not required that the right to just remuneration is exercised by a collecting society. In practice however the respective collecting society will exercise that right. ${ }^{1208}$ The exercise of the right to just remuneration is not required to be claimed only by a collecting society. In practice the respective collecting society however exercises the right.

\subsection{School Broadcasts}

According to $\S 47$ UrhG schools and institutions for teacher training are allowed to make copies of copyright protected works, which are a part of school broadcasts, without consent of the author or right holder and without the obligation to remunerate. The provision restricts exclusive reproduction rights in conformity with article 5 para. 3 a) Information Society Directive and article 10 para. 2 BC. ${ }^{1209}$ The purpose of $\S 47$ UrhG is to enable teachers to display broadcasts not only at a time they are broadcasted but also later in their classes. The provision thus serves justified pedagogical purposes. ${ }^{1210}$

$\S 47$ UrhG applies to all kinds of copyright protected works as long as they are part of the school broadcast. The term broadcast refers to the public display of a protected work $(\S 20$ UrhG), but not to the publicly making available (§ 19a UrhG). ${ }^{1211}$ Only school broadcasts may be copied. Yet, there is no legal definition of the term "school broadcast". But certainly school broadcasts are broadcasts, which are explicitly marked as such by public service broadcasters. ${ }^{1212}$ The beneficiaries of the provision are first of all schools, but also institutions of teacher training. University courses are encompassed as well as long as they exclusively serve the education of teachers. ${ }^{1213}$ Moreover, social institutions such as juvenile shelters benefit from the limitation. ${ }^{1214} \S 47$ UrhG permits to make "single reproductions" ${ }^{1215}$, which means only a few. If more then one copy is necessary to comply with the needs of the school or institution, such copies are covered by $\S 47$ UrhG. ${ }^{1216}$ The provision however only allows the reproduction of broadcasts at the time they are broadcasted; to make copies of

\footnotetext{
${ }^{1207} \S 63$ para. 1 UrhG

1208 Melchiar in Schricker/Loewenheim, 2010, § 46 UrhG, no. 31.

1209 Melchiar in Schricker/Loewenheim, 2010, § 47 UrhG, no. 6.

1210 Idem, no. 1.

1211 Idem, no. 8

1212 Idem, no. 10.

1213 Idem, no. 12

1214 See § 47 para. 1 s. 2 UrhG.

1215 "Einzelne Vervielfältigungsstücke“, see $\S 47$ para. 1 s. 1 UrhG.

1216 Melchiar in Schricker/Loewenheim, 2010, § 47 UrhG, no. 15.
} 
broadcasts, which previously have been recorded are not permitted. ${ }^{1217}$ According to $\S 47$ para. $2 \mathrm{~s}$. 1 UrhG the copies may only be used for instruction. Any other use is forbidden. ${ }^{1218}$ The obligations to name the source and to omit modifications of the work are contained in $\S$ 63 and $\S 62$ UrhG. According to $\S 47$ para. 2 s. 2 UrhG school broadcasts must be deleted no later than the school year following the date of the broadcast. ${ }^{1219}$

Remuneration does have to be paid for the reproduction of copyright protected works, which are contained in a school broadcast. In case schools do not delete the broadcasts within the period established by $\S 47$ para. $2 \mathrm{~s}$. 2 UrhG, they infringe copyright. This can be prevented if just remuneration is paid. ${ }^{1220}$ The exercise of the right to just remuneration is not required to be claimed only by a collecting society. In practice the respective collecting society however exercises the right. $^{1221}$

\subsection{Reproduction for Private and Other Personal Use}

$\S 53$ UrhG permits the analogue or digital reproduction of copyright protected works in full or in part for private and personal/own use. The provision gives a statutory license to use a work for the privileged purpose. ${ }^{1222} \S \S 54$ to $54 \mathrm{~h}$ UrhG establish rules concerning the payment of remuneration for the privileged uses.

\subsection{Private Use}

According to $\S 53$ para. 1 UrhG it is allowed to make reproductions of copyright protected works on analogue or digital data carriers for the private use of natural persons. ${ }^{1223}$ Regarding educational, scientific or library uses the provision is not relevant because it only applies to private uses, which have no professional or commercial purpose. ${ }^{1224}$

\footnotetext{
1217 Idem, no. 16.

1218 It is not allowed to display the recorded broadcast in teacher conferences or at home for the preparation of the instruction, cf. idem, no. 18.

${ }^{1219}$ Other institutions have to delete the school broadcast within a period analogue to the school year taking into consideration the institution's respective time cycle, cf. idem, no. 21.

${ }_{1220} \S 47$ para. 2 s. 2 at the end.

1221 Melchiar in Schricker/Loewenheim, 2010, § 47 UrhG, no. 23, who explains that the period to delete school broadcasts very often will not be respected in practice, which proves that a fair balance between the interests of authors and right holders and school uses was not achieved. He demands that $\S 47$ UrhG - at least the part regarding remuneration - must be reformed.

1222 Loewenheim in Schricker/Loewenheim, 2010, § 53 UrhG no. 2.

${ }^{1223}$ Cf. article 5 para. 2 lit. b) Information Society Directive.

1224 Loewenheim in Schricker/Loewenheim, 2010, § 53 UrhG, no. 15.
} 


\subsection{Personal Use}

$\S 53$ para. 2 UrhG permits reproductions of copyright protected works for personal use. The term "personal use" means that the copies of a work are made for the own use of the person making the copies and are not passed on to third parties. ${ }^{1225}$ "Personal use" thus encompasses private use. ${ }^{1226}$ Personal use covers professional as well as commercial uses and also legal entities, corporations and so forth may rely on it. ${ }^{1227}$ According to $\S 53$ para. 2 UrhG personal use is the internal use of copyright protected works in corporations, authorities, schools, universities, libraries and so forth. ${ }^{1228}$ The provision allows only single copies of a protected work, meaning only a few. ${ }^{1229}$ There is no strict limit on the number of copies, but it is allowed to make the number of copies required to satisfy the personal needs. ${ }^{1230}$ Furthermore it is explicitly allowed to let others make the copies as long as they offer no additional services, such as research. ${ }^{1231}$

Under the prerequisites described before, $\S 53$ para. $2 \mathrm{~s} .1$ no. 1 UrhG permits reproductions for personal scientific use ("eigener wissenschaftlicher Gebrauch"), as long as the reproduction is required for that purpose and has no commercial aim. Additionally, the source must be named. ${ }^{1232}$ Scientists benefit from the provision because they do not have to ask for the authors or right holders permission any time they have to make a copy. ${ }^{1233}$ Scientific use refers to scientific activity, which is defined as the systematic and methodic striving for knowledge. ${ }^{1234}$ This definition does not only apply to universities or scientific institutes, but also to private persons following their scientific interests. ${ }^{1235} \S 53$ para. 2 s. 1 no. 1 UrhG only covers the "own" scientific use. Regarding institutions or corporations the term "own scientific use" means internal use, regarding private persons it means private use (no professional or commercial purpose). ${ }^{1236}$ Above that the reproduction must be required for scientific use, which is not the case if a copy can be easily purchased or lent. ${ }^{1237}$ Because of the implementation of the Information Society Directive into German law $\S 53$ para. 2 s. 1 UrhG now only applies to reproductions, which serve no commercial purposes. This restriction of the scope of the provision is heavily criticised since commercial scientific institutions, corporations and freelancers as well as university teachers writing private scientific articles

\footnotetext{
1225 Idem, no. 34 .

1226 lbid.

1227 lbid.

1228 lbid.

1229 lbid.

1230 Idem, no. 17.

1231 Idem, no. 34. The dispatch of copies by libraries is permitted by $\S 53 a$ UrhG.

$1232 \S 63$ para. 1 s. 1 UrhG.

1233 Loewenheim in Schricker/Loewenheim, 2010, § 53 UrhG, no. 39.

1234 Idem, no. 40

1235 lbid.

1236 Idem, no. 41

1237 Idem, no. 42.
} 
are not covered. ${ }^{1238}$ Thereby the limitation does not serve the actual purpose any more.

$\S 53$ para. 2 s. 1 no. 2 UrhG allows to make reproductions of a copyright protected work for an own archive provided that the reproduction is required for that purpose and the reproduction is made from a work owned by the person or the institution making the copy. The idea behind that provision is that such reproductions for archiving contain no additional exploitation of the work. Reproductions must serve only the purpose of preservation and internal use. ${ }^{1239}$ An archive is an institution for systematic collection and preservation of intellectual goods of any kind, such as books, newspapers, journals, photos, movies court records etc. ${ }^{1240}$ It must be an own internal archive for instance of a corporation. ${ }^{1241}$ The person or the corporation, which owns the archive, must itself carry out the archiving in order to be privileged by $\S 53$ para. 2 s. 1 no. 2 UrhG. ${ }^{1242}$ Only reproductions, which are required for archiving are covered. Not covered are reproductions for the purpose of enlarging the collections of an archive or a library as well as commercial purposes. ${ }^{1243}$ As was said above the reproductions must be made from a work, which is owned by the person making the reproductions. This excludes reproductions made from rented or lent works. ${ }^{1244}$ Moreover it is only allowed to make one reproduction of each work. ${ }^{1245}$ It is therefore not allowed to make several reproductions of one work. This inhibits adequate long-term archiving. Furthermore the provision does not cover copies of websites (web harvesting) for preservation purposes, because such websites are not owned by the person making the reproduction. ${ }^{1245 a}$

The scope of $\S 53$ para. 2 s. 1 no. 2 UrhG is further restricted by $\S 53$ para. 2 s. 2 no. 1 to 3 UrhG. Reproductions for an own archive are only permitted if the reproduction is made by photomechanical copying on paper or a similar data carrier (no. 1), the use is exclusively analogue (no. 2) or the archive serves public interest and has no direct or indirect commercial purpose (no. 3). Digital reproductions are thereby almost completely excluded. Only an archive serving public interest without commercial purpose is allowed to make digital reproductions. ${ }^{1246}$

$\S 53$ para. 2 s. 1 no. 4 UrhG allows reproductions for further personal use ("sonstiger eigener Gebrauch"). This provision does not require that the reproduction is made from a work which

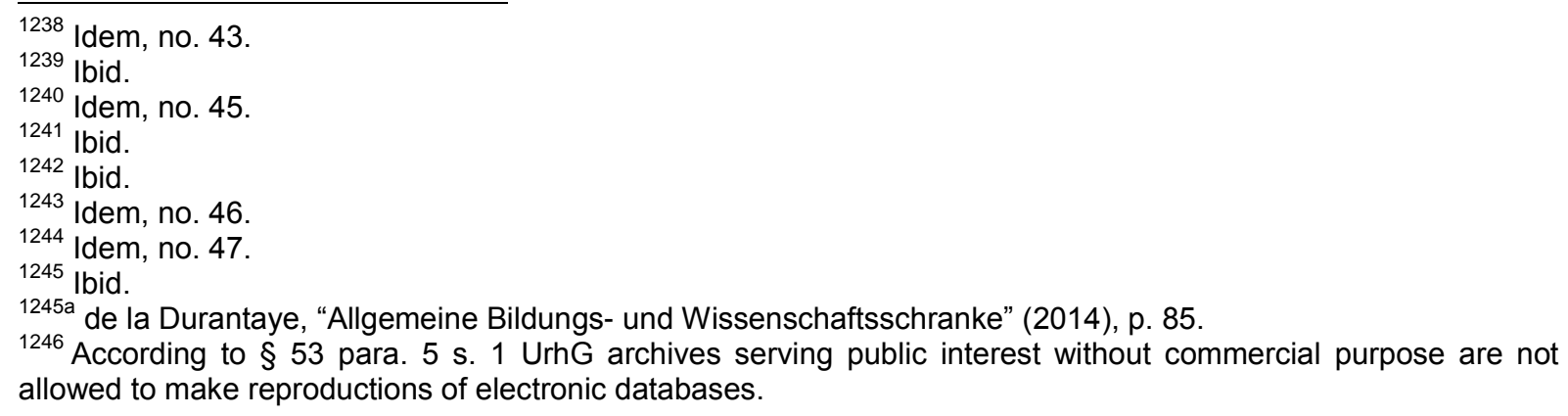


is owned by the person making the reproduction. ${ }^{1247}$

According to $\S 53$ para. 2 s. 1 no. 4 a) UrhG it is allowed to make reproductions of small parts of a published work and of single articles, which have been published in newspapers or journals. The legislator wanted to facilitate the use of the named works in case the user would need only a small part and not the entire work. ${ }^{1248}$ This is why $\S 53$ para. 2 s. 1 no. 4 a) UrhG applies mainly to reproductions made for professional commercial purposes. The provision permits to make reproductions of small parts of published works. In order to find out what is a small part one has to set the part, which is reproduced into proportion with the entire work and find a fair balance between the interests of the authors and the users for each individual case. ${ }^{1249}$

$\S 53$ para. 2 s. 1 no. 4a) UrhG furthermore allows the reproduction of single articles published in newspapers or journals for the purposes of sparing the user to purchases the entire newspaper or journal if he needs only a small part of it. ${ }^{1250}$ It is assumed that an article in relation to the entire newspaper or journal must be considered a small part. ${ }^{1251} \S 53$ para. 2 s. 3 UrhG restricts the scope of $\S 53$ para. 2 s. 1 no. $4 a)$ UrhG by making reference to $\S 53$ para. 2 s. 2 no. 1 and 2 UrhG, which only allows reproductions on paper or similar data carriers by photomechanical copying or if the reproductions are analogue. Digital reproductions thus are not privileged by $\S 53$ para. 2 s. 1 no. 4 a) UrhG.

According to $\S 53$ para. 2 s. 1 no. 4b) UrhG it is allowed to make reproductions of works, which have been out of print for at least two years. This provision aims at facilitating reproductions by libraries and scientific institutes for the purpose of preserving and completing their collections. ${ }^{1252}$ It is also restricted by $\S 53$ para. $2 \mathrm{~s}$. 3 UrhG in conjunction with $\S 53$ para. 2 s. 2 no. 1 and 2 UrhG.

$\S 53$ para. 3 UrhG permits to make as many reproductions of small parts of a work, of works of small size or of single articles, which have been published or made available in newspapers or journals as necessary for instruction and examination. ${ }^{1253}$ Its scope is therefore wider than the scope of $\S 53$ para. 2 UrhG, which only allows to make single

\footnotetext{
1247 Loewenheim in Schricker/Loewenheim, 2010, § 53 UrhG, no. 51.

1248 lbid.

1249 Idem, no. 52: Opinions on the definition of a small part in this context vary. Some demand a limit of $20 \%$ of the entire work. Others say that of a small part is not more than $10 \%$ on the entire work. The term "small part" is used as well in $\S 52 a$ UrhG and has recently been defined in that context by the Bundesgerichtshof, see. BGH Urteil v. 28.11.2013, Az. I ZR 76/12 - Meilensteine der Psychologie.

1250 Loewenheim in Schricker/Loewenheim, 2010, § 53 UrhG, no. 53.

1251 lbid.

1252 Idem, no. 55

${ }^{1253}$ See $§ 53$ para. 2 s. 1 no. 4a) UrhG.
} 
reproductions. The provision takes into account the fact that reproductions of copyright protected print works are an integral part of instruction. ${ }^{1254}$ At the same time it safeguards the (financial) interests of authors and right holders, whose works can be copied but not for free. ${ }^{1255}$ Since the implementation of the Information Society Directive the provision applies to all kinds of works and refers to the publicly making available instead of only publishing. ${ }^{1256}$

$\S 53$ para. 3 s. 1 no. 1 UrhG privileges schools, non-commercial institutions of further education and institutions of vocational training. It does not apply to universities because this would lead to massive copying without prior consent to the detriment of the authors. ${ }^{1257}$ Public and private schools are covered, as long as they are publicly accessible. ${ }^{1258}$ The provision may also cover distance education. ${ }^{1259}$ The prerequisite of "illustration for instruction" ${ }^{1260}$ encompasses the use of protected works in class, for preparation and reworking by the teacher and for homework. ${ }^{1261}$ It is however only permitted to make the number of reproductions necessary for the participants of the instruction. This means that in general the permission covers one reproduction for each student and one for the teacher. ${ }^{1262}$ The reproduction must be necessary for instruction. Reproductions for school administration are not necessary for instruction. ${ }^{1263}$ Whether reproductions are necessary or not is a decision, which is left to the instructor. ${ }^{1264}$ In order to prevent impairments from the schoolbook market according to $\S 53$ para. 3 s. 2 UrhG it is not allowed to reproduce schoolbooks without the consent of the author or right holder. ${ }^{1265}$

$\S 53$ para. 3 s. 1 no. 2 UrhG allows that schools, universities, non-commercial institutions of further education and institutions of vocational training make the reproductions which are necessary for examinations. Examinations are proofs of achievement following a period of study and document which knowledge and skills the person examined has acquired. ${ }^{1266}$ The provision applies to state exams as well as to others exams. ${ }^{1267}$

The limitations to authors exclusive rights are limited themselves by $\S 53$ para. 4,5 and 6 UrhG. $\S 53$ para. 4a) UrhG allows the reproduction of music notes only by manual

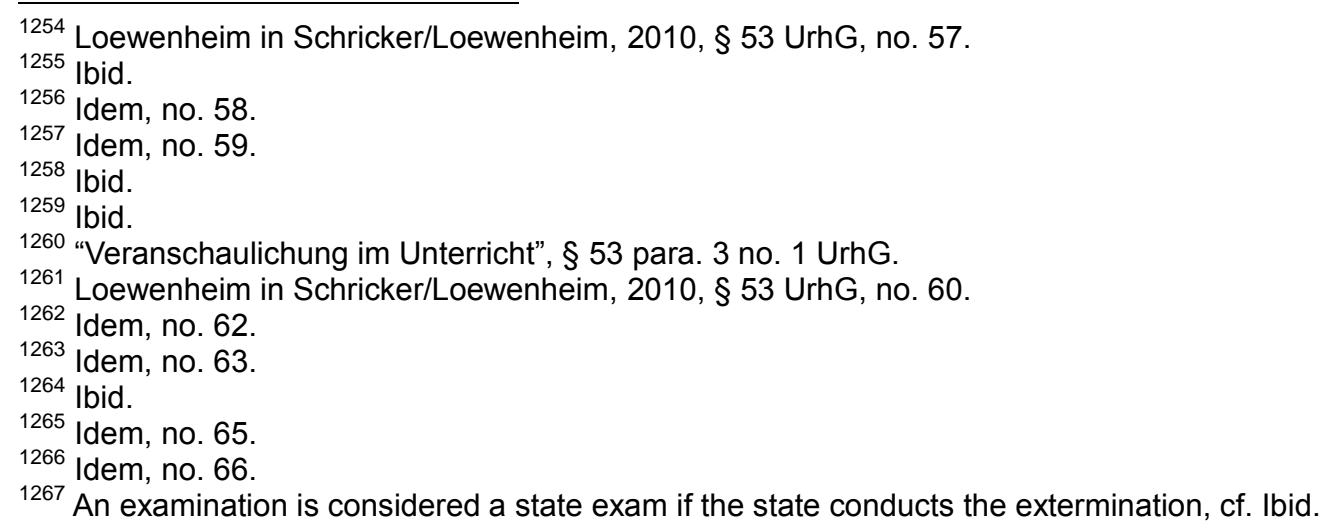


transcription unless the transcription is for an own archive or for personal use, if the work has been out of print for at least two years. This is also true for a basic only complete reproduction of books or journals. ${ }^{1268}$ According to $\S 53$ para. 5 UrhG it is allowed to make reproductions of single, electronically accessible elements of databases for own scientific use and for instruction provided that these uses have no commercial purpose. $\S 53$ para. $6 \mathrm{~s}$. 1 UrhG stipulates that reproductions may not be distributed or used for public performances. $\S 53$ para. 6 s. 2 UrhG establishes that it is allowed to lend reproductions of newspapers and out of print works as well as works, which have been partly damaged or lost and these small damages and losses have been replaced by reproductions. ${ }^{1269}$ Finally $\S 53$ para. 7 UrhG stipulates that the record of public speeches, performances, presentations of a work on image or sound carrier, the execution of plans or sketches regarding works of visual arts and the remake of a work of architecture is only allowed with the author's or right holder's consent.

\subsection{Remuneration}

The remuneration, which has to be paid for the reproductions of copyright protected works covered by $\S 53$ para. 1 to 3 UrhG, is regulated by $\S \S 54$ to $54 \mathrm{~h}$ UrhG.

According to $\S 54$ para. 1 UrhG the author can claim just remuneration if it can be expected that the work because of its nature will be reproduced in accordance with $\S 53$ para. 1 to 3 UrhG. ${ }^{1270}$ This construction is a statutory license, which means that the use of the work is feasible without the consent of the author or right holder, but just remuneration has to be paid. ${ }^{1270 a}$ The claim for just remuneration refers to devices and data carriers, which alone or in connection with other devices, data carriers or accessories is used for reproductions as described in $\S 53$ para. 1 to 3 UrhG. ${ }^{1271}$ The devices must actually be used for reproductions; how much a device is used for reproductions is irrelevant. ${ }^{1272} \S 54$ para. 1 UrhG encompasses all devices, which are suitable for reproductions of copyright protected works,

\footnotetext{
1268 "Im wesentlichen vollständige Vervielfältigung”, cf. idem, no. 74.

1269 Government Draft, BT-Drucks. 10/837, S. $16 f$.

1270 It was unclear whether remuneration had to be paid for the use of works, which were published on the Internet or accessible in digital form. The Bundesverfassungsgericht (BVerfG GRUR 2010, 999, 1002 - Drucker und Plotter) overruled the respective decisions of the Bundegerichtshof (BGH GRUR 2008, 245, 247 - Drucker und Plotter I; BGH GRUR 2009, 53, 55 - PC I), which led to a request for a preliminary ruling by the Bundesgerichtshof to the European Court of Justice (BGH GRUR 2011, 1007 - Drucker und Plotter II; BGH GRUR 2011, 1012 - PC II). The ECJ ruled that the author can claim fair remuneration regardless of whether he has given his consent to any reproduction or not (ECJ, C-457/11-460/11 - VG Wort, no. 37, 40). The mere making available of a work on the Internet does not imply that the author or right holder has given his consent to a reproduction, which means that remuneration can be claimed, cf. Loewenheim in Schricker/Loewenheim, 2010, § 54 UrhG, no. 7.

1270a Loewenheim in Schricker/Loewenheim, 2010, § 54 UrhG, no. 1.

$1271 \S 54$ para. 1 UrhG.

1272 Loewenheim in Schricker/Loewenheim, 2010, § 54 UrhG, no. 12, 13.
} 
no matter if analogue or digital. ${ }^{1273}$ According to $\S 54$ para. 1 UrhG the author`s claim for just remuneration is directed against the producer $^{1274}$ of the devices or data carriers used for reproductions as well as against the retailer ${ }^{1275}$ and/or importer ${ }^{1276}$ of such devices and data carriers. Producers and retailers and/or importers are jointly liable for the author's claim for just remuneration. ${ }^{1277}$ The rationale for the liability of the producer and retailer and/or importer is the fact that it is practically and legally impossible to direct the claim for just remuneration against the person actually making the reproductions under $\S 53$ para. 1 to 3 UrhG. ${ }^{1278}$ The author has no claim of just remuneration in case it is likely that the devices or data carriers are not used for reproductions. ${ }^{1279}$

$\S 54 a$ UrhG stipulates how much remuneration can be claimed. According to $\S 54 a$ para. 1 UrhG the remuneration depends to what extent devices and data carriers are actually used for reproductions under $\S 53$ para. 1 to 3 UrhG. In general remuneration, which is due to the author must be fair. ${ }^{1280}$ At the same time the remuneration shall not unduly harm the producers of devices and data carriers; the relation between the remuneration and the price of the respective device must be economically fair. ${ }^{1281}$

According to $\S 54 \mathrm{c}$ para. 1 UrhG the author can claim just remuneration for reproductions covered by $\S 53$ para. 1 to 3 UrhG from certain operators, who keep devices for reproductions available in schools, universities, institutions of vocational training, research institutions, public libraries or institutions, which keep devices for reproductions against payment available. The claim for just remuneration under $\S 54 \mathrm{c}$ para. 1 is only directed against operators of a certain size, because the legislator assumed that in this context the number of reproductions would be particularly high. ${ }^{1282}$ The list of operators named by the provision is closed. ${ }^{1283} \S 54 \mathrm{c}$ para. 1 UrhG makes no distinction between public and private institutions and also the term "public library" does not mean that a library must be publicly funded but rather that it must be publicly accessible. ${ }^{1284}$ The term "institutions, which keep available devices for reproductions against payment" encompasses copy shops as well as

\footnotetext{
1273 ECJ, C-457/11 - 460/11 - VG Wort, no. 80.

1274 Producer is who has actually produced the device or data carrier, s. Loewenheim in Schricker/Loewenheim $\S$ 54 no. 26.

1275 Retailer is who commercially buys and sells devices and data carriers, s. Loewenheim in Schricker/Loewenheim, 2010, § 54b UrhG, no. 6.

${ }_{1276}$ Importer is who imports or otherwise takes in devices and data carriers into the scope of the Urheberrechtsgesetz, s. § 54b para. 2 s. 1 UrhG.

1277 § 54b para. 1 UrhG.

1278 Loewenheim in Schricker/Loewenheim, 2010, § 54 UrhG, no. 1. The producer is also liable because he produces devices, which are necessary for making reproductions; thus he creates the prerequisites for reproductions.

${ }_{1279} \S 54$ para. 2 UrhG.

1280 Loewenheim in Schricker/Loewenheim, 2010, § 54a UrhG, no. 4.

1281 § 54a para. 4 UrhG

1282 Loewenheim in Schricker/Loewenheim, 2010, § 54c UrhG, no. 5.

1283 Ibid.

1284 Idem, no. 8
} 
other shops, which keep devices for reproductions available, namely photocopiers. ${ }^{1285}$ According $\S 54 \mathrm{c}$ para. 2 UrhG the remuneration, which can be claimed from the operators of reproduction devices, depends on the type of the device and to what extent it is likely to be used. In order to determine to what extent a device is likely to be used especially its location and its typical use must be considered. ${ }^{1286}$ Collecting societies have to negotiate the respective tariffs and/or agreements. ${ }^{1287}$

$\S 54 d$ UrhG establishes a duty to inform the person purchasing a reproduction device about the remuneration allotted to that device. According to $\S 54 \mathrm{e} U \mathrm{rhG}$ the person, which commercially imports reproduction devices is obliged to inform the author about the number of devices imported. $\S 54 \mathrm{f}$ UrhG establishes that the author has the right to ask from the producer and/or retailer and importer for the type and the number of reproduction devices sold or distributed within the scope of the Urheberrechtsgesetz in order to calculate the remuneration. ${ }^{1288} \S 54 \mathrm{~g}$ UrhG provides that if necessary for the calculation of the remuneration, the author has the right to visit the premises of the operator addressed by $\S$ 54c UrhG. ${ }^{1289}$ Finally $§ 54 \mathrm{~h}$ para. 1 UrhG stipulates that the claim for just remuneration can only be exercised by a collecting society. According to $\S 54 \mathrm{~h}$ para. $2 \mathrm{~s}$. 1 UrhG each author and/or right holder is entitled only to a fair share of the remuneration paid under $\S \S 54$ to $54 \mathrm{c}$ UrhG. This means that the money collected may not be distributed arbitrarily, but according to objective and non-discriminatory criteria. ${ }^{1290}$ After $\S 54 \mathrm{~h}$ para. 2 s. 2 UrhG the use of technical protection measures shall not be considered in the context of the distribution.

\subsection{Distribution of Copies on Request}

$\S 53 a$ para. 1 s. 1 UrhG allows the reproduction and transmission of single articles published in newspapers and journals as well as small parts of published works via mail or fax dispatch by public libraries per single request provided that the person making the order is covered by $\S 53$ UrhG. This is the general rule, which is restricted by sentence two and three. The provision implements a decision of the Bundesgerichtshof. ${ }^{1291}$

§ 53a para. 1 UrhG addresses public libraries. Only these institutions are allowed to dispatch reproductions of protected works. Public libraries are libraries, which are accessible to the

\footnotetext{
1285 Idem, no. 9.

1286 § 54c para. 2 UrhG

1287 Loewenheim in Schricker/Loewenheim, 2010, § 54c UrhG, no. 14.

${ }_{1288}$ According to $\S 54 \mathrm{~h}$ para. 1 UrhG this right can only be exercised by a collecting society.

${ }^{1289}$ According to $\S 54 \mathrm{~h}$ para. 1 UrhG this right can only be exercised by a collecting society.

1290 Loewenheim in Schricker/Loewenheim, 2010, § 54h UrhG, no. 5.

1291 BGHZ 141, 13 - Kopienversanddienst. In that decision the BGH had to deal with a dispatch by mail and fax; the government draft however already included dispatch by electronic means, cf. Government Draft BT-Drucks. 16/1828, p. 6.
} 
public, not necessarily publicly funded. ${ }^{1292}$ The provision permits to dispatch reproductions of single articles published in newspapers and journals as well as small parts of published works. It contains no restrictions to certain kinds of works. § 53a para. 1 UrhG only applies if the person making the request is allowed to make reproductions of the works for personal use according to $\S 53$ para. 1 to 3 UrhG, which may as well not be excluded by $\S 53$ para. 4 to 7 UrhG. Because of the restrictions regarding digital reproductions under $\S 53$ UrhG, $\S 53 a$ para. 1 UrhG only covers reproductions for private use (§ 53 para. 1 UrhG), for own scientific use ( $\S 53$ para. 2 s. 1 no. 2 UrhG) or for education and examinations ( $\$ 53$ para. 3 ). ${ }^{1293}$ It is only allowed to make a single request for each reproduction, but it is allowed to file several single requests at once. ${ }^{1294}$ The provision permits reproduction and transmission. Both acts are subject to the restrictions of $\S 53$ a para. $1 \mathrm{~s}$. 2 and 3 UrhG as well as the prerequisites of $\S 53$ UrhG. In the end this means that only the reproductions are covered which are necessary for the following type of transmission. ${ }^{1295} \S 53$ a para. $1 \mathrm{~s}$. 1 UrhG refers to the dispatch by mail or fax. Mail encompasses the transmission of physical copies whereas fax is regarded as an electronic means of transmission. ${ }^{1296}$ The other forms of electronic transmission are addressed by $\S 53$ a para. 1 s. 2 and 3 UrhG. $\S 53 a$ para. 1 s. 2 UrhG stipulates that the reproduction must be transmitted as a "graphic file" ("grafische Datei") for illustration for instruction or for scientific research as long as this is justified for noncommercial purposes. ${ }^{1297}$ Additionally to these prerequisites $\S 53$ a para. 1 s. 3 UrhG requires for the feasibility of electronic transmissions that members of the public do not obviously have the possibility of access to the respective works at places and at times of their choice at reasonable conditions by means of a contractual agreement. ${ }^{1298}$ This provision shall safeguard the interests of publishers who offer a database and at the same time take into account the interests of the public regarding access to information. ${ }^{1299}$ Especially the prerequisite of "reasonable conditions" is difficult to determine. ${ }^{1300}$

§ 53a para. 2 UrhG establishes the claim for just remuneration of the author. This provision also refers to the above mentioned decision of the Bundesgerichtshof. ${ }^{1301}$ The remuneration

\footnotetext{
1292 The term "public library" means the same as in $\S 54 c$ and $\S 52 b$ UrhG. To be considered a public library, it is sufficient that the library is accessible to a group of people, which must be considered "the public". According to $\S$ 15 para. 3 UrhG "the public" is a group of people whose members are not linked by personal relations to each other or to the library making the dispatch, cf. Loewenheim in Schricker/Loewenheim, 2010, § 53a UrhG, no. 9.

1293 Loewenheim in Schricker/Loewenheim, 2010, § 53a UrhG, no. 6.

1294 Idem, no. 8.

1295 These are analogue for mail or fax dispatch as well as electronic transmissions, especially scanning and saving in random access memory or on the library`s server, s. Loewenheim in Schricker/Loewenheim, 2010, $\S$ 53a UrhG, no. 11.

${ }_{1296}$ Loewenheim in Schricker/Loewenheim, 2010, § 53a UrhG, no. 14.

1297 The provision is harshly criticised for its contradictory wording and the fixation on the exclusion of any commercial purposes, see Hoeren/Neubauer, ZUM 2012, 636, 641.

${ }_{1298}$ Loewenheim in Schricker/Loewenheim, 2010, § 53a UrhG, no. 20.

1299 lbid.; Government Draft BT-Drucks. 16/1828, p. 27

1300 Hoeren/Neubauer, ZUM 2012, 636, 642.

${ }^{1301}$ BGHZ 141, 13 - Kopienversanddienst.
} 
has to be paid by public libraries. ${ }^{1302}$ The claim for just remuneration can only been exercised by collecting society.

\subsection{Orphan Works ${ }^{1303}$}

The Orphan Works Directive 2012/28/EU was implemented into German copyright law by the law on the use of orphan and out of print works and one further modification of the code of copyright. ${ }^{1304}$ It came into force on January 1, 2014. ${ }^{1305}$ The law introduced a new limitation privileging the reproduction and making available to the public of orphan works without prior authorisation of the author or right holder, transposing the Orphan Works Directive almost literally. The relevant provisions are $\S \S 61,61 a, 61 b$ and 61c UrhG.

In order to benefit from the limitation publicly accessible libraries, educational institutions, museums archives as well as film or audio heritage institutions have to carry out a diligent search for the right holder of a work without success. ${ }^{1306}$ The requirements for a diligent search for the right holder establishes $\S 61$ a UrhG. As provided by the Orphan Works Directive the sources that have to be consulted at least are specified in the annex to $\S 61 \mathrm{a}$ UrhG. If all prerequisites are complied with and the use of an orphan work is permitted by the limitation of $\S 61$ UrhG no remuneration to the right holder has to be paid. ${ }^{1307}$ In case a right holder, who could not be identified or located in the context of a diligent search, comes forward afterwards, the use of the respective orphan work has to be terminated immediately and the right holder has to be fairly compensated by the organisation, which had used his work in the past. ${ }^{1308}$ According to $\S 61 \mathrm{c}$ UrhG the provisions regarding orphan works apply to public service broadcasting organisations as well.

In addition to the implementation of the limitation for the use of orphan works the German legislator has at the same time introduced provisions regarding the use of out of print works. ${ }^{1309}$ Under the conditions set forth in $\S \S 13 \mathrm{~d}$ and $13 \mathrm{e}$ UrhWG ${ }^{1310}$ it is presumed that collecting societies are entitled to permit the reproduction and the making available of out of

\footnotetext{
1302 Loewenheim in Schricker/Loewenheim, 2010, § 53a UrhG, no. 25.

1303 The German term for orphan works is "verwaiste Werke".

1304 Gesetz zur Nutzung verwaister und vergriffener Werke und einer weiteren Änderung des Urheberrechtsgesetzes vom 01.10.2013 (BGBI I, S. 3728).

${ }_{1305}$ Article 3 Gesetz zur Nutzung verwaister und vergriffener Werke und einer weiteren Änderung des Urheberrechtsgesetzes vom 01.10.2013 (BGBI I, S. 3728).

${ }^{1306} \S 61$ para. 2 UrhG.

1307 Dreier in Dreier/Schulze, 2015, UrhG, § 61 no. 3.

1308 § $61 \mathrm{~b}$ UrhG.

$1309 \S \S 13 \mathrm{~d}$ and 13e UrhWG came into force on April 1, 2014, see article 3 Gesetz zur Nutzung verwaister und vergriffener Werke und einer weiteren Änderung des Urheberrechtsgesetzes of October 1, 2013 (BGBI I, S. $3728)$.

${ }^{1310}$ Urheberrechtswahrnehmungsgesetz.
} 
print works to the public. ${ }^{1310 a}$

The new provisions introduced by the implementation of the Orphan Works Directive especially deal with the digitisation and the making available of orphan works to the public, in particular over the Internet. As a result a great number of works will become accessible to users.

\subsubsection{Summary Germany}

German copyright law contains several limitations privileging the use of copyright protected works for educational purposes and in libraries. The provisions are scattered within the law. In general, they are rather complicated and therefore difficult to understand and apply. The interpretation of several prerequisites is unclear, which increases legal uncertainty for the respective institutions. In order to gain legal certainty costly lawsuits must be risked. Moreover not all provisions apply to digital works with the consequence that their scope of application is very narrow or not even relevant any more.

As a consequence institutions back away from invoking copyright limitations and refrain from certain uses of protected works. Not surprisingly educational and library associations unanimously demand for a reform of the limitations and exceptions in German Copyright Law. ${ }^{1311}$ Although the need for reform in that particular field of copyright law is almost undisputed, opinions differ how to achieve that goal. ${ }^{1312}$

The provisions taking into account the use of digital technologies for educational purposes and in libraries are few. Practically only § 52a UrhG and § 52b UrhG are of importance here. As could be shown both provisions have given rise to long-lasting lawsuits, which however have provided some clearance. Nevertheless, it is questionable, whether these provisions take into account current and future developments appropriately regarding the use of

\footnotetext{
$1310 a$ On June 1, 2016 the UrhWG was superseded by the Gesetz über die Wahrnehmung von Urheberrechten und verwandten Schutzrechten durch Verwertungsgesellschaften (VGG) of May 24, 2016 (BGBI. I, S. 1190). This new law implements the Directive 2014/26/EU of the European Parliament and of the Council of 26 Febuary 2014 on collective management of copyright and related rights and multi-territorial licensing of rights in musical works for online use in the internal market into German law. $\S \S 13 \mathrm{~d}$ and $13 \mathrm{e}$ UrhWG were superseded by the identical provisions $\S \S 51$ and 52 VGG.

1311 See for instance Aktionsbündnis „Urheberrecht für Bildung und Wissenschaft“, Göttinger Erklärung zum Urheberrecht für Bildung und Wissenschaft of July 5, 2004, which demands among others one general limitation regarding education and science („Allgemeine Bildungs- und Wissenschaftsschranke“), available at http://www.urheberrechtsbuendnis.de/ge.html.en?of=on. A proposal for a comprehensive limitation in favour of educational establishments, libraries, archives and similar institutions as well as scientific research is also proposed by the Aktionsbündnis "Urheberrecht für Bildung und Wissenschaft" and is available at http://www.urheberrechtsbuendnis.de/abws-text-2014-12.html.de. As well the "Deutscher Bibliotheksverband e.V." have proposed a general amd comprehensive limitations for education, science and research, available at http://www.bibliotheksverband.de/fileadmin/user_upload/DBV/positionen/2014_06_25_Stellungnahme_Wissensc haftsschranke.pdf.

${ }_{1312}$ Haucap/Loebert/Spindler/Thorwarth, Ökonomische Auswirkungen einer Bildungs- und Wissenschaftschranke im Urheberrecht, 2016, p. 84 - 95, summarise the current proposals.
} 
copyright protected works in education and libraries. In view of the rather narrow scope of application it must be feared that $\S 52 a$ UrhG and $\S 52 b$ UrhG soon will be outdated. On the other hand it must be stated that certain aspects of e-learning, especially distance education, would always infringe copyright if not for $\S 52 a$ UrhG. Therefore it is to be welcomed that the provision is now unlimited in time. Regarding $\S 52 \mathrm{~b}$ UrhG the clarifications of the ECJ and the Bundesgerichtshof have increased legal certainty for the respective institutions. Yet, the scope of application of this provision is also quite limited. Furthermore a provision explicitly permitting libraries to preserve their collections in digital form does not exist in Germany.

The implementation of the Orphan Works Directive into German law however has introduced a new limitation with special regard to digital uses of orphan works by cultural heritage institutions. The new provisions have the potential to enhance access to knowledge and education in the digital age.

With regard to the benchmark of permissible uses the provisions of the German copyright law meet the requirements only to a small extent. Both for educational establishments and libraries, archives and similar institutions there are no broad, open and technologically neutral norms, which could provide for flexibilities. This type of limitation is generally unknown to German copyright law. Rather there are statutory limitations. It is allowed to make works available in public for non-commercial instruction and research, but only small parts. Complete works thus may not be used. The limitation covers digitisations preceding the making available by the institution and also reproductions of the work by the user. In principle the limitation applies to all kinds of works, except for works especially made for education and cinematic works. Concerning libraries, museums and archives there are limitations, which allow to make available works from their collections in digital format on dedicated terminals for research and private study. The provision not covers all kinds of works, but only published works in the collection of the respective institution. The number of digital copies is restricted to the number of analogue copies. As a consequence also the amount of users that can access to work at the same time is thereby restricted. Online access from outside the institution is not permitted. Users may make analogue or digital reproductions of the work. Privileged institutions are allowed to digitise analogue works in the collections in order to make them available, however they are not allowed to digitise their entire collection. Also the limitation for anthologies for the use of protected works in churches, schools and for instruction does not allow the use of entire works, but only parts of it. At least, the provision applies to digital media. Furthermore, limitations and exceptions for educational purposes hardly refer to digital uses, but rather describe traditional educational settings. With regard to preservation and replacement, libraries are allowed to make 
reproductions of works, which have been out of print for the last two years. Public libraries also are allowed to make copies of single articles or small parts of published works upon user request for non-commercial purposes. These copies may be dispatched also electronically. Finally, public educational establishments, libraries and other cultural heritage institutions may now make reproductions of orphan works and make them available to the public. There are no provisions regarding text and data mining, web-harvesting or format shifting. Above that all limitations may be overruled by licensing contracts.

In general, it must be stated that the construction of the system of limitations and exceptions for education and libraries, archives and similar institutions is quite complicated and the wording of the provisions is difficult to understand. There are many undefined legal terms, which only partly have been specified by courts, and thus mostly create uncertainty.

After all it is found that the current provisions of German copyright law in the field to education and knowledge do not consider sufficiently the possibilities of digital technologies and the Internet. In view of the significance of the objectives pursued, namely social development and the right to education, limitations and exceptions in Germany therefore do not provide access to education and knowledge adequately.

\subsubsection{Summary Part 1 Chapter 4}

The objective of Part 1 of Chapter 4 was to find out, whether access to education and knowledge is fostered by the limitations and exceptions in national laws of the USA, the UK and Germany. It could be shown that in all jurisdictions there are limitations and exceptions, which privilege specific uses of copyright protected works for educational purposes and in libraries, archives and/or museums. These provisions generally serve the public interest in access to education and knowledge.

However, it must be noted that limitations and exceptions in these countries mostly have a rather limited scope of application and often do not take into account the new possibilities, because they were enacted long before the advent of digital technologies and the Internet. Educational institutions, libraries and other privileged institutions thus must fear to act illegally, if they make use of the copyright protected works applying new technologies. In general, it was found that most provisions were very complicated and difficult to understand. Often it is therefore unclear, if specific uses of protected works in the digital environment are covered. This leads to considerable legal uncertainty for the respective institutions. As a consequence they back away from using new technologies. Also the risk of costly lawsuits exists. 
In the USA and UK the fair use doctrine respectively fair dealing provide for some flexibility regarding new technological developments. These open clauses have the capacity to adapt the law to changing conditions more easily. By contrast the statutory limitations and exceptions of the German copyright system hardly have this flexibility, because they apply only to specific conditions. The inflexibility is aggravated by the principle of restrictive interpretation of limitations and exceptions and the interdiction of analogy.

So far none of the countries examined complies fully with the benchmark of permissible uses for educational purposes and libraries, archives and similar institutions. In this regard limitations and exceptions do not promote access to education and knowledge in the digital age adequately.

As a consequence the systems of limitations and exceptions in the USA, the UK and in Germany with regard to education and knowledge should be reformed. As one can gather from the country analysis two things are needed from the viewpoint of privileged institutions: laws should be flexible in order to adapt to always changing social and technological environments and laws should provide for legal certainty in order that addressees can act on a reliable basis.

Based on this assumption it appears that a combination of open and flexible fair use like provisions and clearly defined statutory limitations could lead the way to a more balanced system of limitations and exceptions.

In that context it appears sensible to take into consideration more explicitly the significance of the objectives pursued by limitations and exceptions for educational purposes and libraries, archives and similar institutions, which are the promotion of social and human development. The human right to education and the human right to take part in cultural life, which both underpin these objectives, as well as the fundamental rights of authors and right holders to the protection of their property, should be set out as guiding principles, especially in view of the interpretation of fair use provisions. An idea could be to introduce provisions in national copyright laws, which explicitly underscore the importance of the conflicting positions and remind that a fair balance of interests has to be achieved when interpreting and applying the law. Although these reflections are mentioned here and there in most legal systems, there is no explicit reference made with regard to limitations and exceptions in the jurisdictions examined here. 
In view of the state of development of the USA, the UK and Germany and the widespread use of digital technologies and the Internet in all parts of society, statutory limitations and exceptions for education and knowledge should reflect these realities. In the USA, the UK and Germany it is less a question of access to (digital) infrastructure, but much more a question of how new technologies can be used for the promotion of overall social and human progress. Thus, as long as non-commercial purposes are pursued by educational establishments and libraries, archives and similar institutions, statutory limitations should permit far reaching (digital) uses of protected works, as set out in the benchmark. The privileged uses should either be remuneration free or statutory licenses should be issued in order to compensate authors and right holders. Under these conditions limitations should not be overrules be licensing contracts. 


\section{PART 2: Limitations and Exceptions for Educational Purposes and Libraries, Archives} and Similar Institutions in Portugal, Brazil and Mozambique

In the following Part 2 of Chapter 4 limitations and exceptions for educational purposes and libraries, archives and similar institutions in Portugal, Brazil and Mozambique with special attention to the use of digital technologies are examined. Before starting the analysis of the actual limitations and exceptions, each country is introduced with a short country profile. Subsequently there is an overview over the educational system and the national policies regarding the inclusion of ICT for the purpose access to education and knowledge. Afterwards the international obligations, the constitutional underpinnings and the basic principles of the respective copyright law system are explained. The findings are presented at the end of each country analysis and summarised in the end of part 2.

\subsubsection{Portugal}

\subsubsection{Country profile}

Portugal is located on the South Western coast of continental Europe. In the West and in the South it is limited by the Atlantic Ocean. To the North and the East it has a border with Spain of $1214 \mathrm{~km}$. Its territory also includes the archipelagos of the Azores and Madeira in the Atlantic Ocean.

In 2013 Portugal had an estimated population of $10,608,000 .{ }^{1313}$ The population of Portugal is gradually ageing due to a falling birth rate and an increase in life expectancy. In 2013 the population growth was decreasing by $0,3 \% .{ }^{1314}$ Average life expectancy in 2013 was 81 years. ${ }^{1315}$ The population under 14 years of age is $1,567,000 .{ }^{1316} 38 \%$ of the population live in rural areas. ${ }^{1317}$ The average annual income per capita was $\$ 25,389 .{ }^{1318}$ In 2014 Portugal had a gross domestic product of $\$ 229.6$ billion. ${ }^{1319}$ The dominant religion is Roman Catholic. The official language is Portuguese, which is also spoken on the Azores and Madeira as well as in the former colonies of Portugal, namely Angola, Brazil, Cape Verde, Guinea-Bissau, Mozambique, São Tomé e Príncipe and Macau. Also in East Timor and parts of India Portuguese is spoken.

The development of Portugal as a state began in the 12th century with the foundation of the

\footnotetext{
${ }^{1313}$ Unesco, Institute for Statistics, Country Profile Portugal, available at http://www.uis.unesco.org/DataCentre/Pages/country-profile.aspx?code=PRT. 1314 lbid.

1315 lbid.

1316 lbid.

1317 lbid.

1318 lbid.

1319 World Bank, Country at a Glance Portugal, available at http://www.worldbank.org/en/country/portugal.
} 
Kingdom of Portugal after the successful Reconquista. In the 15th century Portugal became a major power, because of its role during the age of discoveries. Portugal had one of the largest colonial empires, reaching from Africa to Asia and South America. However, already in the 17th century the decline of Portugal as a world power began. The Portuguese monarchy was finally abolished in 1910. On October 5, 1910, the First Portuguese Republic was proclaimed. In 1926 a military putsch ended the First Republic and marked the beginning of over 40 years of dictatorship, namely by António de Oliveira Salazar. The dictatorship of Salazar was overthrown by the peaceful Carnation Revolution of April 25, 1974. Since then Portugal has had a stable parliamentary, semi-presidential Republic. The first constitution of the third Republic was passed in 1976 and with several amendments is still in force. The most important political organs are the president, the Prime Minister and his Council of ministers, the parliament and the judiciary. Marcelo Rebelo de Sousa is the president currently. The present prime minister is António Costa.

Portugal has been a founding member of the NATO since 1949 and of the OECD since 1948. It has been also a member of the United Nations since 1955 and the Council of Europe since 1976. Moreover it has been a member of the European Union since 1986. Although Portugal is one of the founding members of the Eurozone and in spite of social and economic development in the late 20th century, the country still finds itself among the poorest members of the EU.

\subsubsection{Educational System}

According the Constitution of Portugal everyone has the right to education and culture. ${ }^{1320}$ The state has the obligation to promote the democratisation of education as well as to guarantee the equality of opportunity regarding access to education and to provide the conditions under which education can contribute to the personal development of the individual, to social progress, mutual understanding, solidarity and responsibility as well as to democratic participation in public life. ${ }^{1321}$ Furthermore the state is obliged to create public educational institutions to cover the needs of the entire population. ${ }^{1322}$ The freedom to learn and teach is guaranteed and the state is not allowed to program education following any philosophical, political, ideological, aesthetic or religious guidelines. ${ }^{1323}$ Moreover public education must be non-confessional. ${ }^{1324}$

\footnotetext{
${ }^{1320}$ Article 73 para. 1 Constitution of Portugal.

${ }^{1321}$ Article 73 para. 2 and article 74 para. 1 Constitution of Portugal.

1322 Article 75 para. 1 Constitution of Portugal.

${ }^{1323}$ Aricle 43 Constitution of Portugal.

1324 lbid.
} 
The Framework Law on the Education System ${ }^{1325}$ (Law no. 46/86, dated October 14, 1986, further amended by Law no.115/97, dated September 19, 1997, Law no. 49/2005, dated August 30, 2005, Law no. 85/2009, dated August 27, 2009 and Law no. 65/2015, dated July $3,2015)$ establishes the basic legal framework of the Educational System. As stipulated by the constitution the framework law on the education system establishes as a general principle that all Portuguese have the right to education and culture. ${ }^{1326}$ According to article 4 para. 1 Lei de Bases do Sistema Educativo the educational system comprises pre-school education (Educação Pré-Escolar), school education (Educação Escolar) and extra school education (Educação Extra-Escolar).

Preschool education is intended to amend and/or complete the education of children in their families ${ }^{1327}$ and is addressed to children between the age of three years and the age of entry to basic education, which is six years. ${ }^{1328}$ The attendance of preschool education is optional. $^{1329}$

School education comprises basic education, secondary education and higher education and includes special modes of education. ${ }^{1330}$ Basic education is universal, compulsory and free. ${ }^{1331}$ It has a duration of nine years. ${ }^{1332}$ The age of entry is six years. ${ }^{1333}$ Basic education is separated into three consecutive cycles. The first cycle has a duration of four years, the second cycle of two years and the third cycle of three years. ${ }^{1334}$ The first cycle focuses on general education, the second cycle is dominated by interdisciplinary areas of basic formation and the third cycle follows a uniform curriculum integrating different vocational areas. ${ }^{1335}$ Secondary education is open to anybody who has completed basic education, which is why students are normally between fifteen and seventeen years. ${ }^{1336}$ Secondary education consists mainly of courses preparing for a working life or of courses preparing for further studies and includes technical, technological and vocational elements, as well as Portuguese language and culture. ${ }^{1337}$ Higher education encompasses university education and polytechnic education. ${ }^{1338}$ Access to higher education is granted to anybody, who posesses secondary or equivalent qualification, or to anybody over the age of 25 , who does

\footnotetext{
${ }^{1325}$ Lei de Bases do Sistema Educativo.

${ }^{1326}$ Article 2 para. 1 Lei de Bases do Sistema Educativo, Lei no. 46/86 de 14 de Outubro.

1327 Cf. article 4 para. 2 Lei de Bases do Sistema Educativo.

1328 Cf. article 5 para. 3 and article 6 para. 2 Lei de Bases do Sistema Educativo.

${ }^{1329}$ Cf. article 5 para. 8 Lei de Bases do Sistema Educativo.

${ }^{1330}$ Cf. article 4 para. 3 Lei de Bases do Sistema Educativo.

1331 Cf. article 6 para. 1 Lei de Bases do Sistema Educativo.

1332 Ibid.

1333 Cf. article 6 para. 2 Lei de Bases do Sistema Educativo.

1334 Cf. article 8 para. 1 Lei de Bases do Sistema Educativo.

1335 Cf. article 8 para. 1 a) - c) Lei de Bases do Sistema Educativo.

1336 Cf. article 10 para. 1 Lei de Bases do Sistema Educativo.

1337 Cf. article 10 para. 3 Lei de Bases do Sistema Educativo.

${ }^{1338}$ Cf. article 11 para. 1 Lei de Bases do Sistema Educativo.
} 
not possess such qualification, provided they prove they have the necessary skills and knowledge. ${ }^{1339}$ In order to guarantee the quality of higher education, the admission to higher education courses may be limited. ${ }^{1340}$ The degrees, which can be obtained in higher education are bacharel, Licenciado, Mestre and Doutor. ${ }^{1341}$ In the polytechnic education the degree bacharel $I^{1342}$ and licenciado can be obtained. School education also includes special modes of education, namely special education (Educação Especial), vocational training (Formação Profissional), recurrent education for adults (Ensino Recorrente de Adultos), distance education (Ensino à Distância) and Portuguese education abroad (Ensino Português no Estrangeiro). Special education has the purpose of integration and recuperation of individuals with special educational needs because of physical or mental deficiencies. ${ }^{1343}$ In order to complement the process of preparation for working life, which begins in basic education, vocational training intends to introduce students to the world of work and to provide them with the necessary knowledge and skills. ${ }^{1344}$ Recurrent adult education is offered to individuals who have passed the normal age of frequency of Basic and secondary education and pursues the primary aim to eliminate illiteracy. ${ }^{1345}$ Distance education is defined not only as one means to complement regular education by making use of multimedia and new information communication technologies but also as an alternative mode to provide school education in general. ${ }^{1346}$ At the time the Lei de Bases do Sistema Educativo was passed in 1986 distance education was seen as a means of delivering education especially in adult education and teacher training. ${ }^{1347}$ The Open University (Universiade Aberta) is the main distance education institution. ${ }^{1348}$ In order to promote the dissemination and the study of the Portuguese language and culture abroad the state supports various initiatives, such as Portuguese teachers in schools and universities in other countries or Portuguese language schools abroad. ${ }^{1349}$ Extra school education encompasses literacy campaigns and fundamental education as well as cultural and scientific development together with professional improvement in an open environment of multiple formal or nonformal initiatives. ${ }^{1350}$ It is embedded into a permanent and global perspective of continuous education and learning. ${ }^{1351}$

\footnotetext{
1339 Cf. article 12 para. 1 a) and b) Lei de Bases do Sistema Educativo.

1340 Cf. article 12 para. 3 Lei de Bases do Sistema Educativo.

${ }^{1341}$ Article 13 para. 1 a) - d) Lei de Bases do Sistema Educativo.

1342 Article 13 para. 4 and 7 Lei de Bases do Sistema Educativo.

${ }^{1343}$ Article 17 para. 1 Lei de Bases do Sistema Educativo.

${ }_{1344}$ Cf. article 19 para. 1 Lei de Bases do Sistema Educativo.

${ }^{1345}$ Article 20 para. 1 and 2 Lei de Bases do Sistema Educativo.

${ }^{1346}$ Article 21 para. 1 Lei de Bases do Sistema Educativo.

${ }^{1347}$ Article 21 para. 2 Lei de Bases do Sistema Educativo.

${ }^{1348}$ Article 21 para. 3 Lei de Bases do Sistema Educativo.

1349 Cf. article 22 Lei de Bases do Sistema Educativo.

1350 Cf. article 4 para. 4 Lei de Bases do Sistema Educativo.

${ }^{1351}$ Cf. article 23 para. 2 Lei de Bases do Sistema Educativo.
} 


\subsubsection{Information Communication Technologies}

Today the use of ICT is vital in education and in libraries. In order to construct a knowledge society and improve the ability of individuals to participate in such society, the Portuguese legislator enacted the Technological Plan for Education (Plano Tecnológico da Educação) in 2007. ${ }^{1352}$ The plan aimed at the far-reaching introduction of ICT in Portuguese schools for basic and secondary education for the purpose of providing ICT improved learning and teaching to everybody until 2010. Therefore, the Portuguese legislator established three main pillars of action. The first pillar relates to technology, the second pillar to content and the third pillar to Training. ${ }^{1353}$ Concerning technology the plan foresaw among others that classrooms should be equipped with computers and Internet access as well as other multimedia gadgets and further be connected to high-speed broadband Internet. ${ }^{1354}$ Regarding content the plan promoted among others the dissemination of information in educational communities within virtual surroundings and over the Internet, for instance through distance education. ${ }^{1355}$ Further the management of schools should have been supported by ICT. ${ }^{1356}$ With regard to training the plan fosters the systematic training and certification of ICT teachers, students and school managers. Moreover the evaluation should be complemented by ICT. ${ }^{1357}$ Vocational training for working students should be facilitated as well through the incorporation of ICT. ${ }^{1358}$ In 2010 surveys among students, teachers and the respective institutions showed that most goals of the plan were achieved. ${ }^{1359}$

In order to further promote the development of the knowledge society Portugal enacted the Digital Agenda 2015 (Agenda Portugal Digital 2015). ${ }^{1360}$ The Digital Agenda 2015 for Portugal goes hand-in-hand with the Digital Agenda for Europe 2020. ${ }^{1361}$ Among others the Digital Agenda 2015 for Portugal includes measures to improve literacy, qualifications and digital inclusion through the promotion of ICT, which comprises the development of digital competency, inclusion of elderly and people with special needs, availability of e-books, mass digitisation and availability of digital platforms and content over the Internet. ${ }^{1362}$

\footnotetext{
1352 Resolução do Conselho dos Ministros no. 137/2007, de 18 de Setembro de 2007.

1353 Plano Tecnológico da Educação, Diario da República, 1.a série, no. 180, 18 de Setembro de 2007, p. 6567.

1354 Plano Tecnológico da Educação, Diario da República, 1.a série, no. 180, 18 de Setembro de 2007, p. 6567 6572.

${ }^{1355}$ Plano Tecnológico da Educação, Diario da República, 1.a série, no. 180, 18 de Setembro de 2007, p. 6572 6574

1356 Ibid.

1357 Plano Tecnológico da Educação, Diario da República, 1.a série, no. 180, 18 de Setembro de 2007, p. 6574 6576.

1358 lbid.

1359 Direção Geral de Estatísticas da Educação e Ciência, available at http://www.dgeec.mec.pt/np4/245.html. See also European SchoolNet / University of Liège, Survey of Schools: ICT in Education, Country Report: Portugal, November 2012.

1360 Resolução do Conselho de Ministros n. ${ }^{\circ}$ 12/2012, de 7 de fevereiro de 2012.

1361 Digital Agenda for Europe - A Europe 2020 Initiative, available at https://ec.europa.eu/digital-singlemarket/en/europe-2020-strategy and https://ec.europa.eu/digital-single-market/country/portugal.

1362 Medidas da Agenda Portugal Digital 2015, available at http://www.portugaldigital.pt/medidas/. See also European Commission, Education and Training Monitor 2014: Portugal, p. 6.
} 
With regard to higher education there are no similar initiatives to promote the use of ICT. Rather higher education institutions are free to decide whether and to what extent they make use of ICT. In this context special attention must be paid to distance education and elearning, which both require the use of ICT. Still in higher education institutions in Portugal the face-to-face model of instruction is dominant. ${ }^{1363}$ Only in 1988 the Open University (Universiade Aberta), the autonomous distance education university, was initiated. ${ }^{1364}$ The general growth in demand for higher education and better accessibility to higher education institutions in Portugal ${ }^{1365}$, has also led to a considerable growth in demand for distance education at all levels. ${ }^{1366}$ Nevertheless only $3 \%$ of higher education students in Portugal participate in distance education. ${ }^{1367}$ The majority of the students, around $90 \%$, are enrolled with the Open University. ${ }^{1368}$ Traditional universities and polytechnic schools are only now starting to offer distance education and to make use of ICT. Most higher education institutions consider distance education and ICT as means to enrich face-to-face teaching, which is why they favour models of blended learning more in the sense of e-learning, than pure distance education. ${ }^{1369}$ From a legal point of view there are no special laws regarding distance education and e-learning in higher education institutions. Distance education and elearning must be provided within the existing legal framework, which is the Framework Law on the Education System. ${ }^{1370}$ Further legislation on the provision of distance education and e-learning in higher education institutions in Portugal is therefore not necessary and rather would have the effect of restricting the pedagogical freedom of higher education institutions to adopt the teaching and models most suited for their situation. ${ }^{1371}$

In Portugal libraries of all kinds, such as school libraries, university libraries and libraries open to the general public, make use of ICT in order to provide and improve their services. The task of school libraries for instance is among others to enrich and complement the teaching and learning process, which is promoted through ICT. ${ }^{1372}$ Libraries open to the general public not only provide access to their collections but also offer Internet access

\footnotetext{
1363 Bielschowsky / Laaser / Mason / Sagra / Hasan, Reforming Distance Learning Higher Education in Portugal, 2009 , p. 5.

${ }_{1364}$ Article 21 para. 3 Lei de Bases do Sistema Educativo.

1365 European Commission, Education and Training Monitor 2014: Portugal, p. 6.

${ }^{1366}$ Bielschowsky / Laaser / Mason / Sagra / Hasan, Reforming Distance Learning Higher Education in Portugal, 2009 , p. 5 ..

1367 Ibid.

1368 lbid.

1369 Idem, p. 6.

${ }^{1370}$ Law no. 46/86, dated October 14, 1986, and amending laws. Article 21 para. 2 explicitly adresses distance education as a appropriate means for providing adult education and teacher training.

1371 Cf. Bielschowsky / Laaser / Mason / Sagra / Hasan, Reforming Distance Learning Higher Education in Portugal, 2009, p. 28.

1372 See Cunha / Barros Figueiredo, O impacto da Web 2.0 nas Bibliotecas Escolares das escolas secundárias do concelho de Lisboa, 2012.
} 
points to the users in order to foster the access to information and knowledge. ${ }^{1373}$ In university libraries the incorporation of ICT in library services and the work of librarians permanently advances and deeply transforms the organisation and the provision of library services. ${ }^{1374}$

\subsubsection{Portuguese Copyright Law}

As a result of the liberal revolution of August 24, 1820, the regime of the privileges was ended. ${ }^{1375}$ The Constitution of $1822^{1376}$ abolished absolutism and aimed at the creation of a Constitutional monarchy. ${ }^{1377}$ The new Consitution of 1822 made reference to freedom of expression and established the "free communication of thoughts" (article 7) and "the freedom of the press" (article 8). ${ }^{1378}$ Already the Carta da Lei de 4 de Julho de 1821 had conferred to the authors of literary works the lifelong right to print their works, in original and translation, and also extended that right for a period of 10 years post mortem. ${ }^{1379}$ In 1826 the Constitution of 1822 was superseded by the "Carta Constitucional". Among other guarantees the "Carta Constitucional" contained promises of the King of Portugal of civil liberties especially concerning private property. Article 145 no. 24 states that "Os Inventores terão a propriedade de suas descobertas, ou das suas produções." 1380 The authors however remained without protection. In 1838 the Portuguese Constitution went one step further and established in article 23 no. 4 that "o direito de propriedade dos inventores sobre as suas descobertas e dos escritores sobre os seus escritos (...) pelo tempo e na forma que a lei determinar" ${ }^{1381}$ Yet, such law regulating the rights of inventors and writers did not exist. It was only in 1851 that the first Portuguese law on author's rights after several difficulties entered into force. ${ }^{1382}$ The driving force behind the project was a man named Almeida Garrett. ${ }^{1383}$ The law on author's rights was in force until 1867 and was then included in the new Civil Code. ${ }^{1384}$ In 1927 the Decree-Law No. 13.725 was enacted with the title "Código sobre a Propriedade Literaria, Centifica e Artistica". ${ }^{385}$ The Code used the rare expression of "Intellectual Property" and consequently followed natural law ideas, considering intellectual property a natural right. In 1966 as a result of the ratification of various international

\footnotetext{
${ }^{1373}$ See Quick / Prior / Toombs / Taylor / Currenti, Users' perceptions of the benefits of ICT in public libraries in Portugal, 2013.

${ }_{1374}$ See Moreira Carvalho, As Bibliotecas Universitárias de Portugal e Nordeste do Brasil, 2013.

${ }^{1375}$ Akester, Direito de Autor em Portugal e nos PALOP, 2013, p. 42.

${ }^{1376}$ Constituição Portuguesa de 1822, approved September 23, 1822.

1377 Akester, Direito de Autor em Portugal e nos PALOP, 2013, p. 42.

1378 Ibid.

1379 lbid.

1380 "The inventors shall have the property of their discoveries or their productions".

1381 "The inventors shall have the property of their discoveries and the writers the property of their writings for certain time and in the way the law determines".

1382 Leitão, Direito de Autor, 2011, p. 32/33; Asensão, Direito de Autor, 2008, no. 6 I.

1383 Writer, poet, politicians (February 4, 1799 - December 9, 1854); Ascenão, Direito de Autor, 2008, no. 6 I.

${ }^{1384}$ Asensão, Direito de Autor, 2008, no. 6 II.

${ }^{1385}$ Code on Property of Literature, Science and Arts.
} 
agreements and the technical development a new code came into force by the Decree-Law No. 46.980. It had the name "Código de Direito de Autor". ${ }^{1386}$ Finally in 1985 the "Código do Direito de Autor e dos Direitos Conexos" ${ }^{\text {1387 }}$ was established by the Decree-Law No. 63/85 of March 14, 1985. This code is still in force today but has been modified several times. ${ }^{1388}$ The latest modifications were caused by the implementation of EU directives. ${ }^{1389}$ As all over Europe the implementation of the Information Society Directive 2001/29/EU as well in Portugal led to the establishment of new provisions regarding limitations and exceptions, now enshrined in article 75 CDA. ${ }^{1390}$ The implementation of the provisions concerning limitations and exceptions into Portuguese Copyright law was effected by Law No. 50/2004, August 24, 2004. Further, the Orphan Works Directive 2012/28/EU was transposed into Portuguese copyright law with Law No. 32/2015, April 24, 2015 and introduced a new limitation to exclusive rights regarding the use of orphan works also enshrined in article 75 CDA.

Also, the Constitution of the Republic of Portugal, enacted on April 2, 1976, and in the current version of 2005, provides a source of Copyright law. Article 42 para. 1 establishes the freedom of intellectual, artistic and scientific creation. ${ }^{1391}$ Article 42 para. 2 continues, that "this freedom encompasses the right to invent, produce and publicise scientific, literary and artistic works and shall include the protection of copyright by law."1392

Portugal's copyright law is also influenced by international obligations. Portugal adheres to the Berne Convention ${ }^{1393}$ and the Rome Convention. ${ }^{1394}$ It has also ratified WIPO Treaties. ${ }^{1395}$ As a member of the WTO Portugal is party to the TRIPS Agreement.

Before taking a closer look at the limitations and exceptions enshrined in article 75 CDA will briefly explain the subject of copyright protection and the rights of authors under Portuguese Copyright law.

\subsection{Protected Works}

According to article 1 CDA Portuguese copyright law protects "intellectual creations" of the

\footnotetext{
1386 Code of Author`s Rights.

${ }^{1387}$ Code of Author's Rights and Related Rights, in the following "CDA".

1388 Asensão, Direito de Autor, 2008, no. 7; Leitão, Direito de Autor, 2011, p. 36.

1389 Copyright legislation available at http://www.dgpj.mj.pt/sections/leis-da-justica/livro-iii-leis-civis-e/leiscivis/direito-de-autor-e/; see also Leitão, Direito de Autor, 2011, p. 36.

${ }^{1390}$ Ascensão, O Direito da Internete em Portugal e no Brasil, 2011, p. 84.

1391 Art. 42 para. 1: "É livre a criação intelectual, artística e científica."

1392 Art. 42 para 2: "Esta liberdade compreende o direito à invenção, produção e divulgação da obra científica, literária ou artística, incluindo a protecção legal dos direitos de autor."

${ }_{1393}$ Accession: March 29, 1911; in force since March 29, 1911.

${ }^{1394}$ Accession: July 17, 2001; in force since July 17, 2002.

1395 Signature: December 31, 1997, ratification: December 14, 2009, in force since March 14, 2010.
} 
literary, scientific and artistic realm. ${ }^{1396}$ Article 2 para. 1 CDA further specifies that intellectual creations are protected independently of their genre, their form of expression and communication, their worth and their objective. Subsequently article 2 para. 1 CDA provides for a non-exclusive list of examples of works ${ }^{1397}$ that are protected by copyright, such as books, dramatic works, choreographies, compositions, cinematic works, paintings, sculptures, works of the applied arts etc. ${ }^{1398}$ The non-exclusive character of the list means that new kinds of works, which are not mentioned also enjoy copyright protection as long as they are intellectual creations. ${ }^{1399}$ Article 2 para. 2 CDA additionally clarifies that follow-up editions of a work are not considered distinct works even if they contain corrections, augmentations, modifications of the title or the format or reproductions of the original work. $^{1400}$

Article 3 para. 1 CDA equates several kinds of works to the original work. ${ }^{1401}$ According to article 3 para. 1 lit. a) CDA translations, arrangements, instrumentations, dramatizations, cinematizations as well as other transformations of a work even if the original work is not protected. ${ }^{1402}$ Further article 3 para. 1 lit. b) CDA equates summaries and compilations of protected and non-protected works, like encyclopaedias and anthologies, which qualify as intellectual creations because of their selection and compilation. ${ }^{1403}$ Eventually, according to article 3 para. 1 c) CDA also systematic or annotated compilations of texts of conventions, laws, regulations and reports or of administrative or judicial decisions or of decisions of any

${ }^{1396}$ Art. 2 para. 1 CDA: "As criações intelectuais do domínio literário, científico e artístico(...)“

${ }_{1397}^{13}$ Akester, Direito de Autor em Portugal e nos PALOP, 2013, p. 55/56.

1398 a) Livros, folhetos, revistas, jornais e outros escritos;

b) Conferências, lições, alocuções e sermões;

c) Obras dramáticas e dramático-musicais e a sua encenação;

d) Obras coreográficas e pantomimas, cuja expressão se fixa por escrito ou por qualquer outra forma;

e) Composições musicais, com ou sem palavras;

f)Obras cinematográficas, televisivas, fonográficas, videográficas e radiofónicas;

g) Obras de desenho, tapeçaria, pintura, escultura, cerâmica, azulejo, gravura, litografia e arquitectura;

h) Obras fotográficas ou produzidas por quaisquer processos análogos ao da fotografia; i) Obras de artes aplicadas, desenhos ou modelos industriais e obras de design que constituam criação artística, independentemente da protecção relativa à propriedade industrial;

j) Ilustrações e cartas geográficas;

I) Projectos, esboços e obras plásticas respeitantes à arquitectura, ao urbanismo, à geografia ou ás outras ciências;

m) Lemas ou divisas, ainda que de carácter publicitário; se se revestirem de originalidade;

n) Paródias e outras composições literárias ou musicais, ainda que inspiradas num tema ou motivo de outra obra.

${ }^{1398}$ Art. 2 para. 2 CDA: "As sucessivas edições de uma obra, ainda que corrigidas, aumentadas, refundidas ou com mudança de título ou de formato, não são obras distintas da obra original, nem o são as reproduções de obra de arte, embora com diversas dimensões."

1399 Cf. Leitão, Direito de Autor, 2011, p. 78/79.

1400 Art. 2 para. 2 CDA: "As sucessivas edições de uma obra, ainda que corrigidas, aumentadas, refundidas ou com mudança de título ou de formato, não são obras distintas da obra original, nem o são as reproduções de obra de arte, embora com diversas dimensões."

${ }^{1401}$ Leitão, Direito de Autor, 2011, p. 79.

1402 Art. 3 para. 1 a) CDA: "São obras equiparadas a originais:

a) As traduções, arranjos, instrumentações, dramatizações, cinematizações e outras transformações de qualquer obra, ainda que esta não seja objecto de protecção;"

${ }^{1403}$ Art. 3 para. 1 b) CDA: "Os sumários e as compilações de obras protegidas ou não, tais como selectas, enciclopédias e antologias que, pela escolha ou disposição das matérias, constituam criações intelectuais;" 
other organ or authority of the state or the administration. ${ }^{1404}$ Article 3 para. 2 CDA states that the protection of these equated works does not prejudice the rights granted to the authors of the respective original work. ${ }^{1405}$

\subsection{Moral and Economic Rights}

Portuguese Copyright law protects not only the moral rights of the author but also his economic rights, as is clarified by article 9 para. 1 CDA. ${ }^{1406}$ Like in most systems of the Droit d'Auteur Copyright tradition as well according to Portuguese law Copyright has a dual nature. ${ }^{1407}$ Following this approach the works of an author are the expression of his personality and at the same time shall allow him to make a living by exploiting them.

\subsection{Moral Rights}

Title I Chapter VI CDA deals with moral rights. ${ }^{1408}$ Moral rights are contained in article 56 to 62 CDA. Most important are article 56 and 57 CDA as they provide the definition of moral rights and determine how moral rights can be exercised.

According to article 56 para. 1 CDA the author enjoys independently from his economic rights and even if he has alienated or burdened his works during his entire lifetime the right to claim the authorship of his work and to safeguard the genuineness and the integrity of his work. He is therefore entitled to oppose the destruction, mutilation, deformation or any other modification of his work and generally any act, which distorts the works and may effect the honour und reputation of the author. ${ }^{1409}$ Article 56 para. 2 CDA further states that the right conferred by article 56 para. $1 \mathrm{CDA}$ is inalienable, non-renounceable and non-lapsing. It perpetuates after the death of the author according to article 57 CDA. ${ }^{1410}$

\footnotetext{
${ }^{1404}$ Art. 3 para. 1 c) CDA: "As compilações sistemáticas ou anotadas de textos de convenções, de leis, de regulamentos e de relatórios ou de decisões administrativas, judiciais ou de quaisquer órgãos ou autoridades do Estado ou da Administração."

${ }^{1405}$ Art. 2 para. 2 CDA: "A protecção conferida a estas obras não prejudica os direitos reconhecidos aos autores da correspondente obra original."

${ }^{1406}$ Art. 9 para. 1 CDA: "O direito de autor abrange direitos de carácter patrimonial e direitos de natureza pessoal, denominados direitos morais."

${ }^{1407}$ See Ascensão, Direito de Autor, 2008, no. $108 \mathrm{I}$, who underlines, that it is heavily debated if copyright has a uniform nature or if it has a personal and a economic dimension. Yet, the CDA separates moral and economic

rights.
1408 Title I, Chapter VI: "Dos Direitos Morais"

${ }^{1409}$ Art. 56 para. 1 CDA: "Independentemente dos direitos de carácter patrimonial e ainda que os tenha alienado ou onerado, o autor goza durante toda a vida do direito de reivindicar a paternidade da obra e de assegurar a genuidade e integridade desta, opondo-se à sua destruição, a toda e qualquer mutilação, deformação ou outra modificação da mesma e, de um modo geral, a todo e qualquer acto que a desvirtue e possa afectar a honra e reputação do autor."

${ }^{1410}$ Art. 56 para. 2 CDA: "Este direito é inalienável, irrenunciável e imprescritível, perpetuando-se, após a morte do autor, nos termos do artigo seguinte."
} 
Article 57 CDA regulates how moral rights granted by article 56 CDA are exercised. Following art. 57 para. 1 CDA after the death of the author moral rights are exercised by the successors of the author as long as the work has not fallen into public domain. ${ }^{1411}$ As a member of the EU Portugal has adopted the Council Directive 93/98/EEC of 29 October 1993 harmonizing the term of protection of copyright and certain related rights (so-called Term Directive) with Decree-Law No. 334/97 of November 27, 1997, which is why in Portugal according to article 31 CDA Copyright expires seventy years after the death of the author. ${ }^{1412}$ Article 38 para. 1 CDA states that after this period works belong to the public domain. ${ }^{1413}$

\subsection{Economic Rights}

The Title II CDA deals with the utilisation of the work. ${ }^{1414}$ Very important among the uses of copyright protected works is of course their economic exploitation. Therefore Title II Chapter I dedicates article 67 CDA to article 71 CDA to the modes of utilisation. ${ }^{1415}$ Most important are article 67 CDA and article 68 CDA.

Article 67 para. 1 CDA establishes that the author has the exclusive right to enjoy and to utilise the work in full or in part, which comprises the possibilities to distribute, publish and exploit the work economically in any form, directly or indirectly, within the limits of the law. ${ }^{1416}$ This is a general rule to Copyright, which is known as well in other copyright systems. ${ }^{1417}$ How basic and essential the rule of exclusive economic utilisation is, clarifies article 67 para. 2 CDA. It says that from an economic point of view the guaranty of the pecuniary advantages, which result form said exploitation, is the fundamental object of legal protection. ${ }^{1418}$

The various forms to use the work are contained in article 68 CDA. Article 68 para. 1 CDA states that the exploitation and in general the utilisation of the work may be carried out, according to its specie and nature, in any form known at the moment or in future. ${ }^{1419}$ After that general statement article 68 para. 2 CDA provides a non-exhaustive list of exclusive

\footnotetext{
${ }^{1411}$ Art. 57 para. 1 CDA: "Por morte do autor, enquanto a obra não cair no domínio público, o exercício destes direitos compete aos seus sucessores."

1412 Art. 31 CDA: "O direito de autor caduca (...) setenta anos após a morte do criador intelectual (...)."

${ }^{1413}$ Art. 38 para. CDA: "A obra cai no domínio público quando tiverem decorridos os prazos de protecção estabelecidos neste diploma."

1414 Title II: "Da utilização da obra".

1415 Title II Chapter I Section I: "Das modalidades de utilização".

${ }^{1416}$ Cf. art. 67 para. 1 CDA: "O autor tem o direito exclusivo de fruir e utilizar a obra, no todo ou em parte, no que se compreendem, nomeadamente, as faculdades de a divulgar, publicar e explorar economicamente por qualquer forma, directa ou indirectamente, nos limites da lei."

1417 Cf. in Germany $\S 11$ UrhG iVm $\S \S 15$ ff UrhG

${ }^{1418}$ Art. 67 para. 2 CDA: "A garantia das vantagens patrimoniais resultantes dessa exploração constitui, do ponto de vista económico, o objecto fundamental da protecção legal."

${ }_{1419}$ Art. 68 para. 1 CDA: "A exploração e, em geral, a utilização da obra podem fazer-se, segundo a sua espécie e natureza, por qualquer dos modos actualmente conhecidos ou que de futuro o venham a ser."
} 
rights belonging to the author. ${ }^{1420}$ According to this the author, by himself or through his representatives, has among other rights the exclusive right carry out or authorise the uses named in the list following thereafter. ${ }^{1421}$ The author may therefore carry out or authorise:

a) The publication by the press or by any other medium of graphic reproduction; ${ }^{1422}$

b) The representation, recital, execution, exhibition or exposition in public; ${ }^{1423}$

c) The cinematic reproduction, adaptation, representation, execution, distribution and exhibition ;1424

d) The fixation or adaptation to any device destined for mechanical, electric, electronic or chemical reproduction and the public exhibition, transmission or retransmission by these means; ${ }^{1425}$

e) The dissemination by photography, telephotography, television, radio broadcast or by any other process of reproduction of signals, sounds or images and the public communication by loudspeakers or similar instruments, with or without wire, namely by Hertzian waves, optic fibres, cable or satellite, if this communication is made by another then the original organism; ${ }^{1426}$

f) Any form of distribution of the original or of copies of the work as well as sale, rental or lending; ${ }^{1427}$

g) The translation, adaptation, arrangement, instrumentation or any other transformation of the work; ${ }^{1428}$

h) Any other use in another work; ${ }^{1429}$

i) The direct or indirect reproduction, temporary or permanent, by whatever means and by any form, in full or in part; ${ }^{1430}$

j) The publicly making available of the work, by wire or wireless, in a way that it is accessible for any person at time and place of her choice, ${ }^{1431}$

\footnotetext{
${ }^{1420}$ Cf. Asensão, Direito de Autor, 2008, no. 136.

${ }^{1421}$ Cf. Art. 68 para. 2 CDA: "Assiste ao autor, entre outros, o direito exclusivo de fazer ou autorizar, por si ou pelos seus representantes:"

${ }_{1422}$ Art. 68 para. 2 a) CDA: "A publicação pela imprensa ou por qualquer outro meio de reprodução gráfica;"

${ }^{1423}$ Art. 68 para. 2 b) CDA: "A representação, recitação, execução, exibição ou exposição em público;"

${ }^{1424}$ Art. 68 para. 2 c) CDA: "A reprodução, adaptação, representação, execução, distribuição e exibição cinematográfica;"

${ }^{1425}$ Art. 68 para. 2 d) CDA: "A fixação ou adaptação a qualquer aparelho destinado à reprodução mecânica, eléctrica, electrónica ou química e a execução pública, transmissão ou retransmissão por esses meios;"

${ }^{1426}$ Art. 68 para. 2 e) CDA: "A difusão pela fotografia, telefotografia, televisão, radiofonia ou por qualquer outro processo de reprodução de sinais, sons ou imagens e a comunicação pública por altifalantes ou instrumentos análogos, por fios ou sem fios, nomeadamente por ondas hertzianas, fibras ópticas, cabo ou satélite, quando essa comunicação for feita por outro organismo que não o de origem;"

${ }^{1427}$ Art. 68 para. 2 f) CDA: "Qualquer forma de distribuição do original ou de cópias da obra, tal como venda, aluguer ou comodato;"

${ }^{1428}$ Art. 68 para. 2 g) CDA: "A tradução, adaptação, arranjo, instrumentação ou qualquer outra transformação da obra;"

${ }_{1429}^{1430}$ Art. 68 para. 2 h) CDA: "Qualquer utilização em obra diferente;"

${ }^{1430}$ Art. 68 para. 2 i) CDA: "A reprodução directa ou indirecta, temporária ou permanente, por quaisquer meios e sob qualquer forma, no todo ou em parte;"

${ }^{1431}$ Art. 68 para. 2 j) CDA: "A colocação à disposição do público, por fio ou sem fio, da obra por forma a torná-la acessível a qualquer pessoa a partir do local e no momento por ela escolhido;"
} 
I) The construction of a work of architecture following the project, whether or not there are repetitions. ${ }^{1432}$

Article 68 para. 5 CDA stipulates that the distribution right regarding tangible copies of a work is exhausted within the EU, if the work is legally sold or transferred for the first time. ${ }^{1433}$ This provision implements article 4 para. 2 Information Society Directive. ${ }^{1434}$ Article 4 Information Society Directive implements article 6 WCT. ${ }^{1435}$ Since Portugal is bound by the principle of regional exhaustion to the common market of the EU, it cannot adopt rules regarding exhaustion going beyond this territory, such as regional exhaustion in relation to other Portuguese speaking countries or international exhaustion. ${ }^{1436}$

\subsection{Limitations and Exceptions}

Some uses of copyright protected works are exempted from the general rule of exclusive rights of the author set forth in article 67 para. 1 CDA and permitted for special purposes privileged by one or more limitations. ${ }^{1437}$ Title II Chapter II CDA, which is entitled "Da Utilização Livre" meaning "On Free Use", contains all limitations concerning the use of copyright protected works granted under Portuguese copyright law. ${ }^{1438}$ Being of the continental author's rights tradition ${ }^{1439}$ Portuguese copyright law knows no open clauses allowing certain uses of protected works like the fair use doctrine in the USA. ${ }^{1440}$ Rather article $75 \mathrm{CDA}$ and following articles provide an exhaustive enumeration of statutory limitations. ${ }^{1441}$ Most important is article 75 CDA, which defines the scope of free use. The Portuguese legislator has made extensive use of the option to implement the limitations and exceptions of the Information Society Directive 2001/29/EC and introduced all limitations and exceptions provided for by the Information Society Directive. ${ }^{1442}$ As well the (mandatory) limitation provided for by the Orphan Works Directive 2012/28/EU has been implemented

\footnotetext{
1432 Art. 68 para. 2 k): "A construção de obra de arquitectura segundo o projecto, quer haja ou não repetições."

${ }^{1433}$ Art. 68 para. 5: "Os actos de disposição lícitos, mediante a primeira venda ou por outro meio de transferência de propriedade, esgotam o direito de distribuição do original ou de cópias, enquanto exemplares tangíveis, de uma obra na União Europeia."

${ }_{1434}$ Akester, Direito de Autor em Portugal e nos PALOP, 2013, p. 92.

${ }_{1435}$ Bechthold in Dreier/Hugenholtz, Concise Copyright, InfoSocDir, art. 4 note 1.

1436 Idem, art. 4 note $3 \mathrm{~g}$ ).

1437 See Acórdão do Supremo Tribunal de Justiça, No. 103/04.2TVLSB.L1.S1, November 17, 2011, conclusion para. 2 - 6, where the court points out that there are exceptions to the exclusive right of the author, in which the use of the work or a part of it is allowed without his consent and without payment of remuneration, "Há, porém, situações excepcionais à regra geral enunciada, segundo as quais é possível a utilização de uma obra ou de parte dela, de modo lícito, independentemente do consentimento do autor e sem direito para aquele, nalguns casos, a qualquer remuneração (....". In that particular case the limitation for citation of article 75 para. 2 g) CDA was discussed.

${ }_{1438}$ Ascensão, O Direito da Internete em Portugal e no Brasil, 2011, p. 86.

1439 Ibid.

1440 Leitão, Direito de Autor, 2011, p. 159.

1441 Cf. Akester, Direito de Autor em Portugal e nos PALOP, 2013, p. 106.

1442 Ascensão, O Direito da Internete em Portugal e no Brasil, 2011, p. 86; Akester, Direito de Autor em Portugal e nos PALOP, 2013, p. 105.
} 
completely. Hereinafter I will examine the respective provisions with regard to the use of protected works for educational purposes and in libraries and archives.

Uses of protected material, which actually infringe copyright but are allowed without the author's or right holder's consent, are contained in article 75 para. 2 CDA. The CDA does not constrain the application of limitations to certain types of works. It only refers to "obras", which means "works". Consequently, analogue and digital works are encompassed.

\subsection{Reproduction and Making Available for the Purpose of Information}

Taking into account the Freedom of information article 75 para. 2 b) CDA permits the reproduction and the making available in public of protected works in extracts or as resumes through means of social communication for the purpose of information, debate, speeches and the public conferences provided that these works are not embraced by article 7 CDA, which excludes certain categories of works from protection such as daily news or political speeches. ${ }^{1443}$ With regard to education article 75 para. 2 b) CDA could provide coverage, because the purpose of information and debate will be given quite often.

\subsection{Reproductions by Libraries and Educational Institutions}

Article 75 para. 2 e) CDA explicitly favours educational uses of (entire) works. According to this provision it is allowed to make reproductions in full or in part of a work previously made available to the public provided that such reproduction is made by a public library, a public archive, a public museum, a non-commercial centre of documentation or a scientific or educational institution and the copies are not destined to the public but are limited to the activities of the institution and pursue no direct or indirect economic or commercial advantage; also encompassed are reproductions necessary for preservation and archiving. ${ }^{1444}$

Hence this provision is the implementation of Article 5 para. 2 c) Information Society Directive one can draw on the rational of the Directive. As already explained above recital 40 Information Society Directive states that a limitation incorporated into national law

\footnotetext{
1443 Leitão, Direito de Autor, 2011, p. 163.

${ }^{1444}$ Art. 75 para. 2 e) CDA: "A reprodução, no todo ou em parte, de uma obra que tenha sido previamente tornada acessível ao público, desde que tal reprodução seja realizada por uma biblioteca pública, um arquivo público, um museu público, um centro de documentação não comercial ou uma instituição científica ou de ensino, e que essa reprodução e o respectivo número de exemplares se não destinem ao público, se limitem às necessidades das actividades própriasdessas instituições e não tenham por objectivo a obtenção de uma vantagem económica ou comercial, directa ou indirecta, incluindo os actos de reprodução necessários à preservação e arquivo de quaisquer obras."
} 
implementing Article 5 para. 2 c) Information Society Directive should be limited to certain special cases and not cover uses made in context of an online delivery of protected works. Consequently, due to this strict and narrow position the interpretation of article 75 para. $2 \mathrm{e}$ ) CDA covers e-learning activities and the use of digital technologies in the respective institutions, e.g. for the purpose of preservation and replacement, only to a very limited extent. Moreover, the provision refers only to the reproduction right, which further restricts the scope of application. However, entire works may be copied and there is no restriction to certain types of works, which means that the provision applies also to digital works. ${ }^{1445}$ The provision only applies if the respective institution pursues a privileged non-commercial purpose such as documentation, archiving, investigation, science and education. ${ }^{1446}$

\subsection{Reproduction, Distribution and Making Available of Parts of a Work}

Also, article 75 para. 2 f) CDA explicitly addresses educational purposes. It states that the reproduction, distribution and making publicly available for educational purposes of parts of a published work is allowed (without the author's or right holder's consent) provided that this is made exclusively for educational purposes in the respective educational establishments and no direct or indirect economic or commercial advantage is thereby pursued. ${ }^{1447}$

This provision implements article 5 para. 3 a) Information Society Directive into Portuguese copyright law and encompasses not only the reproduction right but also the distribution right and the right of making available to the public. In this regard the scope of the limitation is wider than the scope of article 75 para. 2 e) CDA. However, only parts of a published work may be used what reduces the scope of the provision at the same time. A full copy of the work thus is not allowed by the limitation, although such copy would serve educational purposes. ${ }^{1448}$ Recital 42 Information Society Directive yet clarifies that non-commercial educational purposes include distance learning. Thus distance education and e-learning activities at least partly benefit from the limitation.

\footnotetext{
1445 Cf. Akester, Direito de Autor em Portugal e nos PALOP, 2013, p. 109.

1446 Leitão, Direito de Autor, p. 164.

${ }^{1447}$ Art. 75 para. 2 f) CDA: "A reprodução, distribuição e disponibilização pública para fins de ensino e educação, de partes de uma obra publicada, contando que se destinem exclusivamente aos objectivos do ensino nesses estabelecimentos aos objectivos do ensino nesses estabelecimentos e não tenham por objectivo a obtenção de uma vantagem económica ou comercial, directa ou indirecta."

${ }^{1448}$ Acórdão do Tribunal da Relação de Lisboa, No. 565/2008-6, January 31, 2008, para. II.2.3. In this case the court had to decide if the use of a manual, which the defendant had copied to such an extend that the copy appeared to be the original, i.e. almost a full copy, was covered by article 75 para. $2 \mathrm{f}$ ) CDA. It was clear that the copy was used for educational purposes. Nevertheless, the court found that article 75 para. 2 f) CDA was not applicable and ruled that the use was infringing. To make matters worse the defendent had not properly indicated the name of the author, the editor and the title of the work, which is mandantory according to article 76 para. 1 CDA and the copy could thus be confused with the original, which is interdicted by article 76 para. 2 CDA. The latter provision also prohibits reproductions that are so extensive that they interfere with the interests regrading the original. Yet, all this was the case here.
} 


\subsection{Inclusion of Short Pieces of a Work for Education}

Further article 75 para. $2 \mathrm{~h}$ ) CDA allows the inclusion of short pieces or fragments of alien works in own works intended for education. ${ }^{1449}$ This limitation covers some uses of protected works for educational purposes, but it scope of application is rather narrow. The constraint to short pieces or fragments significantly reduces the scope of the provision.

\subsection{Making Available of Works on Dedicated Terminals}

Finally, there is article 75 para. 2 o) CDA. This provision is the almost literal implementation of article 5 para. $3 \mathrm{n}$ ) Information Society Directive into Portuguese Copyright Law. It permits public libraries, museums, archives and schools to communicate or make protected works and other subject-matter, which are contained in their collections, available to individual members of the public on dedicated terminals on the premises of respective institution for the purpose of research or private study, provided that these works are not subject to purchase or licensing terms. ${ }^{1450}$

At first glance the limitation appears to provide real progress regarding the use of new technologies for the purpose of providing access (in digital form) to protected works. ${ }^{1451}$ However, the provision is restrictive and complicated. The terminals via which access is granted must be located on the premises of the institution. Consequently, online access from outside of the institution is not encompassed. ${ }^{1452}$ The works made available are as well limited to works contained in the collection of the respective institution, thus no online access to collections of other institutions is allowed. ${ }^{1453}$ Above that the provision does not apply in case the respective works can be purchased or licensed from right holders. It appears that right holders can decide whether the provision is applicable or not by offering to license the respective work. ${ }^{1454}$ Recently, however, the ECJ decided on this question and found that only existing license agreements between right holders and the institution not the mere offer to conclude a license agreement could exclude the application of the limitation. ${ }^{1455}$ If this decision applies to Portuguese copyright law as well is unclear. With regard to article 75

\footnotetext{
${ }^{1449}$ Art. 75 para. 2 h) CDA: "A inclusão de peças curtas ou fragmentos de obras alheias em obras próprias destinadas ao ensino."

${ }^{1450}$ Art. 75 para. 2 o) CDA: "A comunicação ou colocação à disposição de público, para efeitos de investigação ou estudos pessoais, a membros individuais do público por terminais destinados para o efeito nas instalações de bibliotecas, museus, arquivos públicos e escolas, de obras protegidas não sujeitas a condições de compra ou licenciamento, e que integrem as suas colecções ou acervos de bens."

${ }^{1451}$ Akester, Direito de Autor em Portugal e nos PALOP, 2013, p. 113, points out that the making available of works in digital format on dedicated terminals in libraries was a common practice already before the introduction of article 75 para. 2 o) CDA and deemed legitimate.

${ }^{1452}$ Cf. Bechthold in Dreier/Hugenholtz, Concise Copyright, InfoSocDir, art. 5 note 4 (o).

1453 lbid.

1454 lbid.

1455 See above 4.1.3.2.2.
} 
para. 5 CDA, which establishes that contractual agreements cannot override the exercise of the limitation, this is very much the question.

\subsection{Reproduction and Making Available of Orphan Works ${ }^{1456}$}

Another younger limitation in favour of access to education and knowledge is enshrined in article 75 para. 2 (u) CDA. This provision was introduced in order to transpose the Orphan Works Directive 2012/28/EU into Portuguese copyright law. The implementation was effected by Law No. 32/2015, April 24, 2015. The alteration came into force on April 25, 2015. ${ }^{1457}$ Article 75 CDA was amended and two new provisions were introduced, namely articles $26 \mathrm{~A}$ and 26B CDA. The demands of the Orphan Works Directive transposed for the most part.

The key provision is article 75 para. 2 (u) CDA, which establishes that libraries, educational institutions, museums, archives film and audio heritage institutions as well as public service broadcasting organisations are allowed to reproduce and make available orphan works to the public for the purposes of digitisation, indexing, cataloguing, preservation or restoration and carry out acts functionally connected provided that such uses happen in the context of their public interest goals, namely the right of access to information, education and culture, including the exploitation of intellectual goods. ${ }^{1458}$ Thus, this provision contains the actual limitation of exclusive rights. ${ }^{1459}$

The circumstances under which copyright protected works can be considered orphan works $^{1460}$, the categories of protected works ${ }^{1461}$ as well as the prerequisites for a diligent search for the right holder ${ }^{1462}$ and the sources for a diligent search ${ }^{1463}$ are contained in article $26 \mathrm{~A}$ para. 1 to $4 \mathrm{CDA}$. Article 26A para. 5 and 6 CDA specify the conditions of diligent searches for published and unpublished works. Article 26A para. 7 and 8 CDA establish the obligation for the privileged institutions to maintain registers concerning the diligent searches for right holders they have carried out. Finally, article 26A para. 9 CDA states that the privileged institutions may generate revenues by using orphan works for the exclusive

\footnotetext{
1456 The Portuguese term for orphan works is "obras órfãs".

${ }^{1457}$ Article 5 Law No. 32/2015, which was published in Diário da República N. ${ }^{\circ}$ 80/2015, Série I de 2015-04-24, p. 2055.

${ }^{1458}$ Article 75 para. 2 (u) CDA: "A reprodução e a colocação à disposição do público de obras órfãs, para fins de digitalização, indexação, catalogação, preservação ou restauro e ainda os atos funcionalmente conexos com as referidas faculdades, por parte de bibliotecas, estabelecimentos de ensino, museus, arquivos, instituições responsáveis pelo património cinematográfico ou sonoro e organismos de radiodifusão de serviço público, no âmbito dos seus objetivos de interesse público, nomeadamente o direito de acesso à informação, à educação e à cultura, incluindo a fruição de bens intelectuais."

${ }^{1459}$ See article 6 Orphan Works Directive 2012/28/EU.

1460 Article 26A para. 1 CDA.

${ }^{1461}$ Article 26A para. 2 CDA.

1462 Article 26A para. 3 CDA.

${ }^{1463}$ Article 26A para. 4 CDA.
} 
purpose of covering the costs of digitisation, treatment, safeguarding and preservation of such works. It is also clarified by article $26 \mathrm{~A}$ para. 9 CDA that the privileged institutions may conclude commercial agreements with public or private entities in order to receive financing, as long as these agreements establish no restrictions at all regarding the use of orphan works.

Article 26B CDA deals with the end of the orphan works status. The right to fair compensation for right holders who put an end to the orphan works status is established by Article 26B para. 2 and 3 CDA. Here as well the Portuguese legislator has observed the demands of the Orphan Works Directive closely.

As intended by the European legislator the implementation of the Orphan Works Directive in Portugal enables cultural heritage institutions to make great numbers of orphan works accessible to the public and individual users online. Since libraries and educational are among the privileged organisations, it is to be expected that access to knowledge and education will be improved.

\subsection{Three-Step-Test and Contract Clauses}

According to article 75 para. 4 CDA the application of the limitations contained in article 75 CDA must not harm the normal exploitation of the work and unduly prejudice the legitimate interests of the author. By implementing the Information Society Directive the Portuguese legislator has incorporated this "short version" of the Three-Step-Test, enshrined in article 5 para. 5 Information Society Directive. ${ }^{1464}$ The CDA does not explicitly restrict the application of the Three-Step-Test to "special cases", because the Information Society Directive itself only admits limitations to exclusive rights in the cases explicitly named, which by nature are special cases. ${ }^{1465}$ Therefore this restriction regarded as superfluous by the Portuguese legislator. ${ }^{1466}$ The Three-Step-Test is generally regarded as a limit to limitations, which is the reason behind article 75 para. 4 CDA. ${ }^{1467}$ However, this one-sided understanding of the Three-Step-Test hinders a sensible balance between the protection of authors and other rights and interests, which equally deserve protection. ${ }^{1468}$

Another interesting speciality of the CDA contains article 75 para. 5 CDA, which states that

\footnotetext{
${ }^{1464}$ Cf. Akester, Direito de Autor em Portugal e nos PALOP, 2013, p. 105.

${ }_{1465}^{14}$ Ascensão, O Direito da Internete em Portugal e no Brasil, 2011, p. 86.

1466 lbid.

1467 Ibid; Leitão, Direito de Autor, 2011, p. 160.

1468 Leitão, Direito de Autor, 2011, p. 160/161, with reference to Geiger / Hilty / Griffiths / Suthersanen, Declaration A Balanced Interpretation Of The "Three-Step Test" In Copyright Law. jipitec, Vol. 1, 2010, p. 119 - 121.
} 
any contract clause that aims to eliminate or impediment the normal exercise of limitations provided for in article 75 para. 1, 2 and 3 CDA by the beneficiaries is invalid. ${ }^{1469}$ This rule definitely strengthens the position of individuals and institutions relying on limitations. ${ }^{1470}$

\subsection{Remuneration}

In addition to the different prerequisites of article $75 \mathrm{CDA}$, further requirements of article 76 CDA have to be complied with. According to article 76 para. 1 CDA, just remuneration must be paid to the author or right holder for the use privileged by the limitation. However, article 76 para. 1 CDA does not apply to all limitations contained in article 75 CDA. According to article 76 para. 1 b) CDA just remunerartion has to be paid for the reproduction and making available of protected works for the purpose of information (article 75 para. 2 b) CDA) and for reproductions by libraries and educational institutions (article 75 para. 2 e) CDA). Following article 75 para. $1 \mathrm{c}$ ) CDA remuneration has to be paid also for the inclusion of short pieces of a work for education.

Since article 76 para. 1 CDA does not refer to the other limitations examined here by implication this means that no remuneration has to be paid for the reproduction, distribution and making available of parts of protected works to the public (article 76 para. $2 \mathrm{f}$ ) CDA), for the making available of protected works to the public on dedicated terminals (article 76 para. 2 o) CDA) and for the reproduction and making available of orphan works to the public (article 76 para. $2 \mathrm{u}$ ) CDA).

Further following article 76 para. 2 CDA the law forbids the confusion of the copies of the work and the original as well as the prejudice of the interests of the author or right holder by making extensive reproductions.

\subsubsection{Survey Results}

In order to find out how higher education institutions, publishers as well as government departments and interest groups in Portugal deal with copyright issues regarding e-learning and distance education a survey was conducted. Each type of stakeholder was asked to answer a questionnaire taking into account its special situation and interests. Taking into account that all public universities and several private higher education institutions (in total 28), the major academic publishers in Portugal (in total 3) as well as the Portuguese

\footnotetext{
${ }^{1469}$ Akester, Direito de Autor em Portugal e nos PALOP, 2013, p. 105/106, who points out that article 75 para. 4 CDA itself is overruled by article 222 CDA.

${ }^{1470}$ Ascensão, O Direito da Internete em Portugal e no Brasil, 2011, p. 87.
} 
Copyright Office (GEPAC) ${ }^{1471}$ and the Portuguese Institute of Industrial Property at Ministry of Justice (INPI) $)^{1472}$ received the questionnaire, the response rate was rather poor. In total only two higher educational institutions answered the questionaire.

Both answers to the questionnaire support the assumption that e-learning and distance education in higher education in Portugal is not yet widespread. E-learning courses generally are few. One institution informed that professors, who make use of e-learning methods, normally develop their own content and additionally use audiovisual services provided by the institution and partners of the e-learning project. The other institution informed that only some professors use digital content in their courses, but only few courses are strictly e-learning courses. Concerning the question, whether copyright is an important issue for the institution, especially with regard to e-learning, the answers are contradicting. One institution confirmed that copyright issues are addressed in the institution's regulation on intellectual property. The existence of a similar regulation was not known to the other institution and was alleged that even if such regulation did exist, it would probably be unknown to most of the professors. Only one institution claimed to invoke limitations for educational purposes for the uses of copyright protected material in the context of e-learning. The other institution did not answer this question. Both institutions indicated that no lawsuits were filed against them because of copyright infringement. Furthermore those institutions informed that there were no licence agreements concerning the use of digital content for education and e-learning. As well both institutions claimed neither to be part of an interest group regarding the development of copyright law nor to participate in any corporations concerning the exchange of educational and e-learning content with other higher education institutions of Portuguese speaking countries. However, both institutions confirmed to offer at least some e-learning courses. One institution specified that e-learning courses were provided for vocational training of the public administration as well as for postgraduate studies in Cape Verde. Regarding the future development of higher education and copyright law only one institution answered the question and denied any direct relation between these issues.

Although these answers only reflect the opinion of two higher education institutions and thus of course are not representative for the entirety of stakeholders in Portugal, one can draw the conclusion that questions of copyright law in the context of e-learning and distance education are largely ignored in Portugal. One reason may be that generally there are still only few elearning courses offered by higher education institutions. Another reason may be that there are no legal consequences such as lawsuits in case of infringement. Alone the fact that questions of copyright law in the context of education are not particularly present in Portugal

\footnotetext{
${ }^{1471}$ Gabinete de Estratégia, Planeamento e Avaliação Culturais.

1472 Instituto Nacional da Propriedade Industrial, Ministério da Justiça.
} 
however does not mean that they do not exist. Rather this suggests that Portuguese copyright law does not reflect the reality of higher education institutions as providers of elearning and distance education. It can be assumed that the introduction of broader limitations for educational purposes would promote the use of new technologies to deliver education.

\subsubsection{Summary Portugal}

As was shown above the use of ICT for education, especially distance education, on all levels of education is promoted in Portugal by the Portuguese legislator. The same is true for libraries and similar institutions. In fact, educational establishments as well as libraries and similar institutions use ICT to provide their services in ever-growing numbers.

However, limitations and exceptions for educational purposes and libraries, archives and similar institutions in Portugal only to a small extent reflect these developments. Portuguese copyright law contains several limitations and exceptions to copyright law for educational purposes and libraries, archives and similar institutions. These provisions privilege specific educational activities and activities of libraries and similar institutions, for instance reproductions and publicly making (digital) copies of copyright protected works available. The provisions approaching digital and/or electronic uses for educational purposes and in libraries and archives derive from the European Information Society Directive, which the Portuguese legislator has almost literally implemented. Digital issues thus are at least partly addressed. The limitation going back to the Orphan Works Directive has the potential to further promote the access to education and knowledge, because among other libraries and educational institutions are now allowed to make available great numbers of orphan works in digital format online. Nevertheless, as in other European countries also in Portugal the current legislation in the field of limitations and exceptions neglects widely the possibilities and the potential of digital technologies and the Internet for providers of education and library services. The current system of limitations and exceptions to Copyright in Portugal is complicated. Moreover, the dogma of restrictive interpretation and the one-sided understanding of the Three-Step-Test prevail. Relevant jurisdiction in Portugal in this area does hardly exist. Legal certainty for the respective institutions therefore it is not in site.

This estimate is confirmed with regard to the benchmark of permissible uses. Portuguese copyright law contains no open, broad and technologically neutral limitation either for educational establishments or for libraries, archives and similar institutions. Indeed, there are no limitations to the kind of works that can be used under the limitations. Thus, limitations apply digital works and, in theory, also to born-digital content. But there are restrictions to the 
amount of works that can be used. Educational establishments may reproduce, distribute and make available publicly only parts of published works. These parts may be used in classroom as well for online and distance education. Short pieces of works may be included in works for education. With regard to preservation and replacement public non-commercial libraries, archives, museums, centres of documentation and scientific and educational institutions are allowed to make reproductions of works for these purposes. There is no explicit limitation to the type of reproduction (analogue or digital) or the number of reproductions. Libraries and similar institutions, including schools, furthermore are allowed to make available works from their collections in digital format on dedicated terminals on their premises. The law is silent on the digitisation of analogue works for this purpose as well as on the uses permitted to the persons consulting the work. Remote access is not allowed. Concerning orphan works privileged institutions may now make reproductions, in particular digitisation is of orphan works and make them available online. The most relevant limitations for digital uses, i.e. reproductions for preservation and replacement, making available of parts of works and making available of works on dedicated terminals all are limited to noncommercial purposes. The law in addition clearly states that limitations and exceptions cannot be overruled by contract. There are no provisions on text and data mining and web harvesting. Although the latter as well as format shifting and out-of-commerce works may be covered by the limitation for reproductions for the purpose of preservation and replacement, since this provision is open to any forms of reproduction. In general, the provisions use a rather vague language, which leaves room for interpretations. With regard to the abovementioned dogma of restrictive interpretation of limitations and exceptions it is likely that this leeway will not be used in favour of addressees of the norms. Legal certainty thus is not improved.

This said in advance and in view of the objectives pursued, namely social and cultural development, the right to education and the right to take part in cultural life - both rights are constitutionally protected in Portugal -, it must be stated that limitations and exceptions for educational purposes and libraries, archives and similar institutions in Portugal do not adequately promote access to education and knowledge in the digital age.

The results of the survey conducted among stakeholders suggest that questions of copyright law and access to education and knowledge are largely ignored. A connection between access to education and knowledge and copyright law and limitations and exceptions is denied. 


\subsubsection{Brazil}

\subsubsection{Country Profile}

The Federative Republic of Brazil is the largest country in South America. It is the fifth largest country in the world taking into account its geographical area. It occupies almost half of South America. With a population of 202 million in 2014 Brazil is also the fifth most populous country and the fourth most populous democracy in the world. Its coastline to the Atlantic Ocean on the East is $7491 \mathrm{~km}$ long. To the North Brazil has borders with Venezuela, Suriname, Guyana and French Guiana. To the North West Brazil is bordered by Colombia, in the West by Bolivia and Peru. To the South West Brazil is bordered by Argentina and Paraguay and to the South by Uruguay.

From 1500 on, when Pedro Álvares Cabral landed on Brazilian territory, Brazil was a colony of Portugal until it gained independence in 1822. Before becoming a republic in 1889 Brazil was an empire. The first constitution was ratified in 1824. From 1964 until 1985 Brazil was governed by a military regime. The current constitution of October 5,1988 , makes Brazil a Federal Republic, which consists of the Federal District, 26 states and 5570 municipalities. Brazil is a democracy with a presidential system. The actual president and head of government is Michel Temer, who was inaugurated on August 31, 2016.

According to its gross domestic product Brazil is the seventh largest economy in the world. ${ }^{1473}$ Brazil is a founding member of the United Nations, the G20, the BRIC and the BRICS group, Unasul, Mercosul, the Organisation of American States, and the Organisation of Ibero-American states, CPLP and the Latin Union. Its population is mainly Roman Catholic. The official language is Portuguese. The society is multi-ethnic. Brazil has large natural resources like oil, gas and noble metal. Also, the agricultural sector is strong. Wood industry, cattle breeding and coffee production are important economic branches.

\subsubsection{Educational System}

The Brazilian educational system roots in the Constitution of 1988. The constitution establishes education as a universal right, which should be promoted by the government. ${ }^{1474}$ Based on this fundamental principle the Law of National Education Guidelines and Framework was enacted in 1996. ${ }^{1475}$ This law forms the basis for primary and secondary education on a national level. Together with other legislation such as the Education

\footnotetext{
${ }^{1473}$ Worldbank, Gross Domestic Product 2014, available at http://databank.worldbank.org/data/download/GDP.pdf.

${ }^{1474}$ Art. 205: "A educação, direito de todos e dever do Estado e da família, será promovida e incentivada com a colaboração da sociedade, visando ao pleno desenvolvimento da pessoa, seu preparo para o exercício da cidadania e sua qualificação para o trabalho."

${ }^{1475}$ Lei de Diretrizes e Bases da Educação Nº 9.394, de 20 de Dezembro de 1996.
} 
Development Plan ${ }^{1476}$, which was launched in 2007, the Law of National Education Guidelines and Framework 1996 has improved the educational system of Brazil.

The supervision of education in Brazil is carried out by ministries and government offices. These institutions work together on federal, state and municipality level. It is the responsibility of the municipalities to provide and regulate early childhood education, whereas the states and the federal district have to take care of the provision and regulation of primary and secondary education. Private educational institutions are regulated by the federal government.

Several institutions supervise and regulate education in Brazil. The Ministry of Education provides technical and financial support to the municipalities, the states and to the federal district. Also, the Ministry of Education drafts new legislation regarding education and supports the network of federal education institutions. Moreover, the Ministry of Education supervises the private educational system. The National Committee for Evaluation of Higher Education ${ }^{1477}$ supervises and coordinates the national system of higher education evaluation. ${ }^{1478}$ The tasks of the Committee consist among others in the evaluation of the dynamics, processes and mechanisms of institutional evaluation, of courses and student performances as well as the establishing of guidelines for the organisation and the design of evaluation committees, the analysis of reports, the elaboration of proposals and the making of recommendations to the respective institutions. ${ }^{1479}$ The Coordination for the Improvement of Higher Education Personnel ${ }^{1480}$ is responsible for the evaluation of postgraduate programmes, for the access to and the dissemination of scientific production, investments in the formation high level resources domestically and abroad, the promotion of international scientific co-operation as well as for the formation of teachers for basic present and distance education. ${ }^{1481}$

\footnotetext{
1476 O Plano de Desenvolvimento da Educação, available at http://portal.mec.gov.br/arquivos/livro/livro.pdf.

${ }^{1477}$ Comissão Nacional de Avaliação da Educação Superior (CONAES).

${ }^{1478}$ Sistema Nacional de Avaliação da Educação Superior (SINAES), instituído pela Lei nº 10.861, de 14 de Abril de 2004

${ }^{1479}$ A CONAES possui as seguintes atribuições:

I - propor e avaliar as dinâmicas, procedimentos e mecanismos da avaliação institucional, de cursos e de desempenho dos estudantes; II - estabelecer diretrizes para organização e designação de comissões de avaliação, analisar relatórios, elaborar pareceres e encaminhar recomendações às instâncias competentes; III formular propostas para o desenvolvimento das instituições de educação superior, com base nas análises e recomendações produzidas nos processos de avaliação; IV - articular-se com os sistemas estaduais de ensino, visando a estabelecer ações e critérios comuns de avaliação e supervisão da educação superior;

V - submeter anualmente à aprovação do Ministro de Estado da Educação a relação dos cursos a cujos estudantes será aplicado o Exame Nacional de Desempenho dos Estudantes ENADE;

$\mathrm{VI}$ - elaborar o seu regimento, a ser aprovado em ato do Ministro de Estado da Educação;

VII - realizar reuniões ordinárias mensais e extraordinárias, sempre que convocadas pelo Ministro de Estado da Educação.

${ }_{1480}$ Coordenação de Aperfeiçoamento de Pessoal de Nível Supersior (CAPES).

${ }^{1481}$ Mission and History Fundação Capes, available at http://www.capes.gov.br/historia-e-missao.
} 
Education is divided into preschool, basic and higher education in Brazil.

Preschool education (Educação Infatil) is facultative. It aims to promote the development of children under 6 by assisting in all areas of development such as motor skills, cognitive skills and social skills. Preschool education aims at the preparation for the acquisition of knowledge and learning later. ${ }^{1482}$

Basic education is divided into fundamental and secondary education. Fundamental education (Ensino Fundamental) has a duration of nine years and is compulsory for children aged 6 to 14 years. The curriculum consists of history, geography, science, mathematics, arts, Portuguese and physical education. Secondary education (Ensino Médio) has a duration of three years. In order to enrole for secondary education students must have finished fundamental education. The curriculum comprises Portuguese (including Portuguese language, Brazilian and Portuguese literatures), foreign language (mostly English or Spanish), history, geography, mathematics, physics, chemistry, biology, arts and physical education. Also, the possibility exists for students to enrole in vocational secondary education (Educação Profissional Técnica de Nível Médio), which lasts 3 to 4 years and provides for a specific professional training. ${ }^{1483}$ Additionally to secondary and vocational secondary education students in Brazil may engage in adult education.

The admission to higher education (Ensino Superior) requires the completion of secondary education. There are two types of higher education institutions, public and private. ${ }^{1484}$ Public higher education institutions are run by the federal or the state government or by the municipalities whereas private institutions are run by individuals or legal entities with or without commercial purposes. ${ }^{1485}$ In order to be admitted to higher education institutions students must pass an exam. This admission exam is called the "vestibular". ${ }^{1486}$ Since 1998 there has been another entrance exam, which is called "Exame Nacional do Ensino Médio" (ENEM). The ENEM was introduced for the purpose of assessing the quality of education in Brazil. ${ }^{1487}$ In 2009 ENEM became the official university entrance exam and has now replaced

\footnotetext{
1482 See "Researching Virtual Initiatives for Education: Brazil", available at http://www.virtualschoolsandcolleges.eu/index.php/Brazil\#Pre-School education_.28Educa.C3.A7.C3.A3o_Infan til.29.

${ }^{1483}$ Since 2004 vocational secondary education has been enhanced by the Brazilian government, because of its importance for the qualification of the labour force. Especially the so-called PRONATEC Program (Programa Nacional de Acesso ao Ension Técnico e ao Emprego) provides access to professional education by offering a series of courses and programs. One of these programs is E-Tec Brasil, which stands for Programa Éscola Técnica Aberta do Brasil. It started in spring 2008 and offers technical training in the form of distance education. (http://www.virtualschoolsandcolleges.eu/index.php/Brazil)

${ }^{484}$ Becker-Reifschneider: Distance Education in Brazil and in the United States, 2006, p. 584.

1485 lbid.

${ }^{1486}$ Stanek, The Educational System of Brazil, 2013, p. 4.

1487 lbid.
} 
the "vestibular" in many higher education institutions. ${ }^{1488}$ These entrance exams generally are very competitive. ${ }^{1489}$ The entrance exams at public higher education institutions, which raise no tuition fees, are especially competitive. ${ }^{1490}$ Public higher education institutions run by the federal government are considered to be the best. ${ }^{1491}$ Due to the very difficult entrance exams mostly students from families with higher income, who can afford private tuition as a preparation for the entrance exam, are admitted to public higher education institutions, which are mainly free of charge. ${ }^{1492}$ Students from families with lower income, who cannot afford private tuition as a preparation for the entrance exam, therefore mostly visit private higher education institutions, which charge tuition fees. ${ }^{1493}$ In order to overcome this problem the Brazilian legislator in 2012 enacted several affirmative action laws according to which it is required that $50 \%$ of the new students entering each year at federal higher education institutions must come from public secondary schools. ${ }^{1494}$

Generally higher education can be divided into two levels, which are undergraduate (graduação) and graduate (pos-graduação). ${ }^{1495}$ After 4 to 6 years of undergraduation students will obtain a "licenciado", which is equivalent to a bachelors degree. ${ }^{1496}$ Subsequently graduate students may obtain a master's degree ("mestre") after 18 to 24 months or the title "doutor" after the successful completion of a doctorate, which normally has a duration of four years. ${ }^{1497}$

\subsubsection{Information Communication Technologies}

Both in education and libraries ICT today are indispensable. ICT enrich face-to-face teaching and enable interactive distance education ${ }^{1498}$ as well as help libraries to provide their services online and preserve their collections for the future.

Regarding education ICT generally are related to e-learning and distance education. The term e-learning encompasses all types of technology-based teaching and learning. A clear definition does not exist. In Brazil the term distance education however is defined by art. 1 of the Decree $5.622 / 2005^{1499}$ as follows:

\footnotetext{
1488 Ibid.

1489 Ibid.; Becker-Reifschneider, Distance Education in Brazil and in the United States, 2006, p. 584.

1490 Stanek, The Educational System of Brazil, 2013, p. 4; Becker-Reifschneider, Distance Education in Brazil and in the United States, 2006, p. 584.

1491 Stanek, The Educational System of Brazil, 2013, p. 4.

1492 Ibid.

1493 http://www.virtualschoolsandcolleges.eu/index.php/Brazil.

1494 Costa, A New Era for Higher Education in Brazil, in University World News Global Edition, 2014.

1495 Stanek, The Educational System of Brazil, 2013, p. 4.

1496 lbid.

1497 Ibid.

1498 Cella / Tarrit, Institutional Integration of an ICT in Education Solution in a Brazilian University, 2011, p. 2.

${ }^{1499}$ Art. 1 of the Decree 5.622 of December $19^{\text {th }}, 2005$, regulating art. 80 Federal Law $N^{\circ} 9.394$, December $20^{\text {th }}$
} 
"For the ends of this decree distance education is characterised as a modality of education in which the didactic-pedagogic mediation and teaching and learning process happens with the use of information and communication technologies and with students and professors developing educational activities in diverse places or times."

Since 2007 when the Education Development Plan was released by the Brazilian government, several programs have aimed at the promotion of distance higher education. ${ }^{1500}$ These programs are executed by the Open University of Brazil (Universidade Aberta do Brasil). ${ }^{1501}$ According to the Census carried out by the Brazilian Distance Education Association ${ }^{1502}$ there were 1550 full distance courses in higher education in $2013 .{ }^{1503}$ The majority of courses is offered by private for-profit institutions. ${ }^{1504} 572,389$ students were enrolled in higher education full distance courses. ${ }^{1505}$ The number of blended distance courses, meaning that presence is partly required, in higher education in Brazil by contrast was only 353 , whereas the majority of courses was offered by public non-profit institutions. ${ }^{1506}$ There were 151,304 students enrolled in higher education blended distance courses in Brazil in 2013. ${ }^{1507}$ Compared to the total number of 7,305,977 students enrolled in higher education in Brazil in 2013 the role of distance education appears to be rather small. ${ }^{1508}$ Nevertheless, with the improvement of access to ICT and broadband Internet connections the advantages of distance education in a country like Brazil with great distances to overcome and urgent need for education e-learning and distance education will further grow. Not surprisingly, according to the EaD Census 2013, the great majority of distance education institutions informed that investments in distance education increased in 2013 and they were also expecting further increases of investments for 2014. ${ }^{1509}$ Thus, although relatively small in numbers, distance education in future may provide at least a partial solution to the problem of supply and demand in higher education in Brazil. ${ }^{1510}$

Education, not only in Brazil but also worldwide, is considered to be one of the most important factors for social development. The right to education is laid down in article 26 of the universal declaration of human rights. As was said above the Brazilian constitution of

\footnotetext{
1996.

1500 Cf. Costa, A New Era for Higher Education in Brazil, in University World News Global Edition, 2014.

1501 lbid.

1502 Associação Brasileira de Educação à Distância (ABED).

${ }_{1503}$ ABED, 2013 Brazilian Census for Distance Learning, p. 66.

1504 Ibid.

1505 Idem, p. 69

1506 Idem, p. 72

1507 Idem, p. 75

1508 Becker-Reifschneider, Distance Education in Brazil and in the United States, 2006, p. 590.

1509 ABED, 2013 Brazilian Census for Distance Learning, p. 102.

${ }^{1510}$ Becker-Reifschneider, Distance Education in Brazil and in the United States, 2006, p. 590.
} 
1988 promotes education as a fundamental right. ${ }^{1511}$ To guarantee that fundamental right, access to education of all levels must be granted. This becomes difficult in a country like Brazil with millions of people longing for education. Granting access to higher education is especially difficult because the number of places to study in presence courses at higher education institutions is limited and therefore cannot satisfy the demand. Moreover, the improvement of access to higher education in Brazil is so urging, because the Brazilian higher education system is characterised by selectivity and permanent inequality regarding access. ${ }^{1512}$ At that point e-learning and distance education have the potential to enlarge the access to higher education because due to possibilities offered by ICT great numbers of students may follow and participate courses at higher education institutions, which otherwise would be locked for them. ${ }^{1513}$ This is why e-learning and distance education could be adequate modalities for the educational inclusion of large parts of the Brazilian population, which at the moment have no access to higher education. ${ }^{1514}$ Thereby the constitutional promise of the right of education for the entire population of Brazil could at least partly be delivered. ${ }^{1515}$

Libraries play a key role with regard to access to education and knowledge. Libraries are the main intermediaries for information. This is true for traditional libraries providing access to its collections on their premises mainly in printed form as well as for digital libraries providing access to its collections over the Internet or other networks in digital form. Considering the masses of information available today the task of libraries is also to help people to evaluate the content and the utility of the information they find. ${ }^{1516}$ Thereby libraries promote access to information. As well in the context of distance education and e-learning libraries today are important because they enable access to information and knowledge via the Internet for students who do not have access to a traditional library. ${ }^{1517} \mathrm{~A}$ traditional library is one whose collection consists mainly of documents on paper and also the organisation of the collection is paper-based. ${ }^{1518} \mathrm{~A}$ digital library combines the structure and the collection of information traditionally used by libraries and archives with possibilities of digital and information communication technologies. ${ }^{1519}$ Libraries have always been institutions, which gathered information in a physical place in order to make it available to the community of their users, which led that at the same time to the exclusion of people outside of that user community. ${ }^{1520}$

\footnotetext{
${ }^{1511}$ Art. 205 Constituição Federal de Brasil 1988.

1512 Medeiros De Souza: Do Sernigal à Universidade: O Acesso das Camadas Populares ao Ensino Superior Público no Acre, 2009, p. 16.

1513 Monteiro Cavalcanti Manso Junior, Direito à Educação, 2011, p. $7 \mathrm{ff}$.

1514 Idem, p. 9/10.

1515 Idem, p. 10

${ }^{1516}$ Bastos da Cunha, Das Bibliotecas Convencionais às Digitais, 2008, p. 9.

1517 Pohlman Filho, Ensino à Distância, Bibliotecas Digitais e os Direitos Autorais, 1999, p. 105.

1518 Bastos da Cunha, Das Bibliotecas Convencionais às Digitais, 2008, p. 5.

1519 lbid.

1520 Santiago, Propriedade Intelectual e o Acesso à Informação em Bibliotecas Digitais no Brasil, 2007, p. 23.
} 
This has changed with the Internet, which not only augmented the potential to collect and store information but also has the capacity to make the information stored by libraries available to a much larger public without the limitations of space and time. ${ }^{1521}$

The manifold possibilities provided by ICT and the Internet regarding the use of information by libraries and in the context of e-learning and distance education bring about questions related to copyright law. The information collected by libraries as well as educational materials used in the context of e-learning and distance education regularly consists of copyright protected works, which may only be used with the prior consent of the author or right holder unless there are limitations and exceptions allowing such uses without the author's prior consent.

In Brazil the discussion is however mainly about the protection of the rights of authors, whose works are used by libraries and in the context of e-learning and distance education rather than about the limitations and exceptions privileging certain institutions such as libraries, archives, museums and higher education institutions to make use of copyright protected works without the author's or right holder's consent in the public interest. ${ }^{1522} \mathrm{~A}$ legal regime for distance education and e-learning with regard to copyright law does not exist in Brazil. ${ }^{1523}$ The same is true for the use of copyright protected works by libraries and their users. ${ }^{1524}$ Consequently there is considerable legal uncertainty in Brazil for higher education institutions and libraries as well as for students and library users regarding copyright law. This situation affects the access to education and information in Brazil negatively.

In the context of this study it is of special interest how Brazilian Copyright Law deals with the use of copyright protected works by higher education institutions in the context of e-learning and distance education and by libraries and archives with regard to the access to education, knowledge and information.

In the following I will therefore take a short look at the Brazilian copyright law regime, its history and general principles. Afterwards I will analyse the current limitations and exceptions provided by the Brazilian Copyright Code privileging educational institutions and libraries and archives.

\footnotetext{
1521 lbid.

1522 Alves Teixeira, Algumas Refelxções sobre a Educação à Distância e o Direito de Autor, 2008, p. 8/9; Santiago, Propriedade Intelectual e o Acesso à Informação em Bibliotecas Digitais no Brasil, 2007, p. 26.

${ }_{1523}$ Cf. Jeane Cristina de Oliveira Limas, O Direito Autoral Na Educação à Distância, 2004, no. 4.

1524 Gama, Direito à Informação e Direitos Autorais: desafios e soluções para os serviços de informação em bibliotecas universitárias, 2008 , p. 35/36, who especially addresses the problem of private copies by library users. According to article 46 para. 2 Brazilian Copyright Code it is allowed to make a single reproduction of a "small part" of a protected work for private use. The definition of a "small part" is subjected to a fierce debate in Brazil and particularly effects university libraries.
} 


\subsubsection{Brazilian Copyright Law}

Brazilian Copyright Law has constitutional underpinnings. The Federal Constitution enacted October 5, 1988 is the supreme rule of the country and organises the country as a Federative Republic. ${ }^{1525}$ Article $5 \S 27$ of the Constitution states that "authors have the exclusive right of use, publication or reproduction of their works, which is transmissible to their heirs for the time the law shall establish". According to article 5 of the Constitution this rule applies to Brazilians and to foreigners residing in the country. It is the Constitution that allocates the competence for copyright matters to the Federal State. Consequently, copyright is governed by federal law. ${ }^{1526}$

Brazilian copyright law belongs to the Droit d`Auteur legal tradition. ${ }^{1527}$ However, Brazil is strongly influenced by North America in copyright issues. ${ }^{1528}$ The most important source of copyright law is the federal Brazilian Copyright Act, Statute No. 9.610 of February 19, 1998). ${ }^{1529}$ The Brazilian Criminal Code (Federal Decree No. 2.848 of December 7, 1940) ${ }^{1530}$ also contains provisions regarding copyright, regulating infringements of copyrights, and the Brazilian Criminal Procedure Code (Federal Decree No. 3.689 of October 3, 1941) ${ }^{1531}$ provides rules for a special procedure in case of copyright related crimes. ${ }^{1532}$ The Brazilian Software Law (Federal Decree No. 9.609 of February 19, 1998) ${ }^{1533}$ deals with copyright protection of computer programs. Furthermore, there is a great number of secondary laws, such as resolutions, normative acts and instructions and administrative rules issued by the public authorities etc., which have no significance in the context of this analysis. ${ }^{1534}$

Historically, in Brazil the regime of printing privileges remained the only Copyright protection for a long time even after the independence from Portugal in $1824 .{ }^{1535}$ The first law regulating aspects of Copyright dates from 1830, namely the Criminal Code from 1830 prohibiting the reproduction of works composed or translated by Brazilians. ${ }^{1536}$ Until 1889 there were some efforts to establish a law regulating the protection of authors 'rights, which however were not successful. In the course of the international movement of authors' rights protection Brazil

\footnotetext{
${ }_{1525}^{152}$ Azevedo in Copyright Throughout the World, 2015, no. 6.1.

1526 Ibid.

1527 Ibid; Ascensão, O Direito da Internete em Portugal e no Brasil, 2011, p. 84.

1528 Ibid.

${ }^{1529}$ Azevedo in Copyright Throughout the World, 2015, no. 6.2; Lei dos Direitos Autorais, No. 9.610/1998.

1530 Código Penal No. 2.848/1940.

1531 Código de Processo Penal No. 3.689/1941.

${ }_{1532}$ Azevedo in Copyright Throughout the World, 2015, no. 6.2.

1533 Lei do Software No. 9.609/1998.

1534 Azevedo in Copyright Throughout the World, 2015, no. 6.3.

${ }^{1535}$ Ascensão, Direito Autoral, 1997, no. 6.

1536 Ibid.
} 
concluded a bilateral agreement with Portugal, ${ }^{1537}$ guaranteeing reciprocal national treatment of authors. ${ }^{1538}$ The first notable copyright legislation was enacted only after the proclamation of the republic in 1890 in the Criminal Code. ${ }^{1539}$ But already in 1891 the protection of authors rights was incorporated into the Constitution of the Republic, whose article $72 \S 26$ fixed the authors` exclusive right of reproduction as well as the protection of their heirs. ${ }^{1540}$ By and large this principle has been upheld until today in the successors of the first Constitution. ${ }^{1541}$ Finally, on August 1, 1898 Law no. 496 was enacted and guaranteed authors' rights equally to Brazilians and foreigners. ${ }^{1542}$ The first Brazilian Civil Code from January 1, 1916 then regulated the matter in articles 649 to 673 under the title "On literary, scientific and artistic property" and provided at least some legal certainty. ${ }^{1543}$ Although on January 2, 1928, Decree no. 4.790 was enacted ruling on authors' rights, only with Law no. 4.944 from April 6, 1966, alternated by Decree no. 61.123 from April 1, 1967, authors' rights and related rights were legally regulated. ${ }^{1544}$ In the following period there were no notable developments in Brazilian Copyright law. ${ }^{1545}$ This started to change with the above mentioned Constitution of the Republic in the year 1988 and the ensuing copyright legislation.

Brazil adheres to several international agreements and conventions regarding copyright law, which bring about obligations for the Brazilian legislator. The most important of these conventions and agreements are the Rome Convention of October 26, 1961, ratified with federal Decree no. 57.125 of October 19, 1965, the Berne Convention of September 9, 1886 in the Paris version of July 24, 1971, ratified with federal Decree no. 75.699 of May 6, 1975 and the TRIPS Agreement of April 12, 1994, ratified with federal Decree no. 1355 of December 30, 1994. Since Brazil has ratified the Paris version of the Berne Convention, also the Berne Appendix is in force. However, Brazil has never made a notification to make use of licensing schemes as provided by the Berne Appendix. Moreover, Brazil is party of several bilateral agreements, which have practically no significance hence most subjects are embraced by the Berne Convention and the TRIPS agreement. ${ }^{1546}$

\footnotetext{
1537 Decree No. 10.353, September 14, 1889.

1538 Ascensão, Direito Autoral, 1997, no. 6.

1539 lbid.

1540 lbid.

1541 Idem, p. 12

1542 Ibid.

1543 lbid.

1544 Ibid.

1545 Ibid.

${ }^{1546}$ Azevedo in Copyright Throughout the World, 2015, no. 6.8.
} 


\subsection{Protected Works}

Article 7 Brazilian Copyright Act ${ }^{1547}$ contains a list of types of works, which are protected by copyright. Generally works are protected even if they are not mentioned in that list of article 7 BCA provided that they are "creations of the mind, whatever their mode of expression or the medium, tangible or intangible, known or susceptible of invention in the future, in which they are fixed." In particular the following types of works are listed:

"I. the texts of literary, artistic or scientific works;

II. lectures, addresses, sermons and other works of the same kind;

III. dramatic and dramatico-musical works;

IV. choreographic and mimed works whose stage performance is set down in writing or otherwise;

V. musical compositions with or without words;

VI. audiovisual works, with or without accompanying sounds, including cinematographic works;

VII. photographic works and other works produced by a process analogous to photography; VIII. drawings, paintings, engravings, sculptures, lithographs and works of kinetic art;

IX. illustrations, maps and other works of the same kind;

$X$. drafts, mock-ups and three-dimensional works relating to geography, engineering, topography, architecture, park and garden planning, stage scenery and science;

$X I$. adaptations, translations and other transformations of original works, presented as new intellectual creations;

XII. computer programs;

XIII. collections or compilations, anthologies, encyclopedias, dictionaries, databases and other works which, by virtue of the selection, coordination or arrangement of the subject matter, constitute intellectual creations."

This list however is not exhaustive and Brazilian courts have recognized protection for a number of other creations. ${ }^{1548}$

According to article 7 BCA protected by copyright law are creations of the mind. Albeit only creations of the human mind are protected as article 11 BCA states by declaring "the author of a literary, artistic or scientific work is the natural person who created it." Further the creation of the human mind must fulfil the requirements of expression and originality. The criterion of expression refers to the embodiment of the creation of the human mind, independently of the material that is used to express the creation. ${ }^{1549}$ It may be tangible or

\footnotetext{
1547 In the following "BCA".

${ }^{1548}$ Azevedo in Copyright Throughout the World, 2015, no. 6.9; Plinio Cabral, A Nova Lei de Direitos Autorais, 2003 , p. 26

${ }_{1549}$ Plinio Cabral, A Nova Lei de Direitos Autorais, 2003, p. 26; Ascensão, Direito Autoral, 1997, no. 20; Azevedo in Copyright Law Throughout the World, 2008, no. 6.11.
} 
intangible. The creation thus may be also expressed in a virtual or digital form to enjoy copyright protection so far as there is a concrete manifestation. ${ }^{1550}$ The other criterion for copyright protection is the originality of the creation. In order to receive copyright protection a creation has to be original. This means that the author must have expressed his own idea in his own way. ${ }^{1551}$ This must also include a minimum of creativity. ${ }^{1552}$ Furthermore the creation must be new, however it must not be entirely new because the notion of originality under $\mathrm{BCA}$ is relative, which means that works can be inspired by other works or based on the same idea and still be considered original as long as they are not a mere copy. ${ }^{1553}$ When these criteria are met protection under BCA accrues automatically.

No protection however is granted for ideas or concepts expressed in a work. Article 8 para. 1 BCA therefore establishes that "ideas, normative procedures, systems, methods or mathematical projects or concepts as such;" are excluded from protection. According to article 8 para. 2 to 7 BCA no protection is granted as well for

II. diagrams, plans or rules for performing mental acts, playing games or conducting business; III. blank forms intended for completion with all kinds of scientific or other information, and the instructions appearing thereon; IV. the texts of treaties or conventions, laws, decrees, regulations, judicial decisions and other official enactments; $V$. information in common use such as that contained in calendars, diaries, registers or legends; VI. names and titles in isolation; VII. the industrial or commercial exploitation of the ideas embodied in works. "This enumeration is not exhaustive but gives examples of cases in which due to lack of originality or expression no copyright protection is conferred. ${ }^{1554}$

\subsection{Moral Rights ${ }^{1555}$}

Brazilian copyright law recognises moral rights of the author. Moral rights have the intention to protect the personal and idealistic interests of the author. These rights are "inalienable and irrevocable" as article 27 BCA declares, but they pass over to the successors of the author according to article $24 \S 1 \mathrm{BCA}$. Moral rights protect the personal relationship of the author to his work. The author of a copyright protected work is entitled to certain moral rights arising from the act of creation, which is the expression of his personality as articulated by article 11 BCA. Article 24 BCA enumerates the moral rights of the author.

\footnotetext{
1550 Plinio Cabral, A Nova Lei de Direitos Autorais, 2003, p. 26.

1551 See Rogel / Drummond, Manual de Direito Autoral, 2010, p. 20.

1552 Rodrigo Azevedo in Copyright Law Throughout the World, 2008, no. 6.11; Poli, Direito Autoral, 2008 , p. 112.

1553 See Ascensão, Direito Autoral, 1997 no. 40; Poli, Direito Autoral, 2008, p. 112/113; Azevedo in Copyright Law Throughout the World, 2008, no. 6.11.

${ }^{1554}$ Menezes, Curso de Direito Autoral, 2007, p. 41.

1555 Title III Chapter II Brazilian Copyright Act "Direitos Morais do Autor".
} 
The most important moral right is the Paternity right. ${ }^{1556}$ Actually it comprises two rights, which are the right to claim the authorship of the work, article 24 para. $1 \mathrm{BCA}$, and the right to claim the indication of the author's name, article 24 para. 2 BCA.

According to art. 24 para. 3 BCA the author also has the right to keep his work unpublished. By implication this means that the right of first publication of his work also belongs to the author. ${ }^{1557}$ The right to keep the work unpublished respectively the right of first publication expires when the work is published with the consent of the author for the first time. ${ }^{1558}$ According to art. $24 \mathrm{BCA}$ the author further enjoys the right of integrity (article 24 para. 4 $\mathrm{BCA}$ ), the right of modification (article 24 para. $5 \mathrm{BCA}$ ), the right of withdrawal (article 24 para. $6 \mathrm{BCA}$ ) and the right to access the work under certain conditions (article 24 para. 7 BCA).

With regard to educational activities the most interesting and important rights are the right of first publication and the right to claim authorship respectively the right to claim the indication of the name. The author of any text thus has the right to decide whether the text should be published or not. Once published the author can only control the further exploitation of the work, the right of first publication itself is already exhausted. The author cannot however inhibit certain privileged uses. Even more important is the right to claim authorship and the indication of the author's name. In connection with the use of copyright protected materials (e.g. scientific works) for e-learning in higher education institutions it is essential for authors to be recognized as the creators of their works since this is the only way to make their name known. However, the author of a work may also to a certain extend renounce the right to claim indication of his name in certain cases, for instance in case the author works as a ghostwriter, which is not uncommon in higher education institutions. ${ }^{1559}$ Moreover, employees of higher education institutions sometimes renounce their right to claim the indication of the name in their working contracts. It is a question of the individual case if the renunciation is legally possible or not. In any case the author of a work cannot completely renounce his right to claim indication of his name because of its personal content. For the quality of being author of the work in question cannot be transferred to anybody. ${ }^{1560}$ In so far the principle of article 27 BCA prevails.

\footnotetext{
${ }_{1556}^{156}$ Menezes, Curso de Direito Autoral, 2007, p. 70; Azevedo in Copyright Throughout the World, 2015, no. 6.19f.

1557 Menezes, Curso de Direito Autoral, 2007, p. 71; Acensão, Direito Autoral 1997, p. 133

1558 Menezes, Curso de Direito Autoral, 2007, p. 71

1559 See Taeger/Horn, Hochschule und neue Medien, 2008, p. 89.

1560 Menezes, Curso de Direito Autoral, 2007, p. 68.
} 


\subsection{Economic Rights ${ }^{1561}$}

According to article $28 \mathrm{BCA}$ "the author has the exclusive right to use his literary, artistic or scientific work, to derive benefit from it and to dispose of it." Any kind of use of the work depends on the prior authorisation of the author, as stated by article 29 BCA. This shall be necessary especially in the cases enumerated in article 29 para. 1 to $10 \mathrm{BCA}$ :

“l. complete or partial reproduction;

II. publication;

III. adaptation, setting to music or any other transformation;

IV. translation into any language;

$\checkmark$. incorporation in a phonogram or in an audiovisual production;

VI. distribution where it is not provided for in a contract signed by the author with third parties for the use or exploitation of the work;

VII. distribution for the purposes of offering works or productions by cable, optic fiber, satellite, electromagnetic waves or any other system enabling the user to select a work or production and receive it at the time and place of his choice, provided that the access to the works or productions is made through any system requiring payment on the part of the user; VIII. the direct or indirect use of the literary, artistic or scientific work in one of the following forms:

(a) performance, recitation or declamation; (b) musical performance;

(c) use of loudspeaker or comparable systems;

(d) radio or television broadcasting;

(e) reception of a radio broadcast in places frequented by the public;

(f) provision of background music;

(g) audiovisual, cinematographic or equivalent presentation;

(h) use of man-made satellites;

(i) use of optical systems, telephone or other lines, cables of all kinds and such comparable means of communication as may be devised in the future;

(j) exhibition of works of three-dimensional and figurative art;

$I X$. incorporation in databases, storage in a computer, microfilming and any other means of archiving of that kind;

$X$. any other form of use that exists at present or might be devised in the future."

This enumeration of uses is not exhaustive. ${ }^{1562}$ The Brazilian legislator has also tried to take into account future technological developments, which lead to new forms of use, by declaring

\footnotetext{
1561 Title III Chapter III Brazilian Copyright Act "Dos Direitos Patrimoniais do Autor e de sua Duração".

1562 Poli, Direito Autoral, 2008, p. 38; Paranagua / Branco, Direitos Autorais, 2009, p. 53/54.
} 
in article 29 para. $10 \mathrm{BCA}$ "any other form of use that exists at present or might be devised in the future."

According article $41 \mathrm{BCA}$ economic rights are protected for seventy years after the death of the author. This period is counted from January 1 of the year following the death of the author. If this period has expired the work is in the public domain.

Hereinafter the most important economic rights in the context of education and in libaries shall be analysed shortly. In order to describe the scope of the respective right article $5 \mathrm{BCA}$ provides for some general definitions.

\subsection{Right of Reproduction and Right of Communication to the Public}

The scope of the right of reproduction contained in article 29 para. 1 BCA is defined by article 5 para. $4 \mathrm{BCA}$, which states that reproduction means making one or more copies of a literary, artistic or scientific work or phonogram in any tangible form, including any permanent or temporary storage by electronic means or any other means of fixation that may be devised in the future. Any reproduction of a work, be it complete or partial, made without the consent of the author is prohibited, unless the work is in public domain.

Regarding the right of reproduction it is important to mention article $30 \mathrm{BCA}$, which establishes that "in the exercise of the right of reproduction, the owner of copyright may make the work available to the public in whatever form and place and for whatever time that he considers appropriate, either for a consideration or free of charge." Thus the right of communication to the public is regarded as a subcategory of the right of reproduction. ${ }^{1563}$ Following article 5 para. $5 \mathrm{BCA}$ communication to the public is defined as the act of making a work accessible to the public by any means or process that does not consist in the distribution of copies.

For the purpose of taking the technological development into account article $30 \mathrm{BCA}$ guarantees the author the exclusive right of reproduction independently of the medium and/or place used. ${ }^{1564}$ This provision may encompass the right of making a work available to the public on the Internet. There are however two exceptions in $\S 1$ and $\S 2$ of article 30 BCA.

\footnotetext{
${ }^{1563}$ Article 68 BCA contains special provisions regarding the right of communication to the public for stage works, for musical compositions with or without words and for phonograms.

${ }^{1564}$ Cabral, A Nova Lei de Direitos Autorais, 2003, p. 53.
} 
According to $\S 1$ "the exclusive right of reproduction shall not be applicable where the reproduction is temporary and done for the sole purposes of making the work, phonogram or performance perceptible by means of an electronic medium, or where it is transitory or incidental, provided that it is done in the course of the use of the work that has been duly authorized by the owner." This points to the reproduction occurring due to technological necessities in the cache Internet browser and allows the digitisation of works without the consent of the author, unless it is only temporary. ${ }^{1565}$

$\S 2$ establishes clearly that "Regardless of the manner of reproduction, the number of copies made shall be notified and checked, the person who reproduces the work being responsible for the keeping of such registers as will permit the author to verify the economic profits derived from exploitation."

Finally, in order to clarify what is only logical, article 31 BCA stipulates that "the various forms of use of literary, artistic or scientific works or phonograms shall be mutually independent, and any authorization granted by the author or by the producer, as the case may be, for one such use shall not constitute authorization of any other of the uses."

\subsection{Right of Publication}

The right of publication, which is enshrined by article 29 para. 2 BCA, is defined by article 5 para. $1 \mathrm{BCA}$ as the right to control the act of bringing a literary, artistic or scientific work to the notice of the public, with the consent of the author or other copyright owner, in whatever form or by whatever process.

\subsection{Right of Translation, Adaptation and other Alterations}

According to Brazilian copyright law the author of a work has the right to authorise the creation of derivative works, meaning the creation of new works by transforming the original work. ${ }^{1566}$ The right to translate the work as well as the right to adapt the work and make further alterations and the right to include the work in phonograms or audiovisual productions as provided by article 29 para. 3,4 and 5 BCA belong to this category.

\footnotetext{
1565 Cf. article 5 para. 1 Information Society Directive 2001/29/EC.

${ }^{1566}$ Azevedo in Copyright Law Throughout the World, 2015, no. 6.19d.
} 


\subsection{Right of Distribution}

In accordance with article 29 para. 6 and 7 BCA the right of distribution of the work is protected and exclusively assigned to the author. According to article 5 para. $4 \mathrm{BCA}$ distribution means to make the original or copies of literary, artistic or scientific works, fixed performances and phonograms available to the public by sale, rental or any other transfer of ownership or possession.

Brazilian copyright law contains no clear rule concerning the exhaustion of the distribution right for copyrighted works. Only article $2 \S 5$ Brazilian Software addresses the issue by stipulating that the exclusive copyright of renting a computer program is not completely exhausted after sale, license grant or any other form of assignment of a copy of the program. ${ }^{1567}$ Above that there are no further provisions regarding the topic.

\subsection{Limitations and Exceptions}

Apart from the case that an originally protected work looses copyright protection 70 years after the death of its author as stipulated by art. 41 BCA and falls into public domain, art. 46, 47 and 48 BCA provide for limitations and exceptions privileging different types of use of copyright protected works. Moreover, article 6 Brazilian Software Law, which regulates the protection of intellectual property regarding computer programs ${ }^{1568}$, contains further limitations.

\subsection{Justification, Objectives and Interpretation of Limitations}

Limitations serve social and cultural objectives. ${ }^{1569}$ Brazilian copyright law not only intends to protect the author's moral and economic interests but also wants to safeguard the public interest of accessing and using copyright protected works without the consent of the author or right holder. ${ }^{1570}$ Both objectives of Brazilian copyright law have constitutional underpinnings. As already mentioned, article 5 no. 27 of the Brazilian Constitution establishes the protection of authors' rights, whereas article 23 no. 5 and article 215 of the Brazilian Constitution safeguard the access to culture for the public. ${ }^{1571}$ It is between these two poles that copyright limitations shall help to achieve a just balance of interests. Moreover

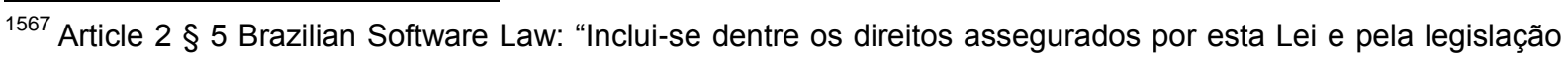
de direitos autorais e conexos vigentes no País aquele direito exclusivo de autorizar ou proibir o aluguel comercial, não sendo esse direito exaurível pela venda, licença ou outra forma de transferência da cópia do programa."

${ }_{1568}$ Lei No. 9.609, de 19 de Fevereiro de 1998.

1569 Cabral, A Nova Lei de Direitos Autorais, 2003, p. 70.

1570 Ibid.; Azevedo in Copyright Throughout the World, 2015, no. 6.21.

1571 Ibid.
} 
the balance must take into account the social function of Copyright law, which can be deduced from article 5 no. 23 of the Brazilian Constitution. ${ }^{1572}$ This provision establishes the social function of property in general and expresses the idea that under certain conditions public interest prevails over individual interest. ${ }^{1573}$ Since copyright law is part of intellectual property and thus is regarded as a property right the social function of property applies to it as well. ${ }^{1574}$ This means that Copyright Law has not only the function of protecting the rights of authors but also to safeguard the access to knowledge and education, which serves public interest. ${ }^{1575}$ Furthermore article 6 para. 1 of the Brazilian Constitution protects the right to education as social right. Therefore limitations privilege certain uses of copyright protected works in order to realise the balance of interests of authors and right holders as well as of the individual and the public. ${ }^{1576}$ The importance of limitations to copyright law is especially great in a developing country like Brazil because restrictive limitations add to the negative effect that access to knowledge and education remains a privilege of the a wealthy minority, which can afford it, leaving the less wealthy majority, which cannot afford it, more or less excluded from it. ${ }^{1577}$ Yet, in practice the current Brazilian Copyright Act is characterised by a great imbalance in favour of the interests of authors and right holders and as a consequence it is very restricted and unsensitive regarding public interest and the interest of the public. ${ }^{1578}$

The uses privileged by the Brazilian Copyright Act have exhaustive character and must be interpreted narrowly. ${ }^{1579}$ This means that literally only the uses described by the law are allowed without the prior consent of the author. ${ }^{1580}$ Besides Brazilian copyright law contains no open or flexible provisions regarding limitations. ${ }^{1581}$ If such open and flexible provisions could be introduced through a liberal interpretation of the Three-Step-Test in addition to

\footnotetext{
1572 Pimenta/Pimenta Filho, A Limitação dos Direitos Autorais e a sua Função Social, 2007, p. 75.

1573 Idem, p. 82 and p. 85.

1574 Branco: Brazilian Copyright Law and how it restricts the Efficiency of the human Right to Education, 2007, p. 118.

${ }^{1575}$ Idem, p. 123

1576 Cf. Rocha de Souza, A Função Social dos Direitos Autorais, 2006, p. 268/269.

1577 Mizukami, Lemos, Magrani, Pereira de Souza: Exceptions and Limitations to Copyright in Brazil: A Call for Reform, 2010, p. 42.

${ }_{1578}^{15}$ Ascensão, O Direito da Internete em Portugal e no Brasil, 2011, p. 85.

1579 Menezes, Curso de Direito Autoral, 2007, p. 95; Azevedo in Copyright Throughout the World, 2015, no. 6.21; Cabral, A Nova Lei de Direitos Autorais, 2003 p. 70; Poli, Direito Autoral, 2008, p. 74; Mizukami, Lemos, Magrani, Pereira de Souza: Exceptions and Limitations to Copyright in Brazil: A Call for Reform, 2010, p. 48.

1580 The principle of strict interpretation of copyright limitations is objected by Rocha de Souza, Direitos Autorais e Acesso à Cultura, 2011, p. 430/431, who takes a contrary position by arguing that due to the constitutional underpinnings of the purposes privileged by copyright limitations and the social function of copyright law an extensive interpretation of copyright limitations is feasible. Rocha de Souza supports his opinion with two decisions of the Brazilian Federal High Court (Supremo Tribunal Federal, Recurso Extraordinário n. 113.505-RJ, Primeira Turma, Relator: Min. Moreira Alves, Brasília, Febuary 28, 1989) and Brazilian High Court of Justice (Superior Tribunal de Justiça, Recurso Especial n. 964.404, Terceira Turma, Relator: Paulo de Tarso Sanseverino, Brasilia, March 15, 2011), which both point out that the scope of the protection of authors 'rights is defined by the significance of fundamental rights privileged by copyright limitations. Thus, the limitations named by the BCA are only examples of privileged uses, which must be interpreted and applied extensively. See also Rocha de Souza, in Hilty/Nérisson, Balancing Copyright, Brazil, 2012, p. 202/203.

${ }^{1581}$ Azevedo in Copyright Throughout the World, 2015, no. 6.21.
} 
statutory limitations remains to be seen. ${ }^{1582}$ Further, it must be noted that the Brazilian copyright limitations are independent of any compulsory or other licences. ${ }^{1583}$ The uses privileged by article 46 to $48 \mathrm{BCA}$ and article 6 Software Law thus are completely free and require not payment to the author or other beneficiary. Although Brazil is a member of the Berne Convention the Three-Step-Test enshrined in article 9 para. 2 Berne Convention has not been implemented completely into Brazilian copyright law as a requirement for the application of limitations. ${ }^{1584}$ But parts of the steps of the Three Step Test can be found article 46 para. $8 \mathrm{BCA}$, which states that "the reproduction in any work of short extracts from existing works, regardless of their nature, (...) does not jeopardize the normal exploitation of the work reproduced or unjustifiably prejudice the author's legitimate interests." shall not constitute a copyright infringement. ${ }^{1585}$

Generally, the limitations have different rationales, which may be important for the interpretation of the scope of the respective provision. First, there are limitations that serve the information society and outweigh private interests of the author. ${ }^{1586}$ Second, there are limitations, which shall promote education and the dissemination of knowledge for the good of society and thus are privileged. ${ }^{1587}$ Third, there are limitations privileging the use of copyright protected works for technical and judicial use. ${ }^{1588}$ To be more specific the various objectives of limitations under Brazilian copyright law can be classified as well as limitations for education and research, for news reporting and access to current information, for governmental and judicial uses, for private and personal uses, for uses by disabled, for quotation, review and parody and for ephemeral recordings. ${ }^{1589}$ Above that there are some other limitations, which do not fit in one of these categories. ${ }^{1590}$

\subsection{Limitations and Exceptions for Educational Purposes and Libraries}

In the context of this study it is of interest, which, if any, limitations of Brazilian copyright law apply to e-learning and distance education as well as to libraries and archives. Therefore, in the following I will review the respective provisions. The limitations to authors rights (Das Limitações aos Direitos Autorais) are enshrined in Title 3 Chapter 4 of the Brazilian Copyright Act and in Chapter 2 of the Brazilian Software Law. Some of these provisions directly relate

\footnotetext{
${ }_{1582}^{1583}$ Ascensão, O Direito da Internete em Portugal e no Brasil, 2011, p. 86.

${ }^{1583}$ Azevedo in Copyright Throughout the World, 2015, no. 6.21.

1584 lbid.

1585 Mizukami, Lemos, Magrani, Pereira de Souza: Exceptions and Limitations to Copyright in Brazil: A Call for Reform, 2010, p. 50.

${ }_{1586}^{158}$ Menezes, Curso de Direito Autoral, 2007, p. 96.

1587 lbid.

1588 lbid.

${ }^{1589}$ Azevedo in Copyright Throughout the World, 2015, no. 6.22a-i.

1590 Idem, no. 6.22h.
} 
to the Berne Convention, the Software Law provisions are inspired by the European Computer Programs Directive ${ }^{1591}$ and some provisions are Brazilian specialties. ${ }^{1592}$

Hereinafter I will first review the limitations in short, which do not apply to e-learning and distance education as well as to libraries and archives respectively to educational purposes at all. Then I will analyse the limitations, which may provide some advantages for e-learning and distance education as well as for libraries and archives, respectively which at least to some extent privilege educational purposes.

Article 46 para. 1 let. a) to d) BCA establishes that the reproductions of copyright protected works constitute no copyright infringement if undertaken for the purposes named therein. Article 46 para. 1 let. a) BCA permits the reproduction of news or information articles in the daily press, provided that the name of the author and the name of the publication are indicated. Article 46 para. 1 b) BCA allows the reproduction of public speeches in daily publications or periodicals. According to article 46 para. $1 \mathrm{c}$ ) BCA the owner of portraits or other visual representations made for hire may reproduce such works provided that the represented person or her heirs do not object. Article 46 para. 1 d) BCA finally stipulates that it is allowed to reproduce literary, artistic or scientific works for the exclusive use of visually impaired persons provided that such reproduction takes place within the Braille system or another procedure supporting visually impaired persons and that the reproduction has no commercial purpose. According to article 46 para. $5 \mathrm{BCA}$ it is no infringement of copyright to use literary, artistic or scientific works as well as phonograms and radio and television broadcasts in stores selling equipment for the audiovisual use of copyright protected works for demonstration purposes. Article 46 para. 7 BCA permits the use of literary, artistic or scientific works for the purpose of producing judicial or administrative evidence. Article 47 BCA deals with paraphrases and parodies, which are permitted as long as they do not constitute actual reproduction of the original work or discredit it. Article 46 para. 8 BCA contains a special version of the Three-Step-Test referring only to the reproduction of small parts of a work. ${ }^{1593}$ Following this provision it is not an infringement of copyright to reproduce small parts of pre-existing works in another work, provided that the reproduction itself is not the main objective of the new work and that it does not interfere with the normal exploitation of the reproduced work nor cause unjustified prejudice to the legitimate interests of the authors. ${ }^{1594}$ The Three-Step-Test has rarely been applied by the courts. ${ }^{1595}$ It was thus far in

\footnotetext{
$\overline{1591}$ EU Council Directive 91/250/EEC of May 14th, 1991.

1592 See Mizukami, Lemos, Magrani, Pereira de Souza: Exceptions and Limitations to Copyright in Brazil: A Call for Reform, 2010, p. 49ff.

${ }^{1593}$ Rocha de Souza in Hilty/Nérisson, Balancing Copyright, Brazil, 2012, p. 198.

1594 Ibid.

${ }^{1595}$ Federal Court of Appeal of the Second Region (AC 2002.51.01.015719-6) and Superior Tribunal de Justiça, (Recurso Especial n. 964.404); see also Rocha de Souza in Hilty/Nérisson, Balancing Copyright, Brazil, 2012, p.
} 
the first place considered by the legislator. ${ }^{1596}$ A consistent application of the Three-Step-Test by Brazilian courts not yet in sight. ${ }^{1597}$ The Three-Step-Test acts both to limit and to widen the statutory limitations of the BCA. Article 48 BCA finally allows that copyright protected works, which are permanently situated in public spaces, may be freely represented by paintings, drawings, photographs or audiovisual procedures.

As was said already above further limitations can be found in article 6 Brazilian Software Law, which declares in article 2 that the protection conferred to literary works under the Brazilian Copyright Act applies to computer programs as well, observing the provisions of the Brazilian Software Law. Accordingly article 6 para. 1 Brazilian Software Law, inspired by the European Computer Programs Directive, establishes that it is no infringement of the rights of the owner of a computer program to make a single full reproduction of a legitimately acquired copy of a computer program provided that the reproduction is made for backup or archival purposes. Article 6 para. 3 Brazilian Software Law, which was also inspired by the European Computer Programs Directive states that copyright regarding a computer program is not infringed in case of similarity of two programmes, provided that this results from functional characteristics, from the observance of technical all normative standards or from the lack of alternative ways of expression. Further according to article 6 para. 4 Brazilian Software Law copyright is not infringed through the integration of a computer program into another system at application or operational level, if this is technically indispensable due to the necessities of the user provided that the programme maintains its essential characteristics and the integration is exclusively for the use of the person conducting it.

The provisions of Brazilian Copyright Law providing limitations to authors' rights with regard to educational purposes in general are few. ${ }^{1598}$ Only article 46 para. 2, 3, 4 and 6 as well as article 6 para. 2 Brazilian Software Law address educational uses at all. To what extent these provisions cover uses of copyright protected works for e-learning and distance education in higher education institutions as well as for libraries and archives in particular is extremely problematic.

Article 46 para. 2 BCA permits a single reproduction of small excerpts of a copyright protected work for private use of the person making the reproduction provided that it is made without commercial intent. The private copy provision, even if it does not address e-learning and distance education or library uses, is essential for the promotion of access to education

\footnotetext{
199.

${ }_{1596}^{159}$ Rocha de Souza in Hilty/Nérisson, Balancing Copyright, Brazil, 2012, p. 199.

1597 lbid.

${ }^{1598}$ Rocha de Souza, A Função Social dos Direitos Autorais, 2006, p. 288.
} 
and the dissemination of knowledge. ${ }^{1599}$ Yet, Brazilian Copyright law forbids the private user, i.e. the student, to make a full copy of a copyright protected work even for private study. ${ }^{1600}$ This is especially astonishing and problematic, because Brazil still is a country with a great number of people living in extreme poverty and thus being unable to purchase learning materials. ${ }^{1601}$ Being allowed to make full copies of copyright protected learning materials for the purpose of private study it is essential for the poor parts of the Brazilian population in order to have access to education and knowledge. Moreover, it is very unclear what is meant by "small excerpts", which increases legal uncertainty for people who have to rely on the private copy limitation. ${ }^{1602}$ Article 46 para. 2 BCA ignores this reality and thus restricts the access to education and knowledge. ${ }^{1603}$

This fact cannot be compensated article $184 \S 4$ of the Brazilian Penal Code, which was enacted in 2003, and provides an "unintended limitation to Copyright". ${ }^{1604}$ The provision stipulates that there is no punishment for copyright infringement if the infringing act is covered by a limitation or exception of the Brazilian Copyright Act or if the infringing act is "a single copy of an intellectual work or phonogram for the private use of the person making the copy without intend of direct or indirect profit. ${ }^{1605}$ Obviously this provision refers to a full copy of a copyright protected work. The provision is broader and therefore more adequate to promote access to education and knowledge then the restrictive article 46 para. 2 BCA. Nevertheless, the limitation of article $184 \S 4$ of the Brazilian Penal Code is largely ignored. ${ }^{1606}$ As becomes clear, article 46 para 2 BCA does neither provide any limitations copyright law in favour of e-learning and distance education in higher education institutions nor uses of copyright protected works by libraries and archives are addressed. ${ }^{1607}$

Article 46 para. $3 \mathrm{BCA}$ declares that it is not an infringement of copyright to make quotations of passages of works in books, journals, magazines or any other means of communication for the purposes of study, criticism or polemics as long as the extent of the respective quote is justified by its purpose. Further, the name of the author and the origin of the work must be

\footnotetext{
${ }^{1599}$ Mizukami, Lemos, Magrani, Pereira de Souza: Exceptions and Limitations to Copyright in Brazil: A Call for Reform, 2010, p. 50.

${ }^{1600}$ Branco: Brazilian Copyright Law and how it restricts the Efficiency of the human Right to Education, 2007, p. 125.

1601 Ibid.; Branco for Unesco/MEC/CAPES, Documento Técnico - Análise da Lei dos Direitos Autorais Brasileira, 2014 , p. 33.

1602 Branco for Unesco/MEC/CAPES, Documento Técnico - Análise da Lei dos Direitos Autorais Brasileira, 2014, p. 34; Branco/Britto, What is Creative Commons?, 2015, p. 37.

1603 Mizukami, Função Social da Propriedade Intellectual, 2007, p. 475.

${ }^{1604}$ Mizukami, Lemos, Magrani, Pereira de Souza: Exceptions and Limitations to Copyright in Brazil: A Call for Reform, in a2Kbrazil, edited by Lea Shaver, 2010, p. 51.

${ }^{1605}$ Article 184 § 4 Brazilian Penal Code.

${ }^{1606}$ Mizukami, Lemos, Magrani, Pereira de Souza: Exceptions and Limitations to Copyright in Brazil: A Call for Reform, 2010, p. 52

${ }^{1607}$ Branco: Brazilian Copyright Law and how it restricts the Efficiency of the human Right to Education, 2007, p. 126.
} 
indicated.

Article 46 para. 4 BCA allows students to take notes of lectures in educational establishments. The publication of these notes in full or in part however is forbidden without the prior consent of the lecturer. In fact, this limitation is no real copyright limitation, because it does not concern the use of the work of a third party. ${ }^{1608}$ It just states the obvious that own notes of classes and lectures can be used for private purposes.

Article 46 para. 6 BCA states that copyright is not infringed by theatrical and musical performances realised in family environment or exclusively for educational purposes in educational establishments, provided that both do not have commercial intent. It is therefore only allowed to make use of pieces of theatre and music. Other types of works such as films, texts and photographies are not addressed and thus may not be used for educational purposes. ${ }^{1609}$ This reveals a very narrow scope of application, although education is a constitutionally protected value. Regarding the importance of education also as a human right a more generous interpretation of limitations for educational purposes is necessary, which takes the social function of copyright law for the promotion of constitutional values into account. ${ }^{1610}$ Thus at least the term "educational establishment" should be understood broadly. $^{1611}$

Article 6 para. 2 of the Brazilian Software Law declares that it is not an infringement of the rights of the right holder of a computer program to make a partial quotation from the programme for educational purposes provided that the program and the right holder are identified.

\subsection{Copyright Law Reform}

Because of the deficiencies and imbalances of the Brazilian Copyright law system, which become especially visible regarding the above described limitations and exceptions, the Brazilian government put a Copyright law reform on its agenda in $2007 .{ }^{1612}$ The then Minister of Culture Gilberto Gil initiated the process by forming a National Copyright Law Forum

\footnotetext{
$\overline{1608}$ Branco for Unesco/MEC/CAPES, Documento Técnico - Análise da Lei dos Direitos Autorais Brasileira, 2014, p. 34 .

${ }^{1609}$ Idem, p. 35, who points out that even this very restrictive provision is interpreted narrowly by some scholars reducing its scope to theatrical schools only, see Abrão, Direitos Autorais e Direitos Conexos, 2002, p. 150.

${ }^{1610}$ Cf. Branco for Unesco/MEC/CAPES, Documento Técnico - Análise da Lei dos Direitos Autorais Brasileira, 2014 , p. 36.

1611 Idem, p. 35.

1612 See Wachowicz, A Revisão da Lei Autoral, 2015, p. 543/544, who points out that the BCA is characterised by an imbalance of private and public interest, which in view of the challeges of the digital era makes a recalibration of interest necessary. Wachowicz stresses two main areas for action, namely new business models for intellectual goods and new social demands regarding the access to intellectual goods for education and development.
} 
(Fórum National de Direito Autoral). ${ }^{1613}$ His successor as Minister of Culture Juca Ferreira continued the reform process. In the years 2007 to 2009 this forum organised several debates between civil society, artists, researchers and representatives of the creative industry in order to prepare the ground for a copyright reform by taking into account the interests of all parties involved. ${ }^{1614}$ With the results of these debates in mind the Ministry of Justice prepared a preliminary draft for a copyright law reform. This draft was made available on an online platform and could be commented by the public in summer $2010 .{ }^{1615}$ The contributions were numerous. ${ }^{1616}$ This process led to another preliminary draft of a new copyright law, which was much more flexible and took into account a fairer balance between the various interests involved, especially the public interest, by presenting a larger list of copyright limitations. ${ }^{1617}$

The preliminary draft proposes at the very beginning to alter article $1 \mathrm{BCA}$. In some kind of a preamble the proposal declares that the BCA protects author's rights including neighbouring rights and that its objective is to balance the constitutional imperatives of protection of the author's rights and the guarantee to fully exercise cultural rights and other fundamental rights as well as the promotion of national development. ${ }^{1618}$ As well, the protection of authors rights shall be harmonised with the principles and norms regarding free enterprise, free competition and consumer protection. ${ }^{1619}$ Obviously, this definition of goals of copyright law shall influence the entire understanding and interpretation of the provisions and shall safeguard more balanced solutions than the old and very one-sided BCA. In the area of limitations and exceptions article 46 of the preliminary draft contains 18 paragraphs and one additional single paragraph compared to only 8 paragraphs of the current version of $1998 .{ }^{1620}$ Initially the preliminary draft clarifies that the uses of protected works enumerated by article 46 are not infringements of copyright even without the previous consent of the author or right holder and without the payment of remuneration. ${ }^{1621}$ With regard to limitations and exceptions in

\footnotetext{
1613 Reia/Mizukami, Reformando a Lei de Direitos Autorais: Desafios para o Novo Governo na Área de Cultura, 2015, p. 4.

1614 lbid.

1615 Direito Autoral na era da Internet: Interview with Marcos Alves de Souza, Revista do Idec, Junho 2010, p. 9/10; Wachowicz, A Revisão da Lei Autoral, 2015, p. 545.

${ }_{1616}$ Reia/Mizukami: Reformando a Lei de Direitos Autorais: Desafios para o Novo Governo na Área de Cultura, 2015 , p. 4, speak of 7.863 contributions. Wachowicz, A Revisão da Lei Autoral, 2015, p. 546, even speaks of 8.431 contributions.

${ }_{1617}$ Reia/Mizukami: Reformando a Lei de Direitos Autorais: Desafios para o Novo Governo na Área de Cultura, 2015, p. 4.

${ }_{1618}$ Article 1: "Esta Lei regula os direitos autorais, entendendo-se sob esta denominação os direitos de autor e os que lhes são conexos, e orienta-se pelo equilíbrio entre os ditames constitucionais de proteção aos direitos autorais e de garantia ao pleno exercício dos direitos culturais e dos demais direitos fundamentais e pela promoção do desenvolvimento nacional.“

${ }^{1619}$ Article 1 single paragraph: "Parágrafo único. A proteção dos direitos autorais deve ser aplicada em harmonia com os princípios e normas relativos à livre iniciativa, à defesa da concorrência e à defesa do consumidor."

${ }^{1620} \mathrm{~A}$ consolidated version of the preliminary draft was published by the Ministry of Culture and is available at http://www2.cultura.gov.br/consultadireitoautoral/lei-961098-consolidada/.

${ }^{1621}$ Article 46 Preliminary Draft: "Não constitui ofensa aos direitos autorais a utilização de obras protegidas, dispensando-se, inclusive, a prévia e expressa autorização do titular e a necessidade de remuneração por parte
} 
favour of educational purposes and libraries and archives the preliminary draft proposes several amendments. Article 46 para. 1 re-introduces the private copy exception of entire works for non-commercial purposes, provided that only one single copy of a legitimately acquired works is made. ${ }^{1622}$ Further, article 46 para. 6 privileges stage plays and recitals as well as the exhibition of audiovisual and musical works in familiar surroundings or by educational institutions, provided that the presentation is directed exclusively to the teaching staff, pounds of students or other members of the educational community; moreover, the presentation must be without commercial intent and the public may persist for free. ${ }^{1623}$ Also article 46 para. 12 allows the reproduction of lectures, conferences and classes by those people who attend them. ${ }^{1624}$ However, the publication is prohibited without the consent of the person who gave the respective lecture etc. Very interesting is article 46 para. 13, which proposes to allow libraries, archives, documentation centres, museums, film archives and other similar institutions the necessary reproduction for conservation and preservation of any kind of work without commercial intent, as far as this is justified for the achievement of the purpose of the respective institution. ${ }^{1625}$ As well, article 46 para. 15 contains an interesting proposal. This provision shall allow stage plays and recitals as well as the exhibition of audiovisual and musical works, which are made without commercial intent, can be assisted by the public for free, are justified by the respective purpose and in addition serve educational purposes. ${ }^{1626}$ Article 46 para. 15 shall also privilege other purposes, which are of public interest such as the dissemination of culture, religious practices, free rehabilitation and treatment purposes and the use in prison. A further interesting proposal contains article 46 para. 16 , which proposes to permit the making available and the communication to the public of protected works which are part of the collections of libraries, archives, museums and similar institutions for the purpose of research, investigation or study, by any means or process, on the inside of the respective institution or via closed IT-networks. ${ }^{1627}$ The

de quem as utiliza, nos seguintes casos".

${ }_{1622}$ Article 46 para. 1 Preliminary Draft: "a reprodução, por qualquer meio ou processo, de qualquer obra legitimamente adquirida, desde que feita em um só exemplar e pelo próprio copista, para seu uso privado e não comercial."

${ }_{1623}$ Article 46 para. 6: "a representação teatral, a recitação ou declamação, a exibição audiovisual e a execução musical, desde que não tenham intuito de lucro e que o público possa assistir de forma gratuita, realizadas no recesso familiar ou nos estabelecimentos de ensino, quando destinadas exclusivamente aos corpos discente e docente, pais de alunos e outras pessoas pertencentes à comunidade escolar;"

${ }^{1624}$ Article 46 para. 12: "a reprodução de palestras, conferências e aulas por aqueles a quem elas se dirigem, vedada a publicação, independentemente do intuito de lucro, sem autorização prévia e expressa de quem as ministrou;"

${ }^{1625}$ Article 46 para. 13: "a reprodução necessária à conservação, preservação e arquivamento de qualquer obra, sem finalidade comercial, desde que realizada por bibliotecas, arquivos, centros de documentação, museus, cinematecas e demais instituições museológicas, na medida justificada para atender aos seus fins;"

${ }^{1626}$ Article 46 para. 15: "a representação teatral, a recitação ou declamação, a exibição audiovisual e a execução musical, desde que não tenham intuito de lucro, que o público possa assistir de forma gratuita e que ocorram na medida justificada para o fim a se atingir e nas seguintes hipóteses: a) para fins exclusivamente didáticos; (...)“

${ }^{1627}$ Article 46 para. 16: "a comunicação e a colocação à disposição do público de obras intelectuais protegidas que integrem as coleções ou acervos de bibliotecas, arquivos, centros de documentação, museus, cinematecas e demais instituições museológicas, para fins de pesquisa, investigação ou estudo, por qualquer meio ou processo, no interior de suas instalações ou por meio de suas redes fechadas de informática;" 
proposed single paragraph of article 46 appears to be very special. In addition to the other limitations of article 46 it provides for a rather open limitation regarding the right of reproduction, distribution and communication to the public, for the purposes of education, information, research or creativity. ${ }^{1628}$ This limitation shall however only be applicable if the named users are justified by the purpose, do not prejudice the normal exploitation of the work and do not cause unjustified prejudice to the legitimate interests of the author. The provision appears to be a mixture of a fair use clause and the Three-Step-Test. As one can see, the proposed amendments are quite far-reaching, already in the realm of education and libraries and archives. Besides, article 46 of the preliminary draft contains further limitations and exceptions. Therefore, it cannot be expected, that it will be accepted by representatives of authors and right holders. Nevertheless, a reform of Brazilian copyright law is unavoidable in order to achieve a fair balance of the interests of all stakeholders, namely authors, rights holders and the public. ${ }^{1629}$

In spite this promising and interesting draft proposal the reform process came to a hold when in 2010 Dilma Rousseff was elected president and appointed Ana de Hollanda as Minister of Culture. The opinion on the new Minister was quite opposite to the one on her predecessors, which may be explained with her connections to the phonographic industry of Brazil, and the will to advance the reform process further was not visible. ${ }^{1630}$ After less than two years in 2012 Ana de Hollanda was succeeded by Marta Suplicy, who indicated that she would continue the process of reforming Copyright law. ${ }^{1631}$ Yet, Marta Suplicy did not achieve more than to modify the latest preliminary draft further (these modifications have not yet been published) and send it to the Casa Civil ${ }^{1632}$ where it still has to be debated. ${ }^{1633}$ Moreover because of two other laws of importance to the government regarding the collective management for music, which was reformed in $2013^{1634}$, and the civil law framework agreement regarding the Internet passed in April 2014 ${ }^{1635}$, and because of the presidential

\footnotetext{
${ }^{1628}$ Article 46 single paragraph: "Além dos casos previstos expressamente neste artigo, também não constitui ofensa aos direitos autorais a reprodução, distribuição e comunicação ao público de obras protegidas, dispensando-se, inclusive, a prévia e expressa autorização do titular e a necessidade de remuneração por parte de quem as utiliza, quando essa utilização for:

I - para fins educacionais, didáticos, informativos, de pesquisa ou para uso como recurso criativo; e

II - feita na medida justificada para o fim a se atingir, sem prejudicar a exploração normal da obra utilizada e nem causar prejuízo injustificado aos legítimos interesses dos autores."

1629 Wachowicz, A Revisão da Lei Autoral, 2015, p. 562.

1630 Reia/Mizukami: Reformando a Lei de Direitos Autorais: Desafios para o Novo Governo na Área de Cultura, 2015, p. 4

1631 lbid.

1632 The Casa Civil is part of the federal government and coordinates the projects of the government and the ministries.

${ }_{1633}$ Wachowicz, A Revisão da Lei Autoral, 2015, p. 546.

1634 Lei 12.853 de 14 de Agosto de 2013.

1635 Lei 12.965 de 25 de Avril de 2014, called Marco Civil da Internet. The Marco Civil da Internet is so far a unique piece of legislation, because it "translates the principles of the Brazilian Constitution to the online world" (Lemos, Feet on the Ground: Marco Civil as an Example of Multistakeholderism in Practice, 2015, p. 26). It contains concepts like Net Neutrality, Data Protection, Limited Liability for Internet Service Providers and the role of public authorities. Furthermore, the Marco Civil sets forth principles for the use of the Internet in Brazil, such as
} 
elections in the second half of 2014, the necessity for the government to further advance a comprehensive Copyright law reform diminished. ${ }^{1636}$ In the beginning of 2015 Juca Ferreira was reappointed Minister of culture and it was expected that he would accelerate the reform process again. ${ }^{1637}$ This has not happened. Since May 24, 2016, Marcelo Calero is Minister of Culture.

\subsection{Survey results}

In order to find out how higher education institutions, publishers as well as government departments and interest groups in Brazil deal with copyright issues regarding e-learning and distance education a survey was conducted. Each type of stakeholder was asked to answer a questionnaire taking into account its special situation and interests. Taking into account that all public federal universities and several private higher education institutions (in total 85), the major publishers in Brazil (in total 20) as well as the Ministry of Culture, the Brazilian Industrial Property Office (INPI) ${ }^{1638}$ and the Brazilian Distance Education Association (ABED) received the questionnaire, the response rate was rather poor. Only three educational institutions and three interest groups answered the questionnaire. No answers at all were received from publishers.

In general, this may lead to the conclusion that the awareness for copyright law in the context of e-learning and distance education is not particularly strong in Brazil, even among stakeholders. This conclusion is underpinned by the fact, that Brazilian copyright law provides no (adequate) solutions for the use of copyright protected materials in the context of e-learning and distance education, as was described above. Consequently, practical copyright law questions encountered especially by higher education institutions in the context of e-learning and distance education are not answered by the law. However, in order to provide legal certainty in this area, particularly regarding limitations and exceptions for educational purposes, sensible copyright legislation is strongly needed. The silence of publishers yet is not surprising, hence the overall objective of copyright law, not only in Brazil, is the protection of the author or more precisely of the right holder. This principle is very

human rights, in particular freedom of expression, individual development, pluralism, openness, free enterprise, free competition and consumer protection as well as the social purposes of the network. In addition, the Marco Civil declares that the purpose of Internet governance in Brazil is among others the promotion of access to the Internet for all and the access to information, knowledge and participation in cultural life and public affairs. The spirit of these ideas can also be found in the proposed preliminary draft for a new Brazilian Copyright Act.

${ }^{1636}$ Reia/Mizukami: Reformando a Lei de Direitos Autorais: Desafios para o Novo Governo na Área de Cultura, 2015 , p. 5.

1637 "Trabalhamos com Dilma para que corte na Cultura não seja burro", Interview with Juca Ferreira in El País on May 3rd, 2015, available at http://brasil.elpais.com/brasil/2015/05/03/cultura/1430679567_100918.html

and „A volta de Juca Ferreira ao MinC é uma ótima notícia para a internet“ in Brasilpost on March 4th, 2015, available at http://www.brasilpost.com.br/tatiana-de-mello-dias/a-volta-de-juca-ferreira-_b 6406042.html.

${ }_{1638}$ Instituto Nacional da Propriedade Industrial, Ministério do Desenvolvimento, Indústria e Comércio Exterior. 
dominant in Brazilian copyright law and in the opinion of the publishing industry must not be touched. All the more the position of educational institutions must be reinforced in order to achieve a fair balance of interests and foster access to education and the dissemination of knowledge in Brazil. These conclusions are sustained by the answers to the questionnaire, which will be shortly analysed in the following.

Regarding the answers provided by interest groups first it leaps to the eye that congruently the protection of the rights of the author is considered the most important task for Brazilian copyright legislation. Only one answer takes also into account the interests of higher educational institutions. The answers to the question whether e-learning and distance education are important issues for copyright legislation in Brazil differ. One answer denies that relevance completely. Another answer suggests that the use of copyright protected materials for educational purposes should be addressed more clearly. Further it is argued that the protection of the author should even be reinforced. Regarding the balance of interests in the area of copyright limitations in the opinions differ. It is confirmed that due to the lack of legislation in the field of limitations for educational purposes practical questions are solved through licence agreements. In that regard it is demanded that the legislator creates legal guidelines, whereby the protection of the rights of authors shall be preferential.

Regarding the answers provided by higher education institutions it is interesting that all three institutions confirmed that copyright law is an important issue for them. One answer proclaims that it relies on copyright limitations in the context of e-learning and distance education, yet it remains unclear which. Both other answers do not rely on copyright limitations and only one explains, that it is avoided to invoke copyright limitations by concluding contracts with the respective author. None of the institutions has been sued for copyright infringement. All institutions generally are in favour of a broader access to educational materials. How this goal shall be achieved is seen differently. Free public access for educational purposes is favoured by two institutions. Further two (Public) institutions declare that they produce digital e-learning content, which they pass on to higher education institutions in other Portuguese speaking countries within the frame of agreements. Regarding the future of higher education and copyright law in Brazil only one institution connects the improvement of access to education with a reform of the respective copyright law provisions. Another institution suggests that the authors shall decide, which of their works will be publicly available and which will not. Moreover, it is argued that the current copyright law system is sufficient.

As one can see the answers vary considerably. The dominant objective is the protection of 
the rights of authors and right holders. Yet, it becomes clear that reliable solutions are missing and problems are solved individually. It appears that the opinion that limitations to copyright law for educational purposes, especially for e-learning and distance education, would foster the access to education and knowledge and thereby promote social development in Brazil is not shared even among higher educational institutions. Nevertheless, in view of the deficiencies of Brazilian copyright law in that area reforms are absolutely necessary. However such reforms, which have been initiated already, will be hard to enforce.

\subsubsection{Summary Brazil}

As was shown above the use of ICT for education, especially distance education and elearning, on all levels of education is promoted in Brazil by the Brazilian legislator. This holds not true for libraries and similar institutions to the same extent. Nonetheless, educational establishments as well as libraries and similar institutions use ICT to provide their services in ever-growing numbers.

However, none of the limitations and exceptions of Brazilian copyright law addresses the issues arising in the context of e-learning and in libraries and similar institutions. Generally, educational purposes are privileged only to a very small extend. Rather it is to say that Brazilian copyright law only provides for the absolute minimum of limitations as required by the Berne Convention. Article 46 para. 4 BCA for instance just states what should be obvious that students are allowed to take notes in class. Actually this provision functions more as a reinforcement of the copyright of the lecturer than as a limitation and has the intention to safeguard the later control of the lecturer over the use of students notes. ${ }^{1639}$ None of the copyright relevant acts, which occur daily in the context of e-learning, distance education and in libraries and archives is addressed at all. The use of digital content and modern media for educational purposes as well for preservation of copyright protected works in libraries and archives is completely ignored. ${ }^{1640}$ Thus each use of a copyright protected work for elearning, distance education and in libraries and archives depends on the prior authorisation of the author or right holder, although all of these activities serve public interest by promoting access to education and knowledge. Furthermore, Brazil has no clear rules regarding the exhaustion of the distribution right. As a result authors and right holders have far-reaching control of the uses made of their works. Limitations and exceptions to Copyright law in Brazil

\footnotetext{
${ }^{1639}$ Mizukami, Lemos, Magrani, Pereira de Souza: Exceptions and Limitations to Copyright in Brazil: A Call for Reform, 2010, p. 51.

${ }^{1640}$ Cf. Mizukami, Lemos, Magrani, Pereira de Souza: Exceptions and Limitations to Copyright in Brazil: A Call for Reform, 2010, p. 55.
} 
are not only constructed very narrowly but also have to be interpreted restrictively. ${ }^{1641}$ Therefore they must be considered a major impediment in a developing country like Brazil, where access to education and knowledge are crucial for human and social development.

These findings are confirmed by to WIPO Studies analysing copyright limitations in favour of educational purposes in Latin American countries and for libraries and archives. ${ }^{1642}$ The only limitation in favour educational activities cited in these studies is article 46 para. 4 BCA. ${ }^{1643}$ As was shown above this provision allows for stage and musical performances. Consequently it is not suited to promote e-learning and distance education at all. Limitations and exceptions permitting uses of copyright protected works in libraries and archives do no exist in Brazil. ${ }^{1644}$ The only provision, which may cover some of the uses occurring in libraries and archives, is article 46 para. 2 BCA. ${ }^{1645}$ However, since this provision deals with private copies, only the users of libraries and archives may invoke the limitation (with the restrictions explained above), whereas the institutions themselves have no legal coverage for their activities and de facto must operate illegally. It is surprising that Brazil as one of the most developed countries in Latin America does not address these issues, considering the key role libraries and archives have for the promotion of access to knowledge and education in developing country. ${ }^{1646}$ After all it is fair to say that Brazil has one of the most restrictive copyright regimes in the world. ${ }^{1647}$

With regard to the benchmark of permissible uses the Brazilian system of limitations and exceptions to copyright law obviously does not meet the requirements. There are no provisions at all, which address educational establishments and libraries, archives and similar institutions, not to speak of digital issues. In view of the state of development of Brazil and the pressing need for access to education and knowledge for large parts of the population, who live in extreme poverty, it is necessary to create a reliable legal framework based on which providers of education and knowledge, namely educational establishments and libraries, archives and similar institutions, can provide their services. Regarding the size

\footnotetext{
${ }^{1641}$ See above chapter 4.2.2.4.4.1.

1642 Juan Carlos Monroy Rodríguez, Study on the Limitations and Exceptions to Copyright and Related Rights for The Purposes of Educational and Research Activities in Latin America and The Carribean, WIPO, SCCR 19/4, September 30th, 2009; Kenneth Crews, Study on Copyright Limitations and Exceptions for Libraries and Archives, WIPO, SCCR 17/2, August 26th, 2008.

1643 Rodriguez, WIPO, SCCR 19/4, p. 249.

1644 Crews, WIPO, SCCR 17/2, p. 129.

1645 lbid.

1646 Dias/Fernández-Molina/Borges, As excepções aos direitos de autor em benefício das bibliotecas entre a União Europeia e América Latina, 2011, p. 16. These authors point out that according to the cited Study Kenneth Crews out of the 149 countries analised only 21 have no limitation for libraries and archives at all.

${ }^{1647}$ Branco, Brazilian Copyright Law and how it restricts the Efficiency of the human Right to Education, 2007, p. 117; Direito Autoral na era da Internet: Interview with Marcos Alves de Souza, Revista di Idec, Junho 2010, p. 8; Reia, Mizukami, Reformando a Lei de Direitos Autorais: Desafios para o Novo Governo na Área de Cultura, 2015, p. 3; cf. Ascensão, O Direito da Internete em Portugal e no Brasil, 2011, p. 86; Wachowitz, A Revisão da Lei Autoral, 2015, p. 552.
} 
of Brazilian territory it appears especially important to further promote e-learning and distance education as well as remote access to library collections, because particularly in rural areas far away from urban agglomerations poverty is widespread and the need for access to education is great. Therefore, non-commercial educational establishments and libraries, archives and similar institutions should be allowed to use copyright protected works, including educational materials, in any form and make them available publicly. New digital technologies and the Internet must by all means be rendered accessible for education and knowledge. Since especially in rural areas of Brazil digital infrastructure may not exist and people may not have the financial resources to purchase computers or other devices for using the Internet, the limitation for a private copies must be reformed, too. A private copying limitation should permit reproductions of complete works on paper and on other data carriers for private purposes, such as learning and study, in order to safeguard affordable access for individual users. Furthermore, it should be ensured that licensing contracts cannot overrule limitations. These ideas however address only the most urging problems of Brazilian copyright system. Anyway, the announced reform of copyright law in Brazil is long overdue.

In terms of adequacy the current system of limitations and exceptions to copyright law in Brazil does not promote access to education and knowledge, neither in the analogue nor in the digital age. Indeed, the human right to education and to human right to take part in cultural life are both constitutionally protected in Brazil and public interest in improving access to education and knowledge is great, given the situation of the country. Also, a fair balance of the interest of authors and right holders - whose rights are constitutionally protected as well - on the one side and the right to education and the take part in cultural life on the other side is inherent to the Brazilian constitution. Yet, the current copyright system does not support the latter through adequate limitations and exceptions, although in a developing country this would be even more important than in developed countries. Rather, copyright law in Brazil is concentrated on the protection of authors and right holders. Thus, a fair balance is not achieved.

As the results of the survey conducted among stakeholders suggest copyright law is either ignored or perceived merely as an instrument to protect the interests of authors and right holders. Copyright's function to promote access to education and knowledge for the greater benefit of the entire society obviously is not recognised in Brazil. The actual state of copyright law in Brazil has the negative effect that the acceptance for copyright law in general decreases. Concerning further social and economic development this is a development, which is not desirable. All the more the need to reform copyright law in Brazil is urgent. 


\subsubsection{Mozambique}

\subsubsection{Country Profile}

Mozambique is located on the South African east coast on the Indian Ocean. It has frontiers with Tanzania to the North, Malawi and Zambia to the North West, Zimbabwe to the West, and Swaziland and South Africa to the South West.

Between the 1st and 5th centuries BC, Bantu-speaking peoples migrated to Mozambican territory from further North and West. Swahili, and later also Arab, commercial ports existed along the coasts until the arrival of Europeans. The area was explored by Vasco da Gama in 1498 and colonized by Portugal from 1505. After over four centuries of Portuguese rule, Mozambique gained independence in 1975, becoming the People's Republic of Mozambique shortly thereafter. After only two years of independence, the country fell into civil war, which lasted from 1977 to 1992. In 1994, Mozambique held its first multiparty elections and has remained a relatively stable presidential republic since. Currently, the president is Filipe Nyusi. The prime minister is Carlos Agostinho do Rosário.

Mozambique is equipped with extensive natural resources. The main economic sector is still agriculture, but industrial sectors are growing, especially chemical manufacturing and the production of aluminium and petroleum. As well tourism becomes a more and more important economic factor. The gross domestic product of Mozambique was $\$ 15.6$ billion in $2013 .{ }^{1648}$ It has been growing very fast in the last 10 to 15 years. In 2014 the annual growth of the GDP has been $7.2 \%$ and is expected to be at $8.0 \%$ in $2015 .{ }^{1649}$ Nevertheless Mozambique is considered a Least Developed Country with very low income level. It ranks at number 29 in the list of the United Nations for Least Developed Countries in 2014. ${ }^{1650}$ Mozambique's situation is underlined by very low life expectancy, which stood by 50 years in $2012 .{ }^{1651}$ The Gross National Income was $\$ 613$ in 2013. ${ }^{1652}$

The official language in Mozambique is Portuguese. However many of the 25,833,752 Mozambicans speak local dialects. In 2009 the average literacy rate was $50.6 \%{ }^{1653}$ The female literacy rate in 2009 was only $36.5 \% .{ }^{1654}$ However, the literacy rate among young people between 15 and 25 years was between 2008 and 2012 79.8\% among males and

\footnotetext{
${ }_{1648}$ World Bank Mozambique, available at http://www.worldbank.org/en/country/mozambique.

1649 Ibid.

1650 United Nations List of Least Developed Countries, available at

http://www.un.org/en/development/desa/policy/cdp/ldc/ldc_list.pdf.

${ }_{1651}$ World Bank Mozambique.

1652 lbid.

1653 Unesco Statitics on Mozambique, available at http://en.unesco.org/countries/mozambique.

1654 lbid.
} 
$56.5 \%$ among females. ${ }^{1655}$ According to the government programme for the years 2015 to 2019 it is a declared goal to further reduce illiteracy by promoting the acquisition of basic writing and reading skills in primary schools. ${ }^{1656}$ The Mozambican government has identified education as the crucial factor for fighting poverty and promoting social development. ${ }^{1657}$

\subsubsection{Educational System}

According to the law for the National System of Education from $1992^{1658}$ the educational system in Mozambique is divided into three subsystems, namely preschool education, school education and extra school education. Preschool education refers to institutions like crèches or kindergartens, often operated by non-governmental organisations or private initiatives. ${ }^{1659}$ The so-called extra school education encompasses all kinds of initiatives, for instance for alphabetisation or cultural and scientific self-improvement, which take place beyond the regular educational system. ${ }^{1660}$ School education comprises general education, technoprofessional education and higher education. ${ }^{1661}$ General education is divided into primary education and general secondary education. ${ }^{1662}$ Primary education is free of charge and provides seven years of basic education for everybody. ${ }^{1663}$ Education is compulsory at the age of six. ${ }^{1664}$ The enrolment of children in primary schools today is $100 \% .{ }^{1665}$ After having finished primary education, students may continue their studies in general secondary education or in techno-professional education. General secondary education requires the payment of tuition fees. ${ }^{1666}$ Lately private schools have emerged in this sector. ${ }^{1667}$ The Mozambican Ministry of Education has also introduced a distance learning program for general secondary education. ${ }^{1668}$ General secondary education has a minimum duration of three years, after which students can continue for two more years in order to prepare for higher education. ${ }^{1669}$ Techno-professional education covers three specific areas, namely commercial, industrial and agricultural education. ${ }^{1670}$ It also requires the payment of tuition fees. ${ }^{1671}$ Techno-professional education on the basic level has a duration of three years, after

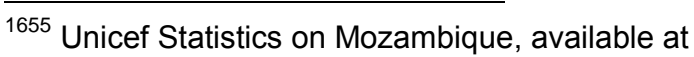
http://www.unicef.org/infobycountry/mozambique_statistics.html.

1656 cf. Proposta do Programa Quinquenal do Governo, February 17th, 2015, no. 32 (a).

1657 Plano Estratégico de Educação 2012 - 2016, Ministério da Educação, p. 12.

1658 Lei no. 6/92 de 6 de Maio, 1992.

1659 Plano Estratégico de Educação 2012 - 2016, Ministério da Educação, p. 12.

1660 Ibid.

1661 Ibid.

1662 lbid.

1663 lbid.

1664 Isaacs, ICT in Education in Mozambique, 2007, p. 4; Lei no. 4/83 de 23 de Março, 1983, Art. 6.

1665 eLA Report 2014, p. 112.

1666 Plano Estratégico de Educação 2012 - 2016, Ministério da Educação, p. 13.

1667 lbid.

1668 lbid.

1669 lbid.

1670 lbid.

1671 Ibid.
} 
which three more years of education on so-called medium level are optional. ${ }^{1672}$ Higher education encompasses universities, higher schools and institutes as well as academies, both publicly and privately funded. ${ }^{1673}$ Students are admitted to higher education, if they have either concluded the entire general secondary education or the entire techno-professional education; in the latter case students additionally have to pass an admission exam. ${ }^{1674}$ Higher education institutions are governed by the Law of Higher Education. ${ }^{1675}$ Apart from the forms of education described above the Law of Higher Education takes several special aspects of education, including distance education into account. ${ }^{1676}$

\subsubsection{Access to Education and Information Communication Technologies}

This said in advance I will now focus on the question of access to knowledge in Mozambique with special focus on the implementation of ICT. In this context of primary interest are elearning, distance education and libraries. Beforehand I will explain the difficulties students in Mozambique regularly have to face when it comes to access to learning materials.

Although the Ministry of Education and Culture has the task to produce learning materials, especially books, which can be used for free during the seven years of compulsory primary education, the price of learning materials still is very often too high for students and their families due to extreme poverty. ${ }^{1677}$ This problem is particularly serious in rural areas, where poverty is widespread. ${ }^{1678}$ Moreover, as soon as primary education is over, students and their families have to pay tuition fees and purchase learning materials. This is true for general secondary education, techno-professional education and higher education. Learning materials for university students frequently are imported from abroad, especially from Portugal and Brazil, and therefore are very expensive. ${ }^{1679}$ This problem is not new. As a least developed country shaken by civil war for decades Mozambique has little domestic intellectual production and therefore was always forced to import foreign works at high prices. ${ }^{1680}$ In this situation the necessary protection of copyright functions as an additional obstacle for the access to knowledge, education and culture. ${ }^{1681}$ In addition university libraries normally cannot provide more than one copy of a book, which is why photocopies of entire books are very common and often the only affordable way for students to access the

\footnotetext{
1672 Ibid.

1673 Plano Estratégico de Educação 2012 - 2016, Ministério da Educação, p. 14.

1674 lbid.

1675 Lei no. 27/2009 de 29 de Setembro, 2009.

1676 lbid.

1677 ACA2K, Country Report Mozambique, 2009, p. 11.

1678 lbid.

1679 lbid.

${ }^{1680}$ Martins da Silva, Situação do Direito de Autor e Direitos Vizinihos em Moçambique, 1986, p. 31.

1681 Ibid.
} 
respective learning material. ${ }^{1682}$ There exists a regular industry specialised on illegal photocopying of copyright protected works/books, whose activities are tolerated or even officially licensed by authorities without respect for the copyright law in force. ${ }^{1683}$ The access to knowledge and learning materials is further complicated by the fact that there are only very few public libraries, especially regarding primary and secondary education. ${ }^{1684}$ At a university level there are specialised libraries for students, yet their collections are often not up to date and very limited. ${ }^{1685}$ Another problem is that the Mozambican publishing industry is rather weak due to the high costs of printing. ${ }^{1686}$ There are only 12 publishing companies in Mozambique. ${ }^{1687}$ The National Institute of Books and Records must be considered as the most established publisher and printer in Mozambique, at least regarding the production of books for educational purposes in Portuguese and other Mozambican National languages. ${ }^{1688}$

Regarding the introduction of ICT and their potential for social development in all respects the government of Mozambique was quite forward-looking. Already in 1998 it created an ICT policy commission ${ }^{1689}$, which had the task to develop an information and communication technology policy and analyse the chances and necessities for the implementation of the policy in all sectors and institutions. ${ }^{1690}$ The ICT policy had to be integrated in the other development policies of the country, such as reduction of poverty, improvement of basic living conditions and public service quality, increase of participation of citizens in democratic and political life and enhancement of education and knowledge development. ${ }^{1691}$ The ICT policy of Mozambique, which was approved in 2000 by the Council of Minister's, proclaims to contribute to fight against poverty, improve living conditions in Mozambique, ensure access to worldwide knowledge for all Mozambicans, improve efficacy and efficiency of state institutions as well as governance and public administration, turn Mozambique into a producer of ICT and make Mozambique a competitive partner in the Information Society. ${ }^{1692}$ In order to achieve these goals the ICT policy identifies six priority areas for the implementation of ICT, namely Education, Human Resource Development, Health, Universal Access, Infrastructure and Governance. ${ }^{1693}$ Education is considered a key factor for

\footnotetext{
${ }_{1682}^{162}$ ACA2K, Country Report Mozambique, 2009, p. 11.

1683 Idem, p. 12

1684 Ministério de Educação, Relatório Sobre os Seis Objectivos da Educação para Todos, 2015, p. 7. 1685 Ibid.

1686 See Nexus Commenwealth Network, available at http://www.commonwealthofnations.org/sectorsmozambique/business/printing_and_publishing/.

${ }_{1687}$ Böcker, Survey on the Publishing Sector in Selected Sub-Saharan Countries, 2012, p. 36.

1688 Ibid.

1689 Presidential Decree 2/98 of May 27th, 1998.

1690 ICT and higher education in Africa, country profile Mozambique, 2007, p. 61

1691 lbid.

1692 Information and Communication Technology Policy, Council of Ministers' Resolution No. 28/2000 of December 12th, 2000, p. 1.

1693 Information and Communication Technology Policy, Council of Ministers' Resolution No. 28/2000 of
} 
development in general, but also for the implementation of ICT. The Mozambican ICT policy therefore declares to introduce electronic networks for sharing educational resources, to promote distance education and virtual schools using multimedia technologies and make online learning materials available for students and teachers alike. ${ }^{1694}$ These measures should extend to formal as well as to informal education and be supported by the international community. ${ }^{1695}$ In order to safeguard the implementation of the ICT policy the Mozambican government introduced a technical implementation unit, called UTICT. ${ }^{1696}$

According to the strategic plan of the Mozambican Ministry of Education the introduction of ICT together with an improvement of infrastructures in schools and reforms of the educational system is one key factor for the improvement of the quality of education. ${ }^{1697}$ One big obstacle to the introduction of ICT is the lack of adequate infrastructure. ${ }^{1698}$ Nevertheless regarding education there are three main fields of implementation for ICT in Mozambique, namely the formation of teachers as well as the use of computer technologies for the production of learning materials by teachers, the administrative organisation of schools and the application of ICT in classrooms. ${ }^{1699}$ The Ministry of Education intends to teach not only the use of ICT but also include ICT in the process of learning and studying different disciplines in order to enrich the entire learning process. ${ }^{1700}$ On a long-term basis the plan is to establish interactive education, sustained by technology or to put it otherwise, introduce elearning in a broad sense. ${ }^{1701}$ In order to promote e-learning and distance education the Ministry of Education intends to bundle the capacities of e-learning and distance education providers and install an e-learning platform for all levels of education. ${ }^{1702}$ Already the strategic plan of the Mozambican Ministry of Education for the years 2006 to 2010/11 promoted distance education in order to enlarge access for everybody to all levels of education. ${ }^{1703}$ Also the National Institute for Distance Education (INED) ${ }^{1704}$ was founded for the purpose of supervising and coordinating the implementation of distance education programs. ${ }^{1705}$

\footnotetext{
December 12th, 2000, p. 3

1694 Information and Communication Technology Policy, Council of Ministers' Resolution No. 28/2000 of December 12th, 2000, p. 12/13

1695 Ibid.

${ }^{1696}$ ICT and higher education in Africa, country profile Mozambique, 2007, p. 62

1697 Plano Estratégico de Educação 2012 - 2016, Ministério da Educação, p. 47. Here the plan refers to the effects of ICT and new technologies in developed countries.

1698 Ibid.

1699 Plano Estratégico de Educação 2012 - 2016, Ministério da Educação, p. 47/48.

1700 Plano Estratégico de Educação 2012 - 2016, Ministério da Educação, p. 48. This encompasses the creation of computer rooms, internet access points, interactive learning content etc.

1701 lbid.

1702 Ibid. Distance education is explicitly mentioned and the evaluation of previous achievements and the elaboration of further strategies in this sector is announced.

1703 Plano Estratégico de Educação 2012 - 2016, Ministério da Educação, p. 49.

1704 Instituto Nacional de Educação à Distância.

1705 Wim Neelemann, Arnaldo Nhavoto: Educação à Distância em Moçambique, Revista Brasileira de Aprentizagem Aberta e a Distância, São Paulo, Setembro 2003, p. 5
} 
Currently there are several ICT projects, which aim at the introduction of ICT in education. There is SchoolNet Mozambique, which was established in 1997 and was then called "Internet for schools". ${ }^{1706}$ The primary goal was to introduce computer literacy into 10 secondary schools and to integrate ICT into the process of teaching. ${ }^{1707}$ The project further should promote the use of the Internet and generally encourage schools to become centres of communication and information sharing. ${ }^{1708}$ In 2002 the actual SchoolNet project was initiated by the Ministry of Education in order to implement the national ICT policy. ${ }^{1709}$ The main goal is to provide access to ICT in all secondary schools in Mozambique and thereby Foster learning and teaching. ${ }^{1710}$ In addition SchoolNet shall prepare Mozambican students for working in the global information society. ${ }^{1711}$ By July 2006 the project had enabled the establishment of computer labs in 75 schools and the access to the Internet in approximately 25 schools of the 280 secondary schools in Mozambique. ${ }^{1712}$ Another project regarding access to knowledge and the introduction of ICT in schools is the New Partnership for Africa`s Development (NEPAD) eSchools programme, which has the purpose of promoting ICT skills in primary and secondary schools and improve education by using ICT and the Internet. ${ }^{1713}$ Also there is a regional project called EPCI located at a secondary school in Inhambane City in the Inhambane province, which started as a pilot in 2000 and now functions as a research and information technology centre promoting the use of ICT. ${ }^{1714}$ Above that the Multimedia Communication Centres (MCC) programme, a UNESCO funded project, which is implemented by the Ministry of Science and Technology and contributed by the Centre of Informatics of the Eduardo Mondlane University (CIUEM) as well as the National ICT Institute (INTIC) ${ }^{1715}$, has the purpose of providing access to information for communities through a single point using all kinds of ICT, such as computers with Internet access, printers, digital cameras, photocopy machines, fax machines and telephones. ${ }^{1716}$

Initiatives to implement ICT in higher education and promote the required skills for the use of ICT also exist in Mozambique. The Centre of Informatics of the Eduardo Mondlane University (CIUEM) ${ }^{1717}$ is most important for the introduction of ICT in higher education in Mozambique.

\footnotetext{
${ }^{1706}$ Internet para Escolas

1707 Isaacs, ICT in Education in Mozambique, 2007, p. 7; eLA Report 2014, p. 112.

1708 Isaacs, ICT in Education in Mozambique, 2007, p. 7.

1709 Ibid.

1710 lbid.

1711 ISTafrica, Guide to ICT Initiatives and Research Capacity, 2014, p. 206.

1712 Isaacs, ICT in Education in Mozambique, 2007, p. 7; eLA Report 2014, p. 112.

1713 Isaacs, ICT in Education in Mozambique, 2007, p. 7/8; eLA Report 2014, p. 112. NEPAD is a demo project, which is conducted in 16 African countries in order to develop best practices and working models for a larger implementation throughout Africa. The project is funded by public and private partners.

${ }_{1714}$ Isaacs, ICT in Education in Mozambique, 2007, p. 8/9.

1715 Instituto Nacional das Tecnologias de Informação e Comunicação.

1716 ISTafrica, Guide to ICT Initiatives and Research Capacity, p. 206; eLA Report 2014, p. 112.

1717 Centro de Informática da Universidade Eduardo Mondlane.
} 
Several projects relating to ICT and higher education have been developed by CIUEM. ${ }^{1718}$ Moreover CIUEM assists in improving and implementing the ICT policy of Mozambique. ${ }^{1719}$ The Instituto Superior de Ciencias e Tecnologia de Moçambique (ISCETEM) is generally considered the best higher education institute for studying computer science and ICT. ${ }^{1720} \mathrm{~A}$ very broad approach regarding the use of ICT is pursued by the Mozambique Information and Communication Technology Institute (MICTI), whose goal is to generally promote higher education through ICT based learning and research. ${ }^{1721}$ Another and very important project is the Mozambique Research and Education Network (MoReNeT) initiated by the Ministry of Science and Technology in 2006, which according to the Ministry`s announcements one day shall connect 25 higher education and research institutions, libraries, museums and nongovernmental organisations in order to enhance education, research and academic services in Mozambique and serve as a link to higher education and research institutions all over the world. ${ }^{1722}$ Currently, MoReNeT connects only six higher education institutions, three research institutions and the Mozambique National Library. ${ }^{1723}$ Generally, the introduction of ICT in libraries helps to improve library services, increase the number of resources, provide new electronic formats and thereby facilitate the access to knowledge, especially in higher education institutions. ${ }^{1724}$ Using ICT in libraries facilitates research and teaching and reduces the digital divide. ${ }^{1725}$ This holds true for developing countries and least developed countries in Africa in general and for Mozambique in particular. ${ }^{1726}$

\subsubsection{Mozambican Copyright Law}

The introduction of ICT in (higher) education and the use of ICT by libraries in Mozambique as described above inevitably raise questions regarding copyright law. After having explained the sources of Mozambican copyright law, namely the international treaties and agreements Mozambique is party of and the Constitution, the provisions of Mozambican Copyright Act regarding copyright protection and limitations and exceptions for educational purposes and libraries and archives are examined.

\footnotetext{
1718 Isaacs, ICT in Education in Mozambique, 2007, p. 9.

1719 lbid.

1720 lbid.

1721 lbid.

1722 Idem, p. 10; Muianga / Hannson / Nilsson / Mondlane / Mutimucuio, ICT in Education in Africa - Myth or Reality, 2013, p. 111.

${ }_{1723}$ Muianga / Hannson / Nilsson / Mondlane / Mutimucuio, ICT in Education in Africa - Myth or Reality, 2013, p. 111.

${ }_{1724}^{1725}$ Kamba, Implication of ICT's in Libraries of Higher Education Institutes, 2011, p. 66.

1725 Ibid.

${ }^{1726}$ The Central Library Brazão Mazula of the Eduardo Mondlane University in Maputo is the example for a digital library in Mozambique. The Library Brazão Mazula has the task to accompany the changes taking place in Mozambican society and Eduardo Mondlane University by facilitanting the aquisition of information and enhancing research as well as the provision of library services for the academic community, see González, Alves, Guambe, Abordagem metodológica para o estudo compartivo entre as Bibliotecas digitais em Moçambique, Brasil e Paraguai, 2013, p. 161.
} 


\subsection{International Obligations}

In 1997 Mozambique decided to adhere to the Berne Convention of September 9, 1886 (Paris Act 1971). A respective resolution of the Council of Ministers was enacted in $1997 .{ }^{1727}$ However the Berne Convention was not ratified properly. Only on August 22, 2013 Mozambique acceded the Berne Convention. On November 22, 2013 the Berne Convention finally entered into force in Mozambique. The Appendix to the Berne Convention allowing developing countries the translation and reproduction of works in analogous form through compulsory licenses was not ratified by Mozambique. ${ }^{1728}$ In spite of the Berne Convention not being in force in Mozambique until 2013 the current Mozambican Copyright Act, which was enacted in $2001^{1729}$, complies with its principles. ${ }^{1730}$ This is because according to art. 9 para. 1 TRIPS Mozambique as a member of the TRIPS Agreement must comply with art. 1 to 21 of the Berne Convention. ${ }^{1731}$

Mozambique signed the Marrakesh Agreement on April 15, 1994 and became a WTO Member on August 26, 1995. ${ }^{1732}$ Thereby Mozambique automatically ratified and adheres to the Agreement on Trade-Related Aspects of Intellectual Property Rights (TRIPS), which is contained in annex $1 \mathrm{C}$ of the Marrakesh Treaty. Like the Berne Convention the TRIPS Agreement demands of its members to establish minimum standards for the protection of intellectual property rights, such as general protection for intellectual property rights, administration enforcement of intellectual property rights and measures against infringements of intellectual property rights as well as the grant of the minimum term of protection for intellectual property rights. Taking into account the differences between WTO member states regarding development, the TRIPS Agreement in article 65 and 66 provides for flexibilities for developing and least developed countries. According to article 65 TRIPS developing countries have more time to implement the provisions of the agreement and according to article 66 para. 1 TRIPS least developed countries may also abstain from the implementation of certain provisions for a period of at most 10 years. Mozambique, which is considered a least developed country, did not take advantage of these flexibilities regarding copyright law. As prescribed by the TRIPS Agreement Mozambique implemented in its Copyright Act of 2001 the exclusion of the protection of ideas, a minimum term of protection (70 years beyond the life of the author, TRIPS demands only 50 years beyond the life of the author), the protection of computer programs and the protection of performers, producers of phonograms and broadcasting organisations (article 14 TRIPS). Concerning limitations and

\footnotetext{
1727 Resolution of the Council of Ministers No. 13/97, June 13th, 1997

${ }^{1728}$ For further information on the Appendix of the Berne Convention, see Ricketson/Ginsburg: International Copyrights and Neighbouring Rights, The Berne Convention and Beyond, Vol II (2006), no. 14.49 ff.

${ }_{1729}$ Law No. 4/2001 of February 27th, 2001.

1730 Akester, Direito de Autor em Portugal e nos PALOP, 2013, p. 228.

1731 Cf. Ricketson/Ginsburg, 2006, no. 14.107.

1732 Resolution of Council of Ministers No. 31/94 of 20 September 1994.
} 
exceptions to exclusive copyrights article 13 TRIPS is most important. This provision contains the Three-Step-Test, which sets limits to the limitation of exclusive rights. ${ }^{1733}$ The test is also enshrined in article 9 para. 2 of the Berne Convention to which adheres Mozambique. Article 9 para. 2 e) Mozambican Copyright Act contains a provision similar to the Three-Step-Test. It refers to reproductions for private purposes only. ${ }^{1734}$

Mozambique is not a member of the WIPO Copyright Treaty (WCT) and the WIPO Performances and Phonograms Treaty (WPPT). Both treaties deal with issues relating to the use of digital technologies and copyright law. Since Mozambique is not a member Mozambican copyright law does basically not address digital issues. ${ }^{1735}$

In this context it is finally interesting to mention the Cultural Charter for Africa of the Organization of African Unity, which was adopted on July 5, 1976 and came into force on September 19, 1990. ${ }^{1736}$ Not only the Cultural Charter for Africa postulates among others "access to education and cultural for all citizens" 1737 as an appropriate means to foster social, economic and cultural development. ${ }^{1738}$ But also it demands for the "Protection of African Works" (Chapter VII) by concluding an "inter-African convention on copyright" and by modifying "existing international conventions to meet African interests. "1739 Moreover, African states are called on to "enact national and inter-African laws and regulations guaranteeing the protection of copyright, set up national copyright offices and encourage the establishment of authors' associations (...)“. 1740

\subsection{The Constitution of Mozambique}

In Chapter V, which bears the title "Economic, Social and Cultural Rights and Obligations", the Constitution of Mozambique establishes in article 94 para 2 the protection of intellectual property by the state. ${ }^{1741}$ According to the explicit wording of that provision this includes copyright as well as the promotion of the practice and the dissemination of literature and

\footnotetext{
${ }^{1733}$ Members shall confine limitations or exceptions to exclusive rights to certain special cases, which do not conflict with a normal exploitation of the work and do not unreasonably prejudice the legitimate interests of the right holder. See Chapter 3.4.

${ }^{1734}$ Art. 9 para. 2 e) Mozambican Copyright Code states that the reproduction of protected works for private use is not allowed in case the reproduction of a copyright protected work prejudices its normal exploitation or classes unjustified prejudice to the legitimate interests of the author.

1735 Only art. 4 and 16 refer to digital uses by adressing computer programs (art. 4), which may be adapted under certain conditions (art. 16). Above that the law is silent with regard to digital issues, especially for education and libraries.

${ }_{1736}$ Cultural Charter for Africa, available at http://www.wipo.int/wipolex/es/treaties/text.jsp?file_id=202867.

1737 See article 2 (a) Cultural Charter for Africa.

1738 The objectives and aims are contained in article 1 Cultural Charter for Africa.

1739 See Article 24 Cultural Charter for Africa.

1740 Article 25 Cultural Charter for Africa.

${ }^{1741}$ Cf. Akester, Direito de Autor em Portugal e nos PALOP, 2013, p. 206.
} 
art. ${ }^{1742}$ As a consequence the Mozambican state is obliged to provide for a legal system, which safeguards intellectual property and copyright and at the same time enhances the dissemination of protected works. In Chapter II article 48 para. 1 of the Constitution of Mozambique guarantees the freedom of expression and the freedom of the press as well as the right to information for every citizen. ${ }^{1743}$ The right to information embraces the access to knowledge. Furthermore, article 88 para. 1 of the Constitution of Mozambique, which is also located in Chapter V, stipulates the right to education for all citizens. ${ }^{1744}$ According to article 88 para. 2 of the Constitution of Mozambique the state is moreover obliged to promote equal access to education. ${ }^{1745}$

\subsection{Mozambican Copyright Act ${ }^{1746}$}

The current MCA was enacted on February 27, 2001 by Law No. 4/2001 and established a more or less modern copyright law comprising 79 articles and a glossary with 32 definitions. It revoked the old copyright act of $1966^{1747}$, which dated back to colonial times. According to article 1303 para. 1 of the Portuguese Civil Code, which was approved by Decree-Law 44344 of November 25, 1966, copyright in Portugal was and still is subjected to special legislation. ${ }^{1748}$ As Mozambique being a colony of Portugal at that time this provision was applied to Mozambique through ministerial decree. ${ }^{1749}$ The special legislation in the field of copyright was the Portuguese Copyright Code, approved by Decree-Law 46980 of April 27, 1966. Again through ministerial decree the application of the Portuguese Copyright Code was extended to Mozambique. ${ }^{1750}$ By the way the same was true for all African colonies of Portugal, the so called PALOP (Países Africanos de Língua Oficial Portuguesa). ${ }^{1751}$

\subsection{Preamble and Objective}

The preamble of the MCA emphasises the importance of artists for the promotion and development of cultural heritage as well as the responsibility of the state in the realm of

\footnotetext{
${ }^{1742}$ Art. 94 para. 2 Constitution of Mozambique: "O Estado protege os direitos inerentes à propriedade intelectual, incluindo os direitos de autor e promove a prática e a difusão das letras e das artes."

${ }^{1743}$ Article 48 para. 1 Constitution of Mozambique: "Todos os cidadãos têm direito à liberdade de expressão, à liberdade de imprensa, bem como o direito à informação."

${ }^{1744}$ Art. 88 para. 1 Constitution of Mozambique: "Na República de Moçambique a educação constitui direito e dever de cada cidadão."

${ }^{1745}$ Art. 88 para. 2 Constitution of Mozambique: "O Estado promove a extensão da educação à formação profissional contínua e a igualdade de acesso de todos os cidadãos ao gozo deste direito."

1746 In the following "MCA".

1747 Law No. 46980 of April 27th, 1966.

${ }^{1748}$ Article 1303 para. 1 Código Civil: "Os direitos de autor e a propriedade industrial estão sujeitos a legislação especial."

${ }_{1749}$ Portaria no. 22869, de 4 de Setembro de 1967.

1750 Portaria no. 679/71, de 7 de Dezembro 1971.

${ }^{1751}$ Akester, Direito de Autor em Portugal e nos PALOP, 2013, p. 206.
} 
culture for society in general. ${ }^{1752}$ Therefore, it is deemed necessary to stimulate, promote and defend initiatives in the realm of art, science and culture taking into account the aspirations of artists and society in general. On that premise article 1 MCA phrases the overall objective:

The objective of the present law is the protection of literarily, artistic and scientific works and of the respective rights of authors, artistic interpreters, producers of phonograms and videograms as well as of or regional broadcasts, as well as to stimulate the creation and production of intellectual work in the realm of literature, art and science. ${ }^{1753}$

The interests of the recipients and users of copyright protected works are obviously not taken into consideration. The emphasis is on the protection of the rights and interests of authors and right holders, which is important and understandable, but with regard to access to knowledge and education and the interpretation of possible limitations and exceptions to exclusive rights this approach is rather short-sighted. ${ }^{1754}$ Nevertheless, the public interest considerations expressed in the preamble of the MCA cannot be ignored and must be taken into account by interpreting and applying the provisions of the MCA in practice.

\subsection{Protected Works}

Article 3 MCA deals with the personal and territorial scope of the Copyright Code of Mozambique. According to article 3 para. 1 a) MCA the law applies to works whose author is Mozambican or whose author is a foreigner but has his usual residence in Mozambique. Following article $3 \mathrm{c}$ ) MCA the law also applies to works published in Mozambique or works published for the first time abroad and edited in Mozambique. Article 3 para. 2 MCA moreover establishes that any author benefits from the rights provided by the law regarding his literary, artistic or scientific work and that the benefit for the author starts with the creation of his work even if incomplete.

Article 4 MCA stipulates which types of works are protected by copyright. Art. 4 para. 1 MCA declares that the law especially applies to literary, artistic and scientific works provided that these works are original intellectual creations in the realm of literature, art and science. Article 4 para. 1 let. a) - k) MCA then namely enumerates the types of works protected:

\footnotetext{
1752 Cf. Akester, Direito de Autor em Portugal e nos PALOP, 2013, p. 228/229.

${ }^{1753}$ Art. 1 Copyright Code of Mozambique: "A presente lei tem como objective a protecção das obras literárias, artisticas e científicas e dos direitos dos respectivos autores intérpretes ou executantes, produtores de fonogramas e de videogramas e dos originais de radiodifusão, e visa estimula a criação e a produção do trabalho intellectual na area da literatura, da arte e da ciência."

${ }^{1754}$ The emphasis on the protection of authors and right holders is also expressed in the "National Intellectual Property Strategy 2008 - 2018" of Mozambique, which was approved by the Council of Ministers on August 28, 2007. In section " 5 . Vision and Goals" priority is given to the protection of rights of authors and right holders rather than to the limitation of these rights in favour of educational institutions and libraries.
} 
a) Written works including computer programs;

b) Lectures, addresses, sermons;

c) Musical works with or without accompanying words;

d) Dramatic and dramatic-musical works;

e) Choreographic and mimed works;

f) Audio-visual works;

g) Works of fine art;

h) Works of architecture;

i) Photographic works;

j) Works of applied art;

k) Illustrations, maps, plans, sketches, 3 dimensional works relating to geography, topography, architecture or science;

l) Expressions of folklore.

According to article 4 para. 2 MCA also derivative works are protected, provided that the selection or the arrangement of the materials have to be considered intellectual creations, which is the case namely for a) compilation of works and b) translations, adaptations, arrangements and other transformations of the original works.

It is not clear whether the enumeration contained in article $4 \mathrm{MCA}$ is exhaustive or not. What speaks against an exhaustive enumeration is the wording "especially" respectively "em especial", which indicates that the works explicitly named shall be protected, but not exclusively. ${ }^{1755}$

\subsection{Economic and Moral Rights}

Article 6 MCA establishes that Mozambican copyright ("Direito de Autor") encompasses economic rights ("Direitos Patrimoniais") and moral rights ("Direitos Não Patrimoniais").

Article 7 MCA deals with economic rights and stipulates in article 7 para. 1 a) - g) MCA that the author of a work has the exclusive right to reproduce and translate his work, to prepare adaptations, arrangements or other transformations of his works, to publicly display copies of his work for sale or for any other way of transferring property, for renting as well as for loan, to present or to execute his work in public, to import or export copies of his work and to communicate his work to the public by broadcast via cable or via any other means. According

${ }^{1755}$ Also Akester, Direito de Autor em Portugal e nos PALOP, 2013, p. 229, assumes that the list of protected works is not exhaustive. 
to article 7 para. $2 \mathrm{MCA}$ the rights of renting and loan to the public conferred in article 7 para. $1 \mathrm{~d})$ MCA are not applicable to computer programs, provided that the program as such is not the essential object of renting.

Moral rights are addressed by article $8 \mathrm{MCA}$. This provision declares that the author of a work has the moral rights to:

a) claim the authorship of his work, in particular the right to claim that his name is indicated to the extent possible and in the usual way on copies of his work in relation to any public use of his work.

b) stay anonymous or to use a pseudonym.

c) object any deformation, mutilation or other modification of his work as well as any assault on his work, which may prejudice his honour, reputation, originality and integrity.

\subsection{Copyright Term}

Chapter IV of the MCA deals with the copyright term, meaning the duration of the protection of copyrights, regarding different types of rights and works. According to article 22 para. 1 MCA the protection of economic rights expires 70 years after the death of the author. ${ }^{1756}$ This holds true as well for works distributed or published posthumously. Regarding moral rights article 22 para. 2 MCA establishes that protection is not limited in time. ${ }^{1757}$ Why Mozambique has implemented such extensive copyright terms is not comprehensible. Implementing the minimum copyright term would have had the effect that protected works fall into the public domain more quickly, which would have facilitated the access to such works and thereby promoted the access to education and knowledge.

\subsection{Limitations and Exceptions}

Regarding the use of copyright protected works for education and in libraries, the MCA contains three relevant provisions, namely article $9 \mathrm{MCA}$ dealing with reproductions for private use, article 11 MCA dealing with educational uses and article 12 MCA dealing with reproduction by libraries and archives.

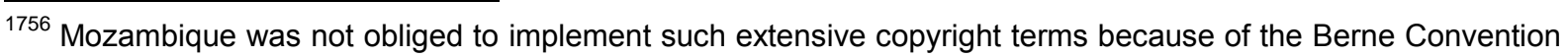
and the TRIPS Agreement. Both the Berne Convention and the TRIPS Agreement only require a minimum Copyright term of 50 years after the death of the author, cf. Akester, Direito de Autor em Portugal e nos PALOP, 2013, p. 233.

${ }^{1757}$ Regarding the copyright term for moral rights both the Berne Convention and the TRIPS Agreement only require that the duration of protection is at least equivalent to the duration of protection for economic rights.
} 


\subsection{Reproduction for Private Use}

Article 9 para. $1 \mathrm{MCA}$ permits the reproduction of a lawfully published work exclusively for the private use of the user without authorisation by the author and without payment of remuneration. ${ }^{1758}$ The provision does not apply to educational institutions, which is why the scope is very limited. The term "reproduction" is defined in no. 31 of the glossary. ${ }^{1759}$ Article 9 MCA may cover educational uses in so far as private study encompasses activities like homework, preparation for exams, seminars and presentations etc. Article 9 para. 2 a) - e) MCA clarifies that the limitation of article 9 para. 1 MCA does not apply to the reproduction of works of architecture (a), to the reprographic reproductions of works of the fine arts in limited edition, graphic presentations of musical works (sheet music), and books and other publications which are used only once (b), to the complete or partial reproduction of essential parts of databases (c) and to the reproduction of computer programs except in the cases provided for by article 16 . Moreover article 9 para. 1 MCA does apply to any reproduction of a work, which prejudices its normal exploitation or causes unjustified prejudice to the legitimate interests of the author. ${ }^{1760}$ This a special version of the Three-Step-Test limited to the reproduction right only.

\subsection{2 Use for Education}

Article 11 MCA deals with the use of copyright protected works for educational purposes. The provision allows without authorisation by the author and without payment of remuneration, but without prejudice to the obligation to indicate the source and the author's name if it appears in the source the following acts:

a) to utilise a lawfully published work on trial for illustration in publications, radio broadcastings or sound or video recordings for the purpose of education.

b) to reproduce by reprographic means, isolated articles lawfully published in journal or periodical, short extracts of a lawfully published work or a lawfully published short work for educational purposes or for examination within educational establishments, whose activities

\footnotetext{
1758 However, according to article 21 para. 1 MCA, the reproduction of an audiovisual work, which has been lawfully published, is feasible without the consent of the author only against the payment of fair remuneration. The remuneration has to be paid by the producers and importers of reproduction devices and data carriers to a collectiing society, as stipulates article 21 para. 2 MCA.

${ }^{1759}$ No. 31 Glossary: "Production of one or more copies of a work or of a part of it, independently of the material used, including sound and visual recordings. The production of one or more threedimensional copies of a work or of a part of it in a computer system, both on an internal or external computer memory, is also a reproduction."

${ }_{1760}$ Art. 9 para. 2 Berne Convention establishes the Three-Step-Test, which provides a general rule for the scope of copyright limitations. It states: "It shall be a matter for legislation in the countries of the Union to permit the reproduction of such works in certain special cases, provided that such reproduction does not conflict with a normal exploitation of the work and does not unreasonably prejudice the legitimate interests of the author." The prerequisites therein set forth normally are understood cumulatively. The copyright code of Mozambique drops the first step and further provides that the second and third step apply alternatively.
} 
have no direct or indirect commercial advantage and to the extent justified by the goal to be achieved, provided that such use is in conformity with customs and traditions.

The scope of application of article 11 a) MCA is very limited, but it obviously refers to any use of a copyright protected work by using the term "utilise" ("utilizar"). There is no restriction regarding the addressee of the limitation and the non-profit or for-pofit nature of the purpose. The scope of application of this provision is difficult to imagine. Its practical relevance is questionable.

Article $11 \mathrm{~b})$ MCA allows educational institutions to make reproductions of a protected work by reprographic means. ${ }^{1761}$ Article $\left.11 \mathrm{~b}\right)$ MCA has greater practical relevance than article 11 a) MCA, because it refers to reproductions occurring daily in educational institutions, provided that the institution making the reproduction pursues no direct or indirect commercial activities. The provision permits reproductions of "isolated articles", "short works" and of "short extracts" of works. However, the actual amount, which can be can be lawfully reproduced, is not specified by the law. Specific regulations clarifying this issue do not exist. ${ }^{1762}$ It appears that it is tolerated to copy an amount up to $10 \%$ of a protected work. ${ }^{1763}$

\subsection{Reprographic Reproduction by Libraries and Archives}

Article 12 MCA provides for limitations and exceptions to exclusive rights in favour of libraries and archives. These institutions serve public interest by enabling access to education and knowledge and promoting the dissemination of information as well as by preserving cultural heritage. With regard to access to education and knowledge libraries play a key role as the providers of learning materials and information. Especially in a least developed country like Mozambique, where learning materials are not affordable for most of the students, libraries often provide the only possibility to access learning materials. Mozambican Copyright Law permits the use of copyright protected works by libraries and archives under the prerequisites set forth by article 12 MCA.

Article 12 MCA allows reprographic reproductions ${ }^{1764}$ by libraries and archives, which have

\footnotetext{
${ }^{1761}$ The term "reproduction by reprographic means" is defined by number 32 of the Glossary to the Copyright Code of Mozambique and says: "The production of facsimile of the original or of copies of the work by means other then painting. A production of facsimile copy, which is reduced or enlarged, is also considered a "reproduction by reprographic means".

1762 ACA2K, Country Report Mozambique, July 2009, p. 26.

1763 Ibid.

1764 The term "reproduction by reprographic means" is defined by number 32 of the Glossary to the Copyright Code of Mozambique and says: "The production of facsimile of the original or of copies of the work by means other then painting. A production of facsimile copy, which is reduced or enlarged, is also considered a "reproduction by reprographic means".
} 
no direct or indirect commercial purpose. This means that the provision only covers reprographic reproductions by public libraries and archives. ${ }^{1765}$ Given the further prerequisites set forth in article 12 para. 1 to 3 MCA reproductions are feasible without the authorisation of the author or right holder. ${ }^{1766}$

Article 12 para. $1 \mathrm{MCA}$ allows the isolated reproduction of a copyright protected work. This probably means that a work may be reproduced in its entirety, but not several entire works, for this would unduly harm the interests of the author or right holder.

According to article 12 para. 2 MCA this also applies to articles, short works or short written extracts except for computer programmes, with or without illustration, published in a collection of works or in an issue of a journal or periodical, provided that the objective of the reproduction is to respond to the request of a physical person. Additionally, the following prerequisites must be given:

a) the library or the archive must safeguard that the copy will be solely used for the purpose of study, research or for private purposes.

b) the reproduction must be an isolated act, or in case repeated, the reproductions must take place on separated occasions and without relation to each other.

c) there must be no collective licenses available permitting the use of such copies.

Article 12 para. 2 MCA provision is problematic for several reasons. First, it is rather complicated and difficult to apply. Second, as said above, it only applies to public libraries. Not very surprisingly private libraries are excluded, which is not uncommon in Copyright laws of various countries. However, with regard to Mozambique`s special situation and the great need for access to education and knowledge, it would make sense to include private institutions respectively commercial libraries under certain conditions as well. Third, it is not defined by the law what is a short work or a short extract of a work. ${ }^{1767}$ Court decisions on this topic do not exist. Thus, the institution relying on article 12 para. 2 MCA has no legal certainty, if the use of a work infringes copyright. Forth, it is impossible for the institution to comply with article 12 para. a) MCA, because practically it cannot be safeguarded that the user of the copy will actually use it solely for study, research and private purposes. Again, the institution is left with considerable legal uncertainty. Fifth, the obligation to check if collective licenses are available for reproductions according to article 12 para. 2 MCA is not always

\footnotetext{
1765 There is no example of a commercial library in Mozambique, see ACA2K, Country Report Mozambique, July 2009 , p. 27.

${ }^{1766}$ Art. 12 MCA however does not mention the remuneration, which normally must be paid to the author as a compensation for the use of his work. Also Section II of the Copyright Code of Mozambique, which is entitled "Remuneração Equitativa" does not address this issue. Thus, it appears that remuneration must not be paid.

${ }^{1767}$ See above 4.1.3.2.1.
} 
easy to comply with and binds forces of the institution. Moreover, nothing is said in case licenses are available. It is unclear if the institution in that case is obliged to acquire such licenses or if article 12 para. 2 c) MCA only refers to licenses already acquired. ${ }^{1768}$ In view of these difficulties it must be stated that access to knowledge and education is rather not promoted by article 12 para. 2 MCA.

Article 12 para. 3 MCA addresses issues of preservation of copyright protected works by libraries and archives. The wording of article 12 para. $3 \mathrm{MCA}$ is not entirely clear regarding the nature of the institution, but since the entire provision deals with limitations of the reproduction right, it seems logical that article 12 para. $3 \mathrm{MCA}$ also applies only to libraries and archives without direct or indirect commercial purpose as named by article 12 para. 1 MCA. The preservation of library collections regularly requires the reproduction of copyright protected works. In case of loss or destruction of a work or in case it has become un-usable, article 12 para. 3 MCA permits the reproduction of the entire work if the copy is destined to preserve the work and if necessary to replace it in a permanent collection of works in a library or in an archive provided that:

a) it is impossible to find a copy of the work within reasonable conditions;

b) the reproduction must be an isolated act, or in case repeated, the reproductions must take place on separated occasions and without relation to each other.

This provision is also difficult to apply because the law does not specify what is meant by the term "reasonable conditions". The privileged institutions thus are left with the undefined obligation to investigate for copies of the work before invoking the limitation. This hardly contributes to legal certainty. Institutions may therefore rather abstain from relying on the limitation.

\subsubsection{4.}

Also in Chapter III Section I "Livre Utilização" article 18 MCA establishes rules on resale and public lending of protected works. Article $18 \mathrm{MCA}$ stipulates that it is permitted without authorization by the author or payment of any remuneration:

"(a) to resell or otherwise transfer ownership of the copy of a work, after the first sale or other transfer thereof, to a library or archive service whose activities are not directly or indirectly profit-making;"

\footnotetext{
${ }^{1768}$ Ibid.
} 
(b) to lend the copy of a written work to the public solely for consultation, provided that it is not a computer program." "1769

Obviously this provision intends to allow the circulation of works within the country as well as to promote access to knowledge for the public benefit. Article 18 para. (a) MCA at the same time contains a form of the principle of exhaustion, which however only shall apply to the transfer of ownership in copy of a work after its first sale to libraries or archives with noncommercial purposes. Since there are no other provisions dealing with the exhaustion of rights, the principle of exhaustion applies only to the specific case of article $18 \mathrm{MCA}$. In all other cases the rights of authors and right holders are not exhausted.

\subsection{5 Import for Personal Purposes}

In the context of exhaustion mention should be made also of article $20 \mathrm{MCA}$, which allows for imports of protected works for personal purposes. Article 20 MCA stipulates:

"A natural person or legal entity is permitted, without authorization by the author or any other owner of copyright, to import a copy of a work by a natural or legal person for personal and collective purposes. ${ }^{\text {1770 }}$

It seems that this provision is intended to foster access to knowledge on a personal level as the work can only be used for such purposes or the purposes of the respective legal entity. If the latter includes commercial activities is unclear, but it must be doubted in view of the relation to personal uses and the fact that neither authorisation is required nor remuneration has to be paid. Although the possible uses in accordance with article 20 MCA are limited to personal purposes, this provision obviously permits parallel importation to a certain extend. The author or rightholder has no possibility to interdict such imports. Article 20 MCA thus is a limitation to the distribution right, which cannot be exhausted in Mozambique, promoting access to knowledge at least on a personal level. As a result cheaper copies of protected works may be imported under said conditions from abroad.

\footnotetext{
${ }^{1769}$ Article 18 MCA: "(a) revender ou transferir de outra maneira, a propriedade do exemplar de uma obra, depois da primeira venda ou outra transferência da propriedade do exemplar a uma biblioteca ou serviço de arquivo, cujas actividades não visem directa ou indirectamente um lucro comercial;

(b) emprestar ao púplico o exemplar de uma obra escrita, para fins meramente de consulta, desde que não seja um programa de computador."

1770 Article 20 MCA: "É permittida a importação do exemplar de uma obra por pessoa física ou moral, para fins pessoais e colectivas, sem autorização do autor ou de qualquer outro titular do direito de autor da obra."
} 


\subsubsection{Survey Results}

In order to find out how higher education institutions, publishers and government departments in Mozambique deal with copyright issues regarding e-learning a survey was conducted. Each type of stakeholder was asked to answer a questionnaire taking into account its special situation and interests. Questionnaires were sent to all public universities in Mozambique, to the Mozambican Copyright office and several publishers of educational and fictional materials. Unfortunately, the response rate was very poor. Only one educational institution and the National Copyright Office answered the questionnaire. This may be interpreted as an indication of the significance of copyright law in Mozambique. According to the response rate, questions of copyright law are ignored to a large extent. In view of the practical difficulties encountered in Mozambique this is no surprise.

The responding educational institution confirmed that digital content is used for e-learning. The material is either produced by the institution itself or open content is used. The entire content is made available on an e-learning platform. The institution also confirmed that there is Copyright awareness and that the dealing with copyright questions and digital content is guided by a kind of Copyright Policy. The learning platform is only available to enrolled students. There was no comment on the question whether the institution applies limitations and exceptions for educational purposes. The institution had no knowledge of legal actions because of copyright infringements regarding the use of copyright protected works for elearning. Also the institution had not concluded any license agreements. The opinion that limitations and exceptions for educational purposes should be broader in order to promote access to knowledge and education was supported by the institution. The institution stated that learning content should be open. International co-operations for the exchange of learning materials between higher education institutions in countries of the Portuguese language do not exist. Generally, e-learning is endorsed by the institution. It was confirmed that the protection of e-learning activities through limitations and exceptions would have a positive effect because the demand for e-learning in higher education is great. In the future distance education and e-learning will grow further, using locally produced open content.

The Mozambican Copyright office confirmed that the protection of authors rights is of primary importance. Nevertheless, the improvement of access to education in the digital age also is an important goal. It was pointed out that in Mozambique less than $5 \%$ of the population have no access to the Internet or to a computer and therefore the most urgent problem of education in Mozambique is the access to books. In that area the legislator is very active and eager to create a climate, which stimulates intellectual production of Mozambican authors and promotes reading and the access to books for all kinds of 
purposes, especially education.

\subsubsection{Summary Mozambique}

The use of ICT for the improvement of access to education and knowledge is supported by the Mozambican government through public policies. The use of ICT relates to all levels of education and has led to the creation of various institutions, which promote ICT for access to education and knowledge. Both educational establishments and libraries are the addressees of these public policies.

Mozambican copyright law provides for limitations and exceptions in favour of educational institutions and libraries and archives. Yet, issues regarding digital uses of copyright protected works for educational purposes and in libraries are not addressed at all. Concerning the implementation of ICT for education and in libraries Mozambican copyright law is unable to provide solutions and legal certainty for educational institution and libraries and archives. This is particularly problematic because of the increasing number of digital learning materials in Mozambique. ${ }^{1771}$ The practice of using digital technologies for educational purposes was sustained by the survey conducted among stakeholders. It was pointed out that meanwhile $95 \%$ of Mozambicans have access to the Internet. The demand for e-learning, especially in higher education, is great. Moreover, digital technologies allow to produce learning materials and e-learning content at low cost. All the more digital issues must be addressed by copyright law in order to promote access to education and knowledge in the digital age.

Difficult remains the access to schoolbooks. The production costs are very high compared to digital content. This is why the Mozambican legislator promotes the production and dissemination of (school) books by Mozambican authors. One means to achieve this goal is effective intellectual property and copyright protection, which is fostered by the Mozambican legislator in order to provide incentives to create and invest for authors and right holders. Not surprisingly, the dominant opinion regarding the objectives of copyright law in Mozambique is that the protection of rights of authors and right holders has top priority. This view is sustained by the results of the survey. Compared with this the role of copyright limitations and exceptions as a means of promoting access to education and knowledge is rather neglected. Although broader limitations and exceptions for educational purposes are supported by educational institutions, in practice open content such as open educational resources for e-learning is used instead of relying on limitations and exceptions for the use of copyright protected works for educational purposes. Moreover, legislative activities in the

${ }^{1771}$ ACA2K, Country Report Mozambique, July 2009, p. 33. 
area of copyright law in Mozambique do not focus on digital issues.

With regard to the benchmark of permissible uses of copyright protected works by educational establishments and libraries, archives and similar institutions it must be noted that the provisions of the MCA do not meet the requirements. This is not surprising since the access to education and knowledge issue arises already on the level conventional educational materials, such as textbooks. Moreover, digital infrastructure is not fully developed. Apart from that the current system of limitations and exceptions for education and knowledge in Mozambique contains no open and flexible fair use like provisions. Digital aspects are not explicitly addressed. However, there is no restriction to only analogue works, which means that in principle the provisions apply also to digital works. The reproduction of works for non-commercial education is restricted to reprographic reproductions and short extracts. Digital copies thus are not permitted and the amount of the work that can be used is restricted. The same is true for libraries and archives, which are only allowed to make reprographic reproductions for non-commercial purposes, such as reproductions on behalf of users of the library for private use or reproductions for preservation purposes. Yet, only one copy of a complete work is permitted. Mozambique does not have a clear rule regarding exhaustion of rights, but it allows parallel importation for personal uses. Since nothing is said to the contractual overridability of limitations, this is obviously possible.

This is said in advance limitations and exceptions of the MCA do not adequately promote the access to education and knowledge in the digital age. Given the fact that the constitution of Mozambique establishes the right to education and the right to information including the access to knowledge copyright law should support these objectives in particular with regard to new digital technologies and Internet. This is however not the case. Mozambican copyright law rather focuses on the protection of authors and right holders, whose rights are equally protected by the constitution. The overprotection of authors and right holders under the MCA is further highlighted by the preamble, which declares as an objective of the MCA the protection of authors and other right holders and only indirectly refers to the public interest in the stimulation of intellectual production. In view of the state of development of Mozambique and the urgent need for access to education and knowledge, the right to education and to take part in cultural life should therefore explicitly be mentioned in the preamble of the MCA in order to safeguard that these positions are adequately observed when applying and interpreting provisions of the MCA. In principle, a reform of the Mozambican copyright law is necessary. However, this would be only one of various approaches to improve access to education and knowledge. 
Altogether, it must be stated, that copyright law in Mozambique does not correspond with practical reality. From the answers of the survey it can be deduced that there is little or no copyright enforcement in Mozambique. Intellectual production, including the production of educational content, is low. A major problem for access to education and knowledge remains the access to printed (school) books, which are very expensive. Generally, the cost for the access to copyright protected material of any kind is one of the main issues in Mozambique. Here, broad limitations facilitating access at low or no cost could be a useful means. Certainly, copyright law in Mozambique is only one of several reasons hindering access to education and knowledge.

\subsubsection{The Community of Portuguese Speaking Countries}

Portugal, Brazil and Mozambique are linked by the Portuguese language. They share a long history of cultural and economic ties, beginning with Portuguese discoveries and colonialism in the late 15th century and continuing to the present day. Together with Angola, Cabo Verde, Guiné-Bissau, São Tomé e Príncipe and Timor-Leste they form the community of Portuguese speaking countries, A Comunidade dos Países de Língua Portuguesa (CPLP).

The CPLP was established on July 17, 1996, in Lisbon through the constitutive declaration of the heads of state and government of these countries. ${ }^{1772}$ In this document member states point out that Portuguese speaking countries in their entirety are indeed a disconnected geographic space, which however is linked by the common language. For that reason it is declared to reinforce the ties of solidarity and co-operation in order to promote economic and social development among the people of the member states as well as the reinforcement and the divulgation of the Portuguese language. For these purposes far reaching collaborations in all areas are agreed upon, including education, health, science and technology, defence, agriculture, public administration, communication, justice, public security, culture, sport and social communication. In addition political and diplomatic harmonisation between the member states is declared, namely for the purpose of strengthening their international presence. ${ }^{1773}$ The principal objectives of the CPLP are sovereign equality of member states, non-interference with internal affairs of member states, respect for national identity, reciprocal treatment, primacy of peace, democracy, state of law, human rights and social justice as well as respect for territorial integrity and the promotion of development and mutually

\footnotetext{
1772 Declaração Constitutiva da Comunidade dos Países de Língua Portuguesa (CPLP), July 17, 1996, available at www.cplp.org/Admin/Public/DWSDownload.aspx?File=\%2fFiles\%2fFiler\%2fcplp\%2fDeclaraoConstitutivaCPLP.pd

${ }_{1773}$ Article 3 Estatutos da CPLP, com revisões de São Tomé/2001, Brasília/2002, Luanda/2005, Bissau/2006 e Lisboa/2007, available at

http://www.cplp.org/Files/Filer/Documentos\%20Essenciais/Estatutos_CPLP_REVLIS07.pdf.
} 
advantageous co-operation. ${ }^{1774}$

According to the statutes of the CPLP there are several directive and executive organs, namely the Conference of the Heads of State and Government (A Conferência de Chefes de Estado e de Governo), the Council of Ministers (O Conselho de Ministros), the Committee of Permanent Consultation ( $\mathrm{O}$ Comité de Concertação Permanente) and the Executive Office (O Secretariado Exectuivo). ${ }^{1775}$ Furthermore, organs of the CPLP are the Parliamentary Assembly of the CPLP (A Assembleia Parlamentar da CPLP), the Reunion of Focal Points of Corporation (A Renuião dos Pontos Focais de Cooperação) and the Ministerial Reunions (As Reuniões Ministeriais). ${ }^{1776}$ The organs of CPLP meet regularly in different stated intervals and maintain a regular exchange, which may lead the adoption of plans of action and to practical co-operations.

The co-operation between the member states of the CPLP has not led to creation of a common market, which is by the way not intended as to the Constitutive Declaration and the statutes of the CPLP. Yet, there are various strategies and plans of action regarding the above-mentioned issues, in particular concerning education and culture. In that context the mutual exchange of intellectual goods, such as learning materials, literary and cinematic works as well as other artistic creations, between member states is deemed of special importance and thus promoted particularly through several declarations of Ministerial Reunions of the ministers of education and culture. The questions of copyright law arising in this context of cross-border exchange of protected works are not addressed at all or at least not from the viewpoint of access to education and knowledge, but rather with regard to the protection of authors and right holders.

\subsubsection{Copyright Relevant Issues and the CPLP}

Nevertheless, there is copyright awareness among the members of the CPLP, since the CPLP as an intergovernmental organisation is an Accredited Observer at the WIPO. ${ }^{1777}$

In various declarations the ministers of culture of the CPLP have made reference to aspects of copyright law in connection with the policies adopted regarding the dissemination of

\footnotetext{
1774 Article 5 para. 1 Estatutos da CPLP, com revisões de São Tomé/2001, Brasília/2002, Luanda/2005, Bissau/2006 e Lisboa/2007.

${ }^{1775}$ Article 8 para. 1 Estatutos da CPLP, com revisões de São Tomé/2001, Brasília/2002, Luanda/2005, Bissau/2006 e Lisboa/2007.

${ }^{1776}$ Article 8 para. 2 and 3 Estatutos da CPLP, com revisões de São Tomé/2001, Brasília/2002, Luanda/2005, Bissau/2006 e Lisboa/2007.

${ }_{1777}$ WIPO, Cooperation Agreement Between the Secretariatof the Community of Portuguese-Speaking Countries (CPLP) and the World Intellectual Property Organization (WIPO), WO/CC/48/2, Annex VI, July 22, 2002, available at http://www.wipo.int/edocs/mdocs/govbody/en/wo_cc_48/wo_cc_48_2.pdf.
} 
protected works within the member states of the CPLP. For the first time the importance of the dissemination of and the access to culture was addressed in the Declaration of Estoril of May 5/6, 2000. ${ }^{1778}$ Therein culture is declared a fundamental right, which is especially important in view of the positive effects on human development and participation in a democratic society. Furthermore the significance of cultural activities for social and economic development is highlighted and at the same time the endangerments of a globalised economy and ICT to culture are underscored. Together with this declaration the ministers of culture agreed on a plan of action in order to promote the dissemination of culture. ${ }^{1779}$ The plan of action explicitly refers to the acquisition of books for the purpose of dissemination in public libraries in order to promote cultural exchange. ${ }^{1780}$ In addition the ministers agreed on projects in the fields of production, distribution, promotion as well as conservation and restoration of cinematic works. ${ }^{1781}$ In that context the plan of action refers to copyright and related rights and encourages the establishment of a programme to elaborate copyright legislation related to the above projects. ${ }^{1782}$ The resolution of the ministers of culture on cinematographic archives of May 13/14, 2005, is however silent on the question of copyright. ${ }^{1783}$ But at the same session the ministers of culture issued a resolution concerning the corporation between the members of the CPLP regarding copyright and neighbouring rights. ${ }^{1784}$ In this resolution the function of intellectual property as an incentive to the creation of cultural goods and technological and scientific innovation and the importance of this issue to the actual stage of development of the member states is pointed out. Further, it is highlighted that intellectual property has to achieve a harmonic equilibrium between the rights of authors and right holders and the legitimate interests of users in order to allow access and use of protected works on the conditions that guarantee the social-cultural development of different human communities. ${ }^{1785}$ By making reference to the relevance of modern ICT for the creation and the dissemination of knowledge, it is underscored that the

\footnotetext{
1778 Cimeira de Ministros da Cultura da CPLP, Declaração de Estoril, May 5/6, 2000, available at http://www.cplp.org/Admin/Public/DWSDownload.aspx?File=\%2fFiles\%2fFiler\%2fcplp\%2fredes\%2fcultura\%2fDE CLARACAODOESTORIL.pdf.

${ }_{1779}$ Cimeira de Ministros da Cultura da CPLP, Plano de Ação, May 5/6, 2000, available at http://www.cplp.org/Admin/Public/DWSDownload.aspx?File=\%2fFiles\%2fFiler\%2fcplp\%2fredes\%2fcultura\%2fDE CLARACAODOESTORIL.pdf.

${ }_{1780}$ Cimeira de Ministros da Cultura da CPLP, Plano de Ação, May 5/6, 2000, I.2.1 b).

1781 Idem, I.2.1 c).

1782 Idem, 2000, I.2.3.

1783 IV. Reunião de Ministros de Cultura, Resolução sobre is Arquivos Cinmatográficos, May 13/14, 2005, available at http://www.cplp.org/Admin/Public/DWSDownload.aspx?File=\%2fFiles $\% 2 \mathrm{fFiler} \% 2 \mathrm{fcplp} \% 2 \mathrm{fredes} \% 2 \mathrm{f}$ cultura\%2fRESOLU\%ef\%bf\%bd\%ef\%bf\%bdO_SOBRE_OS_ARQUIVOS_CINEMATOGR\%ef\%bf\%bdFICOS.pdf. ${ }_{1784}$ IV. Reunião de Ministros de Cultura, Resolução sobre a Cooperacão em Matéria de Direito de Autor e Direitos Conexos entre os Estados Membros da CPLP, May 13/14, 2005, available at http://www.cplp.org/Admin/Public/DWSDownload.aspx?File=\%2fFiles\%2fFiler\%2fcplp\%2fredes\%2fcultura\%2fRE SOLU\%ef\%bf\%bd\%ef\%bf\%bdO_SOBRE_A_COOPERA\%ef\%bf\%bd\%ef\%bf\%bdO_EM_MAT\%ef\%bf\%bdRIA_D E.pdf.

1785 "Reconhecendo igualmente que a propriedade intelectual deve integrar um adequado e harmonioso equilíbrio entre direitos do autor e demais titulares e interesses legítimos dos utilizadores, em ordem a permitir o acesso e o uso de obras e prestações às pessoas, em condições que garantam o desenvolvimento sociocultural das diversas comunidades humanas;", see IV. Reunião Ministerial, Resolução sobre a Cooperacão em Matéria de Direito de Autor e Direitos Conexos entre os Estados Membros da CPLP, May 13/14, 2005.
} 
diversity of the member states of the CPLP regarding their state of development must be cautiously taken into consideration. The conclusions drawn from these general reflections mostly relate to the formation of better copyright awareness and to collective management of existing rights in member states. Finally, the ministers of culture issued the declaration of Luanda in April 2012, which refers to the resolution on cinematographic archives and declares that among others member states in corporation with WIPO should reinforce their actions in the defence of copyright and the fight against piracy. ${ }^{1786}$ This statement is a bit surprising with regard to the older statements of the ministers of culture and the frequent references to the significance of the dissemination of culture for social and human development. The importance of the latter issue was again emphasised by the strategic plan of multilateral cultural co-operation of April 11, 2014, issued by the Executive Office of the CPLP. ${ }^{1787}$ This plan contains detailed projects and priority actions generally speaking the purpose of promoting the circulation of cultural goods within the area of the CPLP. The plan foresees as its first strategic axis the strengthening of cultural industries and the creative economy. It explicitly addresses the creation of mechanisms that facilitate the free circulation of cultural goods in the area of the CPLP. ${ }^{1788}$ Further, an information system regarding copyright and related rights shall be introduced in order to provide information concerning copyright legislation in the member states, create a manual of best practices and raise awareness for the economic importance of cultural industries and copyright. ${ }^{1789}$ Above that under strategic axis 4 the plan addresses the issue of digitisation of cultural heritage of members states of the CPLP by creating common cultural heritage institutions and establishing digitisation policies, including the making available online. ${ }^{1790}$ As well the preservation of audiovisual heritage and a network of museums within the area of the CPLP is planned. ${ }^{1791}$ The final declaration of the ministers of culture of April 10/11, 2014, which refers to the above strategic plan, finally stipulated that the Executive Office of the CPLP should elaborate a comparative study on copyright and related rights within member states. $^{1792}$

Regarding the field of education there are also several declarations and resolutions to promote education on all levels among member states of the CPLP. Already in the first

\footnotetext{
1786 VIII. Reunião de Ministros de Cultura, Declaração de Luanda, April 2/3, 2012, para. 6, available at

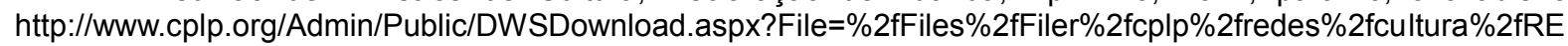
UNI\%26Atilde\%3bO+MINISTERIAL+DA+CULTURA+VIII+RMC-declara\%26ccedil\%3b\%26atilde\%3bo+da+Luan da+2012.pdf.

${ }^{1787}$ CPLP, Plano Estratégico de Cooperação Cultural Multilateral da CPLP (2014 - 2020), April 11, 2014, available at http://www.cplp.org/Admin/Public/DWSDownload.aspx?File=\%2fFiles\%2fFiler\%2fcplp\%2fPECCML-Oficial.pdf.

${ }_{1788}$ Idem, para. 1.1.

1789 Idem, para. 1.4.

1790 Idem, para. 4.1.

1791 Idem, para. 4.2 and 4.3.

1792 Reunião de Ministros de Cultura, IX. Sessão, Declaração Final, April 10/11, 2014, para. 4, available at http://www.cplp.org/Files/Billeder/cplp/Declarao-Final-IX-Reunio-CPLP.pdf.
} 
conference of the ministers of education the need to develop and promote distance education was highlighted. ${ }^{1793}$ The fundamental importance of education as a human right, which is vital for the exercise of citizenship and democratic participation and as a means to overcome poverty and promote economic growth, was emphasised by the latest declaration of the ministers of education in May 2016. ${ }^{1794}$ Yet, there is no relation to copyright aspects of education. The plan for action in the area of education, which was approved by said declaration, is also intended to promote education on all levels within the area of the CPLP and provides for specific measures to achieve this goal. ${ }^{1795}$ However, it is completely silent with regard to copyright, too.

\subsubsection{Findings}

As was shown above there are a number of policies concerning the exchange and the dissemination of intellectual works, such as cultural creations and educational materials, within the area of the CPLP. Their intention is to promote social, human, cultural and economic development to the mutual benefit of the member states of the CPLP. The area of the member states of the CPLP is not a common market, but consists of a bundle of historical, cultural, economic ties, above all the Portuguese language. It is obvious that questions related to copyright emerge in view of the measures set out by the above policies and plans, which include the use of literary works and learning materials as well as the digitisation, preservation and making available of cultural heritage. Nonetheless, these issues related to copyright are not specifically addressed, although the policies are aware of the significance of copyright law. Yet, it appears that also in this regard the author centred approach to copyright law is dominant, since the focus on the protection of authors and right holders is explicitly mentioned. As regards access to education and knowledge and the use of digital technologies, which are also encompassed by these policies, this is regrettable, but not surprising because in Portugal, Brazil and Mozambique this is the prevailing opinion.

In view of the co-operations between the member states of the CPLP in the field of education and culture it would make sense to deal with copyright issues more expressly. Based on the mutual exchange, which is encouraged by the CPLP through its policies, it seems favourable to allow parallel importation, for instance with regard to textbooks, and to apply the

\footnotetext{
1793 I. Conferência de Ministros de Educação, Conclusões, November 24/25, 1997, para. V.1., available at http://www.cplp.org/Admin/Public/DWSDownload.aspx?File=\%2fFiles\%2fFiler\%2fcplp $\% 2$ fredes $\% 2$ feduc $\% 2 f C O N$ CLUSOESCONFERENCIALISBOA.pdf.

${ }_{1794}$ IX. Conferência de Ministros de Educação, Declaração Final, May 24, 2016, available at http://www.cplp.org/Admin/Public/DWSDownload.aspx?File=\%2fFiles\%2fFiler\%2f1_CPLP\%2fEducacao\%2flXREUNI\%26Atilde\%3bO-DE-MINISTROS-DA-EDUCA\%26Ccedil\%3b\%26Atilde\%3bO_DEC.pdf.

${ }^{1795}$ CPLP, Plano de Ação de Cooperação Multilateral no Domínio da Educação da CPLP (2016 - 2020), available at http://www.cplp.org/Admin/Public/DWSDownload.aspx?File=\%2fFiles\%2fFiler\%2f1_CPLP\%2fEducacao\%2fPla no_A\%26ccedil\%3b\%26atilde\%3bo_Coop_multi_educacao_cplp.pdf.
} 
exhaustion rule both to analogue and digital works, either to uses occurring between two member states of the CPLP or between all member states. Thereby access to education and knowledge in the digital age could be promoted to a large extent. In particular, such exhaustion rule would be an appropriate means to permit access to the collections of libraries and similar institutions in more developed member states for students from least developed members of the CPLP, e.g. Mozambique, over the Internet. The same would be true for e-learning services. This idea appears to be especially promising, since due to the common Portuguese language, no language barriers would restrict access. So far, however, there are no provisions in national copyright laws in Portugal, Brazil and Mozambique regarding analogue or a digital exhaustion. Regarding the digitisation and cross-border making available of cultural heritage additionally the problem of orphan works exists and should be addressed.

\subsubsection{Summary Part 2 of Chapter 4}

The objective of Part 2 of Chapter 4 was to find out, whether access to education and knowledge is promoted by the limitations and exceptions international laws of Portugal, Brazil and Mozambique. The copyright laws of these countries all contain limitations and exceptions privileging specific uses of copyright protected works for educational purposes and in libraries, archives and similar institutions. The rationale for limitations and exceptions is public interest in the promotion of access to education and knowledge as well as the human right to education and to take part in cultural life. However, it appears that in Portugal, Brazil and Mozambique copyright law in general and the respective provisions of national legislation in particular give priority to the protection of the rights of authors and right holders. Compared with this the role of limitations and exceptions and their underpinnings in fundamental rights to enable a fair balance of interests for the greater good of society is underestimated.

Portugal, Brazil and Mozambique promote the use of ICT in education of all levels in order to facilitate the access to knowledge and education. The countries have implemented respective educational and ICT policies. From a practical point of view, the countries make use of the advantages of digital technologies and the Internet. From a legal point of view, it can be noted that to a certain extent the copyright laws of each country provide for limitations and exceptions for educational purposes and libraries and archives. Concerning digital issues and limitations and exceptions the copyright laws of Brazil and Mozambique are silent. Portugal addresses digital issues in this field because of the implementation of the Information Society Directive and the Orphan Works Directive. As was shown above the respective provisions grounding on the Information Society Directive in Portuguese copyright 
law are very complicated and partly outdated. Brazilian copyright law contains an extremely narrow limitation for educational purposes and no limitation for libraries at all. This problem is aggravated by the dogma of narrow interpretation of limitations and exceptions and the general one-sided and author centred approach on Brazilian copyright law. In comparison Mozambican copyright law appears rather modern. At least it contains limitations and exceptions in favour of education and libraries and archives. The scope of application yet is narrow and difficult to understand. Moreover, it must be questioned, if these provisions have any practical relevance. It appears that as a least developed country Mozambique has more urgent problems than the question of adequate limitations and exceptions to copyright law. In Portugal, Brazil and Mozambique in general the level of copyright enforcement is rather low, which means that the unauthorised use of copyright protected works for educational purposes and in libraries and archives normally has no legal consequences.

Furthermore, it was found out that the exchange of learning materials and cultural goods is promoted by various declaration and policies of the CPLP. As the results of the surveys suggest, these policies are put into practice rarely by the respective institutions in Portugal, Brazil and Mozambique. A common market for learning materials and cultural goods does not exist from a legal point of view. Nevertheless, the exchange of intellectual works between the member states of the CPLP is a declared objective, in particular in the fields of education and culture. This is true as well for digital uses and online dissemination. Insofar, territoriality, exhaustion of copyright and parallel importation with regard to both analogue and digital works are relevant issues, even if at the moment awareness among member states of the CPLP is not particularly strong, at least in terms of access to education and knowledge. However, the more e-learning and digital learning content will be used and ICT-infrastructure is improved, the more these issues will become significant, since territoriality and geoblocking have the effect of impeding (online) access to copyright protected works. Permitting parallel importation for instance in Brazil and in Mozambique could be an appropriate means to promote access to education and knowledge with regard to analogue learning material, especially textbooks, at affordable prices.

With regard to the benchmark of permissible uses none of the system of limitations and exceptions examined in Portugal, Brazil and Mozambique meets all requirements. Only Portugal, which is a developed country and member of the EU, addresses digital issues and complies with some of the requirements. In Brazil there are no limitations in force that sufficiently deal with the topic of access to education and knowledge in general, not to mention concerning the digital age. Also in Mozambique limitations and exceptions do not relate to digital uses of protected works. 
In terms of adequate promotion of access to education and knowledge in the digital age and the objectives pursued by limitations and exceptions to copyright law it stands out that Portugal, Brazil and Mozambique all establish constitutional protection for the right to education and the right to take part in cultural life as well as for the right to (intellectual) property, namely the right of authors and right holders to protection of their interests. Still, these fundamental value decisions are not appropriately reflected within the respective copyright system. The dominant approach is an author-centred one. Adequacy is thus not achieved in any of the countries.

In Portugal this fact has the least severe consequences because of the country`s state of development. Indeed, Portugal is one of the poor members of the EU, but nonetheless in terms of access to education and knowledge through educational establishments, libraries, archives and similar institutions as well as to ICT infrastructure and computers and other web enabled devices, the level of access is comparatively high. This means that in spite of a restrictive regime of limitations and exceptions, access to education and knowledge, at least in a traditional context, is safeguarded.

By contrast in Brazil a restrictive regime of limitations and exceptions has severe consequences in view of the country's state of development. Being a developing country Brazil has to cope among others with problems such as extreme poverty and illiteracy. Both may be successfully fought with education and knowledge. In order to promote education and knowledge, people must have access to providers of both, i.e. educational establishments and libraries and similar institutions. Yet, access has a practical and a legal side, which mutually complement each other. On the practical side access depends on infrastructure and financial resources. On the legal side access depends on a legal framework, which permits specific uses related to a desired objective. It is suggested that a balanced framework in the field of copyright limitations and exceptions, which takes into account especially the human rights dimension of education and knowledge, would promote access in so far as educational establishments and libraries, archives and similar institutions could provide their services on a reliable basis instead of acting in legal uncertainty. It is further assumed that based on such framework public investments in infrastructure necessary for access to education and knowledge would increase. In addition, it is likely that a balanced copyright system would foster the dissemination of protected works and thus would be an incentive for the creation of new works, which desirable form the viewpoint both of the general public and authors. As a result the practical side of access would be improved. Besides, improving the practical side of access alone would have the negative effect of 
continuing legal uncertainty and unlawfulness for providers of education and knowledge.

With regard to Mozambique it must be doubted whether the current restrictive copyright and unfavourable limitations and exceptions have any practical effects, since the law is not or at least not consequently enforced. As a least developed country Mozambique and its state of development problems relating to access to education and knowledge are encountered largely on a practical level. Yet, it must be also noted that, would the current copyright law be enforced, access to education and knowledge were not promoted adequately, in particular concerning digital uses of protected works. In view of the public policies the Mozambican government has issued regarding education and ICT these initiatives should be complemented by a copyright reform taking into consideration more appropriately the constitutionally protected right to education and to information, including the right to access to knowledge. A balanced system of limitations and exceptions could contribute to enhance the creation of new works by Mozambican authors and promote the dissemination of knowledge. It could also stimulate public investments in educational infrastructure and libraries and archives in order to foster access on the practical side, which is urgently required. This is not only true concerning the access to traditional learning materials, especially textbooks, but equally concerning digital infrastructure and the access to ICT given the advantages of digital technologies in terms of affordability of educational content. In addition, there should be measures undertaken by authorities to improve the enforcement of copyright, in particular with regard to the promotion of domestic intellectual production.

Based on the above country analysis Portugal, Brazil and Mozambique alike should incorporate in their national codification explicit references to the human right to education and to take part in cultural life as desirable objectives for copyright law in addition to the protection of authors' rights. Further, the significance of a fair balance of these rights should be highlighted. With regard to limitations and exceptions it appears generally favourable for access to education and knowledge to provide for a fair use like provision relating distinctly to these objectives and their fundamental rights underpinnings in order to guide the interpretation. In addition, both Portugal and Brazil and Mozambique should introduce further statutory limitations regarding digital uses, as proposed by the benchmark of permissible uses.

In Portugal these limitations should apply only to non-commercial purposes and be connected with statutory licenses in order to remunerate authors and right holders adequately. 
In Brazil and Mozambique, however, regarding the state of development of both countries, it may be an idea to apply limitations not only to non-commercial but also to commercial educational purposes in order to promote access to education and knowledge. Only in case commercial purposes are pursued by the respective institution remuneration would have to be paid to authors and right holders in form of statutory licenses. Non-commercial purposes would not be bound to remuneration. Such approaches would however come into conflict with the Three-Step-Test. Authors and right holders would argue that limitations interfere with the normal commercial exploitation of their works and would unreasonably prejudice their legitimate interests. Yet, if one follows an interpretation of the Three-Step-Test, which takes into consideration not only economic but also human rights and public interest, as it is the case here, the proposed approach for Brazil and Mozambique could pass the test due to the significance of the objectives promoted by the respective limitations. It should also be stipulated that licensing contracts cannot overrule limitations and exceptions. Furthermore, with regard to the co-operations in the fields of education and culture, which promote the dissemination of intellectual works within the area of the CPLP, another approach to enhance access to education and knowledge could be the extension of the principle of exhaustion online uses of protected works and permit cross-border digital uses for educational purposes, research and private study. Brazil and Mozambique have no clear rules regarding the exhaustion of rights. Mozambique however allows parallel importation for personal purposes. Yet, further rules on exhaustion should be implemented in both countries, in particular with regard to the dissemination of knowledge via digital means.

Above that it is questionable whether a market for (digital) learning materials exists in developing and least developed countries in view of their inability to pay for these goods. In that case there is no or only little conflict with the normal exploitation of protected works. ${ }^{1796}$ Developing and least developed countries could therefore be permitted to use learning materials without payment or at very low prices. However, it had to be safeguarded that reproductions of these works are not exported for commercial purposes to sound markets for this would interfere with the normal exploitation of the works. ${ }^{1797}$

A situation of market failure also occurs when no market exists due to the lack of enforcement of intellectual property and copyrights. Authors and right holders cannot control the use of their works and derive commercial benefits from it. In sound markets, for instance in Continental Europe, limitations are applied in these situations and authors and right holders receive remuneration in form of statutory licenses. Yet, this solution is not workable

\footnotetext{
${ }^{1796}$ Foster, The Conflict between the Human Right to Education and Copyright, in Intellectual Property Law and Human Rights (2015), p.365.

${ }_{1797}$ Idem, p. 366.
} 
when there is market failure both due to the lack of enforcement and the inability to pay for uses of the work. In that case authors and right holders cannot control the use of their works and remain without remuneration. As a consequence there are no incentives for the creation of new works, which is disadvantageous for the dissemination of knowledge and social development.

Market failure certainly occurs in Mozambique, and partly in Brazil, too.

It appears that this dilemma can only be solved through the implementation of stimulating intellectual property and copyright regimes, including well balanced limitations and exceptions, taking into account appropriately the interests of all stakeholders involved and the underpinnings of their positions in fundamental and human rights, especially the right to education and the right to take part in cultural life. The implementation of new laws should go hand in hand with the improvement of copyright enforcement. As was said above, especially in Mozambique domestic production of intellectual works, including learning materials, is comparatively low. A reliable copyright system could help to enhance the production and dissemination of new works.

In addition Brazil and Mozambique could apply the limitations provided for by the Berne Appendix, which relates to the reproduction right and the translation right. Being members to the Berne Convention both countries could in principle benefit from compulsory licenses under the Appendix. Since the current version of the Berne Appendix is very complicated and the practical advantages for developing and least-developed countries are questionable, it is rarely used. Brazil and Mozambique have not deployed the Appendix. Yet, a reform of the Berne Appendix, which considers more appropriately the situation of developing and leastdeveloped countries as well as digital issues, could make this instrument more attractive. So far this is not insight.

After all it must be stated that limitations and exceptions to copyright law for educational purposes and libraries and archives in Portugal, Brazil and Mozambique do not (sufficiently) take into account neither the possibilities of the Internet and ICT nor the use of copyright protected works for educational purposes and in libraries and archives at all. As a consequence, they do not adequately promote access to education and knowledge. 


\subsection{Summary Chapter 4}

Part 1 of chapter 4 showed that in the USA, the UK and in Germany there is a high level of copyright protection and enforcement. Copyright infringements have legal consequences and may end up in lawsuits. Awareness of copyright law and the significance of limitations and exceptions to copyright law is high, at least among stakeholders. The national copyright laws reflect to some extent the possibilities of new digital technologies and the Internet for educational institutions and libraries, archives, museums and similar institutions. However, apart from being very complicated and difficult to apply many limitations have been introduced before the advent of digital technologies and the Internet. Furthermore, the inflexibility of statutory limitations is a problem. The laws hardly adapt to new developments. This is especially problematic in Germany, where no open clauses like the fair use doctrine in the USA or the fair dealing provisions in the UK allow some flexibility. The limitations and exceptions to copyright law for education and libraries, archives, museums and similar institutions have been reformed lately in the UK. The reform has led to a greater consideration of digital issues. Nevertheless, it was found that limitations to copyright law in the USA, the UK and in Germany do not sufficiently reflect the possibilities of digital technologies and the Internet for educational purposes and for libraries, archives and similar institutions. In Germany therefore reforms are discussed. Also in the USA revisions are expected. In the UK the effects of the 2014 reform must still be evaluated in practice.

With regard to the benchmark of permissible uses none of the countries examined in Chapter 4 Part 1 meets fully the requirements. In terms of adequacy it was found that fundamental rights, especially the human right to education and the human rights take part in cultural life, are not considered sufficiently in the current system of limitations and exceptions.

Based on these findings it was proposed to combine the advantages of fair use provisions regarding flexibility with the advantages of clearly defined statutory limitations regarding legal certainty and granting statutory licenses to educational establishments, libraries, archives and similar institutions. Altogether it appeared favourable to make explicit reference in national copyright codifications to the significance of underlying objectives, in particular the human right to education and the human right to take part in cultural life, and to remind that these positions have to be brought into a fair balance with the equally important rights of authors and right holders to their intellectual property and the protection of their interests.

In Part 2 of Chapter 4 it was found that the existing limitations and exceptions to copyright law for educational purposes and libraries, archives and similar institutions are very different from each other. This has to do with the current stage of social and economic development of 
each country. Portuguese copyright law contains the most advanced provisions, which go back to the Information Society Directive. Digital issues are at least partly covered. Many provisions are however outdated. New developments are not reflected and cannot be taken into account because of inflexible statutory limitations. Mozambican copyright law provides for limitations and exceptions in favour of educational institutions and libraries and archives. Digital issues however are not addressed and the scope of application of the respective provisions is narrow and of little or no practical relevance. Open clauses for a flexible adaption to new developments do not exist. The most restrictive and outdated system of limitations and exceptions to copyright law has Brazil. Educational uses of copyright protected works are addressed, but the respective provision is not relevant in practice. Provisions in favour of libraries, archives or similar institutions do not exist. Digital issues are not addressed at all. Brazilian copyright law knows no provisions providing flexibility through open clauses. Especially in Mozambique and Brazil the focus is mainly on the protection of the rights of authors and right holders. To a certain extent this is true in Portugal, too. The role of limitations and exceptions as promoters of access to education and knowledge is underestimated or neglected.

With regard to the benchmark of permissible uses none of the countries examined in Chapter 4 Part 2 complies with the requirements entirely. In terms of adequacy it was found that fundamental rights, especially the human right to education and the human right to take part in cultural life, are indeed addressed explicitly in the constitution of each country. But this fact is not considered sufficiently in the current system of limitations and exceptions.

Different than the USA, the UK and Germany, Portugal, Brazil and Mozambique find themselves in very different states of development. As a result the conclusions drawn from the analysis of limitations and exceptions differ significantly. Concerning Portugal a reform of the current system of copyright limitations and exceptions similar to the one suggested for the USA, UK and Germany appears recommendable. As regards Brazil and Mozambique the situation is more complicated. On the one hand it is necessary in both countries to remodel limitations and exceptions in order to promote access to education and knowledge adequately, both concerning analogue and digital uses. In so far the ideas proposed for the countries in Chapter 1 Part 1 and for Portugal apply to Brazil and Mozambique, too. The only difference in this regard was that it was considered to permit not only non-commercial but also commercial uses of protected works for educational purposes and in libraries and similar institutions. Only in case the use was commercial the respective institutions had to pay remuneration by means of statutory licenses. On the other hand practical problems regarding access to education and knowledge were encountered, such as insufficient infrastructure and 
lacking financial resources. It was also found that situations of market failure may occur, which have negative effects in societies as a whole and result in a dilemma, i.e. no protection for authors and right holders and no access to education and knowledge. Thus, it was proposed as a solution to establish stimulating copyright regimes, which in particular take into account fundamental rights such as the right to education and the right to take part in cultural life. In addition parallel importation of both analogue learning materials, such as textbooks, and the extension of the exhaustion rule to digital media and online uses as well as the application of a reformed version of the Berne Appendix could promote access to education and knowledge.

In summary, it must be stated that the current copyright legislation in the field of limitations and exceptions in the countries examined here does not provide adequate solutions for the use of copyright protected works for educational purposes and in libraries, archives and similar institutions in the digital age. Generally, it was found that the respective provisions are either outdated and do not address digital issues at all or they are very complicated, narrow and unable to adapt to changing practical conditions. Furthermore, the significance of the human right of education and the human right to take part in cultural life is not sufficiently taken account of. Only the fair use doctrine in the USA and fair dealing in the UK allow some flexibility. In view of this general disadvantageous stage of limitations and exceptions the assumption was confirmed that copyright law restricts the access to education and knowledge. The findings also confirmed that this problem is especially urging in Brazil and Mozambique, where copyright law merely focuses on the strong protection of authors and right holders, ignoring the need for (affordable) access to education and knowledge for large parts of the population. 


\section{Conclusion}

\section{Results}

The balance of interests in copyright law is troubled. The reasons are complex. In light of the changes of the digital age a unilateral expansion of copyright protection in favour of authors and right holders must be observed. At the same time fundamental rights, such as the human right to education and the human right to take part in cultural life as well as public and individual interest interests in access to education and knowledge are not sufficiently taken into consideration. Yet, it is copyright's purpose to protect authors and promote the dissemination of knowledge, including the access to education equally.

As the findings of the study show this shift in the balance of interests towards more protection of and less access to copyright protected works is a universal phenomenon. The manifestations and effects vary from country to country and depend on the respective copyright system and the national specialities.

The analysis of limitations and exceptions to copyright law for educational purposes and libraries and archives in the USA showed that digital developments were taken into account already years ago. However, these provisions meanwhile are outdated to a large extent. Moreover, they are very complicated and difficult to apply for the respective institutions. Also, the scope of application is often too narrow in order to promote access to education and knowledge. The same is true for limitations and exceptions in favour of libraries and archives. The current technological possibilities to provide library services to the public and conduct preservation and replacement of protected works is not reflected by the law. Yet, the fair use doctrine provides for flexibilities in copyright law. It is especially important in the field of access to education and knowledge, because of the human rights underpinnings of these positions and public interest considerations. The utilitarian approach of copyright law in the USA favours this understanding. The fair use doctrine is not restricted to specific purposes of users of copyright protected works, but rather is a completely open provision, which is applied by courts from case to case. This openness however corresponds with legal uncertainty. Compared with the rigidity of statutory limitations legal uncertainty, at least to some extent, seems tolerable. Despite its deficiencies and need for reform the system of limitations and exceptions in the USA has the ability to adapt to changing conditions through the open fair use doctrine. In this respect it promotes the access to education and knowledge in the digital age.

The situation of limitations and exceptions for educational purposes and libraries, archives 
and museums in the United Kingdom slightly differs from the USA. Both countries belong to the copyright tradition. Therefore, the utilitarian approach to copyright law is distinct. As a member of the EU the UK is bound by European directives, especially the Information Society Directive. The implementation of this provision was only accomplished in 2014, although the directive itself has been in force since 2001. The British legislator has finally adopted the provisions of the Information Society Directive, including limitations and exceptions for educational institutions and libraries and archives, as well as the Orphan Works Directive. It must be stated that in the latest copyright reform in the UK digital issues have been considered to a greater extent than in the national laws of other member states of the EU, e.g. Germany and Portugal. However, the effect on access to knowledge and education in the digital age remains to be seen. Anyway, since copyright law in the UK knows the concept of fair dealing, which is comparable to fair use in the USA, the system of limitations and exceptions contains flexibilities in order to adapt to changing technological conditions. The 2014 copyright reform has partly modified the concept of fair dealing in favour of education and libraries, archives, museums and similar institutions. Different to the fair use the doctrine in the USA, the concept of fair dealing refers to specific purposes privileged by the law, among which are education and libraries, archives and museums. In the context of these purposes courts have ample room for interpretation if the use of a copyright protected work can be considered fair dealing or not. In this context, however, the human rights dimension of access to education and knowledge should be re-emphasised. Another notable addition in the context of limitations and exceptions for educational purposes and libraries, archives and museums was made in the UK. Several provisions stipulate that the exercise of limitations and exceptions for specific privileged purposes in the context of access to education and knowledge cannot be excluded by contract. Validity and enforcement of limitations and exceptions is thereby strengthened. Both the concept of fair dealing and the inhibition to exclude limitations and exceptions by contract are principles, which enable and aim at the promotion of access to education and knowledge in the digital age.

The analyses of copyright limitations and exceptions for educational purposes and libraries and archives in Germany and Portugal highlighted the influence of the European legislator. The shape of copyright laws of both countries and the limitations and exceptions in force to a large extent follow the prescriptions of the Information Society Directive and the Orphan Works Directive. As was shown the provisions of the Information Society Directive themselves however do not provide adequate solutions for the digital age. This is particularly true with regard to access to education and knowledge. The European legislator has understood the necessity for a comprehensive copyright reform, which should take into 
account more appropriately the interests of individuals and to general public. Yet, in view of the significance of the human rights underpinnings of access to education and knowledge the provisions of the Information Society Directive are not sufficient. Both for Germany and Portugal, apart from the Orphan Works Directive, the Information Society Directive is the main source for legislation in the field of copyright limitations and exceptions. The introduction of limitations and exceptions for educational purposes and libraries and archives adequately considering fundamental and human rights in access to education and knowledge with regard to the challanges to the digital age is blocked due to non-favourable presettings of the European legislator. The lack of consideration for the fundamental rights aspects of access to education and knowledge thus carries forward on the national level. The dogma of restrictive interpretation of limitations and exceptions, which is dominant in continental European jurisdiction and scholarship, and an author centered approach to copyright law especially in Portugal, aggravate the situation. This problem is not solved by the Orphan Works Directive, which both countries have implemented almost literally. Indeed, the Oprhan Works Directive has the potential to make accessible great numbers of orphan works from collections of cultural heritage institutions. Still, the required comprehensive diligent searches for right holders are obstacles for the privileged institutions. Only within a reformed European legal copyright framework sensible adjustments of national laws will be possible. Such reforms are discussed currently. With regard to national laws the technique of statutory limitations and exceptions, which is used both in Germany and in Portugal, must be questioned. In view of digital developments and the Internet statutory limitations and exceptions hardly keep pace with the changes ahead. Compared with this the argument of legal certainty is rather weak. It appears therefore sensible to introduce open clauses into national copyright laws of Germany and Portugal, which provide for more flexibility, as they are known from the USA and the UK, in combination with certain statutory limitations for education and libraries and archives. Further, the significance of fundamental rights in general and of the human right to education in particular and the objective of a fair balance of interests should be expressly highlighted within a copyright codification. In Germany limitations and exceptions should in addition not be excludable by contract. Portuguese copyright law already contains a similar provision.

With regard to Brazil it was found, that there is no system of limitations and exceptions in force, which adequately enables educational institutions and libraries and archives to provide their services, let alone to do so in view of the possibilities of digital technologies and the Internet. Brazilian copyright law is completely focused on the protection of authors and right holders. At the same time the demand for education of all levels is great in view of many people living in poverty. According to national policies ICT for education, such as e-learning 
and distance education, and in libraries are fostered by the state. However, copyright law does not reflect these developments and providers of educational and library services often act illegally. The same is true for the individual user, who may not even copy a book for purposes of private study. Although the right to education and the right to access to culture are constitutionally protected, Brazilian copyright law is charactarised by an extremely restrictive author-centered understanding. Fundamental rights are not reflected by the law, which is emphasised by the factual absence of favourable limitations. The promised copyright law reform has unfortunately come to a standstill, but is essential for limitations and exceptions for educational purposes and libraries and archives promoting access to education and knowledge in the digital age. Since Brazil is only obliged to meet the criteria of the Berne Convention and the TRIPS agreement, the legislator has ample room for possible limitations and exceptions, which would have to comply with the Three-Step-Test, as set forth in the Berne Convention and the TRIPS agreement. Yet, interpreting the Three-Step-Test in a liberal, human rights focused manner Brazil could use it as a tool to introduce flexible limitations and exceptions, for instance a combination of statutory limitations and open clauses like the fair use doctrine in the USA. A progressive system of limitations and exceptions could adequately take into account the current social and economic situation in Brazil, in which access to education and knowledge is especially important to fight poverty and promote economic and social development. In this context the human right to education and the human right to culture should be considered to a large extend, for instance by permitting commercial uses of protected works for educational purposes in connection with statutory licenses. In any case the role of educational institutions and libraries and archives as promoters of access to education and knowledge in a developing country and the advantages of digital technologies should be appropriately observed. As well, limitations and exceptions for educational purposes and libraries and archives should not be excludable by contract.

In Mozambique the situation is again different, even if in some regards it is comparable to Brazil. As a least developed country Mozambique has to cope with fundamental practical problems, for instance electricity and infrastructure supply. Apart from these questions, access to schoolbooks is a big problem due to high prices. Therefore, digital copies of learning materials are interesting, because they are available at no or very low cost. Regarding the (physical) access to such materials infrastructure may be problematic, too. Taking into account the ICT policy and the educational programs in Mozambique, the use of ICT in education, e-learning and distance education programs as well as the access to the Internet and digital materials in libraries are promoted. This means that digital media is increasingly used for education and in libraries. As the survey conducted among 
stakeholders in Mozambique produced, $95 \%$ of Mozambicans have access to a computer. Another question is however in how far devices for the use of learning material are readily available. With regard to copyright law the current system provides for some limitations and exceptions for educational purposes and libraries and archives. However, digital issues are not explicitly addressed. As well, limitations and exceptions for educational purposes and libraries and archives are very restrictive and of little or no practical relevance. The focus is on the protection of the rights of authors and right holders. The reason for this focus is to create an incentive for Mozambican authors and producers of literature and learning materials to create new works, hence the local production is very low. Same as in Brazil also in Mozambique the right to education and the right to take part in cultural life are guaranteed by the constitution. Nevertheless, this is not manifested in copyright legislation. Public interest in intellectual creations is addressed by the preamble of the Mozambican Copyright Act, but this has no effect on favourable limitations. In practice copyright law in Mozambique is not in force, which leads to a situation of market failure. In view of widespread poverty and the lacking public financial resources the market failure phenomenon is reinforced, because not even via statutory licences authors receive remuneration. Copyright law thus cannot provide incentives for authors to create. Still, the only approach to solve this problem is a stimulating copyright system, balancing sensibly the rights of authors to the protection of their interests and the right to education and access to culture. This could be not only an incentive for domestic authors to produce works for the national market but also for investments in infrastructure. Altogether, it appears that Mozambican copyright law and limitations for educational purposes and libraries and archives are not the only obstacle to access to education and knowledge. However, in view of increasing digital uses for providing educational and library services it is recommendable to enact provisions taking into account the necessities of Mozambique as a least developed country already now. A reliable system of limitations and exceptions could promote the access to education and knowledge and moreover be favourable for investments in that field. An open and flexible fair use provision, which could take into consideration fundamental rights and the state of development of the country, combined with statutory limitations permitting both commercial and non-commercial uses of copyrighted works for educational purposes without payment of remuneration, at least for non-commercial uses, could be possible solutions. In addition a reformed Berne Appendix applicable both to analogue and digital works could facilitate the availability of learning material in Mozambique.

With regard to the benchmark of permissible digital uses it was found that none of the limitations and exceptions of the countries examined fully complies with the requirements. Statutory limitations in developed countries permit partly to make works available online for 
educational purposes (except for the USA, which only allow performances and displays), but contain restrictions regarding the amount of the work that can be used. With regard to libraries remote access to library collections is not permitted. Concerning digital access to collections via on-site consultation there are limits to the amount of users that can access a work simultaneously. The same is true for e-lending, if even allowed. Regarding preservation and replacement most laws contain restrictions on the number of copies that can be made and do not explicitly allow web-harvesting. Text and data mining is not allowed, except for the UK. In the USA the digitisation and making available of orphan works is not permitted by statutory limitations. The digitisation of out-of-commerce works is not addressed at all. Format shifting is only covered in the UK. In Germany and the USA limitations can be overruled by licensing contracts. In general, all provisions use a complicated language, which makes it difficult for addressees to understand and apply the limitation. Open and flexible fair use provisions are only used in the US and the UK. In the UK the fair dealing provisions are applicable to special purposes such as education or text and data mining. In the US such references do not exsist. The fair use and fair dealing clauses allow to compensate to a certain extend the insufficiencies of statutory licenses. In Portugal and Germany this is not possible. The limitations and exceptions in Brazil and Mozambique do not deal with digital issues at all.

In terms of adequacy it was found that fundamental and human rights, in particular the right to education and the right to take part in cultural life are not considered sufficiently in either of the systems. And yet a larger consideration of these fundamental human rights equally alongside with the rights of authors and right holders both in national and international copyright law could significantly contribute to achieve a fair balance of interests, especially with regard to developing and least developed countries.

After all the answer to the initial research question "Do limitations and exceptions to copyright law adequately promote the access to education and knowledge in the digital age?" is the following:

Limitations and exceptions to copyright law for educational purposes and libraries, archives, museums and similar institutions both in national laws and internationally do not adequately promote the access to education and knowledge in the digital age. Thus the initial assumption that Copyright law hinders the access to education and knowledge was largely confirmed. In order to readjust the balance of interests in copyright law a whole series of efforts in international, European and national copyright laws is vital. 


\section{Policy Recommendation}

The findings of the study show that throughout the countries analysed here copyright systems in general and limitations and exceptions for educational purposes and libraries, archives, museums and similar institutions do not provide for adequate and balanced solutions for the issue of access to education and knowledge in the digital age. The findings presented here suggest that measures have to be taken in order to restore the balance of interests in copyright law in the digital age. Obviously, national legislators have to address these issues on a national level. However, with regard to the Internet as a global network creating a global knowledge society, measures have to be taken on an international level, too, in order to provide consistent solutions. Therefore, the double track approach is proposed.

First, on the level of international copyright law it is high time to pass a treaty explicitly dealing with limitations and exceptions for educational purposes and libraries, archives, museums and similar institutions. Such a treaty should include compulsory minimum limitations, which members of the Berne Convention must implement into national law as it is the case with the rights of authors and right holders. In the last years lobbying for such a treaty has been strong, but not yet successful. However, the Marrakesh Treaty showed that it is possible to create mandatory limitations and exceptions on a global scale. In view of the human rights underpinnings of copyright law, an international treaty could be a signal for and an effective instrument of promoting access to education and knowledge in the digital age. National legislators would be forced to introduced respective provisions.

This said in advance a treaty regarding educational establishments and libraries, archives and similar institutions could look like this:

\section{Proposal for a Treaty on Limitations and Exceptions for Educational Establishments and Libraries, Archives and Similar Institutions}

\section{Preamble}

Contracting parties, recognising the human right to education and the human right of everyone to take part in cultural life as well as the human right of authors to the protection of their moral and material interests, as stipulated by the International covenant on economic, social and cultural rights, being aware of the importance of access to education, knowledge, culture and information in the digital age for social and economic development, acknowledging the significance of educational establishments and libraries, archives and similar institutions for the dissemination of and the access to education, knowledge, culture 
and information as well as for the preservation of cultural heritage, recognising the importance of access to education and knowledge for developing and least developed countries and in view of the relevance of the Internet and digital Information Communication Technologies in a rapidly changing globalised world, agree as follows:

\section{Article 1: Definitions}

\section{Work}

For the purpose of this treaty the term "work" refers to any intellectual creation of artistic, literary, dramatic, musical or scientific kind, protected by copyright, independently of the data carrier used for its fixation, including orphan and out-of-commerce works.

\section{Educational Institution}

for the purpose of this Treaty the term "educational institution" refers to a non-profit establishment with public interest mission to promote education, learning, knowledge, science and culture, which provides instructional services to individuals or education-related services to individuals for the greater public good.

\section{Libraries, archives and similar institutions}

For the purpose of this treaty the terms "library", "archive" and "similar institution" refer to non-profit establishments with public interest missions to promote education, learning knowledge, science and culture, which disseminate, preserve and restore all types of works for the greater public good.

\section{Article 2: Minimum Mandatory Limitations}

This treaty has the purpose to establish minimum mandatory limitations and exceptions in favour of educational institutions, libraries, archives and similar institutions that contracting parties have to implement in their national copyright legislation.

\section{Article 3: Limitations for Educational Institutions}

(1) Contracting parties have agreed to implement in their national legislation provisions that permit educational institutions, without the authorisation of the author, for non-commercial educational purposes only, in accordance with their public interest mission of promoting education, learning, knowledge, science and culture, to reproduce, make available to the public, perform, display, broadcast, translate or lend any work as defined by this treaty, including but not limited to digital distance education, e-learning, text and data mining.

(2) Contracting parties are obliged to implement measures in their national legislation to 
safeguard that fair remuneration for a use of the work permitted by paragraph 1 is paid to the author or the right holder.

(3) With regard to developing and least developed countries contracting parties shall take into consideration the actual state of social and economic development when determining the amount of fair remuneration that has to be paid for a use of the work. It is left to the discretion of contracting parties whether under special circumstances it is provided by national legislation that a use of the work in accordance with paragraph 1 is not subject to the payment of fair remuneration in developing and least developed countries for a limited period of time.

(4) Contracting parties shall ensure in their national legislation that limitations for a use of the work in accordance with paragraph 1 cannot be overruled by licensing contracts or undermined by technological protection measures.

\section{Article 4: Limitations for Libraries, Archives and Similar Institutions}

(1) Contracting parties have agreed to implement in their national legislation provisions that permit libraries, archives and similar institutions, without the authorisation of the author, for non-commercial educational purposes only, in accordance with their public interest missions of promoting access to knowledge and education and preserving cultural heritage, to reproduce, make available to the public, distribute, translate or lend any work as defined by this treaty, including but not limited to on-site and remote access to collections, mass digitisation, e-lending, format-shifting, web-harvesting, text and data mining.

(2) Contracting parties are obliged to implement measures in their national legislation to safeguard that fair remuneration for a use of the work permitted by paragraph 1 is paid to the author or the right holder. In case an orphan work is used no remuneration has to be paid, if the author is unknown. In case the author or right holder of an orphan work emerges, he or she must not be compensated for the use made of his work in the past.

(3) With regard to developing and least developed countries contracting parties should take into consideration the actual state of social and economic development when determining the amount of fair remuneration that has to be paid for a use of the work. It is left to the discretion of contracting parties whether under special circumstances it is provided by national legislation that a use of the work in accordance with paragraph 1 is not subject to the payment of fair remuneration in developing and least developed countries for a limited period of time.

(4) Contracting parties shall ensure in their national legislation that limitations for a use of the work in accordance with paragraph 1 cannot be overruled by licensing contracts or undermined by technological protection measures. 


\section{Article 5: Moral Right}

Contracting parties have agreed to implement into their national legislation the obligation for privileged institutions to indicate the source and the name of the author of the work used under the limitations and exceptions provided by this treaty.

\section{Article 6: Regional and International Exhaustion}

Contracting parties have agreed to implement into their national legislation provisions regarding the exhaustion of the distribution right on an regional or international level.

\section{Article 7: Cross-border Uses}

Contracting parties have agreed to implement into their national legislation provisions that permit educational establishments and libraries, archives and similar institutions to use protected works across border provided that this is necessary in order to excercise the limitations and exceptions established by this treaty.

\section{Article 8: Three-Step-Test}

With regard to the international Three-Step-Test contracting parties, when implementing or interpreting the test, shall take into consideration, besides the legitimate interests of authors and right holders, other legitimate interests of stakeholders, such as fundamental and human rights, in particular the right to education and culture, as well as public interests, such as the promotion of social and economic development as well as the advancement of science, creativity, the arts and culture.

The proposed treaty sets forth mandatory limitations and exceptions for both educational establishments and libraries, archives and similar institutions. It applies to non-profit institutions acting in public interest only. The open language used in the proposal is intended to encompass all kinds of works and uses, both analogue and digital, and to leave ample space to contracting parties to implement national legislation. Furthermore, more specific formulations would carry the risk that the provisions could not adapt to new technological developments, which is exactly the problem of many current legal texts relating to the Internet and digital technologies. The limitations and exceptions cover all kinds of works and all kinds of economic rights. This is justified, because limitations and exceptions can only be invoked by non-profit organisations, which pursue non-commercial interests, and the right to fair remuneration for authors and right holders and the moral right of authors to an indication of their name are ensured. Further, the far-reaching permission to use works by the privileged organisations is justified with regard to the purpose of promoting access to education and knowledge and the fundamental and human rights, which underlie these 
purposes. The special needs of developing and least developed countries are addressed in the preamble and can be taken into account with regard to fair remuneration as well as within the interpretation of the Three-Step-Test. In addition, it makes sense that contracting parties introduce provisions regarding the exhaustion of the distribution right on regional or international level. The unspecific wording could allow for the application of exhaustion rules also to intangible goods. The cross-border use of protected works under the limitations is explicitly permitted. In general, the treaty proposal highlights the significance of access to education and knowledge including the underpinnings in human rights. In that context also the human rights dimension of the protection of authors and right holders is expressly mentioned in order to safeguard a fair balance of interests. It is finally clarified that these issues are particularly important with regard to the global challenges of the digital age.

In order to achieve a more liberal and human rights oriented interpretation of the international Three-Step-Test and the TRIPS Agreement it could also be an idea to make explicty reference to the UDHR in the preamble of the Agreement.

In combination with a reform of the Berne Appendix developing and least developed countries would benefit additionally. However, if such reform would be still necessary in case the above treaty or a similar one was enacted, can be doubted.

Second, regarding national copyright laws and limitations and exceptions for educational purposes and libraries, archives and similar institutions the introduction of a combination of open clauses like the fair use doctrine in the USA or the concept of fair dealing in the UK and statutory limitations and exceptions must be recommended. This approach unites the flexibility of open clauses, which adapts to the rapid developments of digital technologies, and the legal certainty of statutory limitations. What is exactly meant is that an open fair use like provision is merged with explicitly named examples of permitted uses guiding the interpretation. In general a limitation or exception constructed in that way is a sensible solution for the countries analysed here, because it combines the advantages of the Copyright and the Droit d’Auteur system.

What is proposed is an open clause, which is set out as a general rule and which is in the following concretised by several specific cases. ${ }^{1798}$ The advantages of this approach are that in contrast to statutory limitations, which due to their nature always remain limited to their specific scope, an open general clause can flexibly adapt to various situations. ${ }^{1799}$ Either a

\footnotetext{
1798 In Germany this approach is endorsed by de la Durantaye, „Allgemeine Bildungs- und Wissenschaftsschranke“ (2014), p. $207 f$.

1799 Idem, p. 211.
.
} 
use is already covered by one of the examples or, if not, it may be covered by the general clause. Even if not applicable, the examples would however always function as guidelines for the interpretation. ${ }^{1800}$ With regard to legal certainty this approach is of course not as certain as a statutory limitation can be, but, as was implied above, legal certainty would be improved by the specific examples. ${ }^{1801}$ Results of the interpretation of such general clause with examples could thus be more easily predicted than in case of a completely open fair use clause, like in the USA. The already mentioned flexibility would facilitate the application of the limitation to new technological developments. Above that an open general clause with examples would not only be favourable to the beneficiaries of the limitation but could due to its flexibility enable to balance interests more adequately, which would also be in the interests of authors and right holders. ${ }^{1802}$ Such provision should finally ensure the claim for fair remuneration of authors and right holders through statutory licenses for the permitted uses. In order to safeguard fair remuneration a flat-rate system appears to be the right solution, because a payment for each single use results in the conclusion of a licensing contract for each use and thus causes enormous administrative efforts. ${ }^{1803}$ The claim for fair remuneration should be exercised by collecting societies. In addition, also national copyright laws should clarify that limitations and exceptions cannot be overruled by contracts or are subordinate to them. ${ }^{1804}$

A general template of a general clause with examples for educational establishments could have the following wording: ${ }^{1805}$

It is permitted to reproduce, make available to the public, perform, display, broadcast, translate or lend a published work for instruction and learning in a non-profit educational establishment provided that the purpose of the use of the work is non-commercial and the amount used is justified by its purpose.

Ensuing several examples of permitted uses, starting with "in particular it is permitted to...", would be added, containing a non-exclusive list of examples, such as use works for preparation and/or reworking of instruction by students, for examination or for the creation of coursepacks.

\footnotetext{
1800 Idem, p. 209/210.

1801 Idem, p. 211.

1802 Idem, p. 212

1803 With regard to flat-rate payment of remuneration in Germany see Haucap/Loebert/Spindler/Thorwarth, Ökonomische Auswirkungen einer Bildungs- und Wissenschaftschranke im Urheberrecht, 2016, p. 77.

${ }_{1804}$ With regard to the precedence of licensing contracts over limitations and exceptions in Germany, see Haucap/Loebert/Spindler/Thorwarth, Ökonomische Auswirkungen einer Bildungs- und Wissenschaftschranke im Urheberrecht, 2016, p. 78/79.

1805 In its general structure the proposed template partly follows the detailed provision for Education and Research presented by de la Durantaye for Germany, see de la Durantaye, „Allgemeine Bildungs- und Wissenschaftsschranke" (2014), p. 214f., however goes beyond that.
} 
A general template of a general clause with examples for libraries, archives and similar institutions could have the following wording: ${ }^{1806}$

It is permitted to reproduce, make available to the public, distribute, translate or lend a work for information, education, science, culture, preservation and replacement in a non-profit library, archive or similar institution provided that the purpose of the use of the work is noncommercial and the amount used is justified by its purpose.

As well for libraries and archives several examples of permitted uses, starting with "in particular it is permitted to...", would be added, containing a non-exclusive list of examples, such as making a work from the collection of the privileged institution available for users online for the purpose of private study and/or own scientific research.

The precise construction of such provisions is left to national legislators ${ }^{1807}$ and had to comply with the requirements of international and European copyright law. For reasons of clarity it seems also feasible to address both educational establishments and libraries, archives and similar institutions in one comprehensive provision. ${ }^{1808}$

With regard to the Three-Step-Test it appears that a general clause with examples for the purpose of access to education and knowledge would meet the requirements. In view of the specific examples such provisions would comply surely with the first step of the test ("certain special cases"). The introduction of statutory licenses to safeguard the payment of fair remuneration alone would probably not be enough to pass the second step. ("do not conflict with a normal exploitation of the work"). In view of the profits authors and right holders can derive from digital uses in the area of education and libraries and archives, indicates that they are maybe a conflict with normal exploitation. If such provisions would however "unreasonably prejudice the legitimate interests of the right holder" must be doubted regarding the objectives of the limitation, namely promoting access to education and knowledge and thus relating to fundamental rights. In total, the proposed limitations and exceptions would certainly pass the test, if a liberal and balanced, human rights and public interest orientated interpretation of the Three-Step-Test is followed, as advocated in this

\footnotetext{
${ }^{1806}$ In its general structure the proposed template partly follows the detailed provision for Libraries, Museums and Archives presented by de la Durantaye for Germany, see de la Durantaye „Allgemeine Bildungs- und Wissenschaftsschranke" (2014), p. 245f., but goes beyond that.

1807 See Haucap/Loebert/Spindler/Thorwarth, Ökonomische Auswirkungen einer Bildungs- und Wissenschaftschranke im Urheberrecht, 2016, p. 84 - 95, who summarise the various proposals and reform approaches in Germany.

${ }^{1808}$ In Germany a comprehensive limitation, including scientific uses, is promoted by the Aktionsbündis "Urheberrecht für Bildung und Wissenschaft", proposal available at http://www.urheberrechtsbuendnis.de/abwstext-2014-12.html.de.
} 
study. Such understanding would allow to subject the test to an overall assessment, taking into consideration the purpose of copyright law in general and of the respective limitation and exception in particular, namely the underlying fundamental rights and interests. In the present case public interest in the promotion of access to education and knowledge, the human right to education and to take part in cultural life and the right of authors and right holders to the protection of their interests would have to be balanced against each other. Given the specific limitation, its objectives and the statutory license ensuring the author's fair remuneration, altogether access to education and knowledge would prevail and the limitation would pass the test.

If an ample limitation in favour of educational establishments and libraries, archives and similar institutions, as proposed here would meet the requirements of the Information Society Directive, must however be doubted, since the provisions of the Information Society Directive 2001/29/EC regarding education and libraries and archives related to "illustrations for teaching" (Article 5 para. 3 (a) Information Society Directive). Moreover, with regard to libraries and archives the Information Society Directive refers only to the reproduction right and the right of making available. The latter right is addressed in the context of consultation on "dedicated terminals on the premises of the institution" (Article 5 para. 3 (n) Information Society Directive), which is why a limitation permitting remote access would encroach on this requirement. The limitations could be in conformity with the Orphan Works Directive 2012/28/EU, yet whether this is really the case depends on specific national legislation, in particular on the conditions of diligent searches prior to the use set forth therein. For the UK, Germany and Portugal to implement provisions similar to the ones proposed, European Copyright directives would probably have to be changed.

Both the USA and Brazil and Mozambique have to comply with international copyright law, namely the Berne Convention and the TRIPS Agreement. The USA are also bound by the WIPO Internet treaties, Brazil and Mozambique are not. As was shown with regard to the Three-Step-Test the proposed national limitations and exceptions are likely to pass the test, especially if a liberal and balanced, human rights and public interest orientated interpretation is practised.

Thus, the suggested limitations and exceptions for educational institutions and libraries, archives and similar institutions would be in accordance with the norms of international copyright law, namely the Three-Step-Test.

With regard to Brazil and Mozambique as developing and least developed countries further 
measures should be taken to promote the access to education and knowledge in the digital age. As the proposed international treaty for educational establishments and libraries, archives and similar institutions stipulates, developing and least developed countries could implement limitations and exceptions for education and knowledge that permit the use of copyrighted works for such purposes and in view of the social and economic situation of these countries without remuneration having to be paid to authors and right holders. This could reduce the cost of learning materials, which is a major obstacle to access to education and knowledge due to widespread poverty. Furthermore, since Brazil and Mozambique are linked by the Portuguese language and both members of the CPLP, it would be favourable that both countries introduce rules for regional exhaustion of copyright with regard to the area of the CPLP or at least mutually in Brazil and Mozambique. So far Brazil and Mozambique have no clear provisions regarding national, regional or International exhaustion. Portugal is bound by the principle of regional exhaustion in relation to the common market of the EU (article 4 para. 2 Information Society Directive and article 68 para. 5 CDA). Therefore, the distribution right regarding tangible copies of works sold with the author's consent in Portugal is exhausted within the EU common market. Since the Portuguese legislator must comply with European directives, further exhaustion rules for instance in relation to Brazil and Mozambique or the area of the CPLP are excluded. The implementation of provisions regarding exhaustion would have the effect that copyright law in tangible media, including learning materials would be exhausted once the respective copy is sold with the consent of the author in one of the two countries or one of the countries of the CPLP. By all means this would allow parallel imports of protected works embodied in tangible media for instance from Brazil to Mozambique, but also vice versa. Whether the exhaustion rule would apply also to intangible media and digital learning materials and thus facilitate the free circulation of these goods within for instance the area of the CPLP is not entirely clear, but imaginable. To refer to the area of the CPLP in that context would be reasonable as well because the policies of the CPLP promote intensive exchange among members states on all levels, but especially in the area of education and culture, including the free circulation of intellectual goods, and due to the common language no language barriers exist. This could facilitate for instance crossborder remote access to library collections or e-learning courses in Brazil for students in Mozambique.

In addition, it seems recommendable that national copyright laws move from one-sided focus of author and right holder protection to a comprehensive copyright concept, taking into account more appropriately fundamental and human rights as well as in the public interest. In particular the human right to education and the human right to cultural participation should be explicitly emphasised in national copyright codifications. The same is true for public interest 
in access to education and the dissemination of knowledge, which is underpinned by fundamental rights. As well the protection of authors, whose rights are equally fundamental, should be expressly mentioned. This could for instance be done in a preamble of the respective national copyright codification or in the context of the chapters dealing with limitations and exceptions to copyright. The importance of an equalised copyright system providing for incentives for authors to create as well as for limits to their rights in order to promote social and economic development and fundamental rights should be clearly pointed out. The objective of achieving a fair balance of interests in copyright law should be the explicitly declared objective. As a result, limitations and exceptions for education and knowledge could be interpreted along these principles.

\section{Outlook}

The issue of limitations and exceptions lies at the heart of copyright law. All along finding a fair balance of interests has been heavily debated among copyright stakeholders and it must be expected that in future discussions will not come to an end. Challenges are huge and there is too much at stake for all parties. In light of the complexity of the problems to solve there are no simple solutions.

However, adjusting the balance of interests in copyright law, in particular with regard to limitations and exceptions for educational purposes and libraries, archives and similar institutions is one important factor in the struggle against social inequality and injustice. Sensible measures in this area will improve the access to education and knowledge and thus promote social and economic development of societies. This is of great importance not only for developing countries but also for societies of the industrialised world. In view of the potential of the Internet and digital technologies for the dissemination of knowledge and the access to education as well as for social and cultural participation, these issues have a global dimension and have to be addressed in particular on a global level in order to fight the digital divide and foster worldwide digital inclusion.

In the near future it will be interesting to see if the efforts to conclude an international copyright treaty concerning education and research purposes as well as libraries and archives in the digital age, as it is debated at the WIPO, will be successful. There is hope that such treaty would have positive effects on access to education and knowledge in developing countries and least developed countries like Mozambique. In addition, the process to reform copyright law in the EU will continue. Here, among others one main topic of debate is the construction of limitations and exceptions for educational purposes and libraries and 
archives. Furthermore, it remains to be seen how the Brazilian copyright reform advances and to what extent the progressive reform proposal for a new copyright law can prevail.

Altogether, there is some reason for optimism. 


\section{Epilogue}

The issue of the present study is highly topical. Both at the international and European level as well as at the level of national states reforms and amendments of the current legal framework of limitations and exceptions to copyright in favour of access to education and knowledge are discussed.

On September 14, 2016 the European Commission presented a new proposal for a copyright directive and emphasised the importance of limitations and exceptions therein. ${ }^{1809}$ Only on November 10, 2016 in the case of Vereniging Openbare Bibliotheken vs. Stichting Leenrecht, C-174/15, the ECJ has decided on the lending of ebooks by libraries. ${ }^{1810}$ Also, the Standing Committee on Copyright and Related Rights at WIPO has again discussed limitations and exceptions for educational purposes and libraries and archives. ${ }^{1811}$

These developments have been included into the printed version of this study. However, since the publication of the printed version the German Ministry of Justice has published an interesting proposal for new limitations and exceptions in favour of education, research and libraries and archives on February 1, 2017. ${ }^{1812}$ The proposed provisions aim at the adaption of German copyright limitations and exceptions to the challenges of the digital age with regard to education and research. ${ }^{1813} \mathrm{~A}$ reform of copyright limitations and exceptions for educational and research purposes was promised by the German government already in 2013..$^{1814}$

For the digital version of this study, which will be made available by the Maastricht University Library, the proposal from Germany will be analysed in short hereinafter. In doing so, reference will be made to the above mentioned proposal of the European Commission as well as to the developed benchmark of permissible uses.

\section{Overview}

The proposal of the German Ministry of Justice consists of a problem definition, the actual proposal for the modifications of the law and a rather extensive explanation and justification for the proposed modifications.

\footnotetext{
${ }^{1809}$ Commission of the EU, Proposal for a Directive of the European Parliament and of the Council on Copyright in the Digital Single Market, COM (2016) 593 final.

${ }_{1810}$ ECJ, Judgement of the Court of November 10, 2016, Case C-174/15; see 3.2.3.

${ }^{1811}$ WIPO SCCR/33/4, November 14 to 18, 2016.

1812 Referentenentwurf des Bundesministeriums der Justiz und für Verbraucherschutz of February 1, 2017 (hereinafter abreviated as "Referentenentwurf BMJV"), available at http://www.bmjv.de/SharedDocs/Gesetzgebungsverfahren/Dokumente/RefE_UrhWissG.pdf?_blob=publication File\&v=1.

${ }^{1813}$ See idem, p. 1.

1814 Koalitionsvertrag CDU/CSU, p. 22/23.
} 
In the beginning the need for reform is stated. The proposal points out that the current provisions in the area of education and research are about 20 years old. ${ }^{1815}$ Since then the possibilities to use copyright protected works in digital form have changed significantly, but limitations and exceptions have not been adapted to these changes. ${ }^{1816}$

Current limitations and exception for educational and research purposes are complicated, difficult to find and contain legal terms, which have to be interpreted, and thus are not easy to understand and to invoke for the addressees of the norms. ${ }^{1817}$ According to the proposal the current provisions often refer to analogue uses, which is why they cannot or only partly cope with the problems of practical realities in an increasingly digital environment. ${ }^{1818}$ As a consequence the potentials of the modern knowledge society are not fully exploited, which is also disadvantageous to authors and rightholders, because they receive no compensation, either since a protected work is not used at all or because it is used illegally. ${ }^{1819}$

In order to solve these problems the proposal aims at a clearer and simplified system of limitations and exceptions for educational and research purposes. ${ }^{1820}$ Further, new limitations will be introduced as far as they are feasible according to European law. ${ }^{1821}$ Also, the uses permitted by law are all subject to fair remuneration for authors and right holders. ${ }^{1822}$

As a solution for the above said problems the German Ministry of Justice proposes to introduce a new consistent chapter into the German code of copyright ("Unterabschnitt 4 Gesetzlich erlaubte Nutzungen für Unterricht, Wissenschaft und Institutionen"). ${ }^{1823}$ This is the main part of the reform. It is intended to introduce $\S \S 60 \mathrm{a}$ to $60 \mathrm{~h}$ UrhG, which shall encompass the provisions for instruction, research and institutions like libraries as well as a new provision privileging text and data mining. ${ }^{1824}$ Thereby, each group of privileged users is specifically addressed in one provision. ${ }^{1825}$ The idea obviously is to improve clarity and legal certainty. For that reason some provisions shall be cancelled completely, such as $\S \S 47,52 a$, 52b and $\S 53 a$ UrhG. ${ }^{1826}$ Others will be modified, such as $\S 46$ UrhG and $\S 53$ UrhG. ${ }^{1827}$

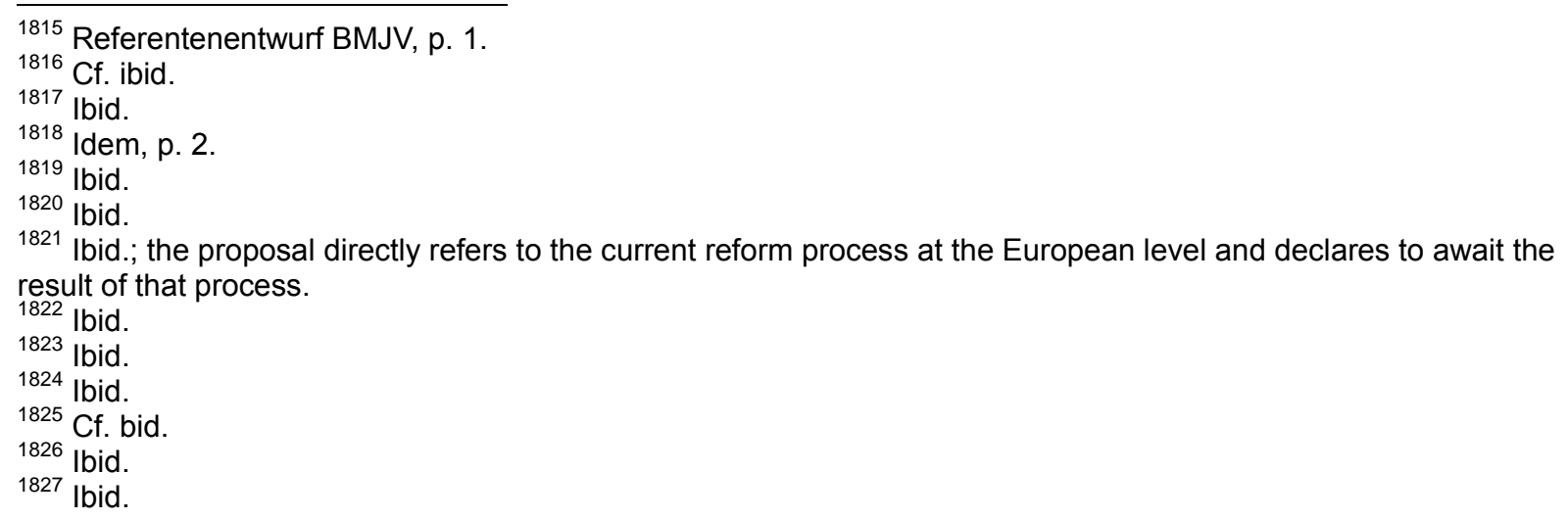


Further, the extension of permitted uses goes hand-in-hand with the payment of fair remuneration. ${ }^{1828}$ What is completely new to the German system of copyright limitations and exceptions is that these privileges granted by the law cannot be overruled by licensing contracts in order to enforce the balance of interests in practice. ${ }^{1829}$

The proposal does not contain a coherent open and flexible limitation for education and libraries archives and similar institutions, although the introduction of such provision was strongly advocated by scholars and interest groups. ${ }^{1830}$ The shortness and flexibility of such provision is, according to the Ministry of Justice, outweighed by legal uncertainty of undefined legal terms. ${ }^{1831}$ Therefore, it is preferred to introduce several detailed but understandable provisions, which clearly define the uses that are permitted by the law. ${ }^{1832}$ Insofar the German Ministry of Justice stays true to the traditional construction of limitations and exceptions to copyright in Germany. Like all Continental European copyright systems also German law knows no open general clauses, as they are common in the United Kingdom ("fair dealing") or in the USA ("fair use").

\section{Interesting Aspects of the Reform}

The proposal contains an extensive explanation of the targeted reform. The most interesting aspects of these explanations will be described in the following.

\subsection{Limitations and Exceptions and Balance of Interests}

In the detailed explanation of the proposal the Ministry of Justice first states that copyright is intended to protect authors and right-holders. ${ }^{1833}$ However, the importance of a fair balance between the interests of authors and rightholders on the one side and the interests of users of protected works on the other side is highlighted. ${ }^{1834}$ Especially, public interest in education and research is underscored by making reference to the preamble of the WIPO Copyright Treaty. ${ }^{1835}$ It is clearly pointed out that the objective of copyright is not only to protect existing works but also to create incentives for the future production of new works. ${ }^{1836}$ This objective can be promoted by sensible limitations and exceptions. ${ }^{1837}$ This is a remarkable statement, because it recognises the position of the individual user and the general public. At the same

\footnotetext{
1828 Idem, p. $2 / 3$.

1829 Idem, p.3.

${ }^{1830}$ de la Durantaye, „Allgemeine Bildungs- und Wissenschaftschranke“ (2014), p. 207ff.; Aktionsbündnis „Urheberrecht für Bildung und Wissenschaft“, proposal available at http://www.urheberrechtsbuendnis.de/abwstext.html.de; see also Haucap/Loebert/Spindler/Thorwarth, Ökonomische Auswirkungen einer Bildungs- und Wissenschaftsschranke im Urheberrecht, 2016, p. 84 - 95, who summarise all proposals.

${ }_{1831}$ Referentenentwurf BMJV, p. 3.

1832 lbid.

1833 Idem, p. 16.

1834 lbid.

1835 lbid.

1836 lbid.

1837 lbid.
} 
time it is implicitly acknowledged that the current copyright system is out of balance.

\subsection{No General Clause and Undefined Legal Terms}

As was said before the proposal contains no broad and open general clause. This is explained with the objective of the reform to enable privileged users and institutions to determine as precisely as possible the uses that are permitted by the law. ${ }^{1838}$ It is stated that also general clauses have to be specified in order to be applicable to individual cases in practice. ${ }^{1839}$ In order to specify the content of a provision lengthy and costly lawsuits must be risked, which could be observed in the last years. ${ }^{1840}$ The Ministry of Justice argues that these risks and uncertainties speak against open general clauses with undefined legal terms and in favour of a more specified wording. ${ }^{1841}$ Indeed, this brings about a loss of flexibility, which is however accepted in view of the alleged disadvantages of legal uncertainty and the risk of lawsuits. ${ }^{1842}$ As an example the proposal refers to the case of "Google books", in which the parties argued for years whether Google could rely on fair use or not. ${ }^{1843}$ Therefore, the Ministry of Justice found that the argument of legal certainty had to be given the preference. ${ }^{1844}$

Yet, it seems natural to apply already existing German and European court decisions regarding limitations and exceptions to define the scope of an open general course. In this regard the interpretation of such open general clause would certainly not have to start at zero.

\subsection{New Structure}

The proposal intends to bundle already existing limitations and exceptions for education and research in one subchapter. ${ }^{1845}$ The same subchapter shall contain new limitations for libraries, museums and archives. ${ }^{1846}$ In general, the chapter on limitations and exceptions in the German code of copyright shall be structured more conceivably in order to facilitate the comprehension and application of the provisions by users and for purposes of clarity. ${ }^{1847}$

\subsection{No Contractual Overrule}

According to the proposal the positions granted by limitations and exceptions cannot be

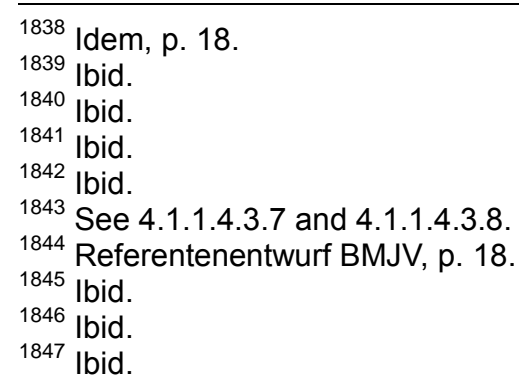


overruled by contract. Agreements regarding uses, which fall into the scope of limitations and exceptions, thus are invalid. ${ }^{1848}$ This rule defines the relation between exclusive rights of authors and legally privileged uses meaning that where the permitted use begins, the exclusive right ends. ${ }^{1849}$ Thereby it is safeguarded that limitations and exceptions are enforceable in practice. ${ }^{1850}$

\subsection{Information Society Directive 2001/29/EC}

The main source for the proposed reform is the Information Society Directive 2001/29/EC, in particular article 5, which contains the basis for limitations and exceptions to copyright in national laws of the member states. ${ }^{1851}$ In addition, it is highlighted that the German legislator is bound by the decisions of the ECJ regarding the interpretation of the directive. ${ }^{1852}$ With regards to limitations for educational purposes of the proposal refers explicitly to the judgement of the ECJ of September 11, 2014 in the case C-117/13 - TU Darmstadt vs. Eugen Ulmer KG, which deals with questions of licensing contracts and the scope of limitations and exceptions. ${ }^{1853}$

Furthermore, it is pointed out that the proposed provisions meet the requirements of the Three-Step-Test, which is enshrined in article 5 para. 5 Information Society Directive 2001/29/EC. ${ }^{1854}$ The provisions refer to "certain special cases" and "do not unreasonably prejudice the legitimate interests of the right holder" because the right to fair remuneration is safeguarded. ${ }^{1855}$ The question whether there is a conflict with "a normal exploitation of the work" has to be answered in each individual case, but altogether it is said that the proposed provisions pass the Three-Step-Test. ${ }^{1856}$

\subsection{Current EU-Copyright Reform}

The proposal of the Ministry of Justice also makes reference to the above mentioned proposal of the Commission of the EU of September 14, 2016. ${ }^{1857}$ The latter contains in articles 3, 4 and 5 new limitations and exceptions for text and data mining, digital crossborder uses for educational purposes and reproductions by cultural heritage institutions for the preservation of their collections. Yet, the German proposal does not take the proposal of the commission of the EU into account since the integration and the end of the European

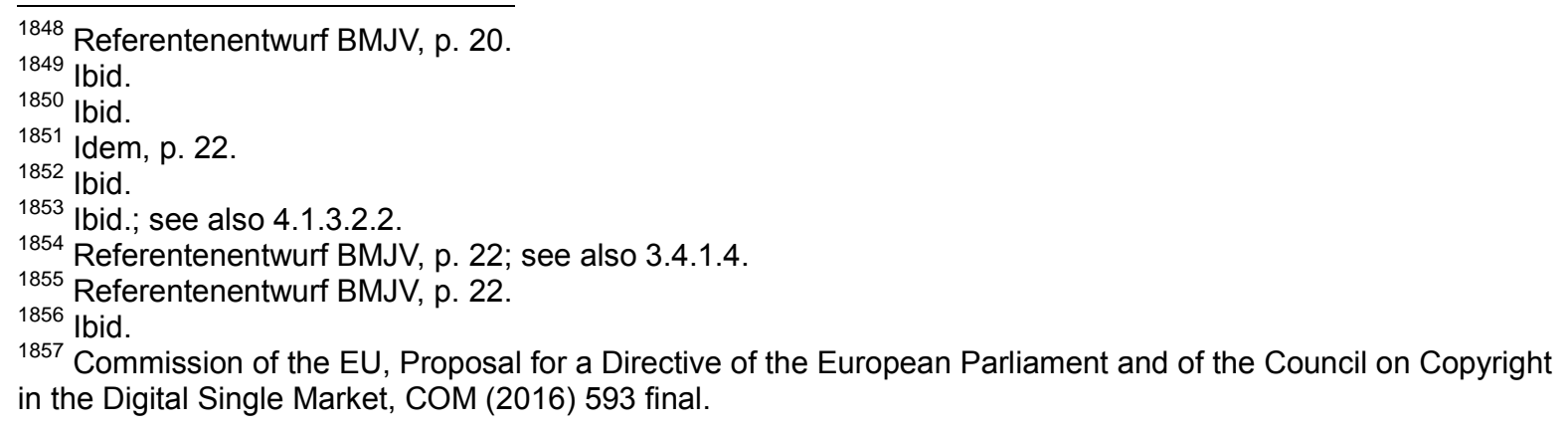


reform process is not in sight. ${ }^{1858}$ This is why the new provisions are based on the current European legal copyright framework. ${ }^{1859}$ However, it is pointed out that the new structure of limitations and exceptions for education and research can easily be adapted to the expected changes of European law. ${ }^{1860}$ Against this background the German proposal does not yet address remote access to library collections (which was not explicitly addressed either by the Commission's proposal) ${ }^{1861}$ or take into consideration the judgement of the ECJ on the lending of ebooks of November 10, 2016. ${ }^{1862}$

\section{New Provisions}

As was said above the centrepiece of the proposed reform are $\S \S 60 \mathrm{a}$ to $60 \mathrm{~h}$ UrhG, which shall be implemented in one consistent subchapter. Hereinafter the most important aspects of these new provisions shall be briefly analysed.

\section{$3.1 \S 60 a$ UrhG-E and § 60c UrhG-E}

$\S 60$ a UrhG-E deals with permitted uses of protected works for teaching and instruction. § 60c UrhG-E relates to uses of protected works for the purposes of scientific research. Both provisions now coherently state that it is allowed to use $25 \%$ of a protected work. ${ }^{1863}$ So far it was only permitted to use "small parts". ${ }^{1864}$ This clarification also is intended to define the prerequisite of "non-commercial purposes" contained in the Information Society Directive 2001/29/EC and to improve legal certainty both for rightholders and users. ${ }^{1865}$ Additionally, according to $\S 60$ a para. 2 and $\S 60$ para. 2 UrhG-E it shall be allowed to use images ("Abbildungen") for said purposes, i.e. photographies. ${ }^{1866}$ As well it shall be permitted to use works of small size ("Werke geringen Umfangs") entirely ("vollständig"). ${ }^{1867}$

The new limitation of $\S 60 a$ UrhG-E for teaching and instruction bundles several permitted uses in one provision, namely $\S \S 47,52$ para. $1 \mathrm{~s} .1$, 52a para. $1 \mathrm{~s} .1$ and 53 UrhG. ${ }^{1868}$ The new provision roots in article 5 para. 3 (a) and para. 4 Information Society Directive $2001 / 29 / E C .^{1869}$ What is also new about the provision is that $\S 60$ a para. 4 UrhG-E contains a legal definition of the institutions that may invoke the limitation. It encompasses e-learning as well as and distance learning and covers uses of protected works for illustration of teaching

\footnotetext{
${ }_{1858}$ Referentenentwurf BMJV, p. 24.

1859 lbid.

1860 Ibid.

1861 Ibid.; see also 3.2.4.

1862 Referentenentwurf BMJV, p. 24; ECJ, Judgement of the Court of November 10, 2016, Case C-174/15 -

Vereniging Openbare Bibliotheken vs. Stichting Leenrecht; see also 3.2.3.

1863 § 60a para. 1 UrhG-E and § 60c para. 1 UrhG-E.

1864 Referentenentwurf BMJV, p. 33; see also 4.1.3.2.5.2.

1865 Referentenentwurf BMJV, p. 33.

1866 Idem, p. 34

1867 Ibid.

1868 lbid.

1869 lbid.
} 
and instruction, which may occur before, during or after of the instruction. ${ }^{1870}$ Only uses for non-commercial purposes are permitted. In accordance with European law it is not important if the institution is run by the state or a private entity. ${ }^{1871}$ What is decisive is that teaching and instruction themselves are not intended to generate financial profit. ${ }^{1872}$

$\S 60 a$ UrhG-E now provides for limitations to the right of reproduction, the right of making available to public and the right of communication to the public. The latter is interdicted by $\S$ 53 para. 6 s. 1 UrhG. The proposal argues that the extension of the limitation of $\S 60 a$ UrhG$E$ to the broad right of communication to the public will cover future forms of incorporeal (“unkörperlich") uses. ${ }^{1873}$

$\S 60$ a para. 3 UrhG-E determines the cases in which uses are not allowed. This provision is intended to take into consideration appropriately the Three-Step-Test. ${ }^{1874}$ It refers to reproductions and live streaming of cinematic works or live performances, i.e. concerts, as well as to school books and music notes. ${ }^{1875}$

\section{2 § 60b UrhG-E}

This provision permits to reproduce, distribute and make available to the public $10 \%$ of a published work for the purpose of creating a collection, i.e. a schoolbook. ${ }^{1876}$ It is based on article 5 para. 3 (a) Information Society Directive 2001/29/EC. ${ }^{1877}$ Different than the current $\S$ 46 UrhG, which refers to parts of a work ("Teile eines Werks"), the proposed provision clearly defines the amount that can be used. ${ }^{1878}$

\section{$3.3 \S 60 d$ UrhG-E}

A completely new provision shall be introduced by $\S 60 \mathrm{~d}$ UrhG-E. It is intended to permit socalled text and data mining for scientific research, which so far has never been addressed before by German law. ${ }^{1879}$ The proposal explains the technique of text and data mining and its relevance to copyright. ${ }^{1880}$ So far the only legal basis in European law is article 5 para. 3 (a) Information Society Directive 2001/29/EC, the right of reproduction. ${ }^{1881}$ In this context the proposal refers to the proposal of the Commission of the EU of September 14, 2016, which

\footnotetext{
1870 Idem, p. 35.

1871 Ibid.; see recital 42 s.2 Information Society Directive 2001/29/EC.

1872 lbid.

1873 lbid.

1874 Idem, p. 37.

1875 Ibid.

1876 lbid.

1877 lbid.

1878 Idem, p. 38.

1879 Idem, p. 40.

1880 lbid.

1881 Ibid.
} 
contains limitations and exceptions for the purpose of text and data mining in article 3 . German law shall be adapted in case such limitations and exceptions should be introduced at the European level. ${ }^{1882}$ It is important to underscore that $\S 60 \mathrm{~d}$ UrhG-E does not permit the access to the copyright protected material, which is subject to text and data mining, but rather takes the access to the materials analysed as a precondition. ${ }^{1883}$ Further, it is required that uses only pursue non-commercial purposes. $\S 60 \mathrm{~d}$ UrhG-E also determines that the entirety of the reproductions of the materials analysed, the so called corpus, must be deleted when the research is terminated. ${ }^{1884}$ However, the corpus may be transmitted to libraries and archives for preservation purposes. ${ }^{1885}$

\section{$3.4 \S 60 \mathrm{e}$ and $\S 60 f$ UrhG-E}

In order to highlight the importance of (public) libraries in the of digital knowledge society $\S$ 60e UrhG-E concentrates limitations and exceptions, which so far are scattered within the law, in one provision. ${ }^{1886}$ The term libraries ("Bibliotheken") is now defined by the law and encompasses any publicly accessible library, which does not pursue any direct or indirect commercial purposes. ${ }^{1887} \S 60$ e para. 1 UrhG-E relates to the right of reproduction, whereas paras. 2 to 5 stipulate how these reproductions may be used, namely for distribution to other libraries, also for purposes of restoration, and making available on dedicated terminals to users for the purposes of private study and research. ${ }^{1888}$ Multiple reproductions are permitted for the purpose of making available, indexing, cataloguing, preservation and restoration, including technical induced modifications. ${ }^{1889}$ This means that so-called format shifting shall be allowed. Thereby digital long-term archiving shall be enabled and facilitated. ${ }^{1890} \S 60 \mathrm{e}$ para. 4 UrhG-E stipulates that libraries are permitted to make available to other users via dedicated terminals on their premises a work from their collection for research and private study. The provision now explicitly allows that users make reproductions of no more than $10 \%$ of works made available via terminals, $\S 60$ e para. 4 s. 2 UrhG-E. It is intended to implement the respective judgements of the $\mathrm{ECJ}$ and the $\mathrm{BGH} .{ }^{1891}$

$\S 60 f$ para. 1 UrhG-E declares that $\S 60$ e UrhG-E is applicable as well to archives, institutions of film and audio heritage and publicly accessible museums and educational

\footnotetext{
1882 Ibid.

1883 lbid.

${ }^{1884} \S 60 d$ para. 3 s. 1 UrhG-E.

1885 § 60d para. 3 s.2 UrhG-E.

1886 Referentenentwurf BMJV, p. 42.

$1887 \S 60$ e para. 1 UrhG-E.

1888 Referentenentwurf BMJV, p. 42.

$1889 \S 60$ e para. 1 UrhG-E.

1890 Referentenentwurf BMJV, p. 43.

1891 ECJ, Judgement of the Court of September 11, 2014, C-117/13 - TU Darmstadt vs. Eugen Ulmer KG; BGH, Urteil v. 16.04.2015, Az.: I ZR 69/11 - Elektronische Leseplätze II; cf. Referentenentwurf BMJV, p. 44; see also 4.1.3.2.2.
} 
institutions, which pursue no direct or indirect commercial purposes. The terms archive and institutions of film and audio heritage are legally defined by $\S 61 a$ para. 1 UrhG, which addresses orphan works. ${ }^{1892}$

\section{$3.5 \S 60 \mathrm{~g}$ and $\S 60 \mathrm{~h}$ UrhG-E}

$\S 60 \mathrm{~g}$ para. 1 UrhG-E stipulates that licensing contracts concerning uses permitted by $\S \S 60 \mathrm{a}$ to $60 f$ UrhG-E are invalid. This means that the exclusive right of authors and rightholders is limited where the legislator has privileged specific uses. ${ }^{1893}$ As a consequence, according to $\S 60 \mathrm{~h}$ UrhG-E fair remuneration has to be paid for the use of a work covered by a limitation. In case the intended use exceeds the scope of the limitation the user needs a license and has to pay the remuneration agreed upon by contract only. ${ }^{1894}$ By establishing that limitations and exceptions cannot be overruled by licensing contracts $\S 60 \mathrm{~g}$ para. 1 UrhG-E shall resolve the structural imbalance between users of protected works and authors and rightholders. ${ }^{1895}$ Yet, there is an exception to this rule. $\S 60 \mathrm{~g}$ para. 2 UrhG-E exempts the making available on dedicated terminals in libraries and archives from the scope of $\S 60 \mathrm{~g}$ para. 1 UrhG-E, which is a result of article 5 para. 3 (n) Information Society Directive 2001/20/EC. ${ }^{1896}$ In this case licensing contracts may overrule limitations and exceptions. As the proposal points out it is however necessary that a contract has been concluded; a mere offer to conclude a licensing contract is not sufficient. ${ }^{1897}$

$\S 60 \mathrm{~h}$ UrhG-E clarifies that fair remuneration has to be paid for the uses privileged by $\S \S 60 \mathrm{a}$ to $60 f$ UrhG-E as it was the case already before. ${ }^{1898}$ The provision contains the principle of fair remuneration ( $\S 60 \mathrm{~h}$ para. 1 UrhG-E), specifies the uses that are remuneration free ( $\S$ $60 \mathrm{~h}$ para. 2 UrhG-E), establishes how to calculate fair remuneration (§ 60h para. 3 UrhG-E), stipulates that the right to fair remuneration can only be exercised by a collecting society ( $\S$ $60 \mathrm{~h}$ para. 4 UrhG-E) and determines who has to pay remuneration ( $\S 60 \mathrm{~h}$ para. 5 UrhG-E). According to $\S 60 \mathrm{~h}$ para. $5 \mathrm{~s}$. 1 UrhG-E this is regularly the institution, not the user himself. ${ }^{1899}$

\section{Benchmark}

Concerning the benchmark of uses ${ }^{1900}$ that should be permitted by the law for the purposes

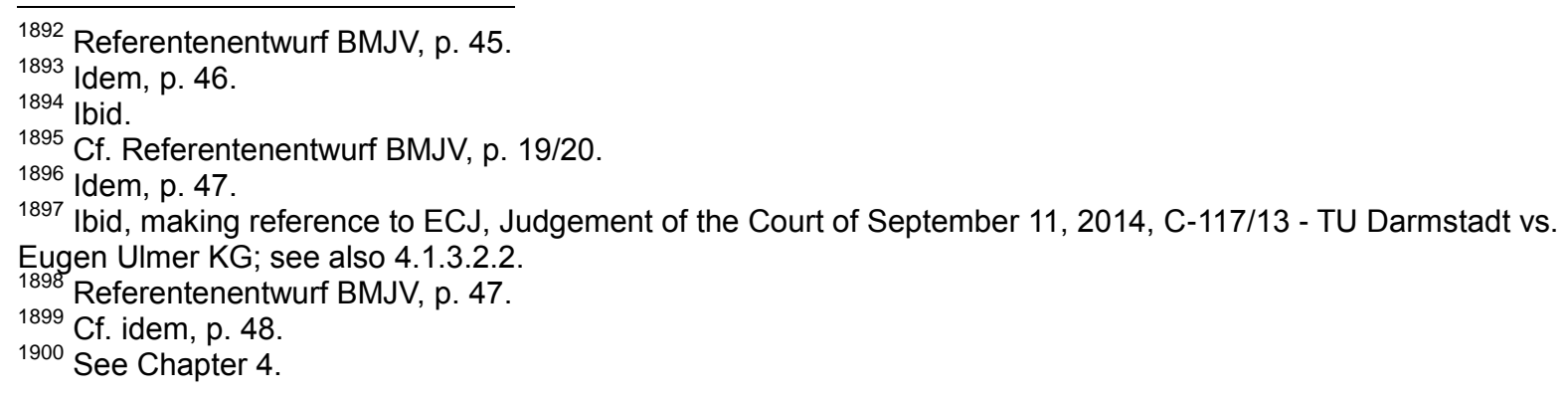


of education and with regard to libraries, archives and similar institutions it must be stated that the German proposal meets the criteria only in part.

In general, the proposal explicitly refrains from introducing a broad, open and technologically neutral limitation or exception. Neither for educational purposes nor for libraries and archives such a provision shall be introduced. This however was a central demand of stakeholders in order to achieve flexibility. The German Ministry of Justice has justified this step with the argument of legal certainty. ${ }^{1901}$ Although using a clear and uncomplicated wording, as the proposal does, was also one of the demands of stakeholders, nonetheless it would have been desirable to present a more forward-looking solution in form of an open general clause, which can adapt to changing technological environments. It must be feared that the solution proposed now will soon be outdated to.

The provisions proposed for educational purposes ( $\S \S 60 a, 60 b$ UrhG-E) obviously apply to all kinds of published works. Also, under $\S 60$ a para. 1 UrhG-E works may now be reproduced, distributed, made available publicly and communicated to the public in other ways. The scope of permitted uses thus is larger, which also was demanded by stakeholders. The benchmark is met clearly in so far as now digital uses in classroom are permitted as well as online and distance education. In addition limitations and exceptions for educational purposes cannot be overruled by licensing contracts. However, there are still restrictions to the amount of a work that can be used.

With regard to limitations and exceptions proposed for libraries, archives and similar institutions $\S 60$ e UrhG-E allows that publicly accessible libraries reproduce, distribute and make available all kinds of works from their collections. Stakeholders however demanded that limitations and exceptions should apply to all kinds of uses, which is not the case. Yet, there is no restriction to the number of copies that can be made for purposes of preservation. As well, format shifting is now allowed ( $\S 60$ e para. 1 UrhG-E). The proposed provisions contain limitations and exceptions for on-site access to collections of libraries, archives and similar cultural heritage institutions, but it is silent to remote access. Remote access to collections is one of the demands of stakeholders. Nevertheless, remote access to library collections is not addressed, either by the German proposal or by the proposal of the EUCommission of September 14, 2016. ${ }^{1902}$ According to $\S 60$ para. 1 UrhG-E privileged institutions are allowed to digitise analogue works from their collections for the purpose of making them available on dedicated terminals. Additionally, it is now permitted to make

\footnotetext{
1901 See above Epilogue 2.2.

1902 Commission of the EU, Proposal for a Directive of the European Parliament and of the Council on Copyright in the Digital Single Market, COM (2016) 593 final.
} 
available such digital copies to an unlimited number of recipients. ${ }^{1903}$ Under current law (§ 52b s. 2 UrhG) the number of digital copies that may be made available to users depends from the number of analogue copies of the work owned by the respective institution. The proposal contains no rules on e-lending ${ }^{1904}$ and web-harvesting. According to $\S 60 \mathrm{~g}$ para. 1 UrhG-E also limitations and exceptions in favour of libraries, archives and cultural heritage institutions cannot be overruled by licensing contracts. ${ }^{1905}$ This also was an important demand of stakeholders.

Furthermore, the German proposal contains a limitation for text and data mining for noncommercial scientific research. Generally, stakeholders uttered that limitations and exceptions for educational purposes and libraries, archives and similar institutions should only cover non-commercial activities, which is in line with the German proposal and the prerequisites of European law, namely article 5 para. 3 (a) Information Society Directive 2001/29/EC.

\section{Evaluation}

The German Ministry of Justice has made an interesting proposal, which appears to be a step into the right direction as regards access to education and knowledge in the digital age. However, several demands of stakeholders remain unsatisfied. In particular an open and flexible general clause for educational purposes and libraries, archives and similar institutions was not presented. The argument of legal certainty invoked by the German Ministry of Justice is understandable, but maybe short-sighted. Indeed, the proposed provisions use a clearer wording, which makes them easier to understand by users and institutions. Nevertheless, the impression arises that the Ministry of Justice wanted to act quickly because of forthcoming elections in Germany in autumn of 2017. With that in mind and discussions regarding the EU copyright framework pending the Ministry of Justice was afraid to make a more courageous proposal. Finally, it is only a proposal and it remains to be seen what will be left of it in the end. Given the numerous and controversial statements of stakeholders and lobby groups ${ }^{1906}$, it must be expected that a long and difficult legislative process lays ahead.

\footnotetext{
1903 Referentenentwurf BMJV, p. 44.

1904 The German proposal (see p. 24) does explicitly not take into consideration the respective decision of the ECJ, Judgement of the Court of November 10, 2016, Case C-174/15.

${ }^{1905}$ Except for $\S 60$ e para. 4 UrhG-E, see Epilogue 3.5.

${ }^{1906}$ All comments are available at http://www.bmjv.de/SharedDocs/Gesetzgebungsverfahren/DE/UrhWissG.html.
} 


\section{Bibliography}

\section{Literature}

Abrão, Eliane Y., Direitos de Autor e Direitos Conexos, São Paulo: Editora do Brasil, 2002

Afori, Orit Fischmann, The Battle over Public E-Libraries - taking stock and moving ahaed, IIC (2013), p. 392 - 417

Akester, Patricia, A Practical Guide to Digital Copyright Law, EIPR Practice Series, Sweet \& Maxwell, 2008

Akester, Patricia, Direito de Autor em Portugal, nos PALOP, na União Europeia e nos Tratados Internacionais, Edições Almedina, 2013

Alves Teixeira, Rosane, Algumas Refelxções sobre a Educação à Distância e o Direito de Autor, 2008

Ambient Insight, Excecutive Overview: Worldwide Market for Self-paced elearning Products and Services: 2011 - 2016 Forecast and Analysis, August 2012

Ascensão, José de Oliveira de, O Direito da Internete em Portugal e no Brasil, Lusíada. Direito. Lisboa, no. 8 / 9 (2011), p. 83 - 101

Ascensão, Jose de Oliveira, Direito Autoral, Renovar, Rio de Janeiro, 2nd Edition, 1997

Asensão, José de Oliveira, Direito Civil, Direito de Autor e Direitos Conexos, Coimbra Editora, 2008

Aufderheide, Patricia / Jaszi, Peter, Reclaiming Fair Use - How to put the Balance back in Copyright, The University of Chicago Press, 2011

Azevedo, Rodrigo, Volume 1, Chapter 6: Brazil in v. Lewinski, Copyright Throughout the World, Thomson \& Reuters, Rel. 7 11/2015

Bacon, Francis, Meditationes Sacrae, 1597

Bacon, Francis, Novum Organum, 1620, translated by James Spedding et al., edited by Spedding, Ellis, and Heath (1858)

Ballard, Tony, Fair use and fair dealing, Entertainment Law Review, 2006, p. 239 - 241

Bastos da Cunha, Murilo, Das Bibliotecas Convencionais às Digitais: Diferenças e Convergênçias, Perspectivas em Ciência da Informação, Volume 13, No. 1, Jan./Apr. 2008, p. 2 - 17

Bates, Tony / UNESCO, National Strategies for E-Learning in Post-Secondary Education and Training, Fundamentals of Educational Planning - No. 70, 2001

Becker-Reifschneider, Marina, Distance Education in Brazil and in the United States: a comparative view, in E-Learing, Volume 3, Number 4, 2006, p. 583 - 592

Benkler, Yochai, Intellectual Property and the Organization of Information Production, October 1999 
Bentham, Jeremy, An Introduction into the Principles of Moral and Legislation, 1789

Bently, Lionel / Sherman, Brad, Intellectual Property Law, Oxford University Press, 3rd Edition, 2009

Bently, Lionel / Sherman, Brad, Intellectual Property Law, Oxford University Press, 4th Edition, 2014

Bently, Lionel, The History of Copyright in Global Copyright: Three Hundred Years Since the Statute of Anne, from 1709 to Cyberspace, Edward Elgar Publishing, Editors Lionel Bently, Uma Suthersanen, Paul Torremans, 2010, p. 7 - 14

Berger, Christian, Die öffentliche Zugänglichmachung urheberrechtlicher Werke für Zwecke der akademischen Lehre Zur Reichweite des § 52a Nr. 1 UrhG, GRUR 2010, p. 1058 - 1064

Besek, June M., The Development of Digital Libraries in the United States, in Global Copyright: Three Hundred Years Since the Statute of Anne, from 1709 to Cyberspace, Edward Elgar Publishing, Editors Lionel Bently, Uma Suthersanen, Paul Torremans, 2010, p. $187-215$

Bielschowsky, Carlos / Laaser, Wolfgang / Mason, Robin / Sagra, Albert / Hasan, Abrar, Reforming Distance Learning Higher Education in Portugal, Study prepared for the Ministry of Science, Technology and Higher Education Portugal, Juli 2009

Böcker, Bernadette, Survey on the Publishing Sector in Selected Sub-Saharan Countries, 2012

Boytha, György, Whose Right is Copyright?, GRUR Int. 1983, p. 379 - 385

Bracha, Oren, Early American Printing Privileges. The Ambivalent Origins of Authors Copyright in America, Privilege and Property Open Book Publishers, Editors Ronan Deazley, Martin Kretschmer, Lionel Bently 2010, p. 89 - 114

Branco, Sergio, Brazilian Copyright Law and how it restricts the Efficiency of the human Right to Education, International Journal on Human Rights, 6 SUR 2007, p. 115 - 135

Brindley, Dame Lynne J., Phoenixes in the Internet Era - The Changing Role of Libraries, in Global Copyright: Three Hundred Years Since the Statute of Anne, from 1709 to Cyberspace, Edward Elgar Publishing, Editors Lionel Bently, Uma Suthersanen, Paul Torremans, 2010, p. $176-186$

Butcher, Neil, A basic Guide to Open Educational Resources (OER), Commenwealth of Learning \& UNESCO, 2011 and 2015

Cabral, Plinio, A Nova Lei de Direitos Autorais, 4th Edition, Harbra São Paulo, 2003

Cella, José Renato Gaziero /Tarrit, Claude René, Institutional Integration of an ICT in Education Solution in a Brazilian University, European Journal of Law and Technology (EJLT) Vol. 2, No. 1, 2011

Chon, Margaret Intellectual Property "from Below": Copyright and Capability for Education, 40 U.C. Davis Law Review (2007), p. 803 - 854

Commission of the EU, (Internal) White Paper - A Copyright Policy for Creativity and Innovation in the European Union, Brussels, XXX, (2014) XXX draft 
Commission of the EU, Commission Staff Working Paper Impact Assessment on the crossborder online access to orphan works accompanying the document "proposal for a directive of the European Parliament and of the Council on certain permitted uses of orphan works'", May 24, 2011, SEC (2011) 615 final.

Commission of the EU, Education and Training Monitor: Portugal, 2014

Commission of the EU, Green Paper Copyright in the Knowledge Economy, Com (2008) 466/final

Commission of the EU, Proposal for a Directive of the European Parliament and of the Council on Copyright in the Digital Single Market, COM (2016) 593 final

Commission of the EU, Report to the Council, the European Parliament and the Economic and Social Committee on the application of Directive 2001/29/EC on the harmonisation of certain aspects of copyright and related rights in the information society, SEC (2007) 1556

Committee on Economic, Social and Cultural Rights, Implementation of the International Covenant on Economic, Social and Cultural Rights, General Comment No. 13, the right to education (article 13 of the Covenant), E/C.12/1999/19, December 8, 1999

Committee on Economic, Social and Cultural Rights, Substantive Issues arising in the Implementation of the International Covenant on Economic, Social and Cultural Rights, General Comment No. 11, plans of action for primary education, (article 14 of the Covenant), E/C.12/1999/4, May 10, 1999

Committee on Economic, Social and Cultural Rights, The Right of Everyone to take part in Cultural Life (art. 15, para. 1 (a), of the International Covenant on Econimic, Socail and Cultural Rights), General Comment No. 21, E/C.12/GC/21, December 121, 2009

Committee on Economic, Social and Cultural Rights, The Right of Everyone to benefit from the Protection of the Moral and Material Interests resulting from any Scientific, Literary or Artistic Production of which he or she is the Author (article 15, paragraph 1 (c), of the Covenant, General Comment No. 17, E/C.12/GC/17, January 12, 2006

Copinger \& Skone James, On Copyright by K.M. Garnett, J.E. Rayner James and G. Davies, Sweet \& Maxwell,Volume 1, 16th Edition, 2011

Cornish, William; Llewelyn, David; Aplin, Tanya, Intellectual Property: Patents, Copyrights, Trademarks \& Allied Rights, Sweet \& Maxwell, 2013

Costa, Danilo de Melo: A New Era for Higher Education in Brazil, in University World News Global Edition, Issue 328, July 11th, 2014

Coudert, Fanny / Werkers, Evi, In the aftermath of the Promusicae case: How to strike the balance?, International Journal of Law and Information Technology / Oxford University Press 2008, Vol, 18 No. 1, p. 50

Crews, Kenneth, Study on Copyright Limitations and Exceptions for Libraries and Archives, WIPO, Standing Committee on Copyright and Related Rights, 2008

Cunha, Thiago M. / Barros Figueiredo, Marina, O impacto da Web 2.0 nas Bibliotecas Escolares das escolas secundárias do concelho de Lisboa, in Actas do Congresso Nacional de Bibliotecários, Arquivistas e Documentalistas, n. 11 (2012): Integração, Acesso e Valor Social, Lisboa - Fundação Calouste Gulbenkian, 18, 19 e 20 de Outubro de 2012 
Davies, Philippa, Access v Contract: Competing Freedoms in the Context of Copyright Limitations and Exceptions for Libraries, E.I.P.R, 2013, p. 402 - 414

de la Durantaye, Katharina, „Allgemeine Bildungs- und Wissenschaftsschranke“, Verlagshaus Monsenstein und Vannerdat, 2014

de la Durantaye, Katharina, Orphan Works: A comparative and international perspective, International Intellectual Property: A handbook of contemporary research, Edward Elgar Publishing, Editor Daniel J. Gervais, 2015, p. 190 - 214

Deutscher Bibliotheksverband e.V., Eine allgemeine Bildungs- und Wissenschaftsschranke im Urheberrecht, Statement June 25, 2014, available at http://www.bibliotheksverband.de/fileadmin/user_upload/DBV/positionen/2014_06_25_Stell ungnahme_Wissenschaftsschranke.pdf

Dias, Maria do Carmo Ferreira / Fernandez-Molina, J. Carlos / Borges, Maria Manuel, As excepcoes do direito de autor em favor das bibliotecas: uma analise comparative entre a Uniao Europea e America Latina, Perspectivas em Scienca de Informacao, Vol. 16 No. 1, 2011 , p. $5-20$

Dreier, Thomas / Schulze, Gernot, Urheberrechtsgesetz, Verlag C.H. Beck, 5th Edition, 2015

Dreier, Thomas, Limitations: The Centerpiece of Copyright in Distress - An Introduction, 1 (2010) JIPITEC, p. 50 - 54

Dreier, Thomas/Hugenholtz, P. Bernt,Concise European Copyright Law (Concise European IP), Kluwer Law International, Second Edition, 2016

Eggert, Astrid, Der Rechtsschutz der Urheber in der römischen Antike, UFITA 138, 1999, p. $183-217$

eLA ( E-Learning Africa), Report 2014, Mozambique

Eleni-Synodinou, Tatiana, The Lawful User and a Balancing of Interests in European Copyright Law, IIC 2010, p. 819 - 843

European SchoolNet / University of Liège, Survey of Schools: ICT in Education, Country Report: Portugal, November 2012

Fechner, Frank (Editor), Die Privatkopie - Juristische, Technische und ökonomische Betrachtungen, Universitätsverlag IImenau, 2007

Foster, Sharon E., The Conflict between the Human Right to Education and Copyright, in Intellectual Property Law and Human Rights, Wolters Kluwer, edited by Paul L.C. Torremans, 2015, p. 335 - 366

Freytag, Stefan, Digital Millennium Copyright Act und europäisches Urheberrecht für die Informationsgesellschaft, MMR 1999, p. 207 - 213

Fuchs, Christian / Horak, Eva, Africa and the Digital Divide, Telematics and Informatics 25, 2008, p. 99-116

Gama, Janete Gonçalves de Oliveira, Direito à Informação e Direitos Autorais: desafios e soluções para os serviços de informação em bibliotecas universitárias, 2008

Geiger, Christophe / Hilty, Reto M. / Griffiths, Jonathan / Suthersanen, Uma, (2010),

Declaration A Balanced Interpretation Of The "Three-Step Test" In Copyright Law. JIPITEC 
Vol. 1, p. $119-121$

Geiger, Christoph, Reconceptualizing the Constitutional Dimension of Intellectual Property, in Intellectual Property Law and Human Rights, Wolters Kluwer, edited by Paul L.C. Torremans, 2015, p. $115-161$

Geiger, Christoph; Gervais, Daniel J.; Senftleben, Martin, The Three-Step Test Revisited: How to Use the Test's Flexibilities in National Copyright Law, American University International Law Review, Volume 29, Issue 3, p. 581 - 626

Geiger, Christophe, Der urheberrechtliche Interessenausgleich in der Informationsgesellschaft - Zur Rechtsnatur des Urheberrechts, GRUR Int. 2004, p. 815 - 821

Geiger, Christophe, Die Schranken des Urheberrechts als Instrumente der Innovationsförderung - Freie Gedanken zur Ausschließlichkeit im Urheberrecht, GRUR Int. 2008, p. $459-468$

Geiger, Christophe, Die Schranken des Urheberrechts im Lichte der Grundrechte - Zur Rechtsnatur der Beschränkungen des Urheberrechts in Hilty/Peukert (Editors):

Interessenausgleich im Urheberrecht, Nomos Baden-Baden, 2004, p. 143- 157

Gervais, Daniel J., How Intellectual Property and Human Rights: Can Live Together: An Updated Perspective, in Intellectual Property Law and Human Rights, Wolters Kluwer, edited by Paul L.C. Torremans, 2015, p. 3 - 26

Gervais, Daniel J., The TRIPS Agreement: Drafting History and Analysis, Sweet \& Maxwell, 4th Edition 2012

Goldhammer, Klaus, Wissenschaftsgesellschaft und Informationsgüter aus ökonomischer Sicht in Wissen und Eigentum : Geschichte, Recht und Ökonomie stoffloser Güter, Bundeszentrale für Politische Bildung, 2006, p. 81 - 106

Grosheide, F.W., Auteursrecht Op Maat, Deventer/Kluwer 1986

Guibault, Lucie, Why Cherry-Picking Never Leads to Harmonisation - The Case of the Limitations on Copyright under Directive 2001/29/EC, JIPITEC vol. 2, 2010, p. 55 - 66

Guibault. Lucie, Copyright Limitations and Contracts, An Analysis of the Contractual Overridability of Limitations on Copyright, Kluwer Law, 2002

Haase, Florian F., Einführung in die Methodik der Rechtsvergeleichung, Juristische Arbeitsblätter 3, 2005, p. 232 - 237

Haucap, Justus / Loebert, Ina / Spindler, Gerald / Thorwarth, Susanne, Ökonomische Auswirkungen einer Bildungs- und Wissenschaftsschranke im Urheberrecht, in Ordnungspolitische Perspektiven Nr. 86, Düsseldorfer Institut für Wettbewerbsökonomie, Juli 2016

Helberger, Natalie / Hugenholtz, P. Bernt, No Place like Home for making a Copy: Private Copying in European Copyright Law and Consumer Law, Berkeley Technology Law Journal Vol. 22, 2007, p. 1061

Helfer, Laurence R., The Right to Education and Copyright in Learning Materials, in Human Rights and Intellectual Property, Cambridge University Press, Laurence R. Helfer and Graeme W. Austin, 2011, p. 316 - 360 
Hilty, Reto M., "Exhaustion" in the Digital Age, Max Planck Insitute for Innovation and Competition Research Paper No. 15-09

Hilty, Reto M., Urheberrecht in der Wissengesellschaft: "Wer will was von wem woraus? - Ein Auftakt zum zweiten Korb, ZUM 2003, p. 983 - 1005

Hilty, Reto M., Vergütungssystem und Schrankenregelungen Neue Herausforderungen an den Gesetzgeber, GRUR 2005, p. 819 - 828

Hoeren, Thomas, Kleine Werke? - Zur Reichweite von § 52a UrhG, ZUM 2011, p. 369 - 375

Hoeren, Thomas/Neubauer, Arne, Zur Nutzung urheberrechtlich geschützter Werke in Hochschulen und Bibliotheken, ZUM 2012, 636-643

Holyoak, and Torremans, Paul, Intellectual Property Law, Oxford University Press, 7th Edition, 2013

House of Representatives, Copyright Law Revision 17 USC $\S 110$ (1976) by the House of Representatives, House Report No. 94 - 1476

Hugenholtz, P. Bernt (Editor), Adapting copyright to the information superhighway in: THE FUTURE OF COPYRIGHT a Digital Environment, Kluwer Law International, 1996, p. 81 102

Hugenholtz, P. Bernt / Okediji, Ruth L., Conceiving an International Instrument on Limitations and Exceptions to Copyright, IVIR / University of Minnesota Law School, Final Report 2008

Hugenholtz, P. Bernt / Senftleben, Martin, Fair Use in Europe. In search of flexibilities, IVIR / Vrije Universiteit Amsterdam, 2011

Hugenholtz, P. Bernt, Copyright Territoriality in the European Union, Briefing Note for Directorate General for Internal Policies, Policy Department C: Citizens` Rights and Constitutional Affairs, Legal Affairs, 2010

Hugenholtz, P. Bernt, Fierce Creatures Copyright Exemptions: Towards Extinction? Rights, Limitations and Exceptions: Striking a proper balance, IFLA/IMPRIMATUR 30 - 31, October 1997.

Hughes, Justin, The philosophy of intellectual property, Georgetown Law Journal, December 1988

ICT and higher education in Africa, Centre for educational technology (CET), University of Cape Town, South Africa, country profile Mozambique, 2007

Isaacs, Shafika, ICT in Education in Mozambique, in Survey of ICT and Education in Africa, 2007

Kamba, Manir Abdullahi, Implication of ICT's in Libraries of Higher Education Institutes: A Panacea Catapulting Library Development in Africa, DESIDOC Journal of Library \& Information Technology, Vol. 31, No. 1, January 2011, p. 65 - 71

Kuhlen, Rainer, Die Allgemeine Bildungs- und Wissenschaftsschranke im Urheberrecht, in Information. Wissenschaft \& Praxis 2016; 67 (1), p. 51 - 60

Laddie, Prescott and Vitoria, The Modern Law of Copyright and Designs, 4th Edition, LexisNexis, 2011 
Landes, William M. / Posner, Richard A., An Economic Analysis of Copyright Law, 18 Journal of Legal Studies 325, 325-33, 344-53 (1989)

Latournerie, Anne, Petite Histoire des Batailles du Droit d’Auteur, Multitudes 2001/2 No. 5, p. $37-62$

Leistner, Matthias / Hansen, Gerd, Die Begründung des Urheberrechts im digitalen Zeitalter Versuch einer Zusammenführung von individualistischen und utilitaristischen

Rechtfertigungsbemühungen, GRUR 2008, p. 479 - 490

Leitão, Luís Manuel Teles de Menezes, Direito de Autor, Almedina 2011

Lemos, Ronaldo, Feet on the Ground: Marco Civil as an Example of Multistakeholderism in Practice, in Pereira de Souza, Carlos Affonso / Viola, Mario / Lemos, Ronaldo, Understanding Brazil's Internet Bill of Right, Instituto de Tecnologia e Sociedade do Rio de Janeiro, 2015

Limas, Jeane Cristina de Oliveira, O Direito Autoral Na Educação à Distância, Maio 2004

Loewenheim, Ulrich, Handbuch des Urheberrechts, C.H. Beck, 1st Edition, 2003

Loewenheim, Ulrich, Handbuch des Urheberrechts, C.H. Beck, 2nd Edition, 2010

Lorenz, Bernd, Braucht das Urheberrecht eine Schranke für die öffentliche

Zugänglichmachung für Unterricht und Forschung (§ 52a UrhG)?, ZRP 2008, p. 261 - 264

Martins da Silva, Daniel, Situação do Direito de Autor e Direitos Vizinhos em Moçambique, in Direitos de Autor, Jornadas Jurídicas No. 3, Edtion Edicil, Maputo, 1986

McNair, Stephen, The Emerging Policy Agenda, in OECD, Learning to Bridge the Digital Divide, Schooling for Tomorrow, OECD Publishing, Paris, 2000

Medeiros De Souza, Maria do Socorro Neri, Do Sernigal à Universidade: O Acesso das Camadas Populares ao Ensino Superior Público no Acre, 2009

Menezes, Dias Elisangela, Curso de Direito Autoral, Del Rey Editora Belo Horizonte, 2007

Metzger, Axel, Urheberrechtsschranken in der Wissensgesellschaft: "Fair Use" oder enge Einzeltatbestände?, in Leistner, Matthias (Ed.), Europäische Perspektiven des Geistigen Eigentums, Tübingen 2010, 101-122.

Ministério de Educação de Moçambique, Relatório Sobre os Seis Objectivos da Educação para Todos, 2015

Mizukami, Pedro Nicoletti, Função Social da Propriedade Intelectual: Compartilhamento de Arquivos e Direitos Autorais na CF/88 Pontifícia, Dissertation, 2007

Mizukami, Pedro Nicoletti / Lemos, Ronaldo / Magrani, Bruno / Pereira de Souza, Carlos Affonso: Exceptions and Limitations to Copyright in Brazil: A Call for Reform, in a2Kbrazil, edited by Lea Shaver, 2010, p. 41 - 73

Monteiro Cavalcanti Manso Junior, Glauco, Direito à Educação: A EaD e o Acesso ao Ensino Superior Público, I. Congresso Nacional Educação e Diversidade, 08 - 10 Setembro de 2011 
Moreira Carvalho, Luciana, As Bibliotecas Universitárias de Portugal e Nordeste do Brasil: estudo sobre o impacto e mediação das tecnologias digitais, Doctoral Disseration, University of Porto, 2013

Muianga, Xavier / Hannson, Hendrik / Nilsson, Anders / Mondlane, Avelino / Mutimucuio, Inocente, ICT in Education in Africa - Myth or Reality: A Case Study of Mozambican Higher Education Institutions, The African Journal of Information Systems, 2013, Volume 5, Issue 3, Article 5, p. $106-117$

$\mathrm{Ng}$, Alina, Copyright Law and the Progress of Science and the Useful Arts, Elgar Law, Technology and Society, 2011

Nordemann, Wilhelm; Vinck, Kai; Hertin, Paul W.; Meyer, Gerald, International copyright and neighboring rights: Commentary with special emphasis on the European Community, $\mathrm{VCH}$ Verlagsgesellschaft mbH, 1990

OECD, E-Learning in Tertiary Education, OECD Policy Brief, 2005

Office of the High Commissioner for Human Rights, Sub-Commission on Human Rights, Intellectual Property Rights and Human Rights, resolution 2000/7, UN Doc.

E/CN/Sub.2/RES/2000/7, August 17, 2000

Okediji, Ruth L., The International Copyright System: Limitations, Exceptions and Public Interest Considerations for Developing Countries, UNCTAD - ICTSD Project on IPRs and Sustainable Development, Issue Paper No. 15, 2006

Paranaguá, Pedro / Branco, Sérgio, Direitos Autorais Editora FGV, Rio de Janeiro, 2009

Picciotto, Sol, Copyright licensing: the case of higher education photocopying in the United Kingdom, European Intellectual Property Review (EIPR), 2002, p. 438 - 447

Pimenta, Eduardo Salles Pimenta / Filho, Eduardo Salles Pimenta, A Limitação dos Direitos Autorais e a sua Função Social, in Direitos Autorais, Estudos em homenagem a Otávio Afonso dos Santos, coordenação Eduardo Salles Pimenta, São Paulo - Editora Revista dos Tribunais, 2007

Plovnick, Lucy / Nguyen, Kimberly, All's fair in university copying case, Intellectual Property Magazin Nov. 2012

Poli, Leonardo Macedo, Direito Autoral Parte Geral, Del Rey Editora Belo Horizonte, 2008

Quick, Susannah / Prior, Gillian / Toombs, Ben / Taylor, Luke / Currenti, Rosanna, Users' perceptions of the benefits of ICT in public libraries in Portugal, Final Report, March 2013

Ramalho, Ana, Conceptualising the European Union`s Competence in Copyright - What Can the EU Do?, IIC (2014), p. 178 - 200

Register of Copyrights, Report of the Register of Copyrights, Library Reproduction of Copyrighted Works (17 U.S.D. 108), 1983

Reia, Jhessica / Mizukami, Pedro Nicoletti, Reformando a Lei de Direitos Autorais: Desafios para o Novo Governo na Área de Cultura, RECIIS, 2015 Jan. - Mar., 9 (1), p. 1 - 6

Reichman, Jerome H. \& Okediji, Ruth L., When Copyright Law and Science Collide: Empowering Digitally Integrated Research Methods on a Global Scale, 96 Minnesota Law 
Review, p. 1362 - 1480, 2012

Reinbothe, Jörg, Neue Entwicklungen in der EU-Urheberrechtspolitik, in Zeitschrift für geistiges Eigentum / Intellectual Property Journal, Vol. 7, 2015, p. 145 - 169

Ricketson, Sam, Study on limitations and exceptions of copyright and related rights in the digital environment, WIPO, Standing Committee on Copyright and Related Rights, 2003

Ricketson, Sam / Ginsburg, Jane, International Copyright and Neighbouring Rights: The Berne Convention and Beyond, Oxford University Press, 2nd Edition, 2006

Rocha de Souza, Allan, A Função Social dos Direitos Autorais: Uma Interpretação CivilConstitucional dos Limites de Proteção Jurídica. Brasil: 1998 - 2005, Coleção José do Patrocínio, Volume IV, 2006

Rocha de Souza, Allan, Brazil, in Hilty, Reto M. / Nérisson, Sylvie, Balancing Copyright - A Survey of National Approaches, MPI Studies on Intellectual Property and Competion Law, Springer 2012

Rocha de Souza, Allan, Direitos Autorais e Acesso à Cultura, Liinc em Revista, v.7, n.2, setembro, 2011, Rio de Janeiro, p. 416- 436

Rodriguez, Juan Carlos Monroy, Study on the Limitations and Exceptions to Copyright and Related Rights for the Purposes of Educational and Research Activities in Latin America and the Caribbean, WIPO, Standing Committee on Copyright and Related Rights, 2009

Rogel, Carlos / Drummond, Vide Victor, Manual de Direito Autoral, Lumen luris 2010

Rosati, Eleonora, The Orphan Works Directive, or throwing a stone and hiding the hand, Journal of Intellectual Property Law \& Practice, 2013, Vol. 8, No. 4, p. 303 - 310

Santiago, Juliana da Silva, Propriedade Intelectual e o Acesso à Informação em Bibliotecas Digitais no Brasil, 2007

Santos, Fernando dos, Sitoi, Julieta Nhana and Filipe, African Copyright and Access to Knowledge (ACA2K), Country Report Mozambique, 2009

Schack, Haimo, Urheber- und Urhebervertragsrecht, Verlag Mohr Siebeck, 7th Edition, 2015

Schmidt-Szalewski, Joanna, Die theoretischen Grundlagen des französischen Urheberrechts im 19. und 20. Jahrhundert, GRUR Int. 1993, p. 187 - 194

Schricker, Gerhard, Urheberrecht zwischen Industrie- und Kulturpolitik, GRUR 1992, p. 242 247

Schricker, Gerhard/Loewenheim, Ulrich, Urheberrecht, C.H. Beck, 4th Edition, 2010

Secker, Jane, Copyright and e-learning - A guide for practioners, facet publishing, 2010

Section 108 Study Group Report, An Independent Report sponsored by The United States Copyright Office and the National Digital Information Infrastructure and Preservation Program of the Library of Congress, March 2008

Senftleben, Martin, Copyright, Limitations and the Three-Step-Test, Kluwer Law, 2004. 
Sganga, Caterina, Right to culture and copyright: participation and access, in Research Handbook on Human Rights and Intellectual Property, Edward Elgar Publishing, edited by Christoph Geiger, 2015, p. 560 - 576

Shaver, Lea, Intellectual Property, Innovation and Development: The Access to Knowledge Approach, Chapter 1 in Access to Knowledge in Brazil, 2008

Silberberg, Carol M., Preserving Educational Fair Use, Southern Califonia Law Review 2001, p. $617-655$

Spedicato, Giorgio, Online Exhaustion and the Bounderies of Interpretation, in Caso, Roberto / Giovanella, Federica (eds.), Balancing Copyright in the Digital Age, Springer-Verlag Berlin Heidelberg, 2015

Stanek, Christina, The Educational System of Brazil, in IEM Spotlight, Volume 10, Issue 1, March 2013

Sterling, J.A.L., World Copyright Law, Sweet \& Maxwell, 3rd Edtion, 2008

Strömholm, Stig, Copyright - National and International Development, International Enzyclopedia of Comparative Law: Copyright, Edited by Ulmer, Eugen/Schricker, Gerhard, Volume XIV, Chapter 2, May 2007

Strowel, Alain, Copyright et Droit d`auteur: Divergences et convergences Etude de droit comparé, Bruylant, Bruxelles, Paris 1993

Suthersanen, Uma and Frabboni, Maria Mercedes, The Orphan Works Directive, EU Copyright Law - A Commentary, Edward Elgar Publishing, Editors Irini Stamatoudi, Paul Torremans, 2014, p. 653 - 695

Synodinou, Tatiana-Eleni, The Lawful User and a Balancing of Interests in European Copyright Law, IIC 2010, p. 819 - 843

Taeger, Jürgen / Horn, Janine, Rechtsfragen der Nutzung neuer Medien und des Internets an Hochschulen, Oldenburger Verlag für Wirtschaft, Informatik und Recht, 2008

Thomas, Nicole M., An education: the Three-Step-Test for Development, E.I.P.R. (2012), p. $244-260$

Tichenor, P.J. / Donohue, G. A. / Olien, C. N., Mass Media Flow and Differential Growth in Knowledge, in The Public Opinion Quarterly, Vol. 34, No. 2 (1970), p. 159-170

Tiedtke, Esther, GATS als unmittelbar geltendes Recht in der EU und Deutschland mit besonderem Blick auf "Bildungsdienstleistungen" am Beispiel von elearning, Kassel University Press, Dissertation, 2012

U.S. Copyright Office, Report of the Register of Copyrights on Copyright and Digital Distance Education, 1999

U.S. Senat Report 107-31, 2001, Technology, Education and Copyright Harmonization Act of 2001

U.S. Senate Report 105 - 190, 1998, The Digital Millennium Copyright Act of 1998 
United Nations, General Assembly Human Rights Council, Report of the special rapporteur in the field of cultural rights, Farida Shaheed, "copyright policy and the right to science and culture“", December 24, 2014

Ulmer, Eugen, Urheber- und Verlagsrecht, Springer Verlag, 1980

Vickers, Brian, Francis Bacon and the Progress of Knowledge, Journal of the History of Ideas, Vol. 53, No. 3, (1992), p. 495-518

Vogel, Martin, From Privilege to Modern Copyright Law, Global Copyright: Three Hundred Years Since the Statute of Anne, from 1709 to Cyberspace, Edward Elgar Publishing, Editors Lionel Bently, Uma Suthersanen, Paul Torremans, 2010, p. 116 - 121

Wager, Hannu; Watal, Yayashree, Human Rights and International Intellectual Property Law, in Research Handbook on Human Rights and Intellectual Property, Edward Elgar Publishing, edited by Christoph Geiger, 2015, p. 149 - 172

White, Ben, Guaranteeing Access to Knowledge: The Role of Libraries, WIPO Magazine, August 2012

World Bank Group, Education Stretegy 2020, Executive Summary, 2011

World Bank, World Development Report: Digital Dividends, 2016

WTO Document DS160, United States - Section 110 (5) of US Copyright Act, p. 33 para. $6.108-6.110$

Xalabarder, Raquel, Google Books and Fair Use: A Tale of two Copyrights?, 5 (2014) JIPITEC 53, p. 53 - 59

Xalabarder, Raquel, Study on Copyright Limitations and Exceptions for Educational Activities in North America, Europe, Caucasus, Central Asia and Israel, WIPO, Standing Committee on Copyright and Related Rights, 2009

\section{Documents}

Access to Knowledge Treaty, May 9, 2005, available at http://www.cptech.org/a2k/a2k_treaty_may9.pdf

Aktionsbündnis „Urheberrecht für Bildung und Wissenschaft“, Bildungs- und Wissenschaftsklausel, December 4, 2014, available at http://www.urheberrechtsbuendnis.de/abws-text-2014-12.html.de

Aktionsbündnis „Urheberrecht für Bildung und Wissenschaft“, Göttinger Erklärung zum Urheberrecht für Bildung und Wissenschaft of July 5, 2004, available at http://www.urheberrechtsbuendnis.de/ge.html.en?of=on

Aktionsbündnis "Urheberrecht für Bildung und Wissenschaft", press release 2/16, October 11, 2016, available at http://www.urheberrechtsbuendnis.de/pressemitteilung0216.html.en

American Archivists, Society of, What Are Archives and How Do They Differ from Libraries?, available at http://archivists.org/usingarchives/whatarearchives 
Ansip, Andrus, The Future of Copyright Reform in EU, Speech given at the CEIPI of the University of Strasbourg, November 24, 2015, available at http://europa.eu/rapid/pressrelease_SPEECH-15-6156_de.htm

Associação Brasileira de Educação à Distância (ABED), Brazilian Census for Distance Learning, 2013, available at http://www.abed.org.br/censoead2013/CENSO_EAD_2013_PORTUGUES.pdf

Berkman Center, The Digital Learning Challenge: Obstacles to Educational Uses of Copyrighted Material in the Digital Age (A Foundational White Paper), August 2006, Berkman Center Research Publication No. 2006-09, available at http://cyber.law.harvard.edu/media/files/copyrightandeducation.html\#9

Bracha, Oren (2008) 'Commentary on the Connecticut Copyright Statute 1783', in Primary Sources on Copyright (1450-1900), eds L. Bently \& M. Kretschmer, www.copyrighthistory.org, available at http://www.copyrighthistory.org/cam/tools/request/showRecord.php?id=commentary_us_178 3a

Bracha, Oren (2008) 'Commentary on the U.S. Copyright Act 1790', in Primary Sources on Copyright (1450-1900), eds L. Bently \& M. Kretschmer, www.copyrighthistory.org, available at http://www.copyrighthistory.org/cam/tools/request/showRecord?id=commentary_us_1790

Branco, Sérgio / Britto, Walter, What is Creative Commons? - New Copyright Models in a more Creative World, Publit Soluções Editoriais, 2015, available at http://itsrio.org/projects/what-is-creative-commons/

Branco, Sergio for Unesco/MEC/CAPES, Documento Técnico - Análise da Lei dos Direitos Autorais Brasileira, 2014, available at http://itsrio.org/projects/documento-tecnico-analise-dalei-de-direitos-autorais-brasileira/

Brasilpost, „A volta de Juca Ferreira ao MinC é uma ótima notícia para a internet“ in Brasilpost on March 4th, 2015, available at http://www.brasilpost.com.br/tatiana-de-mellodias/a-volta-de-juca-ferreira-_b_6406042.html

Canat, Jean-François; Guibault, Lucie; Logeais, Elisabeth, Study on Copyright Limitations and Exceptions for Museums, WIPO, SCCR/30/2, April 30, 2015, available at http://www.wipo.int/edocs/mdocs/copyright/en/sccr_30/sccr_30_2.pdf

Commission of the EU, A Digital Single Market for Europe: Commission sets out 16 initiatives to make it happen, Press Release, May 6, 2015, available at http://europa.eu/rapid/pressrelease_IP-15-4919_de.htm

Commission of the EU, European SchoolNet, University of Liège, "Survey of Schools: ICT in Education Benchmarking Access, Use and Attitudes to Technology in Europe's Schools, Final Study", February 2013, available at https://ec.europa.eu/digitalagenda/sites/digital-agenda/files/KK-31-13-401-EN-N.pdf

Commission of the EU, Proposal for a European Parliament and Council Directive on the harmonization of certain aspects of copyright and related rights in the Information Society, COM/97/628 final - 97/0359 (COD), 1997, available at http://aei.pitt.edu/6216/1/6216.pdf

Commission of the EU, Proposal for a REGULATION OF THE EUROPEAN PARLIAMENT AND OF THE COUNCIL on ensuring the cross-border portability of online content services in the internal market, $\operatorname{COM}(2015) 627$ final, available at

http://ec.europa.eu/newsroom/dae/document.cfm?action=display\&doc_id=12524 
Commission of the EU, Report on the responses to the Public Consultation on the Review of EU Copyright Rules, July 2014, available at

http://ec.europa.eu/internal_market/consultations/2013/copyright-

rules/docs/contributions/consultation-report_en.pdf

Commission of the EU, Towards a modern, more European copyright framework, $\operatorname{COM}(2015) 626$ final, available at

http://ec.europa.eu/newsroom/dae/document.cfm?action=display\&doc_id=12526

CPLP, Cimeira de Ministros da Cultura da CPLP, Declaração de Estoril, May 5/6, 2000, available at

http://www.cplp.org/Admin/Public/DWSDownload.aspx?File=\%2fFiles\%2fFiler\%2fcplp\%2fred es\%2fcultura\%2fDECLARACAODOESTORIL.pdf

CPLP, Cimeira de Ministros da Cultura da CPLP, Plano de Ação, May 5/6, 2000, available at http://www.cplp.org/Admin/Public/DWSDownload.aspx?File=\%2fFiles\%2fFiler\%2fcplp\%2fred es\%2fcultura\%2fDECLARACAODOESTORIL.pdf

CPLP, Declaração Constitutiva da Comunidade dos Países de Língua Portuguesa (CPLP), July 17, 1996, available at

www.cplp.org/Admin/Public/DWSDownload.aspx?File=\%2fFiles\%2fFiler\%2fcplp\%2fDeclarao ConstitutivaCPLP.pdf

CPLP, Estatutos da CPLP, com revisões de São Tomé/2001, Brasília/2002, Luanda/2005, Bissau/2006 e Lisboa/2007, available at

http://www.cplp.org/Files/Filer/Documentos\%20Essenciais/Estatutos_CPLP_REVLIS07.pdf

CPLP, Plano de Ação de Cooperação Multilateral no Domínio da Educação da CPLP (2016 2020) available at

http://www.cplp.org/Admin/Public/DWSDownload.aspx?File=\%2fFiles\%2fFiler\%2f1_CPLP\%2 fEducacao\%2fPlano_A\%26ccedil\%3b\%26atilde\%3bo_Coop_multi_educacao_cplp.pdf

CPLP, Plano Estratégico de Cooperação Cultural Multilateral da CPLP (2014 - 2020), April 11, 2014, available at

http://www.cplp.org/Admin/Public/DWSDownload.aspx?File=\%2fFiles\%2fFiler\%2fcplp\%2fPE CCML-Oficial.pdf

CPLP, Reunião de Ministros de Cultura, IV. Sessão, Resolução sobre is Arquivos Cinmatográficos, May 13/14, 2005, available at

http://www.cplp.org/Admin/Public/DWSDownload.aspx?File=\%2fFiles\%2fFiler\%2fcplp\%2fred es $\% 2 f$ cultura $\% 2 f$ RESOLU\%ef\%bf\%bd\%ef\%bf\%bdO_SOBRE_OS_ARQUIVOS_CINEMATO GR\%ef\%bf\%bdFICOS.pdf

CPLP, Reunião de Ministros de Cultura, IX. Sessão, Declaração Final, April 10/11, 2014, available at http://www.cplp.org/Files/Billeder/cplp/Declarao-Final-IX-Reunio-CPLP.pdf

CPLP, Reunião de Ministros de Educação, I. Sessão, Conclusões, November 24/25, 1997 , available at

http://www.cplp.org/Admin/Public/DWSDownload.aspx?File=\%2fFiles\%2fFiler\%2fcplp\%2fred es $\% 2$ feduc\%2fCONCLUSOESCONFERENCIALISBOA.pdf

CPLP, Reunião de Ministros de Educação, IX. Sessão, Declaração Final, May 24, 2016, available at

http://www.cplp.org/Admin/Public/DWSDownload.aspx?File=\%2fFiles\%2fFiler\%2f1_CPLP\%2 fEducacao\%2fIX-REUNI\%26Atilde\%3bO-DE-MINISTROS-DA-

EDUCA\%26Ccedil\%3b\%26Atilde\%3bO_DEC.pdf 
Crews, Kenneth, What is Fair Use?, available at http://copyright.columbia.edu/copyright/fairuse/what-is-fair-use/

Deazley, Ronan (2008) 'Commentary on Donaldson v. Becket (1774)', in Primary Sources on Copyright (1450-1900), eds L. Bently \& M. Kretschmer, www.copyrighthistory.org, available at http://www.copyrighthistory.org/cam/tools/request/showRecord?id=commentary_uk_1774

Deazley, Ronan (2008) 'Commentary on Millar v. Taylor (1769)', in Primary Sources on Copyright (1450-1900), eds L. Bently \& M. Kretschmer, www.copyrighthistory.org, available at

http://www.copyrighthistory.org/cam/commentary/uk_1769/uk_1769_com_972007181852.ht $\mathrm{ml}$

Digital Agenda for Europe - A Europe 2020 Initiative, available at https://ec.europa.eu/digitalsingle-market/en/europe-2020-strategy

Digital Preservation Coalition, 2012, available at

http://www.dpconline.org/advice/preservationhandbook/glossary\#B

Direção Geral de Estatísticas da Educação e Ciência, available at http://www.dgeec.mec.pt/np4/245.html

Donaldson v. Becket (1774), Primary Sources on Copyright (1450-1900), eds L. Bently \& M. Kretschmer, www.copyrighthistory.org, available at

http://www.copyrighthistory.org/cam/tools/request/showRecord.php?id=record_uk_1774

El País, "Trabalhamos com Dilma para que corte na Cultura não seja burro", Interview with Juca Ferreira in EI País on May 3rd, 2015, available at http://brasil.elpais.com/brasil/2015/05/03/cultura/1430679567_100918.html

Encyclopaedia Britannica, Newly industrialized country, available at http://www.britannica.com/topic/newly-industrialized-country

European Court of Justice, Press Release No. 123/16, Case C-174/15, available at http://curia.europa.eu/jcms/jcms/p1_241154/en/

European Parliamentary Research Service, EU Copyright Reform: Revisting the Principle of Territoriality, Briefing, September 2015, available at http://www.europarl.europa.eu/RegData/etudes/BRIE/2015/568348/EPRS_BRI\%282015\%29 568348_EN.pdf

European Parliament resolution of 9 July 2015 on the implementation of Directive 2001/29/EC of the European Parliament and of the Council of 22 May 2001 on the harmonisation of certain aspects of copyright and related rights in the information society (2014/2256(INI)), available at http://www.europarl.europa.eu/sides/getDoc.do?type=TA\&reference=P8-TA-2015$0273 \&$ language $=\mathrm{EN}$

European Parliament, "Copyright reform: promote cultural diversity and ensure access to it, say MEPs", Press Release of July 9, 2015, available at http://www.europarl.europa.eu/news/en/newsroom/content/20150703IPR73903/html/Copyright-reform-promote-cultural-diversity-andensure-access-to-it-say-MEPs

French Literary and Artistic Property Act (1793), Primary Sources on Copyright (1450-1900), eds L. Bently \& M. Kretschmer, www.copyrighthistory.org, available at 
http://www.copyrighthistory.org/cam/tools/request/showRecord.php?id=record_f_1793

González, José Antonio Moreiro / Alves, Fernanda Melo / Guambe, Martins Fernando, Abordagem metodológica para o estudo compartivo entre as Bibliotecas digitais em Moçambique, Brasil e Paraguai, Revista Electrônica de Biblioeconomia e Ciência da Informação, Vol. 18, No. 37, May/August 2013, p. 157 - 174., available at http://www.redalyc.org/pdf/147/14729734009.pdf

GSV Advisors, Education Sector Factbook 2012, available at http://gsvadvisors.com/wordpress/wp-content/uploads/2012/04/GSV-EDU-Factbook-Apr-132012.pdf

Guibault, Lucie, The Nature and Scope of Limitations and Exceptions to Copyright and Neighbouring Rights with Regard to General Interest Missions for the Transmission of Knowledge: Prospects for their Adaptation to the Digital Environment, E-Copyright Bulletin, October / December 2003, available at http://unesdoc.unesco.org/images/0013/001396/139671e.pdf

Hargreaves, Ian, Digital Opportunity, A Review of Intellectual Property and Growth, 2011, available at

https://www.gov.uk/government/uploads/system/uploads/attachment_data/file/32563/ipreview -finalreport.pdf

Hinze, Gwen, Making Kowledge Accessible across Borders: the Case for Mandantory Minimum International Copyright Exceptions and Limitations for Education, Capacity Building and Development, October 2008, available at https://www. eff.org/files/eff-making-knowledgeaccessible-whitepaper.pdf

IBIS Capital, Global E-Learning Investment Review 2013, available at http://www.ibiscapital.co.uk/index.php/insights-research/

IFLA Statement on Text and Data Mining (2013), available at http://www.ifla.org/files/assets/clm/statements/iflastatement_on_text_and_data_mining.pdf

IFLA, Global library and archives community welcomes new report from United Nations special rapporteur on copyright policy and the right to science and culture, 2015, available at http://www.ifla.org/files/assets/clm/statements/global-library-and-archives-communitywelcomes-new-report-from-un.pdf

IFLA, Key Initiative 2.2, Advocating for an equitable copyright framework, Activity 2.2.3 Work to improve the elending framework, available at http://www.ifla.org/node/10086

IFLA, Treaty Proposal on Limitations and Exceptions for Libraries and Archives", version 4.4, December 6, 2013, available at http://www.ifla.org/files/assets/hq/topics/exceptionslimitations/tlib_v4_4.pdf

IFLA/UNESCO, Manifesto for Digital Libraries, 2011, available at http://www.ifla.org/files/assets/digital-libraries/documents/ifla-unesco-digital-librariesmanifesto.pdf

Instituto Brasileiro de Defesa do Consumidor (Idec), Direito Autoral na era da Internet: Interview with Marcos Alves de Souza, Revista di Idec, Junho 2010, available at http://www.idec.org.br/uploads/revistas_materias/pdfs/2004-06-ed144-entrevista.pdf

Intellectual Property Office (IPO), "UK opens access to 91 million orphan works", Press Release, October 29, 2014, available at https://www.gov.uk/government/news/uk-opens- 
access-to-91-million-orphan-works

Intellectual Property Office (IPO), IPO Intellectual Property - Guidance, Excetions to Copyright, November 18, 2014, available at https://www.gov.uk/guidance/exceptions-tocopyright

Intellectual Property Office (IPO), MODERNISING COPYRIGHT: A modern, robust and flexible framework, Government response to consultation on copyright exceptions and clarifying copyright law, 2012, available at

http://webarchive.nationalarchives.gov.uk/20140603093549/http://www.ipo.gov.uk/response2011-copyright-final.pdf

International Telecommunication Union (ITU), ICT Facts \& Figures 2015, available at: http://www.itu.int/en/ITU-D/Statistics/Documents/facts/ICTFactsFigures2015.pdf

Internet World Stats 2015, available at http://www.internetworldstats.com/stats.htm

ISTafrica, Guide to ICT Initiatives and Research Capacity, v1,Nov. 28th, 2014, available at http://www.ist-africa.org/home/files/IST-

Africa_ICTInitiatives_ResearchCapacity_v1_281114.pdf

Jaszi, Peter, Fair Use and Education - The Way Forward, Law \& Literature, Vol. 25 No. 1, 2013 , p. 33 - 49 and available at http://www.arl.org/storage/documents/publications/jaszieducation-and-fair-use.pdf. The internet document is cited.

Keller, Deidré A. / Vats, Anjali S., Centering Education in the Next Great Copyright Act: A Response to Professor Jaszi, 54 Duquesne Law Review, 2015, available at http://papers.ssrn.com/sol3/papers.cfm?abstract_id=2595733\&download=yes

Kostylo, Joanna (2008) 'Commentary on Johannes of Speyer's Venetian monopoly (1469)', in Primary Sources on Copyright (1450-1900), eds L. Bently \& M. Kretschmer, www.copyrighthistory.org, available at http://www.copyrighthistory.org/cam/tools/request/showRecord.php?id=commentary_i_1469

Liebowitz, Stan J. \& Watt, Richard, How to Best Ensure Remuneration for Creators in the Market for Music? Copyright and its Alternatives (2006), available at http://www.utdallas.edu/ liebowit/surveys.pdf

Liebowitz, Stan J., Filesharing - Creative Destruction or Just Plain Destruction? (2005), available at http://www.utdallas.edu/ liebowit/intprop/destruction4.pdf

Locke's Second Treatise on Government (selected extracts) (1690), Primary Sources on Copyright (1450-1900), eds L. Bently \& M. Kretschmer, www.copyrighthistory.org, available at http://www.copyrighthistory.org/cam/tools/request/showRecord.php?id=record_uk_1690

Marco Antonio Sabellico's Printing Privilege (1486), Primary Sources on Copyright (14501900), eds L. Bently \& M. Kretschmer, www.copyrighthistory.org, available at http://www.copyrighthistory.org/cam/tools/request/showRecord.php?id=record_i_1486

Mazziotti, Guiseppe, Copyright in the EU Digital Single Market, Report of the CEPS Digital Forum, 2013, available at https://www.ceps.eu/system/files/Copyright\%20in\%20the\%20EU\%20Digital\%20Single\%20M arket\%20FINAL\%20e-version.pdf

Medidas da Agenda Portugal Digital 2015, available at http://www.portugaldigital.pt/medidas/ 
Mezei, Péter, Digital First Sale Doctrine Ante Portas - Exhaustion in the Online Environment, JIPITEC Volume 6 (1), 2015, available at http://nbn-resolving.de/urn:nbn:de:0009-29-41733

Michael, Norbert, The Impact of Digital Filesharing on the Music Industry: An Empirical Analysis (2006), available at https://www.riaa.com/wp-content/uploads/2004/01/art-theimpact-of-digital-file-sharing-on-the-music-industry-michel-2006.pdf

National Commission on New Technological Uses of Copyrighted Works (CONTU), Final Report, 1978, available at http://digital-law-online.info/CONTU/PDF/index.html

Nielsen, Lynge, Classifications of Countries Based on Their Level of Development: How it is Done and How it Could be Done, IMF, 2001, available at https://www.imf.org/external/pubs/ft/wp/2011/wp1131.pdf

Oberholzer, Felix / Strumpf, Koleman, The Effect of Filesharing on Record Sales - an Empirical Analysis (2004), available at https://www.unc.edu/ cigar/papers/FileSharing_March2004.pdf

Pohlman Filho, Omer: Ensino à Distância, Bibliotecas Digitais e os Direitos Autorais, 1999, p. 103 - 113, available at http://www.egov.ufsc.br/portal/sites/default/files/anexos/27259-272691-PB.pdf

Reda, Julia, Draft Report on the implementation of Directive 2001/29/EC of the European Parliament and of the Council of 22 May 2001 on the harmonisation of certain aspects of copyright and related rights in the information soc iety, 2014/2256(INI), January 15, 2015, available at http://www.europarl.europa.eu/sides/getDoc.do?pubRef=-

//EP//NONSGML+COMPARL+PE-546.580+02+DOC+PDF+VO//EN\&language=EN

Reitz, Joan M., Online Dictionary for Library and Information Science (ODLIS), updated January 10, 2013, available at http://www.abc-clio.com/ODLIS/odlis_about.aspx

Stationers' Charter, London (1557), Primary Sources on Copyright (1450-1900), eds L. Bently \& M. Kretschmer, www.copyrighthistory.org, available at http://www.copyrighthistory.org/cam/tools/request/showRepresentation?id=representation_uk 1557

Statute of Anne, London (1710), Primary Sources on Copyright (1450-1900), eds L. Bently \& M. Kretschmer, www.copyrighthistory.org, available at http://www.copyrighthistory.org/cam/tools/request/showRecord.php?id=record_uk_1710

The Hague Declaration on Knowledge Discovery in the Digital Age, available at http://thehaguedeclaration.com/the-hague-declaration-on-knowledge-discovery-in-the-digitalage/

UNESCO, Concepts of Openess and Open Access, 2015, available at http://unesdoc.unesco.org/images/0023/002322/232207e.pdf

UNESCO, Education Counts - Towards the Millenium Development Goals, 2011, available at http://unesdoc.unesco.org/images/0019/001902/190214e.pdf

UNESCO, Education Strategy 2014 - 2021, 2014, available at http://unesdoc.unesco.org/images/0023/002312/231288e.pdf

UNESCO, Institute for Statistics, Country Profile Portugal, available at http://www.uis.unesco.org/DataCentre/Pages/country-profile.aspx?code=PRT

UNESCO, Policy Brief, Introduction to MOOCs: Avalanche, Illusion or Augmentation?, July 
2013, available at http://iite.unesco.org/pics/publications/en/files/3214722.pdf

UNESCO, Public Library Manifesto, 1994, available at

http://www.unesco.org/webworld/libraries/manifestos/libraman.html

UNESCO, School Library Manifesto, 1999, available at

http://www.unesco.org/webworld/libraries/manifestos/school_manifesto.html\#3

UNESCO, Statitics on Mozambique, available at http://en.unesco.org/countries/mozambique

Unicef, Statistics on Mozambique, available at

http://www.unicef.org/infobycountry/mozambique_statistics.html

United Nations, List of Least Developed Countries, available at

http://www.un.org/en/development/desa/policy/cdp/ldc/ldc_list.pdf

United Nations, Education for All, available at

http://www.un.org/en/globalissues/briefingpapers/efa/index.shtml

Wachowicz, Marcos, A Revisão da Lei Autoral Principais Alterações: Debates e Motivações, 2015, PIDCC, Aracaju, Ano IV, Edição no 08/2015, p.542 - 562, available at http://www.pidcc.com.br/artigos/082015/21082015.pdf

WIPO Intellectual Property Handbook: Policy, Law and Use, 2004, available at http://www.wipo.int/about-ip/en/iprm/

WIPO SCCR/16/2, available at

http://www.wipo.int/edocs/mdocs/copyright/en/sccr_16/sccr_16_2.pdf

WIPO SCCR/17/2, available at

http://www.wipo.int/edocs/mdocs/copyright/en/sccr_17/sccr_17_2.pdf

WIPO SCCR/19/4-8, available at

http://www.wipo.int/meetings/en/details.jsp?meeting_id=17462

WIPO SCCR/20/11, available at

http://www.wipo.int/edocs/mdocs/copyright/en/sccr_20/sccr_20_11.pdf

WIPO SCCR/22/12, available at

http://www.wipo.int/edocs/mdocs/copyright/en/sccr_22/sccr_22_12.pdf

WIPO SCCR/23/3, "The case for a treaty on exceptions and limitations for libraries and archives: background paper by IFLA, ICA, EIFL and INNOVARTE" , November 18, 2011, available at http://www.wipo.int/edocs/mdocs/copyright/en/sccr_23/sccr_23_3.pdf

WIPO SCCR/23/4, available at

http://www.wipo.int/edocs/mdocs/copyright/en/sccr_23/sccr_23_4.pdf

WIPO SCCR/23/5, available at

http://www.wipo.int/edocs/mdocs/copyright/en/sccr_23/sccr_23_5.pdf

WIPO SCCR/24/6-8, available at http://www.wipo.int/meetings/en/details.jsp?meeting_id=25014

WIPO SCCR/26/3, 4 and 8 , available at

http://www.wipo.int/meetings/en/details.jsp?meeting_id=29944 
WIPO SCCR/27/8, available at

http://www.wipo.int/edocs/mdocs/copyright/en/sccr_27/sccr_27_8.pdf

WIPO SCCR/30/2, available at

http://www.wipo.int/edocs/mdocs/copyright/en/sccr_30/sccr_30_2.pdf

WIPO SCCR/31/1 Prov., available at

http://www.wipo.int/edocs/mdocs/copyright/en/sccr_31/sccr_31_1_prov.pdf

WIPO SCCR/31/4, available at

http://www.wipo.int/edocs/mdocs/copyright/en/sccr_31/sccr_31_4.pdf

WIPO SCCR/32/1 Prov., available at

http://www.wipo.int/edocs/mdocs/copyright/en/sccr_32/sccr_32_1_prov.pdf

WIPO SCCR/32/4, available at

http://www.wipo.int/edocs/mdocs/copyright/en/sccr_32/sccr_32_4.docx

WIPO, SCCR/33/1 Prov. available at

http://www.wipo.int/edocs/mdocs/copyright/en/sccr_33/sccr_33_1_prov.pdf

WIPO SCCR/33/4, available at

http://www.wipo.int/edocs/mdocs/copyright/en/sccr_33/sccr_33_4.pdf

WIPO, Cooperation Agreement Between the Secretariat of the Community of PortugueseSpeaking Countries (CPLP) and the World Intellectual Property Organization (WIPO), $\mathrm{WO} / \mathrm{CC} / 48 / 2$, Annex VI, July 22, 2002, available at

http://www.wipo.int/edocs/mdocs/govbody/en/wo_cc_48/wo_cc_48_2.pdf

WIPO, Standing Committee on Copyright and Related Rights, Civil Society statement on exceptions and limitations for education, Geneva, 16-24, July 2012, available at https://www. eff.org/de/document/civil-society-statement-exceptions-and-limitationseducation-wipo-24th-sccr-geneva-16-24

World Bank Mozambique, available at http://www.worldbank.org/en/country/mozambique

World Bank, Country at a Glance Portugal, available at http://www.worldbank.org/en/country/portugal

Worldbank, Gross Domestic Product 2014, available at http://databank.worldbank.org/data/download/GDP.pdf

Xalabarder, Raquel, Copyright exceptions for teaching purposes in Europe (Working Paper), Internet interdisciplinary institute, July 2004, available at https://in3.uoc.edu/opencms_portalin3/export/sites/default/galleries/docs/INTERDRET/Xalab arder_2004_CopyrightExceptionsForTeachingPurposes.pdf

\section{Cases}

\section{Brazil}

Tribunal Regional Federal da Segunda Região, Apelação Civel 2002.51.01.015719-6, Sgeunda Turma Especializada, Relatora: Desembargadora Federal Liliane Roriz, Rio de Janeiro, November 24, 2009 
Superior Tribunal de Justiça, Recurso Especial n. 964.404, Terceira Turma, Relator: Paulo de Tarso Sanseverino, Brasília, March 15, 2011

Supremo Tribunal Federal, Recurso Extraordinário n. 113.505-RJ, Primeira Turma, Relator: Min. Moreira Alves, Brasília, Febuary 28, 1989

\section{Europe}

ECJ, Judgement of the Court of July 14, 2005, C-192/04, Lagardère Active Broadcast ECJ, Judgement of the Court of December 1, 2011, Case C-145/10 - Painer

ECJ, Judgement of the Court of July 16, 2009, Case C-5/08 - Infopaq

ECJ, Judgement of the Court of June 16, 2011, Case C-462/09 - Stichting de Thuiskopie vs. Opus Supplies Deutschland GmbH

ECJ, Judgement of the Court of October 21, 2011, Cases C-403/08 and C-429/08 Football Association Premier League Ltd

ECJ, Judgement of the Court of July 3, 2012, C-128/11, UsedSoft vs. Oracle

ECJ, Judgement of the Court of June 27, 2013, Cases C-457/11 to 460/11 - VG Wort

ECJ, Jugdement of the Court of September 11, 2014, C-117/13 - TU Darmstadt vs. Eugen Ulmer KG

ECJ, Judgement of the Court of November 10, 2016, Case C-174/15 - Vereniging Openbare Bibliotheken vs. Stichting Leenrecht

\section{Germany}

BGH GRUR 2008, 245 - Drucker und Plotter I

BGH GRUR 2009, 53 - PC I

BGH GRUR 2011, 1007 - Drucker und Plotter II

BGH GRUR 2011, 1012 - PC II

BGH GRUR 2013, 503 - Elektronische Leseplätze

BGH, Urteil v, 28.11.2013, Az. I ZR 76/12 - Meilensteine der Psychologie

BGH, Urteil v. 16.04.2015, Az.: I ZR 69/11 - Elektronische Leseplätze II

BGHZ 141, 13 - Kopienversanddienst

BGHZ 17, 266 - Grundig-Reporter

BVerfG 31, 270 - Schulfunksendungen 
BVerfG GRUR 2010, 999 - Drucker und Plotter

BVerfGE 31, 229, 239 - Kirchen- und Schulgebrauch

BVerfGE 49, 382 - Kirchenmusik

LG Frankfurt a.M. GRUR 2011, 616 - Elektronische Leseplätze

LG Frankfurt a.M. GRUR-RR 2009, 330 - Elektronische Leseplätze

OLG Frankfurt a.M. GRUR-RR 2010, 1 - Elektronische Leseplätze

OLG Frankfurt, Urteil v. 24.11.2009, Az. 11 U 40/09

\section{Portugal}

Acórdão do Supremo Tribunal de Justiça, No. 103/04.2TVLSB.L1.S1, November 17, 2011

Acórdão do Tribunal da Relação de Lisboa, No. 565/2008-6, January 31, 2008

\section{United Kingdom}

Donaldson v. Becket (1774) Hansard, 1st ser., 17 (1774): 953-1003

HM Stationery Office v. Green Amps (2007) EWHC 2755 (Ch)

Millar v. Taylor (1769) 4 Burr. 2303

Universities U.K. v. Copyright Licensing Agency Ltd. (2002) RPC 693

\section{United States of America}

American Geophysical Union v. Texaco Inc., 60 F. 3d 913, 920 (2d Cir. 1994).

Authors Guild, Inc. v. Google Inc., No. 13-4829-cv (2d Cir. Oct. 16, 2015)

Authors Guild, Inc. v. Hathi Trust, 755 F. 3d 87 (2d Cir. 2014)

Authors Guild, Inc. v. Hathi Trust, 902 F. Supp. 2d 445 (S.D.N.Y. 2012)

Basic Books, Inc. v. Kinko`s Graphics Corp., 758 F. Supp. 1522 (S.D.N.Y. 1991)

Cambridge University Press v. Becker, 863 F. Supp. 2d 1190 (N.D. Georgia 2012)

Campbell v. Acuff-Rose Music, Inc. 510 U.S. 569 (1994).

Capitol Records, LLC v ReDigi Inc., 934 F. Supp. 2nd 640 (S.D.N.Y. 2013) 
Encyclopaedia Britannica Educ. Copr. v. Crooks, 542 F. Supp. 1156 (S.D.N.Y. 1982)

Folsom v Marsh, Folsom 9 F. Cas. 342 (D. Mass 1841).

Harper \& Row Publishers, Inc. V. Nation Enterprises, 471 U.S. 539 (1984)

Princeton University Press v. Michigan Document Services, 99 F.3d 1381 (6th Cir. 1996)

Sony Corp. of America v. Universal City Studios, Inc. 464 U.S. 417 (1984)

US Circuit of Appeals for the 11th Circuit, Cambridge University Press, et al v Becker, et al, Civil Action No. 1:08-cv-1425-ODE, October 17, 2014.

Williams \& Wilkins Co. v. United States , 487 F.2d 1345 (1973) 


\title{
Executive Summary
}

\section{Copyright Law and the Access to Education and Knowledge in the Digital Age \\ Matching Limitations and Exceptions in Portugal, Brazil and Mozambique}

\author{
Philipp Maximilian Usadel
}

The present study aims essentially at exploring one question: Do limitations and exceptions to copyright law adequately promote the access to education and knowledge in the digital age?

To come straight to the point, the results of the study altogether lead to the conclusion that access to education and knowledge in the digital age is not adequately promoted by limitations and exceptions to copyright law. Rather, the results show that especially in Brazil and Mozambique, but also in Portugal, the USA, the UK and Germany, limitations and exceptions promoting access to education and knowledge are not fit for coping with the challenges of the Internet and digital technologies.

Therefore, in many regards copyright law must be identified as an obstacle for the access to education and knowledge. This effect is particularly serious in developing and least developed countries, where access to education and knowledge is even more essential for social and economic development than in industrialised countries. Both copyright and the access to education and knowledge have underpinnings in fundamental rights. Authors and right holders on the one hand can invoke their right to property. Individuals and the general public as users of copyright protected works on the other hand can claim the fundamental right to education and to take part in cultural life. It is the task of international and national copyright law to fairly balance these conflicting interests. In that context copyright legislation must take into account appropriately that the Internet and digital technologies have fundamentally changed the possibilities to use copyright protected works, in particular as regards access to education and knowledge. According to the findings of the study this has been the case only to a very limited extent. Rather an overprotection of the rights of authors and right holders must be observed. Yet, the unilateral focus on the protection of authors and right holders in copyright law neglects the fundamental significance of access to education and knowledge and the possible benefits of the Internet and digital technologies for social and economic development. As a result, copyright law is out of balance. 
However, the results of the present study also show that many countries are undertaking legislative efforts to adapt their copyright systems to the Internet and new digital environments, not only but especially with regard to copyright limitations and exceptions promoting access to education and knowledge. At the same time there are legislative initiatives both on international and European level to further harmonise copyright law and copyright limitations and exceptions. The study describes and explains the reform plans. Yet, it suggests that these reforms do not go far enough and further legislation, both on the international and national level is necessary to recalibrate the balance of interest in copyright law.

The issues described above are analysed with special focus on copyright legislation in Portugal, Brazil and Mozambique. These countries have in common not only colonial history but are also linked by the Portuguese language. All three countries belong to the Droit d'Auteur tradition of copyright, each one with its own specialities. Besides Portugal, Brazil and Mozambique find themselves in different stages of social and economic development. Portugal is an industrialised country and a member of the European Union. Brazil is a newly industrialising and developing country. Mozambique is a least developed country. It is pointed out if and how the stage of social and economic development of a country corresponds to issues of copyright law. It is further underscored that the need for access to knowledge and education is of particular importance in Brazil and Mozambique, where large parts of the population live in poverty and illiteracy is a major problem. Since the study concentrates on questions of copyright law and access to knowledge and education in the digital age, the respective national policies to implement information and communication technologies are of interest, too. In view of the Internet's global nature and the linkage of Portugal, Brazil and Mozambique by the Portuguese language, it is examined, if a common market for digital goods, especially for educational materials, exists between these countries and to what extent the principles of territoriality and exhaustion impact on the access to copyright protected works for educational purposes within such area.

The goal of this study is to highlight the role of copyright limitations and exceptions for the benefit of access to knowledge and education in the digital age. The findings show that the current systems of limitations and exceptions in the countries analysed here are not suitable in light of the importance of access to knowledge and education, especially in developing and least developed countries. These results are further underlined by the analysis of copyright provisions for the benefit of access to education and knowledge in the United States of America, the United Kingdom and Germany, which promote access to education and knowledge only to a rather limited extend, given the potentials of the Internet and digital 
technologies to use copyright protected works in favour of access to education and knowledge. Especially in view of the underpinnings of access to education and knowledge in human rights the study advocates for reforming current frameworks of copyright limitations and exceptions.

The principal methodological approach the study pursues is the comparison of laws. Therefore the relevant legal sources are analysed, including historical legislative developments and philosophical justifications of limitations and exceptions to copyright law. To put the findings into context also the current political, social and economic situation in Portugal, Brazil and Mozambique, including educational and IT-related policies, is taken into account. In addition empirical data regarding e-learning activities and copyright limitations and exceptions in Portugal, Brazil and Mozambique is provided and evaluated.

The study comprises four chapters. Chapter 1 provides information on the background and the context of the study. Terminology is clarified and the positions of the relevant stakeholders, namely educational institutions and libraries, archives and museums, are described taking into account the changes brought about by digital technologies and the Internet as well as the effects of these developments on the work of the respective institutions, e.g. e-learning and digital libraries. Based on these findings the desiderata of the respective stakeholders are presented. Above that the area of conflict between copyright law and access to education and knowledge is outlined, including an overview of the situation of developing and least developed countries and the general significance of limitations and exceptions to copyright. Chapter 1 concludes with a short summary of international copyright policy, namely the developments before the WIPO Standing Committee of Copyright and Related Rights (SCCR).

Chapter 2 deals with the historical origins of copyright protection and explains the philosophical foundations of copyright law as well as the role of limitations and exceptions within the copyright system, in order to apply these findings to the ensuing analysis. This includes the description of the different rationales within the anglo-american Copyright and the continental-European Droit d’Auteur legal tradition. Moreover, justifications for limitations and exceptions to copyright law are analysed, namely fundamental rights, public interest and market failure.

Chapter 3 examines the international and European legal framework of limitations and exceptions to copyright law. The focus is laid on the provisions of the Berne Convention, the European Information Society Directive 2001/29/EC and the Orphan Works Directive 
2012/28/EU. With regard to the EU the actual copyright reform plans are scrutinised. Also the human and fundamental rights dimension of access to education and knowledge on the one side and of copyright on the other side and the entrenchment of these positions in international law is analysed in detail. Special attention is paid to the Three-Step-Test, which is contained in the Berne Converntion, the TRIPS Agreement, the WIPO Internet Treaties (WCT and WPPT) and the Information Society Directive. The provisions of the Three-StepTest must be considered by legislators in case of introducing limitations and exceptions into national law. In the context of the Three-Step-Test the study argues in favour of an interpretation taking into consideration the fundamental rights to education and to take part in cultural life.

Chapter 4 contains the analysis of national copyright laws. In Part 1 of Chapter 4 the limitations and exceptions for educational purposes and libraries, archives, museums and similar institutions in the USA, the United Kingdom and Germany are examined. These countries have elaborate copyright systems and a high level of copyright enforcement. Due to this fact and their economic situation the USA, the UK and Germany are examples for other countries in the field of legislation in general and in particular in the field of copyright law. At the same time these countries have different copyright traditions and provide different legal solutions to the challenges of the digital age. In particular the pros and cons of the US and UK fair use respectively fair dealing provisions are explained. National limitations and exceptions are examined in detail, taking into account international and European obligations, constitutional underpinnings and relevant court decisions. The findings show that national systems of copyright limitations and exceptions in the USA, the UK and in Germany are mostly are not able to provide adequate solutions for the challenges of the digital age. Relevant stakeholders, namely educational establishments, libraries, archives and similar institutions find themselves in considerable legal uncertainty. However, in contrast to the rigid German system of statutory limitations, copyright law in the USA and the UK is more flexible, because, in addition to statutory limitations and exceptions, the fair use doctrine respectively fair dealing, which is applied from case to case, may cover certain uses of copyright protected works not explicitly foreseen by the law. The findings suggest that such open clauses are one possible means to adapt copyright to the challenges of the digital age.

Part 2 of chapter 4 subsequently examines limitations and exceptions for educational purposes and libraries, archives, museums and similar institutions in Portugal, Brazil and Mozambique. For background information the analysis of each country starts with a short profile, providing historical, geographical and statistical information. Afterwards the educational policies and the educational system as well as the integration of information 
communication technologies in education and in libraries, archives and similar institutions are explained. An overview of national copyright law is given before limitations and exceptions for educational purposes and libraries and archives are examined. Finally, empirical data regarding e-learning activities of educational institutions as well as the respective policies and legislative initiatives is evaluated in order to put the law into practical context. In addition, it is explored whether the common Portuguese language as well as historical, political and economical linkages between Portugal, Brazil and Mozambique, especially through the Community of Portuguese Speaking Countries (CPLP), provide for common copyright policies and legislation with regard to the promotion of access to education and knowledge. It is further examined, whether in this context the advantages of digital technologies and the Internet can be made useful in terms of providing cross border (remote) access to educational materials and library collections. Special focus is therefore laid on the question of exhaustion of copyright. In general, the results of the analysis of national laws show that only Portugal has adressed digital issues regarding copyright at all. Yet, it mainly suffers from the rigidity of statutory limitations and exceptions. In Brazil limitations and exceptions in favour of access to education and knowledge hardly exist. Digital issues are neglected by the current code of copyright. However, there are significant reform efforts in Brazil, which unfortunately have come to a stillstand. Finally, in Mozambique there are some provisions privileging educational establishments and libraries and archives. However, digital issues are not explicitly addressed in that context. Both in Mozambique and partly also in Brazil the enforcement of copyright law is problematic. In this regard the study argues that reformed copyright systems may lead to improved enforcement, which could stimulate domestic production of copyrighted works and thus also be favourable to access to education and knowledge.

Based on these findings the main issues in the area of copyright limitations and exceptions for educational purposes and libraries and archives are summoned in the Conclusion. Considering the differences and similarities of the countries under analysis possible solutions for improving the access to knowledge and education through limitations and exceptions to copyright law are outlined. The findings suggest that both international and national copyright systems must be reformed. The study concludes with concrete proposals for legislative amendments of international copyright law, namely a proposal for an international copyright treaty privileging educational institutions and libraries, archives and similar institutions. The proposed treaty sets forth mandatory limitations and exceptions for both educational establishments and libraries, archives and similar institutions. It applies to non-profit institutions acting in public interest only. With regard to the Thee-Step-Test the treaty makes explicit mention not only of the legitimate interests of authors and right holders but also of 
other legitimate interests of stakeholders, such as fundamental and human rights, in particular the right to education and culture and promotion of social and economic development, in order to guide the interpretation and application of the test into a more balanced direction. Further, changes of national copyright law are proposed. In view of the findings of the study it seems favourable to introduce provisions, which contain both open clauses like the fair use doctrine for the purpose of flexibility and non-exhaustive lists of examples of explicitly permitted uses for the purpose of legal certainty. In addition, it is advocated to include references to the human right to education and to take part in cultural life in national copyright laws in order to highlight the overall importance of these issues for society and to interpret and apply copyright law along these guiding principle in practice. The proposed amendments to national laws are measured against international and European standards, in particular the Three-Step-Test. Finally, the study provides an outlook for future developments. 


\section{Valorisation Addendum}

\section{What is the social and/or economic relevance?}

The significance of education and knowledge for individual and social development as well as for economic progress is undisputed. What is crucial and much debated is the access to education and knowledge, not only in industrialised countries but also an even more in developing and least developed countries, where large parts of the population live in poverty and illiteracy is a major problem. In that context education and knowledge are of fundamental importance in the fight against poverty and illiteracy. Improved access to education and knowledge is expected to foster social and economic development and enable developing and least developed countries to participate in the global knowledge society and economy.

Both educational establishments and libraries, archives and similar institutions use copyright protected works in order to provide their services and to enable access to education and knowledge. From that point of view a preferably unrestricted use of copyrighted works appears advantageous. However, since copyright law assigns the exclusive right to control any use of a copyrighted work to the author, who is interested in deriving (financial) profit from uses of his work and who therefore supports a more restrictive approach to copyright law, the access to education and knowledge may be limited by copyright law. This is not principally wrong and besides it is inherent to almost any copyright system. Yet, considering the significance of education and knowledge for overall social and economic benefit, it must be carefully analysed and examined how far the right of the author (and right holder) to control the use of a work may reach and under which conditions the right to control the use of a work has to stand back in favour of higher ranking interests.

With the advent of the digital age the issue of balancing interests fairly, which is essential to copyright law in order to both stimulate creation and to promote the dissemination of knowledge, has emerged with great urgency. The Internet and digital technologies have multiplied the possibilities to access copyright protected works. This is generally favourable with regard to access to education and knowledge. However, the extended possibilities to use copyright protected rights over the Internet and by means of digital technologies are not or at least not sufficiently reflected by current copyright regimes all over the world. Rather, the reaction to the digital change and its effects on copyright law is a protectionist one, supported mainly by authors and right holders. As a result, the possibilities to make the Internet and digital technologies useful for improving access to education and knowledge by educational establishments, libraries, archives and similar institutions are limited by restrictive copyright provisions and a onesided author-centered interpretation and application 
of these norms. In particular, limitations and exceptions to copyright law often do not correspond with practical realities and necessities of providers of education and knowledge. That is why said institutions find themselves in considerable legal uncertainty and back away from uses of certain works for fear of commiting copyright infringements to the detriment of access to education and knowledge. Considering the above said fundamental significance of education and knowledge this is an adverse development, which must be opposed.

Therefore, this study advocates for reforming international copyright law as well as national copyright limitations and exceptions, focussing on the use of digital media and the Internet for access to education and knowledge. As the results of the study show copyright limitations and exceptions are not adequately promoting access to education and knowledge, neither in developed nor in developing and least developed countries because numerous uses of copyrighted works for educational purposes and in libraries and archives are not in conformity with the respective national copyright law or it is at least unclear whether these uses infringe the law or not. The study thus argues that reforming copyright law both internationally and nationally is necessary in order to improve the access education and knowledge. With regard to developing and least developed countries, namely Brazil and Mozambique, the findings of the study suggest that access friendly copyright limitations and exceptions taking appropriately into account the possibilities of the Internet and digital technologies could be one important means to promote access to education and knowledge and thereby enhance social and economic development.

The relevance of the present study thus is, on the one hand that it comprehensively analyses the current state of copyright limitations and exceptions for educational purposes and libraries, archives and similar institutions with regard to international copyright law and as well with regard to national copyright laws in the USA, the UK, Germany, Portugal, Brazil and Mozambique. On the other hand, the study proposes solutions for adequate limitations and exceptions for the benefit of access to education and knowledge taking into consideration especially the situation in Brazil and Mozambique as well as in Portugal, the potentials of the Internet and digital technologies and the human right to education and to take part in cultural life.

The issues discussed in this study concern authors, right holders, educational establishments, libraries, archives, museums and other cultural heritage institutions as well as individuals seeking access to education and knowledge. The interests of stakeholders involved thus relate not only to social issues such as the access to education itself but also to economic issues like financial investments in the creation of copyright protected content by 
right holders or the construction of (digital) libraries through educational establishments or other institutions. These issues are examined against the backdrop of the situation in developing and least developed countries in which broad access to education and knowledge is especially vital in order to promote development. But also in developed countries the issues of the present study are essential in terms of participation and equality as well as social, economic and scientific progress. Considering this a study of copyright law and access to education and knowledge is of high social and economic relevance.

\section{To whom are the research results of interest?}

The results of this study can be useful to interest and lobby groups in the field of education and access to knowledge, for instance international and national associations of educational establishments or libraries as well as stakeholder organisations. Besides, educational establishments and libraries, archives and similar institutions may use the results of the country analysis as guidelines for the interpretation and application of the respective national copyright limitations and exceptions currently in force. Above that the findings may serve as a basis for decisions regarding investments of educational establishments and libraries, archives and similar institutions. Insofar the study provides legal certainty which might result in increasing investments in the educational and knowledge sector, for instance in the construction of digital libraries. Furthermore, policy and lawmakers, both on an international and national level, might use the results and in particular the proposed solutions as a basis for legislative initiatives and amendments, both at international and national level.

The results of the study might also be of interest for the respective stakeholders with regard to the ongoing discussions before the WIPO Standing Committee of Copyright and Related Rights (SCCR) concerning an international treaty for limitations and exceptions for educational, teaching and research institutions as well as for libraries and archives. Since the EU is discussing a fundamental copyright reform, the results of the study may as well be interesting for the EU legislator and the organisations and stakeholder groups involved in that process. Above that the results could be interesting for international organisations focusing on the Portuguese-speaking world, such as the Community of Portuguese Speaking Countries (CPLP), in order to intensify copyright related policies and co-operations in the field of access to education, knowledge and culture among member states of the CPLP.

Finally, the study examines the role of limitations and exceptions as a means of promoting social and economic development in general. It supports the approach of a more value and human rights oriented understanding of copyright law in general. The study applies this approach in concreto to the interpreation of copyright limitations and exceptions for access to 
education and knowledge, in particular in Portugal, Brazil and Mozambique, and thereby demostrates how a recalibration of the balance of interests in copyright law might be feasible. Thus the study is of value also from an academic point of view.

\section{How can the research results be applied in practice?}

In particular in Brazil and Mozambique the results of the study of current copyright provisions privileging access to education and knowledge as well as the proposed solutions for adequate limitations and exceptions might be used by national policymakers and legislators in order to develop legislative initiatives for the purpose of reforming national copyright law. In Brazil this reform process has already started but meanwhile has stalled. Nevertheless, reforming Brazilian copyright law, especially limitations and exceptions, is absolutely necessary, since the current legal framework neglects the issue of access to education and knowledge completely. The results of the study are intended to help resume the reform process in Brazil and make a contribution towards a balanced, more value and human rights oriented copyright system. As regards Mozambique it is assumed that a more access related, user friendly and value oriented system of copyright limitations and exceptions for education and knowledge would have positive effects on social and economic development and thus is one important means in the fight against illiteracy and poverty. Further, it is assumed that broad access to education and knowledge enabled by updated copyright provisions would be beneficial to social and economic development. In addition, it is expected that fairly balanced copyright laws will increase the acceptance of copyright protection and thereby enhance domestic production of copyrighted works, which would be favourable for education and knowledge, especially in Brazil and Mozambique. Thus, the findings of the study might also contribute to a reform of Mozambican copyright law. Moreover, the results of the study could be useful in the context of building co-operations and knowledge exchange programs between (higher) educational institutions as well as between libraries, archives and similar institutions, in particular in Portugal, Brazil and Mozambique.

Furthermore, stakeholders in the USA, the UK and in Germany might have an interest in the results of the study. Especially the focus on the human rights dimension of access to education and knowledge in the field of copyright law as supported by this study may provide policymakers and legislators with another perspective on limitations and exceptions. Considering for instance the growing knowledge gap within industrialised countries a shift towards a more value and human rights based understanding of copyright law and limitations and exceptions for overall social and economic benefit appears necessary in order to counter societal and digital divide. In this regard the study might have an effect on relevant decisionmakers and thereby influence future copyright legislation. 


\section{What is the innovative character of the research?}

So far, at least to the author's knowledge, there is no study that analyses copyright limitations and exceptions in Portugal, Brazil and Mozambique with regard to access to education and knowledge in the digital age. In particular, the conception of a common market or common area for copyright protected works in the field of education and knowledge between these countries has not yet been analysed. The study carves out the potentials of co-operations in these areas with special regard to the Internet and digital technologies. Also it provides a comprehensive evaluation of not only legal but also factual and political circumstances on which educational establishments, libraries, archives and other providers of education and knowledge may rely in case of future co-operations and/or investments. In addition, the study is innovative in so far as it lays the grounds for further research concerning copyright limitations and exceptions for access to education and knowledge in Portuguese speaking countries.

Above that, the study connects issues of access to education and knowledge in the digital age with policies for social and economic development in an in-depth analysis and examines the potentials of digital technologies and the Internet for providing access to education and knowledge in developing and least developed countries, which has not yet been done with regard to Portuguese speaking countries. In general, the study is one of the few if not the only, which examines copyright law in Portuguese speaking countries with special focus on limitations and exceptions. Research in this area of copyright law is scarce, although as the study shows the need for access to education and knowledge is particularly urging in countries like Brazil and Mozambique as well as in other Portuguese speaking countries, since most of them are developing and least developed countries. Thus, the study is innovative also in this regard.

\section{Schedule \& Implemetation}

The issues arising in connection with copyright law and education to access and knowledge have been debated controversially in the last years. WIPO is discussing a treaty concerning limitations and exceptions for educational purposes and libraries and archives. The European Union finds itself in the process of reforming European Copyright law. One essential part of the discussion is about limitations and exceptions for educational establishments and libraries and archives. In several countries reforms of the copyright systems are debated, too. The UK has quite recently reformed parts of the Copyright Designs and Patents Act, in particular the section for limitations and exceptions. In Germany, limitations and exceptions for educational purposes are discussed as well. A fundamental 
copyright reform is necessary also in Brazil. Some efforts have been made but have come to a stillstand. Yet, the new Brazilian government may take up the thread again. All in all, the issue of copyright law and access to education and knowledge in the digital age is of great importance and highly topical. In view of the accelerating technological progress and an increasingly networked and globalised world, the need to adapt copyright provisions, in particular limitations and exceptions to these developments, therefore is of great social and economic importance.

The author plans to address the above said target groups quickly. The book, being already published, will be sent to relevant stakeholders. Since the study contains concrete proposals for legislative amendments, these ideas and findings might contribute to current discussions about reforming international and national copyright law with regard to access to education and knowledge. Besides, the German publisher of the study will promote the book to interested academics, institutions and authorities over his sales network. In addition, the author plans to offer the study or parts of it to publishers in Brazil, Portugal and Mozambique. The relevant parts of the study may as well be translated into Portuguese. Above that, the study will be made available online. 


\section{Curriculum Vitae}

Philipp Usadel, born 1979 in Ulm, Germany, is a lawyer with his own chambers in Aachen focussing on copyright, media, competition and trademark law.

Philipp studied law at the University of Passau, the Catholic University of Lisbon and the University of Freiburg, where he graduated with the 1. State Examination in 2006. Subsequently, he began the legal clerkship at the district court Karlsruhe working for civil and administrative courts, the public prosecution department and a Brazilian law firm in Rio de Janeiro. In 2008 he passed the 2. State Examination and began master studies at the University of Applied Sciences in Cologne specialising in media law and economics. During that time he worked as a research assistant at the Cologne Research Centre for Media Law. In 2010 Philipp graduated with a master thesis on copyright law. Since then he holds a Master's degree (LL.M.). Also, in 2010 he was admitted to the bar in Germany and started working as a lawyer in 2011 joining a law firm in Aachen. In 2012 he opened his own office. 